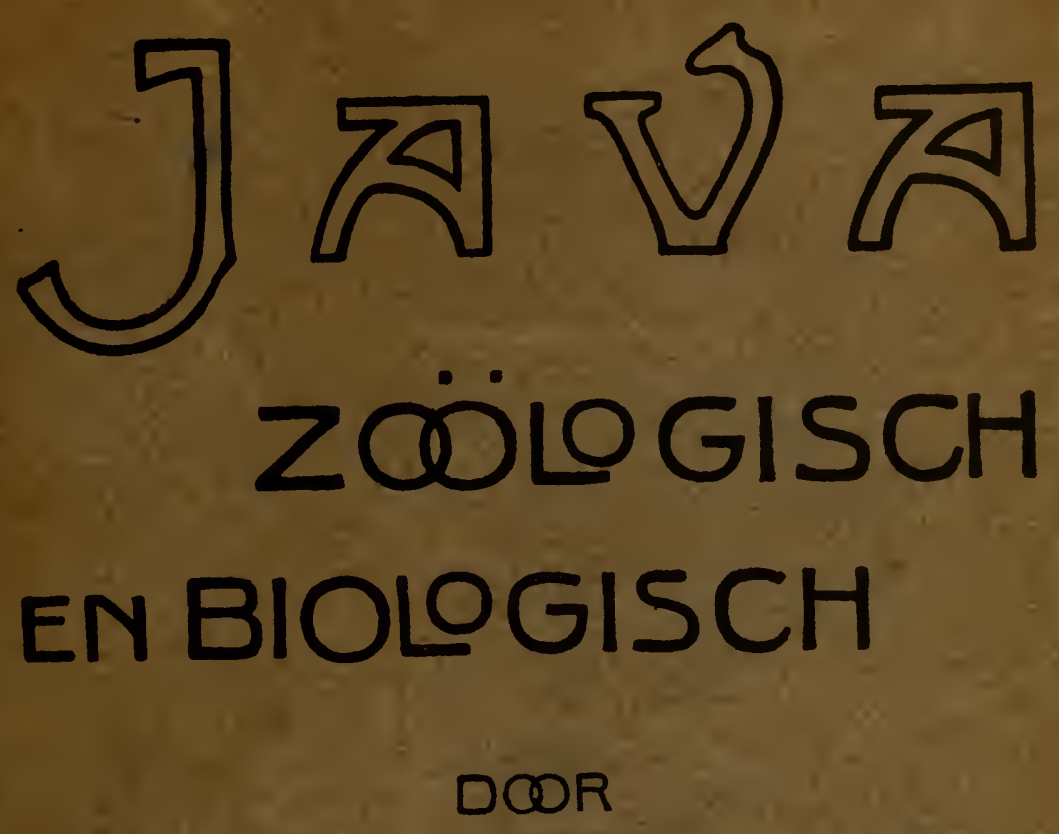

DRJ.C.KONINGSBERGER

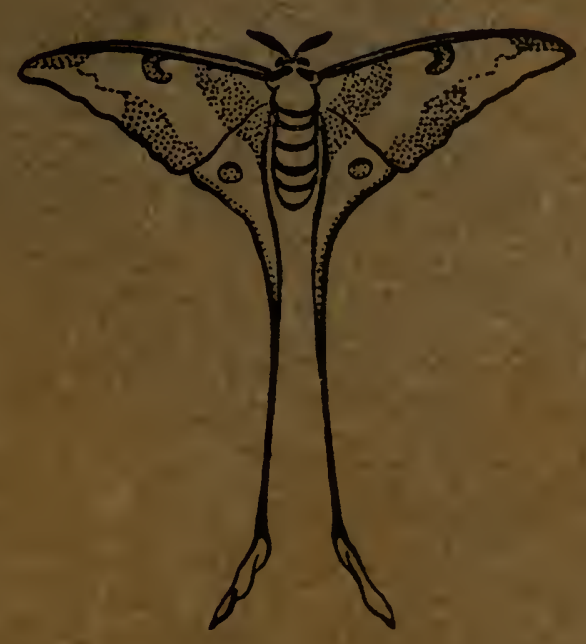

DRUKKERIJ DEP. v. L. N. en H.

BUITENZORO 1913. 
TIE D. H. HILL LIBD,ARY NORTH CROLINA STATE COLLEGE

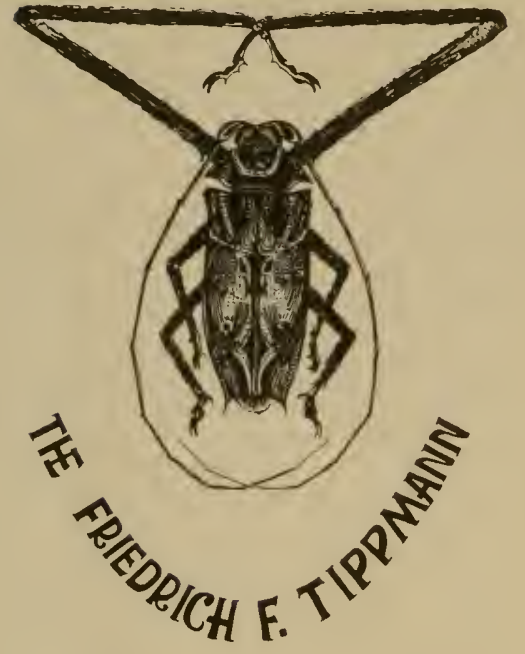

ENTOMOLOGICAL COLLECTION 
This book may be kept out TWO WEEKS ONLY, and is subject to a fine of FIVE CENTS a day thereafter. It is due on the day indicated below:

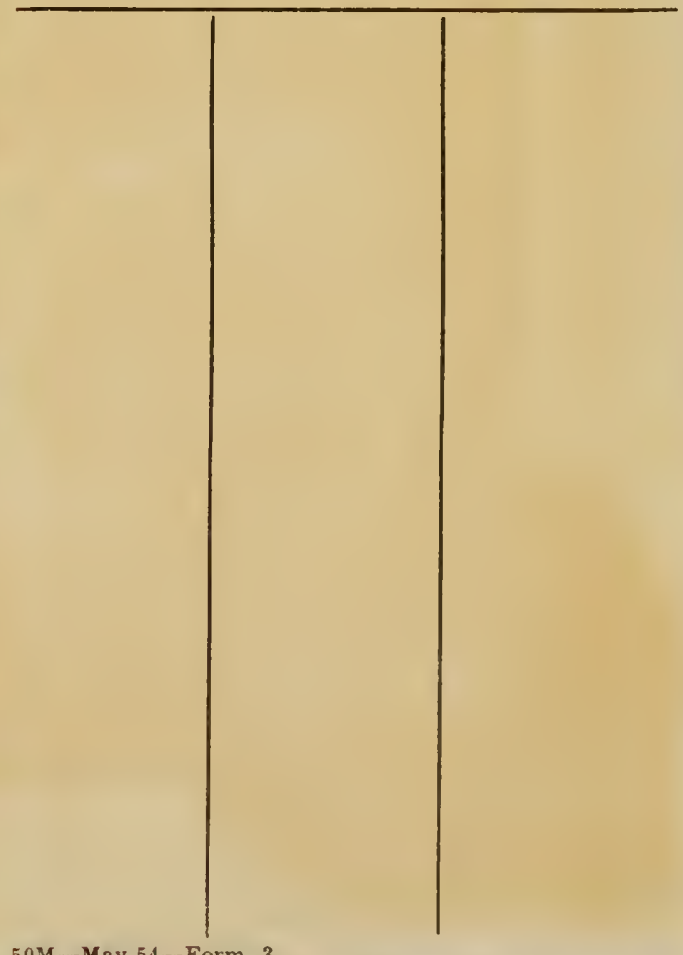







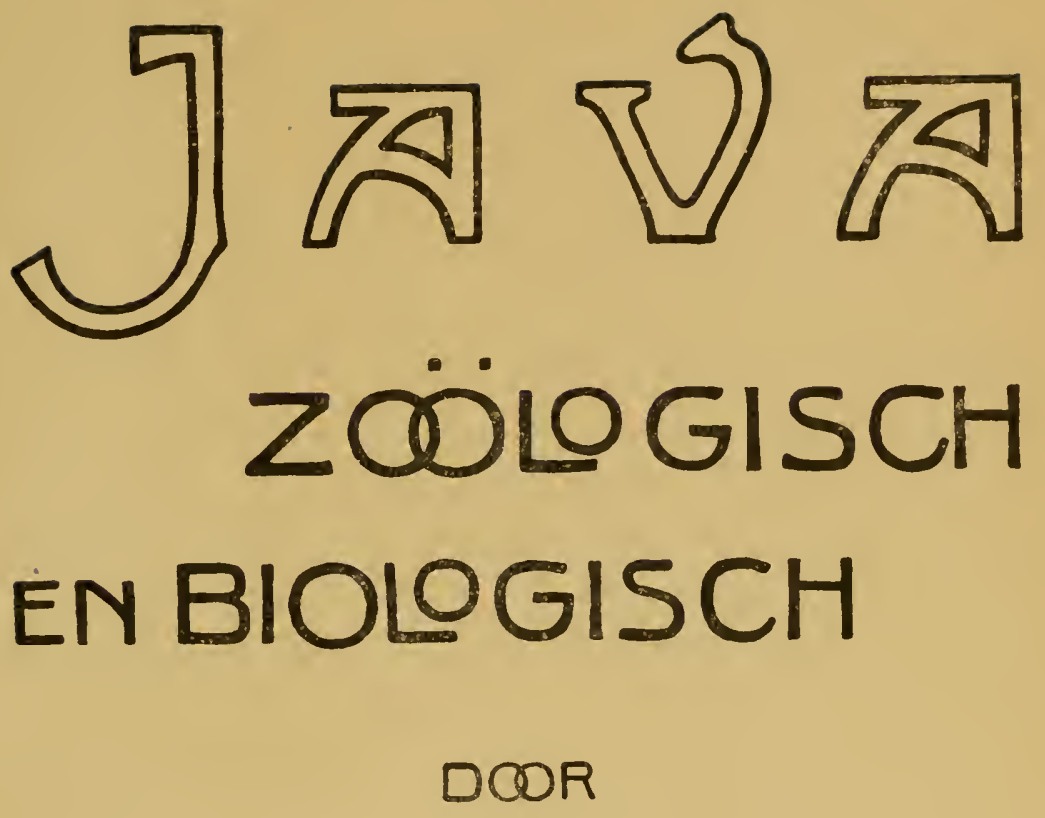

DRJ.C.KONINGSBERGER

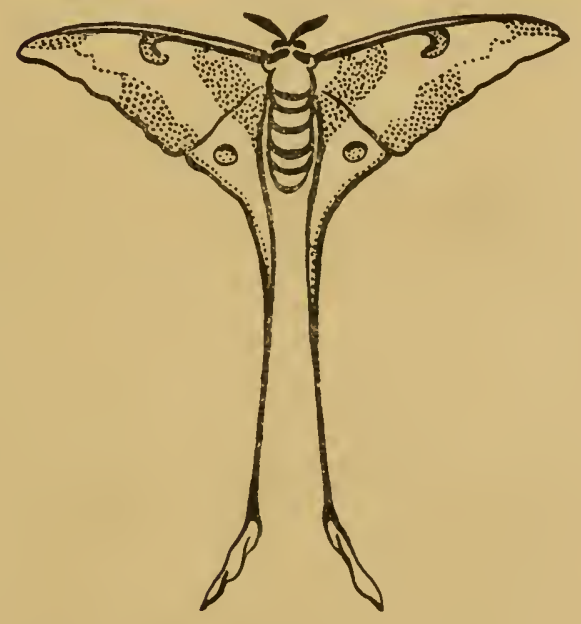

DRUKKERIJ DEP. v. L. N. en H.

BUITENZORG 1915. 



\section{INHOUDSOVERZICHT.}

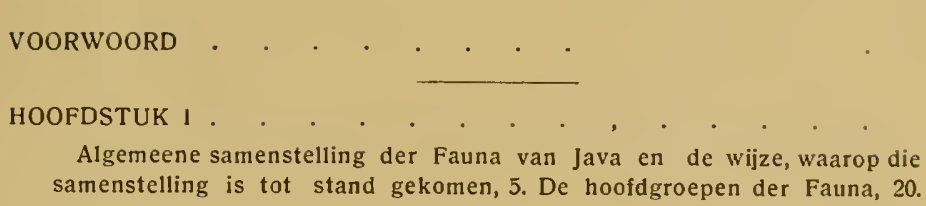

HOOFDSTUK 11 .

pag.

1.

5.

Overgangen van de eene groep in de andere, 22. Morphologische gevolgen daarvan, 23. Voorbeelden van vormen, die in overgang zijn, 28. Nachtelijke en diurne levenswijze, 32.

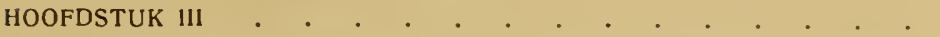

Invloed van jaargetijden, regen, wind en zonneschijn, 37. Vergelijking met andere eilanden van den Indischen Archipel, 47.

\section{DE CULTUURFAUNA.}

HOOFDSTUK $1 \mathrm{~V}$.

Kort overzicht der verschillende gebieden, 51. De Cultuurfauna bij uitnemendheid: De Diervormen der grootere plaatsen, 55. Zoogdieren, 55. Vogels, 60. Kruipende en Tweeslachtige Dieren, 76.

HOOFDSTUK V. . . . . . . . . . . . . . . 90

De Diervormen der grootere plaatsen. Insecten, 90. Orthoptera, 90. Neuroptera, 98. Rhynchota, 104. Diptera, 108.

HOOFDSTUK VI.

De Diervormen der grootere plaatsen. Coleoptera, 116. Lepidoptera, 127. (Rhopalorera, 127; Heterocera, 137).

HOOFDSTUK VII. 157.

De Diervormen der grootere plaatsen. Hymenoptera, 157. Apterygota, 179.

HOOFDSTUK VIII.

De Diervormen der grootere plaatsen. Schorpioenen en verwante vormen, 180. Spinnen en Mijten, 182. Duizendpooten, 189. Kreeftachtige Dieren, 193. Weekdieren, 194. Wormen, 195.

HOOFDSTUK $1 \mathrm{X}$.

De Fauna der Dessa's. Dessa's in het open veld, 199. Diervormen op klapper, 200; doekoe, 205; bamboe, 206; pisang, 209; manggistan, 210; djamboe, 211; waroe, 211.

Dessa's in boomrijke omgeving, 212. Diervormen op mangga, 213; sawoe manila, 216. Roovende Zoogdieren en Vogels, 217. Overige Zoogdieren 223. 
HOOFDSTUK $\mathrm{X}$

De Fauna der Dessa's. De avifauna der dessa's in boomrijke omgeving, 227.

HOOFDSTUK XI

De Sawahfauna. De diervormen in het sawahwater, 247. Kikvorschen en Slangen op de sawah's 251. Diervormen op de paddi, 256. Verdere diervormen op de sawah's, 262.

HOOFDSTUK XII

De Fauna van het Bouwland. Zoogdieren en Vogels, 273. Slange11, 275. Orthoptera, 276. Diptera, 279. Lepidoptera, 281. Hymenoptera, 29\%. Diervormen op Katjang-soorten, 284; Mais, 288; Katoen, 289; Solanaceae, 292.

HOOFDSTUK XIII.

De Fauna van het Bouwland. Diervormen op Tabak, 295; Suiker, 300.

HOOFDSTUK XIV.

De Fauna van Braakliggend Land en Weidevelden. Vlinders, 310. Zoogdieren en Vogels, 310. Bloedzuigende Diptera en Teken, 316. Spinnen, 318.

HOOFDSTUK XV. . . . . . . . . . . . . . . 322

De Fauna van het Gebied der Overjarige Cultuurgewassen. De diervormen der Djati-bosschen, 322. De diervormen der Koffie-aanplantingen en Schaduwboomen, 327 .

HOOFDSTUK XV1.

De Fauna van het Gebied der Overjarige Cultuurgewassen. De Diervormen der aan plantingen van Cacao, 351; Thee, 355; Kina, 363; Hevea en andere, rubber produceerende gewassen, 368; Palaquium, 371.

HOOFDSTUK XVII.

De Zoetwaterfauna van het Cultuurgebied, 373. Zoogdieren, 374. Kruipende en Tweeslachtige Dieren, 374. Visschen, 380. Gelede Dieren, 399. Weekdieren, 404. Wormen en Lagere Dieren, 406.

De Detritusfauna van het Cultuurgebied, 408.

\section{DE FAUNA DER GRASWILDERNISSEN.}

HOOFDSTUK XVIII.

De Fauna der Graswildernissen. Zoogdieren, 415. De toekomst der grootere, op Java in het wild levende Zoogdieren, 428. Vogels, 432. Slangen, 436. Insecten, 438.

\section{DE FAUNA VAN HET KUSTGEBIED.}

HOOFDSTUK XIX.

De Fauna van het Kustgebied. Litorale diervormen, facultatieve en verplichte kustbewoners, 441. Het Rhizophoren Gebied, 443. Strand en Duinen 449. Rawah's, 461. 


\section{DE FAUNA DER BOSCHRANDEN.}

HOOFDSTUK XX.

476.

De Fauna der Boschranden. Dagulinders. 478. Hymenoptera, 481. Coleoptera, 482. Wantsen, 486. Diptera, 488. Entomobrya, 489. Spinnen, 490. Vogels, 492. Zoogdieren, 497. Slangen, 498.

\section{DE BOSCHFAUNA.}

HOOFDSTUK XXI. 500.

De Boschfauna in het algemeen. Zoogdieren, 502. Vogels, 503. Eu-neuroptera, 509. Sesiidae, 511. Hymenoptera, 511. Nymphalidae, 519.

HOOFDSTUK XXI1.

522.

De Boschfauna der lagere streken. (0-2500 voet). Zoogdieren, 522. Vogels, 524. Vlinders, 531, Kevers, 532. Wandelende Blaren en Takken, 536. Mierenplanten, 538 .

HOOFDSTUK XXIII. 540.

De Boschfauna van 2500-5000 voet boven zee. Zoogđieren, 540. Vogels 543. Kruipende Dieren, 555. Kikvorschen, 556.

\section{HOOFDSTUK XXIV.}

De Boschfauna van 2500-5000 voet boven zee (Vervolg). Slakken, 560 . Kevers, 561. Vlinders, 568. Rhynchota, 573. Locustidae, 584. Mantidae, 585. Hooiwagens 585 .

HOOFDSTUK XXV.

De Boschfauna van $5000-7500$ voet boven zee. Prionodon, 589. Vogels, 590. Hommels, 594. Vliegen, 595.

\section{HOOFDSTUK XXVI.}

De Detritus-fauna der Bosschen. Wormen, 597. Duizendpooten, 600. Phrynichidae, 601. Amphipoda, 602. Isopoda, 602. A pterygota, 603. Rhynchota, 603. Orthoptera, 604. Coleoptera, 606. Diptera, 609. Hymenoptera, 610.

\section{DE FAUNA VAN HET HOOGGEBERGTE.}

HOOFDSTUK XXVI1.

De Fauna van het Hooggebergte. Geringe uitgestrektheid van het gebied, 613. Armoede aan grootere diervormen, 613. Het geslacht Merula, 615. Insecten, 617. 



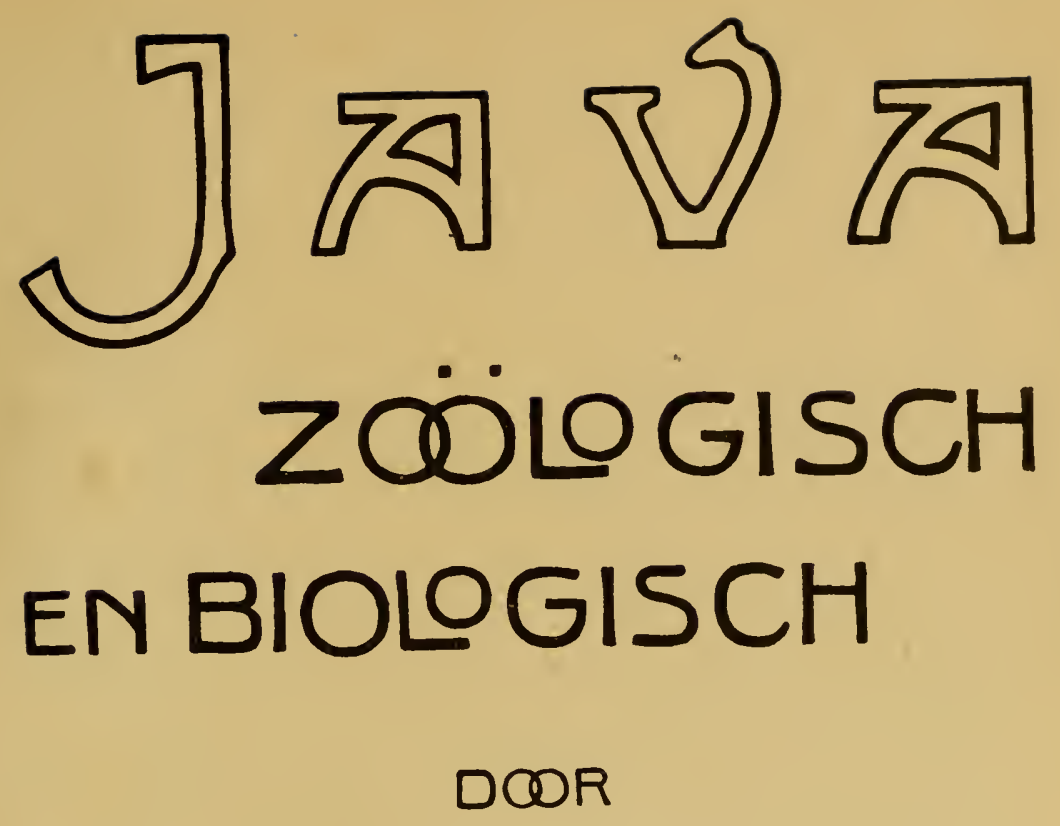

DRJ.C.KONINGSBERGER

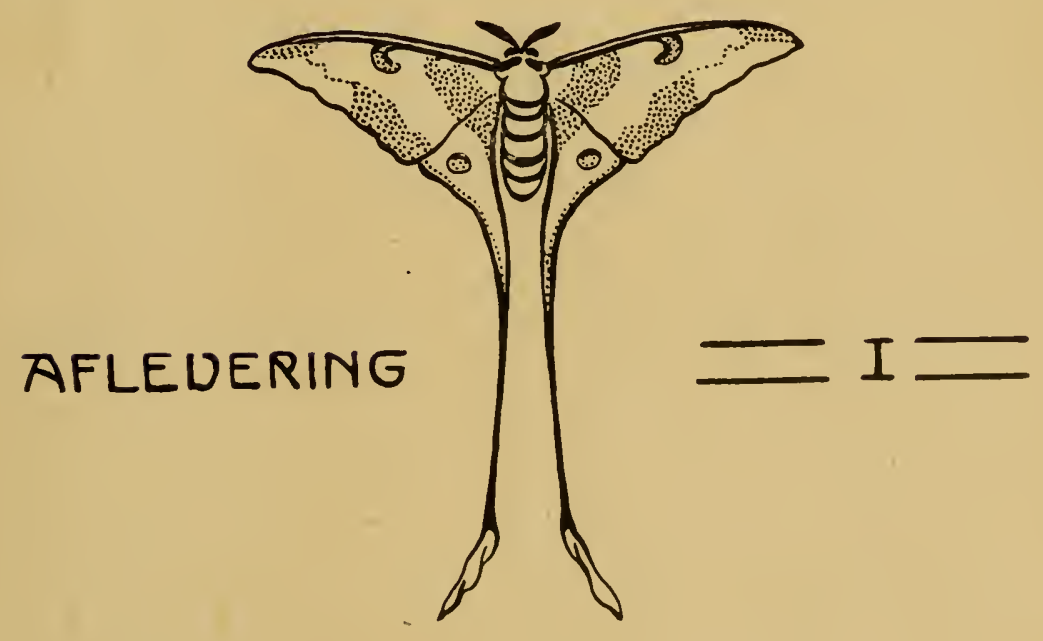

DRUKKERIJ DEP. v. L. N. en H.

- BUITENZORG 1911.

Verkrijgbaar bij

G. KOLFF \& Co. Batavia.

Prijs $f$. 


\section{IN HOUD.}

\section{AFLEVERING I.}

VoORwoond pag.

VOORWOORD . . . . . . . . . . . . . . . . . . 1.

HoofDSTUK I. Algemeene samenstelling der Fauna van Java

en hare wordingsgeschiedenis. De Hoofdgroepen . . . . . 5.

HoofDSTUK II. Overgangen van de eene groep in de andere. Morphologische gevolgen daarvan. Voorbeelden van vormen, die in overgang zijn. Nachtelijke en diurne levenswijze . . . . 22.

HoofDSTUK III. Invloed van jaargetijden, regen, wind en zonneschijn. Vergelijking met andere eilanden . . . . . 37 . 


\section{VOORWOORD.}

Een langdurig verblijf op Java, gewijd aan de studie van planten- en dierenwereld en meer in het bijzonder aan het onderzoek der onderlinge verhoudingen, die tusschen beide hestaan, heeft mij een aantal verschijnselen doen kennen, waaraan tot heden slechts weinig aandacht werd geschonken door hem, die zich in dit, slechts ten deele in cultuur gebrachte, tropische land met faunistische en biologische onderzoekingen hebben bezig gehouden.

Wanneer men de, in Europa en elders aanwezige, oudere. verzamelingen van dieren nagaat, treft men daarin aangaande de plaats van herkomst aanwijzingen aan als "Java”, „Sumatra” of, erger nog, "India orientalis", aanwijzingen, die weinig meer waarde hebben clan het etiquet "zuur" of "zout" in. een magazijn van scheikundige stoffen.

Toen men langzamerhand het lacunaire van dergelijke opgaven inzag, werd eenige meerdere naurkeurigheid bij het verzamelen in acht genomen.

Daarom vindt men bij hetgeen in den lateren tijd is bijeengebracht niet alleen de landstreek, het gebergte, de rivier enz. aangegeven, waarin of waarop het dier werd gevonden, maar ook eene, zij het ook approximatieve opgave van de hoogte boven den zeespiegel, waarop de rondst plaats had.

Deze opgaven mogen eenigermate voldoende zijn voor een landstreek, die nog geheel in den oorspronkelijken natuurstaat verkeert, voor een land als Java zijn zij in den regel niet in staat, het geringste denk- 
beeld te geven ran de omgeving, waaruit het dier afkomstig is, eene omstandigheid, des te meer te betremen, daar Java in den loop der tijden een zoo belangrijk aandeel voor vele wetenschappelijke rerzamelingen lererde.

De hierbij stilzwijgend aangenomen stelling, dat bij faunistisch onderzoek de systematiek hand in hand behonrt te gaan met de biologie, en de orerweging; dat de wetenschap slecht in beperkte mate is gebaat met opgaren ran dierrormen, in deze of gene streek voorkomende, wanneer niet terens eenige meerdere gegerens orer die rormen worden rerstrekt, hebben mij doen besluiten, in algemeene trekken een, zoo men wil, oecologisch beeld te ontwerpen ran de samenstelling der fauna van Jara, welk beeld, mutatis mutandis, ook ran toepassing zal zijn op andere en rooral op tropische landen, die slechts gedeeltelijk in cultuur zijn gebracht.

Nog een andere oorzaak heeft mij ertoe gebracht, de hierachter rolgende bladzijden het licht te doen zien. De specialiseering op wetenschappelijk gebied, die in Europa reeds een bedenkelijke hoogte heeft bereikt, houdt ook in Indië rrijwel gelijken tred met het toenemend aantal natumonderzoekers, dat in de laatste twintig jaren in allerlei nieurve betrekkingen herraarts is gekomen. Het zal daarom in de toekomst niet licht meer roorkomen, dat, gelijk in den loop der jaren het deel ran schrijrer dezes is gerveest, roor één en dezelfde persoon de meest uiteenloopende. groepen ran dieren een onderwerp ran studie moeten uitmaken, wat uit den aard der zaak berorderlijk is ror het rerkrijgen ran een overzicht orer de geheele materie, al legt het aan het rolledig onderzoek der enkele groepen groote hinderpalen in den weg. 
Daal bovendien de bedoelde onderzoekingen gepaard gingen met veelvuldige reizen, gedurende welke zelf's de lange uren, in spoortrein en andere, meer primitieve vervoermiddelen doorgebracht, door allel'ei waarnemingen konden worden gekort, werd langzamerhand een inzicht, niet alleen in de samenstelling, mad ook in de rerdeeling der fauna verkregen, warrvan de publicatie allicht aan tijdgenooten en latere onderzoekers eenigen dienst kan bewijzen.

Toor het werk is een titel gekozen, die natuurlijk in de allereerste plaats doet denken aan het beroemde werk ran Juxghuns, dat wij, trots zijn rele onnauwkeurigheden en trots zijn onvolledigheid, nog heden ten dage met onverdeelde bewondering lezen. Ik noem die gebreken met opzet, omdat zij ook aan deze eel'ste poging in zoölogische en biologische richting; in hooge mate zullen aankleven. Naal volledigheid is bovendien niet gestreefd. Het zou geen zin hebben, den lezer te vermoeien met lange opsommingen van soorten, die slechts waarde hebben voor den specialist en dikwijls alleen door dezen behoorlijk van elkaar zijn te onderscheiden, of met het noemen van vormen, die roor den totalen indruk eener fauna van geheel ondergeschikte beteekenis zijn. Wat met dit verk bedoeld wordt, is niet ander's, dan den algemeen natuulwetenschappelijk ontwikkelden bewoner of bezoeker ran Java, of hem, die elders van dit land een studie maakt, een soort van vademecum in handen te geven, dat tot een eerste en globale orienteering kan leiden. En hieraan bestaat - ik heb het gedurende de eerste jaren van mijn verblijf op Java pijnlijk gevoeld-een dringende behoefte.

Het was aanvankelijk mijn roornemen, dit werk in ééns of hoogstens in twee deelen te doen verschijnen, 


\section{$-4-$}

maar de uitvoering van dit plan zou, ten gevolge van vele andere bezigheden, stellig een aanzienlijke vertraging in de verschijning ervan hebben medegebracht. Daarom besloot ik, de laatste bij afleveringen te doen plaats hebben van twee tot drie vel druks. Het aantal dier afleveringen kan thans nog niet worden bepaald, maar wordt door mij op 12 tot 15 geschat. Ten aanzien van den spoed, waarmede zij elkander zullen opvolgen, kan ik niet anders doen, dan de verzekering van mijn goeden wil neerschrijven.

$$
\text { J. C. K. }
$$




\section{HOOFDSTUK I.}

\section{Algemeene Samenstelling der Fauna van Java en hare wordingsgeschiedenis. De Hoofdgroepen.}

Voor wie zich een denkbeeld wenscht te vormen van de wijze, waarop de samenstelling van Java's fauna, zooals deze zich thans aan ons voordoet, is tot stand gekomen, is een korte terugblik in den vóórhistorischen tijd in de eerste plaats noodzakelijk. Want lang vóórdat de, op dit dichtbevolkte eiliand zoo buitengewoon groote invloed van den mensch zich deed gevoelen, hebben in dat verre verleden reeds andere factoren samengewerkt, om in den oorspronkelijken toestand verandering te brengen.

Hoe die oorspronkelijke toestand is geweest, laat zich met vrij groote zekerheid aangeven: die van een vlak of althans slechts weinig geaccidenteerd land, bewoond door eene, over de geheele oppervlakte tamelijk homogene fauna, welke een even belangwekkend als samengesteld, biologisch geheel vormde met de uitgestrekte, ongerepte, tropische wouden, die alom den bodem bedekten.

Toen nu, ongeveer in het begin der krijtperiode, wellicht reeds iets vroeger, de afkoeling der aarde haar invloed deed gevoelen en eene, aan de polen beginnende, naar den aequator roortschrijdende omrorming der organismen inleidde, konden de levende

\section{H. HILL LIBRARY}

North Carolina Staie College 
wezens der tropen zich voorloopig volkomen veilig gevoelen. Anders echter werd het, toen aldaar in den tertiairen tijd de hooggebergten ontstonden; want daarbij moet aan een deel dier organismen iets dergelijks zijn overkomen als voorheen op groote geographische breedte plaats had en kon de plaatselijke opheffing van den bodem tot een aanzienlijke hoogte boven den zeespiegel niet zonder invloed blijven op de plantaardige en de dierlijke bewoners van het jonge hooggebergte.

De afspiegeling van dit proces wordt ons in de eerste plaats onwederlegbaar aangeboden door de plantenvormen der hoogere bergistreken binnen de keerkringen. Men denke slechts aan de Conifeeren, die in de koudere luchtstreken orer uitgestrekte terreinen nagenoeg de alleenheerschappij wisten te veroveren, in de tropen daarentegen in den regel slechts op vrij aanzienlijke zeehoogte worden aangetroffen.

Ook is er door vele natuuronderzoeker's reeds op gewezen, hoe in het algemeen de flora van Java's bergtoppen in tal van plantengeslachten (Gnaphalium, Artemisia, Valeriana, Viola, Primula, Ramunculus enz.) en zelfs soorten (Artemisia vulgaris, Poa annua e.a.) herinnert aan die van het Noorden en zelfs aan die van Europeesche hooggebergten als de Alpen.

Maar ook de diervormen zijn daar, om van dit proces te getuigen, hoewel het roor deze uit den aard der zaak gemakkelijker moet zijn geweest, de afkoeling te ontvluchten en zich, bij langzame opheffing van den bodem, binnen de grenzen van het warme klimaat terug te trekken. Om het even echter, of wij ons de fauna van het hooggebergte hebben voor te stellen als in loco ontstaan of secundair in boven- 
waartsche richting afgescheiden uit haar, die zich naar lagere streken had geretireerd, zeker is het, dat ook zij eene. althans representatieve rerwantschap met die der gematigde en koudere luchtstreken rertoont.

Zoo vertoonen vele Zoogdieren en Vogels, die op Jara op groote zeehoogte - en alleen dáál-worden aangetroffen, zoodanige rerwantschap met Europeesche en Noord-Aziatische rormen, dat men ze met het volste recht tot dezelfde geslachten (o.a. Mustela, Turdus, Fringilla) heeft gebracht. Ook gaat op Java in het algemeen de klemrenpracht der lagglanden in het hooggehergte roor een aanzienlijk deel verloren, om te worden rerrangen door de minder sprekende kleuren, die bijroorbeeld in Europa den boventoon roeren.

De homogeniteit der fauma van het stuk aardoppervlakte, dat thans den naam ran Java dlaagt, is echter nog op andere wijze rerbroken.

Het westelijke gedeelte ran den Indischen Archipel, dat eenmaal een deel uitmakkte van het Aziatische vasteland, werd door niveau-veranderingen ran den bodem gesplitst in grootere en kleinere eilanden. omspoeld door een zee, aan welker stranden zich eene kustfauna vestigde en vormde.

Vestigde, roor zoorerre een reeds bestaande en bij roorkeur of uitsluitend nabij het zeestrind reltoevende fauna de nieuwe kustlijnen rolgde: rormde, voor zooverre diervormen, die tot dusverre een binnenland berwoonden, zich accommodeerden aan een rerblijf in de nabijheid der zeè.

Het eerste is ongetwijfeld geschied met tal ran dieren, die zich ran ourlsher aan de zeekusten ophielden, zonals Krokodillen, rele TVaadrogels en 
Zwemvogels, eenige Roofvogels en voorts met Crustaceeën, Mollusken en dgl., wanneer men deze, nu en dan op het zeestrand vertoevende dieren tot de landfauna wil rekenen.

Voorbeelden ran het laatste zijn moeilijker met zekerheid aan te geven, maar het komt mij, om een hypothese te wagen, niet onwaarschijnlijk voor, dat een dierrorm als Myristicivora bicolor, een Duif, die reeds door Honsfield als Columba litoralis werd beschreven en die thans alleen in de nabijheid der zee wordt aangetroffen, eerst in den lateren tijd haar tegenwoordige levensivijze heeft aangenomen en oorspronkelijk, evenals nog thans met hare verwanten het geval is, tot de binnenlandsche fauna heeft behoord.

Zoo werden dus reeds in de dagen, die aan het begin onzer geschiedenis roorafgingen, aan de oorspronkelijke fauna van Java twee grenzen gesteld, één aan de bovenzijde, waar zij allengs in die van het hooggebergte overgaat, en één aan de benedenzijde, waar zij, niet minder geleidelijk, met de kustfauna samensmelt.

Al bleef zij echter binnen die grenzen in hoofdzaak overal hetzelfde karakter vertoonen, zoo mogen wij toch niet over het hoofd zien, dat zich onder den invloed van allerlei omstandigheden, onder meer afhankelijk van klimaat, aard van den bodem en hoogte boven zee, grootere en kleinere grebieden rormden, welker dierenwereld een plaatselijke physionomie vertoonde.

De zooeven genoemde en andere, ereneens thans nog werkzame factoren vormen echter in hunne samenwerking een zóó gecompliceerd stelsel van krachten, dat aan eene algemeene ontleding daarvan 
thans niet meer valt te denken. Verspreid echter ontmoeten wij niet zelden feiten, die op de bijzondere werking van één of meer dier factoren wijzen.

Aan den invloed van klimaatsverschil meen ik o.a. te moeten toeschrijven de afwezigheid, in het Oostelijk gedeelte van Java, van eene Cryptorhynchus-soort, een Snuitkevertje, dat in West-Java algemeen in vele variëteiten der Mangifera-vruchten voorkomt. In Oost-Iava toch, met zijn sterk geprononceerden, drogen moesson, bloeien alle Mangifera's ongeveer in denzelfden tijd en brengen evenzeer hunne vruchten in eenzelfde, niet zeer lang tijdbestek tot rijpte, zoodat er gedurende minstens de helft van het jaar geen bloeiende of vruchtdragende boomen zijn te vinden. Anders is het in West-Java, waar het vochtige, regenrijke, maar veel gelijkmatiger klimaat eene zoodanige schommeling in dit opzicht toelaat, dat de laatste Mangiferavruchten van het ééne jaar zich weder aansluiten aan de eerste bloemen van het volgende, zoodat er altijd wel bloeiende en vruchtdragende boomen zijn. Daar nu deze Cryptorhynchus, voor zijn geheele ontwikkeling op deze vruchten aangewezen, zijn levenscyclus in 60-90 dagen volbrengt, wordt het begrijpelijk, dat hij in West-Java wèl, in Oost-Java daarentegen niet kan bestaan.

De hoogte boven zee is een factor, waarmede zeer zeker rekening moet worden gehouden, maar die toch in zijn determineerende werking dikwijls veel te hoog is geschat. Hierop werd reeds, en zeer terecht, in 1882 door Vorderman gewezen. "Wel is waar", zoo zegt 1) deze ijverige onderzoeker der Indische vogelwereld, „hebben de vroegere natuuronderzoekers

1) Natuurk. Tijdschr. v. Ned.-Indië, Deel 41, afl. 4. 
meestal de plaats bekend gesteld, vanwaar hunne verzamelde voorwerpen afkomstig waren, doch de omstandigheid, dat bijna al hunne tochten zich in de bergstreken uitstrekten, heeft een aantal vogels dcen beschouwen als alleen tot die streken beperkt. Zoo is het voorkomen van Drymocataphus capistratus en Pitta cyanura in de onmiddellijke nabijheid ran Batavia een feit, dat de opmerkzaamheid der ornithologen niet zal ontgaan, doch tevens een bewijs, dat deze vogels volstrekt niet uitsluitend als bergbewoners mogen worden beschreven".

Hetzelfde geldt van de Vorkstaarten (Henicuridae), die evenmin tot de bergstreken beperkt zijn, maar tot weinige meters boren den zeespiegel afdalen, wanneer zij aldaar slechts twee voorwaarden rerruld vinden: de eenzaamheid ran het woud en helder, stroomend water

In het algemeen schijnen de clieren, althans binnen zekere grenzen, niet zoo geroelig roor temperatuursverschillen te zijn, als men gewoonlijk aanneemt en het komt mij daarom voor. dat hunne verticale verspreiding op Java reel meer door andere factoren en slechts indirect door de hoogte boven zee wordt bepaald.

Er rallen dus in de fauna van Jara, zooals zij zich in het begin van den historischen tijd moet hebben voorgedaan, drie onderdeelen te onderscheiden, die in het rerrolg zullen worden aangegeren met de namen oorspronkelijke kustfauna, verfauna en fauna van het hooggebergte. Terwijl de eerste en de laatste zich vrijwel ongestoord hebben gehandhaafd, hebben ten aanzien van de oerfauna, onder den invloed van den mensch, diep ingrijpende veranderingen plaats gehad, met 
welker bespreking wij ons thans hebben bezig te houden.

Men mag aannemen, dat het ongerepte, tropische woud de oudste, nog in leven zijnde overblijfselen bevat van het plantaardig en het dierlijk landleven van den róórhistorischen tijd, ook in hun onderlingen samenhang. Wat men dáár aantreft, is niet alleen eene, ran den invloed van menschelijk leven en menschelijke beschaving geheel rrij gebleven natuur, maar bovendien diezelfde natuur, zooals zij zich reeds in algemeene trekken moet hebben voorgedaan onmiddelijk vóór de aardperiode. waarin wij ons thans bevinden.

Daarop wijzen de overblijfselen zoowel der flora als der fauna, die voor ons uit het einde van den mesozoïschen tijd, meer bepaald uit de krijtformatie, zijn bervaard .gebleven. Vormen, die thans in de tropische wouden der laaglanden, berghellingen en hoogrlakten van middelmatige hoogte op den voorgrond treden, vormden ook toen reeds een voornaam bestanddeel van de plantenwereld. Wij denken hier in de eerste plaats aan de Vaatcryptogamen (in het bijzonder de Tarens) en de Cycadeeën, voorts aan Palmen en Pandaneeën, bij welke zich later ook dicotyle familiën voegden als Artocarpaceae, Lauraceae, Sterculiaceae, Myrtaceae e.a., die nog heden aldaar een groote rol spelen. Evenzoo behooren de belang. wekkende vormen van boschbewonende Orthoptera, de Libellen, die daar boven de bergstroompjes zweven, en de geheimzinnige Termieten, die er in het verborgene hun opruimingswerk verrichten, tot de naaste verwanten van het eerste insectenleven op aarde.

Ware Java onbewoond gebleven, dan zouden der- 
gelijke oorspronkelijke toestanden aldaar nog algemeen heerschen; thans praedomineeren ze nog slechts in die gedeelten, die om de eene of andere reden buiten den invloed van den mensch zijn gebleven. Overal elders heerschen toestanden, die slechts door den mensch en zijn culturen, dus langs kunsmatigen weg, in het leven worden geroepen en gehouden.

Dit laatste nu vinden wij op Java vooreerst over verreweg het grootste gedeelte van alle terreinen beneden 2000 voet zeehoogte, die samen het dichtbevolkte deel van Java vormen, waar de bodem druk en reelal zeer intensief wordt bebouwd. Het zijn de uitgestrekte laaglanden met hun tallooze dorpen, hun culturen van rijst, suikerriet, indigo, tabak en tal van andere gervassen, hun dorpsregetatie van bamboe en vruchtboomen, die het hoofdbestanddeel van het gecultiveerde land uitmaken. Ben en ander breidt zich verder uit orer de lagere berghellingen, waar het zich aansluit aan de aanplantingen van koffie, rubber, cacao en, hoofdzakelijk in WestJava, thee en kina, terwijl het op enkele plaatsen, in het bijzonder op den Diëng enhet Tenggergebergte, ook een deel der hoogere bergstreken in beslag heeft genomen.

In de tweede plaats op de terreinen van 2000 roet zeehoogte en daarboven, ' die ten behoeve der zooeven genoemde culturen zijn ontgonnen.

Op al deze terreinen is de oerfauna als zoodanig verdwenen. Zij worden thans bevolkt door een dierenwereld, die ik in het vervolg met den naam van cultuurfauna zal aanduiden en die zich in den loop der jaren uit de eerste heeft afgezonderd.

Nen kan zich gemakkelijk een voorstelling maken 
van de wijze, waarop deze cultuurfauna is ontstaan en-voegen wij dit reeds dadelijk hieraan toe-nog schier dagelijks met nieuwe vormen wordt vermeerderd.

De grond, door wegkapping van de oorspronkelijke vegetatie aan de wildernis ontnomen, wordt met verschillende cultuurgewassen beplant en het gedierte, dat aanvankelijk voor de vernielende hand van den mensch heeft moeten wijken en zich heeft teruggetrokken in de schuilhoeken van het bosch, komt langzamerhand weder te roorschijn. Het meerendeel zal zich echter in die nieuwe omgeving niet thuis gevoelen; zij vinden er in en bij de cultuurplanten geen voedsel naar hun smaak en trekken zich weder in het woud, hun oude verblijfplaats, terug. Maar enkele van die diervormen zullen in het nieuwbebouwde land wèl voedsel vinden, dat in hun smaak valt; zij vinden er zelfs niet zelden hunne levensroorwaarden in die mate vervuld, dat hunne invasie door een blijvende vestiging wordt gerolgd.

Op deze hoogst eenvoudige wijze hebben wij ons het ontstaan voor te stellen van de fauna, die op Java in de omgeving van den mensch en zijn culturen voorkomt en die in den loop der eeuwen is aangegroeid, tot een biologisch geheel van aanzienlijken omvang. Dit geheel, in hoofdzaak een derivaat dus ran de oerfauna, omrat, naast vele onverschillige diersoorten, alle diervormen, die nuttig of schadelijk, in eenig opzicht van oeconomische beteekenis zijn. Een deel erran komt ook nog in de bosschen en wildernissen voor, maar het meerendeel heeft ze voor goed verlaten.

Wat er, na deze afzondering, van de oerfauna 
overblijft, zal ik met den naam van boschfauna aanduiden.

De laatste laat drie onderdeelen onderscheiden, de fauna van het eigentijke bosch, die van de boschranden en die van de graswildernissen. Deze verdeeling eischt een enkel woord ter verklaring.

Vele boschbewonende diersoorten begeven zich zelden of nooit in het diepst van het bosch, maar houden zich zoo goed als uitsluitend op nabij de randen of in de nabijheid van grootere, open plekken. Voor zooverre zij nabij de randen vertoeven, maken zij dikwijls grootere of kleinere strooptochten in het naburige cultuurgebied en zijn dan te beschouwen als een soort van overgangsfauna. Uit den aard der zaak is het uit deze vormen, dat de gelederen der cultuurfauna voortdurend nieuwe versterkingen ontvangen.

De, op Java algemeen voorkomende terreinen, die zijn opengekapt, maal na eenigen tijd van bebouwing weder aan hun lot zijn overgelaten of, om welke reden ook, onbebouwd zijn gebleven, geven veelal het aanzijn aan wat ik zooeven graswildernissen noemde. Een spontane reboisatie vindt daar in den regel niet plaats. Wel is waar komen verspreid weder boomen of boomachtige gewassen of groepen daarvan voor den dag, maar de heerschappij over deze terreinen wordt gevoerd door hooggroeiende grassoorten, warrvan alang-alang (Imperata arundinasea), glagah of kasso (Saccharum spontaneum), Phragmites-soorten en dgl. de meest algemeene zijn. Deze grassen vormen met de tjinteh (Lantana spec.) en, in West-Java, met eene Eupatorium-soort (E. javanicum), die zich in den laatsten tijd buitengewoon snel verbreidt en zelfs de Lantana hier en daar verdringt, 
een tamelijk ondoordringbare regetatie ran eigenaardig kal'akter, die reeds door Jusarums werd vergeleken met de Sarannen, met welk vegetatie. type zij inderdaad meer orereenkomst rertoont dan met eenig ander.

In die vegetatie houdt zich eene fauna op, die aan rormen niet zeer rijk is, maar door enkele, geregeld voorkomende diersoorten een eigen karakter bezit. Daar rerder de gezamenlijke oppervlakte van deze grastrildermissen op Java zeer aanzienlijk is, meende ik van de berroners daarvan eene afzonderlijke biologische groep te moeten maken van dezelfde orde als die der boschranden, waarmede zij orerigens rele diersoorten gemeen heeft. Dit laatste zal niemand rerwonderen, die de strooken graswildernis kent, welke bijna zonder uitzondering de, nabij het bosch gelegen aanplantingen van dit laatste scheiden.

Het ligt in den aard der zaak, dat de fauna ran de bewoonde en bebouwde streken, evenals die ran het bosch. in biologische groepen kan worden reldeeld. Maar wegens het rerspreid door elkander liggen van uitgestrektheden grond met verschillende cultuurgewassen vloeien deze groepen in zoodanige mate door en in elkander, dat aan een scherpe scheiding erran niet valt te denken. Dit geldt in de eerste en roornaamste plaats roor de lagere landen, die zich, ran boven gezien, roordoen als een mozaïekvloer in verschillende tinten van groen; in mindere mate roor de bergstreken, waar in den regel grootere uitgestrektheden door eene en dezelfde, meerjarige cultuurplant zijn bedekt.

Al kumnen wij dus wel een fauna der tabaksvelden, der koffie-ondernemingen enz. beschrijven en al zal 
het daarbij blijken, dat elk van deze eenige specialisten heeft, die in hun onderhoud en hun voortbestaan direct of indirect aan een bepaalde plantensoort zijn gebonden, toch vormen deze geen afzonderlijk naast elkaar staande groepen met nauwkeurig aan te geven grenzen.

Slechts ééne uitzondering ware hier wellicht te maken en wel met de bevolking der bevloeide rijstvelden, die op Java eene oppervlakte van ettelijke millioenen Hectaren beslaan. Daar deze reusachtige oppervlakte echter niet gelijktijdig over hare geheele uitgestrektheid wordt bevloeid, is de sawchfauna, zooals ik haar in den vervolge zal noemen, verplicht, een ietwat $z$ wervend leven te leiden en zich naar gelang van omstandigheden te verplaatsen. Zij ontleent haar bijzonder karakter in de eerste plaats aan de aanwezigheid van het bevloeiingswater, in de tweede plaats nog aan iets anders. Het grootste gedeelte van den rijstbouw heeft namelijk plaats gedurende den regentijd, die, hoewel plaatselijk verschillend, in het algemeen samenvalt met de wintermaanden van het Noorden, als wanneer talrijke vogelsoorten, voor een aanzienlijk deel watervogels, de koude ontvluchten en zuidwaarts tot Java trekken, waar hunne levenswijze hen natuurlijk onmiddellijk naar de rijstvelden voert. Daarom maken deze trekvogels in verbinding met een aantal, hier vast verblijvende verwanten een opvallend bestanddeel van de sawahfauna uit en dragen er niet weinig toe bij, daarop een bijzonderen stempel te drukken.

Nog op een ander punt zij hier de aandacht gevestigd, in verband met het dikwerf locaal karakter 
ran de groepen der cultuufauna in de bergstreken en die der boschfauna.

Toen Java nog grootendeels met bosschen was bedekt, werden deze ran de benedengrens tot waar zij in de rormen der hoogere bergstreken overgaan, bewoond door de oerfauna, waarroor wij, op grond van hetgeen wij thans nog waarnemen, een tamelijk groote mate ran homogeniteit mogen aannemen.

Naarmate echter steeds meer gronden ten behoeve der verschillende culturen in beslag werden genomen, steeg de benedengrens ran het bosch al hooger en hooger. Door de verticale gesteldheid nu van den lodem van Java, dat ruor een groot deel niet anders is dan een rij van afzonderlijke rulkanen en vulkanische bergstelsels, die zeer glooiend in de vlakte uitloopen, werden de, met bosschen bedekte, hoogere streken door uitgestrekte lage landen en valleien grootendeels van elkander geïsoleerd.

De, van elkander afgezonderde boschcomplexen hadden dus op een g'egeven oogenblik elk haar eigen fauna. Wel is waar mogen voor die verschillende fauna's, zooals wij zooeven reeds opmerkten, geen verschillen van beteekenis worden aangenomen, maar een onderlinge uitwisseling van vormen en individuen was toch niet meer of slechts in beperkte mate mogelijk. Elke fauna stond eenigermate, hier en daar zelfs geheel, op zich zelve en daar de numerieke verhoudigen der vormen, die haar samenstellen, door invloeden van zeer plaatselijken aard worden beheerscht, kunnen zelfs naburige bergen in dit opzicht groote verschillen vertoonen. Zoo kan een diervorm, die op den G. Salak in grooten getale voorkomt, op den naburigen $G$. Gedeh zeldzaam zijn, daar beide bergen door een breede vallei van gecultiveerd land zijn 
gescheiden. Zelfs kan het voorkomen, dat zulk een vorm op den anderen berg geheel ontbreekt, terwijl hij eenige bergen verder weder tot de gewone verschijningen behoort.

Dit verschijnsel is natuurlijk niet zonder invloed gebleven op het karakter der aangrenzende cultuurfauna en daarom komt het niet zelden voor, dat een diersoort op den éénen berg op een cultuurplant is terecht gekomen en aldaar tot een ware plaag is geworden, terwijl zij op een anderen berg niet de minste oeconomische beteekenis heeft, ja, soms geheel onbekend is. Met dergelijke vormen heeft men "bij de beschrijving der plaatselijke fauna's in de eerste plaats rekening te houden; zij zijn als de "Leitfossilien” der palaeontologen en zouden in de toekomt ook zeker als zoodanig worden beschouwd, wanneer de levende natuur van Java op eenmaal versteende en in dien toestand voor een volgend geslacht bewaard bleef.

Evenals de fauna van het hooggebergte niet denkbaar is zonder het ruwe en koude bergklimaat, zoo waren de diervormen van de oorspronkelijke kustfauna om de eene of andere reden gebonden aan de nabijheid der zee. Liggen die redenen in vele gevallen onmiddeliijk voor de hand, in andere gevallen zijn zij minder gemakkelijk op te sporen en soms tot heden tevergeefs gezocht.

Juist dat gebonden zijn aan de nabijheid der zee is oorzaak, dat de oorspronkelijke kustfauna een groot deel van haar oud karakter heeft bewaard. In het Noorden van Java heeft de breede, moerassige, voor een deel met vloedbosschen (mangrove-vegetatie) 
bedekte strook een dergelijk isolement tot stand gebracht als op cle toppen der bergen is te vinden en zij herbergt tal van diervormen die uitsluitend dààr voorkomen. In het Zuiden, waar de kuststreek over het algemeen veel minder is ontwikkeld en de invloed van den mensch veel geringer is gerveest, treft men den oorspronkelijken toestand bijna of geheel onveranderd aan.

Toch moet het in den loop der jaren zijn voorgekomen, dat, althans aan de Noordkust, diervormen uit de oorspronkelijk kustfauna in de aangrenzende cultuurfauna zijn overgegaan, zoodat daar thans een definitieve kustfauna bestaat, die intusschen slechts weinig van de oorpronkelijke verschilt. Dezelfde wisselwerking, dezelfde overgang van vormen, die wij aan de bovengrens der cultuurstreken aantreffen, kan, zij het ook in mindere mate en minder duidelijk, in sommige gevallen ook aan de henedengrens worden aangetoond.

Wij moeten nog even terugkomen op de tegenstelling tusschen de Noordkust en de Zuidkust van Java, die zich weerspiegelt in de fauna.

De eerste is laag en vlak en zet zich voort in de uitgestrekte rlakten, die van oudsher werden bewoond en bebouwd. De laatste daarentegen is voor verreweg het grootste gedeelte bergachtig, moeielijk toegankelijk en tot de onmiddellijke nabijheid der zee met oorspronkelijk bosch bedekt. Men vindt er veelal slechts een smal strand, zoodat van een eigenlijke kustfauna nauwelijks sprake kan zijn en het beter is, hier van een strandfauna te spreken. Slechts in een gedeelte van Midden-Java vindt men soortgelijke toestanden als aan de Noordkust. 
Het behoeft dus wel geen betoog, dat op de tegenwoordige fauna's ran beide kusten geheel verschillende factoren hun invloed hebben doen gevoelen. Heeft op die van de Noordkust de nabijheid ran cultuurstreken eenigen invloed gehad, met die van de Zuidkust is dat niet het geval; wij vinden daar de boschfauna afdalend tot aan het oppervlak der zee en daardoor geheel ineenvloeiend met de, niet zeer talrijke diervormen, die roor de nabijheid van het strand karakteristiek zijn.

Dat het hier namelijk toch tot de rorming" van een strandfauna is gekomen, blijkt o.a. uit het roorkomen der zoogenaamde Strandvarkens, die door velen voor eene afzonderlijke diersoort worden gehouden, maar in werkelijkheid niet anders zijn dan een roode, langharige strandvorm van het gewone, Javaansche, Wilde Zwijn Sus vittatus, dat op geringen afstand van de zee weder in zijn gewone voorkomen optreedt.

Ten aanzien der kustfauna moeten derhalve het Noorden en het Zuiden van Java scherp van elkander worden gescheiden en moet op den voorgrond worden gesteld, dat de Noordelijke meęr verwantschap vertoont met de cultuurfauna, in welker onmiddellijke nabijheid zij zich eeuwen lang ontwikkelde, de Zuidelijke daarentegen ten nauwste is verwant met de boschfauna, waarmede zij sinds den roorhistorischen tijd in innigen samenlang stond.

Wij krijgen derhalve voor de fauna van Java in hoofdtrekken de volgende samenstelling: 


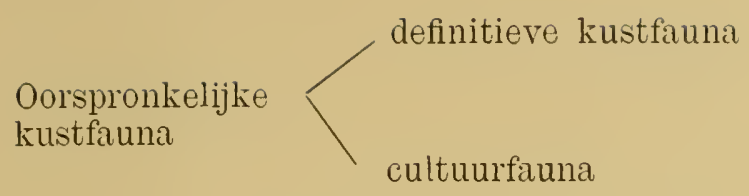

Oerfauna-- -

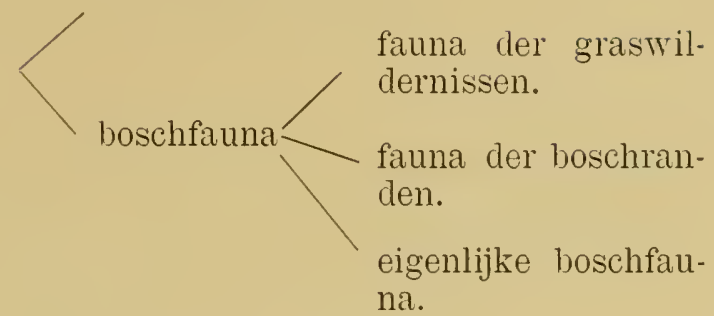

Fauna van het hooggebergte.

Voordat wij echter tot de bespreking dezer verschillende fauma's en harer onderdeelen overgaan, moeten nog eenige opmerkingen van algemeenen aard worden gemaakt, die in de beide volgende hoofdstukken een plaats mogen vinden. 


\section{HOOFDSTUK II.}

\section{Overgangen van de eene groep in de andere. Morphologische gevolgen daarvan. Voor- beelden van vormen, die in over- gang zijn. Nachtelijke en diurne levenswijze.}

Wanneer wij ons de wordingsgeschiedenis van den tegenwoordigen toestand voor oogen houden, zooals die in het vorige hoofdstuk in algemeene trekken werd aangegeven, dan vinden wij daarin tevens een antwoord op de vraag, welke overgangen nu wel het meest plaats vinden. Het is in hoofdzak de cultuurfauna, die uit de aangrenzende ge- . bieden steeds nieuwe vormen tot zich heeft getrokken, daarmede nog heden ten dage voortgaat en dat ongetwijfeld ook in de toekomst zal blijven doen.

Wij mogen echter niet orer het hoofd zien, dat naast deze processen, die ons uit den aard der zaak het best bekend zijn, een aantal andere moeten plaats grijpen. Zoo valt wel is waar de vorming: van de fauna van het hooggebergte voor een belangrijk deel reeds in den vóórhistorischen tijd, maar er zijn, zooals wij later zullen zien, diervormen aan te wijzen, die zich thans reeds vrij hoog in het gebergte ophouden en daarbij eene onmiskenbare neiging vertoonen, zich nog hoogerop te begeven.

Er zijn andere, die zich in omgekeerde richting 
bewegen; wederom andere, bij welke een soort van recidirisme ralt waar te nemen; kortom, wij moeten aannemen, dat overal, waar twee fauna's aan elkander grenzen, nog steeds een voortdurende, zij het ook dikwijls zwakke wisselwerking bestaat. Juist de omstandigheid, dat hier nog geen definitieve toestand ran, zij het ook labiel evenwicht is opge. treden, maakt Java tot een zoo buitengewoon belangwekkend veld van onderzoekingen op dit gebied, die in de toekomst zonder twijfel nog zeer veel aan het licht zullen hebben te brengen.

In de tweede plaats rijst de vraag, of de overgang ran de eene fauna in de andere eenigen, zich uitwendig openbarenden invloed uitoefent op de diersoort, die den overgang doormaakt.

Ik meen deze vraag voor vele gevallen in bevestigenden zin te moeten beantwoorden. Zoo is het zeer waarschijnlijk, dat de dieren van het hooggebergte, die zich reelal door grooten eenvoud van voorkomen onderscheiden, uit een voorgeslacht met meer opvallende kleuren zijn ontstaan.

Iets dergelijks geldt voor een aantal diersoorten, die reeds in overoude tijden den overgang ran de oerfauna in de cultuurfauna hebben doorgemaakt en zich in hooge mate aan de nabijheid van den mensch hebben aangepast.

Evenals bij rele van onze huisdieren (honden, katten, runderen) in den loop der tijden, onder den invloed der cultuur en der kunstmatige teeltkeuze, het voorkomen zoodanig is veranderd, dat van sommige de wilde stamrorm niet meer met zekerheid kan worden aangewezen, nemen wij bij andere diersoorten, die, zonder te worden aangekweekt, om 
en bij den mensch verblijven, een dergelijk verschijnsel waar. Ik denk hier aan ratten, muizen, kakkerlakken, huishagedissen en dergelijk gedierte, die alle als clirecte of indirecte parasieten onafscheidelijk aan den mensch zijn verbonden en in hooge mate van hem afhankelijk zijn. Ook van deze dieren, die toch reeds vóór den mensch hebben bestaan, is de herkomst dikwijls niet meer na te gaan. Zij komen met geen enkele, buiten de menschelijke omgeving levende diersoort meer geheel orereen en men moet dus wel aannemen, dat, voor zooverre zij zich niet als diersoort en bloc aan het leven nabij den mensch hebben geaccommodeerd, ook deze half gedomesticeerde diervormen in den loop der eeuwen onder den invloed hunner levenswijze bepaalde veranderingen, vermoedelijk vereenvoudigingen, hebben ondergaan.

Staan wij bij deze dieren, waarvan ik sommige om hun cosmopolitisch karakter niet eenmaal tot de eigenlijke fauna van Java wil rekenen, voor een voltooid veranderingsproces, er moeten,-wanneer de zooeven geuite hypothese juist is, een aantal andere zijn, bij welke wij dit proces in zijn verloop kunnen gadeslaan. Een groote moeielijkheid ligt hier echter in het betrekkelijk korte tijdsbestek, waarover onze waarnemingen zich uitstrekken. Het is niet veel meer dan honderd jaar geleden, dat de eerste, voldoende nauwkeurige beschrijvingen, gebaseerd op aanschouwing der levende dieren, werden gegeven door onderzoekers als RAFFLes en HoRsFiELD, op wier werk later is voortgebouwd door KüHL, van HAsselt, Boif en anderen.

Dit tijdsverloop nu is te kort om behoorlijke gegevens te verschaffen. Want hoewel het vrijwel 
vaststaat - een roorbeeld daarvan zal hieronder worden besproken - dat sommige diersoorten in die eeuw van levenswijze zijn veranderd, kan toch kwalijk worden verwacht, dat hun uitwendig roorkomen daarran reeds zóó duidelijke sporen zou dragen, dat vergelijking ran de individuen ran heden met de beschrijvingen van destijds die rerandering aan het licht \%ou brengen.

Naar aanleiding van hetgeen zooeven werd gezegd, dat zulk een verandering als gerolg ran orergang in de cultuurfauna in den regel eene rereenvoudiging zou beteekenen, zal allicht de opmerking worden gemaakt-en hare juistheid wordt onmiddellijk beaamd -, dat het juist de, in uiterlijk minst opvallende diersoorten moeten zijn geweest, die zich in die fauna hebben weten staande te houden en dat derhalve verandering in de richting van vereenvoudiging overbodig was. Toch houd ik het ervoor, dat zij plaats heeft en wel niet zoozeer op utiliteitsgronden, als wel, omdạt voor vele diersoorten het behooren tot de cultuurfauna medebrengt, clat ze in groote getalsterkte van individuen roorkomen, waardoor een soort van panmixie plaats heeft, die de scherpe kanten der kenmerken doet verdwijnen.

Men treft voorts in de cultuurfauna niet zelden een verschijnsel aan, dat vooral in de insectenwereld duidelijk aan den dag treedt en aan het zooeven besprokene verwant is, doch daarvan niettemin scherp moet worden gescheiden.

Voor vele plantenetende insecten, die zich op een cultuurgewas hebben gevestigd, is aldaar in den regel een nagenoeg onbeperkte hoeveelheid voedsel voor. handen, zoodat voor de individuen eener zelfde soort 
slechts in zeer geringe mate een strijd om het bestaan valt te voeren. Daardoor komen ook de zwakkere, die het anders waarschijnlijk zouden afleggen, tot ontwikkeling en voortplanting en daardoor vindt men onder de soorten, die tijdelijk of chronisch in groot aantal op een cultuurplant voorkomen, steeds een aantal individuen, die aanmerkelijk kleiner zijn dan de andere en daarbij soms verschillende kenmerken niet of minder duidelijk vertoonen.

Een goed voorbeeld hiervan levert Batocera albofasciata, een groote Boktor, waarvan de larven zeer algemeen worden aangetroffen in het hout van verschillende cultuurboomen (Erythrina-soorten, Ficus elastica e.a.). In haar gewone voorkomen is deze fraaie keversoort gekenmerkt door het bezit van tree halvemaanvormige, steenroode vlekken op het pronotum en vier, in een onregelmatige, overlangsche rij geplaatste, zwavelgele vlekken op elk der dekschilden. Niet zelden nu vindt men in de aanplantingen kleine exemplaren, waarbij de achterste van laatstgenoemde vlekken geheel of nagenoeg geheel ontbreken. Men krijgt den indruk, alsof het bij deze dieren op een volledige ontwikkeling der kenmerken niet aankomt; ze komen er toch wel onder de, voor hen zoo gunstige levensomstandigheden.

Een tweede voorbeeld levert Terias hecabe, een kleine, gele Piëride, die tamelijk gewoon is, maar onder normale omstandigheden niet in grooter aantal voorkomt dan andere algemeene soortèn van dezelfde familie. $\mathrm{Nu}$ en dan echter (o. a. Ivas dit in 1896 in bijzondere mate het geval) schijnen de omstandigheden voor de ontwikkeling en de vermeerdering dezer diersoort zóó bijzonder gunstig te zijn, dat zij zich bij duizend- en millioentallen vertoonen en dat niet in ééne, 
maar in vier tot vijf generaties. Onmiddellijk ziet men dan ook kleinere, men zou kunnen zeggen pygmaeïsche individuen rondvliegen; het zijn de zwakke exemplaren, die van deze gunstige gelegenheid hebben geprofiteerd om den volwassen toestand te bereiken en die ook weder verdwijnen, zoodra die gelegenheid ophoudt en de diersoort tot hare normale getalsterkte wordt teruggebracht.

Dergelijke pygmaeïsche vormen zoekt men tevergeefs, wanneer een diervorm in grooten getale optreedt als gevolg van andere omstandigheden, zooals nu en dan voorkomt bij een andere Piëride, Catopsilia crocale, waarvan de rupsen leven op Cassia florida (de djoear), een in West-Java langs de wegen en elders algemeen aangeplanten boom. Wanneer, zooals in 1902, een langdurige en felle droogte van eenige maanden, zooals in die streek zelden voorkomt, een soort van winterstilstand in de natuur veroorzaakt, worden zoowel het uitkomen der eieren en der poppen, als de groei der rupsen in hooge mate vertraagd. Maar komen eindelijk de regens door, dan neemt de ontwikkeling der dieren plotseling zulk een vaalt, dat weldra de vlinders in overgroot aantal verschijnen. Pygmaeën treft men dan echter niet aan; de zwakkere en kleinere individuen hebben den ongunstigen, drogen tijd niet kunnen doorstaan en zijn dientengevolge te gronde gegaan.

Een dercle voorbeeld moge hier worden aangehaald, dat er tevens op wijst, hoe de invloed der zich uitbreidende cultuurgebieden ook indirect kan werken. Dit voorbeeld wordt ons geleverd door Aegus acuminatus, een der weinige Lucaniden, die tot de cultuurfauna zijn te rekenen. De larven van dezen kever leven in de rottende, langzaam tot vermolming overgaande stam- 
men, die van gevelde woudboomen afkomstig zijn en in de jonge aanplantingen dikwijls in grooten getale blijven liggen. Verzamelt men een honderdtal exemplaren van dit, in den regel zeer algemeene insect, dan zal men daaronder exemplaren vinden, die de dubbele grootte hebben bereikt ran andere, ter'wijl de laatste roor het overige, ook in de ontwikkeling der voorkaken, volkomen normaal zijn. Schaarschte van voedsel gedurende het larvale leven kan hier de oorzaak der geringe afmetingen niet zijn; deze pleegt zich bovendien bij de rolwassen Lucaniden, zooals bij kevers in het algemeen, in mindere ontwikkeling der hypertelische organen, in casu der kaken, te openbaren; het zijn eenvoudig de kleine individuen, die zich ongestoord naast de groote hebben ontwikkeld en die stellig te gronde zouden zijn g'egaan, wanneer er tusschen de soortgenooten een scherpe strijd om het bestaan had geheerscht.

Het lijdt geen twijfel, of er zijn buiten de cultuurfauna een aantal diervormen, die in den loop der tijden een poging hebben gewaagd, zich in het bebouwde land te restigen en die daarin ook zeker geslaagd zouden zijn, wanneer zij niet, loor de vervolging van de zijde van den mensch of wel van vijandige diersoorten, na korteren of langeren tijd weder waren verdreven. Dit laatste moet vooral het geval zijn gerveest met dagdieren, die door het verlaten van hun natuurlijke schuilplaats zich aan allerlei gevaren blootstellen, maar in het algemeen met alle dieren, die temidden der culturen het hooge geboomte of het dichte gras missen, dat hun een rustplaats, een nestplaats of beide aanbiedt. 
Daarom zien wij, dat vele grootere dagdieren (apen, talrijke vogelsoorten) wel strooptochten ondernemen in het naburige cultuurgebied, maar zich tegen den arond-en bij naderend gevaar zoo spoedig mogelijk-in hun oorspronkelijke verblijfplaats terugtrekken.

Hoerele van deze er mettertijd toch nog in zullen slagen, zich roor goed in het bebourde land te vestigen, zal de toekomst moeten leeren. Zeker is echter, dat men sommige vormen kan aanwijzen, waarbij het orergangsproces in gang is. Dit wordt ons o.a. op bijzonder leerrijke wijze aangetoond door Pomatorhinus montanus, een heden ten dage tamelijk algemeenen rogel, die in sommige streken met den inlandschen naam boeroeng liopi wordt aangeduid.

Of deze sierlijke Krruiplijster dien naam heeft te danken aan de omstandigheid, dat hij gaarne rijpe koffiebessen nuttigt, of aan den klank van zijn stemgeluid, waaruit men met een weinig goeden wil dien naam wel zou kunnen hooren, zij hier in het midden gelaten: hij is sedert ruim een eeuw aan de wetenschap bekend en het is van groot belang, na te gaan, wat in dien tijd door betrouwbare natuuronderzoekers aangaande hem rordt medegedeeld. ,

In de eerste door plaats Horsfield, die hem beschreef en over zijn levenswijze en rerspreiding. daaraan het rolgende toevoegt:

"Pomatorhinus montanus behoort tot die rogelgroepen, die op Java uitsluitend in de hooge bergstreken worden gevonden. Hij begeeft zich nooit van daar in de lagere streken. Daardoor noodzakelijkerwijze in zijn verspreidingsgebied beperkt en begrensd tot de kegelvormige toppen van ver uit 
elkander liggende bergen, komt hij toch op sommige plaatsen in zeer grooten getale voor. Ik trof hem op talrijke plaatsen aan, maar het koude klimaat van den Merbaboe en de top van den Tangkoeban Prahoe schijnen zijn geliefkoosde verblijfplaats te zijn. Hier bouwt hij zijn nest op hooge boomen en vindt er rijkelijk voedsel in de bessen vall verschillende Rubus-soorten en in de vruchten van allerlei andere gewassen. Omstreeks het midden van den dag ziet men hem in kleine troepen rondvliegen."

Volgens Horsfield dus, circa honderd jaar geleden, een echte, vruchtenetende boschvogel van het hooggebergte. Vergelijken wij nu daarmede, wat de bekende ornitholoog Dr. Bernstein vijftig jaar later over hetzelfde dier weet mede te deelen 1):

"Deze vogel komt in de lagere landstreken in het algemeen slechts zelden voor en bewoont meer de met woud of kort hout bedekte hellingen der bergen. Hier zijn het hoofdzakelijk de nagenoeg ondoordringbare, uit dicht kreupelhout, wilde pisang, alang-alang, varens enz. samengestelde wildernissen, waarin hij zich bij voorkeur ophoudt. In geringer aantal, doch geenszins zelden, ontmoet men hem in het eigenlijke woud, doch ook hier steeds in de dichte, tusschen het hooge geboomte staande struiken, nimmer in de kruinen der boomen zelve........ Het nest heb ik slechts één keer verkregen. Het stond midden in het kreupelhout op een klein, open plekje, onmiddellijk op den grond en heeft eene in het algemeen regelmatige, half bolvormige gedaante."

1) Natuurk. Tijdschrift voor Nederl. Indië, Deel XXII, pag. 12. 
Ware het niet, dat Horsfield zijne beschrijving geeft aan de hand eener goede afbeelding en dat elder's uit Bernstein's opstel blijkt, dat hij wel degelijk Pomatorhinus montanus hedoelt, dan zou men geneigd zijn te rermoeden, dat hier eene vergissing in het spel was en beide natuuronderzoekers niet over dezelfde vogelsoort spraken.

Over het voeder zegt Berssters niets, maar de mij ten dienste staande opgaren over den inhoud van tien onderzochte magen luiden als volgt: 1 . kevers, sprinkhanen en vruchten; 2. groote sprinkhanen; 3. kevers en vruchten; 4 . kevers en spinnen; 5. kevers; 6. kevers en rupsen; 7. kevers en cicaden; 8. kevers en sprinkhanen; 9. boschrruchten; 10. kevers en viuchten.

Voegt men nu hieraan toe, dat Bernsters zijn waarnemingen hoofdzakelijk verrichtte in het boven Buitenzorg op ongeveer 2000 voet zeehoogte gelegen Gadok en dat ik zelf den vogel meermalen waarnam onmiddellijk boven Buitenzorg op hoogstens 1600 voet zeehoogte, dan kan men uit het medegedeelde wel geen andere gevolgtrekking maken dan deze: dat Pomatorhinus montanus in de 100 jaar, waarin hij aan de wetenschap bekend is, van een vruchtenetenden boschvogel der hoogere bergstreken geworden is tot een bewoner van boschranden, graswildernissén en daaraan grenzende aanplantingen, waarin hij soms zeer ver doordringt; dat hij van vruchteneter hoofdzakelijk insecteneter is geworden en dat de schade, die hij aan de rijpe koffiebessen toebrengt, niet anders is dan eene herinnering aan rroeger dagen, toen de veelkleurige vruchten van het ongerepte woud hem tot voedsel strekten. 
Een ander roorbeeld ran overgang ran de boschfauna naar de cultuurfauna lerert ons Xylotrechus javanicus, een kleine Boktor, die nauw verwant is aan Xylotrechus quadrupes, die in het midden van de vorige eeuw groot nadeel toebracht aan de koffie in Coorg, Hycierabad en andere streken van Britsch Indië. Eigenlijk mogen wij bij Xylotrechus javanicus nog niet ran een overgang spreken; deze diersoort bepaalt zich tot pogingen daartoe. Zij heeft blijkbaar dezelfde voorliefde roor een bepaalde plantensoort als haar Britsch Indische verwant en tracht zich telkens in de koffie-aanplantingen eener bepaalde streek van Oost-Java te vestigen, waar zij, door de levenswijze harel larven, tot een ernstige plaag zou kunnen worden. Deze vestiging ralt haar echter niet meer zoo gemakkelijk, als in vroeger jaren het geral zou zijn geweest; de planters zijn thans over het algemeen zeer op hun hoede tegenorer nieuwe rijan: den en zoodra de zoogenaamde "witte boorder" zich vertoont, worden. de noodige maatregelen genomen om hem uit te roeien en zijn verder voortdringen te beletten. Het geval behoeft zich echter slechts roor te doen, dat deze plaag zich vestigt in een rerlaten aanplanting, waar de insecten zich ongestoord kunnen rernhenigruldigen: er is dan weldra een infectiecentrum tot stand gekomen, waarvan men zich niet meer zoo gemakkelijk kan ontdoen en de lijst der parasieten van den koffieboom is weder met eene, daarop blij. vende soort rermeerderd.

Het laat zich hooren, dat dieren met een nachtelijke levenswijze in vele opzichten, ook ten aanzien van den mensch, in gunstiger omstandigheden verkeeren 
dan de dagdieren en dat zij zich daarom kunnen staande houden in een omgeving, waar het bestaan voor de laatste vrijwel onmogelijk is, m. a. w., dat het gebied der cultuurfauna voor nachtdieren gemakkelijker bewoonbaar is dan voor dagdieren. Men ziet dit zeer duidelijk bij de Zoogdieren, waarvan verreweg. het meerendeel tot de eerste groep behoort. Het aantal Zoogdieren, dat tot de cultuurfauna behoort, is namelijk veel grooter dan men zou vermoeden, te oordeelen naar het uiterst geringe aantal soorten, dat men in de bewoonde streken te zien krijgt. Met uitzondering van klappereekhoorns, schemeringvleermuizen, muizen, ratten (de beide laatste meer bemerkbaar aan de sporen, die hun vraatzucht achterlaat) en wilde zwijnen, bemerkt men van Zoogdieren weinig of niets. Toch zijn er niet weinige. Ik laat hier nog buiten beschouwing de bosch en wildernis bewonende soorten, die uitvallen doen in naburige cultuurstreken (zooals apen, herten, grootere roofdieren) en herinner alleen maar aan algemeen bekende dieren, zooals de loewak (Paradoxurus hermaphroditus) de rassi (Viverricula malaccensis) de spitsmuizen (Crocidura-soorten) en den otter (Lutra leptonyx), terwijl er nog een aantal minder bekende soorten zijn, die toch plaatselijk in grooten getale in de bewoonde streken en zelfs in de onmiddellijke nabijheid van den mensch voorkomen. Zoo komen op enkele plaatsen Sciuropterus sagitta en Chiropodomys gliroides in grooten getale in de cocospalmen voor, maar deze kleine zoogdieren, die in de kruinen dier boomen, in de leeggeknaagde vruchten nestelen, verlaten nooit hun verheven verblijfplaats en komen zelfs dààr alleen gedurende de duisternis te voorschijn, zoodat zij natuurlijk zeer gemakkelijk aan de aandacht van den 
mensch ontgaan. Zoo komt voorts Helictis orientalis, (de bioel) in de omgeving van het marktplein te Buitenzorg in vrij groot aantal voor, doch houdt zich op in onderaardsche waterleidingen en dergelijke ontoegankelijke plekken, die het niet dan onder zeer veilige omstandigheden verlaat.

Met de nachtvogels is het evenzoo gesteld. Zooals bekend is, komt de tjelepoek (Scops lempiji) zeer algemeen voor; er gaat bijna geen avond voorbij, waarop men het geroep van dezen uil niet hoort. Maar ook andere uilen zijn veel algemeener, dan men gewoonlijk vermoedt: Bubo orientalis komt in de omstreken van Batavia en Buitenzorg in het geheel niet zelden voor; Strix javanica nestelt zelfs onder de daken van oude gebouwen en van Phodilus badius, dien ik vroeger voor. een zeldzamen boschvogel hield, kreeg ik in de laatste jaren verschillende levende exemplaren, die op de bebouwde hellingen van den G. Gedeh, ten Zuidoosten van Buitenzorg, waren gevangen. Ook Caprimulgidae (Geitenmelkers) zijn hoogst algemeen; zelfs Batrachostomus javensis is in de onmiddellijke nabijheid van Batavia aangetroffen. ${ }^{1}$ )

In niet mindere mate worden vele Kruipende Dieren door een nachtelijke levenswijze beschermd. Op plaatsen, waar overdag nooit slangen zijn te vinden, hoort men gedurende de duisternis dikwerf het eigenaardige, deerniswekkende geluid van een kikvorsch, die door een slang wordt gegrepen.

Daar de Insecten de aanwezigheid of de nabijheid van den mensch in veel mindere mate noteeren dan de hoogere dieren en bovendien veel minder

1) Vorderman, Nat. Tijdschr. Ned. Ind. Deel XLIV, pag. 252. 
aan vervolging zijn blootgesteld, levert voor hen een diurne levenswijze aanzienlijk minder gevaar op.

Bovendien zijn de vormen, die het meest in het oog vallen, zooals de grootere en fraaiere soorten van Dagvlinders, veelal tamelijk vlug in hunne bewegingen en daardoor moeielijk zonder bijzondere hulpmiddelen te vangen. Sommige soorten van Ridderkapellen (Papilio-soorten) hebben een zóó wilde en onberekenbare vlucht, dat men maar zelden een exeinplaar kan bemachtigen, terwijl de grootste soorten, die van het geslacht Ornithoptera, zich bij vervolging gewoonlijk dadelijk in de hoogere gedeelten van het geboomte terugtrekken.

Andere vormen weten zich op andere wijze te redden: vele kevers laten zich op den grond vallen en zijn daar in den regel slechts met groote moeite terug te vinden; vele Orthoptera en Hemiptera weten zich met werkelijk verwonderlijke vaardigheid en berekening altijd zóó te plaatsen, dat zich een blad, een tak of eenig ander voorwerp tusschen hen en een werkelijken of vermeenden vervolger bevindt. Niettegenstaande dit alles spelen toch in het insectenleven der cultuurfauna de vormen met crepusculaire of met nocturne levenswijze wederom een zeer groote rol en winnen het in aantal verre van de diurne vormen, waaruit wij wel weder mogen opmaken, dat de eerste eenigszins in het voordeel zijn bij de laatste.

Merkwaardig is het hierbij op te merken, hoe tal van insecten, die overdag rust houden of althans niet door snelle bewegingen de aandacht trekken, een onmiskenbare overeenkomst in kleur en dikwijls ook in vorm, vertoonen met voorwerpen die in den regel niet aan eenige vervolging van de zijde van 


\section{$-36-$}

menschen of van dieren zijn blootgesteld (korstmossen, takjes, levende en doode bladeren enz.), hoe zij door die gelijkenis over het hoofd worden gezien en daardoor niet zelden aan vernietiging ontkomen. 


\section{HOOFDSTUK III.}

\section{Invloed van jaargetijden, regen, wind en zonneschijn. Vergelijking met andere eilanden.}

Het regelmatige, op gezette tijden van het jaar terugkeeren van bepaalde verschijnselen komt in de tropen in reel mindere mate voor dan in de gematigde luchtstrekken, rooral wanneer, zooals op Java, de invloed van de zee gedurende het geheele jaar aan het klimaat een groote gelijkmatigheid verleent. Het ontbreken ran een koud jaargetijde, waarin de lerende natuur roor een aanzienlijk deel verkeert in een periode van rust of althans van langzaam verloopende, inwendige processen, moet uiteraard als hoofdoorzaak van dit verschijnsel worden beschourd; de "levée en masse", die men buiten de keerkringen in het voorjaar bij planten- en dierenwereld waarneemt, zoekt men daarbinnen tevergeefs. Slechts reroorzaken de moessons, welker gemiddelde temperaturen echter niet veel ran elkander verschillen, een zekere periodiciteit, die, uithoofde van bijkomende, klimatologische factoren, op de ééne plaats in veel sterkere mate aan den dag treedt dan op de andere.

Op Java is de tegenstelling tusschen een droger. en een natten tijd in het Oostelijk gedeelte veel grooter dan in het Westelijk en, in het algemeen, in de lagere streken veel grooter dan in de hoogere. Het verschil tusschen Oost-en West-Java wordt 
veroorzaakt door de omstandigheid, dat de droge, uit de richting van het Australische vasteland komende Zuidoostenwind zich, ongeveer van Mei tot November, in eerstgenoemde helft van het eiland gewoonlijk in hevige mate doet gelden, terwijl men in de Westelijke helft slechts weinig ervan bemerkt. Het manifesteert zich in de plantenwereld natuurlijk op meer opvallende wijze dan bij de dieren, bij welke bovendien een geregelde observatie zooveel moeielijker is. Maar in het algemeen ziet men, zooals trouwens a priori was te verwachten, dat het droge jaargetijde physiologisch met den winter der gematigde luchtstreken overeenkomt, dat het aanbreken van den regentijd een verhooging der levensenergie teweeg brengt en dat derhalve de tegenstelling der seizoenen in het Oosten van Java veel scherper haar uitdrukking vindt in de physionomie der natuur dan in het Westen.

Het is intusschen opmerkelijk, dat slechts een betrekkelijk gering aantal planten en dieren zich voor die tegenstelling zóó gevoelig toont, dat bij hunne levensverschijnselen van een, daarmede verband houdende periodiciteit kan worden gesproken. Een bekend voorbeeld van dit laatste uit de plantenwereld levert de djati (Tectona grandis), die in Oost- en Midden Java gedurende den Oostmoesson zijn bladeren verliest en zich daar in het algemeen geheel gedraagt als een boom in de gematigde luchtstreken, terwijl hij in West-Java nooit geheel bladerloos staat, maar ook nooit zulk een rijken bladertooi draagt als ginds in het begin van den regentijd, m. a. w. afval en vernieuwing van het blad tamelijk gelijkmatig over het geheele jaar verdeelt.

Bij andere planten openbaart de tegenstelling der jaargetijden zich niet in de bladwisseling, maar in 
het bloeien, resp. vrucht dragen, in bepaalde maan. den. Hier leveren de Mangifera's, waarover reeds vroeger (pag. 9) werd gesproken, een goed voor. beeld; de mangga-tijd duurt bijvoorbeeld in de Residentie Pasoeroean veel korter dan in de om. streken van Batavia, waar gedurende het grootste deel van het jaar hier en daar vruchten zijn te vinden. Wat bladwisseling, of liever bladuitloop betreft, vertoont deze boom althans in West-Java een buitengewone onafhankelijkheid van seizoenen en weersgesteldheid. Zoo nam ik eens waar, dat een mangga-boom te Buitenzorg in het midden van een, voor deze plaats zeer regenarme periode, tweemaal binnen één maand nieuw loof maakte, terwijl dit tevoren gedurende ruim twee jaar niet had plaats gehad. 1)

Met vele andere boomen is het evenzoo; zeer willekeurig bijv. gedraagt zich soms de peteh (Parkia speciosa), daar het bij dezen boom voorkomt, dat niet alleen de seizoenen geheel zonder invloed blijken, maar dat zelfs de verschillende hoofdtakken van denzelfden boom een geheel zelfstandig bestaan leiden, wat betreft bladafval, vorming van nieuw blad en bloei. Men neemt niet zelden exemplaren waar, die aan hun verschillende deelen alle denkbare vegetatie-phasen vertoonen.

Het behoeft wel geen verwondering te baren, dat bij de fauna, die in zoo hooge mate van de plantenwereld afhankelijk is, in het algemeen een overeenkomstige afwezigheid van regelmaat valt waar te nemen, ook hier echter in West-Java in meerdere mate dan in het Oostelijk gedeelte. Dit laatste

1) De juiste tijden van uitloop waren begin en einde Maart 1908, Mei 1908, begin en einde Juli 1910. 
wordt ons o.a. duidelijk aangetoond door de verschillende soorten van Bladsprietige Kevers (geslachten Lachnosterna, Anomala, Exopholis e.a.), die hier te lande de engerlingenplagen veroorzaken. Een algemeene vliegperiode dezer kevers bestaat in West-Java niet; men treft ze gedurende het geheele jaar aan, wat tengevolge heeft, dat ook het leggen der eieren en het schadelijic optreden der larven over het geheele jaar gelijkmatig worden verdeeld, zoodat het laatstgenoemde slechts zelden de aandacht trekt. In Oost-Java is het geheel anders; dáál valt in het begin van den regentijd een vliegperiode waar te nemen, spoedig gevolgd door het leggen van millioenen eieren. De jonge engerlingen, die uit deze eieren tevoorschijn komen en zich gedurende de eerste weken van hun bestaan met plantaardigen detritus voeden, worden alle ongeveer in denzelfden tijd schadelijk, als wanneer zij zich werpen op de wortels der cultuurgewassen, die daardoor dikwijls een hevigen aanval hebben te doorstaan. Het klimaatsverschil is hier dus oorzaak van het verschijnsel, dat in het ééne gedeelte van het eiland, in een bepaald gedeelte van het jaar, dezelfde insecten tot een besliste plaag kunnen worden, die in de andere helft wellicht in een even groot aantal optreden, maar zich over het geheele jaar verdeelen en daardoor in hun schadelijke werkzaamheid zooveel minder de aandacht trekken.

Een dergelijke periodiciteit bestaat hier bij talrijke soorten van insecten, maar toch vormen deze slechts een kleine minderheid tegenover het heirleger, dat zich, zonder seizoenen te noteeren, gedurende het geheele jaar in alle stadiën van ontwikkeling vertoont. 
Bij de Vogels ziet men hetzelfde. Sommige soorten broeien orn een zeker aantal maanden, onverschillig, of de broeitijd valt in den drogen of in den natten tijd; andere daarentegen toonen voor een der laatste een besliste voorliefde, waarvan ze niet afwijken.

Van de Zoogdieren planten, voor zooverre men dit heeft kunnen nagaan, de meeste vormen zich gedurende het geheele jaar voort. Slechts bij enkele grootere soorten, welker jongen bijzonder gevoelig zijn voor minder gunstige, uitwendige invloeden, zooals die der herten, heeft het werpen in een bepaald jaargetijde plaats, waarin die invloeden (o.a. groote vochtigheid) zich het minst doen gevoelen.

In verband met het bovenstaande laat het zich hooren, dat het, in de gematigde luchtstreken tamelijk veelvuldig voorkomende seizoendimorphisme hier bij slechts weinig dieren wordt aangetroffen; er bestaat in den regel geen voldoende aanleiding daartoe. Duidelijk treft men het aan bij sommige vertegenwoordigers van de Dagvlinderfamilie der Satyridae, de zoogenaamde Zandoogjes, waarvan o.a. Melanitis (Cyllo) leda hoogst algemeen voorkomt. De Oostmoesson-vorm van dit insect onderscheidt zich van den Westmoesson-vorm, doordat de kleur van de onderzijde der vleugels veel helderder en lichter bruin is en de kleine, gerande vlekjes (oogjes) veel duidelijker zijn ontwikkeld. Vermoedelijk wordt dit verschijnsel veroorzaakt door het sterke zonlicht en de hoogere temperatuur in den drogen tijd, die de verschillende kleuren in meer geprononceerde mate op den voorgrond doen treden dan het geval is bij den vorm, die gedurende den wolkenrijken regentijd 
den poptoestand doorbrengt. Het heeft tengevolge (en daarom ook als uitgangspunt, voor eene teleologische verklaring gediend), dat deze vlinder in den regel een bedriegelijke gelijkenis in kleur vertoont met den grond, waarop hij zich neerzet om te rusten. Ook deze is in den drogen tijd tamelijk helder bruin, in den regentijd meer onbestemd bruinachtig donkergrijs, zoodat men den vlinder eerst bespeurt, wanneer hij opvliegt en gewoonlijk weder uit het oog verliest, wanneer hij zich neerzet.

Is derhalve, alles samengenomen, de invloed der jaargetijden op de planten- en dierenwereld van Java betrekkelijk gering, veel dieper wordt dikwijls ingegrepen door de processen van meer tijdelijken aard, die in den dampkring plaats hebben, waarbij in het bijzonder een groote rol wordt gespeeld door den regenval en wat daarmede in onmiddellijk verband staat. Wie de tropen nooit bezocht, is geneigd zich het klimaat aldaar als regelmatig en gestadig voor te stellen, doch, op Java althans, is zulks in geenen deele het geval. Hier geeft het klimaat, mutatis mutandis, dikwijls dezelfde verrassingen, dezelfde wispelturigheid te zien als bijvoorbeeld in Europa, al bewreegt de temperatuur zich daarbij tusschen engere grenzen, terwijl wederom West-Java in dit opzicht Oost-Java rerre overtreft, zooals ook met de bergstreken ten aanzien van het lage land het geval is. Een periode van eenige weken droogte in het midden van den regentijd behoort evenmin tot de zeldzaamheden als een plotselinge, hevige, zich soms eenige achtereenvolgende dagen herhalende regenval in de maanden, waarin men droogte zou verwachten. Het landbourwend gedeelte der berol- 
king weet van dergelijke verschijnselen mede te spreken, omdat zij niet zelden aan hare verwachtingen, hetzij ten goede, hetzij ten kwade, een geheel andere richting geven.

Wat hun invloed op de fauna betreft, mogen hier in de eerste plaats een paar voorbeelden aan de praktijk worden ontleend.

In de thee-aanplantingen heeft men dikwijls te kampen met een kleine, roode Mijt (Tetranychus bioculatus), die op de bovenzijde der bladeren leeft en aldaar is blootgesteld aan allerlei atmosferische invloeden, van welke droogte en zonneschijn gunstig, regen en in het algemeen vochtigheid, ongunstig op haar werken. Tegen de laatste trachten deze diertjes zich eenigermate te beschermen door over de oppervlakte der bladeren een uiterst fijn, bijna microscopisch spinsel te maken, waaronder zij zich echter vrijelijk kunnen bewegen. Bij droog weder helpt dit middel uitstekend; de dauw, die in zulke dagen juist het sterkst is en de bladeren voor deze kleine organismen onbewoonbuar zou maken, blijft boven dit spinsel liggen en deert hen dus niet. Ook een zachte regen dringt er niet doorheen, maar een paar zware regenbuien spoelen de bladeren volkomen schoon en doen de Mijten verdwijnen. Vallen deze buien nu na een langdurige droogte, dan kunnen ze aan aangetaste aamplantingen een geheel nieuw aanzien geven, zooals omgekeerd een regenlooze periode in den Westmoesson de plaag op eenmaal kan doen herleven.

Een tweede voorbeeld biedt ons een der op Java meest bekende vertegenwoordigers der cultuurfauna, Leptocorisa acuta (mal. walang sangit), een Langwants, die zich bij voorkeur voedt met den vloeibaren inhoud der rijpende rijstkorrels en als een der scha- 
delijkste insecten is te beschouwen. Het is een van nature traag en indolent insect, dat gewoonlijk zijn geheele leven op de rijstvelden doorbrengt, maar in den volwassen, gevleugelden toestand niet zelden in groote troepen nachtelijke zwerftochten onderneemt. Dit heeft echter alleen plaats, wanneer na het invallen van de duisternis zware regens zijn gevallen. Wanneer het overdag regent, weten deze dieren wel spoedig een schuilplaats in de nabijheid te vinden, maar wanneer de regen valt gedurende de duisternis, worden zij onrustig, vereenigen zich tot groote troepen en gaan op goed geluk aan het zwerven. Men vindt dan den volgenden dag de zwermen somtijds op grooten afstand van de rijstvelden neergestreken, terwijl ze eveneens niet zelden tijdens hunne vlucht een verlichte woning binnenvliegen, waar zij dan spoedig tegen muren en zoldering in hun gewone rust vervallen.

Eindelijk is het van algemeene bekendheid, hoe zware regens vooral bij Mieren en Termieten den stoot kunnen geven aan het uitkomen der gevleugelde individuen uit de poppen, die zich in de nesten, gewoonlijk onder den grond, bevinden. Wordt nu de bodem, en bijgevolg ook de nesten, geheel doorweekt, dan zwelt en barst de pophuid door het opgezogen water en korten tijd daarna ziet men de insecten bij duizendtallen uitvliegen.

Kunnen alzoo zware regeubuien van invloed zijn op de fauna, die deze of gene streek te zien geeft, ook de wind mag niet geheel buiten beschouwing blijven.

Op de hoogste gedeelten der gebergten, die op Java gedurende een groot deel van het jaar aan een hevigen Zuid-oostenwind zijn blootgesteld, komen slechts weinig vlinders voor en de vormen, die er zijn, wagen 
zich op onbeschutte plekken madr zelden boven de kruid-en heesterachtige regetatie, die op deze terreinen wordt aangetroffen. Blijkbaar is de wind hun onaangenaam, zooals ook blijkt in de lagere streken, waar men op winderige dagen nagenoeg geen insecten, in het bijzonder wederom geen vlinders, ziet rliegen. Ook de nachtelijke vormen der laatste houden zich dan schuil en worden op zulke aronden bij de lichten onzer woningen niet zelden vervangen door verschillende soorten van Diptera, inzonderheid Lucilia's, die gewoonlijk den nacht in geboomte en struikgewas doorbrengen, doch daar thans geen rust kunnen rinden en door het licht worden aangelokt.

Overigens mag de invloed ran den wind op de verspreiding van insecten niet te hoog worden aangeslagen, daar passieve medevoering minder veelvuldig plaats heeft, dan men vroeger meende en zelfs dan nog de richting der beweging voor een deel door de dieren zelf wordt bepaald. Dit laatste mag men afleiden uit het feit, dat vuurtorens niet zelden door zwermen van insecten worden bezocht, die, al worden ze voor een deel door den wind gedragen, toch nog kracht genoeg blijken te bezitten om, al laveerende, een bepaald doel te bereiken. Ook waarnemingen op kleine eilanden en op hooge bergtoppen hebben mij geleerd, dat, zelfs bij sterken wind, van passief medevoeren in den regel weinig sprake is: kleine vliegjes en wespen bewegen zich aldaar vrijelijk rondom de bloemen der strandplanten en der bergkruiden, zonder zich ook maar eenigszins te bekommeren om den wind, waarmede zij zich blijkbaar, als met iets onvermijdelijks, hebben verzoend. Slechts voor vlinders moet misschien een uitzondering worden gemaakt; deze bieden, door hun groote vleugels, den 
wind een veel grooter oppervlak dan andere insecten, zoodat het hun moeielijker moet vallen, zich staande te houden.

De laatste factor van de weersgesteldheid, waaraan eenige regels moeten worden gewijd, is de zonneschijn. Werken regen en wind in hoofdzaak mechanisch, de werking der zonnestralen mag worden beschouwd als voor een aanzienlijk deel van psychischen aard.

Men mag in het algemeen wel aannemen, dat de meeste dàgdieren den zonneschijn gaarne zien en dat deze op vele hunner levensverrichtingen een bevorderenden invloed heeft. Vele vogels hoort men slechts in de zonnige morgenuren; later op den dag, wanneer, zooals in de bergstreken bijna regel is, een dicht gordijn van wolken zich heeft gevormd, zwijgen ze stil. Sommige insecten komen zelfs alleen bij zonneschijn voor den dag en zijn bij een bedekte lucht, ook als het niet regent, volkomen onvindbaar. Dit is o.a. het geval met verschillende soorten van Graafwespen en, in nog meerdere mate, met vele Cicindeliden, welke laatste nog te vinden zijn op zandige, aan de felle zonnehitte blootgestelde hellingen, wanneer andere dieren, zelfs Hagedissen, die reeds lang voor meer beschaduwde plaatsen hebben verlaten. Want al zien de dagdieren den zonneschijn gaarne, de directe bestraling door de zon wordt slechts tot een bepaald, voor verschillende diersoorten uiteraard verschillend uur, opgezocht en daarnà vermeden. Dit leeren ons in de eerste plaats de grootere zoogdieren: buffels, die dikwijls geen schaduwrijke plekken tot hun beschikking hebben, kruipen tegen tien of elf uur in het 
water; de grootere roofdieren brengen de warmste uren van den dag slapende door in rustige, verborgen schuilhoeken; herten verlaten de open plekken en trekken zich terug onder het geboomte. Doch ook vele kleinere dieren geven hetzelfde te zien: de Lycaeniden, in de morgenuren in het gras en op bloeiende kruiden te vinden, zoeken in den middag bescherming aan de onderzijde van bladeren; vele Bloemwantsen (Capsidae), die op dergelijke plaatsen, maar ook op heesters en boomen hun voedsel zoeken, verdwijnen reeds in de latere uren van den voormiddag; tal van kleinere rogels, die des morgens veelal onder luidruchtig geroep en gesnater de heesters en lagere boomen afzoeken (Orthotomidae, Nectarinidae) worden later op den dag zelden gehoord.

Tele vragen omtrent het ontstaan van den toestand, zooals wij dien heden ten dage op Java aantreffen, zullen ongetwijfeld kumnen worden beantwoord door overeenkomstige onderzoekingen op naburige eilanden, die nog in een meer oorspronkelijken toestand rerkeeren. Ongelukkigerwijze zijn dergelijke onderzoekingen tot heden slechts in hoogst beperkte mate ingesteld, zoodat wij slechts beschikken over een klein aantal gegevens, die overal in de literatum zijn verspreid en dikwijls niet veel meer zijn dan eene, in weinige woorden rervatte aanteekening, haastig in een reisjournaal neergeschreven.

Bij het zoeken naar gegevens ter vergelijking zal men in de eerste plaats het oog hebben te richten naar Sumatra, omdat dit eiland zoölogisch de grootste verwantschap met Java rertoont. Er is aldaar in den loop der jaren reel rerzameld, maar bijzondere 
aandacht aan de biologische groepeering der fauna heeft men daarbij niet gewijd. Eerst in de laatste jaren wordt in Deli, Residentie Sumatra's Oostkust, door en onder leiding van Dr. L. P. DE Bussy een onderzoek ingesteld naar de, voor de tabakscultuur aldaar schadelijke diervormen en dit onderzoek zal ook voor het hier behandelde onderwerp waarderolle resultaten opleveren.

Het voor verschillende planten, maar in den aanvang uitsluitend voor tabak in cultuur genomen deel der genoemde Residentie verkeert thans faunistisch onder zeer eigenaardige omstandigheden. Veertig jaar geleden was het nog nagenoeg geheel met oorspronkelijk bosch bedekt. Toen kwam opeens de zich snel uitbreidende cultuur, die de bosschen bij honderden Hectaren tegelijk deed verdwijnen en daarvoor weinig anders in de plaats stelde dan tabak en een reboisatiegewas (Albizzia en een paar andere boomsoorten) op de, na afloop der beplanting met tabak, voor eenige jaren braakliggende velden. Wat bleef er dus voor de rijke boschfauna over, dan zich in de, meer landwaarts in, gespaarde bosschen terug te trekken en het nieuwbebouwde land vrijwel zonder bewoners achter te laten? Immers, de levensvoorwaarden waren zóó geheel anders, zóó uitermate ongunstig geworden, dat de kans, om zich in de nieuwe omgeving staande te houden, in den aanvang vrijwel nihil was.

Als gevolg daarvan is de fauna van die streek ook thans nog arm. Natuurlijk heeft zich in den loop dier veertig jaren uit de bosschen van het binnenland aan de ééne, uit de moerasbosschen van de kust aan de andere zijde eene cultuurfauna afgescheiden en die fauna zal steeds rijker worden, 
naarmate de plantengroei, aangebracht of spontaan gevorden, eveneens rijker wordt, maar voor het tegenwoordige vertoont Deli nog een vrij treurig beeld van faunistische devastatie. Juist diarom echter is het zeer instructief; men ziet er het proces in vollen gang, dat op Java voor een aanzienlijk deel reeds in de laatstverloopen eeuwen werd afgespeeld.

Voor zooverre ik de resultaten van dat proces op Deli heb kunnen nagaan, deels door eigen aanschouwing gedurende een kort verblijf aldaar, deels door hetgeen er door anderen is verzameld, kon reeds worden vastgesteld, dat de physionomie van die, overigens nog arme cultuurfauna een groote gelijkenis vertoont met die van Java: het zijn dezelfde of zeer verwante diervormen, die zich aldaar het eerst aan de nabijheid van den mensch en de, door dezen aangeplante of gedulde vegetatie hebben geaccommodeerd of daarmede nog bezig zijn.

Dit laatste verschijnsel valt trouwens van alle andere eilanden van den Archipel op te merken, vanwaar eenige, zij het ook spaarzame, gegevens konden worden verkregen. Voor zooverre het dier. vormen betreft, die in eenig, dikwijls zeer verwijderd, biologisch verband staan met den mensch en zijne omgeving, ligt de verklaring ervan voor de hand, maar bij vele dieren is dat niet het geval en daar staat men voor een open vraag. Hoe komt het, om een paar voorbeelden te noemen, dat het Wespengeslacht Eumenes steeds en dikwijls met verrassende snelheid, in de cultuurfauna overgaat, terwijl het nauw verwante geslacht Zethus de nabijheid van den mensch angstvallig vermijdt? Waarom zijn de menschlijke woningen dadelijk door 
Xylocopa's omringd, terwijl de Bombus-soorten noode voor eenige oogenblikken de wildernis verlaten? Waarom zijn geheele familiën van insecten (Geometridae, Sesiidae, Cetonidae, Lucanidae e.a.) bijna geheel boschdieren gebleven, terwijl van andere (Chrysomelidae, Melolonthidae, Fossores, Limacodidae enz.) wellicht de helft en meer in de cultuurfauna is overgegaan?

Op deze en vele dergelijke vragen moeten wij voorloopig het antwoord schuldig blijven. Zij. betreffen nog iets meer dan de zuiver materieele aangelegenheden, die, weliswaar voor een overwegend deel, maar toch niet uitsluitend, de levenswijze der dieren determineeren. Men kan zich toch zonder bezwaar voorstellen, dat in vele gevallen, waarin overigens pro en contra tegen elkander opwegen, de neigingen van het geestesleven den doorslag geven bij de keuze van het gebied, waarin eene diersoort zich zal vestigen. 


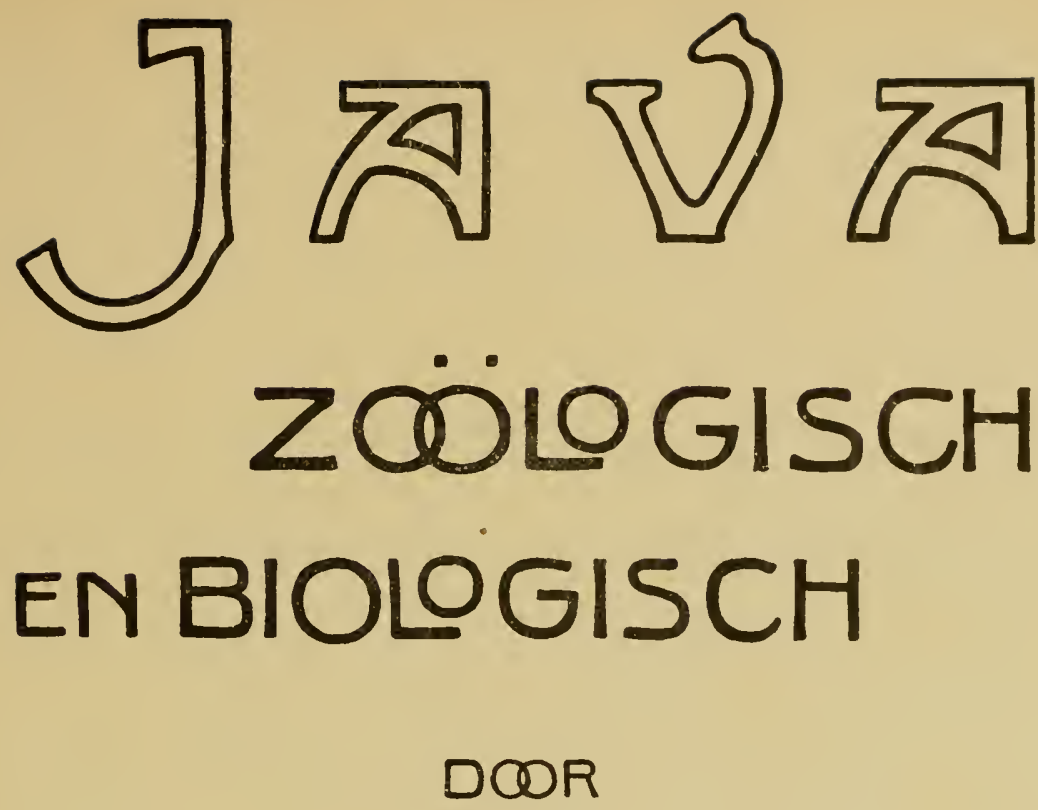

\section{DR.J.C.KONINGSBERGER}

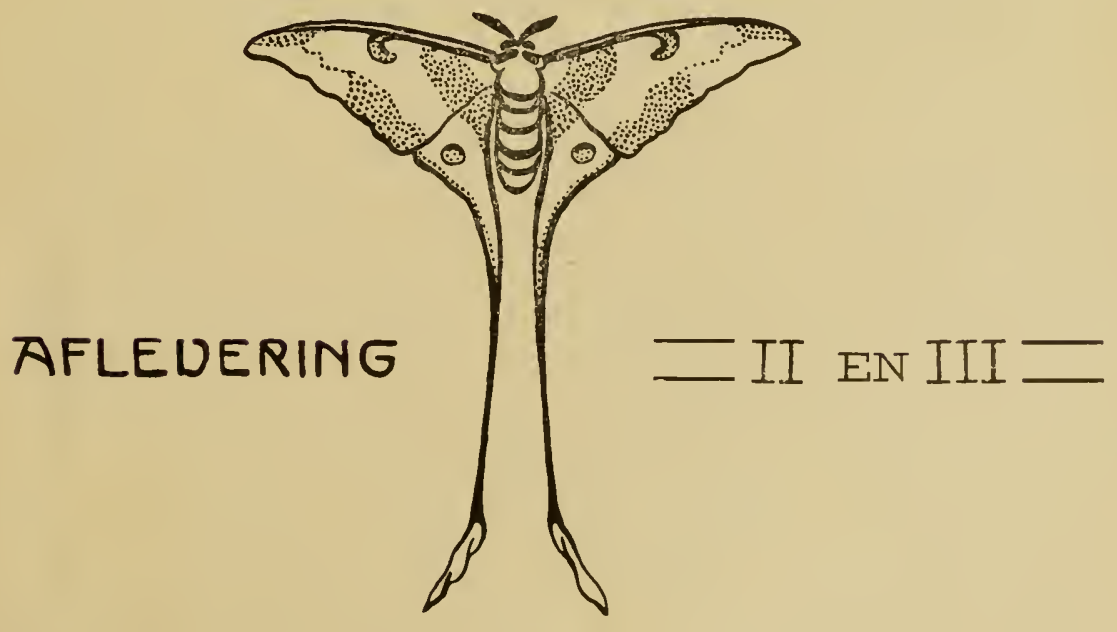

DRUKKERIJ DEP. v. L. N. en H. BUITENZORG 1912.
Verkrijgbaar bij

G. KOLFF \& Co. Batavia.

Prijs $f 2$. 


\section{IN HOUD.}

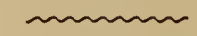

AFLETERING I.

pag.

VOORWOORD

1.

Hoofdstuk I. Algemeene samenstelling der Fauna van Java en hare wordingsgeschiedenis. De Hoofdgroepen. . . . .

Hoofdstuk II. Overgangen van de eene groep in de andere. Morphologische gevolgen daarvan. Voorbeelden van vormen, die in overgang zijn. Nachtelijke en diurne levenswijze. .

Hoofdstuk III. Invloed van jaargetijden, regen, wind en zonneschijn. Vergelijking met andere eilanden.. . . .

37.

\section{AFLEVERING II en III.}

Hoofdstuk IV. Kort overzicht der verschillende gebieden. De Cultuurfauna bij uitnemendheid: de diervormen der grootere plaatsen . . . . . . . . . . . . . . 51 .

A. Zoogdierex. . . . . . . . . . 55 .

B. VoGELS . . . . . . . . . . . . 60.

C. Kruipende fin Tweeslachtige Dieren . . 76.

Hoofdstuk V. De Dier'vormen der grootere plaatsen.

(Vervolg). . . . . . . . . . . . . . . 90

D. Insecten . . . . . . . . . . . 90.

1. Orthoptera . . . . . . . . . 90.

2. Neuroptera . . . . . . . . . . 98.

3. Rhynchota . . . . . . . . . 104.

4. Diptera . . . . . . . . . . 108.

Hoofdstuk VI. De Diervormen der grootere plaatsen.

(Verrolg). D. Insecten. (Velvolg) . . . . . . . . 116.

5. Coleoptera . . . . . . . . . . 116.

6. Lepidoptera. . . . . . . . . . 127. 


\section{HOOFDSTUK IV.}

\section{Kort overzicht der verschillende gebieden. De Cultuurfauna bij uitnemendheid: de diervormen der grootere plaatsen.}

De op bladz. 21 aangegeren samenstelling van de fauna van Java noemt slechts de hoofdgroepen, die daarin vallen te onderscheiden. Waar thans met de bespreking dier groepen een aanvang zal worden gemaakt, lijkt het mij wenschelijk, dat vooraf een kort overzicht wordt gegeven van de voornaamste onderdeelen, waarin zij kunnen worden verdeeld, en van de rolgorde, waarin deze zullen worden behandeld.

Het lag voor de hand, te beginnen met de dierrormen, waarmede ieder, die zich in de omringende dierenwereld eenigszins wenscht te orienteeren, in den regel het eerst in aanraking komt, derhalve met de Culturrfauna. En wel met dat gedeelte, dat ten aanzien ran den mensch het meest geavanceerd is en mag worden beschouwd als de cultuurfauna bij uitnemendheid: de diervormen der grootere plaatsen. Hiermede worden bedoeld de plaatsen, die naast een talrijke, inlandsche en dikwijls ook Chineesche bevolking een grooter of kleiner aantal Europeanen tellen, dus in het algemeen de hoofdplaatsen van de residenties en hare afdeelingen, waar Europeesche 
woningen, in den regel met groote, boom- en plantenrijke erven, en inlandsche kampongs met niet minder verscheidenheid van flora, zonder veel regelmaat naast en door elkander zijn gelegen.

De in dit gebied voorkomende dieren maken de kern uit van het heirleger der vormen, die men op Java vooral of uitsluitend aantreft, waar de mensch zich heeft gevestigd en rondom zijn verblijfplaats een grooter of kleiner terrein in geregelde cultuur houdt. Die kern, die hoofdmacht, vindt men overal in het bewoonde Jand min of meer volledig terug; naarmate men zich nu in het eene of in het andere gebied der cultuurstreken bevindt, voegen zich allerlei andere vormen daarbij, waaraan dat gebied zijn eigen karakter ontleent.

Ook dáárom is het aangewezen, met die hoofdmacht te beginnen: men zou anders telkens in herhalingen moeten vervallen.

Aan dit eerste gebied sluit zich zeer geleidelijk het tweede aan, dat van de inlandsche dorpen, welker fauna kan worden beschouwd als een eerste ampliatie van die der grootere plaatsen, en zulks in meerdere mate, naar'mate de kampongs in een meer houtrijke omgeving zijn gelegen.

Als derde gebied zal worden besproken het bevloeide rijstveld; reeds op bladz. 16 werd erop gewezen, dat de sawahfiuna een belangrijk en interessant biologisch geheel uitmaakt. Het laat zich hooren, dat dit geheel weder in relatie staat met de diervormen der kampongs, die als groene eilanden in de geïnundeerde streken verstrooid liggen.

Daarna komt het bouwland aan de orde, waaronder hier zullen worden verstaan de, met zoogenaamde tweede gewassen beplante velden, om het 
even of deze al of niet in wisselbouw met natte rijstcultuur worden beplant, alsmede de uitgestrekte terreinen, die voor Europeesche culturen, vooral suiker en tabak, worden gebezigd.

Als vijfde gebied kan, in aansluiting hieraan, worden onderscheiden het, tijdelijk of chronisch, braak liggende land, met inbegrip der zoogenaamde weidevelden, die niet veel ander's zijn dan onverzorgde, slechts zeer extensief benutte terreinen, waar het vee overdag en na gedanen arbeid een karige hoeveelheid eetbaar groen bij elkaar moet zoeken.

Het zesde gebied is dat der overjarige cultures, wartoe ook de djatibosschen zullen worden gerekend. Achtereenvolgens zal worden nagegaan, wat deze, alsmede de aanplantingen van Hevea brasiliensis, cacao, Ficus elastica, koffie, thee, kina enz. op dierkundig gebied te zien geven.

Eindelijk zal de bespreking der Cultuurfauna worden besloten met een korte behandeling van de diervormen der rivieren en beken, dịe het bebouwde land doorstroomen, alsmede van de detritus-fauna aldaar.

De tweede hoofdgroep, de Fauna der Graswildernissen, is van minder omvangrijken aard en is slechts in twee gebieden te verdeelen, die overigens niet scherp van elkander kunnen worden gescheiden. Het éene is dat der wildernissen met een vegetatie, die geheel of nagenoeg uitsluitend uit grasachtige planten bestaat: in het tweede is deze vegetatie onderbroken door boomgroepen of boschjes, waardoor verschillende diersoorten worden aangelokt, die in het eerste in den regel ontbreken. 
De hoofdgroep Kustfauna laat in de eerste plaats de vormen van het Rhizophoren gebied onderscheiden. Weliswaar kan een deel daarvan nauwelijks tot de landfiuna worden gerekend, een ander deel daarentegen bestaat uit typische landdieren en juist dit deel is merkwaardig door zijne adaptatie aan eene omgeving, waar elke andere dan een arboreale. levenswijze vrijwel geheel is uitgesloten.

Als tweede gebied zal in beschouwing worden genomen dat van het zandige strand en de, gewoonlijk daarachter voorkomende, duinachtige vormingen, terwijl in de derde plaats valt te onderscheiden de fauna van de rawah's, de dikwijls vrij ver landwaarts in gelegell kustmoerassen.

De vierde hoofdgroep, de Fauna der Boschranden, is, zooals voor de hand ligt, niet scherp te scheiden van die der graswildernissen, waar deze aan de bosschen grenzen, en evenmin van de boschfauna zelve, maar bezit toch een voldoende aantal eigen vormen, om voor een afzonderlijke behandeling in aanmierking te komen. Onder bepaalde omstandigheden kan dit aantal zelfs zóó aanzienlijk worden, dat wij daarin aanleiding vonden, haar als een hoofdgroep en niet als een onderdeel van de eigenlijke boschfauna te beschouwen.

Bij de behandeling der Boschfauna zal in de eerste plaats aandacht worden gewijd aan de vormen, die een groote verticale verspreiding hebben en even goed aarden in de warme streken bij de kust, als in het koude bergland, mits er maar bosch is. Voor het overige zal een verdeeling worden gemaakt in terreinen van geringe, van middelbare en van aan- 
zienlijke hoogte boven den zeespiegel. Bepaalde cijfer's zijn hier moeielijk te geren; zeer globaal genomen zou ik de bovengrenzen van deze drie gebieden op resp. ongereer 2500 , 5000 en 7500 roet willen stellen.

Wat op laatstgenoemde hoogte en daarboren leeft, zal als Fauna van het Hooggebergte worden besproken.

Om redenen van practischen aard zullen de diervormen, die de grootere plaatsen op Java bewonen, worden besproken in een volgorde, die in hoofdzaak overeenkomt met die, welke in de elementaire leer. boeken der dierkunde wordt gevolgd; een wijze van behandelen, waarvan later, bij de bespreking van andere gebieden, nu en dan zal worden afgeweken.

\section{A. Zoogdieren. ${ }^{*}$ )}

Dat cosmopolieten als ratten en muizen ook op Java in geen huis ontbreken, behoeft wel nauwelijks te worden vermeld. Terwijl echter in Europa en in verschillende andere deelen ran de beschaafde wereld de Bruine Rat (Mus decumamus) sedert een paar eeuwen als parasiet bij uitnemendheid ran de

*) Voor meer uitroerige besprekingen en beschrijvingen ran de Zoogdieren en de Vogels, zoowel van dit, als van andere gebieden moet ik den lezer verwijzen naar mijne werken: De Zoogdieren van Java. (Mededeelingen uit's Lands Plantentuin,
No. 54) 1902.

De Vogels van Java en hunne oeconomische beteekenis. Deel I (Ibid., No. 50) 1901; Deel II (Mededeelingen van het Dep. van Landbouw, No. 7) 1909. 
menschelijke samenleving optreedt en erin is geslaagd, de Zivarte Rat (Mus rattus) grootendeels te verdrijven, heeft de laatste hier nog voor een groot deel de alleenheerschappij weten te behouden. Vroeger, o.a. nog, toen ik in 1902 een overzicht gaf van de Zoogdieren van Java, was ik van een andere meening, deels door het niet steekhoudende van verschillende der gewoonlijk opgegeren kenmerken, in het bijzonder ran die betreffende de kleuren, deels omdat ik destijds nog niet over voldoende materiaal beschikte. Het voortgezette onderzoek heeft echter aangetoond, dat Mus rattus hier nog verre ervandaan is, door haar krachtiger verwanten te worden verdrongen.

Sedert het optreden der pestziekte op Java, in het voorjaar van 1911, heeft het vraagstuk betreffende cle, hier voorkomende rattensoorten bijzondere actualiteit gekregen. Als vaststaande mag thans worden aangenomen, dat Mus decumamus hier en daar op Java voorkomt en dat derhalve de mogelijkheid bestaat, dat zij, krachtiger en ondernemender van aard dan Mus rattus, deze op den duur zal overvleugelen en verdringen, zooals zij dat elders deed. Wat hiervan de gevolgen zouden zijn, laat zich met rrij groote zekerheid voorspellen: in hygiënisch opzicht een zward van Danocles boven de bevolking; op oeconomisch gebied een nog heel wat geduchter vijand dan degeen, die thans reeds zoo menige calamiteit (o.a. bij de rijstcultuur) veroorzaakt.

Voor het tegen woordige bespeurt men de aanwezigheid van ratten - en hoofdzakelijk dan van Mus rattus - in onze woningen rooral aan de sporen, die haar rraatzucht achterlaat en aan het verdwijnen van alles, wat eetbaar is en niet behoorlijk is beveiligd. In het nachtelijk uur echter kan deze diersoort zeer 
luidruchtig worden en tusschen de zolderingen en de daken een geraas reroorzaken, dat men in den aanrang geneigd is aan een veel grootere diersoort toe te schrijren. Daarbij zou echter slechts sprake kunnen zijn van Paradoxurus hermaphroditus, (mal. loervak *), soend. tjareuh), die eveneens dikwijls in deze omgering is te vinden, maar zich bij roolkeur buitenshuis ophoudt en des nachts niet zelden pogingen in het werk stelt om in hoenderhokken of volières binnen te dringen. Want hoevel voor een aanzienlijk deel planteneter (o.a., zooals wij later zullen zien, verzot op rijpe koffiebessen), heeft hij, trots zijn rolledigen orergang in de cultuurfauna, zijn roofdiernatuur in geenen deele verloren en geniet hij dezelfde ongunstige reputatie als zijn verwant Paradoxurus leucomystax op Borneo, die aldaar volgens BÜtTIKofER ${ }^{* *}$ ) eveneens tot cultuurdier is geworden.

In mindere mate dan door ratten worden de huizen hier ook bewoond door muizen, die tot de gewone soort Mus musculus behooren. Men treft ze echter in reel kleiner aantal aan, wat rermoedelijk in rerband staat met een zware concurrentie, die ze met de ratten hebben te roeren.

Eindelijk worden onze woningen en rooral de bijgebouwen daarran, bewoond door Spitsmuizen (tjeroeroet). Deze kleine Insecteneters, die om den sterken muskusgeur, dien ze hoofdzakelijk in den rolwassen

*) Van inlandsche namen zal in dit werk slechts cen matig ge. bruik worden gemaakt. Voor het meerendeel zịn zij onbetroumbaar en onzeker, dikwijls zeer plaatselijk en niet zelden een nabootsing van het stemgeluid der dieren, waarbij zij dan slechts afhangen van hetgeen men daaruit gelieft te hooren. Slechts de meer bekende en de algemeene vormen der Gewervelde Dieren en zeer enkele der Ongervervelde hebben vaste namen.

**) Notes Leyden Museum, XIX, pag. 43. 
toestand verspreiden, dikwijls met clen geheel verkeerden naam van muskusratten worken aangeduid, behooren in den regel tot de soort Crocidura murina en zijn veeleer als nuttige gasten te beschouwen, die een aantal schadelijke en lastige insecten (krekels, kakkerlakken en dgl.) verdelgen. Een zeer schel gepiep verraadt in den regel hunne aanwezigheid.

Terwijl men buiten, in de vruchtboomen, een later uitvoeriger te bespreken Eekhoren (Sciurus notatus), algemeen onder den naam badjing bekend, niet zelden ziet rondspringen, wordt een wereld op zich zelf gevormd door cie ongemeen talrijke Vleermuizen, die vóól en tijdens de avondschemering van alle zijden teroorschijn komen. Uit de kruinen der palmon, uit de holten en het dichte gebladerte van hoogere boomen, uit de ruimten onder dakpannen en ijzeren dakbedekkingen, uit de holten der bamboes, waarop deze dikwijls zijn gelegd, uit elk hoekje, dat overdag maar voldoende beschutting kan aanbieden, komt een heirleger van deze dieren roor den dag. In de eerste plaats merkt men op de grootere, vruchtenetende vormen (soend. tjetjodot): Xantharpyia amplex caudata, Cynopterus marginatus en Cynopterus brachyotis, die, dikrvijls onder luid gepiep, rondom en in de kruinen ran vruchtdragende boomen fladderen. Grootere rruchten als papaja (Carica papaja), sawoe manila (Achras sapota), nangka (Artocarpus integrifolia) e.a. worden aangeveten, kleinere worden geheel afgeplukt en, als het eten ervan eenige krachtsinspanning vereischt, zooals bij die van de, algemeen langs de wegen aangeplante Kanarieboomen (Canarium commune), nilir een rustige plek medegenomen. Dikwijls blijken ze clan voor het dier te zwaar; het laat onderweg 
de rrucht vallen, die niet zelden op de pannen of zinken afdaken der huizen terecht komt en dan door luid geraas de stilte van avond of nacht verstoort. Een begrijpelijke voorliefde wordt aan den dag gelegd voor zachte en sappige vruchten, zooals die van Lansium domesticum (doekoe); een langs de dikkere takken met duizende vruchten behangen boom kan in een paar nachten geheel worden leeggeplunderd, waarbij dan des morgens de grond bedekt is met de schillen, die, waarschijnlijk vanwege het melksap, cloor de dieren worden versmaad.

De insectenetende vormen van Vleermuizen verspreiden zich in het algemeen meer dan de vruchteneters. Sommige der grontere soorten, zooals Nyc. ticejus kühli, Hipposiderus diadema e.a. vliegen bij het verlaten ran hun dagverblijf veelal rechtstreeks naar een of ander rerwijderd oord, vanwaar ze eerst teyen den morgen terugkeeren: de kleinere soorten blijven meestal dichter bij huis, terwijl men ze soms herhaaldelijk naar hun verblijf ziet terugkomen. Zij zijn in de vlucht uiterst moeielijk van elkander te onderscheiden, tenzij ze zich door een bijzondere eigenschap daarbij kenmerken. Dit is o.a. het geval met de Vesperugo-soorten, die zich zeer snel bewegen en daarbij allerlei onverwachte wendingen en bochten maken, en met Miniopterus schreibersi, die reeds vóór de schemering roor den dag komt en gekenmerkt is door zeer lange vleugels. Deze vleermuis is een zóó goede en rustige vlieger, dat het inderdaad eenige moeite kost, hem te onderscheiden van de gierzwaluwen, waarmede hij dikwijls nog gelijktijdig rondvliegt.

In een moeielijk te schatten, maar stellig zeer groot aantal, dat misschien niet onderdoet voor dat van alle 
vogels bij elkaar, die in dezelfde omgeving voorkomen, bevolken de Vleermuizen het nachtelijk duister; eerst tegen de morgenschemering verdwijnen ze weer, waarbij men de soorten, die onder de daken der woningen huizen, gewoonlijk hóort terugkeeren, aangezien het bezetten der dagkwartieren in den regel met groote oneenigheid over het innemen der beste rustplaatsen gepaard gaat.

\section{B. VOGELS.}

De avifauna vall het gebied, waarmede wij ons bezighouden, is over het algemeen tamelijk rijk; rijker, naarmate het terrein meer verscheidenheid ran vegetatie biedt.

Van de Roofvogels herbergt het zeer algemeen Scops lempiji (mal. tjelepoek), een kleinen Ooruil, die in de holten van oude boomen of in de kruinen van daartoe geschikte palmen, als Elaeis guineensis, nestelt en wiens soendaneesche naam boeěl vrij nauwkeurig het geluid weergeeft, dat hij vourtdurend doet hooren, het reelvuldigst in de latere uren van den nacht, wanneer de jacht op kevers, kakkerlakken en andere insecten hem voldoende roedsel heeft opgeleverd.

Een tweede [Til is ereneens niet zeldzaam, rooral op plaatsen, waar oude, hooge gebouwen onder hun daken een geschikte, nestplaats aanbieden. Het is Strix flummea, var. javanica (mal. serak), een variëteit van de ver verspreide diersoort, die in Holland met den naam van Kerkuil wordt aangeduid. Daar deze vogel gaarne rleermuizen eet, hoort men zijn geroep des avonds niet zelden in de buurt, van vruchtdragende boomen, die door de laatste worden bezocht. Hij 
schijnt zich dan ergen: in de nabijheid neer te zetten en nu en dan zijn slag te slaan.

De overige Roofvogels, die men op de groote plaatsen nu en dau te zien of te hooren krijgt, zijn slechts toevallige of zeer tijdelijke bezoekers, die in den regel in andere g'ebieden nestelen.

Van de vormen, die men onder den naam van Javaansche tuinvogels zou kunnen samenvatten, trekt het eerst de aandacht Pycnonotus aurigaster (mal. koetilang; soend. tjangkeurilang), e€n cultuurvogel bij uitnemendheid, die het geheele bebourvde land bewoont, van de nabijheid der kust tot de randen van bosch of wilçernis. Hij is een der levendigste en vroolijkste vogels en leeft buiten den broedtijd in kleine troepen, die den geheelen dag rondzwerven en des avonds eerst na het invallen der schemering ter ruste gaan. Zijn voedsel is ran gemengilen aard, terwijl o.a. de groote, roode bloemen der algemeen aangeplante spathodea campanulata, die bij elke regenbui een kleine hoeveelheid watel rerzamelen, hem tot drinkbeker dienen. Op sommige plaatsen, vooral in Oost-Java, is hij minder talrijk en wordt aldaar voor een deel verrangen door Pycnonotus analis, (mal. tjeloektjoek; soend. djokdjoli), die een veel rustiger natuul heeft, zıch zelden tot troepjes vereenigt en in zijn verspreiding meer tot de lagere streken is beperkt.

'Tot dezelfde familie (Ixodidae) behoort Aegithina scapularis, die zich bij voorkeur ophoudt op bloem. dragende heesters en grootbloemige slingerplanten, waar hij jacht maakt op insecten. Aan het geroep, dat hij daarbij voortdurend doet hooren, is zijn inlandsche naam tjipôh ontleend; hij beweegt zich dikwijls op de wijze der Meezen, maar staat in lenigheid 
verre bij deze ten achter. Het, in dicht gebladerte verborgen nest is merkwaardig door de groote hoeveelheden spinneweb, waarmede de bestanddeelen aan elkander en aan een tak zijn verbonden en die uitwendig aan het nest een zilverachtigen glans geven.

Terwijl de beide, zooeven genoemde Pycnonotussoorten bijna overal naast elkander voorkomen, levert het Lijstergeslacht Copsychus twee soorten op, die plaatselijk scherp van elkander zijn gescheiden, maar elk in zijn gebied een nooit ontbrekend bestanddeel van de tuinvogelwereld uitmaken. Het zijn Copsychus musicus en Copsychus amoenus, waarvan de eerste in West-Java, de tweede in Midden-en Oost-Java wordt gevonden. Algemeen onder den naam koetjita bekend, behooren zij tot de tamelijk goede zangers, wier stemgeluid men niet zelden ook in heldere, door de maan verlichte nachten kan hooren. In levenswijze, bewegingen en voorkomen herinneren beide soorten zeer sterk aan den Europeeschen Turdus merula.

Een ietwat eigenaardig type geeft de eenige Tliegenvanger te zien, die in dit gebied voorkomt: Rhipidura javanica, die met waaierrormig uitgespreiden staart, half uitgespreide vleugels en eenigszins ingehouden pooten zich door het struikgewas leweegt en daarbij zulk een vlugheid aan den dag legt, dat men hem nauwelijks de takken ziet aanraken. "Waaierrogel” (mal. boeroeng kipas) is de naam, dien de iblanders hem naar de houding ran zijn staart hebben gegeren; ook hij behoort tot de zeer alledaagsche verschijnigen, hoewel men nooit meer dan één paar op hetzelfde terrein aantreft.

Dit laatste geldt ook voor de Javaansche mees, Parus 
cinereus (mal. giatik batoe); die zoowel door zijn stemgeluid als door zijn roorkomen darlelijk is te herkennen en het eerste vooral in de vroege morgenuren doet hooren, over het algemeen de beste tijd, om op Java de rogelwereld waar te nemen. Want de koole atmosfeer en de nog niet hinderlijke zonnegloed schijnen vok op har een opwekkenden invloed uit te oefenen. Dat ziet men aan de Honigzuigers, in dit gebied vertegenwoordigd door de fraaie Cinnyris pectoralis (mal. djantiengan; soend. manoek madoe), die alsdan een buitengewone bedrijrigheid aan den dag legt, waarbij het merkwaardig is, op te merken, hoe hij in het geheel niet uitsluitend bloemen bezoekt, maar, evenals zoovele andere, kleine jagers, alle takken, alle kleine schuilhoeken onderzoekt, waar hij zijn voornaamste roedsel hoopt te rinden. Het is mij, wat dit roedsel betreft, door het onderzoek ran talrijke magen ran verschillende soorten dezer familie gebleken, dat de naam ,honigzuiger" grootendeels op fantasie berust en dat het liefst kleine spinnetjes worden gegeten, geheel in orereenstemming met clen bouw ran den snavel, waarran boren-en onderstuk als een fijn getand pincet in elkaar grijpen. Zulke kleine spinnen nu, voor: een aanzienlijk deel tot de rormenrijke familie der Springspinnetjes (Attidae) behoorend, zijn roolal te vinden op en in de kronen ran groote bloemen, waar ze op hunne beurt de talrijke, bloemenbezoekende vliegjes afwachten.

Van geheel verschillende levenswijze is Dicaeum rubrum (mal. boeroeng tjabeh; soend. manoek sepa), een der zoogenaamde Bastaard-honigzuigers, die relantwoordelijk moet worden gesteld roor het groote aantal Lorcunthus-parasieten, die alom op het'geboomte 
zijn te vinden en soms het voornamste loof daarvan uitmaken, terwijl zij zelf dikwijls weder een voedingsbodem zijn voor een rijke vegetatie van Viscum articulatum, die in dikke trossen afhangt. Want het zijn de Dicaeum's, die de zaden van deze woekerplanten, met welker vruchten ze zich bij voorkeur voeden, ran boom tot boom overbrengen, hetzij met humne uitwerpselen, hetzij door het afvegen van den snavel tegen de takken. Ongetwijfeld in hooge mate schadelijk, zijn zij echter door de fraaie kleur der mannetjes en door hun levendige bewegingen een element, dat zeer bijdragat tot verlevendiging der omgeving, zooals de kleine Sylviide Prinia familiaris (nıal. priendjak; s. petikrak) hetzelfde bereikt op andere wijze en wel door zijn bijzondere luidruchtigheid. Door een, voor zijn afmetingen buitengewoon krachtig stemgeluid, dat hij des morgens voortdurend doet hooren, trekt dit rogeltje dadelijk de aandacht, terwijl het ijverig aan de algemeene jacht op insecten deelneemt. Zijn soortnaam verdient het ten volle, daar het dikiwijls ook de. in de voorgalerijen der huizen geplaatste sierplanten afzoekt, rooral wanneer daarop nog overblijfselen aanwezig zijn van mieren-invasies van den vorigen avond.

In nestbouw nadert het tot de echte Orthotomidue (Snijderrogels), die hier zijn vertegenwoordigd door twee soorten, Sutoria edela en Orthotomus sepium, (mal. tjitji), beide niet zeldzaam, maar van stillere natuur, waardoor zij minder op den voorgrond treden.

Waal opgaand geboomte hem een geschikte gelegenheid tot nestelen aanbiedt, komt, ook in het midden der steden, Oriolus maculatus, de Indische Wielewaal, (m. kapodang; s. bientjarong) voor. In 
tegenstelling met den Europeeschen Oriolus galbula, die zich het liefst in de bosschen terugtrekt, is deze soort op Jara geheel tot cultuurrogel geworden. Hij komt er algemeen rerspreid voor en volgt den mensch gaarme tot hoog in de bergstreken, maar vermijdt het oorspronkelijke woud. In de steden ziet men hem dikwijls in de kruinen der cocospalmen, waal de groote rupsen van Amathusic phidippus en Discophora celinde hem aanlokken, maar, omniroor ran nature, nuttigt hij ook gaarne kleine rruchten, zooals die ran verschillende Ficus-soorten en de smakelijke bessen ran Antidesma bunias (woenie), terwịl hij in pepertuinen zelfs schadelijk kan worden. Het nest wordt hoog in het geboomte gemaakt en hangt, erenals dat van de Europeesche soort, aan een rorksgervijze gedeelden tak.

Een andere vorm, dien men, naar analogie ran welbekende, Europeesche diersoorten evenmin in de tuinen der steden zour vervachten, is Halcyon chloris, naal zijn stemgeluid algemeen met den inlandschen naam liahki aangeduid. Deze luidruchtige en bewegelijke IJsrogel is een ran de meest rraat-en roofzuchtige dieren ran zijne omgeving. Op een kalen tak gezeten. reelal in de nabijheid ran zijn wijfje en, na den broedtijd, ran de jongen, slaatt hij aandachtig zijne ongeving gade en men rerbaast zich dikwijls over de scherpte van het gezichtsrermogen, dat hem op groote afstanden kleine dieren kan doen onderscheiden. Rupsen, rormen, duizendpooten, kevers en keverlarven, zelfs wantsen worden door hem gegeten, maar hij ralt ook grootere dieren, zooals krabben en hagedissen aan en, is de buit roor hem alleen te groot of te zwaar, dan komen op zijn 
geroep alras eenige soortgenooten of leden van zijn gezin te hulp. Bekend zijn voorts zijn aanvallen op jonge hoenders, die hij in volle vaart met zijn snavel in het achterlijf vliegt, juist in de cloacale opening. Wat hierbij zijn doel is, heb ik nog niet kunnen uitmaken; niet onmogelijk is het, dat een Platworm, een op vochtige plaatsen niet zelden voorkomende Bipalium-soort, die soms als tijdelijke parasiet in het rectum van hoenders leeft, zijn begeerte daarbij heeft. opgewekt.

Een vorm, die meer wordt gehoord dan gezien en wiens eentonig geroep men in het hier beschreven gebied van den vroegen morgen tot het vallen van den avond kan hooren, is Xantholaema rosea, een kleine Baardrogel, algemeen onder den inlandschen naam boeroong engkoet-engknet bekend. Hoewel hij, blijkens zijn algemeen voorkomen, ook in het centrum der groote plaatsen, de nabijheid van den mensch in geenen deele schuwt en niet nalaat, voortdurend door zijn geroep diens opmerkzaamheid te trekken, daalt hij toch in de meer bedrijvige uren van den dag zelden in che lagere gedeeilten van het geboomte af en weet zich in de kruinen der boomen altijd zóó te houden en, in de lengterichting over de takken huppelend, zóó te bewegen, dat men hem moeielijk in het gezicht krijgt. Vandaar, dat ieder op Java den boeroeng engkoet-englioet bij name kent, maar slechts zeer weinigen hem ooit goed hebben gezien. Toch is hij een typische cultuurvogel, die in hooge mate hecht aan de nabijheid van den mensch en ver van diens woningen slechts sporadisch, buiten het bebouwcle land in het geheel niet wordt aangetroffen. In dit opzicht is hij de evenknie van 
Passer montanus, de Huismusch van Java, maar in den grond der zaak niet anders dan een, van elders ingevoerde, Oost-Aziatische variëteit van de ver verspreide diersoort, die in Holland met den naam van Ringmusch wordt aangeduid. Van zulk eene soort, die in het land harer herkomst waarschijnlijk reeds van ouds tot de cultuurfauna behoorde en bovendien door den mensch zelf is ingevoerd, laat het zich hooren, dat zij den laatste trouw blijft; slechts moet men zich erover verwonderen, dat zij zich in dit nieuwe vaderland met zijn, voor haar geheel vreemd klimaat, zoo uitnemend heeft weten te schikken. Want trots de groote concurrentie, haar door tal van verwante vormen, in het bijzonder door de Ploceidae, aangedaan, heeft zij zich niet alleen algemeen verspreid, maar ook dermate aan het tropische klimaat geaccommodeerd, dat zij gedurende het geheele jaar nestelt en broedt. Dit laatste geschiedt echter alleen onder de bescherming van den mensch, speciaal onder die van de daken der met pannen gedekte huizen, welker nabijheid slechts wordt verlaten door de individuen, die buiten een broedperiode verkeeren en zich met jonge dieren tot kleine troepjes vereenigen, die overdag op naburige relden rondzwerven.

Van de Ploceidae, waarvan zooeven sprake was, komen drie soorten in dit gebied algemeen voor: Munia oryzivora, IInnia nisoria en Uroloncha leucogastroides, resp. met de inlandsche namen glatik, peking en priet aangeduid. Tan deze drie komt de laatstgenoemre de huismusch het meest nabij in miate van samenleving met den mensch; zij nestelt onder de daken en in de klimplanten (Clematis-soorten, Ipomaea's, 
Allamanda's, Clerodendion's enz.), die dikwijls tegen stellages van bamboe worden opgeleid, vagabondeert op de plaatsen, waar culinaire afval is te vinden en beschadigt niet zelden de, algemeen in de open galerijen en onder afdaken gekweekte, fijne Adiantum's en zachtbladige palmen, om het loof daarvan voor haar nestbouw te gebruiken. Munia oryzivora heeft slechts hier en daar een ongeveer gelijke levenswijze aangenomen, terwijl Munia nisorix een echt tuinvogeltje is, dat veelal nestelt in de kruinen van middelmatig hooge palmen, zooals jonge exemplaren van Areca catechu, de pinang, welker gladde stam moeielijk voor kleinere roofdieren is te beklimmen, terwijl de onderste gedeelten der oudere bladscheden een uitmuntende nestplaats aanbieden. Overigens mag men van de drie, hier genoemde soorten aannemen, dat ze in dit gebied nog slechts een eerste schrede hebben gezet; de groote massa ervan behoort nog elders thuis, waar wij ze later zullen ontmoeten en eerst de toekomst zal kunnen leeren, welke hun hoofdzakelijke verblijfplats zal worden.

Wij komen thans tot de Spreeuwen, die, als overal ter wereld, ook op Jara neiging vertoonen tot aansluiting bij den mensch. De suort, die hier in dit opzicht roorgaat, is Sturnopastor jalla, de sierlijke en rroolijke djalak, een bewoner ran alle bebouwde en bewoonde streken, die roor zijn levensonderhoud geen andere eischen stelt dan een zekere uitgestrektheid grasrijk terrein, waar hij den dag al zoekende en spelende kan doorbrengen en waar de vroege zonneschijn hem zijn levensvreugde in een niet onaardig gezang doet uiten. Op vele der grootere plaatsen van Java komt deze soort bij duizendtallen voor, die 
zich overdag verspreiden, maar zich tegen den avond gewoonlijk in de hoogste boomen verzamelen en dan hun schel gefluit tot een oorverdoovend geraas doen samensmelten.

Even algemeen rerspreid, maar stiller van aard en minder talrijk is Acridotheres javanicus, de kaleng, die ook als kooirogel en, met gekortwiekte vleugels, in tammen staat veelruldig wordt aangetroffen. Ook deze soort ziet men, op roet van rolkomen vrede met de vorige, dikwijls in de grasperken der tuinen rondhuppelen, maal toch ligt haar eigenlijke gebied meer buiten de grootere plaatsen.

Een verwante vorm, de Purperspreeuw Calornis chalytea (mal. tjamperling en seling) is minder algemeen verspreid, doch komt dáár, waar zij is te rinden, troepsgewijze roor. In hale gewoonten en allures, o.a. door het gaarne op rijen zitten op de nokken der daken, komt zị, meer dan de zóoeven genoemde soorten, met den Europeeschen Sturnus vulgaris overeen.

Niet minder dan drie Hirundo-soorten (mal. voalet, kupinis) komen voorts in dit gebied voor, waarvan echter Hirundo gutturalis Java slechts in den Westmoesson bezoekt, als wanneer zij de koude van noordelijker streken (China, Japan) ontrlucht. De beide andere soorten zijn Hirundo javanica en de grootere Hirundo striolata, welke laatste ook wel naar het noorden schijnt te trekken om te broeden. Alle drie staan op goeden voet met de menschelijke samenleving, zooals onder meer blijkt uit het feit, dat zij gaarne nestelen in de galerijen der woningen en in het algemeen onder de afdaken van allerlei gebouwen, terwijl men ze dikwijls rustig ziet rond- 
huppelen op de begrinte voorpleinen, zonder zich eenigszins te storen aan het verkeer op den naburigen weg.

Een even gewone verschijning als de Hirundo's is de Gierzwaluw Macropteryx longipennis, hier en daar boeroeng tepèkiong genoemd, die op plaatsen, waar hoog geboomte haar een goede nestplaats kan verschaffen, een karakteristiek bestanddeel van de cultuurfauna uitmaakt. Deze zwaluw jaagt bijna uitsluitend vrij hoog in de lucht en men ziet hem slechts langs den grond scheren, wanneer een, op het midden van den dag plotseling neerkletterende regenbui een menigte kleine insecten uit gras en kruiden opjaagt. Merkwaardig is zijn uiterst klein nest, dat den vorm heeft van het vierde gedeelte ran een eischaal en zijdelings tegen een horizontalen tak wordt bevestigd, zoodat het dier bij het broeden meer op den laatste dan op het eerste rust. Telkens wordt slechts één ei gelegd en het uitkomende jong zou in zijn onbeschutte positie stellig spoedig een prooi worden van roovende dieren, wanneer het niet door roorkomen en houding een volmaakte gelijkenis vertoonde met een uitstekend stompje rerweerd hout of schors.

De andere Gierzwaluwen ran dit gebied weten hun nest beter te beschutten. Tachomis infumata bouwt het tegen de onderzijde van de bladeren van waaierpalmen, zooals Livistona-soorten, waar deze diersoort in koloniën leeft; Cypselus subfurcatus kiest de onderzijde van uitstekende dakgedeelten en dergelijke plekken ervoor uit. Collocalia linchii eindelijk, die vooral in de groote centra langs de noordkust veelvuldig en in groote troepen voorkomt, nestelt gaarne 
onder bruggen, waar men de nesten soms bij duizendtallen kan aantreffen. Zij zijn daar gemakkelijk bereikbaar, maar worden ongemoeid gelaten, omdat ze, in onderscheid met die der later te bespreken Collocalia fuciphaga, geen handelswarde hebben, opgebouwd als ze zijn uit kleine plantendeelen (het liefst de fijne, naaldrormige blaadjes der Casuarina's), die door de dieren met een groote hoeveelheid rerhardend speeksel aan elkander zijn verbonden.

Dat de Zwaluwen in het algemeen geen boschbewoners kummen zijn in den eigenlijken zin van het woord, brengt de aard hunner levenswijze reeds mede. Zij zijn aangewezen op de nabijheid ran open terreinen, voor de meeste soorten liefst met veel water, omdat dit de aanwezigheid ran reel kleine Diptera medebrengt; maar of deze insecten nu af. komstig zijn uit bevlóeide rijstvelden of uit woeste, door een boschachtige regetatie omringde en deels zelfs daarmede bedekte moerassen, is hun onverschillig, zooals hieronder bij Collocalia fuciphaga duidelijk zal blijken, maar ook reeds wordt aangetoond door Collocalia linchii, die zich overdag even goed in de moerassige, wilde kuststreek, als boren de gecultiveèrde terreinen vertoont. Tegen den avond begreren de Gierzwaluwen zich alle naar humne woonplaatsen, waar zij tot het rallen der duister'nis de omgering doorkruisen en dikwijls nog een rijken arondmaaltijd rinden in de uitvliegende mieren en termieten. Een maaltijd, dien ze echter moeten deelen met de rroeg uitrliegende rleermuizen, met ver'schillende der reeds genoemde vogelsoorten, maar vooral met de Buchanga's.

Deze vogels, algemeen onder de namen salagoenting (mal.) en sciëran (s.) bekend, maken een typische rerschijning uit van het geheele cultumgebied op Java. 
Tusschen de beide, hier roorkomende soorten, de grootere Buchanga longa en de kleinere Buchanga cinerea, schijnt echter, vermoedelijk tengevolge van geheel overeenkomstige levenswijze. zulk een livaliteit te bestaan, dat zij slechts zelden dezelfde plaats bewonen. Het zij intusschen opgemerkt, dat ook, en vooral bij Buchanga longa, tusschen de individuen van dezelfde soort slechts zelden vrede heerscht en dat zelfs het geraas van een voorbijgaanden trein hen niet ertoe kan brengen, voor eell oogenblik hun onderlinge veeten te rergeten.

Terwijl zij zich gedurende de warme uren van den dag in het geboomte schuil houden, zijn de Buchanga's des morgens en des avonds vol actie. Zij kiezen dan het hoogste topje van een boom of een kalen tak als uitkijk en storten zich vandaar op elk insect, dat hun begeerte gaande maakt en met buitengerrone vlugheid en behendigheid wordt bemachtigd. Tegen het vallen ran de schemering, wanneer de insecten, die overdag vliegen, hun rustplaatsen hebben opgezocht, worden zij echter kalmer. Maar zich zeer goed ervan bewust, dat hun dagtaak vermoedelijk nog niet is afgeloopen, blijven ze waakzaam; eenigszins in elkander gedoken, de gerorkte staart slap afhangend, zitten ze dan onbewegelijk en wachten slechts op het rerschijnen der eerste schemering-insecten on weder in volle actie te komen. Tooral op de volwassen. gerleugelde vormen der termieten (mal. laron's) zijn ze zeer belust, een voorliefde, die zij, zooals wij reeds zagen, met tal van insectivore dieren gemeen hebben. Wat er dientengevolge ran deze insecten overblijft, kan inderdaad niet meer zijn dan een fractie ran het aantal, dat is uitgerlogen. Want op de plek, waar 
het nest door de arbeidsters onder leiding der soldaten is geopend, zitten reeds spreeuwen en lijsters de laron's, nog róóldat deze de rleugels roor de eerste maal hebben gabruikt, bij honderdtallen te verorberen. Verjaagt men deze rogels, door het nitkomen der insecten van nabij gade te slaan, dan wordt men omfladderd door dozijnen zwaluwen, vleermuizen enz., terwijl de zeer enkele insecten, die er nog in slagen, zich enkele meters te verheffen, aan de nooit falende Buchanga's ten prooi vallen of worden gegrepen door Libellen, die hun het achterlijf afbijten en daarna hulpeloos op den grond laten vallen, waar ze door kikvorschen verder worden verorberd.

Erenals de Buchanga's, hoewel zij den geheelen dag werkzaam zijn, tegen den avond het meest worden gezien, trekken ook de Duiren op dat uur van den dag, meer dan op andere uren, de aan. dacht. In het bijzonder geldt dit roor de Papegaai duiren (Treronidae; m. katik; s. watik; jav. poenai), die alsdan in kleinere of grootere troepen rondrliegen om een rustplats te zoeken roor den nacht. Overdag houden zij zich op in de hooge kruinen ran vruchtdragende boomen, rooral van sommige Ficus-soorten, waar zij door hunne kleur moeielijk zijn te ontdeklien. Het zijn vooral Osmotreron vernans en Osmotreron griseicanda, die de grootere plaatsen bewonen; veel minder algemeen is de soort olax.

Van de zoogenaamde Jufferduiven treft men in dit gebied Ptilopus melanocephalus (m. katiti liembang: s. manoek petir) reelvuldig aan; ook deze soort is rustig van aard en verbergt zich gaarne in het gebladerte, maar doet op alle uren van den dag-haar dof en niet zeer opgewekt stemgeluid hooren. 
Het Javaansche duifje bij uitnemendheid is echter Geopelia striata, de perkoetoet, de zelden ontbrekende huisgenoot van den Javaan. Deze soort komt algemeen in het wild voor, waar de mensch haar is voorgegaan. Haar rollend, niet onaardig stemgeluid is ook in de steden een der meest gewone klanken en levert voor het, in dit opzicht zeer geoefend oor van den inlander allerlei trappen van volmaaktheid, waarvan de hoogste het dier tot een zeer begeerd voorwerp maken, tot welks bemachtiging moeite noch tijd wordt gespaard. Van nature is de perkoetoet niet zeer schuw; ook in dichtbewoonde buurten ziet men haar dikwijls op den grond vertoeven en allerlei zaden van grassen en kruiderı oppikken.

Een tweetal Scansores sluit de tamelijk lange rij der Javaansche tuinvogels. De eerste is Dendrocopus analis, de platok, een algemeene verspreide Specht, die door het hameren op doode takken een eigenaardig geluid voortbrengt, dat men in den aanvang niet dadelijk weet thuis te brerigen. Het klinkt, alsof twee zware takken door den wind tegen elkaar werden geschuurd. Maar hij tast ook levend hout aan en menige boom, vooral natuurlijk van de soorten, die veel ran borende larven hebben te lijden (Parkia speciosa, Odina gummifera, de Mangifera-soorten), vertoont duidelijk de sporen van zijn werkzaamheid.

De tweede Klimvogel is Cacomantis merulinus, een Koekoek, die, naar zijn stemgeluid, bij de Europeesche bevolking onder den naam "Piet van Viiet" bekend staat. Erenals de meeste koekoeken, léidt deze vogel een \%wervend bestian en komt op zijn tochten dikwijls in de tuinen der steden, vooral wanneer aldaar de Kanarieboomen langs de wegen door de rupsen van 
Cricula trifenestrata zijn aangetast. Men hoort alsdan zijn gefluit niet alleen overdag, maar ook, en misschien nog meer, gedurende den nacht en dat niet een enkele maal, maar, met korte tusschenpoozen, soms uren achtereen.

Behalve de, in de vorige bladzijden genoemde vogelsoorten worden in dit gebied nog wel eens andere aangetroffen, hetzij omdat ze er op hunne zwerftochten toevallig zijn terecht gekomen, hetzij omdat ze er zich periodiek of met onregelmatige tusschenpoozen plegen te vertoonen. Een tamelijk algemeene zwerver, die hier, wanneer zich een bijzonder geschikte gelegenheid daartoe voordoet, ook wel eens nestelt, is Corvus macrorhynchus, de grootste der twee op Java voorkomende kraaiensoorten (mal. gaok). Op sommige plaatsen, rooral war oude, hooge gebouwen zijn te vinden, is hij zelfs een permanente verschijning.

Veel minder algemeen is de Boomklever Sitta frontalis, (m. glatik moengoek; s. tjeladi loemoet), een zeer sierlijke verschijning, die zich met merkwaardige vlugheid lang stammen en takken berveegt en een deel van haar voedsel bemachtigt op de wijze der Muscicapidae, voor welke zij in behendigheid niet onderdoet. Betrekkelijk zeldzaam eindelijk is de Rupsvogel Lalage terat (mal. kapasan), wien men het kan aanzien, dat hij zich in deze omgeving nog niet thuis gevoelt; hij is onrustig en schuw, terwijl de minste stoornis hem onmiddellijk doet verwijnen.

Tot de tweede der zooeven genoemde categorieën moeten een paar soorten van Reigers worden gerekend. Zoo treft men in sommige steden van Midden- en Oost-Java Herodias-soorten nestelend aan in de tama- 
rindeboomen, waarmede vele wegen aldaar zijn be. plant. De oorzaak hiervan moet waarschijnlijk worden gezocht in de omstandigheid, dat de omgeving dier plaatsen, wat aanwezigheid van voedsel betreft, voor deze dieren zeer geschikt is, maar tevens door de intensieve bebouwing zóó arm aan boomen, dat zij voor de laatste op de wegen der steden zijn aangewezen. Iets dergelijks geldt voor den nachtreiger Nycticorax griseus (m. koendoel malam), die soms (o.a. te Buitenzorg) in zeer talrijke troepen het hooge geboomte berwoont. Veel behoefte aan rust schijnen deze vogels niet te hebben. Gedurende den geheelen dag heerscht el bij deze troepen rumor in casa, terwijl zij zich tegen den avond onder luid geschreeuw naar het omliggende land begeven en eerst tegen den morgen op even Inidruchtige wijze naar hun dagverblijf terugkeeren.

\section{Krutpende en Tweeslachtige Dieren.}

Van de Kruipende Dieren treden in dit gebied in de eerste plaats de binnenshuis levende Hemidactylussoorten, de tjitjalis, op den roorgrond. Deze kleine munihagedissen van onbestemde kleur, waarvan de soorten eerst bij nauwkeurige beschouwing van el kander zijn te onderscheiden (het meest algemeen zijn de soorten frenatus, garnoti en mutilatus), zijn cultuurdieren bij uitnemendheid geworden, welker uiterlijk voorkomen in hooge mate de sporen draagt van hunne levenswijze. Gedurende den dag verschuilen zij zich in spleten van muren en zolderingen on op allerlei plaatsen, waar bijna geen daglicht doordringt en in verband daarmede is het, bij andere Reptielen dikwijls zoo kleurenrijke pigment zeer weinig ont- 
wikkeld. Dat hier de levenswijze van determineerenden invloed is en dat men hier derhalve een roorbeeld heeft ran de vereenvoudiging ran roorkomen, waarvan rroeger (pag. 25) sprake was, kan worden opgemaakt uit het feit, dat de pigmentatie in veel sterkere mate optreedt bij de individuen, die men wel eens op plaatsen aantreft, die meer aan het licht zijn blootgesteld, wat rveder zou roeren tot het rermoeden, dat de versihillende Hemidactylussoorten over het algemeen veel geprononceerder waren gekleurd, róórdat zij in nauwe samenleving. traden met den mensch.

Dit rermoeden wordt rersterkt, wanneer men ze vergelijkt met een nauw verrvanten rorm, den rvel. bekenden Ptychozoon homalocephahum, die buiten in de rrije natuu leeft en dien men, hier en daar in het geheel niet zeldzaam, ook in de grootere tuinen der steden kan aantreffen. Deze Geckonide, die rooral merkwaardig is om de, aan weerszijden ran het lichaam aanwezige zweefhuid en den platten, gelubden staart, vertoont namelijk een zeer sterke pigmentatie en een scherpe tegenstelling tusschen gitzwarte en helder grijswitte plekken, welke tegenstelling echter geen afbreuk doet aan de moeielijke zichtbaarheid tegen de, met korstmossen en andere epiphyten begroeide boomstammen, waarop deze diersoort zich roornamelijk ophoudt. Hare eieren zijn eveneens niet zeldzaam; men rindt ze; niet zeel. verborgen, steeds ten getale van twee bij elkaar. Zij zijn wit, iets meer dan half-bolvormig, hardschalig. en worden met de afgeplatte zijde tegen de onderzijde van bladeren of in de oneffenheden van schor's bevestigd. Nu en dan ontmoet men van deze diersoort exemplaren, welker staart slechts aan het basale gedeel- 
te gelobd, voor het overige gaafrandig is; vermoedelijk is hier de staart vroeger afgebroken geweest, waarna dan het geregenereerde gedeelte een gaven rand heeft gekregen.

Zoowel buitenshuis, als onder de beschutting van daken leven de als tokkè bekende Gecko-soorten, waarvan Gecko verticillatus de meest gewone is, Gecko stentor en Gecko monarchus minder algemeen worden aangetroffen. De fraaie; maar zeer matte kleuren dezer dieren getuigen eveneens van een niet meer dan gedeeltelijke blootstelling aan het daglicht. Ook zij zijn hoofdzakelijk nachtdieren, welker eentonig geroep gedurende de stille uren van den nacht op aanzienlijken afstand hoorbaar is. Stoutmoedig en vechtlustig van nature, ontzien zij zich niet, grootere dieren, zooals ratten, aan te vallen, terwijl zij zich dikwijls met een verren sprong op groote insecten, zooals Sabelsprinkhanen, werpen, die des avonds het verlichte terrein hunner woonplaats komen binnenvliegen.

De familie der Boom-Agamen is in dit gebied eveneens algemeen vertegenwoordigd en wel in de eerste plaats door de Vliegende Draken, Draco volans en Draco fimbriatus. Vooral de eerste is een gewone verschijning; men ziet haar zeer vlug langs de dikkere takken der boomen loopen, waarbij de zwavelgele keelzak telkens naar roren wordt gestrekt. Bij het springen ran den eenen tak op den anderen wordt de, naar verhouding tot het dier zeer groote zweefhuid slechts zelden in haar volle breedte uitgestrekt; zij schijnt inderdaad meer een valscherm te zijn, dat bij het mislukken van een sprong in dienst wordt gesteld. 
Niet minder behendige boombewoners zijn de Calotes-soorten (mal. londok), waarvan hier Calotes jubatus, ginds Calotes cristatellus de meeste vertegenwoordigers telt. Beide soorten zijn brutale roofdieren van een zeer nijdig karakter; hoewel hun hoofdvoedsel uit insecten bestaat, gelukt het hun nu en dan ook, kleine vogeltjes te bespringen. Hun moed is inderdaad bewonderenswardig. Wanneer ze door grootere dieren worden achtervolgd, nemen ze niet de wijk, maar verdedigen zich tot het uiterste. Ik heb eens een gevecht gadegeslagen tusschen een Calotes en een kat, waarbij laatstgenoemde feitelijk een nederlaag leed en van verdere vervolging afzag; want de Calotes vloog haar telkens naar den' snuit, beet daarin herig en hield zich met de tanden zóó vast, dat de kat har slechts door krachtig schudden kon verwijcleren en ten slotte met een bebloede neus afdroop. Op den grond gevoelen zij zich niet zeer thuis; zij bervegen zich dan met spronger, waarbij rooral de lange achterpooten worden gebruikt, zoodat men meer den indruk krijgt van een huppelenden, groenen rogel dan ran een kruipend dier en nooit heb ik de, in het woord Ornithosauriërs neergelegde verwantschap tusschen Vogels en Reptielen meer gevoeld, dan toen ik voor de eerste maal ran die gelijkenis de dupe werd.

De geelwitte, torpedo-rormige eieren worden op allerlei verborgen, liefst vochtige plaatsen neergelegd.

De echte Lacertiden treden hier verre op den achtergrond tegenover de Scinken. Terwijl toch eerstgenoemde familie hier slechts wordt vertegen. woordigd door Tachydromus sexlineatus, die geen alledaagsche verschijning kan worden genoemd, telt 
de hoofdgroep der cultuurfauna drie soorten ran de laatste. Twee daarvan behooren tot het geslacht Lygosoma, de derde en meest algemeene is Mabuia multifasciata, die overal tusschen de hodemvegetatie is te rinden en, trots den plompen, loggen lichaams. vorm, zeer vlug in zijn bewegingen is.

Lygosoma olivaceum, die in den volwassen toestand in habitus geheel met Mabuia multifasciata (mal. kadal) overeenkomt, is merkwardig om de groote veranderingen, die zich tijdens de ontwikkeling in zijn uitwendig voorkomen voordoen. Het jonge dier namelijk is, kort na zijn uitkomen uit het ei, donker olijfgroen met een groot aantal fijne, gele dwarsstreepjes over het lichaam en gelijkt daardoor zóó wveinig op den rolivassen vorm, dat men, de tusschenvormen niet kennende, aan twee geheel verschillende diersoorten zou denken.

Van geheel ander roorkomen is Lygosoma chalcides, die met zijn wormrormig lichaam en zeer gereduceerde ledematen op het eerste gezicht herimnert aan de slangetjes ran het straks te bespreken geslacht Typhlops en zich, erenals deze, in den bodem verbergt.

Als laatste vertegenwoordiger der Hagedisachtige Dieren in dit gebied kan worden genoemd Varanus salvator (mal. minjawaki), hier algemeen met den naam van leguaan aangeduid. Dit roofdier, waarran oude individuen soms twee meter lang worden, is, ook in de grootere plaatsen, oreral te vinden, war vijvers, rivieren of kanalen hem een geschikte verblijfpliats aanbieden. Hoewel in hoofdzaak waterbewoner, begeeft hij zich niet zelden rrij rer op het land en 
koestert zich gedurende de warme uren van den dag gararne op een rustig plekje in de zon.

Hoewel men op Java, in de groote plaatsen, in het dagelijksch leven niet veel van Slangen bemerkt, is toch een aanzienlijk aantal in de cultuurfauna orergegian en houdt zich veel meer op in de onmiddellijke nabijheid van den mensch, dan gerroonlijk wordt vermoed. Daartoe werken mede de dikwijls nachtelijke levenswijze van rerschillende soorten, de rerborgenheid der plaatsen, waar zij zich ophouden, het omringd zijn der huizen door soms groote en daarbij weinig verzorgde tuinen en eindelijk de aanvezigheid van reel leidingen met stroomend, maar troebel water en dikwijls ruig begroeide kanten. Nemen deze leidingen de afmetingen aan van kleine riviertjes met, in den loop der jaren, diep geworden beddingen, dan herbergen ze niet zelden zelfs Python reticulatus, (mal. oelar santja) die zich schuil houdt, hetzij in het water, hetzij in holen, door het water of door andere dieren in de kanten uitgegraven. Zoo is een der grootste exemplaren, die in de verzameling van het Zoülogisch Museum alhier aanwezig zijn, gevangen in het centrum van Buitenzolg, in de breede waterleiding, die deze plaats in hare geheele lengte doorstroomt. Het bleek niet, minder dan drie groote hoenders in de maag te hebben, die op geheimzinnige wijze ran een naburig erf waren rerdwenen en welker opsporing leidde tot het rinden ran dit dier, dat rustig in het riviertje lag te slapen.

Eenige soorten van slangen leven onder den grond en ontgaan reeds daardoor de aandacht. Dit is o.a. 
het geval met de hierboven reeds genoemde Typhlopssoorten (mal. doevoa), warrvan Typhlops braminus de meer algemeene, Typhlops lineatus de minder voorkomende is. Bij het graven in den grond, bijv. voor den aanleg van fundamenten, ontmoet men niet zelden deze dieren, waarvoor in den regel een volkomen ongemotiveerde rrees worlt gekoesterd, evenals zuiks het geval is met den fraai gekleurden en geteekenden, maar in vorm plompen Cylindrophis rufus (mai. oelar kiepala doea; soend. oraj teropong), die een dergelijke, verborgen levenswijze leidt. Minder berreesd is men roor de, eveneens rolkomen ongevaarlijke Cularnariu's (soend. o. soerapari), die in een groot aantal soorten, waarvan C. linncaei, C. tesselata, C. multimaculata, C. reticulata hier mogen worden genoemd, hier en daar zeer algemeen worden aangetroffen. Daarentegen ziet men de inlanders en zelfs kleine kinderen wel eens op de meest roekelooze wijze omgaan met de zeer vergiftige Bungarussoorten (Bungarus fusciatus, mal. oelar welang, en Bungarus candidus, mal. oelar weling), die ze zonder eenige voorzorgsmaatregelen in de hand ronddragen, niet bedenkend, dat een onverwachte en ook onberekenbare verstoring ran het phlegmatieke temperament dezer dieren hun een weinig minder dan doodelijke beet kan bezorgen. Ook deze giftslangen leven in het verborgene en richten zich een verblijf in onder steenen, onder de vloeren ran woningen, stallingen enz., waar men in den regel ook eieren of jonge exemplaren kan aantreffen.

Een andere, in dit gebied niet zeldzame giftslang, rooral gevaarlijk, omdat zij een aggressief karakter heeft, is Naja tripudians, var. sputatrix, een nauwe rerwant van de Britsch-Indische Cobra, waarmede 
zij in harr gedragingen groote overeenkomst rertoont. Het hoog oprichten ran het roorste gedeelte van het lichaam, het lepelvormig verbreeden van het halsgedeelte. waaraan de inlandsche naam oelar sendoq is ontleend, het spuwen roordat zij tot den eigenlijken aanral orergaat, doet zij geheel op dezelfde wijze. TTanneer zij zich gaarne verschuilt onder en achter allerlei roorwerpen, geschiedt dit zeer zeker niet uit rrees, maar alleen om in een rustig hoekje te kunnen slapen en de opgenomen spijs te verteren.

Tan eene, roor een slang zeer levendige natuur is Zamenis korros (mal. o. korros); deze soort, die een tamelijk rechtlustige natuur heeft, maar waarvan de beet niet zeer gevaarlijk is, is gedurende den geheelen dag in de weer en ontziet zich soms niet om op klaarlichten dag een tamelijk druk beganen en bereden weg over te steken, wairbij zij, ingeval ze zich achtervolgd meent, spoedig met een vluggren sprong in het troebele water eener naburige leiding weet te rerdwijnen. Doet zij hetzelfde gedurende de duisternis, dan gebeurt het wel eens, dat ze wordt orerreden. Het is, althans in Buitenzorg, volstrekt geen zeldzaamheid, dat men de, aan de groote, geelachtige buikschilden en de groote oogen gemakkelijk herkenbare overblijfselen van deze slang des morgens op den weg aantreft.

Ly:odon aulicus en Lycodon subcinctus zijn eveneens niet zeldzaam; de laatste wordt niet zelden aangezien voor een Bungarus-soort, maar de witte banden zijn bij deze soort veel minder ontwikkeld, althans bij de oudere individuen. Van de jongen moet worden erkend, dat zij door hun voorkomen alle aanleiding geren tot de zooeven genoemde vergissing. 
Van de Coluber-soorten is de fraaie, groene Coluber oxycephalus (mal. o. boengkia laoet) zeer algemeen. Zelfs in de onmiddellijke nabijheid der woningen ziet men haar soms door de boomen glijden, op jacht naar rogels, waarop zij bijzonder belust is. Op eenigen afstand is zij licht te verwarren met Dendrophis pictus (mal. oeiar tambang), een slang van zeer onverschillige natuur, die een zekere voorliefde schijnt te hebben voor het stekeldraad van omheiningen. Ik nam ten minste deze soort dikwijls waar, terwijl zij zich met zeer lange windingen daaromheen had geslagen en in die houding rustig van den zonneschijn genoot. De nabijheid van meṇschen schijnt haar daarbij niet in het minst te deren en zij laat zich rustig van alle kanten bezien, zonder eenige pogingen tot vluchten of zich verdedigen in het werk te stellen. De genoemde Coluber oxycephalus is minder onverschillig ten aanzien ran den mensch, doch men moet haar al in hevige mate irriteeren, roordat zij hare gevechtspositie inneemt. Gaat zij eindelijk daartoe over, dan strekt zij het grootste gedeelte ran het lichaam recht naar voren, slechts de halsstreek een weinig terzijde gebogen. Daarbij rekt zij het lichaam in het mediane rlak zoodanig uit, dat het sabelrormig wordt en, door het van elkander verwijderd geraken van de schilden, de huid schitterend azuurblauw doorschijnt.

Een tweede, dikwijls voorkomende soort van dit geslacht is Coluber melanurus (mal. oelar babi), die zich meer nabij den grond ophoudt, evenals de Tropidonotus-soorten, waarvan er niet minder dan vier, namelijk trianguligerus (mal. oelar tjahe), vittatus (nal. oelar kisik), subminiatus (mal. oelar pitjoeng) en quin- 
cunciatus, tot de fauna van dit gebied behooren, laatstgenoemde echter hoofdzakelijk in lagere streken.

Een boomslang bij uitnemdheid daarentegen is Dryophis prasinus (in Buitenzorg oraj gadoeng), die in den rusttoestand op de bovendeelen en langs de flanken egaal groen is. Zoodra hij echter in de eene of andere emotie komt, zet het lichaam zich op en komen er tusschen de uiteenwijkende schilden donkere, ge broken dwarsstrepen voor den dag. Ditzelfde is ook het geval, wanneer hij een prooi van eenigen omvang heeft doorgeslikt; er komen dan, ter hoogte van den opgezetten slokdarm, zulke donkere, geheel zwarte strepen te voorschijn, dat men het dier van zooeven bijna niet herkent.

Ook Dipsadomorphus dendrophilus(soend. o. taliwangsa of 0 . santja manoek) leeft op de boomen, hoofdzakelijk van de jacht op vogels. Deze fraaie slang, die, trots zijn helder gele ringen op het donkergrijze lichaam, minder gemakkelijk in het oog valt, dan men zou vermoeden, wanneer men haar buiten haar natuurlijke omgeving ziet, is niet zoo algemeen als de vorige soort, maar toch in geenen deele zeldzaam. Hetzəlfde geldt, maar meer voor iets hoogere streken (1000-3000 voet), voor Dipsadomorphus multimaculatus, (soend. oraj bedoedak) die, aanzienlijk minder fraai dan $D$. dendrophilus, tot de, voornamelijk op den grond levende vormen behoort.

Noemen wij thans nog de algemeene Homalopsis buccuta (mal. oelar kadoet), waarvan de jonge individuen weder geheel in voorkomen van de oudere afwijken, en het kleine giftslangetje Doliophis intestina- 
lis, dat merkwaardig is om de, naar verhouding tot de grootte van het lichaam, reusachtige giftklieren en gemakkelijk herkenbaar aan den, van onderen karmijnrooden staart, waaraan het den inlandschen naam oelar tjabeh heeft te danken, dạn zijn hiermede de roornaamste vormen opgesomd, die in dit gebied voorkomen. Men stelle zich echter erenmin voor, dat men er niet nog andere kan ontmoeten, als dat de genoemde vormen steeds aanwezig zijn. Veel hangt hier af van de omgering; waarin de plaats van waal'neming is gelegen en rantwaar rooral de rondzwervende rormen gemakkelijk naar de nabijheid van den mensch kunnen rerdwalen. Echter moet, met betrekling tot dit rondzwerren, weder de restrictie worden gemaakt. dat het zich beperkt tot een bepaalde categorie ran gebieden en dat bijvoorbeeld een sawahslang zich nooit rer ran de bevloeide velden, noch een boschslang ver buiten de sfeer van de beschuttende wildernis zal vertwijderen.

Daar Salamander's nog niet van Jara bekend zijn en ran de Blindwormen mij slechts één Javaansch exemplaar van Ichthyophis glutinosa, zonder nadere opgave van herkomst dan Soerabaja, bekend is, komen van de Tweeslachtige Dieren slechts de Butrachia voor een nadere beschouwing in aanmerking.

Het laat zich hooren, dat deze in een zoo waterrijk land als Java goed zijn vertegenwoordigd, zoowel naar het aantal der soorten als naar dat der individuen. De verzameling van het Zoölogisch Museum alhier telt reeds 26 soorten van Kikrorschen en Padden en het is niet onwaarschijnlijk, dat er door 
verdere onderzoekingen nog meer zullen worden geronden.

Van de rormen, die ook in de grootere steden roorkomen, moeten in de eerste plats een drietal Padden worden genoemd: Bufo melanostictus. Bufo asper en Bufo biporeutus. Van deze drie schijnt de laatste de grootste rerticale rerspreiring te hebben. terwijl de eerste het reelruldigst is aangetroffen in lagere streken en de tweede in streken ran geringe hoogte (in Buitenzorg is zij bijr. hoogst algemeen). In levenswijze komen zij rijwel met elkander orereen en met de menschelijke samenlering staan zij op roet ran volkomen rrede. Tramneer op regenachtige aronden de gerleugelde mieren en de termieten soms bij zwermen in de rerlichte woningen komen, worden ze gerroonlijk gerolgd door een aantal Padden, waaronder soms, rooral van Bufo usper, reusachtige exemplaren, die niet alleen'in de open galerijen, maar ook in de kamers doordringen. Zij laten zich niet rerdrijren, mar keeren telkens terug; zelfs wanneer men ze heeft opgenomen of met den roet een eindreegs op zijde heeft geschoren. Meestal zitten ze onbewegelijk bij een muur, waarlangs de ronddolende, door aanlaking met de lampen reeds half rerongelukte insecten ryeder naar boren trachten te komen en men hoort duidelijk; zúreel maal per minuut, het tikkend geluid ran de uitslaande tong; waarmede de diertjes worden gegrepen. Het aantal ervan, dat wordt rerorberd, is ongeloofelijk en is toch na één etmaal blijkbaal geheel verteerd: want in den regentijd zijn zij des anderen daags, róól het vallen ran de duisternis, reder aanwezig; als wanneel ze zich reeds tijdig rór de stoep rerzamelen, on het ontsteken der lampen af te wachten. 
Van de Rana-soorten komt vooral Rana erythraea in de woningen binnen en trekt aldaar gewoonlijk de aandacht door de geweldige en onberekenbare sprongen, waartoe har lange achterpooten haar in staat stellen. Bij voorkeur houdt zij zich echter buiten op, in den lichtschijn der huizen en doet daar voortdurend haar onmelodisch, krakend geluid hooren, waarmede zij reeds vóór de schemering een aanvang maakt. De overige Rana-soorten van dit gebied mogen zich, evenals de algemeene Oxyglossus lima, een enkele maal in 's menschen woning wagen, haar gewone verblijfplaatsen zijn toch de grasvelden en de omgering van het water. Deze soorten zijn de kleinere Rana limnocharis, de grootere Rana tigrina en de, soms reusachtige afmetingen bereikende Rana macrodon, wier stemgeluid, dat een metaalklank heeft en op grooten afstand hoorbaar is, dikwijls gedurende een groot deel van den nacht wordt vernomen.

De Boomkikvorschen zijn hier vertegenwoordigd door het geslacht Polypedates (Rhacophorus auct.) en wel door de soorten leucomystax en reinwardti, waarvan de laatste in het laagland schijnt te ontbreken, terwijl overigens beide soorten tot hoog in het gebergte naast elkaar voorkomen. Het zijn nachtdieren, die overdag rust houden. Zij zitten dan op bladeren of tegen boomstammen, geheel ineengevouwen en in elkander gedoken, zoodat men niets anders ziet, dan een ovale, groene verhevenheid. Tegen den avond komen ze in beweging en doen dan hun niet onwelluidend geroep hooren, dat aan de, door SiedLecki ${ }^{*}$ ) uitvoerig beschreven paring

*) Biolog. Centralbl. Bd. XXIX, pag. 704. 
voorafgiat. De eieren worden gelegd in eene, tusschen één of meel bladeren hangende, slijmerige, schuimende massa, waarin zich ook de jonge larven eenigen tijd ophouden, roordat ze door den regen naar een volgende verblijfplaats, in het water, worden medeg'espoeld.

De laatste Batrachiër, die van dit gebied moet worden vermeld, is de, aldaar overigens verre van algemeene Callula baleata, van welker levenswijze nog slechts weinig bekend is. Wellicht is zij niet zeldzaam, maar houdt zij zich in moeielijk toegankelijke plaatsen op, vanwaar zij nu en dan in de nabijheid van den mensch terecht komt. Een verwante vorm, Callula pulchra, is te Singapore zeer algemeen en aldaar geheel in de cultuurfauna overgegaan. Op dit kleine eiland moest, toen de mensch het in beslag nam, een keus worden gedaan tusschen dien overgang en rerdwijnen; blijkbaar hebben de dieren het eerste gekozen en, als men des nachts te Singapore hun aanhoudend geroep hoort, krijgt men den indruk, dat zij zich daarbij zeer wel hebben beronden. Koint de Javaansche soort in levenswijze met de laatstgenoemde overeen, dan voedt zij zich het liefst met termieten, die zij des nachts al rondklimmende op dood hout bemachtigt. VAN KAupen nam bij Callula baleata waar, dat zij, als ze zich bedreigd acht, zich opblaast, waardoor de geelroode teekeningen op kop en roorste gedeelte van het lichaam duidelijker aan den clag treden. 


\section{HOOFDSTUK V.}

\section{De Diervormen der grootere plaatsen.}

\section{(Vervolg)}

Waar het bij de Gewervelde Dieren mogelijk was, een tamelijk rolledig orerzicht ran de, in dit gebied roorkomende rormen te geren en waar dit ook voor andere gebieden mogelijk zal blijken, zal bij de Ongewervelde Dieren, en in het bijzonder bij de Arthropoden, uit den aard der zaak ran een dergelijke mate van rolledigheid moeten worden afgezien. TTij zullen ons, zoowel hier als later, moeten beperken tot het aangeven der hoofdtrekken en het met name noemen ran de meer op den roorgrond tredende soorten en g'eslachten.

\section{Ixsectex.}

1. Orthoptera.

$\mathrm{Er}$ is geen orde ran Insecten, die zich, in de menschelijke samenlering op Java, zóó op rerschillende wijzen op clen voorgrond dringt als die der orthoptera. Men denkt hierbij natuurlijk in de eerste plaats aan de Blattidae (Kakkerlakken), clie alom aanwezige plaaggeesten, clie geen enkel voorwerp onaangeroerd 
kunnen laten, dat eenige orginische stof bevat, en dikwijls in de ongeloofelijkste schuilhoeken een bestaan leiden, dat weinig beter is dan dat van een minimumlijcler. Het zijn vooral Blatta mientulis, de ongevleugelde Blatta rhombifolir en Periplaneta anstralasicue, die de Europeesche woningen bewonen en daar door het knagen aan allerlei voorwerpen schadelijk en lastig worden, daargelaten nog, dat zij ook den mensch in zijn slaap wel eens bijten en wondjes veroorzaken, die zeer moeielijk genezen, omdat hunne monddeelen in den reg'el door de aanklerende microben infectie veroorzaken.

De eieren, ten getale ran $12-20$ rereenigd tot de welbekende, handtaschrormige pakketten, worden in allerlei verborgen hoeken gedeponeerd. Toch zijn er. parasieten, en wel verschillende soorten ran het Vespengeslacht Evania, die ze aldaar weten op te sporen en hunne eieren in die der Blattiden leggen. Vandaar dat men die Evania's, voolal Evania appendigaster, dikwijls binnenshuis aantreft. overal zoekend en het zonderling aangéhechte, kleine en, van terzijde gezien driehoekige, abdomen roortdurend zenuwachtig bewegend.

De Forficulidae (Oorwormen) komen weinig in de huizen roor, aangezien ze daarbuiten alle voorwaarden roor een ruim bestaan aanwezig vinden. Men treft ze aan onder steenen, onder loslatende stukken boomschors, in plantaardigen detritus, in het algemeen overal, waar de omstandigheden gunstig zijn voor de ontwikkeling van kleine, veelal weekhuidige insecten, die hun tot roedsel strekken. Ze komen echter ook op plaatsen voor, waar humne aanwezigheid een andere oolzaak moet hebben. Zoo trof ik 
eens bij honderd, wellicht bij duizendtallen en in alle toestanden ran ontwikkeling eene Forficulasoort aan in de reusachtige vruchtkolven van een gevelden oliepalm (Elaeis guineensis), waar zij zich tusschen de dicht opeengedrongen rruchten schuil hielden en eerst mijne aandacht trokken, toen ze, na het invallen van de schemering; als een glinsterende, wriemelende massa de geheele, kolf bedekten en weder onmiddellijk verdwenen, toen ik eenig licht ontstak om te zien, wat er eigenlijk gaande was.

Het verdient weder de aandacht, dat de vormen van Oorwormen, die in dit gebied voorkomen, en in het algemeen zij, die in de cultuurfauna zijn overgegaan, zich kenmerken door eenvoud van voorkomen. Voor het meerendeel behoorend tot de geslachten Forficula. Psalis, Labia en dgl., munten zij noch door in het oog rallende teekeningen, noch door bijzondere ontwikkeling van de forceps uit. De meer sierlijke, nu en dan door de ontwikkeling ran het laatstgenoemde orgaan zelfs fantastische vormen behooren geheel of grootendeels tot de boschfauna.

Dit laatste geldt eveneens roor de nog resteerende groepen der Orthoptcra Cursoria, namelijk de Phasmidae en de Mantidae. Terwijl de eerste in dit en aanverwante gebieden geheel ontbreken of hoogstens door enkele eenvoudig gebouwde, kleine, weinig opvallende scorten zijn vertegenwoordigd, vindt men er van de laatste niet meer dan eenige Mantis-soorten (walang nomna, valang sembah), die eveneens de eigenaardigheden missen, waardoor de boschvormen dadelijk als zoodanig zijn te herkennen, en zonder onderscheid een groote gelijkenis vertoonen met de, uit Zuid-Europa welbekende, Mantis religiosa. Twee uit- 
zonderingen worden hier echter gemakkt; de eerste door een der soorten van het hoogst merkivardige geslacht Parutoxodera, dat ongetwijfeld de meest grillig gevormde insecten omvat. Deze soort (cornicollis is verre van alledaagsch, maal de weinige exemplaren, die ik in den loop van vele jaren ervan heb verkregen, zijn alle uit de onmiddellijke omgeving van den mensch afkomstig; één ervan vond ik in mijn tuin te Buitenzorg. Het verdient hierbij afzonderlijke vermelding, dat, roor zooverre ik door eigen waarneming en door naviaag heb kunnen constateeren, deze dieren zich ophouden in de doekoeboomen (Lansium domesticum), hoewel ze, als insectivol'en in het algemeen, ook élders rijkelijk (en wellicht nog beter) in hun onderhoud zouden kunnen voorzien. Neemt men nu in aammerking, dat zij, zooals de ervaring met het zooeven bedoelde exemplaar mij leerde, een meer dan bedriegelijke gelijkenis vertoonen met de steeltjes der vruchttrosjes, die na den vruchtafval nog geruimen tijd aan stammen en takken aanwezig blijven, en dat zelfs de opgedroogde inelksapdruppels en de schubjes, vooral bij de nog ongevleugelde individuen, door witte plekken en aanhangsels op het takrormige abdomen zijn vertegenwoordigd, dan valt het niet te ontkennen, dat hier aanleiding bestaat om te denken aan een, met bewustzijn gebruik maken van een voordeelige gelijkenis.

De tweede der bedoelde uitzonderingen levert een niet minder frappant geval van nabootsing. Zij betreft Hymenopus coronatus, een Mantide, die in den Botanischen 'Tuin alhier niet zeldzaam is en mij ook meermalen ran elders, eveneens in tuinen van Europeesche woningen aangetroffen, werd toegezon- 
den, terwijl zij mij niet van de fauna der wildernis bekend is. Trekt reeds het rolwassen insect door zijn eigenaardig roorkomen, door zijn teere, geelwitte tint met eenige weinige, groenachtig bruine teekeningen en door de rliesrormige rerbreedingen aan het trveede en het derde paar pooten in hooge mate de aandacht, reel merkwaardiger nog is het roorkomen der larren, die terecht den naam ran wandelende bloemen mogen dragen. Wanneer zij de eieren rerlaten, die. zooals bij de Nantiden gewonnte is, in grooten getale tot een ronde, bruine, sponsachtige massa rereenigd. rondom dume takjes of tegen bladeren worden gelegd, zijn de jonge dieren alle geheel gelijkvormig gekleurd, helderrood op het lichaam, metaalachtig blaur op den kop en, gedeeltelijk, op de pooten. Spoedig verspreiden zij zich. Een groot aantil gaat natuurlijk te gronde: de orerige slagen erin, planten, reelal heesters of lage boomen, te bereiken, die rooltdurend bloeien $\Theta n$ bij welker inflorescenties zij zich nu restigen. Hunne bizarre gedaante herinnert na elke rervelling meer aan die eener bloem, raarbij het abdomen, dat opwaarts gebogen wordt gedragen, geheel het roorkomen krijgt ran het labellum van sommige Orchideeën. Om nu het bedrog rolkomen te maken, nemen zij geheel de kleur aan ran de bloemen, te midden warrvan ze leven: ze zijn wit, geel, rose of blauw al naar gelang ran humne omgering en worden volkomen orer het hoofd gezien. wat hun ongetwijfeld ran roordeel moet zijn tegenorer Honigzuigers, Aegithina's, Meezen en dergelijke insecteneters, die lenig en licht genoeg zijn om hun op de bloemtrossen concurrentie aan te doen en hen stellig niet zouden sparen, als ze ontdekt werden. 
Tegenorer deze, in onze schatting rrijwel rol. miakte bescherming maakt het een zonderlingen indruk, dat de rolwassen dieren, waarop het ten slotte roor de instandhouding der soort het meest aankomt. wederom alle wit zijn en horendien zeer Ireinig moeite doen om zich te verbergen of op andere wijze onopgemerkt te blijren.

Van de Orthoptern Saltatoria behoeven roor dit gebied de Acrididae (Veldsprinkhanen) slechts rluchtig te worden rermeld. TTel is raar komen ze er in groot aantal en in rele soorten roor. maar geen ran deze trekt in bijzondere mate de aandacht. In het gras, op kruiden en heesters. treft men ze overal aan. de kleinere (xya's en Attractomorpha's, de grootere Mastax-en Tryxalis-soorten. hier en daar zelfs een ran elder's rerdwaalde Acridium, maar het eigenlijke gebied dezer dieren ligt buiten. waar wij ze later, in de relden, zullen ontmoeten. Ook des aronds worlen wij aan hunne aanwezigheid herinnerd, wanneer enkele der kleine. donkerbruine Tetrigidae op het lamplicht afkomen en door hun rerre en krachtige sprongen onze aandacht trekken, mar orer het atgemeen bemerken wij meer ran de groep der $L o$ custidae (Sabelsprinkhanen). Niet alleen. omclat rele, ook van de grootere soorten, door het lamplicht worden aangelokt en soms met reel geraas komen binnenrallen, maar rooral door het geluid, dat ze gedurende de duisternis roortbrengen. Ik denk hier rooral aan de talrijke, dikwijls zeer fraaie soorten met bladvormige roorrleugels, waarran wij het geslacht Pseudophyllus als type mogen noemen. Deze insecten toch, die raak aanzienlijke afmetingen bereiken, hebben het rermogen, door bepaalde inrich- 
tingen an de bases der roorvleugels, zulke krachtige geluiden voort te brengen, dat men bij het hooren ervan aanvankelijk denkt aan een vogel of een nachtelijk zoogdier. Zoodra de duisternis volkomen is, beginnen ze hun eentonig, voor elke soort verschillend geroep, dat veelal onafgebroken doorgaat, totdat het opkomen van de maan of het naderen van den dageraad de duisternis doet verminderen. Een van de meest algemeene soorten huist bij voorkeur in de nangkabboomen (Artocarpus integrifolic), vermoedelijk, omdat zij zich met de blaren ervan voedt en deze soort is zóó gevoelig voor licht, dat men des nachts aan har stemgeluid een ruwe tijdsbepaling kan ontieenen, wanneer men bekend is met het uur van opkomst of ondergang van de maan; men kan bij het hooren ervan met zekerheid zeggen, dat dit uur nog niet is angebroken, resp. reecis voorbij is.

Verschillende der kleinere soorten brengen eveneens geluiden voort, maar het is uit den aard der zaak zeer moeielijk, in de duisternis de juiste herkomst ervan na te gaan, daar de meeste plotseling zwijgen, zoodra ze eenig onraad bespeuren.

Ook in verscheidenheid van vormen overtreffen de Locustidae in dit gebied verre de Acrididae; de groep der Conocephalinae in het bijzonder is hier rijk vertegenwoordigd, zooals de vele kleine, hoofdzakelijk in het gras levende soorten kunnen getuigen. Afzonderijke vermelding verdient eindelijk ie niet zeldzame en in roorkomen zeer gespecialiseerde Dehaania femorata, die zich op boomstammen, tusschen de grijze korstmossen ophoudt en waarvan vooral de larven in die omgeving uiterst moeielijk zijn te ontdekken. Want niet alleen werken hier kleur, sculptuur en teekening mede om een groote gelijkenis met 
Lichenen tot stand te brengen, maar het dier weet borendien zijn houding zóó te kiezen, dat van een en ander zoo roordeelig mogelijk wordt gebruik gemaakt. In dit laatste, speciaal in het nagenoeg verborgen houden der pooten en het, tegen een gelijk gekleurden achtergrond rechtlijnig naar roren leggen der sprieten, waardoor deze zoo goed als onzichtbaar worden, hebben de larven der-Sabelsprinkhanen het orer het algemeen zeer rer gebracht. Dit erroer ik o.a. eens aan die ran een der grootere, groene soorten, die op het abdomen eenige fraaie, gele en blauwe teekeningen vertoonde en zich, met behulp van uitgroeiingen en plooien op romp en pooten, op de hoofdnerf ran een blad van Ficus clastica zoodanig wist roor te doen, dat ik haar een oogenblik hield voor de rups ran Setora (Miresa) nitens, een ran de insekten, die men. om hun gerveldig werkende brandharen; liever uit den weg gaat.

Aan het nachtelijk concert, dat in dit gebied den bewoner evenmin hespaard blijft als hem, die in een vrijere omgering woont, nemen, zooals begrijpelijk is, ook de Gryllidae een lerendig aandeel. IJen kan daarbij rerschillende soorten als Gryllidae herkennen aan de omstandigheid, dat, hetgeen ze doen hooren, niet is een één- of meersylbig geroep, maar een, soms constante, soms rijzende en dalende toon, die dikwijls uren achtereen wordt roortgebracht. Ook zijn er, nar het mij voorkomt. soorten bij, welker toon zóó hoog stijgt, dat het geluid gedurende eenigen tijd voor het menschelijk oor onhoorbaar wordt, om daarna weder in te rallen op de hoogte, waarop het schijnbaar ophield. Bijzonder zwaal van klank, in aanmerking genomen de geringe afmetingen ran het insect, waardoor het wordt roort- 
gebracht, is het geluid van de zeer algemeene Veenmol Gryllotalpa africana (andjing tanah, gaüng), die zich niet zelden in de bloempotten der sierplanten, ook binnenshuis, ophoudt. Gelukkig duurt het niet lang en wordt het des nachts slechts een enkele maal even remomen; het weerklinkt bijna uitsluitend in de arondschemering en duurt dan 10, hoogstens $1.5 \mathrm{mi-}$ buten, waarna de dieren hun arondzang eindigen en uitgaan op roedsel of op arontum.

Overdag ziet men ran de Krekels niet reel meer dan de sporen van hun schadelijke, nachtelijke werkzaamheid, die zich in dit gebied vooral op jonge bloemperken openbaart. Daar worden de plantjes, reelal onder aim den stengel, aan-en doorgerreten, zoodat ze des morgens verwelkt ter aarde liggen: de grootere krekels, rooral Brachytrupes achatimus, trachten ze borendien nog mede te sleepen naar hun onderaardsch rerblijf, maar dit gelukt hun in den regel slechts ten deele en le plantjes. die in de ingangen daarTan blijren steken en niet verder naar binnen kunnen worden getrokken, wijzen dan terens de plaats aan, waal zich de schuldige ophoudt.

\section{Neuropteru.}

De insectengroepen, die rroeger tot de Orde der Touroptera werden rereenigd, eene rangschikking; die wij hier gemakshalve zullen blijren rolgen, spelen, met uitzondering ran de Termieten, in dit gebied een tamelijk ondergeschikte rol. Intusschen moet worden erkend, dat het ontzettend groote aantal Odonata, dat men gedurende den geheelen dag allerwege kan waarnemen, niet nalaat de aandacht 
te trektien, rooral ran den nieuw aangekomene, die de Glazenmaker's slechts kent als een zomersche verschijning van niet meer dan middelmatige getalsterkte. Terwijl de fraaiere en meer delicate vormen van deze, op Java zeel vormenrijke groep aan hun oute omgering. het bosch en de heldere bergstroompjes, zijn getrouw gebleren, zijn het ook hier weder de, naar uitwendiş voorkomen eenvoudige soorten, die naar de cultuurfauna zijn orergegaan en aldaar, zoowel in den larvalen, als in den volwassen toestand, hun roofbedrijf uitoefenen. Zij hebben zich hier vermeerderd tot een getalsterkte, die kwalijk in cijfers zou zijn weer te geven en op hare beurt eenig inzicht geeft in den ongeloofelijken rijkdom der tropische natum an kleinere, veelal tweevleugelige insecten, die vool dit heirleger als voedsel moeten dienen. Edoch, al zweven ook de Libellen boven wegen en tuinen, al lust er een op elk blaadje en takje, dat rrij uitzicht geeft op de omgeving (noemen we ook nog de draden van telegraaf en telefoon als een geliefkoosde zitplaats), hun bakermat is elders, op het bevloeide rijstreld, waar wij later nog op deze, oeconomisch en hygiënisch zeer belangrijke dieren telugkomen.

Bij de verwante Myrmeleontidae, de zoogenaamde mierenleeuwen, zien wij juist het omgeleerde: want hier zijn liet de larven, die in dit gebied de aandacht trekken, terwijl de imagines betrekkelijk zelden worden gezien, omdat zij voor het meerendeel nachtdieren zijn, die slechts bij uitzondering; bijv. wanneer ze door zware regens worden opgejaagd, in de verlichte woningen binnenkomen. Deze larven, die voor het aanleggen van hun valkuilen volmaakt drogen, 
zeer fijn rerdeelden grond noodig hebben, vinden een uitnemende verblijfplaats, vooreerst in de ruimten onder de huizen, wanneer deze, zooals vroeger veelal placht te gebeuren, een paar roet boven den grond zijn gebouwd en op steenen zuiltjes of bogen rusten, in de tweede plaats onder de breede afdaken. Dat verblijf wordt nog geperfectionneerd door den mensch, die ter bevestiging en om, op hellend terein, den grond bij elkaar te houden, op deze plekken gewoonlijk van kiezelsteenen ter grootte van een ei een soort van bestrating maakt, waarbij natuurlijk de ruimten tusschen de steenen den insecten een rerblijf aanbieden, dat reeds ten halve voor hen is gereed gemaakt. Men vindt ze daar in grooten getale en het maakt dikwijls een spel nit voor de inlandsche jeugd, de vechtlustige dieren in een stukje stroo te doen bijten en ze alsdan voor den dag te halen; een tijdverdrijf, waaraan nu en dan ook commerciëele overwegingen ten grondslag liggen, aangezien de larven der Myrmeleon's hier en daar worden opgekocht door Chineezen, op wier lange lijst van geneesmiddelen ze voor een, mij niet nader bekend doel een plaats innemen.

Terwijl wij de Psocidae (Houtluizen), die hier geen grooter rol spelen dan elder's, stilzwijgend kumnen voorbijgaan en slechts terloops melding behoeven te maken van de Ephemeridae, die des avonds dikwijls in rrij grooten getale komen binnenvliegen, moeten eenige woorden worden gewijd aan de Termitidae, die, zooals algemeen bekend is, in de warme streken gewoonlijk tot de ernstigste plagen behooren. Hoewel men zich, wat Java betreft, van hun optreden geen te ernstige voorstellingen moet maken, staat 
het toch vast, dat ze rijivel overal in den bodem aanwezig zijn en ook oreral roor den dag komen, waal iets van hunne gading is te vinden. Hun speurzintuigen moeten van bijzondere scherpte zijn. Het komt bijr. voor, dat voorwerpen in een kast van djatihout (Tectona grandis, een der weinige houtsoorten, die niet door hen worden aangetast), waarvan de planken niet geheel aan elkander sluiten, plotseling zijn aangetast, terwijl den rorigen dag nog niets van Termieten viel te bespeuren. De dieren hebben derhalve die bepaalde voorwerpen, trots de wanden van de kast en trots de grondlaag, waaronder ze zich beronden, moeten ruiken. Zijn er in zulk een geval geen vaste voorwerpen roor het aanleggen van een orerdekten verbindingsweg in den vorm van een aarden tunnel, dan bouwen ze eenroudig adrden buizen, bijr. van, de muur naar den achterwand van de kast. Dergelijke buizen storten niet zelden door hum eigen gervicht in, vóordat het eindpunt is bereikt, maar de onvermoeide dieren vatten onmiddellijk het werk weder op en rusten in den regel niet, voordat het is voltooid.

Een merkwaardig staaltje van hum overleg is het volgende, dat in dit verband een plaats moge vinden, hoewel het ons in een geheel ander gebied rerplaatst.

Gezonde, krachtige planten worden, zoolang el' ander roedsel is te vinden, niet door Termieten aangetast. Dringt hen echter de honger, dan knagen zij die planten aan den wortelhals door, zoodat deze op den grond vallen, laten ze een paar dagen liggen en verklaren ze alsdan roor goede buit. Op deze wijze traden ze eens op in een gedeelte van een jonge thee-aanplanting, waar een rrij schrale bodem bovendien geheel van onkruid was gezuiverd, zoodat 
er voor hen geen ander voedsel aanwezig was. De beheerder trachtte toen dit aanrreten te beletten, door de stammetjes, die ongeveer 1 centimeter doorsnede hadden, nabij den wortelhals over een lengte van circa 5 centimeter in te smeren met een mengsel ran teer en ret. Dit middel hielp echter weinig; want de vindingrijke insecten bourden eenvoudig uit den omringenden grond, onder een hoek ran ongeveer $60^{\circ}$, hun aarden buizen naar dat gedeelte der stammetjes, dat boren het ingesmeerde gedeelte lag, en knaagden ze dáál door.

Over het uitrliegen ran de gevleugelde, geslachtsrijpe dieren werd vroeger (bladz. 73) reeds gesproken naar aanleiding van de aanzienlijke bijdrage, die dit verschijnsel levert in de voeding ran vleermuizen en vele soorten van vogels en wij merkten toen reeds op, dat, vooral wanneer dit uitvliegen róor het invallen van de schemering geschiedt, slechts een fractie van de dieren, soms zelfs geen enkel humner, aan de verrolging ontkomt. Dit is orerigens ook. maar zeer gelukkig, want de rraag ligt roor, de hand: wat zou er van Jara worden, wanneer eens een aanzienlijk percentage van die talrijke dieren erin slaagde, nieuwe maatschappijen te stichten? Men kan hoogstens eenige deernis geroelen met de talrijke arbeidsters en soldaten, die bedrijvig rondloopen op de plek, wasil het nest werd geopend om de imagines wit te laten en die daarbij voor een oogenblik hunne lichtschuwheid afleggen. Voor deze, die eenigszins den indruk maken van zeer bezorgde bruidsjonkers en bruidsjuffers, moet het een hard ding zijn, dat de voorwerpen hunner langdurige zorgen zoo meedoogenloos worden vervolgd en opge- 
geten, maar, bij de afwezigheid ran een gezichtsorgaan. blijft de aanblik daalvan hun bespaard en, als ze straks het nest weder sluiten, rragen nieuwe werkzaamheden humne aandacht.

Tot die werkzamheden moet ook worden gerekend de zorg' roor de talrijke gasten, die een 'Termietenkolonie herbergt en waarorer de onderzoekingen ran WAssmaxr reel licht hebben verspreid. In lioever'e het resblijf ran die gasten in de kolonie een rrijwillig karakter draagt, of in hoeverre het weinig anders is dan gerangenschap, is ran de meeste termitophiele insecten moeielijk te zeggen: zeker is het, dat sommige, rooral de Paussidcue, ran de, door het uitrliegen der imagines reroorzaakte rerwarring gebruik maken om ereneens het nest te rerlaten.

De buitengewone getalsterkte en de algemeene rerspreiding der 'Termieten rinden ongetwijfeld roor' een groot deel hare rerklaring in de omstandigheid, dat zij, zoolang ze maar onder den grond blijren, zoo goed als geen naturulijke rijanden hebben. In de borenste lagen van den bodem zijn ze nog bereik. baar roor rogels en andere, gewervelde insecteneters, doch daarbeneden zijn ze geheel reilig. De eenige, mij bekend geworden, naturrlijke rijand is een plantaardige; het is een Cordyceps-soort, die niet zelclen in de nesten optreedt en wel op die plaatsen, waar de aanstaande imagines de laatste phasen humner ontwikkeling doorbrengen. Soldaten en arbeidsters tast zij niet aan. Zij doodt de nvmfen in grooten getale en rormt daarna een dik-draadvormig mycelium, clat zeer lang kan worden. De gezamenlijke mycelia romen dan met de lichamen der gestorven dieren een dicht kluwen, dat in zijn 
geheel uit het nest kan worden genomen. Zij komen in uiterlijk geheel overeen met de wortels van grootere grassoorten, in het bijzonder van Imperata arundinacea, de als onkruid zeer gevreesde en moeielijk uitteroeien alang-alang, en hebben daarom bij de inlanders aanleiding gegeven tot de tamelijk algemeen verspreide meening, dat deze grassoort haar oorsprong neemt in de nesten van de Termieten.

\section{Rhynchota.}

De Rhynchota spelen in dit gebied eveneens een niet meer dan bescheiden rol, hoewel het aantal soorten, dat men er zou kunnen bijeenbrengen, rrij aanzienlijk is. Zoo zijn de verschillende Citrus-soorten, die alom in de tuinen worden aangetroffen en aldaar om de vruchten worden gekweekt, een geliefkoosde verblijfplaats voor allerlei Schildluizen, die zoowel op de bladeren en de jonge takken, als op de vruchten in groote verscheidenheid zijn te vinden en een besliste voorliefde aan den dag leggen voor deze, aan aetherische olieën ongemeen rijke planten. Zoo komen voorts de vruchten van de ramboetan (Nephelium lappaceum) zelden op tafel, zonder dat men tusschen de harige aanhangsels een aantal Coccidcue van het geslacht Dactylopius (veelal D. adonidum en $D$. longrfilis) kan aantreffen, welke parasieten eveneens zelden op de vruchten van de zuurzak (Anona muricata) ontbreken en bovendien dikwijls een ware plaag worden voor de algemeen als sierplarften gekweekte Adiantum-soorten. 
Dat, zoowel hier, als op Java in het algemeen, de Aphidae (Bladluizen) in vergelijking met de Schildluizen zulk een ondergeschikte rol spelen, moet on. getwijfeld worden toegeschreven aan de zware slagregens, die in deze streken roorkomen. Zelfs rozestruiken, die in de gematigde luchtstreken zelden zonder deze teere parasieten worden aangetroffen, zijn hier gewoonlijk rrij erran, wanneer ze maar geheel in de open lucht staan. Plaatst men de planten echter onder de beschutting ran een afdak, dan treden Bladluizen in den regel spoedig op, zooals men ook kan warmemen bij de, toevallig tegen den regen beschutte deelen van verschillende, om de bloemen aangekweekte slingerplanten als Porana volubilis, Antigonum's, Ipomoea's e.a.

De Homoptera geven het meest ran hunne aanwezigheid blijk door de luidruchtige, dikwijls hinderlijke wijze, waarop zij door de Cicaden (mal. tongèrret) zijn vertegenwoordigd in het samenstel van geluiden, dat de arondschemering te hooren geeft. $O p$ eenigen afstand nog dragelijk; is het geluid dezer insecten, van nabij gehoord, soms een marteling voor de ooren. De soort, die men in dit gebied aantreft en die zich in geboomte ran middelbare hoogte ophoudt, is Iundubia mannifera; haar geroep, dat men op regenachtige namiddagen reeds tegen vier uur verneemt, herinnert aan een herig piepend kruiwagenwiel. Zij laat het langen tijd achter elkaar hooren en zwijgt slecht nu en dan eenige oogenblikken, om nieuwe krachten te verzamelen. Later op den avond komen de Dundubia's dikwijls op het lamplicht af en kenmerken zich dan door de wilde, 
onbesuisde vlucht, waarmede ze in volle vaart tegen alles aanvliegen.

Kleinere Homoptera van de familie der Fulgoridae en van die der Jussidxe zijn des avonds eveneens zeer gewone, nagenoeg dagelijksche verschijningen in de verlichte huizen. Niet zelden komen ze in talrijke zwermen binnenvliegen, die nu eens uit individuen van dezelfde soort, dan weder uit talrijke soorten bestaan, maar steeds in hooge mate hinderlijk zijn. Veelal zijn ze door den regen opgejaagd uit het gras en andere, laaggroeiende planten, waar men ze overdag in groote verscheidenheid kan aantreffen.

Iet een enkel woord moet eindelijk melding worden gemaakt ran de familie der Membracidae, in het bijzonder van het geslacht Centrotus, dat in dit gebied rooral door de soorten $C$. (Leptobelus) dama en C. cornutus is vertegenwoordigd. Merkwaardig is, dat deze, door den grilligen vorm van het pronotum zeer in het oog vallende insecten een groote roorliefde hebben voor de snelgroeiende ranken van slingerende en klimmende planten in het algemeen, terwijl de overige eigenschappen dier planten hun tamelijk onverschillig zijn. Zoo vindt men ze zoowel op de ranken van Gnetum als op die ran Aristolochia en ran Ipomaea; de larven zitten daarbij steeds in verschillende stadiën van ontwikkeling opeengehoopt nabij de bases der bladeren, terwijl de volwassen dieren zich rrijer bewegen en, bij een poging om ze te grijpen, in den regel met een sprong zijn rerdwenen.

De Heteroptera zijn, roor zooverre zij in dit ge. bied door optreden in grooten getale de aandacht 
trekken, van andere terreinen afkomstig. In het bijzonder is dit het geval met Loptocorisa acuta, waarvan op pag. 43 reeds werd gesproken, en met sommige Podops-soorten (vooral $P$. vermiculatus). Laatstbedoelde wants, die eveneens op de sarvah's thuis behoort, kan men bijv. te Batavia niet zelden bij duizendtallen aantreffen rondom de groote, electrische booglampen aldaar, door welker licht zij van verre wordt aangelokt. Anclere soorten, zooals $\mathrm{Ne}$ zara viridula, Antestia histrio, Agonoscelis nubila e.a., strekken hun nachtelijke zwerftochten ook wel eens uit tot in het midden der grootere steden, maar dan toch zelden of nooit in zoo grooten getale als de beide eerstgenoemde.

Terwijl de cosmopolitische Cimex lectularius ook hier niet ontbreekt, zijn er twee Roofwantsen, die een enkele maal, als incidenteele parasieten, den mensch aanvallen. De eerste is een der eigenaardige, sterk behaarde, kleine Ptilocerus (Maotys)-soorten, die onder gewone omstandigheden op mij niet nader bekende wijze in vochtige hoeken in haar levensonderhoud voorziet *). Zij is reel zeldzamer dan de tweede, Conorlinus rubrofasciatus, die des avonds dikwijls komt binnenvliegen en met welke ik tweemaal op pijnlijke wijze kennis makte. De eerste maal, toen ik haar nog niet kende, nam ik haar

${ }^{*}$ ) Van Ptilocerus ochraceus werd onlangs door JAcoBson de hoogst merkwaardige levenswijze beschreven (Tijdschrift voor Entomologie, Deel 54, pag. 175). Deze soort heeft aan de buikzijde van den thorax een door haren omringde klieropening, dio door een bepaalde soort van mieren (Dolichoderus bituberculatus) wordt afgelikt. Hot product van do klier oefent op de mieren een bedwelmenden invloed uit en zoodra de mier duidelijke teekenen van bedwelming begint te geven, drukt de wants haar zuigsnuit tusschen de naden van de chitinehuid (dikwijls ook in de inplantingsopening der sprieten) en zuigt dan haar slachtoffer leeg. Niet onwaarschijnlijk voeden ook andere Ptilocerus-soorten zich op dergelijke, perfide wijze. 
tusschen vinger en duim, van welke, ongetivijfeld onvoorzichtige, handelwijze zij gebruik maakte om haar zuigsnuit diep onder den nagel van den duim te doen doordringen. De tweede maal werden mij door een exemplaar, dat toevallig onder het bedgordijn terecht was gekomen, eenige steken in den bovenarm toegebracht, die weken lang hevig gloeiende en jeukende bulten veroorzaakten. Toch schijnt de steek van dit insect minder venijnig te zijn dan die van zijn Amerikaanschen verwant Conorhinus sanguisugus, die langdurig etterende wonden veroorzaakt.

Voegen wij aan het bovenstaande toe, dat in de nabijheid van water dikwijls verschillende kleine Corixidue en Notonectidae in zwermen komen binnenvliegen en dat men ook wel eens een enkele maal wordt opgeschrikt door de groote Belostoma indicum, dan zijn hiermede de voornaamste Rhynchoten genoemd, die in deze omgeving op eene, voor den mensch merkbare wijze optreden.

\section{Diptera.}

Van de Diptera eischen in de eerste plaats de Culicidae een oogenblik de aandacht om de groote rol, die deze insecten hier in de menschelijke samenleving vervullen. Vooral in de kustplaatsen en in het algemeen in alle streken, waar stagneerende wateren voorkomen zonder de dierrormen, die daarin het voor den mensch gewenschte evenwicht bewaren, treden de muggen op als een ware plaag, waaraan, zooals bekend is, de Anopheles-soorten bovendien een gevaarlijk karakter kunnen verleenen. Dit laatste echter alleen in die plaatsen, waar nog niet geheel opgehelderde omstandigheden de ontwikkeling der malaria. 
plasmodiën toelaten. Het is namelijk oprallend, dat plaatsen, waar malaria niet inheemsch is en die zelfs als herstellingsoorden voor lijders aan die ziekte een goeden naam bezitten, zooals Soekaboemi, dikwijls veel rijker zijn aan Anopheles-muggen dan lager gelegen plaatsen (ter vergelijking met Soekaboemi zij hier Buitenzorg genoemd), waar malaria een gewoon verschijnsel is. Daar nu de bloedtemperatuur van den mensch overal dezelfde is, de lichaamstemperatuur der muggen daarentegen zich regelt naar die van de omgeving, zou men geneigd zijn, aan te nemen, dat het gedeelte van den ontwikkelingscyclus der plasmodiën, dat in de muggen en hunne larven wordt afgespeeld, door het koelere klimaat onmogelijk wordt gemaakt. Tegen die onderstelling spreekt echter het feit, clat ook in koelere streken van Java dan het, als voorbeeld gekozen Soekaboemi, malaria voorkomt.

Over het algemeen zijn de Muggen nachtdieren, de Anopheles-en Megarhina-soorten in mindere mate dan die van het geslacht Culex, van welke laatste echter eene overdag rliegende, vooral in de morgenuren dikwijls zeer hinderlijke en aan de zilverwitte ringen op de pooten gemakkelijk herkenbare soort eene uitzondering maakt. Maar in den regel is hun bloedgierigheid zóó groot, lat voor hen, ook orerdag. de gelegenheid den dief maakt.

Naast de Echte Muggen maken ook andere, bloedzuigende Diptera het den mensch hier lastig. In het bijzonder denk ik hier aan de, dikwijls naurvelijks een millimeter groote, insecten, die algemeen onder den inlandschen naam meroetoe bekend staan en waarvan een aantal door De Meijere *) zijn be-

*) Tijdschrift voor Entomologie, Deel 52, pag. 191. 
schreven als soorten van de geslachten Ceratopogon, Phlebotomus, Culicoides e.a. Verschillende van deze parasieten veroorzaken niet alleen een brandend, jeukend gevoel op de bulten, die ze, bij voorkeur op de ooren en de oogleden, doen ontstaan, maar geven ook aanleiding tot het optreden van kleine blaasjes op de huid, die soms nog dagen lang, bij het wasschen en afdrogen, open gaan en waarmede, ter voorkoming van infectie, eenige voorzichtigheid is geboden.

De Tipulidae, op Java in schier elk gebied ruim vertegenwoordigd, trekken ook hier de aandacht, zoowel om de buitengewone afmetingen, die sommige soorten bereiken, als om een eigenaardigheid, die men bij verschillende der kleinere vormen kan waarnemen. Niet zelden toch ziet men, vooral in de morgenuren, een geheele reeks, soms twintig en meer, van deze dieren, als een keten uitgespannen tusschen een paar takjes of een paar andere voorwerpen. Zij hebben elkander dan aan weerszijden met twee pooten vast en vertoonen geen andere beweging, dan door den wind wordt veroorzaakt. Van tijd tot tijd echter begint een van de uiterste dieren, die aan de ééne zijde een behoorlijk houvast heeft, een heen en weer gaande, schommelende beweging op de pooten te maken, welke beweging zich dadelijk voortplant door de geheele rij en geruimen tijd kan aanhouden. Zij is, vooral bij de middelste dieren, zóó krachtig; dat deze zich bepaald stevig aan hunne buren moeten vasthouden, om den keten niet te verbreken. Aanvankelijk meende ik, dat het wellicht juist om dit laatste te doen was, doch daarvoor is zulk een krachtsinspanning niet noodig; want zoodra men één van de rij maar even aanraakt, stuift deze 
in alle richtingen uit elkaar. Eerst dan wordt het duidelijk, dat een dunne spinragdraad als steun roor den keten heeft gediend: de bekentenis moet intusschen worden afgelegd, dat oorzaal en beteekenis van het verschijnsel geheel in het duister liggen.

Een andere merkwardige Tipulide, die men des morgens dikwijls tegen witte muren aantreft, is Limnophila (Conosia) crux. Dit dier onderscheidt zich dool de zeer bijzondere houding, die het in den rusttoestand aanneemt en waaraan, met rolkomen juistheid, zijn soortnaam is ontleend. Wie het insect niet kent, denkt aanrankelijk niet anders, dan dat twee stukjes ran de zwarte rezels ran den arènpalm (Arenga sacharifera), die hier veelvuldig roor het rervardigen ran zachte bezems worden gebruikt, bij het afregen ran den muur tuevallig in gekruisten tcestand daaraan zijn blijren rastzitten.

Terwijl de talrijke soorten van Rouwmugjes, reelal tot het geslacht Sciara behoorend, slechts terloops behoeven te worden genoemd, is de rerwante Plecia fulvicollis, ran de familie der Bibionidae, een geregelde verschijning in dit gebied, gelijk in alle andere, waar opeenhooping ran plantaardigen en dierlijken afval tot de rolming ran mesthoopen aanleiding geeft. De rliegjes komen des avonds af op het lamplicht, raarbij zij door de groote, dofzwarte rleugels en den fraaien, steenrooden prothorax zeer de aandacht trekken. Hunne larven leven in en op de zooeren bedoelde verzamelplaatsen ran afral en zijn gekenmerkt door het bezit van talrijke dikke, haarachtige huidvormingen, tengerolge raarvan zij, naar onjuiste analogie met verschillende andere insecten, de geheel onrerdiende reputatie hebben ran bij aanraking jeuk 
en pijn te reroorzaken. Vooral merkwaardig is bij deze dieien het ongeloofelijke aantal, waarin ze bij elkar roorkomen; ik zag ze meermalen door inlandsch stalpersoneel, dat voor aanraking der larven met hun bloote voeten beducht was, bij geheele bakken vol in een naburige waterleiding werpen of verbranden.

De gerwone Huisvlieg, Musca domestica, ontbreekt op Java in geenen deele en men moet zich eenigszins erover verwonderen, dat in een land, waar gedurende het geheele jaar de voorwarden voor hare vermenigvuldiging zoo gunstig zijn, hare getalsterkte slechts plaatselijk en tijdelijk eenigermate nabij komt aan die, waarin zij zich, gedurende de warme maanden, in de gematigde luchtstreken rertoont. Het is moeielijk na te gaan, wat de oorzaak is van dit verblijdend verschijnsel, maar het vermoeden ligt voor de hand, dat de, aan endoparasieten en insectenetende rormen rijke, tropische natuur aan een numeriek krachtige ontwikkeling der Musca's ernstige belemmeringen in den weg stelt, ja, die hier en daar zelfs geheel onmogelijk maakt. In dit laatste geral worden zij in hare hoedanigheid van huisvlieg door andere vliegen vervangen, die niet eenmaal uit haar naaste verwantschap behoeven te komen; zoo nam ik te Nalang eens waar, dat de genoemde rol werd gespeeld door de Ortaline Stenopterina aenea.

De hier eveneens ruim vertegenwoordigde geslachten Lucilia, Calliphora en dergelijke onderscheiden zich in hunne levenswijze niet door iets anders, dan hetgeen zij ook elders te zien geren; evenmin de Syrphidae, waarvan wij in dit gebied, behalve de zeer algemeene Megaspis erruns, verschillende kleinere Syrphus-soorten opmerken, die, bij 't zich zwevende 
houden in den zonneschijn, door het buitengewoon sterk glinsterende pronotum de aandacht trekken.

Van de Stratiomyidae treden hier het meest op den voorgrond Ephippium bilineatum en Ptiloceru quadridentata, de eerste zeer levendig in hare berre. gingen, de laatste rustig en weinig schuw, als gaf zij den waarnemer gaarne gelegenheid, haar fraaie kleeding te bewonderen. Een dergelijke rust leggen de Tabanussoorten aan den dag, waarran Tabanus rubidus, de meest algemeene, zich dikwijls ook binnenshuis rertoont en soms geheele dagen onbervegelijk op dezelfde plaats blijft zitten. Daarentegen zijn de Tabaniden Chrysops dispar en Chrysops fasciatus veel bewegelijker en geren daarbij de voorkeur aan buitenlucht en zonneschijn.

De Bombylidue en de Asilidae ontbreken in dit gebied weliswaar niet geheel, maar spelen hunne rol toch veel meer elders. Ook de Dolichopodidae zullen wij in andere omgevingen in veel grooter aantal aantreffen dan hier, waar slechts enkele langpootige, metaalachtig glanzende, kleinere Psilopus sool ten orer heesters en bloemen rondrliegen.

Tachinidae komen daarentegen in groot aantal roor, maar hun groote, zij het ook oppervlakkige gelijkenis met de ereneens talrijke, slechts bij nadere beschouwing ran elkander te onderscheiden Muscidae makkt, dat men orer het algemeen wel den indruk krijgt ran de aanwezigheid ran veel "vliegen”, maar dat geen van alle in den regel op dit gedeelte der fauna een bijzonderen stempel drukt. Slechts een paar der grootere Parasietvliegen, zooals Crossocosmiu sericariae en Stilbomyia fuscipenmis, zijn terloops te her- 
kennen, als ze zich voor een oogenblik op een, door de zon verlichte plek nesrzetten, om gewoonlijk dadelijk weer te verdwijnen, welke handelwijze ook door vele Anthumyidae in practijk wordt gebracht.

De Calobatidae zịn dadelijk als een afzonderlijke groep te onderscheiden, waartoe niet alleen het langwerpige lichaam, maar ook de ligging van de vlcugels, op elkaar boven het abdomen, medewerkt. De Nerius-soorten komen plotseling als. uit de lucht neervallen op blaren en bloemen, zitten een tijdlang rustig en verdwijnen dan weder; de Calobata's hebben een veel onrustiger natuur en herinneren, niet alleen in hun uiterlijk, maar ook in hunne manieren, aan Sluipwespen. Die gelijkenis wordt bij de, in dit gebied algemeene Calobata albitarsis in de eerste plaats reroorzaakt door het drukke manoeuvreeren met de voorpooten, op dezelfde wijze, als waarop vele Sluipwespen dat met de sprieten doen, terwijl zij aanzienlijk wordt rerhoogd door de witte tarsen, die den witten band op de sprieten der laatste nabootsen, alsmede door de don. kere vlekken op de vleugels. Merkwaardig is de wijze, waarop de Calobata's drinken ran de kleine waterdruppels, die des morgens op de blaren liggen. Daar zij hoog op de pooten zijn, is het uiteinde van haar monddeelen tamelijk rer verwijderd van het oppervlak, waarop zij zich bewegen en om nu haar snuit daarmede in aanraking te brengen, zakken ze een weinig door op de roorpooten en brengen daardoor het lichaam in een naar roren hellenden stand, een beweging, die ze herhaaldelijk en met zooreel gratie uitvoeren, dat men den indruk krijgt, alsof ze het blad kusten. 
Tot de sierlijkste vliegjes van dit gebied behooren ook de Dacus-soorten, maar deze en vele andere 'Trypetiden zullen wij elders meer in hun element vinden, erenals Celyphus obtectus, die door de enorme ontwikkeling van het blauwe scutellum veel meer den indruk maakt van een wants of zelfs van een kevertje, dan van een vlieg.

Ten slotte zijn voor dit gebied nog de Hippoboscidae en de Nycteribidae te noemen. Van de eerste familie is vooral Olfersia spinifera een even algemeene als lastige vertegenwoordiger, die het hier vooral op de minder behaarde huidgedeelten der paarden heeft voorzien, en elders soms bij dozijnen ook op runderen en andere huisdieren is te vinden. T'erwijl de inlandsche paardenrassen deze vasthoudende parasieten met vrij groote gelatenheid verdragen, vermoedelijk omdat zij een minder teere en gevoelige huid hebben, zijn de van elders (vooral van Australiě) ingevoerde paarden veel minder tegen haar steek bestand en slaan soms als razend om zich heen, wanneer zij den indringer niet op eenige wijze kunnen bereiken en verwijderen.

Van de Nycteribidae bemerkt men uiteraard weinig, verborgen als zij leven tusschen de haren en de veeren der dieren, waarop ze parasiteeren. Zij komen voolal op vleermuizen in grooten getale voor en hebben daardoor aanleiding gegeven tot de fabel, dat deze avondbezoekers onzer woningen op den mensch gemakkelijk een deel hunner parasieten zouden overbrengen. 


\title{
HOOFDSTUK VI.
}

\section{De Diervormen der grootere plaatsen.}

\author{
(Vervolg) \\ D. Insecten (Tervolg).
}

ว. Coleoptera.

De Kevers, die in dit, ten aanżien van den mensch meest geavanceerde gedeelte van de Cultuurfauna worden aangetroffen, zijn vrij talrijk, maar het aantal, dat geheel daarin is overgegaan en niet meer elders wordt aangetroffen, is zeer gering. Verreweg de meeste komen ook in éen of meer andere gedeelten van het cultuurgebied voor. De Cicindelidae ontbreken hier vrijwel geheel: hoogstens treft men op bloeiende heester's een enkele Collyris aan. die zich met groote vlugheid, deels loopend, deels rliegend, daarop beweegt. Ook de Carabidae zijn hoofdzakelijk vertegenwoordigd door een aantal kleinere rormen, waarvan Morio orientalis, Chlaenius bihamatus, MIsscelus unicolor, Acanthogenius distactus en eenige Orthogoniusen Abacetus-soorten mogen worden genoemd, die alle een verborgen levenswijze leiden onder afgerallen blad, onder de gebarsten schors van oude boomen, onder steenen enz., zoodat men ze bepaald moet zoeken, om hunne aanwezigheid te constateeren. Des avonds echter komen de meeste soorten wel 
eens binnenvliegen, evenals een kleine Ophionea-soort, die, zooals haar heldere kleuren reeds doen vermoeden, ook overdag het licht in geenen deele schuwt: Tot de arondgasten behoort verder Pheropsophus javanus, een van de "bombardeerkevers", bij wien het apparaat, waaraan deze laatste naaın is ontleend, tot een zóo krachtige ontwikkeling is gekomen, dat de daarin gevormile, damp rerspreidende, stinkende en bijtende vloeistof tot een afstand ran $.0-3()$ centimeter wordt weggeslingerd. Van alle werkelijke of rermeende verdedigingsmiddelen, waarmede de tropische natuur allerlei insectenvormen heeft toegerust, komt dit apparaat, waarvan Dienckx ${ }^{1}$ ) den bouw en de functie in bijzonderheden heeft nagegaan, mij svel het meest effectief roor: niet alleen om de wijze, waarop het werkt, maar ook, omdat de kevers in den regel een vrij spoedig gebruik ervan maken en daardoor een aanral roorkomen, die, zoo hij eenmaal had plaats gehad, trots de krachtige verdediging roor het dier noodlottige gevolgen zou hebben.

De Dytiscidae, Hydrophilidcue en verwante, kleinere familiën laten zich hiel eveneens slechts des aronds zien, als wanneer zij ran elders komen aanvliegen. Vooral Dineutes australis schijnt zich over vrij aanzienlijke afstanden te kumen verplaatsen. maar noch deze, noch eenige andere soorten ran zeer gewone Waterkevers, die wij later zullen ontmoeten, zijn bij het lamplicht zulke alledaagsche verschijningen als verschillende soorten van Staphyliniden, aan welke detritus-dieren de natuur hier in het algemeen zeer rijk is. El gaat wel geen arond voorbij, waarop

1) Étude comparée des Glandes pygidiennes chez les Carabides et les Dytiscides; "La Cellule”, t. XVI, fasc. 1.

Les Glandes pygidiennes des Coléoptères; ibid. t. XVIII, fasc. 2. 
men niet een of meer soorten van deze familie kan verzamelen. In het algemeen voorzien van pygidiale afscheidingsklieren in den geest van hetgeen zooeven bij Pheropsophus javanus werd vermeld, zijn deze zooveel kleinere kever's echter zonder bezwaar aan te raken, met uitzondering van ééne soort, die afzonderlijk moet worden vermeld. Het is Pasderus peregrinus, die een groote geographische verspreiding heeft over Zuiduostelijk Azië en nu en dan in groote getalsterkte schijnt te trekken. Er is mij een geval bekend geworden, waarbij, in een winderigen nacht, een der vuurtorens nabij de Noordkust van Java plotseling door millioenen van deze diertjes werd bezocht, lie zich weldra in alle localiteiten verspreidden, zeer ten ongerieve van het bewonend personeel. Want deze kleine insecten veroorzaken bij aanraking met de menschelijke huid een kwaadaardigen en moeielijk genezenden uitslag, gevolg van de werking van de stof, die door de, zooeven genoemde klieren wordt afgezonderd. Een dergelijke talrijke invasie heeft zich voorgedaan op eene onderneming in de nabijheid van Djember, in Oost-Java, terwijl een derde geval mij bekend is geworden van Buitenzorg, waar zich onder logés en personeel ran een der hôtels plotseling eene, naar het scheen epidemische huidziekte vertoonde, waarvan de behandelende geneesheer het karakter niet kon vaststellen. Totdat, op zekel oogenblik, een der inlandsche bedienden zijn aandacht vestigde op kleine insecten, die zich, in overigens niet groot aantal, in de plooien der bedgordijnen verscholen hielden en niet anders bleken te zijn dan de hier bedoelde Staphylinide, die gelukkig niet tot de dagelijks voorkomende soorten behoeft te worden gerekend. 
Terwijl over de Paussidae reeds rrneger (pag. 103) met een enkel woord werd gesproken en de Sylphidae in dit gebied geheel ontbreken, kunnen wij een aantal familiën, die nagenoeg uitsluitend kleinere rormen omvatten (Pselaphidae, Scydmacnidae, Scaphididae, Nitidulidae, Cucujidae, Trogositidae, Mycetophagidae, Dermestidae enz.), met stilzwijgen voorbijgaan, aangezien deze dieren zich hier door niets bijzonders onderscheiden, ja, naar het mij voorkomt, in mindere mate dan elders van hunne aanwezigheid doen blijken. Vele soorten erran behooren tot de gasten van mieren en termieten, andere leven in en ran detritus, wederom andere leven van droge voedingsmiddelen. Tot deze laatste categorie behooren verschillende vormen, die door het handelsverkeer cosmopoliet zijn geworden, zooals Trogosita man itanica, Silvamus surinamensis, Carpophiius hemiptrus e.a., terwijl die van beide eerstgenoemde categorieën orel het algemeen sytematisch nog weinig zijn bestudeerd. aangezien het stelselmatig verzamelen erran in den regel vele bezwaren ontmoet. die eerst zullen worden overwonnen, wanneer wellicht in de toekomst specialisten, die orer reel tijd kunnen beschikken, hier hun arbeidskracht in dienst willen stellen ran het onderzoek ran deze en rele dergelijke groepen ran insesten.

Dat in dit gebied, en in de cultuurfauna in het algemeen, de Lucanidae zoo goed als niet zijn rertegenwoordigd, vindt zeer gereedelijk zijne verklaring in de omstandigheid, dat er geen rottend hout aanwezig is, waarin de larven zich zouden kunnen ontwikkelen. De behoefte aan brandmateriaal is in de bewoonde streken zóó groot, dat er roor deze dieren inderdaad geen 
plaats is. Des te rijkelijker daarentegen gedijen er de Coprophaga, daar aanzienlijke hoeveelheden plantaardige en dierlijke afvalstoffen, die als mest zouden gebruikt kunnen worden, dikwijls onbenut blijven liggen en uitnemende kweekplaatsen vormen voor Mestkevers, ook in de grootere plaatsen, die ten slotte toch alom met inlandsche kampongs zijn doorzaaid. Het zijn, met uitzondering ran Catharsius molossus, vooral de middelmatige en de kleinere vormen, die hier voorkomen: Copris sulcicollis en C. punctulatus, Oniticellus tesselatus en O. femoratus, Ontophagus trituber en O. sagittarius, Aphodius marginellus e.a en het is wederom de arond, die ze ons het gemakkelijkst doet ontdekken.

Lag bij de beide laatstgenoemde familiën de oorzaak van het ontbreken, resp. rijkelijk rertegenwoordigd zijn zeer voor de hand, de Cetonidue plaatsen ons voor de, nog onopgeloste rraag; waarom ze niet of hoogstens zeer sporadisch roorkomen in eene omgeving, waarin, te oordeelen naar hunne levenswijze elders, alle voorwaarden roor een behoorlijk bestaan, zoowel van de kever's als van de larren, aanwezig. zijn. Een enkele maal rindt men, gewoonlijk op de bloemen van Crinum en andere, lelie-achtige gewassen, een der eenvoudig gekleurde Glycyphana's of Ifacronota's, maar dan niet meer dan een enkel exemplaar, waaruit men wel mag opmaken, dat men met verdwaalde individuen te doen heeft, omdat Bloemkevers in hun eigenlijke terreinen meestal in grootere of kleinere troepen bij elkander worden aangetroffen.

Temeer verwondert ons deze afwezigheid der $C e$ toniclae, waar twee van de Dynastidae, welker larven een overeenkomstige levenswijze hebben, zich niet 
alleen in het cultuurgebied hebben weten staande te houden, maar er zelfs door hum aantal een rol ran beteekenis spelen. Dit geldt wel het meest roor Oryctes rhinoceros, om zijn later te bespreken levenswijze de Klappertor bij uitnemendheid, die op Jara tot minstens 2000 roet boven zee nergens ontbreekt, waar ook Cocos mucifera is te vinden: in iets mindere mate roor Tylotrupes gideon, waarvan de rolwassen individuen algemeen worden aangetroffen in de kruinen van waaierpalmen, zooals Livistonasoorten, die in de grootere plaatsen allerwege, hier en daar zelfs als lanen, ter versiering zijn aangeplant. Dat het intusschen dezen dieren in hunne jeugd niet altijd erenzeer rór den wind gaat, dat rele zelfs een moeielijken strijd hebben te roeren om den rolwassen toestand te bereiken. blijkt. wel uit de zeer verschillende afmetingen der imagines, waaronder er zijn, dıe niet alleen geheel den indruk maken van prgmaeën, maar bij relke bovendien de aanhangsels ran kop en pronotum, ongetwijfeld hypertelische rormingen, die bij krachtige indiriduen soms een buitengerrone lengte bereiken, zich als niet meer dan rudimenten roordoen: wel een berijs, dat hier gedurende het larvale leven niet ineer clan het allernoodigste materiaal roor de toekomst kon worden bijeengebracht.

Hoerel het eigenlijke ter'ein der Phyllophaga buiten, te midden der culturen, ligt, laten de omstandigheden oreral de ontwikkeling toe, zij het ook in gering aantal, ran talrijke soorten. die daardoor tot de meest alledaagsche insecten behooren. Allerlei Serica's en Apogonia's komen des aronds, ook in de steden, de huizen binnenvliegen: Anomala ypsilon is 
zelfs in dit gebied zeer veelvuldig aan te treffen, Anomala chalcites en Anomxla aerea zijn verre van zeldzaam; hetzelfde geldt van Adoretus umbrosus, Exopholis hypoleusa, Lepidiota stigma, Tricholepis grandis en van verschillende sourten van de geslachten Lachnosterna en Ancylonycha. Deze alle zijn ware cultuurdieren geworden, die elk plekje grond bewonen, dat de mensch hier op de terreinen van zijn meest intensieve samenleving heeft vrijgelaten of voor zijn genoegen als tuin heeft ingericht. Een voorbeeld, dat door verschillende, voor het meerendeel echter kleine Elateridne is gevolgd: Megapenthes- en Melanotus- soorten, Heteroderes malaisianus en Curdiophorus javamus strekken huu verspreidingsgebied eveneens orer de tuinen der steden uit en zelfs de kleine, fraaie Cardiophorus carduelis kan men nu en dan des avonds bij het lamplicht waarnemen.

De Buprestidcue daarentegen nemen tegenover den mensch een meer gereserveerde houding aan. Op zich zelf reeds is het aantal hunner, dat in de cultuurfauna is overgegaan, verre van aanzienlijk en wat daarvan nu en dan in dit gebied voorkomt, bepaalt zich tot Chrysochroa fulminans, die zijn jeugd in weekhoutige Leguminosen doorbrengt, en een enkel exemplaar van. Agrilus armatus, warrvan de levensrijze mij nog niet bekend is.

Een zeer eigenaardig bestandcleel van de keverfauna maken, ook in druk bewoonde buurten, de Malacodermidae uit, voor zooverre zij tot de lichtgevende soorten behooren (Pyrocoelia lateralis, Luciola vittata e.a.). Overdag zitten deze insecten stil, maar nauwelijks is de duisternis goed ingevallen, of ze komen tot actie en het verlichtings-apparaat wordt in werking gesteld. Vooral boven waterleidingen met eenigs- 
zins ruig begroeide randen ziet men ze soms in grooten getale zweven, waarbij het intermitteeren van het licht den eigenardigen indruk nog verhoogt en de intensiteit ervan grootel doet schijnen, dan ze in werkelijkheid is. Een andere Weekhuidige, Horia cephalotes, verdient eveneens vermelding. Men vindt dezen fraaien, rooden kever wel eens op den grond liggen onder de afdaken der huizen, in den eenigszins hulpeloozen toestand van een insect, dat pas uit het pophulsel is te roorschijn gekomen. Zulke exemplaren zijn dan komen vallen uit het houtwerk van het dak en wel uit de groote, ronde gaten, die daarin door de Houtbijen (Yylocopa's) zijn gemaakt. Van deze, op Java trouwe metgezellen van den mensch zijn namelijk de Horia's een veelvuldig roorkomende parasiet, die in een zeer jong stadium weet binnen te dringen in het verblijf der Houtbijlarve, vermoedelijk op het oogenblik, waarop laatstgenoemde, nog in den eitoestand, daarin door de moeder wordt gedeponeerd. Deze lerenswijze verklaart terens de aanwezigheid van de sterke kaken, waarvan Horia cephalotes, geheel in onderscheid met zijn verwanten, is voorzien; want de tusschenschotten, die de Houtbijen aanleggen tusschen de verschillende afdeelingen van het larvale verblijf, worden na het opdrogen zóó hard, dat de gewone mondwerktuigen van deze kevergroep zeer zeker niet in staat zouden zijn, ze door te knagen.

De Tenebrionidae geven, nietteg'enstaande het groote aantal, waarin zij, zoowel in dit gebied, als elders op Java voorkomen, geen aanleiding tot opmerkingen. 'Talrijke soorten ran Uloma (waal'van U. denticomis een der meest gewone is), Cropria, Eucyrtus, Stron- 
gylium en Amarygmus komen algemeen voor en het verdient alleen vermelding, dat men hunne, voor het meerendeel nog onbekende larven zoo zelden aantreft. Wel is waar vindt men hier en daar, vooral op plaatsen, waar, zooals in boorgangen, plantaardige en dierlijke detritus gemengd voorkomen, larven, die ongetwijfeld tot deze familie behooren, maar het opkweeken daarvan vereischt zoovele zorgen, dat ook hier wederom speciale en tijdroorende onderzoekingen zullen noodig zijn, om over deze groep meer licht te verspreiden. De insectenvormen toch, welker levenswijze meer of minder in bijzonderheden is onderzocht, zijn, zooals voor de hand ligt, diegene, die oeconomisch voor den mensch van directe beteekenis zijn. Wat men van de andere weet, bepaalt zich in een land als Java voorshands tot hetgeen, naast het onderzoek van eerstbedoelde, incidenteel kon worden waargenomen en aangeteekend en tot hetgeen op dit gebied werd verricht door de, tot heden slechts weinigen, die een deel van hun vrijen tijd aan het waarnemen der natuur besteedden.

De Bostrychidae, die op Java in het algemeen tegenover de Scolytidae op den achtergrond treden, doen in dit gebied hunne aanwezigheid het best bemerken door het langzame vernielingswerk, waaraan zij zich ten aanzien van verschillende houtsoorten en ran bamboe schuldig maken. Vooral meubilair, dat van elders, veelal uit Europa, is medegebracht en bamboe, die vóor het gebruik niet behoorlijk is uitgeloogd, vallen vroeg of laat ten prooi aan de boeboek, d.w.z. aan de Dinoderus- en Sinoxylon-soorten, die het soms geheel in boormeel en fijne, korrelige excrementen omzetten. Hetzelfde is het geval met vele inlandsche houtsoorten, die, ook bij het 
bouwen der grootere huizen, dikwijls worden gebruikt voor doeleinden, waarbij het op draagkracht of stevigheid minder aankomt.

Ook de cosmopolitische Lasioderma testaceum van de rerwante familie der Ptinidae is hier geen zeldzame rerschijning, heeft het vooral voorzien op sigaren en sigaretten, maar stelt zich, bij gebreke daarvan, ook tevreden met andere gedroogde, plantaardige en zelfs dierlijke producten. In dit opzicht is zij de evenknie van Araeocerus fasciculatus, het zoogenaamde Koffie-Snuitkevertje, eene eveneens vrijwel cosmopolitische Anthribide, die ook alle genoemde stoffen voor lief neemt, wanneer zij haar geliefkoosd voedsel, koffieboonen in voor de markt bereiden toestand, niet kan verkrijgen.

De vormenrijkdom der Jaraansche Curculionidae kan zeker niet worden afgeleid uit de weinige soorten, die men in dit gebied ontmoet. Hier en daar vindt men, knagend aan de randen ran velschillende blaren, Myllocerus isabellinus, Eugnathus viridanus, een Dermatodes-, een Lixus- of een Cleonus-soort; in meer buitenaf gelegen tuinen bovendien nog Apoderus melanopterus en, ofschoon zeldzaam, Attelabus bispinosus, maar daarmede is dan ook rrijwel alles gezegd, terwijl slechts twee soorten zich ook binnenshuis vertoonen. Ééne daarvan is de Rijstklander (Calandra oryzae), de oostersche tegenhanger van Calandra granaria, met welke zij echter roor een deel het verspreidingsgebied gemeen heeft; de tweede is de reeds vroeger (pag. 9) genoemde Cryptor hynchus mangiferae, die in West-Java en een deel van MiddenJava in den regel bij het opensnijden der mangga's te voorschijn komt. 
Met de Cerambycidae is het weinig anders gesteld daar echter het meerendeel der imagines nacht. dieren zijn, die door kunstlicht worden aangelokt, komen de hier aanwezige vormen des avonds wel eens bimnenvliegen. Daardoor kan men het voorkomen constateeren o.a. ran Xystrocera festiva, warvan de larven in weekhoutige Leguminosen, van en Batocera hector; waarvan ze bovendien in de, in dit gebied roor verschillenden doeleinden aangeplante Odina gummifera (kajoe-koeda) leven; van eene Rhytidoder $t$-soort, die ik uit Mangifera indica opkweekte, waarin ook nu en dan de larren ran Epepeotes luscus worden aangetroffen. en ran Pelargoderus bipunctatus, die hier in Canarium commune, elders in peper en cacao parasiteert. Eindelijk ran eenige soorten, welker levenswijze mij nog onhekend is en waarran hier Atmodes marmorea. Palimna tesselata, Nupserlia fricator en een paar Cacia-soorten mogen worden genoemd.

Voor de Coccinellidae is het terrein hier niet gunstig; noch roor de plantenetende rormen, hoofdzakelijk Epilachna-soorten, die beter elders ter sprake worden gebracht, noch roor de carnivore, waarvan men hoogstens enkele kleine scymmus-soorten tamelijk algemeen aantreft tusschen de Coccidae, die op de citroenachtige gerrassen leven. De Crysomelidue daarentegen. waartoe tal ran polyrore soorten behooren, zijn hier rrij goed rertegenwoordigd: zeer algemeen door Cerophysa nodicomis, Graptodera cyanea, Gchralea flava, Hoplosoma ventralis en het geslacht Colaspoides, terwijl ook Euphitrea micans, Aulacophora quinqueplagiata, Aulacophora flavomarginata, Mimastra violaceipennis en Monolepta quadrinotatc tamelijk verspreid worden aangetroffen, waarbij 
het weder opmerking rerdient, dat men ran al deze rormen steeds de rolwassen dieren en zeer zelden de larven ontmoet.

Eene uitzondering $\mathrm{op}_{\mathrm{p}}^{\mathrm{s}}$ dit laatste maken een par soorten van Hispidae, roornamelijk oncocephula angulata en Gonophora orientalis, die zijn te vinden op de verschillende soorten van Orchideeën, welke hier algemeen worden gekweekt. Zij bewonen deze planten gedurende hun geheelen levenscyclus en brengen ze vooral schade toe in den larralen toestand, die bij de ééne soort in, bij de andere op de bladeren wordt doorgebracht.

De Erotylidae ontbreken in dit gebied niet geheel, zijn er o.a. door T'tralmangria elongata vertegenwoordigd, maar geren roor het orerige geen aanleiding tot bijzondere bespreking; ran de Endrmugchidae daarentegen moet worden genoemd Eumomphus murginatus, dien men, in gezelschap van zijn stekelige larven en van de poppen, dikwijls in grooten getale kan aantreffen op de boven , maal rooral aan de onderzijde ran de tafelromige Fungi ran de familie del Polyporacene, die, rooral ol, rochtige plekken. reelruldig op oude boomstammen roorkomen en dezen insecten tot roedsel dienen.

\section{Lepidoptera.}

Het betrekkelijk gering aantal Vlinders. in het bijzonder Rhopalocera, dat zich op Jara in bijna elke omgering rertoont, heeft reeds menigeen teleurstelling gebaard, die herwarts kwam met de verwachting, een tropischen rormenrijkilom te zullen aantreffen. Daartoe werken twee oorzakien mede. De eerste is - en deze geldt niet alleen roor de 
vlinders -, lat het insectenleven, dat zich, voor zooverre het voor den mensch gemakkelijk waarneembaar is, in een kleiner gedeelte van het jaar concentreert, narmate de geographische breedte toeneemt, in de tropen over het geheele jaar of althans orer een aanzienlijk gedeelte daarvan is verdeeld. In de tweede plaats treft men onder de Vlinders slechts een gering aantal omnivore en polyvore vormen aan; verreweg de meeste soorten zijn in den larvalen toestand specialisten en hunne verspreiding is daarom gebonden aan die van de plantensoort, waarmede zij zich als rupsen voeden. Daar nu de planten aan hunne omgeving veel meer bijzondere eischen stellen dan de dieren, welken het voor een zeer hoog percentage slechts om voedsel is te doen, terwijl zij het niet zoo nauw nemen met andere zaken-zoods de meteorologische toestanden, waal'voor juist de planten zoo gevoelig zijn en die op Java zoo sterk uiteenloopen -, laat het zich hooren, dat de meeste Lepidoptera slechts in bepaalde gebieden voorkomen en elders ontbreken.

Dit werd reeds jaren geleden (1876) in het licht gesteld door Piepers *), die voor de vlinderfauna ran Batavia, over een kuststrook van niet meer dan 10 Kilometer breedte en van geen hooger verheffing dan eenige weinige Meters boven den zeespiegel, reeds drie gebieden kon onderscheiden, waarvan elk, naist rele gemeenschappelijke, zijn eigen vormen vertoonde.

In verband met het bovenstaande is ook het aantal Dagrlinders, dat men in het thans te behandelen gebied aantreft, tamelijk beperkt; toch is het niet arm aan opvallende vormen, al ware het alleen,

${ }^{*}$ Tijdschrift voor Entomologie, Deel XIX, pag. 141. 
omdat de Papilio's er rrij ruim zijn vertegen. woordigd.

Men kan de Papilioniden van Java, met inbegrip ran de Ornithoptera's, naar den larvalen toestand, rool zooverte deze bekend is, in drie groepen verdeelen, die te dezen aamzien nogal uiteenloopen. Bij de rupsen der eerste groep, rvartoe die van Ormithoptera pompeus en Papilio aristolochicle behooren, is het lichaam ran een aantal rijen langwerpige papillen voorzien en in hoofdzaak vaalbruin van kleur: men rindt deze rupsen o.a. op rerschillende Aristolochia-soorten, en waar deze planten in rol. donnde aantal roorkomen, zijn de genoemde vlinders niet zeldzaam.

Bij de tweede groep is het, in hoofilatak groene lichaam gekenmerkt door den, naar achteren sterk toenemenden omvang ran den thorax, waarbij een lichte, eenigszins wrattige streep, die de drie dorsale helften der thoracale geledingen gezamenlijk omsluit, een soort ran schild doet ontstaan. Voorts rindt men aan beide zijden ran het abdomen gervoonlijk twee lichte zijstrepen, die achterwadrts schuin naar boren loopen. Tot deze groep behooren de lupsen van Papitio memonon, $P$. polytes, $P$. demolion, $P$. coon en $P$. arjuna, die alle bij roorkeur op rerschillende C'itrus-soorten worden aangetroffen. Daal nu deze planten in dit gebied zeer veelvuldig worden aangekweekt, komen de genoemde Pupitio's, met uitzondering ran $P$. arjma, die in hoogere streken thuis behoort, in dit gebied algemeen roor, waarbij nu eens deze, dan gene rorm de andere in getalsterkte overtreft.

De rupsen ran de derde groep hebben grondkleur en algemeenen lichaamsvorm als die ran de tweede, 
maal het nagebootste schild en de zijstrepen ontbreken. Daarentegen dragen de thoracale geledingen elk twèe. buitenwaarts gerichte stekels, waarvan de achterste het grootst zijn, de voorste soms ontbreken. Bovendien loopt de achterste geleding ran het achterlijf reelal in twee scherpe punten uit. Deze rupsen nu, waartoe die van Papilio agamemnon, $P$. sarpedon, $P$. antiphates en $P$. jason behooren, zijn vooral op Anonaceae te vinden, welke familie in dit gebied algemeen (o.a. door de zuurzak, Anona muricata) is vertegenwoordigd.

De verschillende, hierboven genoemde Papilioniden dragen natuurlijk in ruime mate bij tot decoratie ran de omgering. De wijze, waarop zij zich daarin bewegen. loopt bij de verschillende soorten zeer uiteen. ornithoptera pompeus rliegt rustig rond, is echter steeds op hare hoede en rerdwijnt bij naderend geraar in de hoogere gedeelten van het geboomte. Papilio demolion blijft in dén regel dicht bij den grond en tracht zich steeds door haar snelle vlucht te redden. $P$. conon, met haar lange, smalle rleugels, is als de zwaluw van het genus, terwijl $P$. aristolochicue voor de colibri ervan kan doorgaan, daar zij zich gaarne róór de bloemen in de lucht staande houdt en stootsgerijze ran plaats verwisselt. $P$. memnon rliegt rustig, maar in een onregelmatige lijn, terrvijl $P$. surpedon en rooral $P$. agamemnon een woeste en volkomen onberekenbare vlucht hebben, welke aan die ran vele Sphingiden herinnert.

Onder de vertegenwoordigers in dit gebied ran de Danaïden trekt het geslacht Euploea het meest de azndacht, meer in het bijzonder de fraaie Euploea midamus. waarvan men de rupsen op Nerium oleander kan aantreffen. Ook deze zijn niet ran uiterlijk schoon ontblout, doch ran de drie ontwikkelingsstadieën van 
dit insect is stellig de pop wel het meest de aandacht waard; deze toch doet zich voor, alsof zij van gepolijst goud of zilver was vervaardigd, welk verschijnsel een gerolg is van een dun laagje lucht tusschen de dunne, glasachtige pophuid en het integument der nymphe en bijgevolg verdwijnt na hét uitkomen van den vlinder.

Minder algemeen verspreid, maar dan plaatselijk in den regel nogal talrijk, zijn de Danais- en Radenasoorten. Zoo zijn Danais juventa en D. genutia te Batavia zeer gewone vlinders, terwijl men te Buitenzorg Danais aspasia, var. crocea het meest ziet vliegen, wederom elders Radena vulgaris en Danais melaneus. De genoemde vlinder's vicariëeren echter niet alleen naar plaats, maar ook naar tijd, terwijl er ook perioden roorkomen, waarin ze plaatselijk geheel ontbreken.

Dit laatste is niet het geval met vele Satyriden van dit gebied, die ten allen tijde aanwezig zijn en waarvan Melanitis leda ongetwijfeld wel de meest typische vertegen woordiger is. Deze schemeringvlinder, waarvan vroeger (pag. 41) reeds sprake was in verband met zijn seizoen-dimorphisme, is een zeer alledaagsche verschijning, die in de vrije natuur overdag rustig, met toegevouwen vleugels, op den grond en op het gevallen blad zit en daar, om de rroeger reeds opgegeven redenen, zoo goed als onzichtbaar is. Toch mag men niet aannemen, dat men hier te doen heeft met een bewust gebruik maken van een beschermende eigenschap, aangezien dit insect de voorliefde voor de zooeven genoemde rustplaatsen in dit gebied paart aan eene voor witte muren, en het is vooral deze idiosyncrasie, waaruit men tot zijn algemeenheid aldaar kan besluiten. De rups behoort, zooals wij later zullen zien, hoofdzakelijk op de rijstvelden thuis, 
maar voedt zich ook met andere Graminecue, die in vorm en samenstelling van het blad met de rijst overeenkomen.

Andere Satyriden, die men eveneens gedurende de schemering veelvuldig kan waarnemen, hier de ééne, ginds de andere soort, zijn Elymnias undularis en $E$. lais, die alsdan de voorgalerijen bezoeken om de eieren te leggen op verschillende soorten van sierpalmen. De rupsen, die in voorkomen aan die van Melanitis leda herinneren, verraden dan later hunne aanwezigheid vooral door de uitwerpselen; zij zitten gewoonlijk aan de onderzijde der bladeren en komen daarmede in algemeene kleur geheel overeen, zoodat men ze eerst bij nauwlettende waalneming in het oog krijgt.

Voor het overige levert dit gebied aan Satyriden nog verschillende Ypthima-en Myculesis-soorten, die trouwens ook elders zeer gewoon zijn, alsmede plaatselijk Lethe mekara, doch geen van deze behoort tot de vormen, die in eenig opzicht de aandacht op zich vestigen.

De Nympaliden zijn hier vrij talrijk; de groote Amathusia phidippus, de zoogenaamde Visitekapel, vertoont zich dikivijls hinnenshuis en zet zich dan hoog tegen een muur, mabij de zoldering, ter ruste. Ook deze kapel vliegt tijdens de schemering en legt dan de eieren op de bladeren der cocospalmen, evenals de verwante Discophora celinde, die nagenoeg even groot, maar minder algemeen is. De overige Nymphaliden van dit gebied zijn echte dagvlinders, die op vele plaatsen wel het hoofdbestanddeel der Rhopaloceren-faund uitmaken. Zoo zijn hoogst algemeen Junonia asterie, J. erigone en J. atlites, Precis iphita en $P$. ida, Cupha erymanthis en Limenitis procris alsmede 
verschillende soorten van de geslachten Neptis en Athyma, rondom welke vormen zich dan plaatselijk weder andere groepeeren, in samenhang met omstandigheden, die men voor elk afzonderlijk geval zou moeten nagaan, maar die voor een groot deel wel in verband zullen staan met het al of niet, het meerder of minder voorkomen van de voedsterplanten der rupsen. $\mathrm{Er}$ is bijvoorbeeld een tijd geweest, waarin men zich op Java met bijzondere voorliefde toelegde op het kweeken, in de tuinen der Europeesche woningen, van verschillende, fraaibladerige Croton's, Codicueum's en verwante planten, waarvan men thans nog op zeer vele erven de overblijfselen aantreft. In die dagen zag men, veel talrijker dan thans, Doleschallia bisaltide rondvliegen, waarvan de ongemeen fraaie rupsen op die planten leven. Op sommige plaatsen treft men voorts, soms langs drukke wegen, Hypotimnas bolina en vooral Hypolimnas misippus aan, waarvan de mannetjes zeer in het oog vallen door de gewoonte, zich met half geopende, als in balanceerende beweging gehouden vleugels op den grond te zetten, zoodat de fraaie, donkerblauw schemerende bovenzijde, met de drie paar witte vlekken, duidelijk wordt ten toon gespreid. Elders, waar op de erven veel Mangifer'a's, inzonderheid Mangifera foetida, zijn aangeplant, zijn verschillende Euthalia-soorten niet zeldzaam, welker bizarre, als met een krans van veeren omkleede rupsen, zich met de bladeren dier boomen voeden. Ten slotte zij nog genoemd Charaxes athamas; een vlinder van wilde vlucht, waarvan het wijfje zich vóór de paring op of nabij den grond neerzet, terwijl het mannetje, na eerst eenigen tijn op eenige meter's hoogte in het geboomte van plek tot plek te hebben 
gevlogen, zich plotseling met bliksemsnelheid op haar stort.

De Lycaenidae, die op Java in een groot aantal, waaronder vermoedelijk nog veel onbeschreven soorten, voorkomen, vertoonen alhier volmakkt dezelfde biologische eigenschappen als elders. Waar het terrein voor hen gunstig is, waar bloemrijke ruigten en heesters hun een goede verblijfplaats aanbieden, daar vliegen ze overdag in grooten getale en daar gaan ze tegen den arond ter ruste. Oprallende vormen, zooals wij er elders eenige zullen ontmoeten, levert dit gebied niet op.

De Pitridae spelen noch hier, noch in andere omgevingen, physionomisch zulk een groote rol, als men geneigd zou zijn te verwachten, wanneer men de tamelijk lange lijst der Javaansche soorten nagaat, terwijl ook bij deze familie groote plaatselijke rerschillen zijn waar te nemen, wat de rerdeeling naar getalsterkte der verschillende vormen betreft. Terschillen, die vermoedelijk roor een deel wederom zijn te verklaren op de wijze, zooals bij de Nymphaliden werd aangegeven en dadelijk, bij een meer nauwkeurige beschouwing der locale fauna's, in het oog springen. Zoo geeft Piepers (l.c.) Pirris coronea en P. amasena voor Batavia op als gerroon, terwijl deze beide soorten in Buitenzorg wel roorkomen, maar stellig niet tot de alledaagsche vormen mogen worden gerekend. Omgekeercl is Detias belisama in Buitenzorg nu en dan niet alleen gewoon, maar zelfs in 't oog vallend talrijk, terwijl ik liaar te Batavia nooit waarnam en Plepers, die daar gedurende vijf jaar de vlinderfauna observeerde, haar ook niet voor die plaats opgeeft. Daar echter de Loranthus. 
soorten, waarmede de rupsen ran dezen rlinder zich voeden, op beide plaatsen gelijkelijk overrloedig zijn, ook het klimaat het onderscheid niet te weeg brengt, daar. ik hem op verschillende andere kustplaatsen waarnam, moet hier een andere oorzaak in het spel zijn, waarbij wellicht moet worden gedacht aan de aanwezigheid van een parasiet, een Ichneumonide, een Tachinide of iets dergelijks, die te Batavia het bestaan roor deze diersoort moeilijk of onmogelijk maakt.

Dat, in het algemeen, de Pieriden in dit gebied door parasieten binnen tamelijk enge grenzen worden gehouden, is eene erraring; die men bij het kweeken der vlinders uit toevallig gevonden poppen reeds zeer spoedig opdoet; het aantal Sluiprespen, dat uit dergelijke poppen te roorschijn komt, is reel grooter dan bijr. bij de Papilioniden of bij de Nymphaliden, waar ze betrekkelijk zeldzaam zijn. Mogen deze Sluipwespen al eens tijdelijk in hun optreden verslappen, dan weten zij toch gerroonlijk het rerloren terrein weder te herwinnen, zooals op zeer instructieve wijze bleek in het geval met Terias hecabe, waarorel op pag. 26 reeds werd gesproken. De derde generatie werd toen slechts sporadisch aangetast door een Chalcidide, die men ook in gewone tijden nu en dan uit de poppen van dezen vlinder kan verkrijgen, maar die rermoedelijk een tijdlang haar plicht had verzaakt; bij de rierde generatie ras de aantasting reeds veel sterkel en de rijfde werd rrijwel geheel vernield, zoodat het op eenmaal gedaan was met de Terias-plaag, die een oogenblik rrij bedenkelijke afmetingen begon aan te nemen.

De bedoelde evenwichtsrerstoring had plaats in 1896 en heeft zich sedert dien tijd niet herhaald; Terias hecabe en de naur verwante Terias sari zijn 
alledaagsche vormen gebleven, zonder zich verder in hun optreden door iets bijzonders te kenmerken.

Van het geslacht Delias noemde ik zooeven reeds de soort belisama; daaraan kunnen nog de soorten hyparete en egialea als zeer gewoon worden toegevoegd, wat plaatselijk ook geldt voor Hebomoia glaucippe.

De naar verspreiding en aantal meest gewone Pieriden van dit gebied zijn echter ongetwijfeld de Catopsilia's en wel de soorten crocale, catilla en scylla, van welke eerstgenoemde reeds op pag. 27 ter sprake werd gebracht naar aanleiding van het, in 1902 door mij waargenomen, bij millioentallen verschijnen der vlinders in geheel West-Java. Bij dit belangwekkende verschijnsel was geen sprake van trekken in zwermen; men ontving veeleer den indruk van een zeer ijle sneeuwbui van groote vlokken, die door den wind langzaam werden voortgedreven, waarbij het zeer waarschijnlijk was, dat elk individu op zich zelf slechts over een betrekkelijk korten afstand medevloog en daarna weder door een ander werd vervangen.

De eenige Hesperide van dit gebied, die afzonderlijke vermelding verdient, is Erionota thrax, waarvan de rupsen de overal aangeplante pisang, Musa paradisiaca, bewonen en niet weinig bijdragen tot het vernielen van de fraaie bladeren, waarvan dikwijls slechts de hoofdnerf overblijft. Daaraan hangen dan, op onregelmatige afstanden, eenige kokervormig opgerolde bladstukken, die den rupsen tot verblijfplaats dienen en inwendig bekleed zijn met een witte, krijtachtige stof, afkomstig van de insecten, die haar over het geheele lichaam afscheiden en ook zelf dik ermede bekleed zijn. Rolt men 
den bladkoker van een volvassen rups af, dan staat men verbaasd over de groote oppervlakte blad, die zij voor het vervaardigen ervan heeft noodig gehad en die in geen verhouding staat tot de vrij geringe hoeveelheid, die als roedsel is gebruikt. Intusschen schijnt het opgerolde bladstuk niet geheel voor de plant verloren te gaan, want het blijft groen en de monocotyle nervatuur makt een blijvende, vitale gemeenschap met de hoofdnerf mogelijk. Ook de langwerpige pop is in den bladkoker te vinden en men ziet niet zelden den pas uitgekomen vlinder up de buitenzijde daarvan het strekken en hard worden der vleugels afwachten.

Voor ieder, die niet in de gelegenheid is, geregeld waarnemingen in de rrije natuur te rerrichten, spelen op Java de Heterocera een aanzienlijk grooter rol dan de Dagrlinders, aangezien het meerendeel ran eerstgenoemde des avonds bij het lamplicht verschijnt. Dat hun aantal, zelfs in de groote bevolkingscentra, aunzienlijk is, blijkt wel uit de omstandigheid, dat Prepers in Bataria, exclusive de Microlepidoptera. 123 soorten verkreeg, terwijl ik in Buitenzorg, waar door ligging en omgeving meer soorten mogen worden verwacht, in den loop der jaren binnenshuis meel dan 300 soorten van Macro-heterocera rerzamelde. Het heeft daarbij steeds mijne opmerkzaamheid getrokken, dat er, geheel onafhankelijk ran jaargetijden, weersgesteldheid en alle andere factoren, die men ermede in verband zou willen brengen, vlinderarme en vlinderrijke tijden zijn; maanden, waarin men slechts de allergewoonste of in het geheel geen soorten ziet; andere, waarin een of meer soorten in 
meer dan gewoon aantal optreden; wederom andere, waarin het aantal soorten groot, dat der individuen gering is en eindelijk tijden, die zich door een buitengewonen rijkdom aan beide kenmerken. Zoo was voor Buitenzorg $189 S$ een Pyralidenjaar bij uitnemendheid, terwijl in het algemeen de rijkste tijd van mijn verblijf alhier in het voorjaar van 1903 is gevallen, als wanneer ik een aantal soorten waarnam en verzamelde, die ik vóór noch na dien tijd ooit in deze ongeving aantrof.

Wij hebben ons hier echter tot de typische vormen te bepalen en kunnen ran de Sphingidcue in de eerste plaats als zoodanig noemen Protoparce convolvuli, volkomen dezelfde als de Europeesche soort, waarvan de rupsen hier niet alleen op verschillende Convolvulacere, maar ook op windende Leguminosen, als Phaseolus e.a., zijn te vinden. Deze vlinder is in de langdurige, nachtelijke duisternis van de tropen een van de lastigste indringers, omdat hij in onbesuisde vlucht tegen alles aan vliegt, overal het stof van zijn lichaam en zijn vleugels rerspreidt en zelfs door een uiterst geringen lichtschijn wordt aangelokt, zoodat men hem, ook in het midden van den nacht, tusschen de latten der zonneblinden naar binnen hoort fladderen, wanneer in het slaapvertrek maar een minimum van licht aanwezig is.

In de tweede plaats moet het genus Chaerocamma worden genoend, waarvan verschillende soorten tot de gervone avondbezoeker's behooren (Ch. alecto, $\mathrm{Ch}$. oldenlandiae, Ch. theylia, Ch. mydon, Ch. silhetensis, Ch. vigil, Ch. butus en Ch. luc(usi). De algemeenheid van deze dieren wordt gemakkelijk verklaard, daar, met uitzondering van de laatstgenoemde, de rupsen zich roeden met de blaren van verschillende Aroï- 
deeën (soorten van Arum, Caladium, Alocasia e.a.), die overal rijkelijk en dikwijls in reusachtige afmetingen als onkruid opschieten, waar de 'hand ran den mensch zich eenigen tijd heeft teruggetrokken, en waarvan ook een paar soorten (0.a. Alocasia antiquorum) door de inlandsche bevolking op schier elk beschikbaar stukje grond worden aangeplant. Chaerocumpa lucasi is in den larvalen stact te vinden op de zoogenaamde Indische Vlier (Leea sumbucina), een boomachtigen heester, die eveneens vij algemeen in de tuinen der Europeesche woningen en in de kampongs is te rinden. Daarentegen komen de Theretra soorten nessus en actea als rupsen weder op de zooeven genoemde Aroideeën voor en zijn dientengevolge, hoewel minder algemeen dan de Chaerocampa's, in dit gebied gewone verschijningen.

Tot de minder algemeene soorten van dit gebied moeten worden gerekend Daphnis nerii, welks aanwezigheid uiteraard samenhangt met het, al of niet, aanwezig zijn ran den Oleander, die hier veelal in den vollen grond wordt geplant en tot een spichtig. gevas opschiet; Daphnis hypothous, waarvan de rups op verschillende, om de bloemen aangeplante Rubiaceae leeft (Ixora, Pavetta, Guettarda e.a.), en eindelijk Calymnia panopus, waarvan de rupsen zich met de bladeren van Mangifera indica voeden. Bij deze laatste Sphingide heeft ook de verpopping op de plant zelve plaats, terwijl men gewoonlijk een aantal poppen bij elkaar aantreft, die gelijktijdig uitkomen. Dit uitkomen geschiedt in de morgenuren en de reusachtige rlinders, die in den zonneschijn een fraai gezicht opleveren, blijven den geheelen dag zóó rustig zitten, dat zelfs het afsnijden en mede- 
nemen van den tak, waarop ze zich bevinden, geen verandering in hunne houding teweegbrengt.

De Saturnidae behooren door hunne afmetingen tot de Heterocera, die het eerst de aandacht trekken. De grootste, de Atlasvlinder (Attacus atlas) is op Java in het geheele cultuurgebied een algemeen en veelvuldig voorkomend insect, dat door het omnivoor karakter van zijn rupsen overal kan bestaan. De vraatzucht der rupsen is buitengewoon groot; want terwijl de meeste andere rupsen bij gebrek aan voedsel, dat in hun smaak valt, eenvoudig doodhongeren, vreten deze dieren zich liever dood aan bladeren, die voor hen vergiftig zijn (o.a. van vele Euphorbiacecue), dan dat ze zonder voedsel zouden blijven. De vlinders komen in het algemeen niet af op kunstlicht van de sterkte ran gewone petroleum-en gaslampen; slechts enkele malen nam ik ze binnenhuis waar, maar dan zochten ze daar een toevlucht tegen langdurigen en zwaren regen. Dat zij soms in zeer grooten getale aanwezig kunnen zijn, daarvan kon ik mij eens orertuigen op een kina-onderneming. Hoewel daar geen bijzondere rupsenschade van deze soort viel te constateeren en er dus ook geen aanleiding bestond, har in zoo grooten getale aanwezig te rermoeden, werd naar aanleiding eener, over dit onderwerp gevoerde discussie, des avonds een vrouwelijk exemplaar in een kleine rogelkooi buiten gezet, in de onmiddellijke nabijheid ran het huis van den administrateur. In den loop ran den avond nu werden rondom deze kooi niet minder dan 273 mannetjes gevangen, die, blijkbaar veel sterker in aantal dan de wijfjes en door hun fijne zintuigen op ditééne vrouwelijke exemplaar opmerkzaam gemaakt, met zoo- 
veel drift kwamen aanrliegen, dat zij zich zonder eenige moeite met de hand lieten grijpen.

De verwante soort Attacus ricini komt in dit gebied ook voor, is hier en claar zelfs verre van zeldzaam, maar vertoont overigens, zooals zoovele andere insecten, het verschijnsel, dat er korte perioden zijn, waarin men ze dikwijls aantreft, afgewisseld door langere, waarin er geen spoor van hen is te ontdekken. Bepaald zeldzaam in dit gebied, maar toch niet geheel ontbrekend (o.a. te Buitenzorg eenige malen door mij verkregen) is de fraaie Maanvlinder Actias maencus.

In algemeenheid en talrijkheid worden hier echter alle Saturniden overtroffen door. Cricula trifenestrata, deze parasiet bij uitnemendheid van Canarium commune en Persea gratissima, den Advocaatboom. Zij behoort tot de vormen, die ten allen tijde aanwezig zijn, doch zoo nu en dan in een ontzettende getalsterkte optreden. Heeft dit laatste plaats, dan worden soms geheele lanen van Kanarie-boomen in korten tijd kaalgevreten, terwijl de neervallende uitwerpselen der rupsen een geluid maken als een zachte regen. Men vindt dan spoedig daarna overal de poppen, die in een sterk, tamelijk dicht, fraai goudkleurig spinsel zijn gehuld, dat echter geen industriëele waarde heeft (o.a. omdat ook de haren van de rups ermede zijn dooreengesponnen), terwijl weldra ook de vlinders des avonds kommen binnenvliegen, daarbij tamelijk hinderlijk kunnen zijn en niet zelden hunne zeer talrijke eieren op allerlei huiselijke voorwerpen deponeeren.

Anthercaea paphia, van welke soort de rupsen zich het liefst voeden met de bladeren van Terminalia catappa (ketapang), is het meest gewoon op de plaatsen, waar ook deze boom het meest voorkomt, namelijk 
in de nabijheid van de kust; in de plaatsen van het binnenland ziet men haar zelden. Daarentegen heeft Loepa katinka een grootere verticale verspreiding, daar de rupsen leven op Leea rubra en Leea sambucina, welke planten in dit gebied zoowel in de vlakte als rrij hoog in het gebergte voorkomen.

Ocinara dilectula, die ik voor dezelfde soort houd, die elders ${ }^{*}$ ) door mij onder den naam Bombyx waringi werd besproken, is de eenige Bombycide, die in de groote plaatsen nu en dan de aandacht trekt door het aantal, waarin de rupsen op den waringin (Ficus benjamina) kunnen optreden. Zij hebben daarbij de gewoonte, zich tegen den arond aan een draad te laten zakken en dan een tijdlang ongeveer op manshoogte boren den grond te zweren. Deze handelwijze schijnt echter niet met plannen tot rerpopping in rerband te staan; de laatste heeft bij roorkeur plaats langs de afhangende, dunne luchtwortels. Daarbij wordt niet zelden de ééne cocon boren op de andere gemaakt, zoodat er ten slotte een geheele klomp ontstaat, waarvan slechts de buitenste laag later kan uitrliegen, terwijl de onderste individuen opgesloten blijien en in dien toestand een ongelukkig einde vinden.

Van de rerwante familie der Eupterotidae treden de rupsen ran Tagora amoena soms in rrij groot aantal op, waarbij ze nu eens op Premna-soorten (fam. Verbenaceae), dan weder op sirih (Chavica betle) of op dadap (Erythrina-soorten). soms zelfs op éénzaadlobbige gewassen, als Dioscorea, zijn te rinden. Veel zeldzamer, maar door de buitengewone beharing: veel opvallender, zijn de rupsen ran Dreata udiana, die op het eerste gezicht meer gelijken op een klein,

*) Mededeelingen uit 's Lands Plantentuin, Deel LIV, 1903, pag. $i 8$. 
wollig zoogdier, dat in elkaar zit gedoken, dan op een insect; men treft ze een enkele maal aan op Butea frondosa, een heesterachtige Leguminose met fraaie, gele bloemen.

Tarsolepis remicauda en eene Dudusa-soort zijn de eenige Notodontidae, die roor dit gebied afzonderlijke vermelding rereischen. Tooral de eerstgenoemde. heeft de wilde beweging der Sphingiden, maar zet zich spoedig ergens neder, waarbij het puntige abdo. men wordt opgericht en de haren ran het laatste segment tot een kleinen raagbol worden opgezet. Nu en dan komen de rleugels in een trillende beweging en het dier geeft dan geheel den indruk, aan zijne omgering schrik of rrees te willen inboezemen.

Een ran de fraaiste, maar terens een ran de lastigste Syntomidae. die vooral in de tuinen der Europeesche woningen wordt aangetroffen, is Euchromia horsfieldi. Waarvan de rupsen met groote hardnekkigheid parasiteeren ol) Ipomoea brexii, in den bloeitijd een der mooiste en rijkbloemigste klimplanten, die in de laatste jaren onder den geheel verkeerden nam van "roode Stephanotes" rrij algemeen wordt gekweekt. Want niet alleen de blaren, maar ook de bloemknoppen worden grootendeels weggerreten door de rupsen van deze Euchromia, die steeds in tahrijke troepen optreden en wellicht, maar dan op zeer eigenaardige wijze; tegen de aanvallen ran Sluipwespen, in het bijzondel ran Microgastridae, zijn beschermd. Toen ik mamelijk deze rupsen roor de eerste maal waarnam, rerkreeg ik een oogenblik den indruk, dat zij reeds waren aangetast geweest door larren ran Sluiprespen, als hier bectoeld en, dat deze 
reeds naar buiten waren gekropen en op het lichaam der rups de welbekende, witte coconnetjes hadden vervaardigd. Het bleek mij intusschen spoedig; dat hier bedrog in het spel was en dat de vermeende coconnetjes niet anders waren dan witte, penseelvormige haarbundels tusschen de, voor het overige zwarte beharing. Wanneer ook de Microgaster's dupe zijn van dit gezichtsbedrog, dan laat het zich verklaren, waarom de Euchromialrupsen althans van deze parasieten niet hebben te lijden.

De Euchromic-vlinders, hunne fraaie, hier en daar metaalachtig schitterende kleuren wijzen reeds daarop, zijn dagdieren, evenals vele Chalcosidae, waarran talrijke soorten sterk aan Rhopalocera herinneren. De meeste soorten dezer familie leven echter elders en zijn aan hunne oorspronkelijke omgeving getrouw gebleren; hier treft men weinig meer aan dan de gele Chalcosia thallo en Pintia mefachloros, welke laatste weliswaar overdag rliegt, maar zich toch gaarne op een beschutte plaats, zooals aan de onderzijde van een blad, nederzet.

Wij komen thans tot een parr van de - en terecht - meest gevreesde rupsen ran Java, die beide in deze omgeving verre van zeldzaam zijn. De eerste is die van Setora nitens ran de familie der Limacodidae, een polyvoor insect, dat op allerlei gewone tuinplanten is aan te treffen. Evenals de meeste Slakrupsen, is zij ran harde, stekelige aanhangsels roorzien, die bij aanraking met de huid daarin doordringen, afbreken, een hevige pijn veroorzaken, en, wanneer zij bijv. in de hand zijn gedrongen, zelfs de klieren nabij het schoudergewricht doen opzwellen. Zoolang de rups rustig zit, zijn de stekels, die bundelsgewijze op verhevenheden der huid zijn inge- 
plant, tot penseelen bij elkaar gevoegd, maar naurelijks bespeurt zij onraad, of de stekels worden zoo wijd mogelijk uitgespreid: drukt men haar met-een potlood midden op den rug, dan heft zij zelfs de beide uiteinden van het lichadm omhoog, om het vijandelijke roorwerp ran alle kanten met haar wapenen te treffen.

De treede is de rups van Suana concolor, die, geheel in tegenstelling met die van Setora nitens, ook in uiterlijk roorkomen iets terugstootends heeft. Men rindt deze Lasiocampide o.a. dikwijls op Persea gratissima en op Psidium guajava (djamboe). Zij is in hoofdzaak grijsachtig wit van kleur, met zijdelingsche, eenigszins naar beneden gerichte, aan de uiteinden verbreede haren. Op het tweede en het derde segment ran den thorax berindt zich een dwarse, uitstulpbare huidplooi, die nagenoeg onzichtbaal is, wamneer het dier zich in rust bevindt. Nauwelijks echter dreigt er gevaar; of het voorste gedeelte ran het lichaam kront zich dreigend en uit de, zich daardoor ontspannende, huidplooien komen dicht opeen geplaatste korte, harde brandharen te roorschijn, die bij aanraking een dergelijke pijn veroorzaken als de stekels ran de rorige soort. Ook de vlinders van Suana concolor hebben iets terugstootends, zoowel de plomp gebouwde wijfes, als de. meer dan de helift kleinere, slanke mannetjes. Dit wordt reroorzaakt door de, in de rust uitgestrekte, zijdelings behaarde pooten, waardoor het dier, op het eerste gezicht, meer aan een langlijrige spin dan aan een vlinder doet denken.

Een andere, in dit gebied niet zeldzame, Lasiocampicle is Trabala vishnu, waarran de rupsen eveneens dikwijls op djamboe-soorten, maar ook op 
Terminalia catappa zijn te rinden. Ook deze vlinder heeft in den rusttoestand een eigenaardige houding, doordat de achtervleugels verder naar voren worden gehouden dan de voorvleugels, iets, dat ook bij een verwanten, Europeeschen vorm roorkomt.

De Lymantriidae leveren een zeer aanzienlijk contingent van de rupsen, die in dit gebied op allerlei planten zijn te vinden. De zeer talrijke, voor het meerendeel polyvore Borstelrupsen, die men gedurende het geheele jaar kan aantreffen, behooren vooral tot de soortenrijke geslachten Dasychira en Euproctis, terwijl ook het geslacht Lymantric door een paar soorten (ascetria, similis) is rertegen woordigd, die echter meer door de, ss aronds binnenkomende vlinders, dan door de rupsen, ran hunne aanwezigheid blijk geren. Ditzelfde geldt van het geslacht Hypsa, waarvan men de rupsen slechts zelden aantreft, terwijl des avonds het lamplicht de rlinders in talrijke soorten naar binnen lokt. Hypsa monycha, $H$. complana, H. heliconia, $H$. egens, $H$. javana, H. alciphron, $H$. producta en wellicht nog meerdere soorten, komen alle in dit gebied voor, niet echter de, in kleur en teekening eenigs. zins afwijkende Hypsa marmorea, die zich, wat verblijfplaats betreft, aan het, in de bosschen en wildernissen roorkomende geslacht Euplocia ran dezelfde familie der Hypsidae aansluit.

Ook de Arctiictce vertoonen zich in dit gebied voornamelijk in den volwassen volm, terwijl de rupsen vooral elders, op het bouwland, worden aangetroffen, waaruit men, gelijk in zoovele andere gevallen, de gevolgtrekling mag maken, dat de 's nachts vliegende insecten zich soms orer vrij groote afstanden ver- 
plaatsen. Creatonotus lactineus en $C$. interruptus, Phissama transiens, de Spilosoma-soorten maculifascia en strigatulum, verschillende fraaie Cyanc-soorten en eindelijk Deinpeia pulchella zijn in alle plaarsen zeer gewone arondgasten, waaraan nog kunnen worden toegeroegd een aantal kleine Miltochrista's en Aemene's, terwijl Nyctemeru latistrigu, $N$. coleta e.a. eveneens hier thuis behooren, maar in mindere mate door het kunstlicht worden aangelokt. Ook Argina cribraria en zelfș de fraaie Eligma narcissus verdwalen wel eens herwaarts, maar moeten hier toch tot de zeldzame verschijningen worden gerekend.

De Noctuidcue zijn, zoowel wat rijkdom aan, als wat fraaiheid ran vormen betreft, het best vertegenwoordigd door de groep der Quadrifincre. Maar ook de andere groepen ontbreken in geenen deele. Van de Trifinue treden, zooals te verwachten is, de geslachten Agrotis, Hadena en Leucania het meest op den voorgrond; vele soorten daarvan zijn alledaagsche verschijningen, die in den regel echter weinig de aandacht trekken, tenzij ze zich door iets bijzonders kenmerken, zooals o.a. bij Leucania hamifera het geval is. Bij deze soort namelijk hebben de mannetjes de onderzijde der vleugels voor het grootste gedeelte bedekt met schubbetjes, die schitteren als gepolijst zilver en daardoor het, rondom de lamp fladderende dier dadelijk in het oog doen vallen.

Zeer gewoon is voorts Prodenia litoralis, die echter voor andere terreinen meer karakteristiek is, erenals de cosmopolitische Heliothis armigera. Ook Calogramma festiva komt in dit gebied een enkele maal roor, terwijl Glottula dominica platselijk algemeen is. Laatstgenoemde is hier de eenige der Trifincre, die zijn aanwezigheid vooral in den larvalen toestand doet 
bemerken, daar de rupsen leven van, en gedeeltelijk in, de dikke, saprijke bladeren van verschillende, als sierplanten aangekweekte soorten van de geslachten Crinum, Eucharis e.d. De wildgroeiende rerwanten van deze gerwassen behooren voor een aanzienlijk deel tot de kustflora; vandaar, dat men Glottula dominica meer aantreft in de plaatsen, die aan zee zijn gelegen, dan in die van het binnenland.

Terwijl de Acontiinae hier zijn vertegenwoordigd door Acontia transversa en voorts door een aantal kleinere vormen van de geslachten Xanthoptera, Tarache, Bryophila, Metachrostis enz., de Palindiinae door de, overigens verre van alledaagsche Callyna jugaria en de Sarrothripinae door de rrij algemeene Hyblxea puera, waarvan de rupsen o.a. op Tectona grandis worden geronden, ontbreken de Euteliinae zoo goed als geheel en behooren ook de Stictopterince en de Gonopterinae meer elders tehuis. Van de laatste groep moet hier slechts het geslacht Cosmophila worden genoemd, waarvan de soort erosa des aronds niet zelden komt binnenrliegen.

De Quadrifincue vormen, gelijk zooeven reeds werd opgemerkt, rerreweg het meest oprallend bestanddeel ran de Noctuidenfauna ran dit gebied, waarvan slechts de grootere en tevens meer algemeene soorten hier mogen worden vermeld. Vooreerst het geslacht der Nachtpau woogen. overal door Nyctipao crepus. cularis en plaatselijk bovendien door $N$. hieroglyphica en $N$. macrops vertegenwoordigd. De eerstgenoemde socrt is des avonds een rustige gast, die zich dadelijk, liefst zoo hoog mogelijk, tegen den muur nederzet en daar den verderen nacht en, zoo hij niet wordt ge- 
stoord, ook den geheelen volgenden dag in een toestand van lethargische rust doorbrengt. Zeer gewoon zijn verder Hylodes caranea, Homoptera umbrina en eenige Polydesma-soorten, minder Agonista cndoleuca, Cyclodes omma, Catephia acronyctoides, Sphingonorpha chlorea, Lacera alope e.a.

Afzonderlijke vermelding verdient verder het geslacht Ophiusa, naar aanleiding van een verschijnsel, dat ook, maar in veel mindere mate, bij andere geslachten valt waar te nemen, namelijk het tijdelijk op den voorgrond treden van het geheele genus. Dat een bepaalde soort zulks doet, zonder dat de oolzaak ervan is na te gaan, kan men hier zeer dikwijls waarnemen, maar dat het geheele geslacht, voor zooverre het althans tot de plaatselijke fauna behoort, nu en dan (en gewoonlijk met jarenlange tusschenruimten) op zulk een opvallende wijze een abnormaal groote plaats in de insectenwereld inneemt, is een rerschijnsel, dat nergens zoo duidelijk als bij de Ophiusa's kan worden geconstateerd en waarvan ik de verklaring tot heden tevergeefs heb gezocht. In zulk eene periode is het aantal soorten in dit gebied talrijk; mijne aanteekeningen over het vlinderrijke voorjaar van 1903 en die van het najaar van 1906, waarin speciaal weder het geslacht Ophiusa optrad, vel'melden de soorten melicerte, serva, illibata, palumba, adustci, absentimacula, arcuata, joviana, simillima, algira, arctotannia, onelia, coronata, honesta en fulvotaenia, terwijl in normale tijden slechts nu en dan een enkele Ophiusa zich vertoont.

Ook het geslacht Ophideres vertoont iets dergelijks; er zijn tijden, waarin 0 . hypermnestra, O. fullonica en 0 . salaminia in dit gebied tamelijk gewone verschijningen zijn, terwijl er dan weder maanden en 
jaren kunnen verloopen, zonder dat men op dezelfde plaats een enkel exemplaar ontmoet.

Van de overige Quadrifinae zijn hier algemeen Remigia frugalis en $R$. archesia, verschillende Trigonodesen Grammodes-soorten, Sympis rufibasis, Ischyja manlia, Spirama retorta, Calpe minuticornis en rerschillende Plusia-soorten, terwijl van de minder veelvuldig voorkomende rormen mogen worden genoemd Lagoptera juno, die de aandacht trekt door de; als raagbollen opgezette haarbundels aan de basis van het abdomen, Hypaetra bubo, Serrodes inara, Claterna cidonia, Episparis variabilis e.a.

Van de rupsen ran al deze Nociuiden bemerkt men in deze omgering weinig of niets. Deels leren ze op boomachtige gewassen en onttrekken zich daardoor aan de waarneming; deels leven ze elders, waar wij enkele hunner later zullen ontmoeten. De eenige rups van deze groep, die men dikwijls kan aantreffen, is die van Tinoleus eburneigutta, welk ongemeen fraai dier leeft op de bladeren ran Thunbergia javanica, een klimmende Acanthacee, die niet zelden als sier. plant wordt geduld en zelfs aangekweekt. Behalve door hun uiterlijk, trekken deze rupsen de aandacht door het gebruik, dat zij maken ran het tweede paar der lintrormige aanhangsels van den rug, dat in voortdurende beweging is en ongetwijfeld als tastorgaan dienst doet. Van deze diersoort geldt overigens juist het tegenorergestelde van hetgeen aangaande de andere Quadrifinae werd opgemerkt: zijn de rupsen een zeer gewone verschijning, de vlinders ziet men zelden of nooit.

De resteerende Noctuidae (de Focillinae en de Deltoidinae) spelen in dit gebied een zeer bescheiden rol. 
De roornaamste geslachten (Egnasia, Capnodes, Simplicia, Hypena e.a.) zijn hier vertegenwoordigd, maar geven geenerlei aanleiding tot opmerkingen. Het eigenlijke gebied ran deze groepen ligt nog temidden der oorspronkelijke flora, waar men ze in grooten rijkdom ran soorten kan aantreffen. Dáár behooren ook de meeste Epiplemidae en Uraniidae thuis, hoerel ran laatstgenoemde familie o.a. Strophidia fasciata en Acropteris striataria in dit gebied roorkomen en ook Nyctalemon patroclus wel eens naar de omgeving ran den mensch afdwaalt.

Zooals reeds rroeger (pag. 50) werd opgemerkt, zijn ook de Geometridae in het algemeen weinig geneigd, zich te schikken naar de omstandigherlen, die in het leven zijn geroepen door het ingrijpen ran den mensch in den oorspronkelijken toestand der natum. Hun eigenlijke gebied is het bosch met zijn reelsoortige flora en daarom zijn zij, in rergelijking met andere rlinderfamilies, in dit gebied slechts spaarzàam vertegenwoordigd. In de eerste plaats treft men hier verschillende soorten an ran het groote en rosmopolitische geslacht Boarmia, roorts een aantal teere, in hoofdzaak groene vlindertjes ran het geslacht Thalassodes en zijn verwanten, eenige fijngemarmerde, oranjeroode Eumelea's en, door hun witte rlekken zeer in het oog rallende Macaria's, mar daarmede is dan ook, wat typische representanten betreft, vrijwel alles gezegd. Een aantal andere soorten is te weinig algemeen. om hier met name te worden genoemd.

Geheel anders is het met de Pyralidae, de eenige familie ran de-Nicrolepidoptera, waarran, dank zij rooral onzen landgenoot Sxeluex, ran de Javaansche 
vormen een percentage van beteekenis is beschreven. De Lichtmotten toch ontbreken, in den letterlijken zin van het woord, geen enkelen dag op het avondappèl en alleen reeds door te verzamelen, wat er des avonds komt binnenvliegen, kan men op Java, ook in de groote plaatsen, een vrij aanzienlijke collectie van deze familie bijeenbrengen. Echter bestaat er ook hier weder een scherpe scheiding tusschen de vormen der cultuurfauna en die van onbewoonde, woeste streken, onder welke laatste ongetwijfeld $n o g$ een zeer aanzienlijk aantal onbeschreven soorten schuilt.

Tot de vormen van dit gebied mag men in de eerste plaats rekenen een aantal Crambincie en Schoenobiinae, van welke beide groepen de rupsen voornamelijk leven in gras - en rietdchtige gewassen, en claar van de laatste op Java geene zoo algemeen is verspreid als de rijstplant, mag Schoenobius bipunctiferulis, het vlindertje van den Rijstboorder bij uitnemendheid, hier worden genoemd als meest algemeen en veelvuldigst voorkomende Pyralide. Op sommige plaatsen, die geheel door rijstvelden zijn omgeven, kan dit insect door zijn aantal soms hinderlijk worden, in het bijzonder door de jeuliverwekkende eigenschappen van het stof, vooral van de anaalpluim, dat zij allicht verspreiden, en door de gewoonte, de eihoopjes tegen allerlei roorwerpen te leggen en deze te bedekken nen een bruine, viltige massa, die bij aanraking eveneens jeuk veroorzaakt. Rondom deze soort rangschikken zich nu een aantal verwanten vall minder algemeenheid, waarvan hier mogen worden genoemd een paar Scirpophaga-, Chilo- en Crambussool'ten van dezelfde levenswijze, alsmede Cirrochrista fumipalpis, waarvan de rups mij nog niet bekend is. 
Van de Hydrocampince moeten in de eerste plaats worden vermeld de geslachten Cataclysta, Oligostigma en Aulucodes, niet zoozeer, omdat verschillende soorten erran tot de tamelijk gewone avondgasten behooren, als wel om de, bij vlinders zeldzame gewoonte, ook in den volwassen toestand troepsgewijze bij elkander te blijven. Men vindt deze vlindertjes namelijk in den roormiddag dikwijls aan de onderzijde ran bladeren, soms een paar dozijn bij elkaar en dan steeds gerangschikt op een wijze, die aan regelmatige opstelling in een phalanx doet denken. Is deze handelwijze op zich zelve al eigenaardig, men rraagt zich daarbij tevens af, hue de dieren, die toch elders en allicht ook niet alle op hetzelfde oogenblik, uit de pop zijn gekomen, elkander weder hebben weten te vinden.

In de tweede plaats moet worden genoemd het geslacht Nymphula, waarvan vooral de soorten fluctuosulis en depunctalis zeer gewoon zijn, dé laatste werler een rijstparasiet, waarop wij later nog zullen terugkomen, terwiil ook Parthenodes vagulis in geenen deele tot de zeldzame verschijningen behoort.

Verrerreg het grootste contingent levert echter de groep der Pyraustinae en ran deze treedt weder het geslacht Glyphodes het meest op den voorgrond. Het zijn rooral de soorten indica, bivitralis, bicolor, stolalis, negatalis, psittacalis en caesalis, die men des aronds dikwijls kan waarnemen, terwijl eenige andere soorten, zooals celsalis, spectandalis en dilectalis, althans te Buitenzorg, tot de meer zeldzame behooren. Voorts kunnen als algemeene vormen worden genoemd: Zinclienia recurialis, Cnaphalocrocis jolinalis, Rhimphalea ochalis, Caprinia conchylalis, Filodes fulvidor. 
salis, Lygropia quaternalis, Hedylepta ustalis, Sameodes cancellalis, Agathodes ostensalis en A. caliginosalis, Terastia meticulosalis en T. egialealis, Muruca testulalis en Sylepta multilinealis, bij welke dan nog een aantal vormen komen, die, vermoedelijk plaatselijk en tijdelijk, zich nu eens meer, dan weder minder vertoonen. Verschillende der borengenoemde vormen vinden elders gunstiger levensvoorwaarden dan in dit gebied, in rerband waarmede wij later nog op hen terugkomen. Van de rupsen dezer talrijke arondbezoeker's bemerkt men wederom zeer weinig; die van Sylepta multilinealis vindt men wel eens op de algemeen aangeplante kembang sepatoe (Hybiscus rosasinensis en $H$. schizopetalus).

Even reelvuldig als in dit gebied de Pyralidae zijn, eren spaarzaam zijn er de Tortricidae rertegenwoordigd. Trourens, de geheele cultuurfauna is arm daaraan; de lange rij der insecten, die op Java schadelijk zijn, telt er slechts enkele. Het is wederom een ran die families, die aan hare oorspronkelijke omgering zijn getrouw gebleren en, waarschijnlijk alș een gevolg daarran, zijn de Javaansche rormen nog slechts uiterst lacunair bekend.

Niet veel beter is het gesteld met de Tineidae, maar ran deze hebben toch meerdere soorten zich een plaats in de cultuurfauna weten te veroveren en te behouden. Tan deze treft men in dit gebied een drietal aan, die algemeen en karakteristiek genoeg zijn, om hier te worden vermeld.

De eerste is, zoo niet identisch met, dan toch ten nausste verwant aan Tineu granella, de Europeesche Graanmot: zij is eene bewoonster van pakhuizen en provisiekamers en wordt daar even ongilarne gezien als elders binnenshuis Setomorpha tineoides, waarvan 
overigens de rups een zeer alledaagsche verschijning is. Deze woont in een kokertje, clat aan de uiteinden en in het midden een weinig is verbreed en tevens min of meer is afgeplat. Het is donkergrijs en bestaat uit zeer fijne zanddeeltjes, door het rupsje tot een sterig en taai geheel aaneengesponnen. Het rupsje berveegt zich geheel vrij daarin en kan zich zelfs erin omdraaien, zoodat het aan beide zijden uit het kokertje kan tevoorschijn komen. Men ziet deze kokertjes dikwijls tegen de muren, als wanneer het rupsje bezig is, nar boven te kruipen; niet zelden treft men ook leege kokertjes aan, reeds door het vlindertje rerlaten, dat zijn pophuid halverwege in een der openingen heeft laten zitten. Een bijzondere voorliefde roor wollen kleederen heeft aan dit insect terecht een slechten naam bezorgd.

De derde der bedoelde Tineiden, Pyllocnistis minutella, is buitenshuis te vinden, op de jonge blaadjes der citroenaihtige gevassen. Dáál leeft het uiterst kleine rupsje *) onder de opperhuid der borenzijde en maakt er een slingerenden gang, die gervoonlijk nabij den rand ran het blad eindigt in een, iets grootere ruimte, waarin de verpopping plaats heeft. De opperhuid blijft in haar geheel aanwezig en verkrijgt door de, zich daaronder bevindende lucht een wit glinsterend uiterlijk, als had-en zoo wordt de zaak niet zelden rerklaard-een slak over het blad geloopen en een weinig slijm op haar slingerend spoor achtergelaten.

Eindelijk moge nog worden genoemd het geslacht Pterophora, dat de zoogenaamde Vedermotjes omvat,

*) Dit rupsje is in bijzonderheden beschreven door IV. VAN Deventer: Over de ontwikkelingstoestanden van eenige Microlepidoptera van Java, Tijdschrift voor Entomologie, Deel 46, pag. 79. 
diertjes van dikwijls witte, satijnachtige kleur, wier diep ingesneden vleugeltjes den indruk maken van uit kleine veertjes te bestaan.

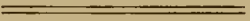




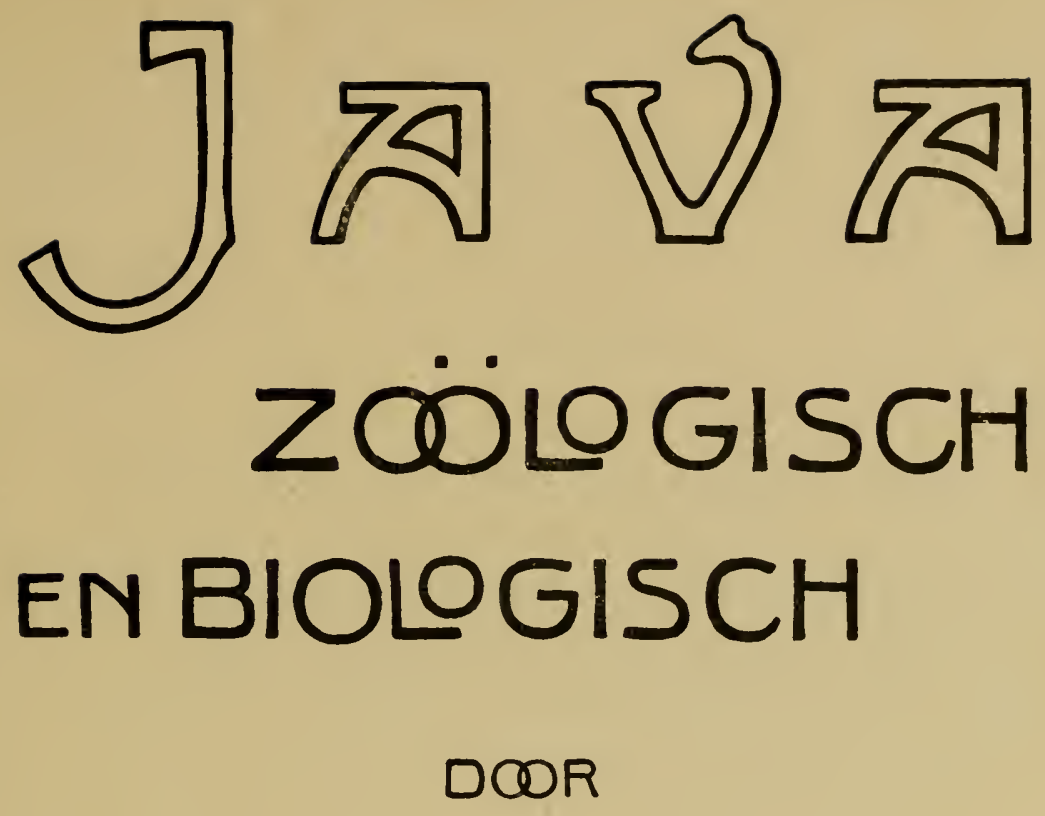

\section{DRJ.C.KONINGSBERGER}

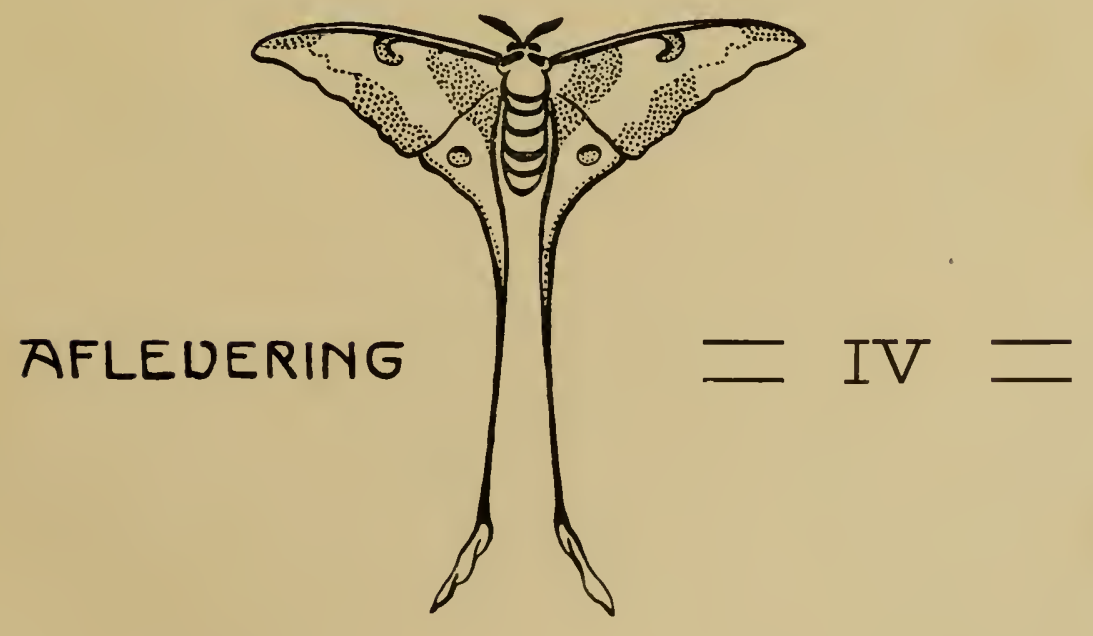





\section{N HOU D.}

\section{AFI_EVERING I.}

VOORTOORD.

pag.

Hoofdstuk I. Algemeene samenstelling der Fauna van Java en hare wordingsgeschiedenis. De Hoofdgroepen. . . . .

Hoofdstuk II. Overgangen van de eene groep in de andere. Morphologische gevolgen daarvan. Voorbeelden van vormen, die in overgang zijn. Nachtelijke en diurne levenswijze. .

HoofDstuk III. Inrloed van jaargetijden, regen, wind en zonneschijn. Vergelijking met andere eilanden. . . . . .

\section{AFLEVERING II en III.}

HoofDstuk IV. Kort overzicht der verschillende gebieden. De Cultuurfauna bij uitnemendheid: de diervormen der grootere plaatsen . . . . . . . . . . . . . 51 .

A. Zoogdierex . . . . . . . . . . 5 . . . . . .

B. Vogels. .. . . . . . . . . . . 60 .

C. Kruipende ex Tweeslachtige Dieren. . 76.

Hoofdstuk V. De Diervormen der grootere plaatsen. (Verrolg). . . . . . . . . . . . . . . 90.

D. Insecten . . . . . . . . . . . . 90.

1. Orthoptera . . . . . . . . . . 90.

2. Neuroptera . . . . . . . . . . 98.

3. Rhynchota . . . . . . . . . . . 104.

4. Diptera . . . . . . . . . . 108.

Hoofdstuk VI. De Diervormen der grootere plaatsen.

(Verrolg). D. Insecten. (Vervolg) . . . . . . . . 116.

5. Coleoptera . . . . . . . . . 116.

6. Lepidoptera . . . . . . . . . . 127. 


\section{AFLEVERING IV.}

Hoofdstuk VII. De Diervormen der grootere plaatsen

pag. (Vervolg). D. Insecten (Vervolg) . . . . . . . . . . 157.

7. Hymenoptera . . . . . . . . . . 157.

8. Apterygota . . . . . . . . . . . 179.

Houfdstuk VIII. De Diervormen der grootere plaatsen. (Vervolg). . . . . . . . . . . . . . . . . 180.

E. Schorpioenen en vertwante voruen . . . 380.

F. Spinnen en Mijten . . . . . . . . 182.

G. Duizendpooten . . . . . . . . . . . 189.

H. Kreeftachtige Dieren. . . . . . . . 193.

I WeEkdieren. . . . . . . . . . . . 194.

K. WORMEN . . . . . . . . . . . . 195.

Hoofdstuk IX. De Fauna der dessa's . . . . . . . 198.

A. DESSA'S IN HET OPEN TELD . . . . . . 199. 


\title{
HOOFDSTUK VII.
}

\section{De Diervormen der grootere plaatsen.}

\author{
(Vervolg) \\ D. Insecten (Vervolg). \\ 7. Hymenoptera.
}

Waar in de tropen van Hymenoptera wordt ge. sproken, is men in de allereerste plaats geneigd te denken aan de mieren, die in de streken aan weerszijden van den evenaar een rol spelen, waarvan men zich slechts door eigen aanschouwing eene voorstelling kan maken. Hoewel zij in de grootere bevolkingscentra natuurlijk veel minder op den voorgrond treden dan daarbuiten, zijn zij toch ook dáár een factor, waarmede de mensch in zijn huiselijk leven rekening moet houden, wil hij zich niet nu en dan vonr onaangename verrassingen zien geplaatst. Deze worden hem het meest bereid door de groep van mieren, waarvan men onder normale omstandigheden het minst bemerkt, namelijk die der Myrmicinae, en dan nog wel door de kleinere soorten, die veelal niet meer dan een paar millimeter lang zijn en, wanneer men een of ander begeerlijk voorwerp onbewaakt laat liggen, in korten tijd bij drommen komen opzetten op plaatsen, waar zij anders niet zijn te bespeuren.

Het eigenlijke terrein der Myrmicinae ligt overigens 
niet hier, maar in de wildernis, waar men ze in hun volle maatschappelijke ontwikkeling kan gadeslaan. In de nabijheid van den mensch houden zij zich, behoudens de zooeven bedoelde rooftochten, op een afstand, nestelen in het verborgene en verraden hunne aanwezigheid roornamelijk door de gevleugelde exemplaren, die des avonds, echter zelden zwermsgewijze, komen binnenvliegen. Als soorten, die in dit gebied voorkomen, mogen o.a. worden genoemd Pheidole javana, Ph. plagiaria, Monomurium pharaonis, Pheidologeton affinis en Tetramorium pacificum. Ook het geslacht Strumigenys, met zijn eigenaardig gevormde kaken, is hier door een vrij groot aantal soorten vertegenwoordigd, maar men moet deze kleine insecten bepaald in hunne verblijfplaatsen (in plantaardigen detritus; onder loslatende stukken boomschors enz.) opsporen om hunne aanwezigheid te kunnen constateeren.

Een nog veel meer verborgen levenswijze leiden de Dorylinae, die, evenals de Termieten, hunne nesten diep in den grond maken. Dat zij echter in dit gebied in geenen deele ontbreken, bemerkt men des avonds aan de gevleugelde mannetjes, waarvan vooral die van het geslacht Dorylus zoozeer op wespen gelijken, dat zij in den regel daarvoor worden gehouden en in gelijke mate worden gerreesd. Het moet inderdaad worden erkend-mijn eerste ervaring dienaangaande staat mij nog levendig voor den geest-, dat een, rondom de lamp vliegende zwerm van de groote Dorylus - mannetjes er schrikverwekkend genoeg uitziet. Dergelijke zwermen behooren echter op de meeste plaatsen tot de zeldzaamheden, wellicht voornamelijk omdat de dieren eerst omstreeks of na middernacht schijnen uittevliegen. 
Meer alledaagsche verschijningen daarentegen zijn de mannetjes van het verwante geslacht Aenictus, waarvan men bijv. te Buitenzorg bijna elken avond een paar exemplaren kan verkrijgen. Door hun geringere grootte en doordat ze altijd afzonderlijk verschijnen, trekken zij echter reel minder de aandacht.

De Poneridae, in de cultuurfauna rijk vertegenwoordigd, komen ook in dit gebied veelvuldig voor, terwijl hunne, in den regel roor mieren aanzienlijke afmetingen ertoe medewerken, dat zij een opvallend bestanddeel van de fauna uitmaken. Zij nestelen gaarne in holten van boomstammen, in den regel niet hoog boven den grond, ook wel onder steenen, en zelfs vond ik wel eens kleine nesten onder afgevallen blad, die echter meer den indruk maakten van een tijdelijk bivak op een, vermoedelijk lange verbindingslijn met het ejgenlijke nest. In den regel zijn, althans in dit gebied, de nesten der Poneridae niet groot en is ook het aantal bewoners niet uitermate talrijk. Men treft er gewoonlijk allerlei overblijfselen van andere insecten aan: chitinestukjes, pooten, dekschilden van kevers, stukjes van vliezige vleugels, alles afkomstig hetzij van reeds doode dieren, hetzij van dieren, die, door omstandigheden in een hulpeloozen toestand geraakt, aan de mieren zijn ten prooi gevallen. Het in colonnes oprukken van Poneridae, vooral eene gewoonte van het geslacht Lobopelta, nam ik in deze omgering nocit waar, wat waarschijnlijk in verband staat met de betrekkelijk geringe getalsterkte der kolonies; integendeel ziet men ze dikwijls geheel alleen rondzwerven, zonder eenig verband met andere individuen.

Tot de meest gewone soorten behooren Odontopo- 
nera transversa, Pachycondyla insularis. Ectomomys. mex astutus, Stigmatomma reclinata en een paar Diacamma-soorten, terwijl ook het geslacht Odontomachus hier door de soorten haematodes en rixusus is vertegenwoordigd. Ik maak van dit laatste afzon. derlijk melding, niet, omdat ik in twijfel trek hetgeen Bingham ${ }^{1}$ ) aangaande het geslacht Odontomachus in Britsch Indië opmerkt: "the species belonging to this genus are eminently forest ants, never, so far as I know, found near human habitations", maar om erop te wijzen, hoe dezelfde diersoorten (O. hacmatodes en 0 . rixosus komen beide ook aldaar voor), wanneer zij worden geplaatst voor de keuze, die het optreden van den mensch hun stelt, in verschillende streken niet steeds hetzelfde doen, maar dcor omstandigheden van plaatselijken aard in geheel verschillende richtingen kunnen worden geleid. Zijn de hier bedoelde insecten in Britsch Indië boschdieren gebleven, op Java kan men ze temidden der menschelijke samenleving waarnemen, hetzij dat men overdag de werkmieren met dikwijls geheel opengesperde kaken ziet rondzwerven, hetzij dat men des avonds de gevleugelde individuen op het lamplicht ziet afkomen of ze den volgenden morgen, met afgebeten vleugels, vrij hulpeloos naar een passend onderkomen vindt zoeken.

Over het algemeen hebben de Poneridae, ook de gevaarlijk uitziende Odontomachus- soorten, een rustig temperament en onderscheiden zich daardoor gunstig van de meeste Camponotinae, wartoe het meerendeel behoort van die mieren, die men overal in dit gebied zonder eenige bedekking of poging om zich te verschuilen aantreft. Gelukkigerwijze is dit tem-

1). Fauna of British India, Formicidae, pag. 46. 
perament het minst ontwikkeld bij de soorten, die men gewoonlijk binnenshuis tegenkomt en die tot de geslachten Lasius, Pseudolasius, Camponotus e.a. behooren. Bij andere soorten ran dezelfde geslachten, die men buiten aantreft, waar zij, in orereenstemming met de algemeene neiging der Camponotinae, in den rorm ran Plantenluizen en jonge Homoptera hun mierenvee houden, valt een meer aggressief karakter waar te nemen. Strijkt men bij ongeluk met de kleeren langs een plant, waarop ze zich in groot aantal bevinden, dan rerspreiden ze zich spoedig in alle richtingen en hebben weldra op hals of handen ran den indringer de gelegenheid, hunne woede orer deze stoornis door nijdige beten kenhaar te maken. Sommige soorten gaan daarbij zóó sanguinisch te werk, dat zij zich, bij cen poging om ze te rerwijderen, eerder in tweeën laten trekken dan loslaten.

Een ran de meest onverdraagzame vormen, die ook wel een enkele maal binnenshuis roorkomt, is Plagiolepis longipes, een licht roodbruine $e n$, zooals de naam reeds aanduidt, langpootige soort, die bij het te lijf gaan van andere soorten den aangevallene op het lichaam springt en hem met ongeloofelijke snelheid een beet tusschen kop en thorax toebrengt, die bij zwakkere en kleinere individuen dikwijls binnen weinige seconden den dood ten gevolge heeft. Wellicht wordt dit proces nog rerhanst door uitstorting, op de gewonde plek, van een weinig vocht uit de abdominale giftklier; er wordt althans net het achterlijf eene beweging gemaakt, die daaraan zou doen denken, maar ik heb het feit nooit met zekerheid kunnen constateeren. Dat echter sommige Camponotinae voor dergelijke doeleinden van de genoemde klier gebruik maken, is duidelijk waarneem- 
baar bij Oecophylla smaragdina, die het vocht zelfs met kracht kan uitspuiten. Deze meest oorlogzuchtige en temperamentvolle van alle Camponotinae komt in dit gebied echter slechts sporadisch roor. $\mathrm{Zij}$ behoort thuis in bosch en wildernis, met een besliste voorliefde voor de nabijheid der zee.

Tot de grootste rormen van de groep behooren in dit gebied die van het geslacht Polyrhachis, die er in grooten vormenrijkdom aanwezig zijn en de aandacht trekken door de, dikwijls sierlijke dorens en tandvormige uitsteeksels op thorax en steel van het achterlijf, vormingen, die aan de, overigens tamelijk vreedzame dieren een min of meer geducht uiterlijk verleenen, maar toch van twijfelachtig nut moeten worden geacht, daar de dieren bijv. door mierenetende vogels even goed als andere, ongedoornde soorten worden gegeten.

Houtwespen en Bladwespen heb ik in dit gebied nooit ontmoet; de laatste vindt men op Java in de hoogere, boschrijke bergstreken. Ook de Galwespen spelen hier een zeer bescheiden rol, wat o.a. kan blijken uit de omstandigheid, dat J. en W. DостERS van Leeuwen-Reijnvaan 1) onder de vele gallen, die zij in de omstreken van Salatiga verzamelden, dus nog niet eenmaal binnen het gebjed, dat wij hier behandelen, niet meel dan 6 Cynipidengallen aantroffen.

Sluipwespen daarentegen ziet men hier tamelijk veel. Waar bladeren en jonge takken met Bladluizen en Schildluizen zijn bedekt, daar zweven kleine Procto-

1). Door deze auteurs zijn in de laatste jaren niet minder dan 350 verschillende Javaansche gallen beschreven; de nos. 1-250 in het tijdschrift "Marcellia", Riv. int. di Cecidologia, Jaargangen .909-1911, de nos. $251-350$ in Bulletin du Jardin Botanique de Buitenzorg, Deuxième Série, No. III. 
trupidae en Chalcididae eromheen; dikwijls ziet men in de rerdroogde schilden der Coccidae de overblijfselen van hum optreden in den vorm van kleine, ronde openingen, waaruit ze als imagines tevoorschijn kwa. men. Elders hangen de tonvormige cocons van Bracomidae aan draadjes of wijzen de overblijfselen van witte, rlokkige Microgaster-cocons de plaats aan, waar de larven zich uit een leeggerreten rups naar buiten boorden, om zich op de huid van hun slachtoffer te verpoppen. Op de zonnige uren van den dag ziet men op bloeiende planten en heesters fraaie Ichne $\boldsymbol{u}$ monidae al zoekend rondzwerven, deels om voedsel voor zich zelf, deels om een legplats roor hunne eieren te rinden. Het zijn roor het meerendeel fraaie, zenuwachtig bewegelijke insecten, waarbij de geslachten Amblyteles, Cryptus, Theronia en Mesostenus het best zijn vertegenwoordigd. Tegen den arond eindelijk komen de Ophionidae voor den dag, die slechts gedurende de duisternis hun slachtoffers besluipen en een enkele maal door het licht onzer woningen naar binnen worden gelokt.

Van de Chrysididac is in dit gebied Stilbum cyanurum de meest algemeene rorm, welke parasiet der straks te bespreken Eumenes-soorten niet zelden orerdag de huizen binnenrliegt in de hoop, aldaar de mesten ran laatstgenoemde aan te treffen. Maar ook kleinere Goudwespen ran het geslacht Chrysis zijn niet zeldzaam; ook deze leven, roor zooverre bekend is, parasietisch in de nesten ran andere Wespen, terwiil ze ook als secundaile parasieten de larven van Sluipwespen aantasten.

Tamelijk groot zijn het aantal en de verscheidenheid ran Graafwespes, die deze omgeving herbergt 
en bijzondere aandacht verdient het aanzienlijke procent daarvan, dat zoozeer alle banden met het verledene heeft verbroken, dat het thans ten aanzien van den mensch is gekomen in een verhouding, die niet zelden grenst aan symbiose, in zooverre elke menschelijke woning op Java ook die van een aantal dezer insecten bevat.

Tot de vormen, die ten aanzien van den mensch het meest geavanceerd zijn, moet ongetwijfeld in de eerste plaats het geslacht Ampulex worden gerekend. Weliswaar maken deze tamelijk kleine, aan de halsrormige verlenging ran den thorax ook in de vlucht gemakkelijk herkenbare wespjes hun nest in den regel niet binnenshuis, maar voor de proviandeering. erran maken ze jacht op jonge kakkerlakken en om deze te bemachtigen, laten zij geen hoekje onzer woningen ondoorzocht. Met de grootste vrijmoedigheid bewegen zij zich overal, waar zij een prooi hopen aan te treffen, en ze storen zich in het geheel niet aan de aanwezigheid der bewoners, als hadden ze eenig besef ervan, dat ze een nuttig werk verrichten, waarvoor men hun slecht dankbaar mag zijn. Inderdaad mag men het erroor houden, dat de overlast, den mensch in de tropen door de Blattidae veroorzaakt, aanzienlijk grooter zou zijn dan thans, wanneer niet deze ondememende diertjes onder de jonge exemplaren voortdurend opruiming hielden.

Binnenshuis nestelen zeer veelvuldig verschillende soorten van de geslachten Trýpoxylon en Sceliphron, waarvan vooral eerstgenoemde, die kleiner zijn dan de laatste ( $T$. bicolor, de meest gewone soort, is hoogstens $15 \mathrm{mM}$. lang), ons dikwijls voor allerlei verrassingen plaatsen. Zij dringen voor den bouw hunner nesten overal door, waar zich de gelegenheid voor- 
doet, in het rerborgene te bouwen. Sleutelgaten, die niet geregeld worden gebruikt, de loop ran een geweer, dat rustig aan den wand hangt, de rugruimte ran een ingebunden boek, een sigarenpijpje, dat eenigen tijn ongebruikt is blijven liggen, dergelijke en rele andere zijn de plekjes, die men ten allen tijde rerspesd kan rinden door de aarden bouwwerken dezer nijvere insecten, die in betrekkelijk korten tijd eene hoereelheid aarde bijeen brengen, die hun eigen lichaamsgewicht ettelijke malen overtreft. Merkwaaldig is daarbij le zekerheid, waarmede ze steeds ran buiten rechtstreeks op de plaats van hun nestbouw komen aanvliegen, en de snelheid, waamede zij een anderen toegangsweg vinden, wanneer men hun de gewone route onmogelijk maakt. Sluit men bijroorbeeld het renster, waardoor zij telkens. komen binnenrliegen, dan komen ze na weinige oogenblikken door een ander, ook al ligt dit aan de tegenorergestelde zijde ran het rertrek. Sluit men alle zonneblinden, dan onderbreken zij hunne werkzaamheid niet. maar komen tusschen de latten door en weten ook in het halfcluister zonder eenige aarzeling hun nest te bereiken.

De Sceliphron-soorten, die, evenals de latstgenoemde, humne nesten met spinnen proviandeeren, kumnen door hun grootere afmetingen niet zoo gemakkelijk overal doordringen en nemen daarom dikrijls plaatsen roor lief, die slechts aan twee zijden beschutting en gelegenheid tot aanhechting bieden, 7ooals de ruimte tussichen een schilderij en den wand, kieren in het houtwerk van deuren en rensters, achterwanden van kasten enz. enz. Het zijn vooral de soorten madraspatanum, violaceum en, in mindere mate, jaramum, die men hier in de woningen aantreft. 
De Ammophila's, die morphologisch aan de zooeven besproken Fossores nauw verwant zijn, staan met den mensch op een minder gemeenzamen voet. Weliswaar zijn Ammophila clava en A. variabilis in de tuinen onzer wouingen niet zeldzaam, maar zij zijn tamelijk schuw en komen slechts bij uitzondering een enkele maal in de galerijen, on tusschen de sierplanten naar spinnetjes te zoeken, waarmede zij zich snel verwijderen. Evenals bij vele vogels is waar te nemen, begeven zij zich dan niet rechtstreeks naar het nest, dat op een afgelegen plekje in den grond is uitgegraven, maar bereiken dit langs een omweg, om een mogelijken rerrolger het spoor bijster te maken.

Behalve de bovengenoemde komen nu en dan in dit gebied nog andere Sphegidae voor, die echter elders meer in hun element zijn en daarom later zullen worden besproken, evenals het meerendeel der Pompilidae. Slecht eenige kleinere Pompilussoorten zijn hier algemeen, maar deze rertoonen, in de vlucht waargenomen, zooveel. gelijkenis met elkander en met verschillende soorten van het rerwante genus Pseudagenia, die hier eveneens voorkomen, dat men slechts door het langdurig en op groote schaal verzamelen dezer dieren zou kunnen komen tot een juiste roorstelling van de rol, die ze spelen en van de onderlinge verhoudingen hunner getalsterkten. In afwijking van hetgeen bij de meeste Pompilidae het geval is, bourven de Pseudagenia's van aarde een geheel zelfistandig nest, dat op clergelijke plaatsen als de nesten der Sceliphron-soorten wordt aangelegd en eveneens spinnen als roedsel roor de nakomelingschap bevat. 
De geslachten Scolia en Elis van de familie der Scoliidae zijn hier, in den regel door talrijke individuen, vertegenw.sordigd door Scolia rubiginosa, $S$. capitata, Elis tristis, E. rubromaculata, E. thoracica en E. lindenii. Laatstgenoemde soort wordt talrịker, nar'mate men op hooger boven zee gelegen plaatsen komt, terwijl, wat de andere soorten betreft, die alle een vrij groote, verticale verspreiding hebber, hier de eene, ginds de andere meer op den voorgrond treedt. Dit laatste bepaalt zich echter tot een, niet zelden op onheilspellende wijze rondvliegen rondom den warnemer; een blik in hun meer belangrijke levensverrichtingen gunnen zij in deze omgeving in den regel niet, daar zij geen nesten bouwen en, voor zooverre hunne levenswijze bekend is, de eieren eenvoudig deponeeren bij larven van Bladsprietige Kerer's, die ze in den bodem opzoeken en op de gebruikelijke wijze paralyseeren.

De Diploptera hebben, zoowel in de familie der Eumenidae, als in die der Vespidae, eveneens talrijke vertegenwoordigers; die neiging vertoonen tot aansluiting aan de menschelijke samenleving. Daarvan zij in de eerste plaats het geslacht Eumenes genoemd, dat in dit gebied rooral door de soorten blanchardi, esuriens en circinalis is rertegenwoordigd, die alle in levenswijze en nestbouw een groote onderlinge overeenkomst vertoonen. Hunne, met geparalyseerde rupsen geproviandeerde nesten worden in den regel bevestigd aan een dun takje of een stevigen stengel en bereiken de afmetingen van een zeer grooten, langwerpigen aardappel. Inwendig bevat het nest een complex van 6 tot 10 cellen, waarvan de wand geheel glad is en bovendien nog met een eigenaardige, 
glinsterende stof wordt bestreken. Het takje, dat dit vrij zware nest heeft te dragen, loopt er in de geheele lengte doorheen, maar niet in het midden, zoodat de inwendige ruimte der cellen geen hinder ervan ondervindt.

Merkwaardig is de onverschilligheid roor stoornis, door de Eumenes-soorten aan den dag gelegd, wanneer zij met den nestbouw bezig zijn. Zij werken rustig door, ook al bekijkt men ze op. een afstand van eenige centimeters, en laten zich nauwelijks verjagen, als men de vorderingen van hun arbeid eens nauwkeuriger wil opnemen. Zelfs dan worden ze niet kwaardaardig en wachten eenvoudig het oogenblik af, waarop ze de nieuwsgierigheid van den waarnemer bevredigd achten. Vermoedelijk tengevolge van den zwaren arbeid, die voor hen aan den nestbouw is verbonden, gaan ze reeds róor zonsondergang ter ruste en kiezen daartoe gaarne heesters en bcomen met zeer fijn loof, waar men ze geregeld des avonds op dezefde plaatsen kan zien terugkeeren.

Het geslacht Rhynchium, waarvan voor dit gebied de soort haemorrhoidale de algemeene en typische vertegenwoordigster is, kiest roor den nestbouw bij roorkeur eene reeds bestaande ruimte, die alsdan met klei wordt bijgewerkt en afgesloten. De tamelijk eenzelrige dieren ran deze soort zoeken een dood takje, dikwijls ook een bamboestengel, waarin zich toevalligerwijze eene opening bevindt; als eisch stellen zij echter, dat die opening eenigszins naar beneden is gericht, zoodat het regenwater zich niet in de holte kan verzamelen. De laatste wordt dan zorgvuldig gezuiverd ran merg en alle daarin niet 
behoorende zelfstandigheden, telwijl, zooals ook bij sommige andere rormen gewoonte is, het ei later aan een draadje wordt opgehangen, rermoedelijk om te roorkomen, dat het in rerdrukking geraikt, wanneer de rupsen, zooals ze, trots hun paralyse, dikwijls doen, met het lichaam een heen en weer slaande bervegirg maken.

Terwijl Rhynchium haemorrhoidals slechts bij uitzondering binnenshuis nestelt, lian men de kleinele odynerus-soorten dikwijls waarmemen op dezelfde plaatsen in onze woningen, die ook den rroeger besproken Graafwespen een nestulats aanbieden. Orerigens gaan deze, door hun uiterlijk en hun geringere grootte, weinig oprallende rormen geheel op dezelfde wijze te werk.

Als een orergangsrorm, wat levenswijze betreft, van de solitaire tot de sociaal levende wespen mogen wij rermoedelijk het geslacht Ischnogastor beschouwen, waarvan de soort mellyi hier een zeel gewone verschijning is. Deze kleine, uiterst slank gehouwde, zwak metaalachtig glanzende irespjes kan men dikwijls voor sleutelgaten en dergelijke openingen zien zweven, die hun een goede nestplaats aanbieden. Soms ziet men, dat eenige individuen samen ian het bouwen zijn, zoodat er een gemeenschappelijk nest wordt aangelegd. In andere gerallen neemt men el maal één waar, tel'wijl, als men dit ééne individu eenige dagen gevangen houdt, in die dagen geen rorderingen aan het nest zijn te bespenlen, waaruit de gerolgtrekking mag worden gemaakt, dat het hier slechts een nest roor één gezin betreft, waaraan de gevangene, zoodra zij op rrije roeten 
wordt gesteld, onmildellijk weder verder arbeidt, alsof er geen stoornis had plaats gehad.

Het is opmerkelijk, dat de sociaal levende Diploptera over het algemeen een veel sanguinischer karakter hebben dan de solitaire. Men kan dit reeds waarnemen bij de Icaria-soorten, die nog maar in tamelijk kleine maatschappijen leven en, dikwijls aan de onderzijde van blaren, dus beschut tegen den regen, hun omgekeerd-pyramidevormige nesten bouwen. Deze nesten, die door middel van een stevigen steel zijn bevestigd, bevatten niet meer dan 25 tot 30 cellen, in den regel zelfs veel minder, en worden door de rolwassen clieren met zóóreel zorg bewaakt, dat zij soms den meest onschuldigen voorbijganger, mensch of dier, op verwoede wijze aanvallen en hoogst pijnlijke steken toebrengen. Intusschen wordt, wanneer daartoe door de nabijheid van roofzuchtige mieren aanleiding bestaat, het nest ook op praeventieve wijze beschermd en wel, door rondom den steel, nabij de aanhechtingsplaats, een tamelijk dikken ring aan te brengen van een speekselachtige, kleverige, niet opdrogende stof, die aan vaseline doet denken. Door deze barrière worden de mieren rolkomen tegengehouden, zoodat de jonge Icaria's, die in dit gebied tot de soorten pendula, bioculata en ferruginea behooren, zich rustig kunnen ontwikkelen.

Van het geslacht Vespa zijn de soorten cincta en anclis in dit gebied het meest algemeen vertegenwoordigd. Zij zijn het, die o.a. tusschen de daken en de plafonds der woningen nesten maken van dikwijls reusachtige afmetingen, waarvan wel eens groote 
stukken door hun eigen gevicht naar beneden storten. Gelukkig behooren deze beide soorten niet tot de gevaarlijkste; daartoe mag o.a. worden gerekend Vespa velutina, die haar nesten hoog in de boomen bourt en, wanneer zij daartoe toevallig een alleenstaanden boom heeft uitgekozen, de geheele omgeving daarvan onveilig makkt. Hoewel deze soort ook in de groote plaatsen van Java roorkomt, behoort zij toch meer thuis in een vrijere omgerirg: zij wordt nu en dan aangetast door een schimmelziekte, waarbij de parasiet een mycelium rormt, dat rooral uit het abdomen naar buiten groeit en zich roordoet als lange, stijve, zwarte, achterwaarts gerichte haren.

Vespa cincta en Vespa analis nestelen intusschen ook in de boomen en stichten daar dikrijls omvangrijke koloniën, waarin den geheelen dag groote bedrijrigheid heerscht. Tot zelfs in de arondschemering neemt men een aanhoudend komen en gaan van talrijke individuen waar; het is een drukte als van een postkantoor van een groote handelsstad, waar de bezoekers geen tijd hebben om een enkel wourd met elkander te wisselen en zich, na afdoening hunner zaken, met haast weder naar alle richtingen rerspreiden. Eerst met de duisternis komen zij tot rust en rereenigen zich dan in en op hun gemeenschappelijk verblijf, om den rolgenden morgen rroeg hun bedrijvigheid weder te hervatten. Geen wonder, dat bij zulke naarstige dieren de nestboum rlug van stapel loopt en men zelfs van verre dagelijks een toename van den omvang kan vaarnemen. Op zeker oogenblik echter is de definitieve grootte berelkt. Langzamerhand zijn alle cellen uitgekomen en het nest begint dan aan overberolking te lijden, 
ten gerolge waarvan een aantal werksters onder aanvoering van een paar geslachtelijke dieren uitzwermt, om elders een nieuwe kolonie te stichten. Bij het zoeken naar zen geschikte plaats diarvoor en gedurende het begin van den bouw, als wanneer, ze nog geen behoorlijk onderkomen hebben, ziet men dan de geheele troep soms, tot één klomp vereenigd, aan een tak of tegen een boomstam hangen. Het oude nest blijft echter ook in gebruik, hetzij door de dieren, die het bouwden, hetzij door een jongere generatie, totdat het, rermoedelijk door atmosferische invloeden, minder bruikbar wordt.

Uit de groep der Bijen treden verschillende vertegenwoordigers den mensch eveneens tamelijk na, wat niet te rerwonderen is bij de verscheidenheid van bloemen, die men gewoonlijk op de elven der Europeesche woonhuizen aantreft. Reeds tamelijk rroeg in den morgen vliegen niet zelden Anthophora zonata en Nomia strigata door onze voorgalerijen, onder een aangenaam gonzend geluid, dat ons aan een warmen zomermorgen op de vaderlandsche heide herinnert. Zij houden zich daarbij gaarne een oogenblik zwevende voor allerlei openingen, in het bijzonder clie ran het vlechtwerk van rottan meubelen, als zagen ze ckarin den toegang tot een of ander nest, op overeenkomstige wijze gebouwd als het hunne, dat men in den srond kan aantreffen.

De reel kleinere Graafbijtjes (soorten ran Andrenc en Halictus) vallen minder op en zijn daarbij zeer moeielijk van elkander te onderscheiden. In talrijkheid leggen zij het verre af tegen de Prosopis-soorten, waar deze in reten van muren of van steenen trappen 
een nestgelegenheid hebben gevonden, waarvóól ze in den regel in dichte zwermen dooreen krioelen.

Op dergelijke plaatsen nestelen ook de Melipona's, maar deze hebbun, door de groote hoeveelheden was en honing, die ze maken, over het algemeen meer ruinte noodig. De was, die deze diertjes vervaardigen, is buitengewoon taai; ik heb eens waargenomen, dat zij hun nest hadden gemaikt in een porceleinen bloempot, tusschen den wand ervan en dien van een zinken binnempot en dat zij deze beide voorwerpen zóó stevig aan elkander hadden vastgebouwd, dat ze slechts met een beitel waren los te maken.

Van de Behangersbijen is in dit gebied Megachile thoracica de meest algemeene soort, waarvan men de sporen dikwijls aan allerlei planten kan waarnemen in den vorm van geheele of gedeeltelijke kringen, die uit de blaren zijn weggesneden.1) Veel kwaad doen zij hier overigens niet, terwijl humne ontwikkeling naar getalsterkte bovendien nog wordt tegengegaan door de aanvallen, die zij in hunne nesten hebben te doorstaan van het verwante geslacht Coclioxys, dat, ook in de vlucht, gemakkelijk aan den puntigen rorm van het achterlijf is te herkennen. Dit laatste geslacht toch is de "koekoeksbij" der Megachile's, die haar eieren legt in de nesten van deze laatste, welker larven daardoor te gronde gaan. Voor het aanleggen van het nest gebruiken de $M e$ gachile's het liefst bestaande, nauwe, buisvormige holten, zooals in vermolmd hout, oude bamboe enz. dikwijls zijn te vinden. Een enkele maal nestelen

1) Ook ran het Chrysomeliden-geslacht Haplosonyx maken een paar soorten zich aan hetzelfde schuldig, bij voorkeur op de groote blaren van Araceae, die vaak als sierplanten worden gekweekt. In de groote plaatsen zijn deze insecten echter zeldzaam. 
zij ook wel binnenshuis en, als geen geschikte holte ter beschikking staat, maken zij er zelf een, veelal in den grond. Die nestruímte nu wordt op de gewone wijze bekleed met de afgesneden bladstukjes en, zoodra genoeg stuifmeel roor ééne larve is bijeengebracht, wordt een ei gelegd en de aanstaande larvenkamer door een groot, rond bladstuk afgesloten. Van het tijdsvelloop, dat tusschen het leggen van het ei en het aanbrengen van dit laatste bladstuk is gelegen, moet de koekoeksbij gebruik maken om haar slag te slaan en daarom ziet men de laatste dikwijls in de nabijheid van het nest op den loer zitten en telkens van de afwezigheid der Megachile gebruik maken, om zich daarbinnen ran den stand ran zaken op de hoogte te gaan stellen.

Wij komen thans tot een geslacht van Apidue, dat met de menschelijke samenleving op een bijzonder goeden roet staat en dadelijk de aandacht trekt van den nieuw in de tropen aangekomene, namelijk dat der Houtbijen of Xylocopa's, hier reelal met de inlandsche namen bangbara en kombang aangeduid. Deze insecten toch bewonen, zooals bekend is, in groot aantal het houtwerk der daken, voor zooverre dit van buiten gemakkelijk is te bereiken en brengen daaraan niet zelden belangrijke schade toe. Met de krachtige voorkaken boren zij gangen in de dikkere latten, eerst loodrecht op de lengterichting, daarna over een veel grooteren afstand evenwijdig daaraan, om ten slotte weder een drarsgerichten uitgang te maken. Deze uitgang wordt echter weder gesloten met een wandje, dat uit aan elkaar geplakte, fijngekauwde houtvezels bestaat. Nabij dit wandje wordt, nadat de noodige hoeveel- 
heid voedsel in den vorm van stuifmeel en honig is bijeengebracht, een eerste ei gelegd, waarop een tweede wand wordt rervaardigd, on het kamertje voor de aanstainde larve aftesluiten. Op dezelfde wijze gaat het dier nu roort met aandragen ran roedsel, leggen van eieren en maken van dwars. wanden, totdat de geheele nestgang; met uitzondering van het ingangsgedeelte, gevuld is. Het aantal kamertjes is bij de verschillende soorten van Xylocopa's en zelfs bij de individuen van dezelfde soort verschillend, maar bedraagt zelden meer dan twaalf. Het is een geluk voor de bezitters der huizen, dat dezelfcle gang vele malen, zelfs ettelijke jaren achtereen, roor hetzelfde doel wordt gebruikt.

Het zijn rooral de grootere, donkere soorten latipes, temuiscapa, coerulea en pictifrons, die op deze ivijze in de menschelijke woningen hospiteeren en overdag niet zelden in kamers en galerijen hun onheilspellend, maar overigens ongevaarlijk gebrom doen hooren. Hetzelfcle gebrom hoort men wel eens des nachts, als wanneer het afkomstig is of van de volwassen dieren, die in den irgang van het nest overnachten, of van de, pas uit de pop gekomen individuen, die het wandje, dat hen van de buitenwereld scheidt, hebben doorgebroken en nu hum vleugels in trillende berveging zetten, alvorens in de morgenschemering voor de eerste maal uit te vliegen.

De kleinere soorten (collaris, aestuans, mesoxantha) komen niet of slechts zelden in onze huizen roor, wellicht omdat het houtwerk hun in den regel te hard is. Zij maken hun gangen in doode en vermolmde takken, in oude bamboe enz., maar hebben overigens, althans voor zooverre bekend is, dezelfde levenswijze. Evenals de grootere soorten, zijn zij 
blootgesteld aan gevaren van de zijde eener groep van Weekhuidige kevers, waarvan in dit gebied de roode, reeds vroeger (pag. 123) genoemde Horia cephalotes de meest bekende vertegenwoordiger is. Men vindt dit laatste insect niet zelden op den grond rondkruipen onder afclaken, warin Houtbijen nestelen, en het is waarschijnlijk, dat zulke individuen dadelijk na het uitkomen door de rechtmatige bezitters met geweld zijn verwijderd uit de nesten, waarin zij ten koste van één der larven zijn opgegroeid. In bijzonderheden is de toedracht der zaak nog niet bekend, maar uit de aanwezigheid van eene Horialarve in sommige gesloten cellen, warin men een Houtbijlarve zou verwachten, mag men opmaken, dat de eerste bijtijds, d.w.z. op het oogenblik, waarop de Houtbij har ei legde, in die cel is gekomen. Naar analogie met verwinte, eveneens parasitische keversourten, waarvan de ontwikkeling volledig bekend is, mag men verder als wararschijnlijk aannemen, dat de Horia-larven zich in jeugdigen toestand in bloemen ophouden, waar zij gelegenheid vinden, zich fluks vast te klampen aan de Houtbijen, die deze bezoeken, en in welker beharing zij een voor. loopige schuilplaats vinden tot het ougenblik, waarop een ei wordt gelegu.

Zij komen dus slechts dan tot ontwilkkeling, wanneer zij zich tot dit beslissende oogenblik op een vrouwelijke Houtbij hebben weten staande te houden en nu kont het mij niet onmogelijk roor, dat de kans daarop, die op zich zelf niet zoo heel klein is, door een derde diersoort zooreel kleiner wordt gemaakt, als overeenstemt met het vrij geringe aantal Horia's, die men in de Xylocopa-nesten aantreft. Men vindt namelijk op het lichaam van de wijfjes 
van vele Xylocopa-soorten (o.a. van alle bovengenoemde soorten met uitzondering van collaris) een zeer eigenaardig logeerverblijf, waarin zich groote mijten ophouden ran het geslacht Greenia, in 1902 door onzen landgenoot A. C. Oudem $A$ ss beschreren naar aanleiding van materiaal, hem uit Ceylon tocgezonden en aldaar rerzameld op Xylocopa temuscapa 1). Wanneer men bij een rrouwelijke Houtbij van een der bedoelde soorten het achterlijf 2) ran het lichaam rerwijdert en van de vóórzijcle bekijkt, ontdekt men, boren den achterlijfssteel, een ronde opening; die door korte, dicht bijeengeplaatste, tamelijk sterige haren is omgeren. Deze opening roert in een groote, bolrormige ruimte, die een eigen, dumnen clitinewand bezit, gelegen is tusschen de blaasvormige luchtzakken van het acterlijf, maar orerigens met de inwendige holte van het lichaam in geenerlei gemeenschap staat. In deze ruimte nu vindt men een aantal individuen van het zooeven genoemde geslacht, die roor mijten zulke aanzienlijke afmetingen hebben, dat men ze op het eerste gezicht roor kleine teken (Ixodidae) zou kunnen houden. Soms treft men slechts een paar erran aan, dikwijls echter is hun aantal zóó groot (als maximum telde ik zestien), dat ze, uoor de vrij lange jooten, als tot één kluwen zijn rereenigd.

Aan de aanwezigheid dezer mijten knoojen zich verschillende rragen rast, welker beantwoording zeer zeker de moeite ran een gedetailleerd onderzoek waard is. In de eerste plaats is men geneigd, zooals ik hierboven reeds pmelkte, verband te zoeken met

1). Tijdschrift der Nederlandsche Dierkundige Vereeniging, 2e Serie, Deel VII, pag. 60.

2). Hoewel het morphologisch niet geheel juist is, zullen wij dit woord hier gemakshalve gebruıken; de bedoeling erran is duidelijk. 
de Horia-larven, die wellicht door de Greenia's, in ruil voor het genoten, vrije onderdak, worden vervolgd, onschadelijk gemaakt en als voedsel genuttigd. Dit verband wordt des te plausibeler gemaakt, omdat de mijten niet worden aangetroffen bij de mannelijke Houtbijen, aan welke de Horia-larven ten slotte weinig kwaad kunnen toebrengen en die, ter aangeduide plaatse van het achterlijf, slecht een kleine indeuking vertoonen. In de tweede plaats rijst de vraag, hoe en wanneer de mijten op de Houtbijen komen, m.a.w., welke hun eigen levensgeschiedenis is, terwijl ten slotte nog het meest belangrijk is de vraag naar den oorsprong en het karakter eener correlatie tusschen twee diersoorten, die, in een zóóver gevorderd stadium van ontwikkeling als den poptoestand, bij de vrouwelijke individuen van de ééne soort eene woning voor de andere doet ontstaan.

Daar Hommels in dit gebied niet voorkomen en beperkt zijn tot de bergstreken, waar zij, naarmate men hooger stijgt, langzamerhand de Houtbijen geheel vervangen, behoeft van de groep der Apidae hier nog slechts te worden genoemd het zeer algemeene, Indische hijtje, Apis indica, dat groote uitwendige gelijkenis met Apis mellificu rertoont, maar dat verschillende pogingen ten spijt, weinig neiging aan den dag legt om zich in het pantser der domesticatie te roegen. Men treft dit insect zeer algemeen aan op allerlei bloeiende planten, waar het zijn voorraden opdoet voor de nesten, die dikwijls een aanzienlijken omvang bereiken, uit hexagonale celletjes zijn ongebouwd en op allerlei goed beschutte plaatsen worden aangelegd (in holle boomstammen, onder daken enz.). 
De hoeveelheid honing, in deze nesten aanwezig, is dikwijls rrij aanzienlijk.

\section{S. Apterygota.}

Deze groep van primitieve insecten behoeft roor dit gebied slechts een korte vermelding. Zij is hier vertegenwoordigd, in het bijzonder in de woningen, door het geslacht Lepisma, in verschillende soorten over de geheele wereld verspreid en in Hollandsche werken gewoonlijk met den naam van Suikergast aangeduid.

Eene op Java zeer algemeene soort is de groote Lepisma cincta, die eene lichaamslengte van meer dan een Centimeter kan bereiken en zich van rerwante soorten dadelijk onderscheidt door een geelwitten dwarsband, langs den achterrand van het voorste thoracaalsegment, over het, als gewoonlijk bij dit geslacht, zilvergrijze, glinsterende lichaam. Men treft cleze soort en hare verwanten in allerlei schuilhoeken van kasten en laden aan, waar eenig organisch roedsel is te vinden, terwijl zij het in het bijzonder op lederwerken hebben voorzien en oreral de sporen van hun optreden achterlaten in den rorm van talrijke en harde excrementen ter grootte ran zandkorrels. 


\title{
HOOFDSTUK VIII.
}

\section{De Diervormen der grootere plaatsen.}

\author{
(Vervolg) \\ E. Schorpioenten EN VERWANte vormen.
}

De Schorpioen bij uitnemendheid van Java is Buthus (Heterometrus) cyaneus, trots zijn soortnaam zwart of groenachtig zwart, veelal met een rossigen weerschijn. Dit dier is, ook in de grootere plaatsen, zóó algemeen, dat men bijvoorbeeld te Buitenzorg, tegen de geringe premie ran een parr centen per exemplaar, dagelijks wel een honderdtal ervan kan krijgen. Toch is er rermuedelijk menigeen, die dit, voor velen. min of meer huiveringwekkende dier, waarvan de grootere exemplaren, ran kop tot stekel gemeten, een lengte van 16 Centimeter bereiken, nooit hebben gezien, daar het zich uitsluitend op tamelijk rerborgen, vochtige plaatsen ophoudt. Men moet het zoeken langs de randen ran rivieren en beken, op moerassige plekken, waar het leeft, deels in den grond, deels onder steenen en onder afgevallen blaren. Zoodra het dier bemerkt, dat het ontdekt is, neemt het zijn verdedigende houding aan, waarbij het zich een weinig op de pooten opricht en zoowel de beide, met scharen gewapende pedipalpen als rooral het, van den giftstekel roorziene achterlijf omhoog steekt. Met zijn zijdelings ge- 
lichten gang en zijn dansende bervegingen makkt het alsclan meer een komischen, dan een gevaarlijken incluk. Evenals alle schorpioenen, is ook deze soort levendbarend; de geelwitte, in den aanvang zeer weekhuidige jongen worden geruimen tijd donr de moeder op het lichaam rondgedragen.

De veel kleinere Hormurus australasiae is ereneens niet zeldzaam en vertoont zich wel eens binnens huis, waar dan een rerborgen plekje tot verblijfplaats wordt gekozen, liefst waar een gordijn of een andere beklimbare stof de jacht ook in verticale richting mogelijk maakt.

Van nog geringer afmetingen zijn de Isometrussoorten, die gemakkelijk als zoodanig zijn te herkennen aan den zeer slanken bouw en rooral aan de smalle, bijna pincetrormige scharen der pedipalpen. Van dit geslacht zijn hier drie soorten (maculatus, formosus en mucronatus) te vinden, waarbij hier de ééne, ginds de andere soort door getalsterkte praedomineert.

Ten slotte zij hier genoemd de groote, maar blijkbaal zeldzame Palamnaeus longimanus (spinifer?), waarran ik slechts een enkele maal hier te Buitenzor'g een exemplaar rerkreeg: In algemeenen habitus herinnert deze soort aan Buthus cyconeus, maar zij is daarvan cloor cle langere geledingen der pedipalpen en rooral door den veel slankeren bouw der scharen dadelijk te onderscheiden.

Van de, aan Schorpioenen verwante vormen moet hier in de eerste plaats worclen genoemd het geslacht Thelyphonus, in dit gebied tamelijk veelvuldig; hier en daar zelfs zeer algemeen, door de soort caudatus vertegenwoordigd. Deze dieren, die met den vrij juisten naam van Schorpioenspinnen worden aangeduid, zijn eveneens op vochtige, donkere plaatsen te 
vinden. Zij verbergen zich onder steenen, doode boomstammen en in dergelijke schuilhoeken en graven zich daarbij nog dikwijls een holte in den grond, wanneer deze zich daartoe leent. In tegenstelling met de zgn. levendbarende Schorpioenen dragen de wijfjes reeds eenigen tijd, in een soort van cocon, de eieren met zich rond, voordat de teere, witte jongen uitkomen, die nog zeer langen tijd in de moederlijke schuilplaats blijren rertoeven.

Vertegenwoordigers ran de rerwante groep der Phrynichidae heb ik in dit gebied nooit aangetroffen, waarmede echter niet gezegd is, dat zij, en rooral de kleine soorten (van de geslachten Sarax en Catageus) hier niet zouden roorkomen.

In de tweede plaats mogen kortelijk worden rermeld de Pseudoscorpiones (Chelonethidae, Chelifercie), die door hun geringe afmetingen en hun verborgen levenswijze al zeer weinig de aandacht trekken. Binnenshuis liomt men wel eens een kleinen Chelifer tegen in de banden van oude boeken en in hoekjes ran kasten, die niet dikwijls worden geopend; buiten moet men ze zoeken onder de korstmossen, die oudere boomen bedekken, onder afstervende bastgedeelten en op dergelijke, niet roortdurend rochtige plekken.

\section{F. Spirvex en Mijtex.}

De buitengewoon talrijke vertegenwoordigers der Spinnen op Jara zijn systematisch nog slecht zeer lacunair bekend. Tel is waar is er in den loop der jaren hier reel rerzameld, maar het bijeengebrachte materiaal is slechts roor een klein gedeelte bewerkt. Daarbij komt nog, dat vele der oudere beschrijvingen 
en afbeeldingen (o.a. die ran DoLEschALL ${ }^{1}$ ) te onvolledig en te onduidelijk zijn, om de roolwerpen behoorlijk te kumnen herkennen. Wij zullen ons derhalve bij de bespreking der Spinnen, zoowel in dit gebied, als elders, grootendeels tot het mededeelen van waarnemingen ran meer algemeenen aard moeten bepalen.

De Spinnen, die men binnenshuis te zien krijgt, behooren, wanneer het huis met vaderlandsche zindelijkheid wordt schoongehouden, uit den aard der zaak tot de zwerrende vormen, die zich geen rast verblijf vervaardigen. Overdag zijn het een aantal Springspinnetjes (Saltigradae), die onze aandacht trekken en zóó vlug in hun bewegingen zijn, dat de genoemde zindelijkheid geen rat op hen heeft. Ze weten zich in den regel bij naderend gevaar zoo goed te bergen, dat ze aan de opmerkzaamheid ontgaan, terwijl ze orerigens, zoowel door hun geringe afmetingen, als door hun dikwijls fraai voorkomen, niet als ongewenschte gasten worden beschourd. Wat ze ook inderdaad niet zijn; want men mag aammemen, dat een groot aantal muggen en andere lastige, kleine insecten door hen wordt opgeruimd.

Het aantal soorten, dat men ran deze familie, zoowel binnenshuis als buiten, rooral op bloeiende planten en heesters, aantreft, is ongeloofelijk groot en van haal geldt wel in de eerste plaats, wat hielboven in het algemeen aangaade de Spinnen ran Java werd opgemerkt. De verscheidenheid is zelfs van dien aard, dat men gemakkelijker van honderd verschillende soorten één exemplaar, dan van ééne soort honderd exemplaren zou kumnen verzamelen. Zijn de binnenshuis levende soorten over het alge-

1) Acta Societatis Scientiarium Indo-Neerlandicae, Vol. T, 1859. 
meen stemmiger van kleur, hoewel ook dikwijls zeer sierlijk van teekening, men vindt onder de vormen, die zich buiten ophouden, de meest schitterende voortbrengselen der tropische natuur. Tot dien indruk werken niet tveinig mede de, veelal in fraaie kleuren glinsterende oogen, in het bijzonder het viertal oogen, dat recht naar voren is gericht en waarvan wederom een tweetal uitmunt door bijzondere grootte en eenigszins den indruk maakt ran de groote frontlantarens ran een automobiel.

In hun bewegingen zijn, zooals reeds werd opgemerkt, de Springspinnetjes, die vroeger roor een groot deel in het geslacht Salticus werden ondergebracht, vlug en behendig, dikwijls zelfs stoutmoedig, doch ook hierin heerscht veel rerscheidenheid; enkele zou men zelfs traag kunnen noemen. Tot de minder vlugge soorten behooren er eenige (wellicht bestaat er verband tusschen beide zaken), die zóó bedriegelijk of mieren, o.a. van het geslacht Odontomachus, gelijken, dat inderdaad een meer nauwkeurige beschouwing noodig is, om haar ware natuur te herkennen.

Zoodra de arond is gekomen, verdwijnen de Saltigradae grootendecls, om het terrein over te laten aan de nachtelijke zwervers, welker roorkomen en optreden meer in orereenkomst is met de minder goede verhouding, die in het algemeen tusschen menschheid en spinnen bestaat. Borendien werkt de wijze van berveging dezer avondgasten nog mede, om den onaangenamen indruk te verhoogen; want het zijn vooral de schrijlings loopende Krabspinnen (Laterigradae), die zich alsdan vertoonen. Vooral de, over een groot deel der tropen verspreide Heteropoda venatoria komt algemeen voor, terwijl voorts 
de geslachten Sparassus, Olios en dgl. mogen worden genoemd. Voor zooverre deze dieren zich niet overdag ergens binnenshuis hebben schuil gehouden, komen ze door de geopende deuren en vensters, of door de openingen der jalouzieën naar binnen, de wijfjes niet zelden beladen met een grooten, platten, geelwitten eierzak, die aan de buikzijde tegen het lichaam wordt gedragen en, bij verrolging, niet dan in den uitelsten nood worlt losgelaten. De moederliefde toch schijnt bij deze dieren zeer sterk te zijn ontwikkeld, want ook de jonge spinnetjes blijren in dezen zak nog geruimen tijd vertoeven. De laatste zijn in honderdtallen daarin aanwezig en in de dagen, nadat zij de moeder voor goed hebben verlaten, kan men deze diertjes oreral in huis zwerrende aantreffen, waarbij zij roor een groot deel weder aan andere dieren ten prooi vallen of op andere wijze omkomen.

De Krabspinnen kunnen, wanneer dat noodig is, een groote vlugheid en behendigheid aan den dag leggen. Eell voorbijrennende, groote Blatta zag ik eens in volle vaart door eene ervan bespringen, vasthouden en spoedig aan een beet in de buikzijde ran het lichaan bezwijken. Het liefst echter voeden zij zich met de kleine, gevleugelde miertjes, die, het dansen om de lampen moede, in de latere avonduren teg'en de muren naar boren trachten te loopen en dan met huid en haar worden opgegeten door de spinnen, die hun komst rustig afwachten en ze, zoodra ze dicht genoeg in de nabijheid zijn, met de kaaktasters naar zich toe schuiven.

In de huizen vindt men voorts verschillende soorten van Wolfsspinnen, waarvan een groote, donkere Lycoscl-soort door haar snellen gang aan den naam der groep (Citigradae) alle recht doet wedervaren. 
Ook zij verschijnt alleen des avouds en is veel minder vreesachtig dan de Krabspinnen, die zich bij het minste geritsel of bij de minste beweging, die men maakt, in een sshuilhoek terugtrekken. Eindelijk vindt men overal, waar niet geregeld wordt schoongemaakt, zeer spoedig de raggen van verschillende soorten van Buispinnen (Tubitelariae), in het bijzonder van de zoogenaamde Trechterspinnen, maar deze onderscheiden zich in geen enkel opzicht van hetgeen dergelijke dieren ook in de gematigde luchtstreken te zien geven.

Buitenshuis spelen, met uitzondering van een paar opvallende vormen, de Spinnen in dit gebied een niet meer dan bescheiden rol. Zooals hierboven reeds werd opgemerkt, is de rijkdom aan Saltigradae zeer groot, mar een groot deel daarvan houdt zich op binnen de kronen van groote bloemen en op anclere plaatsen, waar veel kleine, vooral Tweevleugelige en Vliesvleugelige insecten zijn te verwachten, en hun taktiek brengt mede, dat zij zich daar een weinig schuil houden, zoodat zij niet dadelijk in het oog vallen.

De zooeven bedoelde, meer oprallende rormen zijn rooral de Nephila-soorten, van de groep der Webspinnen (Orbitelariae), waarvan de wijfjes niet zelden reusachtige afmetingen bereiken en waarvan de ongemeen fraaie Nephila maculata haar web bij voorkeur op open, liefst zonnige plekken, dikwijls dwars over de wegen, aanlegt. Minder algemeen dan deze zijn $N$. malabarensis en $N$. kühlii, waarvan de eerste aanzienlijk kleiner, de tweede veel minder fraai geteekend is dan N. maculata. 't Zijn bij deze soorten steeds de wijfjes, die men te zien krijgt; de kleine 
mannetjes zijn moeielijk te vinclen, claal zij, zoo ze aanwezig zijn, zich met een zeer bescheiden plats ergens aan een der uiteinden van het web moeten terreden stellen.

Terwijl het verwante geslacht Argyope in dit gebied wel voorkomt; maar hoofdzakelijk is vertegenwoordigd door de kleinere soorten, die hun anzien trachten te rergrooten door een dicht spinsel te maken in het rerlengde der kruisvornig gehouden, twee aan twee geplaatste pooten, worden ran het genus Araneus (Epcira) talrijke soorten ran allerlei afmetingen hier aangetroffen. Onder de grootste daarvan mogen worden gerekend $A$. dehaanii, kenbar aan het puntig-driehoekige achterlijf en $A$. moluccensis, waarvan het achterlijf naar roren twee puntige schouderuitsteeksels heeft, maar van achteren afgerond eindigt: onder de meer bijzondere rormen A. laglaizei, welker achterlijf dikwijls in een staartvormig aanhangsel is rerlengd. Ten slotte zij hier vermeld het geslacht Tetragnatha, wadrvan in dit gebied verschillende soorten ran middelmatige grootte voorkomen, alle gekenmerkt door een lang, nagenoeg; cylindrisch achterlijf en zeer lange roorkaken, waarvan het basale lid ran dorentjes is roorzien, terwiil het tweede lid eenigszins gebogen is, zoodat de geheele kaak in zijn bour aan een rangpoot herinnert. In den toestand ran rust ziet men van dit alles echter niets; de Tetragnatha's houden dan de beide voorste paren pooten, alsmede de lange kaken en kaakpooten, recht naar roren, de beide achterste paren pooten recht naar achteren gestrekt en hebben in die houding zulk een langwerpig, bijna lijnrormig voorkomen, dat men ze eerder houdt roor een steeltje of een dun takje, lat toevallig in het web is 
terecht gekomen, dan voor de wettige eigenares erran.

Ten aanzien der Acarina kunnen wij kort zijn; men bemerkt in de grootere plaatsen weinig ervan, wellicht zelfs minder dan in de gematigde luchtstreken. Aan de bladeren van verschillende planten ziet men misvorningen, die bij nader. onderzoek dool Phytoptidae blijken te zijn veroorzaakt; op organische stoffen, die in ontleding verkeeren, treft men aanvankelijk talrijke mijten aan, die hier echter, spoediger dan in een koel klimaat, door andere saprophytische diervormen worden vervangen, maar over het algemeen kan men niet zeggen, dat op Java de mijten eren sterk als bijv. de insecten op den roorgrond treden. Slechts voor de Teken (Ixodidae) moet een uitzondering worden gemaakt, daar deze, door hun algemeen voorkomen o.a. bij honden, hier meer de aandacht trekken dan elders. In het bijzonder geldt dit roor de Rhipicephalus-soorten. Op plaatsen, waar een hond heeft geslapen, ziet men des morgens niet zelden eenige volgezogen wijfjes van dit geslacht, die hun prooi hebben verlaten, langzaam roortkruipen, soms zelfs tegen muren, ten einde in eej réilig hoekje het opgenomen voedsel te verteren en eieren te leg'en.

Intusschen boud ik mij ervan orertuigd, dat gedetailleerde onderzoekingen orer de biologie der Acarina op Java nog veel merkwaardigs aan het licht zullen kunnen brengen, zooals trouwens reeds vroeger (pag. 177), naar aanleiding van de Xylocopaberronende Greenic's, werd opgemerkt. 


\section{G. Duizendpooten.}

Deze groep is naar verhouding beter bekend dan de vorige, wat de Javaansche soorten betreft, welker aantal, voor zooverre in 1907 bekend was, ongeveer 110 bedraagt ${ }^{1}$ ). Ongetwijfeld zal in de toekomst dit aantal nog wel grooter blijken te zijn, maar de nog aan te treffen vormen zullen geheel of ten minste grootendeels tot de kleinere behooren, die, hoe belangrijk ook in systematisch en zoögeographisch opzicht, weinig veranderen aan het algemeene beeld, dat aan dit werk ten doel is gesteld.

De Echte Duizendpooten (Chilopoda) zijn in de grootere plaatsen behoorlijk vertegenwoordigd, in de eerste plaats door de Scolopendridrae, waarvan verschillende soorten reeds door hun afmetingen niet kunnen nalaten de aandacht te trekken. Yet name mogen hier worden genoemd Otostigmus spinosus, Rhysida longipes, Scolopendra gracillima en Scolopendra pinguis, die het alle in den volwassen toestand tot een lengte van 6-8 cll. kunnen brengen. Zij worden echter in grootte verre overtroffen door Scolopendra subspinipes, var. dehaani, waarvan de grootste exemplaren een lengte van $25 \mathrm{cM}$. kunnen bereiken. Dat dergelijke dieren ook in dichtbevolkte buurten voorkomen, blijkt wel het best uit de omstandigheid, dat het grootste exemplaar, dat in het Zoölogisch Nuseum alhier aanwezig is, in het centrum van Buitenzorg, in de badkamer eener Europeesche woning werd gevangen, waarin het vermoedelijk cloor de afvoerleiding was binnengedrongen. Geluk-

1) Een lijst dier soorten geeft ATteus in de Mitteilungen aus dem Naturhistorischen Museum, XXIV, pag. 77, Hamburg 1907, naar aanleiding van de bespreking en de beschrijving van het door Prof. KRAEPELIN in 1904 op Java rerzamelde materiaal. 
kig echter ziet men de genoemde vormen slecht zelden binnenshuis; zij houden zich op in de meer afgelegen, rochtige en schaduwrijke, met afgevallen blad bedekte gedeelten der erven, in de nabijheid van waterleidingen en goten, en stellen zich zelden aan het rolle daglicht bloot. Van een aggressieve natuur zijn zij niet, doch men behoeft slecht op de klauwen der roofpooten te letten, om daarin een paar zeer geduchte verdedigingswapenen te zien, des te gevaarlijker, omdat hun greep gepaard gaat met de uitstorting van den inhoud een giftklier, waarvan de uitmondingsopening juist aan het uiteinde der klauwen is gelegen. Dat, rooral bij kinderen en in het algemeen bij daarvoor gevoelige personen, de "beet" van een Reuzenscolopender ${ }^{1}$ ) zeer ernstige gevolgen kan hebben, kan ereneens uit de afmetingen dezer roofpooten gemakkelijk worden opgemaakt.

Een niet zoo geducht voorkomen als de Scolopenders vertoonen de slanke, teere Geophilidae, die zich met hun veel talrijker pooten al kronkelend voortbewegen. Orphnaeus brevilabiatus, Lamnonyx punctifrons, beide over alle tropische landen verspreid, komen, met een paar Mecistocephalus-soorten, ook in dit gebied voor en zijn nu en dan ook binnenshuis aan te treffen, waar zij zich bij voorkeur in de plooien en naden van gevveven stoffen ophouden en slechts gedurende de duisternis op roedsel uitgaan. De zooeven genoemde voorliefde brengt hen ook wel eens binnen de bedgordijnen, bij welke gelegenheid zij den rusten-

1) In de populaire literatuur vindt men voor de hier bedoelde soort nu en dan den naam gigantea opgegeven. Deze heeft echter betrekking op een tropisch-Amerikaansche soort ran ongeveer dezelfde grootte. 
den homo sapiens zonderlinge verrassingen kunnen bezorgen. Deze familie ran Duizendpooten beschikt namelijk vrij algemeen over het vermogen, licht te verspreiden en zelfs een lichtend spoor achter te laten. Nu weet men van de physiologische zijde van dit verschijnsel, dat in de dierenwereld tamelijk verspreid voorkomt, nog zeer weinig, maar, wat de Geophilidue betreft, staat wel vast, dat zij, onder geheel normale omstandigheden, d.w.z., als hun gemoedsrust door niets wordt gestoord, geen licht uitstralen of achterlaten. Naurelijks echter zien zij zich bedreigd, of worden zij op andere wijze in hun evenwicht gestoord, of de uitstraling begint, en deze wordt sterker, naarmate de storing heviger is, om haar hoogtepunt te bereiken, wanneer het dier door een of ander roorwerp wordt vermorzeld en fijngewreven. Elk weefselstukje en elk plekje, dat met hen in aanraking is geweest, gloeit dan nog geruimen tijd na in een schittering van „bleu électrique”. Loopt nu, wanneer men half of grootendeels is ingedommeld, een der bedoelde Geophilidae des nachts over een blooten arm, dan maakt men, tengevolge van de daardoor veroorzaakte kriebeling, onwillekeurig een wrijvende beweging, harder of zachter, maar in allen gevalle voldoende om het dier tot lichten te brengen. Zoo is het mij eens overkomen, dat, bij ontwaken door aanhoudend gekriebel, mijn geheele linkerarm, de rechterhand en een deel van het laken en van de kussens in een fraaien, blauwen lichtgloed stonden, terwijl eenige fragmenten van de onschuldige oorzaak dezer illuminatie nog hier en daar kronkelend l'ondscharrelden en in hun eigen licht duidelijk waren te herkenen. Blijkbaar was ik in mijn slaap reeds eenige malen energiek aan het wrijven gerveest. 
Veel minder talrijk dan de beide vorige families treft men hier de Lithobiidae aan, wat echter voor een deel aan de kleinere afmetingen en de zeer verborgen levenswijze moet worden toegeschreven.

Daarentegen is niet zeer zeldzaam Scutigera (Ortothereua) longicornis, welk merkwaardig dier men o.a. wel eens in een verborgen hoekje der bijgebouwen aantreft. Bij het loopen zijn de buitengewoon lange, dunne pooten eigenlijk niet als zoodanig te onderscheiden, maar vormen, vooral tegen een donkeren achtergrond, een soort van wolk rondom het lichaam van het dier. Men weet aanvankelijk niet goed, wat men ziet en krijgt den indruk, alsof een pluizige stofmassa door den wind werd roortbewogen. Opmerkelijk is daarbij de onverschillige wijze, waarop het dier met zijn ledematen omspringt; bij de minste aanraking laat het eenroudig een paar pooten in den steek, reden, waarom het maar zelden gelukt, een exemplaar in geheel ongeschonden toestand te bemachtigen.

Van de Millioenpooten (Chilognatha) mag, hier in de eerste plaats worden genoemd de familie der Zephroniidae, die de zgn. Oprollers omvat. Maken deze dieren, waarvan 0.a. Zephronia nigriceps in dit gebied voorkomt, gebruik van het vermogen, waaraan hun Hollandsche naam is ontleend, dan doen zij zich vrijwel roor als een geribde knikker, zoo volkomen sluiten kop en achtereinde van het lichaam aan elkaar. Lang blijven ze echter in die houding niet; in den regel strekken ze weder vrij spoedig het lichaam om een goed heenkomen te zoeken.

Dit oprollen van het lichaam is trouwens, zij het ook op minder rolmaakte wijze, een eigenschap van 
de meeste Chilognatha; ieder kent rermoedelijk wel de overblijfselen der reelal roodbruine Spirostreptus (Thyropygus)-soorten, die men dikwijls in de tuinen aantreft, of heeft het lerende dier waargenomen, terwijl het zich, na aanraking, in de bekende houding dood hield. Het is rooral Spirostreptus javanicus, die in dit gebied roorkomt, een soort ran middelbare grootte, die tot 13 cM. lang kan worden. De grootere soorten houden zich in minder berwoonde omgering op.

Dit laatste geldt ook roor de zeer vormenrijke groep der Polydesmidae, waarvan een aantal kleine soorten des avonds dikwijls in onze huizen zijn aan te treffen, als wanneer zij langzaam en rustig rondloopen. Het meerendeel van deze soorten is uiterst moeielijk van elkander te onderscheiden, en levert zelfs den specialen onderzoekers dezer familie reel hoofdbreken op, zoodat ik mij meen te mogen te bepalen tot het noemen, voor dit gebied, van de geslachtsnamen Strongylosoma, Orthomorpha, Platyrhacus, Cryptodesmus en Doratodesmus.

H. Kreeftachtige Dieren.

Voor zooverre de Crustacea zeedieren zijn, zullen zij, met uitzondering van een paar litorale rormen, uit den aard der zaak in dit werk buiten beschouwing blijven. De zoetwatervormen komen in een ander hoofdstuk ter sprake, zoodat roor dit gebied slechts overblijven de Landpissebedden (Isopoda terrestria), die er slechts een zeer bescheiden rol spelen en waarvan de meeste soorten borendien nog tot de detritus-fauna moeten worden gerekend. Onder 
bloempotten en steenen treft men hier deze dieren minder veelvuldig aan dan bijv. in Holland, terwijl ze ook binnenshuis een vrij zeldzame verschijning zijn, slechts in vochtige bijgebouwen te vinden. Van de vormen, die nog het meest voorkomen, mogen hier worden genoemd Armadillo murinus, die over alle warme landen der aarde is verspreid, Porcellio sundaicus en $P$. pruinosus, alsmede het geslacht Philoscia.

\section{WEEKDIEREN.}

Voor dit gebied komen feitelijk slechts de Landslakken in aanmerking, maar van -de zoetwatermollusken zijn de donker gekleurde, peperhuisvormige, spiraalsgewijze gewonden huisjes van verschillende Melania-soorten en de schelpjes van Corbicula-soorten zóó algemeen, in het water veelal met, in het opgebaggerde grint zonder hunne bewoners, dat deze namen hier volledigheidshalve even moeten worden genoemd.

De rijkdom nu aan Landslakken is in dit gebied buitengewoon gering en de redon hiervan is vermoedelijk wel aan te geven. Al is namelijk de gemiddelde vochtigheid van de atmosfeer hier hoog, aanzienlijk hooger zelfs dan op plaatsen in de gematigde luchtstreken, waar veel slakken zijn te vinden, er zijn aan den anderen kant in de grootere bevolkingscentra oogenblikken op het midden van den dag, warop de zonnegloed zóó fel is, dat, niettegenstaande een rochtigheidsgehalte der lucht van 50 tot $60 \%$, de blaren van verschillende planten slap neerhangen 1). Dat slechts

1) Men ziet dit wel het best bij de, vaak in heggen aangeplante Acanthacee Sanchezia nobilis. 
weinig weekdieren daartegen bestand zijn, laat zich hooren: neemt men daarbij in aanmerking de langzaamheid hunner bewegingen, waardoor ze niet in staat zouden zijn, zich tijdig in een voldoende beschaduwd hoekje terug te trekken, clan wordt hun gering aantal in de groote plaatsen daardoor zeer gereedelijk verklaard. De weinige soorten, die zich hier kunnen staande houden, moet men dan ook zoeken op rochtige, steeds beschaduwde plekken; het zijn, van de Naaktslakken, een paar Parmarionsoorten en van de Huisjesslakken een paar vertegenwoordigers van de geslachten Amphidromus, Stenogyra en Vaginula.

\section{K. WORMEN.}

Het ligt niet in de bedoeling; in dit werk de talrijke inwendige parasieten van mensch en dieren te bespreken, die de groote afdeeling der Wormen hier in niet mindere mate dan elders oplevert. Deze parasieten zijn hier nog slechts weinig onderzocht, maar, roor zooverre dat onderzoek heeft plaats gehad, heeft het geen zaken aan den dag gebracht, waarvan men kan aannemen, dat zij slechts voor Java (of vocr Nederlandsch Indië in het algemeen) gelden. Trouwens, bij de groote overeenkomst der levensvoorwaarden, die deze dieren in de lichamen hunner gastheeren aantreffen, met hetgeen hun of humnen verwanten elders wordt aangeboden, waren rerschilpunten ran belang in biologisch opzicht ook niet te verwachten.

Van de Wormen, die parasietisch in planten leven, geldt hetzelfde. Deze behooren in hoofdzaak tot de Familie der Aaltjes (Anguillulidae), en het is van al- 
gemeene bekendheid, dat de aaltjesziekten der cultuurgewassen hier verloopen onder dezelfde verschijnselen als elders. Alleen bereiken de gallen, door Heterodera's veroorzaakt, hier wel eens afmetingen, die aan andere ziekte-oorzaken zouden doen denken. In het bijzonder is dit het geval, wanneer deze diertjes, in afwijking van hun gewone wijze van optreden, een aanval ondernemen op stengeldeelen van klim. of slingerplanten, die op den grond zijn komen te liggen en dus gemakkelijk binnen hun bereik zijn. In dergelijke gevallen doen zij wel eens aanzwellingen ontstaan ter grootte van aardappelen, die men slechts behoeft door te snijden, om de nagenoeg bolvormige, volwassen wijfjes reeds met het ongewapende oog bij dozijnen te kunnen onderscheiden .

Sluiten wij derhalve al deze parasieten uit, dan komen voor dit gebied hoofdzakelijk slechts de Aardwormen voor een nadere beschouwing in aanmerking.

Daar de werkzaamheid dezer dieren hier vrij gelijkmatig over het geheele jaar verdeeld is, krijgt men niet dien indruk van hun talrijkheid en hun oeconomische beteekenis als in de gematigde luchtstreken, in bepaalde tijden van het jaar het geval is. Toch vindt men allerwege op beschaduwde plaatsen en rooral dáár, waar de bodemvegetatie niet zeer dicht is, de sporen van hun werkzaamheid in den vorm der welbekende aardhoopjes.

Terwijl de eigenlijke Lumbricidae hier schijnen te ontbreken, treden vooral de Perichaetidae op den voorgrond. Zij zijn in dit gebied o.a. door de soorten Perichaeta indica, P. capensis en Perionyx violaceus vertegenwoordigd, die in afmetingen vrijwel met den gewonen Europeeschen regenworm (Lumbricus terrestris) overeenkomen en waarvan de laatste en 
kleinste gemakkelijk is te onderscheiden door de bruinachtig violette kleur van de bovenzijde, waartegen het veel lichter gekleurde clitellum scherp afsteekt. Intusschen komen ook van andere families der Oligochata verschillende vormen hier voor, waarvan sommige plaatselijk in groot aantal: van de Acanthodrilidae verschillende Benhamia-soorten en van de Urochaetidae de zeer algemeene Pontoscolex corethrurus, die vóó het staarteinde van het lichaam een opgezwollen gedeelte heeft, dat men op het eerste gezicht voor een tweede clitellum zou kunnen houden, maar dat een andere. nog niet opgehelderde beteekenis moet hebben. Men heeft wel eens de onderstelling uitgesproken, dat hier sprake zou zijn van een plek, waar een gemakkelijke deeling van het lichaam (met daarop volgende regeneratie van het voorste gedeelte) zou kunnen plaats hebben, die de dieren in staat zou stellen, in oogenblikken van gevaar, bijroorbeeld tegenover in den grond wroetende, wormen zoekende zoogdieren, zich te redden met opoffering van het staartgedeelte.

Ten aanzien van de Landplanariën geldt hetzelfde als bij de Weekdieren werd opgemerkt; de atmos. ferische toestanden maken in clit gebied hun bestaan grootendeels onmogelijk en men vindt daarom slechts nu en dan een enkel exemplaar van het genus Bipalium, gemakkelijk aan den verbreeden, halvemaanvormigen kop te herkennen, op de vochtige plekken van vele achtererven, waar zelden een zonnestraal doordringt. 


\section{HOOFDSTUK IX.}

\section{De Fauna der Dessa's.}

De Javaansche dorpen zijn, vooral in de lagere streken, meestal scherp begrensde plekken, waar, onder dicht opeengeplant, opgaand geboomte de huizen van het landvolk in een altijd schaduwrijke en daardoor dikwijls vochtige atmosfeer zijn gelegen. Zij zijn als eilanden in een zee van bouvland en de overhangende bamboe, waaruit in den regel de buitenste gordel der beplanting bestaat, verleent hen, op een afstand gezien,' een sierlijk en aantrekkelijk voorkomen. In sommige streken, waal, zooals in de omstreken van Batavia, veel aan vruchtenteelt wordt gedaan, zet het geboomte der dorpen zich min of meer geleidelijk roort in dat der omgeving; elders, waar veel ree wordt gehouden en daarvoor weidegronden beschikbaar zijn, treft men op de laatste gewoonlijk alleenstaande boomen, o. a. fraai uitgegroeide Mangifera's aan.

In de hoogere streken wordt het in den regel eenigszins ander's; dáár wordt de opgaande flora verrijkt met allerlei boomsoorten, die hetzij bij het vellen der wouden om de eene of andere reden zijn gespaard, hetzij later weder 'zijn opgekomen uit zaden, die zich nog in den bodem bevonden of uit stronken, die men niet opruimde. Ook de kruid-en heesterachtige gewassen vertoonen floristisch een ander 
karakter; de omgeving der dessa's wordt ruwer, minder intensief bebouwd, minder zorgvuldig onderhouden. Men gevoelt, men ziet het bovendien aan allerlei andere verschijnselen, dat men meer in de nabijheid der wildernis komt.

Uit het bovenstaande kan reeds a priori worden opgemaakt, dat de fauna der dessa's, in verband met de omgeving, allerlei bijkomstige karaktertrekken vertoont, maar toch is zij in hoofdzaak over geheel Java tamelijk uniform. Dit geldt des te meer, waar wij in de volgende bladzijden voornamelijk het oog hebben op de dessa's der uitgestrekte vlakten en der lagere berghellingen, dus ongeveer tot het gebied, waar de bergculturen beginnen. Boven die grens verandert haar karakter, staat zij minder scherp afgescheiden tegenover het omringende gebied en ondervindt zij in veel sterkere mate den invloed van het laatste, hier en daar zelfs zóó, dat van een eigen fauna nauwelijks meer kan worden gesproken.

Uit biologisch nogpunt beschouwd, kan men de dessa's der lagere streken nog in twee groepen verdeelen: die, welke in het open veld zijn gelegen en meestal ook in letterlijken zin (namelijk door een hekwerk van bamboe) scherp van het omliggende land zijn gescheiden en die, welke een boomrijke omgering hebben. De fauna van de laatste categorie is veel rijker, inzonderheid aan zoogdieren en vogels en vormt met die der omstreken een geheel, dat een afzonderlijke bespreking vereischt.

\section{A. Dessa's in het OPEN veld.}

In de dessafauna kan men bijna zonder uitzondering alle diervormen terugrinden, die in de rorige hoofdstukken de revue passeerden. Bovendien is zij nog een aantal andere vormen rijk, die in nauven 
samenhang staan met de plantensoorten, in het bijzonder de rruchtboomen, die er overal worden aangekweekt. De biologische groepeering dezer vormen treedt dus het best aan den dag, wanneer wij ze bespreken aan de hand van de meest algemeene soorten dier flora, waaronder de cocospalm, vulgo klapper, (Cocos nucifera) ongetwijfeld de belangrijkste rol speelt. Ook in biologisch opzicht; want zonder overdrijving kan worden gezegd, dat zij een geheel heirleger van diervormen herbergt, voor het meerendeel in de hooge, moeielijk toegankelijke kruin, welker middelpunt ook aan grootere dieren uitnemende en veilige schuilplaatsen biedt. Dààr rusten overdag tal van Vleermuizen, nestelt niet zelden het kleine Uiltje Scops lempiji (pag. 60) en huist de Kilappereekhoorn, gewoonlijk, maar natuurlijk ten onrechte, Klapperrat genoemd, Sciurus notatus. Tot die Vleermuizen behooren niet slechts de kleinere soorten; ook de grootere, reeds rroeger (pag. ass) genoemde vormen vinden er een goed onderkomen, terwijl men er dikwijls zelfs een der beide, op Java voorkomende kalong-soorten, Pteropus nicobaricus, tegen de avondschemering kan zien uitvliegen. Deze soort neemt, evenals haar grootere rerwant, de gewone kalong (Pteropus edulis), overdag" niet eenmaal de voorzorg, zich aan het gezicht te onttrekken; zij hangt geheel onbeschermd aan het basale gedeelte der bladsteelen en valt daarbij door haar helderroodbruinen nekkraag vrij gemakkelijk in het oog. De bedrijvigheid en het heldere licht van den dag schijnen haar rust niet te bederven en het stoort haar blijkbaar niet, als de eekhoorns rondtrippelen op de plek, waar zij zich met de krachtige klauwen der achterpooten rasthoudt of als een djalak of een 
wielewaal nieuwsgierig tracht uit te rorschen, welk hidalgo-achtig wezen daar in zijn nabijheid hangt.

Wat de genoemde eekhoorns betreft, deze staan terecht in een kwaden reuk. Door hun groot aantal en hun algemeene rerspreiding, gepaard met groote vraatzucht en speelsche vernielzucht, berokkenen zij den eigenaars der klappers een aanzienlijke schade, die in geenen deele en allerminst in het oog van den inlander, wordt goed gemaakt door hetgeen zij, sierlijk ran gedaante als ze zijn, in het oog ran den liefhebber der natuur bijdragen tot verlerendiging der omgering.

Intusschen zijn zij niet de eenige knaagdieren, die de kruinen der klappers berronen; mar die andere vormen, waarvan reeds rroeger (pag. 3:3) terloops een paar werden genoemd, rerlaten hun rerblijfplaatsen niet in het volle daglicht. Overdag rertoeven zij in de donkere hoekjes tusschen de rruchten en de onderste deelen der bladsteelen, niet zelden ook in leeggeknaagde, halfrijpe vruchten, die hun tevens een prachtige gelegenheid tot nestelen aanbieden. Aan die gelegenheid is echter één groot gevaar verbonden: de mishandelde vrucht ralt namelijk wel eens af, rerraadt dan den eigenaar, met welke gasten hij de opbrengst ran zijn boon moet deelen en geeft daardoor aanleiding tot razzia's, waaraan wij foitelijk onze wetenschap ran het borenstaande te danken hebben. Want op deze wijze weten wij, dat de Knaagdiersoorten Chiropodomys gliroides en Ch. anna, Sciuropterus sagitta, Sc. lepidus en wellicht ook Sc. genibarbus dikwijls in die. roor ons, Europeanen, volkomen onbereikbare hoogten leven. Aangaande de Chiropodomys-soorten, die men naar verkiezing, tot de groote muizen of tot de 
kleine ratten zou kunnen rekenen, kan daaraan echter worden toegevoegr, dat zij ten aanzien van den mensch reeds een schrede verder zijn gegaan en nu en dan ook in diens woningen zijn aan te treffen. Daarentegen is voor de Sciuropterus - soorten, de kieine, fluweelachtig grijze, vliegende Eekhoorntjes, die met hun struisveervormigen staart een bijzonder sierlijken indruk maken, dit bewonen van de kruinen der klappers niet meer dan een begin van overgang tot de cultuurfauna; hun eigenlijke verblijfplaats is nog het bosch.

Ook aan Insecten herbergen de cocospalmen tal van gasten, welker aanwezigheid men in vele gevallen reeds op een afstand kan constateeren. Het gemakkelijkst en het meest algemeen die van den welbekenden Klappertor Oryctes rhinoceros, een van de Neushoornkevers. Men mag zelfs veilig beweren, dat het uiterst moeielijk is, op Java een klapper te vinden, die geen teekenen van aantasting door dit insect vertoont. In het bijzonder heb ik hier het oog op de wijze, waarop de bladeren worden beschadigd. Zooals bekend is, trachten de kevers van bovenaf in het weeke, binnenste gedeelte van den stam door te dringen en beginnen derhalve dikwijls hun boorgangen in de kruin. Daarbij ontmoeten zij natuurlijk op hun weg de jonge, nog geheel speervormig toegevouwen bladeren en, deels om zich een weg te banen, deels misschien om zich ermede te voeden, knagen zij een zijdelings gelegen stuk uit die speer. Wanneer nu later het blad zich ontvouwt, dragen een aantal zijblaadjes de duidelijke sporen van die verminking; het blad ziet eruit, alsof met een groote schaar een driehoekig stuk eruit was geknipt. Bedenkt men daarbij, dat de levensduur van een 
klapperblad eenige jaren bedraagt en dat elk blad in zijn jeugd groote kans loopt, op de beschreven wijze te worden aangevreten, dan laat het zich hooren, dat er maar weinig boomen zijn, waaraan het optreden van dezen neushoornkerer niet valt te constateeren.

Ook de ronde gaten, die men algemeen in de stammen der klapper's aantreft, zijn van dezen kever afkomstig; want hij tracht ook van de buitenzijde, dwars door de harde bases der bladsteelen, in den stam te dringen. In den regel gelukt hem dit, dank zij zijn krachtigen bouw, terwijl dan later, tengevolge van den lengtegroei van den stam, de gemaakte openingen steeds rerder van de kruin komen te liggen en gedurende het geheele leven yan den boom een toegangsweg rormen roor allerlei ander, saprophytisch en parasietisch gedierte. Van dit laatste zijn wel het meest bekend de groote, roodbruine, klanderachtige Snuitkevers ran de geslachten Rhynchophorus, Omotemnus, Cyrtotrachelus e. a., die men in het algemeen met den naam van Palmensnuitkevers zou kunnen aanduiden, omdat zij het op allerlei vertegenwoordigers dezer plantenfamilie hebben roorzien (Elaeis, Areca, Calamus enz.) Niet zoozeer voor zich zelf (want de hoeveelheid roedsel, die zij tot zich nemen, is hoogst onbeduidend), als wel roor hunne nakomelingschap, die zich ophoudt in het saprijke, ran grove vezels doortrokken inwendige der stammen en bladsteelen. Deze nakomelingen zijn vleezige, pootlooze larren, die door rele inlanders gaarne worden gəgeten en dikwijls zulke groote afmetingen bereiken, dat de bladsteelen wel eens afbreken op de plaatsen, waar zij zich, vóór de verpopping, van de afgekloven vezels een zeer 
behaaglijke rustplaats samenstellen; een verschijnsel, dat men vooral bij den pinang (Areca catechu) kan waarnemen.

Behalve de genoemde, groote kevers is er ook een kleine soort, die de klappers op een, van verre zichtbare wijze kan beschadigen en wel een Hispide van het geslacht Bronthispa. Dit insect, dat in het bezit is van een uiterst plat lichaam, tast eveneens de jonge, nog opgevouwen blaren aan en dringt tusschen de stevig tegen elkaar gedrukte zijblaadjes, zoowel tusschen de rugzijden van twee naast elkaar geplaatste blaadjes, als tusschen de twee helften van één blaadje. Van het blaadje, dat zich aan zijn buikzijde berindt, knaagt het ééne opperhuid en het grootste gedeelte ran het bladmoes weg, terwijl de andere opperhuid daarbij onaangetast blijft. De gevolgen van dit optreden worden aanzienlijk verergerd, doordat de wijfjes, al vretende, talrijke eieren leggen, waaruit zich larven ontwikkelen, die eveneens zeer plat zijn en geheel op dezelfde wijze als de volwassen dieren te werk gaan. Zoodoende wordt soms bijna al het bladmoes weggevreten, wat ten gevolge heeft, dat ò het jonge blad geheel de kracht mist om zich te ontrouwen en weldra afsterft, of zich nog ontplooit, maar dan in een zeer gehavenden, van verre reeds waarneembaren toestand.

Veel algemeener dan deze Hispide is echter een klein rupsje, dat de klappers op dergelijke wijze mishandelt, maar daartoe de oudere, reeds ontplooide blaren uitkiest. Deze rupsjes, die behooren tot de soort Drachartona catoxantha van de familie der Zygaenidae, komen niet zelden in zeer groot aantal op de blaren der klappers voor; zij vreten aan de bovenzijde, laten de opperhuid der onderzijde 

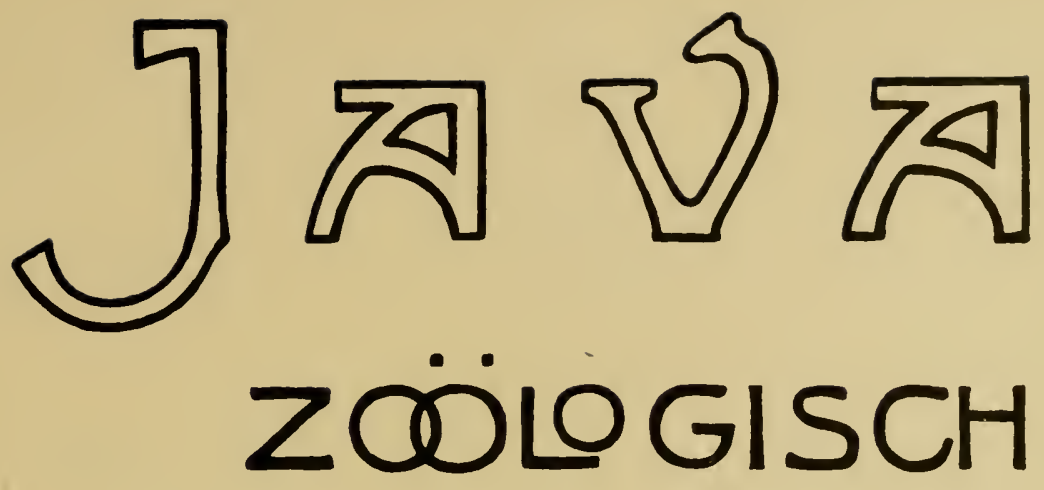

\section{EN BIOLOGISCH}

DOR

DRJ.C.KONINGSBERGER

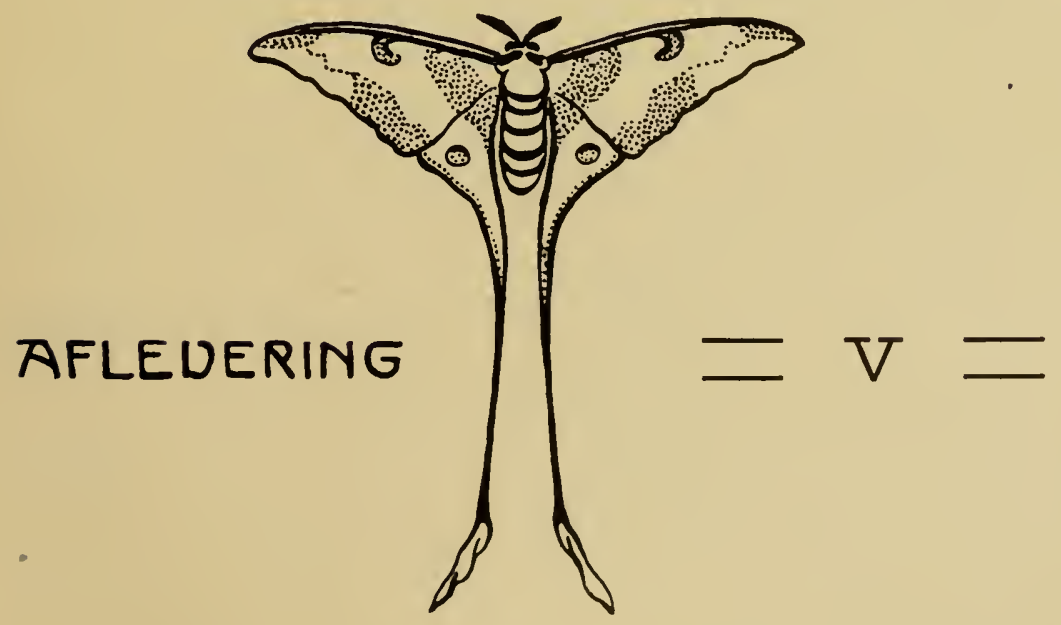




\section{N HO U D.}

AFLEVERING I.

pag.

Hoofdstuk I. Algemeene samenstelling der Fauna van Java en hare wordingsgeschiedenis. De Hoofdgroepen. . . . . .

HoofDStuk II. Overgangen van de eene groep in de andere. Morphologische gevolgen daarvan. Voorbeelden van rormen, die in orergang zijn. Nachtelijke en diurne levenswijze. .

HoofDSTUK III. Invloed van jaargetijden, regen, wind en zonneschijn. Vergelijking met andere eilanden. . . . . .

\section{AFJEVERING II en III.}

HoofDSTUK IV. Kort overzicht der verschillende gebieden. De Cultuurfauna bij uitnemendheid: de diervormen der grootere plaatsen . . . . . . . . . . . 51

A. Zoogdieren . . . . . . . . . 55

B. Vogels. . . . . . . . . . . 60.

C. Kruipende ex Tweeslachtige Dieren. . . 76.

Hoofdstek V. De Diervormen der grootere plaatsen. (Vervolg) . . . . . . . . . . . . 90.

D. Insecten . . . . . . . . . . 90.

1. Orthoptera . . . . . . . . . . 90.

2. Neuroptera . . . . . . . . . . . 98.

3. Rhynchota . . . . . . . . . 104.

4. Diptera . . . . . . . . . . . . . 108.

Hoofdstuk VI. De Diervormen der grootere plaatsen.

(Vervolg). D. Insecten. (Terrolg) . . . . . . 116.

5. Coleoptera . . . . . . . . . . 116.

6. Lepidoptera. . . . . . . . . . . 127. 
AFLEVERING IV.

Hourdstuk VII. De Dierrormen der grootere plaatsen , pag. (Vervolg). D. Insecten (Terrolg). . . . . . . 157.

7. Hymenoptera . . . . . . . . 157.

8. Apterygota. . . . . . . . . . . . 179.

Hoofdstuk VIII. De Dierrormen der grootere plaatsen. (Verrolg) . . . . . . . . . . . . . . 180.

E. Schiorptoenen en verwante Yornen . . 180.

F. Spinden en MiJtex. . . . . . . . 182.

G. Duizendpooten. . . . . . . . . 189

H. Kreeftachifige Dieren . . . . . . . 193.

I. WeEKdierex. . . . . . . . . . . . . 194.

K. WorMen. . . . . . . . . . . . . 195.

Hoofdstur IX. De Fauna del dessa's. . . . . . 198.

A. Dessa's iN het open Veld . . . . . 199.

\section{AFLEVERING V.}

Hoofdstuk IX. (Verrolg). De Fauna der dessa's (Verrolg).

A. Dessa's iN Het open veld (Vervolg) . . . 205.

B. Dessa's in boomriJe oMgeVing . . . . 212.

Hoofdstuk X. De Fauna der dessa's. (Verrolg).

B. Dessa's in boomituke omaeting. (Tervolg) . 227.

Hoofdstuk XI. De sawahfauna . . . . . . . 245. 

onaangetast en maken aldus talrijke, langwerpige vlekken, die in den regel niet meer dan $3 \mathrm{cM}$. lang zijn. Maar het aantal van deze vlekken is soms zóó groot, dat meer dan de helft van de bladoppervlakte erdoor is ingenomen; wederom eene beschadiging; die karakteristiek genoeg is om van den beganen grond te worden herkend.

Eindelijk ziet men dikwijls, hoe de zijblaadjes, met uitzondering van de hoofdnerf, geheel zijn weggevreten. Hier kunnen verschillende schuldigen in het spel zijn. Reeds noenuden wij (pag. 65) de groote rupsen van Amathusia phidippus en Discophora celinde, maar er kan ook sprake zijn van Hidari irava, van de familie der Hesperidae, en zelfs van Parasa hicolor, een polyvore Slakrups (fam. Limacodidae), die wij elders meer binnen ons bereik zullen vinden.

Geen der andere boomen in de dessa heeft zulk een rijkdom van bewoners aan te wijzen als hierboven roor de cocospalm werd beschreven. Veeleer zou men kunnen zeggen, dat vele soorten één of hoogstens een paar speciale gasten hebben, die, voor zooverre zij ook in de groote plaatsen voorkomen, reeds in vorige hoofdstukken werden genoemd. Wij kunnen daaraan thans nog de volgende toevoegen.

Aan de doekoe (Lansium domesticum) kan men zeel dikwijls een verschijnsel waarnemen, dat op het eerste gezicht aan een heksenbezem doet denken. 'Tusschen het gebladerte, niet zelden ook een weinig daaruit stekend, bevinden zich daarbij rijk vertakte, ongeveer uit één punt ontspringende, deels knobbelig gezwollen, deels gelijkelijk verdikte takjes, waaraan nagenoeg alle blaren ontbreken. Bij onderzoek is het mij gebleken, dat hier een Schildluis in het spel is, die zich vestigt 
op de pas uitgeloopen takjes en de schors daarvan aanzienlijk doet opzwellen. Weliswaar groeien de aangetaste takjes nog eenigen tijd in de lengte door, maar de verdere ontwikkeling der blaren wordt belemmerd en er vormen zich zijtakjes, die in den regel hetzelfde lot ondergaan, totdat ten slotte het complex ontstaat, dat aan een heksenbezem herinnert. Elke schildluis op zich zelve doet een ronde opzwelling ontstaan, maar gewoonlijk zijn er zóóveel aanwezig, dat de opzwellingen over aanzienlijke gedeelten der takjes ineenvloeien en daardoor een vrij gelijkmatige verdikking vormen. In het midden van elke opzwelling is een tamelijk diepe, komvormige inzinking, die van boven door het lichaam van de luis wordt afgesloten; licht men de laatste met een naald eruit, dan vindt men de ruimte onder haar soms grootendeels met eieren gevuld.

Een niet minder eigenardige rerminking vertoont dikwijls de bamboe, die in het algemeen al bijzonder weinig relaties met de dierenwereld heeft aangeknoopt. In overigens gezonde bamboestoelen merkt men bij dit verschijnsel één of meer stengels op, waarvan sommige $(6-12)$ opeenvolgende geledingen slechts een gedeelte, soms niet meer dan een vierde of een vijfde, van de normale lengte hebben bereikt, terwijl ze tevens niet zuiver in elkaars rerlengde zijn gelegen, maar een gebroken lijn vormen. Splijt men nu zulk een stengel open, dan blijkt het uiterste paar (en wel gewoonlijk het onderste) der abnormale internodiën een groot aantal kale, licht-vleeschkleurige rupsen te bevatten, terwijl men de dieren natuurlijk ook wel eens in den poptoestand aantreft, als wanneer ze aanvankelijk licht-, later donkerbruin zijn. De in- 
landers, althans die in West-Java, kennen deze rupsen zeer goed (onder den naam tjangkiloeng) en gebruiken ze als aas bij het visschen, waartoe ze, door hadr groote taaiheid en haar welgedaan voorkomen, zeer geschikt zijn. Hoe de rupsen aan dat uiterlijk komen, vraagt men zich terecht af; ten getale van soms een par honderd te zijn opgesloten in een paar geledingen van een bamboestengel strookt nu juist niet met onze begrippen van culinairen overvloed. Slechts de binnenwand der aangetaste geledingen is een weinig afgeschaafd, terwijl de weinige, korrelige overblijfselen ran parenchymatischen aard, die men in normale geledingen aantreft, zijn verdwenen, maar daarmede is dan ook al het eetbare genoemd. Voegen wij hieraan toe, dat de geledingen, waarin de rupsen zich achtereenvolgens hebben opgehouden, slechts door een kleine, blijkbaar doorgeknaagde opening in het harde tusschenschot met elkaar in verbinding staan, dat de laatstgemaakte openingen weder door spinsel worden afgesloten en dat er daarna nog geruime tijd vóó de verpopping verloopt, dan wordt het inderdaad raadselachtig, hoe de dieren zich in het leven houden.

De rlinder is een Pyralide, die echter blijkbaar niet op kunstlicht afkomt. Want als men bedenkt, dat tjangkiloeng in en om Buitenzorg algemeen voorkomt en dat elke aangetaste stengel gemiddeld een honderdtal vlinders moet leveren, dan mag men aannemen, dat ik, in de achttien jaren van mijn verblijf alhier, wel eens een exemplaal bij het lamplicht zou hebben gevangen, wat niet het geval is geweest. De vraag is intusschen bij mij gerezen, of de volwassen dieren normaliter wel behoorlijk ontwikkelde vleugels hebben. Bij het opkweeken 
uit den poptoestand, die maanden lang duurt, krijgen zij die niet dan bij zeer hooge uitzondering, ook, als men de omstandigheden voor de dieren zoo normaal mogelijk maakt, door bij roorbeeld den gespleten stengel weder dicht te binden.

Dan is er nog een onopgeloste vraag: hoe komen, in de vrije natuur, de vlinders naar buiten? De geleding, waarin de poppen zijn opeengehoopt, staat slechts door de genoemde, kleine doorgangsopening, waarvan het spinsel eerst weder moet worden verwijderd, in verbinding met de aangrenzende, die echter nog lang niet als ,. buitenwereld” mogen worden beschouwd. Het is waar, dat sommige der verkorte geledingen op lateren leeftijd overlangsche barsten vertoonen, maar ook dat is niet aitijd het geval. De zaak behoeft dus nog in alle opzichten een nader onderzoek; bij onze huidige kennis ervan kan men bijna niet anders dan aannemen, dat slechts een zeer gering aantal dieren fortuinlijk genoeg is om het te brengen tot den toestand ran rondrliegende vlinders, waarvan de wijfjes hare eieren rermoedelijk leggen in de jonge spruiten, en dat deze laatste de jonge rupsen voeden met haar inwendig parenchym en eerst later, wanneer de geledingen zich zullen gaan strekken, de gerolgen ran deze gastvrijheid ondervinden en op de beschreren wijze openbaren. Merkwaardig is hierbij, dat het stengelgedeelte onder en boven de aangetaste streek gewoonlijk internodien heeft van normale lengte. Ten bewijze daarvan volgt hier een opgave van de lengte der geledingen, van beneden naar boven, van een nagenoeg volwassen stengel, die door tjangkiloeng was aangetast (in cM., de aangetaste geledingen cursief): $33,29,24,32$, $31,16,14,12,13,12,13,11,20,42,45$ enz. De 
verpopping had plaats in de beide onderste der aangetaste geledingen, terwijl men uit deze cijfers tevens kan zien, dat de geledingen, die het eerst en bijgevolg nog in jeugdigen toestand, werden aangetast, het meest de gevolgen daarvan ondervonden.

Ook het fraaie Boktorretje Clytanthus anmularis zou volgens opgave van inlanders in zijn ontwikkeling iets met de bamboe hebben uittestaan, doch het is mij nooit mogen gelukken, den aard dezer betrekking rast te stellen.

Van de pisang werd de meest karakteristieke bewoner, Erionota thrax, reeds rroeger (pag. 136) beschreven; hij is echter niet de eenige gast, dien de blaren huisresten. In jongen toestand nimelijk, rooral wannneer ze nog slechts peperhuisrorming zijn opgerold, dienen ze overdag tot schuilplaats aan een aantal kleine soorten van Vleermuizen, die er een koel en veilig verblijf vinden. De fraaie Cerivoula picta, die voor een Vleermuis bijzonder levendige kleuren en teekeningen bezit, heeft voor dit dagverblijf zelfs een bepaalde voorliefde.

De overige bevoners der pisangplanten houden zich op in de inwendige deelen, speciaal in de saprijke bladscheeden, die samen het grootste gedeelte van den "stam" vormen. Zij behooren, voor zooverre de plant hun niet alleen huisvesting, maar ook voedsel verstrekt, bijna alle tot de Snuitkeversoort Sphenophorus planipennis, een nauwe verwant van de Palmensnuitkevers, maar van geringer afmetingen dan deze. Men kan dit insect hier in alle ontwikkelingstoestanden aantreffen, soms zelfs in grooten getale, maar het schijnt, dat de plant van hunne aanwezigheid weinig nadeel ondervindt. Overigens wordt hunne 
ontwikkeling nogal tegengegaan door het optreden van een andere groep van Kevers, die der Histeridae, in het bijzonder de geslachten Plaesia en Hololepta. Deze glimmend zwarte, platte, breedgeschouderde dieren zijn er geheel op gebouwd om zich een weg te ballen tusschen de aaneensluitende bladscheeden en daar niet alleen roor zich zelf hun prooi op te sporen, maar tevens eieren te leggen, waaruit zich larven ran zeer roofzuchtigen aard ontwikkelen.

De manggistan (Garcinia mangostana) vertuont aan zijn bladeren niet zelden een verschijnsel, dat aan het optreden van een parasietische schimmel doet denken, maar warran de oorsprong toch van dierlijken aard is, al is natuurlijk het secundair optreden van schimmels of van bacteriën niet uitgesloten. De blaren vertoonen alsdan groote, droge, bruine vlekken, die bij nadere beschouwing blijken uit te gaan van kleinere of grootere beschadigingen van den rand, en daar de levensduur van de blaren bij deze boomsoort zeer lang is, óók al zijn ze in hun jeugd op de aangegeven wijze beschadigd, is de eigenlijke oorzaak soms ver te zoeken. Deze is de rups van de Noctuide Stictoptera cuculloides, die nu en dan in groot aantal op de manggistan is te vinden en zich bepaalt tot het aanvreten van den rand der, natuurlijk bij voorkeur jonge blaren. Hoogstens wordt de helft der bladoppervlakte weggevreten. Zooals de meeste Uilenrupsen, vreten ook deze dieren slechts gedurende de duisternis; overdag zitten ze bewegingloos op de dikke hoofdnerf en vallen dan zeer weinig in het oog. De kunst om zich moeielijk zichtbaar te maken zit hun trouwens in het bloed, want de vlinder van deze soort gelijkt in den rusttoestand volmaakt op 
een cylindrisch stukje dood hout of schors. Van pooten en sprieten is alsdan niets zichtbaar, de grijze roorvleugels zijn half om het achterlijf gerold en de langschubbige bekleeding van den prothorax steekt aan weerszijden ran den kop in een dikken bundel naar voren en geeft den indruk, alsof het nagebootste voorwerp op die plaats op onregelmatige wijze was afgebroken.

Op verschillende djamboe-soorten (Psidium guajava en Eugenia-soorten) rindt men roorts de zonderlinge rups van Carea subtilis, eveneens een Noctuide, gekenmerkt door het sterk gezwollen voorkomen ran wat men aanrankelijk roor den kop zou houden. Het blijkt echter hij nadere beschouwing dadelijk, dat deze opzwelling slechts den thorax betreft, die zich daardoor voordoet als een groen bolletje, en dat de kop, hoewel eenigszins verborgen, toch in normalen toestand aanwezig; is.

Eindelijk moet een woord worden gewijd aan de waroe (Hibiscus tiliaceus), die zoowel om het hout, als om de schors in alle dessa's is aangeplant. Men vindt namelijk aan dezen boom zelden een gaaf blad, terwijl de blaren er dikwijls uitzien, alsof men met hagel er doorheen had geschoten. Dit is het werk van talrijke soorten van kleine Chrysomelidae, die voor deze plant een bijzondere roorliefde schijnen te hebben; het is des te opvallender; omdat, trots het groote aantal soorten, waardoor deze kererfamilie op Java is vertegenwoordigd, slechts weinig andere boomen de sporen ran hun optreden rertoonen. Wat hell in de warve-blaren zoo bijzonder aantrekt, is moeielijk te zeggen. Voor de kleinste soorten, die 
dikwijls aan de onderzijde zitten te vreten, kan het de viltige beharing zijn, waartusschen zij zich veilig gevoelen. Merkwardig is, dat men onder de hier bedoelde Chrysomeliclen ook enkele soorten van de Psylliodes-groep aantreft, die, zooals hun Hollandsche naam „aardvlooien" al aanduidt, in den regel meer in de nabijheid van den grond vertoeven. Voor het overige ziet men onder hen eenige van de vroeger (pag. 126) genoemde vormen, alsmede-Plagiodera melusa, Mysothra gemella, Nodostoma bohernanni en Chalcolampra violaceipennis, waarvan de drie laatstgenoemde ook op andere planten van dezelfde familie (Malvaceae), o.a., zooals wij later zullen zien, op katoen, zeer algemeen zijn te vinden.

Dezelfde voorliefde voor Malvaceae rindt men trouwens bij meerdere insecten in zeer sterke mate ontwikkeld, o.a. bij de wantsen Dysdercus cingulatus en Tectocoris cyanipes, die ook wel eens op de waroe voorkomen, doch beter later kunnen worden ter sprake gebracht.

\section{B. DESSA'S IN BOOMRIJKE OMGEVING.}

Als type van dit gebied beschouw ik het platteland, zooals het zich in wijden kring rondom Batavia uitstrekt en den meesten Indischen lezers, zij het ook slechts door aanschouwing uit den trein, bekend zal zijn. Soortgelijke streken vindt men op Java zeer veelvuldig, al bestaat er ook reel variatie in de boom-soorten, die er den boventoon voeren en bijgevolg in den algemeenen indruk van het landschap. Die verscheidenheid weerspiegelt zich echter slechts ten deele in de dierenwereld, welke het in hoofdzaak slechts om de aanwezigheid van opgaand geboomte 
is te doen. Slechts een paar vormen, aan bepaalde plantensoorten gebonden, mogen hier vooraf worden besproken, waarbij ik in de roornaamste plaats het oog heb op de bewoners ran de rerschillende, om de vruchten aangeplante en onclerling zeer rerwante Mangifera-soorten.

Hoewel deze boomen ook in de dessa algemeen zijn te rinden, ontwikkelen zij zich uit den aard der zaak reel beter op een ruimere standplats; men ziet soms vilijstaande boomen en boomgroepen, die niet behoeven onder te doen voor het fraaiste, dat in een Europeeschen parkaanleg in die richting kan worden bereikt. Zoodanig is de indruk op eenigen afstand; beschouwt men de boomen van naderbij, dan blijkt het in den regel, dat zij op allerlei wijzen zijn gehavend. Zoo vertoont de kruin dikwijls plekken, waar de uiteinden ajer takken half afgestorven en nagenoeg hladerloos zijn. Hier is Orthaga enadrusalis aan het werk geweest, een kleine Lichtmot, die haar eieren in grooten getale legt op den, zooals bekend is, zeer snel groeienden uitloop der mangga's. In de weinige dagen, die verloopen tusschen het leggen der eieren en het uitkomen der jonge rupsen, hebben de blaren van het jonge takje bijna hun definitieve grootte en kleur bereikt, maar het weefsel is nog zóó malsch, dat zelfs die uiterst kleine dieren zich eraan tegoed kunnen doen. Indien deze zich nu verspreidden, zou hun aanwezigheid aan de plant nog niet zooveel kwaad doen, maar zij blijven bij elkaar en spinnen zich een gemeenschappelijk nest, dat langzamerhand wordt uitgebreid en ten slotte een veel grooter gedeelte van den boom omhult en verstikt, dan voor hun roeding noodig is. Later, als na den poptoestand de vlindertjes zijn uitgevlogen, 
blijven de overblijfselen van dat nest nog lang aanwezig, maar door regen en wind worden ze op den duur verwijderd en het aangetaste gedeelte blijft dan in onherstelbaren toestand over.

Een andere, algemeen bekende gidst van de mangga, het Snuitkevertje Cryptorhyn hus mangiferae, werd reeds in het Eerste Hoofdstuk (pag. 9) van dit werk genoemd, naar aanleiding van zijn voorkomen in het Westen, zijn ontbreken in het Oosten van Java. Als wij hier nog even op hem terug komen, dan is het om melding te maken van een zeer vernuftige campagne, die op sommige plaatsen tegen hem wordt gevoerd en waarvan de mededeeling: geheel past in het kader van dit boek. Hierbij wordt namelijk gebruik gemaakt van de oorlogzuchtige natuur der, rooral nabij de kust algemeen voorkokomende mierensoort Oecophylla smaragdina (pag. 162), die gaarne in boomen nestelt en haar nest maakt door een groot aantal naburige blaren tot een ronden klomp van soms een halven meter middellijn met elkar te vereenigen. Deze klompen worden nu op de eene of andere, zeer omzichtige wijze afsesneden en in de manggaboomen opgehangen en de mieren, intelligent genoeg om "bonne mine á mauvais jeu" te maken, zetten op die nieuwe woonplaats haar levenswijze voort, die medebrengt, rlat geen ander, roor haar nutteloos insect, dus ook geen eierleggende Cryptorhynchus, in hare nabijheid wordt geduld.

Men zou die mieren derhalve niet in het veld kunnen brengen tegen een ander insect, dat niet zelden op de mangga's is te vinden, en wel in zulk een groot aantal, dat niet alleen de boom, maar ook de omgeving de sporen ervan draagt. De hier 
bedoelde is Poeciloptera (Copsyrna) stollii (familie der Fulgoridae, onderorde der Homoptera), die, evenals het meerendeel harer verwanten, de eigenschap heeft, in den larvalen staat vrij aanzienlijke hoeveelheden "honigdauw" af te scheiden, welke, op zijn beurt, op de roorwerpen, waarop hij neervalt, den welbekenden "roetdauw" doet ontstaan. Dientengevolge vindt men onder de mangga's, wanneer daarin veel Poeciloptera's huizen, soms de geheele bodemvegetatie, en zelfs steenen, met een zwarte laag bedekt, die zich, daar de fijne druppeltjes honigdauw dikwijls door den wind een eindweegs worden medegevoerd, niet zelden ook over naburige voorwerpen uitstrekt. Een ander afscheidingsproduct blijft intusschen aan de larven zitten en doet zich roor als een witte, uiterst teere, vlokkige massa, die de dieren soms geheel bedekt en ook, na de vervelling, op de afgeworpen huidjes aanwezig blijft. Deze stof is van wasachtigen aard en komt ook, hoewel in veel mindere mate, voor op het lichaam der volwassen dieren, die ten onrechte dikwijls voor vlindertjes worden gehouden.

De genoemde honigdauw maakt, zooals bekend is, voor vele soorten van mieren een zeer geliefkoosd voedsel uit en ook de Oecophylla's zijn van zulk voedsel niet afkeerig, zoodat zij met de Poeciloptera's vermoedelijk spoedig een verbond zouden sluiten in plaats van ze te verdrijven.

Bij de mangga kan nog een verschijnsel worden waargenomen, dat aan het optreden van insecten is toe te schrijven, namelijk het uitvloeien van een aan de lucht tot hars opdrogende, terpentijnachtige vloeistof uit de schors van stam en takken. Dit wordt veroorzaakt door de wijfjes van verschillende Boktorren, o.a. van Batocera hector, Epepeotes luscus, 
en van eene Rhytidodera- soort, welker larven in het hout dezer boomen leven. Bij het leggen der eieren worden in de schors, en dikwijls ook dieper; grootere of kleinere wonden gemaakt, waaruit weldra de uitvloeiing begint, die, wanneer toevallig groote harska. nalen zijn getroffen, soms geruimen tijd kan aanhouden.

Eindelijk mogen hier nog worden genoemd de rupsen van een paar Euthalia-soorten, die van de manggablaren leven en de aandacht. trekken door haar fraai, maar eenigszins vreemd roorkomen, voorzien als ze zijn van lange, vedervormige haren, die rondom het lichaam horizontaal in alle richtingen uitsteken. Zit zulk een rups toevallig op de hoofdnerf, dan lijkt het, alsof daaruit groene veertjes ontspringen, die het blad grootendeels bedekken. Met ziet deze rupsen echter niet dikwijls, omdat zij zich in de hoogere gedeelten der boomen ophouden; dat zij niettemin vrij algemeen moeten zijn, mag men wel opmaken uit het groote aantal Euthalia-vlinders, dat in dit gebied rondvliegt.

Een tweede boom in dit gebied, die nog aanleiding geeft tot een bijzondere opmerking, is de sawoe manila (Achras sapota), die men soms vereenigd ziet tot aanplantingen, waaraan men den naam ran boomgaard zou kunnen geven. Dat deze boom wel eens wordt aangetast door Scolytidae (Bastkevers), is op zich zelf nauwelijks der vermelding waard, daar hij dit lot deelt met tal van andere boomsoorten op Jara; het is de wijze van aantasting, die de opmerkzaamheid verdient. Bij alle Scolytidae toch op Java, waarvan de levenswijze min of meer uitvoerig is onderzocht, bepaalt het optreden zich tot het miaken van gangen met nu en dan een enkelen zijgang, of van holten, 
waarin men soms geheele families van dieren in alle toestinden van ontwikkeling kan aantreffen. Bij de soorten, die boomen bewonen, dringen zij daarbij steeds rechtstreeks in het hout. Hierop nu makkt de Scolytide, die men.nu en dan in sawoe manila aantreft, eene uitzondering, daar zij zich geheel gedraagt als bijv. de Hollandsche Hylesinus fraxini en derhalve tot de echte schorsboorders mag worden gerekend. Zij maakt onder de schors een "moedergang", vanwaar de larfjes hun zijgangen maken, zoodat men hier de welbekende figuur te zien krijgt, waaraan voor een van de Europeesche vormen de soortnaam typographus is ontleend.

De buitengewone rijkdom der Javaansche dessa aan hoenders is ongetwijfeld een van de redenen, waarom kleine roofdieren en roofrogels overal ruim zijn vertegenwoordigd, waar, zooals in dit gebied, de omstreken aan deze dieren een goede verblijfplaats verleenen. Daarbij komt nog, dat die hoenders voor hun voedsel zijn aangewezen op afval, dat natuurlijk niet altijd in even ruime mate aanwezig is, en daarom dikwijls genoodzaakt zijn, overdag in den omtrek zwerftochten te ondernemen, welke, vooral voor de jongere dieren, vaak een noodlottig einde nemen. Een van hun grootste belagers is Spizaetus limnaetus, dien men voor Java wel als den kiekendief bij uitnemendheid mag beschouwen. Deze even brutale als slimme roover komt in dit gebied algemeen voor, zoowel in het laagland als op de berghellingen, en wel in twee variëteiten, waarvan de ééne aanzienlijk donkerder is dan de andere. Men ziet hem dikwijls rustig op een dooden tak zitten, hoog in het geboomte, terwijl hij daarbij 
zelfs in het geraas van een voorbijrijdenden trein geen reden tot vluchten ziet, wel wetend, dat hem van die zijde geen gevaar dreigt.

Is hij het, die overdag de hoenders weghaalt, anderen doen het des nachts. Zoo zijn de loewak (Paradoxurus hermaphroditus, pag. 57) en vooral de rassi (Viverricula malaccensis) welbekende, nachtelijke bezoekers der dessa's, waaraan wij nog kunnen toevoegen Helictis orientalis (bioel, njentek), ofschoon deze laatste minder schadelijk is en door het dooden van ratten en muizen zelfs nu en dan aanspraak op eenige waardeering kan maken. Alle drie genoemde Roofdieren zijn in dit gebied algemeen, daar zij zich overdag in reilige schuilplaatsen kunnen terugtrekken, hetzij in holten van oude boomstammen, hetzij in onderaardsche verblijven, waarvan men de ingangen wel eens tusschen de opstaande wortellijsten van verschillende boomen kan waarnemen. Dan is er nog een vierde Roofdier, dat zich niet zelden in de nabijheid der dorpen waagt, maar van nog schuweren aard is dan de reeds genoemde, namelijk Felis minuta (bengalensis), de Wilde Boschkat, mèong tjongkok of koewoek, een dier van wilde en bloeddorstige natuur, waarvan echter de jongen, wanneer ze op zeer jeugdigen leeftijd zijn gevangen, zich wel eenige maanden zeer behonrlijk en zelfs mak kunnen gedragen en gereedelijk kunnen doorgaan roor zeer fraaie, jonge exemplaren van de gewone Huiskat. Op een bepaalden leeftijd krijgt echter bij hen de natuur de overhand boven de leer en dan zijn ze niet meer te vertrouwen; in het bijzonder schijnt de lucht van bloed, zelfs niet meer dan één enkele maal geroken, hen plotseling en volkomen tot den wilden staat terug te brengen. Dat zij ook onderling yerwoede 
gevechten kunnen leveren, bleek eens bij een der kampongs nabij het Krankzinnigengesticht alhier. Dáár waren twee groote, mannelijke exemplaren, vermoedelijk uit jaloezie, elkaar te lijf gegaan; hun woede was daarbij van dien aard, dat zij alle voorzichtigheid uit het oog verloren en zich zonder eenige poging tot vluchten lieten vangen door het kampongvolk, dat was komen toeloopen op het gebrul, dat van reel grootere dieren afkomstig scheen.

Voor de overige roofdieren ran dit gebied hebben wij weder tot de Roofvogels terug te keeren en ontmoeten dan een aantal vormen, die het niet of in veel mindere mate dan de genoemde Spizaetus op het pluimvee hebben voorzien. Niet zeer algemeen, en in West-Java zelfs meer tot de hoogere cultuurstreken beperkt, is Cerchneis occidentalis, een 'fraai, in hoofdzaak bruin valkje, dat in habitus en bewegingen aan den Hollandschen Torenvalk (Falco tinnunculus) herinnert en zich niet alleen voedt met kleine, warmbloedige dieren, maar ook gaarne hagedissen en groote insecten nuttigt. Dezelfde voorliefde voor hagedissen treft men aan bij Astur trivirgatus, een kleinen, algemeenen havik, gemakkelijk herkenbaar aan de drie donkere dwarsstrepen over den staart, waaraan trouwens zijn soortnaam is ontleend. Van geheel anderen aard daarentegen is het voedsel van den fraaien Pernis ptilonorhynchus, zooals reeds blijkt uit den Hollandschen naam van Wespendieven, waarmede dit genus wordt aangeduid. Hịj behoort tot de grootste Roofvogels op Java en, waar men hem in staat zou achten, dieren van vrij aanzienlijke afmetingen te lijf te gaan, maakt het een eenigszins 
zonderlingen indruk, dat hij zich uitsluitend voedt met insecten, hoofdzakelijk met bijen en wespen. Een enkele maal zijn ook overblijfselen van kakkerlakken in "zijn maag aangetroffen. Tamelijk veelvuldig in het geheele gebied, waarmede wij ons bezighouden, schijnt hij toch aan het lagere gedeelte daarvan de voorkeur te geven. De hoeveelheid bijen en wespen, die men in zijn maag kan vinden, is soms aanzienlijk, terwijl zich dikwijls ook de larven dezer dieren daartusschen bevinden. Het schijnt dus, dat hij de nesten open breekt en plundert en wie eenige ervaring heeft aangaande de verwoede wijze, waarop vele soorten van Vespidae zich bij een dergelijke ingrijpende aanranding van hun verblijf te weer stellen, zal moeten erkennen, dat hij de minder dicht beveerde plekken van zijn lichaam (bijv. het aangezicht) op eene of andere bijzondere wijze tegen de steken dezer dieren moet weten te beschermen.

Van de Uilen komt, behalve Scops lempiji, in dit gebied algemeen voor Bubo orientalis, gewoonlijk hiengkiek genoemd, die ook in den gevangen staat blijk ervan geeft, dat de menschelijke samenleving voor hem niets vreemds op vreeswekkends heeft. Ik heb van deze fraaie vogelsoort gedurende twee jaar een levend exemplaar in mijn bezit gehad, dat geheel tot huisdier is geworden. Gekocht als jong in zijn wit en donzig vederkleed, werd het weldra zoo mak, dat het een deel van den dag buiten zijn kooi doorbracht en ten slotte geheel vrij werd gelaten. Hij bleef echter in de buurt van zijn oude woning. Des nachts, als hij op het dak en in het omringende geboomte rondscharrelde, deed hij voortdurend zijn hoog, eénsylbig stemgeluid hooren en zette zich tegen 
den morgen op een lagen tak róol de keuken, om daar de komst af te wachten van een zeer hevriende persoonlijkheid, namelijk den slagersjongen, die dagelijks eene hoeveelheid vleeschafval voor hem medebracht. Kwam deze te laat naal zijn zin, dan kortte hij zich den tijd donrde keukenmeid te plagen of zich in het venster van de eetkamer te zetten en zijn nood te klagen aan het ontbijtend huisgezin. Met een jongen fox-terrier stond hij op zeer goeden voet; beiden stoeiden in het gras als waren ze soortgenooten.

Bij zijn nachtelijke zwerftochten scheen hij het vooral op sprinkhanen te hebben voorzien, want dikwijls verwijderde hij op de, bij Roofrogels gebruikelijke wijze, ballen onverteerd roedsel uit zijn mond, waarin een groot aantal pooten en vleugels dezer dieren waren te vinden. Intusschen heb ik hem ook eens betrapt, terwijl hij bezig was met het plunderen van een nest van de priet (Uroloncha leucogastroides) waarbij de eitjes zeer voorzichtig werden opgenomen, om daarna met een vlugge beweging van den kop te worden ingeslikt.

Mag men van Bubo orientalis aannemen, dat hij van oudsher de nabijheid van den mensch heeft gezocht en sedert lang tot de cultuurfauna is overgegaan, anders is het met Phodilus badius, welke fraaie Katuil waarschijnlijk nog in de periode van overgang verkeert. Bij de oudere auteurs (Honsfiecd e.a.) vindt men dit dier vermeld als ex'n bijzonder zeldzane soort, die zich het liefst in de dichtste gedeelten der bosschen terugtrekt. Dit blijkt echter, zooals reeds vroeger (pag. 34) werd opgemerkt, in geenen deele meer het geval te zijn. Wel is waar 
is mij nog geen exemplaar bekend uit oude cultuurstreken, die reeds lang verre van alle wildernis zijn verwijderd, maar van verschillende plaatsen ken ik hem thans als een diersoort, die het bosch althans gedeeltelijk heeft vaarwel gezegd en daarbij de meeste neiging toont tot vestiging in dit gebied, vermoedelijk, omdat zij aldaar hare levensvoorwaarden het best vervuld vindt. Noemde ik vroeger als plaats van voorkomen reeds de, allengs geheel bewoonde streek ten Z.O van Buitenzorg, ik kan thans daaraan toevoegen, dat zij ook te Sinagar, bij Tjibadak, in de kampongs nestelend is aangetroffen *). Dat zij voorts geenszins tot de hoogere streken is beperkt, blijkt uit een exemplaar, dat werd verkregen te Bandjar, slechts weinige voeten boven zee, waal het zich eveneens in de nabijheid eener kampong ophield.

Behalve de reeds genoernde, zijn er nog eenige Roofvogels, die zich in dit gebied ophouden, doch slechts dáár, waar het langzamerhand in meer open terreinen overgaat, die hun dan tot jachtterrein dienen. Zijn de laatstbedoelde rijk aan water, dan kan men in de eerste plaats vrij zeker zijn van de aanwezigheid van den grooten Ooruil Ketupa javanensis, eveneens veelal hiengkiek genoemd, wiens voedsel voor een aanzienlijk deel uit visch bestaat. Kan hij deze des nachts bemachtigen in de kunstmatig aangelegde vischvijvers der dorpen, dan vindt hij dat natuurlijk gemakkelijker; zoo niet, dan is hij aangewezen op de jacht in de omstreken.

In de tweede plaats treft men er dan dikwijls Spilornis baccha aan, een zeer fraaien, grooten buizerd, die, om het bezit van een breede, opzetbare

*) Volgens mededeeling van den vroegeren administrateur dier onderneming, den Heer L. BN. vaN HeEckeren tOT WALIËN. Het dier draagt aldaar, naar zijn steingéluid, den naam Toelangkoewiwi. 
kuif, hier en daar met den naam oeloeng-oeloeng djamboel wordt aangeduid en in Midden- en Oost.Java vrij algemeen onder den naam bido bekend is. Diens voedsel bestaat echter slechts voor een klein deel uit visschen, roor het meerendeel uit slangen, die op de bedoelde terreinen gewoonlijk eveneens in groot aantal zijn te vinden.

In de clerde plaats, maar veel minder algemeen, gebruikt nog een andere buizerd het boomrijke gebied als operatie-basis voor strooptochten langs naburige wateren, namelijk Butastur liventer, die, behalve op Kruipende Dieren, giarne langs de oevers van rivieren op zoetwaterkrabbetjes en dergelijk gedierte jaagt.

Terwijl de verdere avifauna van dit gebied zóó rijk is, dat daaraan een afzonderlijk horfdstuk zal worden gewijd, moet nog worden melding gemaakt van een drietal Zoogdieren, die oreral in dit gebied huizen, war de ard en de uitgestrektheid van het geboomte schuilplaatsen van voldoende eenzaamheid waarborgen.

De eerste is Manis javanica (s. peusing; j. trenggiling), welbekend als Schubdier of Geschubde Miereneter, de eenige, in Nederlandsch-Indië voorkomende vertegen. woordiger van de orde der Edentata, die vooral in Afrika en Zuid-Amerika thuis behoort. Hoewel in voorkomen een vrij onhandig en zelfs hulpbehoevend dier, is hij dat in werkelijkheid geenszins. Integendeel, hij is van twee markten thuis, daar hij zich niet alleen gemakkelijk voortbeweegt op den grond en daarin met zijn, tot graven ingerichte, klauwen diepe holen kan maken, maal bovendien over zulk een uitnemend klimvermogen beschikt, dat hij zich 
zelfs langs gladde, ijzeren stijlen naar boven weet te werken. Een en ander komt hem natuurlijk in den virijen staat zeer ten goede en het verklaart, hoe hij zich volstrekt niet in de wildernis behoeft te verbergen, maar zich ook staande kan houden in een cultuurgebied als dit, waar, wat roedsel betreft, de omstandigheden dikwijls zeer gunstig voor hem zijn. Termieten en mieren, die hij het liefst eet, zijn hier steeds in overvloed te vinden, de eerste in den grond, de laatste rooral in de boomen, waar hij ze zelfs op de dunnere takjes opzoekt en daarbij blijk geeft van een lenigheid en een handigheid, die men stellig bij een zoo hard en stijf gepantserd dier niet zou verwachten. Bekend is verder zijn gewoonte, zich bij naderend geraar als een bal op te rollen; minder bekend vermoedelijk de rijkdom aan Ixodidae, (vooral Amblyomma sublaeve), die hij in den regel bij zich draagt en die onder de schubben van het pantser natuurlijk een uitgezochte verblijfplaats vinden.

Het tweede der bedoelde Zoogdieren is het stekelvarken de landak, Hystrix javanica, die dit gebied vooral gebruikt als schuilplaats overdag, om onder beschutting van de duisternis op roedsel uit te gaan in naburige velden, waar hij onder het gewas soms geducht kan huishouden. Vandaar, dat hij in de dessa een slechte reputatie geniet en nogal is blootgesteld aan vervolging, waaraan hij zich intusschen dikwijls in onderaarsche schuilhoeken weet te onttrekken. Daarbij heeft hij het groote voordeel, dat losloopende of alléénjagende honden geen vat op hem hebben en, van weinig energieke natuur als Javaansche kamponghonden zijn, gewoonlijk reeds van de ver- 
volging hebben afgezien, vóórdat hun geblaf de noodige aandacht heeft getrokken.

In de derde pliats de Kalong of Vliegende Hond (Pteropus eclulis), over geheel Java een uiterst gewone verschijning, hier en daar door groote talrijkheid zelfs een ware platag voor de vruchtboomen. Hoewel men hem ook in de groote bevolkingscentra gedurende de avondschemering niet zelden ziet rliegen, gewoonlijk op aanzienlijke hougte, is hij torh vooral een bewoner van het gebied, dat ons thans bezig houdt. Dáár houdt hij zich overdag op in de toppen der hoogste boomen, meestal in troepen bij elkar. Zijn die troepen talrijk, dan draagt het geboomte weldra de sporen van de bewezen gistvrijheid; grootere of kleinere gedeelten der toppen raken ontbladerd, worden vernield en leveren dan overdag met de, aan de achterpooten hangende en in hun vleugels gehulde dieren een zeer eigenaardig schouwspel op. Oude kapokboomen (Eriodendron anfractuosum) worden door de dieren met groote voorliefde als dagverblijf gebruikt; men ziet ze daarin wel eens bij honderdtallen hangen. Tegen zonsondergang komt er leven in zulk een kolonie; de dieren worden wakker, rekken de vleugels eens uit, kruipen met behulp van de klauwen der achterste en den duimklauw van de voorste ledematen langs de takken, voor zooverre de ruimte dat toelaat, en vliegen dan uit, alléén of in paren. De terreinen, waarheen zij zich op hun nachtelijke expedities begeven, liggen soms mijlen ver van hunne rustplaatsen verwijderd en worden bepaald door hetgeen er aan vruchten te vinden is. Uitnemende vliegers als de Kalongs zijn, zien zij er geen bezwaar in, ook over zee te trekken. Zoo nam ik eens op Poeloe Oentoeng 
djawa (Amsterdam), een eilandje bewesten de Baai van Batavia, eene kolonie van kalongs waar, die zich had gevestigd in een hoogen njamploeng (Calophyllum inophyllum) en ran daal in kleine troepjes tegen den avond naar den Jara-wal vloog, om tegen het aanbreken van den dag weder terug te keeren. De bewoners van het eiland rertelden mij, dat zij die kolonie reeds hun geheele leven hadden gekend en het kwam mij voor, dat zij haar min of meer patroniseerden en het maar half goed ronden, toen ik, om de juiste soort na te gaan, door een geweerschot een exemplaar naar beneden deed tuimelen. Trouwens, het valt, wellicht in rerband hiermede, niet te ontkennen, dat de dieren, van nabij beschouwd, een aantrekkelijk voorkomen lrebben; de kop is sierlijk en de oogen zijn groot, met een zachte en intelligente uitdrukking. Heeft men de dieren voor zich, dan verkrijgt men een geheel anderen indruk dan dien van het infernale silhouet, dat ze in de vlucht te zien geven. 


\section{HOOFDSTUK $\mathbf{X}$.}

\section{De Fauna der dessa's.}

(Vervolg).

B. Dessa's in Boomrijke omgeving (Vervolg).

Zooals werd opgemerkt, kenmerkt de avifauna van dit gebied zich door een grooten vormenrijkdom, wat wel roor een aanzienlijk deel mag worden toegeschreven aan het feit, dat rele, oorspronkelijk boschbewonende soorten, hier levensomstandigheden terugvinden, die eenigszins aan die van hun voorgeslacht herinneren.

Een raste en zeer typische bewoner is de fraaie IJsrogel Halcyon cyaniventris, zelfs in streken, waal betrekkelijk weinig water is te vinden. Ten aanzien van zijn voedsel toch is deze vogel, die tot heden slechts op Java is aangetroffen, allerminst kieskeurig en in dat opzicht een waardige tegenhanger van Halcyon chloris (pag. 65). Kan hij waterbewonende dieren, van welken aard ook, krijgen, dan zijn die hem natuurlijk zeer welkom, maar hij neemt ook genoegen met kevers, sprinkhanen, kleine hagedissen enz. Zijn onverschilligheid voor water is verder oorzaak, dat hij in zijn verspreiding volstrekt niet tot de lagere streken is beperkt, maar dat men hem ook in de bergstreken, tot een hoogte van ongeveer 3000 voet boven zee, kan aantreffen.

Tot ongeveer dezelfde hoogte stijgt in dit gebied 
de Bijeneter Melitophrgus leschenaulti, die echter nergens algemeen schijnt te zijn. Zijn verwant Merops philippinus daarentegen houdt zich veel meer (ik zou bijnil durven zeggen uitsluitend) in de lagere, warmere streken op en is laar, althans plaatselijk, dikwijls zéér algemeen. Men kan hem $m$ en dan ook in de steden waarnemen en zijn neiging tot aansluiting aan den mensch en diens werken blijkt o. a. ook uit zijn voorliefde tot zich neerzetten op de telegraafdraden langs den spoorweg, die hem tevens een goed uitzicht op de omgeving aanbieden. Zijn vlucht is buitengewoon snel en behendig, terwijl hij den naam van Bijeneter meer eer schijnt aan te doen dan de eerstgenoemde soort, in welker maag ik, behalve bijen, allerlei andere insecten (glazenmakers, kakkerlakken, wespen, mieren en kevers) heb aangetroffen.

Ook de derde vertegenwoordiger der Meropidae op Java, Morops sumatranus, schijnt zich in dit gebied op te houden, maar reel zeldzamer te zijn dan de beide andere. Hij is o. a. in de omgeving van de kampongs nabij de Wijnkoopsbaai te vinden.

De Nectarinidae zijn in dit gebied eveneens ruim vertegenwoordigd. Blijft ook hier Cinnyris pectoralis veelal de minst schuwe en meest algemeene soort, die zich op zonnige avonden gaarne naar de hoogere gedeelten van het geboomte begeeft en daar een soort van avondzang doet hooren, zij wordt plaatselijk vergezeld door haar kleinere, maar ongemeen fraaie verwant Cinnyris hasselti, die in haar donker, maar voor een groot deel metaalachtig glanzend gevederte ongetwijfeld tot de mooiste vogeltjes van Java mag worden gerekend. Door haar schuwheid, 
haar geringe afmetingen en haar vlugge bewegingen valt deze soort echter niet gemakkelijk in het oug. In levenswijze, in het bijzonder in de wijze, waarop zij haar roedsel zoeken, komen beide soorten overeen, d. w. z., dat zij zich volstrekt niet bepalen tot het afzoeken van bloemen, maar wel degelijk ook alle andere plantendeelen naspeuren. Hun geheele gedrag doet daarbij veel meer denken aan dat der kleinere soorten van Meezen (o.a. de Hollandsche Pimpelmees), dan aan dat van de Colibri's. Aan deze laatste herinneren in veel sterker mate de beide, op Java voorkomende Anthothreptes-soorten malaccensis en phoenicotis, die zelfs op eenigen afstand gemakkelijk van de Cinmyris-socrten zijn te onderscheiden door haal meerdere grootte en door het verder achterwaarts, tot den staart, doorloopen van den metaalachtigen gloed van het gevederte der rugzijde. Beide vogeltjes zijn in en om alle kampongs rrij algemeen aan te treffen, vooral wanneer daar boomen bloeien, die door den aard hunner bloeiwijze een geschikt jachtterrein voor hen opleveren. Het is namelijk een feit, waarvan ieder zich gemakkelijk kan overtuigen, dat een groot aantal kleine bloempjes bij elkaar, afgezien nog van kleur en geur, een veel grooter aantal insecten lokt dan een gering aantal groote bloemen, en in verband met dit verschijnsel zien wij bloeiwijzen als o.a. die van mangga's, klappers en dergelijke steeds omzwermd door allerlei Diptera en Hymenoptera. Op dergelijke boomen nu komen de Anthothreptes-soorten gaarne af; men kan ze dan waarnemen, terwijl zij zich vóór de bloempjes in de lucht zwevende houden en zoowel de insecten opeten, die de bloemen bezoeken, als de spinnetjes, die zich daartusschen verschuilen. 
Aanzienlijk minder algemeen zijn de beide Aethopygasoorten, die dit gebied bewonen. Het zijn A. mystacalis en $A$. siparaja, die zich in hoofdzaak van elkander onderscheiden, doordat bij de laatste de roode superciliair-streep ontbreekt en de middelste staartpennen iets minder verlengd zijn. Overigens zijn zij in alle opzichten zeer nau verwant en vertoonen het verschijnsel, dat in dergelijke gevallen meer voorkomt, namelijk, dut zij niet naast elkaar op dezelfde plaatsen leven, althans tot heden niet werden aangetroffen. Hier treft men de ééne soort aan, ginds de andere, maar dikwijls geen van beide. Aangaande hunne levenswijze weet men nog weinig; slechts zij vermeld, dat ik tot tweemaal in de maag van A. mystacalis een vrij groot aantal roode, kale rupsjes aantrof, vermoedelijk van het Mottengeslacht Gracilaria, die alle kenmerken van bladmineerende larven vertoonden. Waren zij dit inderdaad, dan zou daaruit opnieuw blijken, hoe de Honigzuigers niet alleen allerlei insecten voor lief nemen, maar ze ook in hun, dikwijls verborgen schuilhoeken weten op te sporen.

De overige Honigzuigers van dit gebied behooren tot het geslacht Arachnother'a; zij missen den metaalachtigen gloed op het gevederte. Het zijn de soorten longirostris en affinis, beide tamelijk algemeen, de laatste evenwel in mindere mate dan de eerste.

Ook de Araclinothera's zijn niet kieskeurig in de keuze van hun voedsel. In do maag van $A$. affinis vond ik meermalen Cicaden, Fulgoriden en andere Homoptera.

De Caprimulgus-soorten behooren tot dat gedeelte van de cultuurfauna, waarván men uithoofde van 
hun nachtelijke levenswijze slechts weinig bemerkt, maar de algemeenheid, in dit gebied, van hun stemgeluid, waaraan de inlandsche naam tjoehijoer is ontleend, verraadt reeds spoedig na het invallen der duisternis hunne aanwezigheid. Men treft ze vooral aan, waar dicht struikgewas en bambot hun overdag een goede schuil- en nestplaats aanbieden, terwijl zij het liefst jagen in eene vegetatie, waar een sterke tegenstelling tusschen onderlout en opgaand gehoomte bestaat. Dat zij orerigens in de keuze van hun nestpliats niet bijzonder kieskeurig zijn en daarbij in hoofdzaak cenzaamheid en rust beoogen, bewijst de bekende waarneming ran Vorderuan, die ze, zonder eenige beschutting tegen de moorddadige zonnehitte, broedend aantrof op de, te Tandjong Priok aanwezige hoopen steenkool. Deze waarneming betrof $C$. affunis, die, evenals de tweede, grootere soort macrurus, in geenen deele tot dit gebied beperkt is. Hun nachtelijke levenswijze toch verschaft den Geitenmelkers verschillende voordeelen, waardoor zij zich kunnen ophouden op terreinen, die voor dagvogels van dezelfde grootte en levenswijze te veel gevaar zouden opleveren en slechts al jagende kunnen worden bezocht. Zoo vindt men ze zelfs nabij het zeestrand onder de lage kustvegetatie, waaruit ze eerst bij zeer dreigend gevaar opvliegen en daardoor hunne aanwezigheid verraden. Dat voorts op Java nog twee andere soorten voorkomen, weten wij dour de onderzoekingen van BARTEL, die in de theetuinen zijner onderneming op den Panggerango een exemplaar van $C$. jotaka verkreeg, terwijl de vierde soort, die voor de wetenschap nieuw bleek te zijn en naar den ontdekker, C. bartelsi werd genoemd, later, bij de boschfauna, ter sprake komt. 
Van de Klimrogels is in lit gebied de bettet, Palaeornis alexandri, een rertegenwoordiger, die plaatselijk zeer algemeen en in grooten getale kan optreden om elders geheel te ontbreken. Hij bewoont gaarne warme laaglind, maar komt ook tot rrij hoog: in het gebergte in het bewoonde land roor, daar ik hem zelfs aantrof in den, op 4500 voet gelegen Bergtuin te Tjibodas. Voor sommige vruchtboomen is deze diersoort een ware plaag, inzonderheid voor de peteh (Parlia speciosa), die soms volkomen wordt leeggeplunderd; de dieren zijn echter ondernemend genoeg, om zich nu en dan ook in het open veld te wagen en zich op het bouwland met mais of op de sawah's met rijpe padi te roeden. Bekend is hunne gewoonte, zich, althans buiten den broeitijd, tegen den avond op vaste rustplaatsen tot groote troepen te vereenigen, welker geschreeuw een oorverdoovend geraas veroorzaakt, waaraan eerst door de duisternis een einde wordt gemakkt.

Van de overige Klimvogels van dit gebied rereischen rooral de Koekoeken onze aandacht. Het moet worden erkend, dat wij van detalrijke soorten van deze familie, die op Java zijn aangetroffen, nog zeer wenig weten, dikwijls niet eens, of ze behooren tot de vogels, die hier voorttelen. In het bijzonder geldt dit van de Cuculus-soorten, bij welke onze onkunde vooral wordt veroorzaakt door de tamelijk groote, onderlinge gelijkenis, het nogal groote verschil in voorkomen $\mathrm{s}$ p rerschillenden leeftijd en de moeielijkheid om goede exemplaren machtig te worden. Voor zooverre thans onze kennis gaat, zou ik geneigd zijn, bij verschillende soorten van dit geslacht een vrij groote onverschilligheid aan te nemen voor den aard van het terrein, waarop zij zich bewegen. 
Hetzelfde geldt, hoewel in mindere mate, voor het nauw verwante geslacht Cacomantis, waarvan de soort merulinus reeds rrueger (pag. 7t) ter sprake kram. Deze, zoowel als de beide andere, iets grootere soorten sepulchrulis en someratii, konen in dit gebied algemeen roor, maar men hoort hun stemgeluid soms ook in het diepst der bosschen hoog in het gebergte, terwijl ik ze roorts meermalen heb waargenomen op de rijpende savah's, waar zij in den rroegen morgen lustig zaten te fluiten op de bamboe-touwen, die orer het reld waren gespannen om de Rijstuliefjes te verjagen. Die onverschilligheid roor de omgering is overigens wel rerkliarbaar: roedsel roor zichzelf vinden de Koekoeken overal wel en voor humne jongen laten zij anderen zorgen. Het komt er dus voor hen slechts op aan-en dan nog alleen maar, voor zooverre zij hier roorttelen -,op het geschikte oogenblik de nesten van die andere soorten te rinden.

Wat het roedsel aangaat, moge hier nog de opmerking worden gemakkt, dat harige rupsen wel is waar door de meeste soorten gararne worden gegeten, maar lang niet, altijd het hoofdroedsel uitmaken. Ook allerlei andere insecten worden genuttigd. Zoo trof ik eens in de maag van Cuculus sonneratii een dikke, vlokkige brij aan, waarin, in min of meer verteerden toestand, een paar honderd kleine, ongevleugelde insecten aanwezig waren. Het bleken te zijn larven van Fulgoridae, uit de verwantschap van het vroeger (pag. 215) reeds genoemde geslacht Poeciloptera, waarvan de jongen in zeer talrijke troepen bij elkaar leven en, behalre den honigdauw, een vlokkige, yasachtige stof afscheiden, 
waarmede zoowel hun lichaam, als de blären en takken der boomen, waarop zij leven, bedekt zijn.

Wat voorts betreft de noodzakelijkheid, op het juiste oogenblik de nesten van bepaalde, andere vogelsoorten voor het leggen der eieren ter beschikking te hebben, en den invloed, dien deze factor op de verspreiding eener Koekoeksoort kan hebben, dienaangaande geeft de zwarte Koekoek Surniculus lugubris (kedassi itum) het volgende te zien. Men vindt deze soort zoowel diep in het bosch als in het gebied der kampongs en zelfs nam ik haar meermalen waar in de hooge Kanarieboomen vóór het Zoölogisch Museum alhier, waar zij door haar stemgeluid niet alleen mijne aandacht trok, maar tevens verwisseling met een der Buchanga-soorten, waarop zij sterk gelijkt, onmogelijk maakte. De oorzaak van deze, op het eerste gezicht eenigszins vreemde verspreiding is vermoedelijk niet ver te zoeken; in het cultuurgebied legt zij hare eieren in de nesten der Buchanga's (pag. 71) en wanneer zij daarbuiten hetzelfde doet in de nesten van den, aan de laatste nauwverwanten boschvogel Bhringa remifer, dan is er inderdaad geen reden, waarom zij dezen niet in het bosch en tot de uiterste grens van zijn verspreidingsgebied aldaar zou volgen.

Nog grooter onverschilligheid ten aanzien van de omgeving mag uit den aard der zaak worden verwacht bij de soorten, die hier niet voorttelen, als voorbeeld waarvan de Kuifkoekoek Cociystes coromandus zij genoemd. Dit dier, waarvan op Java nog nooit het geluid werd vernomen, gold vroeger (o.a. nog in de mededeelingen van VorderMan) voor een boschvogel, maar hij blijkt een zwerver bij uitnemendheid te zijn, die bovendien niet alleen voorkomt in het gebied, 
waarmede wij ons thans bezig houden, maar ook werd aangetroffen in de strandboschjes langs de noordkust en in het geboomte van 's Lands Plantentuin alhier.

Terwijl van de Hierococcyx-soorten (sparvervides en fugax) waarschijnlijk hetzelfde geldt als van de Cuculi, moet in de laatste plaats van deze f:ımilie, als bewoner van dit gebied, nog worden genoemd de vruchtenetende Eudynamis honorata, vrij algemeen bekend onder de namen toehoe (roor het mannetje) en tjoelik-tjoelik (voor het wijfje), beide ontleend aan het stemgeluid, dat zij vooral gedurende de duisternis dikwijls doen hooren en waaraan, gelijk trouwens aan vele nachtelijke klanken, het bijgeloof der inlanders een buitengewoon onheilspellende beteekenis heeft toegekend. Dit onheil bepaalt zich intusschen tot eenige schade aan de vruchtboomen. Overdag zwijgen ze, tenzij de omgeving zeer eenzaam is, in welk geval ze door een soort van gekakel zelfs bijzonder luidruchtig kunnen worden. Zoo hoort men ze bijvoorbeeld den geheelen dag in de boschjes van het, slechts door den lichtwachter bewoonde eiland Edam (in de Baai van Batavia), waar zij de Kraaien volgen, die tegenover hun kroost als gastheeren optreden.

Terwijl dit gebied aan Spechten niet veel rijker is dan het vorige en, naast Dendrocopus analis, slechts Jyngipicus auritus, die als een kleinere uitgave van deze zou kunnen worden beschouwd, vrij algemeen voorkomt, treden de Vliegenvangers en de Lijsters reeds iets meer op den voorgrond. De eerste zijn hier vrij algemeen vertegenwoordigd door Siphia banyumas, die in veel grootere mate een vogel van het 
cultuurland blijkt te zijn dan vroeger werd vermoed, waarbij het natuurlijk mogelijk is, dat hij zich eerst de laatste jaren da:rin heeft verspreid. Volgens Bersstein bewoont hij "hoofdzakelijk de hooger ge"legen, nabjj bergwouden liggende boschjes, plantages "en tuinen en is ook in de koffietuinen, evenals "lang den zoom der wouden, niet zeldzaam", ter'wijl VORDERMax hem in de struikwildernissen op den Salak, op 2500 voet hoogte, reelvuldig aantrof. Hij blijkt echter ook in lager streken (o.a. in de buurt, ran Buitenzorg) reelruldig voor le komen en eenige, nabij Bandjar rerkregen exemplaren bewijzen, dat hij ook het liagland bewoont. Het moet echter worden erkend, dat hij, trots het indigoblauw der boven-, en de kaneelkleur der onderdeelen, niet gemakkelijk in het oog valt en in de eerste plaats aan zijn manieren als een Vliegenvanger is te herkennen.

De blauwe Hypothymis occipitalis komt ook in dit gebied roor, maar is veel minder algemeen, terwijl in de derde plaats moet worden genoemd de fraaie Tanthopygia tricolor, die hier slechts een winterbezoeker schijnt te zịn en in verband daarmede vermoedelijk niet aan een bepaald gebied is gebonden. Deze soort werd eenige jaren geleden in vrij groot aantal aangetroffen bij de hoomrijke kampongs aan den voet van den Goenoeng Pantjar, ten Z.-O. van Buitenzorg, die nog geheel met bosch is bedekt.

Van de Lijsters mag als tamelijk vaste bewoner ran dit gebied, maar vooral in de hoogere streken, worden genoemd Geocichla rubecula, in West-Java algemeen onder den naam manoek tjatjing bekend. Deze vogel zoekt zijn voedsel, dat inderdaad voor een groot deel uit wormen bestaat, op den grond, op vochtige, dicht beschaduwde en begroeide plekken 
en ralt daardoor weinig in het oog. Borendien is hij ran een stille natuur; in de latere uren van den voormiddag begeeft hij zich echter narar de hoogere deelen ran het geboomte en trekt dan de aandacht door een zeer fraaien zang. Oprallend zijn bij dezen rogel de steeds rolmakkte netheid en zindelijkheid van het rederkleed, terwijl de omgering, warin hij zicl ophoudt, juist geschikt z.ou worden geacht om ziju teere klemen, oranjebruin, wit en blauwgrijs, spoedig te bezoedelen.

Cittocincla tricolor, bekend als lootjita oetan, houdt zich rooral in de stilste gedeelten ran dit gebied op en heeft in lerenswijze reel overeenkomst met de vorige soort, terwijl, wat voedsel betreft, we] allerlei gedierte wordt gegeten, doch daarbij een zekere roorlizfde rool Duizendpooten schijnt te bestaan. Ook deze lijster heeft een fraaien zang, maar door zijn meerdere schuwheid krijgt men dien niet dikwijls te hooren.

Terwijl de gewone Klauwier ran Jara, Lanius bentet, hier en daar (o.a. te Bataria) ook in de grootere plaatsen is doorgedrongen en feitelijk het geheele cultuurland bewoont, onverschillig roor het klimaat ran zijn woonplaats, is hij ouk in en om de kampongs een dagelijksche verschijning, die zich garne ophoudt waar het terrein hier en daar open gedeelten aanbiedt. Hij behoort voorts niet alleen tot de cultuurfauna, maar ook tot de kustfauna, waar wij hem later weder zullen ontmoeten. Van de beide andere Lanius-soorten, die op Java voorkomen, is nog weinig bekend. Lanius tigrinus, die in China broedt, komt slechts om te overwinteren zuidwaarts, waarbij de meeste individuen niet verder gaan dan Siam en Malacca. Lunius super- 
ciliosus is eveneens een zeldzame verschijning, nu en dan in dit gebied aangetroffen.

De zoogenaamde Malabaarsche Mees, Pericocrotus peregrinus, van de verwante groep der Rupsvogels, is de eenige van zijn geslacht, die reeds geheel in de cultuurfaunil is overgegaan. Hij heeft echter nog een vrij groote schuwheid ten aanzien van den mensch behouden en vermijdt diarom liefst de onmiddellijke nabijheid van diens woningen. In de meer afgelegen gedeelten ran dit gebied is hij echter een tamelijk gervone verschijning, die men in kleine troepjes kan zien rondtrekken.

Oreral in dit gedeelte van het bewoonde land verspreid en platatselijk dikwijls zeer algemeen is de eenige Spitsvogel van Java, Artamus leucogaster, in West-Java met den naam Manoek boex aangeduid. In zijn wijze van doen houdt deze vogel het midden tisschen een zwaluw en een Buchanga. Zijn lange vleugels en ranke bouw stellen hem in staat, geruimen tijd in de lucht te zweven, terwijl men hem ook dikwijls kan aantreffen, rustend op een kalen tak en de voorbijvliegende insecten met vlugge bewegingen bemachtigend. Voorliefde voor een bepaalde temperatuur heeft hij blijkbaar niet, daar men hem zoowel in het laagland als in de bergstreken kan waarnemen.

Wanneer in dit gebied de vruchten van de doekoe (Lansium domesticum) tot rijpheid komen, kan men vrij zeker ervan zijn, hier ook Bladvogels (Phyllornidae) aan te treffen. Vorderman zegt in zijn "Salakvogels", dat Chloropsis nigricollis "wel eens naar de lager gelegen kampongs afdwaalt, maar toch meer in het bosch thuis hoort". Mij komt het daarentegen 
voor, dat deze rogelsoort de relatie met het bosch zoo goed als geheel heeft afgebloken; want ik ken hem voornamelijk als een vasten maar weinig hokvasten bewoner ran het geboomte der kampongs, wiens rerschijning slechts afhangt ran het al of niet aanwezig zijn van geschikt roedsel, waarbij aan de doetioe's boven alle andere rruchten de roorkeur wordt gegeren en het dier door zijn groene kleur en zijn rustige manieren een goeilen roorsprong heeft op beter zichtbare en rooral op meer luirruchtige concurrenten als koctilang's enz., die door de eigenaars der boomen spoedig worden opgemerkt en verdreven. Is Chloropsis nigivollis in West-Java algemeen, het schijnt, dat zij meer naar het Oosten in getalsterkte afneemt om langzamerhand door de verwante soort viridis te worden rervangen.

Naast de beide, reeds rroeger (pag. 61) besproken en in het geheele culturugebied met den mensch samonlevende Pycnonotus-soorten aurigaster en analis treedt hier als derde soort $P$. plumosus op, maar dit is zulk een stille en weinig in 't oog' rallend gekleurde vogel, dat men hem nauwelijks opmerkt, zelfs waar hij tamelijk veelvuldig is. Voor de vierde soort, $P$. simplex, geldt dit in nog meerdere mate. De verwante Criniger gularis, in de Soendaneesche streken vrij constant met den naam koriès aangeduid, geeft daarentegen in veel meerdere mate ran zijn aanwezigheid blijk en wel door zijn zonderlinge gebaren en bewegingen. Gewoonlijk trekt deze rogel in troepjes rond, die zich meestal in het lage!e, zelden in het hoogere hout ophouden. Veel geluid maken zij daarbij niet, maar hum bewegingen zijn zeer levendig; men krijgt den indruk, dat de onder- 
linge rerstandhouding reel te wenschen overlat en dat zij roortdurend, zoowel in letterlijken als in overdrachtelijken zin, trachten elkander vliegen af te vangen. Die indruk wordt rooral versterkt, doordat de dieren diarbij niet alleen hun kuif op nijdige wijze opzetten, maar ook de witte kin-en keelveeren naar roren strekken, waardoor ze er, in hun werkelijke of wellicht maar schijnbare gemoedsberveging, eenigszins potsierlijk uitzien.

De Brilvogeltjes (geslacht Zosterops) geven ons de bijzonderheid te zien, althans in West-Java, dat de verschillende soorten wel roor een deel naast elkar voorkomen, maal niet op dezelfde hoggte boven zee hun grootste getalsterkte bereiken. Zij zijn ook in dit gebied zeer algemeen en treklien er in troepjes rond, waarbij het zachte, piepende geluid, dat ze maken, hunne aanwezigheid spoedig verraadt. In de lagere streken nu rindt men hoofdzakelijk Zosterops flava, terwijl men iets hooger, o.a. reeds te Buitenzorg, vooral $Z$. auriventer aantreft. Deze wordt op hare beurt langzamerhand door $Z$. melamu a rerrangen, die speciaal het borenste gedeelte der cultuurstreken bewoont. Boren de boschgrens eindelijk roert $Z$. fallax vrijwei de alleenheerschaplij, die zich tot de toppen van het gebergte uitstrekt. Terwijl de laatste, die zijn soortnaam zeer terecht draagt, bij de dierrormen der hoogere bergwouden nader ter splake zal komen, zij aangaande de andere nog opgemerkt, dat zij geheel de allures aannemen ran Meezen, zoodat men den indruk krijgt, dat ze steeds naar insecten zoeken. Het onderzoek der magen heeft echter aangetoond, dat zij slechts in zeer beperkte mate insecteneters 
zijn; verreweg het grootste gedeelte van hun roedsel bestaat uit viuchten en zaden.

Terwijl de echt? Kraaien dit gebied hoofdzakelijk als nachtrerblijf gebruiken en orerdag hun zwerftochten naar dikwijls verafgelegen terreinen ondernemen, brengt een andere Corvide er zijn geheelen tijd door. De hier bedoelde is Crypsivflina varians, die dikwijls met den inlandschen naam tjetrong wordt aangednid, mail minstens eren raak roor een Buchanga worlt aangsien. Daartoe werken niet alleen zijn zwarte, ran nabij beschouwd fraai groenachtig bronsglanzende kleus, mal ook de rorm ran zijn staart en zijn vlugge beregingen mede. De staart namelijk bestaat uit rijf paar trapsgewijs en geleiclelijk verlengde pennen, waarvan het middelste paar zeer lang is en aan het uiteinde eene verbreeding bezit. Hoewel dus niet vorkrormig, doet de staart toch aan dien van een Buchanga denken. De bewegingen van dezen rogel kunnen voorts met die van een salagoenting in vlugheid wedijveren, wat hem als insecteneter naturlijk goed te pas komt. Hij is echter lang niet zoo algemeen en schijnt nogal plaatselijk voor te komen. Bovendien is hij tamelijk schuw en daarom minder in de kampongs zelve, dan in hare omgeving aan te treffen.

Dit liatste geldt evenzeer van het tweetal grondbewoners, waarmede dit orerzicht kan worden besloten en waarvan Pitta cyanura, de boeroeng paok, er één is. Wie dezen schitterend gekleurden vogel vlak vóór zich ziet, verbaast zich erorer, dat hij in zijn natuurlijke omgాeving zóó weinig opvalt, dat men hem op een afstand van weinige meters geheel over het hoofd ziet, wanneer hij niet toevallig door een beweging de aandacht trekt. De oorzaak hiervan 
is gelegen in de nagenoeg rolslagen afwezigheid van glans op het gevederte, een eigenschap, die aan de geheele familie der Pittidae toekornt. Overigens is het dier niet alleeu fraai ran kleur, maar ook sierlijk van vorm, waaraan de korte staart in het geheel geen afbreuk doet. De lange pooten en de krachtige bek staan in verband met de levenswijze: rooral de eerste zijn, bij zijn tamelijk slecht vliegrermogen, een vereischte roor groote bewegelijkheid. De boeroung paok is in het geheel niet zeldzaam in dit gebied, maar in zijn rerticale verspreiding tot ongeveer 2000 roet hoogte beperkt; hij zoekt er cchter de meer afgelegen gedleelten op, waar het onderhout hem een goede schuilplaats verleent en groote hoeveelheden afgerallen blad het noodige gedierte herbergen, warvan groote mieren, zooals vele Poncrilae (pag. 159) door hem met roorliefde worden gegeten. Wordt hij bij het zoeken naal roedsel gestoord, dan houdt hij zich danvankelijk doodstil, blijkbaar in afwachting, of de oorzaak der stoorais spoedig zal verdwijnen; bliikt dit niet het geval, dan rent hij na eenige oogenblikken plotseling weg en is dan gewoonlijk gauw uit het gezicht verdwenen.

De tweede der bedoelde grondbewoners is de welbeisende poejoeh, Turnix pugnax, die zoowel in dit, als in aangrenzende gebieden een gewone, maar uiterst moeielijk zichtbare verschijning is, het laatste als gevolg der bijzondere adaptatie van het vederkleed aan de levenstrijze. Dat het dier met deze, voor hem zoo bijzonder voordeelige eigenschap ten volle bekend is, blijkt wel uit het feit, dat hij zich nok in een kooi, wanneer daarin slechts een weinig aarde aanwezig is, zóó weet te plaatsen, dat men heni bepaald moet zoeken. Morphologisch van de 
echte Kwartels te onderscheiden door de afwezigheid van een achterteen, komt hij in levenswijze vrijwel met hen overeen, mar hecht in mindere mate aan de aanwezigheid eener grasregetatie. Vandaar, dat men hem ook anntreft op plekken, waar veel laag hout en struiken de rorming van zulk een vegetatie tegenhouden, marl aan den anderer kant het dier een volkomen onzichtbaarheid waalborgen.

Turnix pugnax behoort voorts tot de diervormen, bij welke het vrouwelijk element de likkens uitgeeft en de richting, in de menschelijke matschappij als feminisme aangeduid, hoogtij viert. De eenige huishoudelijke bezigheid, waaraan de wijfjes zich nog niet hebhen weten te onttrekken, is het leggen der eieren. Het uitbroeden daarran en de verzorging der jongen worden geheel aan de mannetjes overgelaten en terwijl deze zich daarmede onledig houden, hebben de wijfjes hun bijeenkomsten, waarvan men niet kan zeggen, dat ze in vechtpartijen ontaarden om de eenvoudige reden, dat ze zulks van den aanvang af zijn en zelfs met dat doel worden georganiseerd. Dat bij die plukpartijen alle voorzichtigheid uit lret oog wordt verloren, is roor de dieren natumlijk verderfelijk; het verraadt, alle adaptatie ten spijt, hunne aanwezigheid en maakt ze tot een zeer gemakkelijke prooi van kleine roofdieren.

Wanneer men bedenkt, dat behalve de vogels, die in dit hoofdstuk werden besproken, in dit gebied ook algemeen voorkomen de soorten, die reeds rroeger (pag 60-70) werden genoemd, en dat er, als toevallige bezoekers, nog wel eens andere vallen waar te nemen, die later zullen ter sprake komen, dan 
komt men tot een vogelbevolking van circa honderd soorten, welk cijfer voor een, in de onmiddellijke nabijheid van den mensch gelegen gebied stellig aanzienlijk mag worden genoemd. De wel eens vernomen klacht, dat men op Java zoo weinig vogels ziet en hoort, is inderdaad niet gegrond, maar de waarneming der dieren - dit valt niet te ontkennenis hier veel bezwaarlijker dan bijv. in Holland. De moeiclijkheden, die terrein, klimaat, vegetatie enz. opleveren, zijn niet gering, zoodat men iets meer dan een gewoon "vogelliefhebber" moet zijn om met de avifauna zijner omgeving op een voet van behoorlijke bekendheid te geraken. 


\section{HOOFDSTUK XI.}

\section{De Sawahfauna.}

De Sawahfauna is een hoogst merkwardig biologisch geheel: waarvan de samenstellende elementen voor een aanzienlijk deel niet alleen in nawwen onderlingen samenhang staan, maar bovendien optreden in een rolgorde, die aan regelmaat weinig te wenschen overlaat. Van het oogenblik, waarop het eerste bevloeiingswater wordt toegelaten, tot dat, waarop de verdroogde stoppels worden rerbrand, zien wij ze als in een bioscoop-vertooning roorbijtrekken. De kracht, die ze draagt en roortbereegt, is in hoofdzaak geen andere dan juist dat water, aan welks aanwezigheid zij borendien grootendeels hun verscheidenheid hebben te danken.

Onmiddellijk vóórdat de eerste aanstalten tot den rijstbouw worden gemaakt, is de diarroor bestemde grond in den regel weinig beter dan „woest en ledig", ; daarbij reelal door de zonnehitte zóó hard en droog, dat geen landbouwwerktuig behoorlijk erin rermag: door te dringen. Men begint dus met op de hoogste gedeelten het bevloeiingswater toe te laten, dat daarin aanvankelijk gretig wordt opgezogen. Binnendringend in den bodem, doet het spoedig een aantal kleine diervormen, vooral insecten, ontwaken, die hetzij in den larvalen, hetzij in den poptrestand een droogteslaap waren ingegaan en nu naar de oppervlakte komen tot voortzetting en voleindiging van hun bestaan. Tot dit laatste brengen zij het reelal niet, 
althans niet op de wijze, waarop zij dat wenschen; want verschillende vogels, onder welke de djalak (Sturnopastor jalla) wel het best is vertegenwoordigd, trippelen lustig rond op den zwellenden grond en doen zich te goed aan hetgeen de aarde hun zoo onverwacht aanbiedt.

Stat de grond eenmaal behoorlijk onder water; dan is weldra het oogenblik roor de grondbewerking daar. De eenroudige, maar niet onpractische ploeg rerschijnt, in West-Jara in den regel getrokken door karbouwen (Bos bubalus), in Mídden- en Oost Java door het Javaansche rund, een mengelmoes ran velerlei herkomst, bij hetwelk nu eens de bult op Bengaalsche afstamming wijst, dan weder cle witte billen het bloed ran den banteng (Bos sundaicus) schijnen te verrarlen. In de week-modderige, spoedig weder vervloeiende rore wordt de ploeg weder door rogels gevolgd. Nu en dan stapt een Steltlooper achter hem aan, roornamelijk echter 'zijn weder Spreeuwen in de meerierheid, terwijl ook Buchanga's zelden ontbreken. In den, met modder orerdekten inlander, die den ploeg bedient, zien zij geen vijand; het ontureekt er slechts aan, dat ze zich op zijn schouders neerzetten, zooals ze dat doen op den rug der trekdieren.

Op een bepaald uur van den voormiddag wordt het zware ploegwerk gestakkt, daar de zonnewarmte het verder ondoenlijk maakt. De karbouwen geven gewoonlijk zelf het oogenblik darartoe aan; zij weigeren verderen dienst en begeren zich, zoodra ze zijn losgemaakt, naar een naburig riviertje of, bij afwezigheid daarvan, naar modderige plassen, waal ze te water gaan en in behagelijke rust raak niet 
veel meer dan het aangezicht en het bovenste gedeelte van den breeden rug te zien geven.

Ni het ploegen rolgen het eggen en het schoon-. maken en rernieuwen der dijkjes, terwijl inmiddels ook de kweekbedden zijn aangelegd en weldra het zachte groen der jonge plantjes te zien geven. Er heerscht dan een oogenblik van rust, doch die rust is maar schijnbaar, want het water begint zijn machtigen biologischen invloed te doen gevoelen. Duizenden kleine Diptera, roor een aanzienlijk deel uit de rerwantschap der Muggen, worden erdoor aangetrokken, zweven erboven en leggen hun eieren erin. Al worden ze gedecimeerd door Zwaluwen, die rusteloos boven de oppervlakte scheren, hun aantal is overvloedig genoeg om het water en zijn weeken bodem te bevolken met tallooze larven, die op hunne beurt aan een geweldige verrolging blootstaan. Want boven het pas geïnundeerde veld zweven eveneens in ontelbaar aantal de Odonata, die hier een uitgezochte - gelegenheid vinden om de toekomst hunner nakomelingschap te rerzekeren. Het zijn vooral Libellulidae en Aeschnidae, die wij hier waarnemen; de Agrionidae, in het algemeen slechts in geringe mate in de cultuurfauna overgegaan, ontbreken hier vrijwel geheel. In vergelijking met het aantal individuen is dat der soorten betrekkelijk gering. Van de eerste familie noemen wij hier als algemeen Orthetrum sabina, O. (Libella) testaceum, O.(L). pruinosum, Pantala flavescens, Trithemis (Diplax) trivialis, Tholymis tillarga, Neurothemis fluctuans; van de tweede Gynacantha subinterrupta, Anaciaescha taïtensis en het geslacht Macrogomphus.

De invloed, dien deze Glazenmakers uitoefenen op de instandhouding van het erenwicht in de natuur, 
in het bijzonder die der sawahrijke laaglanden en lagere berghellingen, kan niet anders dan zeer belangrijk zijn. Gegeven hun roofzuchtige aard zoowel in den volwassen als in den larvalen toestand, moet het aantal kleine insecten, dat hun tot voedsel dient, wel zóó groot zijn, dat, bleef het in leven, dat evenwicht op bedenkelijke wijze zou worden gestoord. In het bijzonder heb ik hier het oog op de culicidae; hadden deze in het water ran de sawah's gelegenheid, zich ongestoord te ontwikkelen, dan zouden zij voor den mensch het leven in de nabijheid daarvan ondragelijk, zoo niet onmogelijk maken. Bedenkt men daarbij, dat juist in deze familie de verspreiders der malariakiemen worden gevonden, dan komt men ertoe, den Glazenmakers ook in hygiënisch opzicht een even grooten als weldadigen invloed toe te schrijven.

De eieren worden door de verschillende soorten van Glazenmakers niet op dezelfde wijze gelegd. Sommige deponeeren ze eenvoudig in het water, andere plakken ze vast aan de waterplantjes, die zich spoedig na de bewerking van den grond beginnen te ontwikkelen, terwijl een derde groep ze, met behulp van een legboor, in het zachte weefsel van die plantjes deponeert. De dieren zijn daarbij soms genoodzaakt, zich onder water te begeven, een handelwijze, die bij soortgelijke insecten zeer zelden wordt waargenomen, maar den Glazenmakers blijkbaar niet moeielijk valt. Uit die eieren ontwikkelen zich spoedig de larven, die, in tegenstelling met de imagines, tamelijk traag in hunne bewegingen zijn en zich gaarne verschuilen, hetzij onder eenig plantendeel, hetzij in de losse, bovenste lagen van den bodem, in welk laatste geval ze geheel onzichtbaar zijn en des te zekerder hun prooi kunnen grijpen. Bij dit laatste bedienen 
zij zich, gelijk bekend is, uitsluitend van de onderlip, die is nitgegroeid tot een langwerpig, op twee plaatsen bewegelijk geleed orgaan, dat aan zijn uiteinde een breede grijptang draagt, waarvan de beide helften zijdelings bewegelijk zijn. In de rust zich voordoend als een onschuldige, helmvormige, soms slechts gedeeltelijke bedekking van het aangezicht, is cie gemetamorphoseerde onderlip in werkelijkheid een zeer verraderlijk werktuig, waarmede niet alleen kleine, teere larfjes, maar ook grootere dieren onverwacht worden gegrepen.

Bij de Glazenmakers roegen zich nu spoedig verschillende soorten van Waterroofkevers ter bevolking van het bevloeiingswater. In de eerste plaats mogen daarvan worden genoemd de Dytiscidcue met Cybister similis en Hydaticus vittatus als meest algemeene vertegenwoordigers in dit gebied. Vooral de eerste speelt hier oeconomisch en biologisch een groote rol. Het lijdt geen twijfel, dat deze dieren voor een deel door het water worden aangevoerd, maar het komt mij roor, dat de eigenlijke bevolking plaats heeft door nachtelijke zwermen, afkomstig van elders, bijroorbeeld van verwijderde rijstvelden, die men laat droogloopen en waarop hun bestaan derhalve moeielijk of onmogelijk wordt gemaakt. Dat dergelijke zwermen bestaan en dat zij op hun tochten vaak aanzienlijke afstanden afleggen, bemerkt men des avonds wel eens aan het binnenvliegen van talrijke exemplaren in woningen, in welker nabijheid overdag zulke kevers niet voorkomen. Ook behoeft men het irrigatiewater slechts gedurende eenige uren door een net van neteldoek te laten loopen om te kunnen waarnemen, hoe gering in het algemeen het aantal medegevoerde dieren is. 
De larven der Dytiscidae doen in roofzucht weinig onder voor die der Odonata, terwijl zij, althans overdag, reel bewegelijker zijn en voortdurend rondscharrelen om een prooi te bemachtigen. Deze wordt ook hier gegrepen met een tang, ditmaal gevormd door de beide, sikkelvormige kaken. Een eigenlijke mondopening is er niet: de kaken zijn hol met een kleine opening aan het uiteinde en dienen dus niet alleen om de prooi te grijpen en rast te houden, maar tevens om haar leeg te zuigen. Is de prooi echter een weinig omvangrijk, dan worden bij het rasthouden ook de pooten gebruilit.

De tweede familie van Waterkevers, die op de sawah's is aan te treffen, die der Hydrophilidae, lijkt mij hier biologisch van minder beteekenis. Zij schijnt zich meer thuis te geroelen in de kalme plekken van beken en ririertjes, wellicht omdat zij, in verband met verschillende bijzonclerheden harer levenswijze, aan dieper water de voorkeur geeft. Toch is Hydrophilus olivaceus in bet sawahwater een gewone rerschijning, evenals zijn larven, die op de Dytiscus-larren gelijken, maar minder krachtige pooten hebben, terwijl de kaken ran normale constructie zijn en de prooi derhalve wordt opgegeten en niet leeggezogen.

De Draaikevers (Gyrinidae) daarentegen, die hier in de derde plaats moeten worden genoemd en die meer op, dan in het water leven, gevoelen zich op de sawah's weder geheel op hun plaats. Vooral bij heldere weersgesteldheid ziet men ze, bij geheele troepen, op de bekende wijze dooreenkrioelen, terwijl ze zich bij regenachtig weer schuil houden. Hun typische vertegenwoordiger in dit gebied is de hoogst algemeene Dineutes australis, die eveneens wel eens 
in talrijlie troejen nachtelijke ziverftochten onderneent, iets, dat ik bij de rertegenwoordigers der vorige familie nooit heb opgemerkt. Wellicht staat dit in verband met de gemakkelijke verspreiding der Hydrophitidae door middel van de eieren, die worden gelegd in een zakrormig, zelf gesponnen nest, dat aan een of ander drijvend roorwerp, veelal een blaadje, wordt bevestigd. Ten einde de bervegelijkheid dezer drijrende broedkamer te vergrooten, wordt aan dat roorwerp een sterig, opstaand gedeelte gesponnen, dat als zeil clienst doet, waarna de nakomelingschap aan haar eigen lot wordt overgelaten.

Naast Glazenmakers en Waterkevers spelen ook een aantal Rhynchoten in het sawahwater ern niet onbelangrijke, biologische rol als roofdieren, die de kleinere vormen der fauna binnen behoorlijke perken houden. In de eerste plaats mogen daarvan worden genoemd de Duikerwantsen (Corixidae), die eigenlijk zelf nog tot die kleine vormen moeten worden gerekend en daarom door hun groote snelheid en behendigheid in duiken en zwemmen moeten goed maken, wat ze aan afmetingen missen. De Javaansche Corixa-soorten toch zijn gemiddeld niet meer dan 5 mil. lang; de Micronecta's zelfs niet meer dan gemiddeld 3 mM. Tan aanzienlijliel afmetingen zijn reeds de Notonertidae, de welbekende Bootsmannetjes of Rugzwemmers, welke laatste naam is ontleend aan de eigenschap, steeds met de rlakke buikzijde van het lichaam naar boven te zwemmen, waarbij de dieren zich in schuine richting voorwarts bewegen. Zij zijn in dit gebied o. a. door verschillende soorter van het geslacht Notonecta vertegenwoordigd, stoutmoedige en roofzuchtige dieren, die met eenige 
voorzichtigheid moeten worden aangepakt, daar ze iederen vijnd onmiddellijk den stevigen zuigsnuit in de huid boren.

De grootste vormen onder de Waterwantsen treft men echter aan in de familie der Belostomatidae, waarvan men de reusachtige Belostoma indicum wel eens in het sawahwater ziet ronddrijven, het uiteinde van het achterlijf even boven het water uitstekend ten einde in de behoefte aan zuurstof te kunnen voorzien. In tegenstelling met de Notonecta's is dit dier van een tamelijk phlegmatische natuur en slechts in beperkte mate een roofdier, daar het zich voornamelijk schijnt te voeden met de kleine lucht- en landdieren, die overdag bij ongeluk in het water vallen en die het afwacht in de zooeven beschreven houding. Daarentegen zijn de Sphaerodema-soorten, van dezelfde familie, hoewel aanzienlijk geringer van afmetingen, wederom ijverige jagers. Men ziet hier de meest gewone soort, de breede Sphaerodema rusticum, voortdurend in beweging, zoowel rondloopend op den bodem, als klimmend.langs alles, waaraan zij maar even houvast heeft, maar steeds loerend op een prooi. Het genus Sphaerodema behoort verder tot de diervormen, bij welke de feministische neigingen, die eigenlijk het geheele dierenrijk door in latenten toestand worden aangetroffen, weder eens op duidelijke wijze tot uiting komen. En wel in dier voege, dat de wijtjes, na het leggen der eieren, de verdere zorgen daarvoor aan de mannetjes overlaten door hun deze liefdepanden eenvoudig op den rug te plakken; soms in zóó grooten getale, dat ze grootendeels ermede bedekt zijn. Het is zelfs zeer waarschijnlijk, dat aan deze manipulatie niet eenmaal een onderzoek naar het vaderschap voorafgaat, zoodat 
bij de Sphaerodema-mannetjes het celibaat nog in geenen deele rrijdom van huiselijke zorgen schijnt te waarborgen.

Eindelijk moeten nog worden genoemd de Waterschorpioenen (Nepidae), die in het ondiepe water der rijstvelden gaarne vertoeven, omdat zij daar kunnen ademhalen zonder genoodzaakt te zijn, telkens hun schuilhoeken te verlaten. Deze dieren hebben namelijk de gewoonte, zich in de bovenste, slibbige lagen van den bodem te verbergen, echter zóó oppervlakkig, dat ze maar voor een gedeelte bedekt zijn en hun eigenaardige grondkleur het overige doet, om hen aan het gezicht te onttrekken. Slechts de lange, aan het uiteinde van het achterlijf geplaatste adembuizen zijn naar boven gericht en bereiken gewoonlijk juist de oppervlakte van het water. Daardoor is de luchttoevoer verzekerd in de houding, warin het dier zijn prooi zit af te wachten. In het bijzonder geldt dit voor Nepa robusta, die adembuizen heeft van bijna 4 cM. lengte; de slanke, bijna staafvormige Ranatra (Cercotinetus) asiatica heeft reel kortere adembuizen en is daarom meer beperkt in de keuze van haar schuilhoek, tenzij ze telkens naar de oppervlakte van het water verkiest te gaan.

Naast Insecten treden voorts vertegenwoordigers der Kreeftachtige Dieren in het sawahwater op, echter, wat de kleinere vormen, speciaal de Copepoda, Cladocera en Ostracoda, betreft, in zóó bescheiden mate, dat het de verwondering gaande maakt vau ieder, die wel eens in Holland in soortgelijke wateren heeft verzameld. Daarentegen zijn de grootere vormen (garnalen van de geslachten Palaemon en Caridina, krabben van de geslachten Telphusa, Sesarma en Atya) 
hier veel algemeener dan ginds, waarbij de krabbetjes, speciaal Atya moluccensis, door hun groot aantal en door de gewoonte, gangen in den grond te graven, voor het samenstel van dijkjes en leidingen wel eens gevaar opleveren.

Alvorens over te gaan tot de bespreking der verdere diervormen, die, voor een deel in biologisch verband met de reeds genoemde, de sawah's bevolken, willen wij eerst de rijstplant zelve als factor invoeren, die tot vergrooting van het fauna-complex natuurlijk het hare aanbrengt. Reeds op de kweekbedden; want daar doet ' dikwijls een Galmugje van de familie der Cecidomyidae op groote schaal een eigenaardige verminking ontstaan door de bladscheede van het bovenste blad te doen uitgroeien tot een lang, bleekgroen, schuin bovenwaarts gericht buisje, aan welks top in den regel slechts een schamel overblijfsel van de bladschijf is te vinden, terwijl de verdere groei van het plantje ophoudt.

Eenmaal uitgeplant, biedt ieder plantje een rustplaats aan allerlei vliegen van de families der Mruscidae, Tachinidae, Psilopidae, Asilidae enz., die, al naar gelang van hunne levenswijze, de rijstvelden met verschillende doeleinden opzoeken en zich daar bovendien gaarne in den zonneschijn koesteren. Vete hunner vallen daarbij ten prooi aan de Kikvorschen, die, het behoeft nauwelijks rermelding, eveneens spoedig de sawah's komen bevolken. Vooral het geslacht Rana is hier goed vertegenwoordigd. Behalve de reeds vroeger (pag. 88) genoemde soorten macrodon, tigrina, limnocharis en erythraea kan men hier waarnemen Rana chalconota, terwijl ook Oxyglossus lima zeer gewoon is en waarschijnlijk nog wel meerdere der van Java bekende Rana-sórten (o.a. grunniens, nicobariensis, 


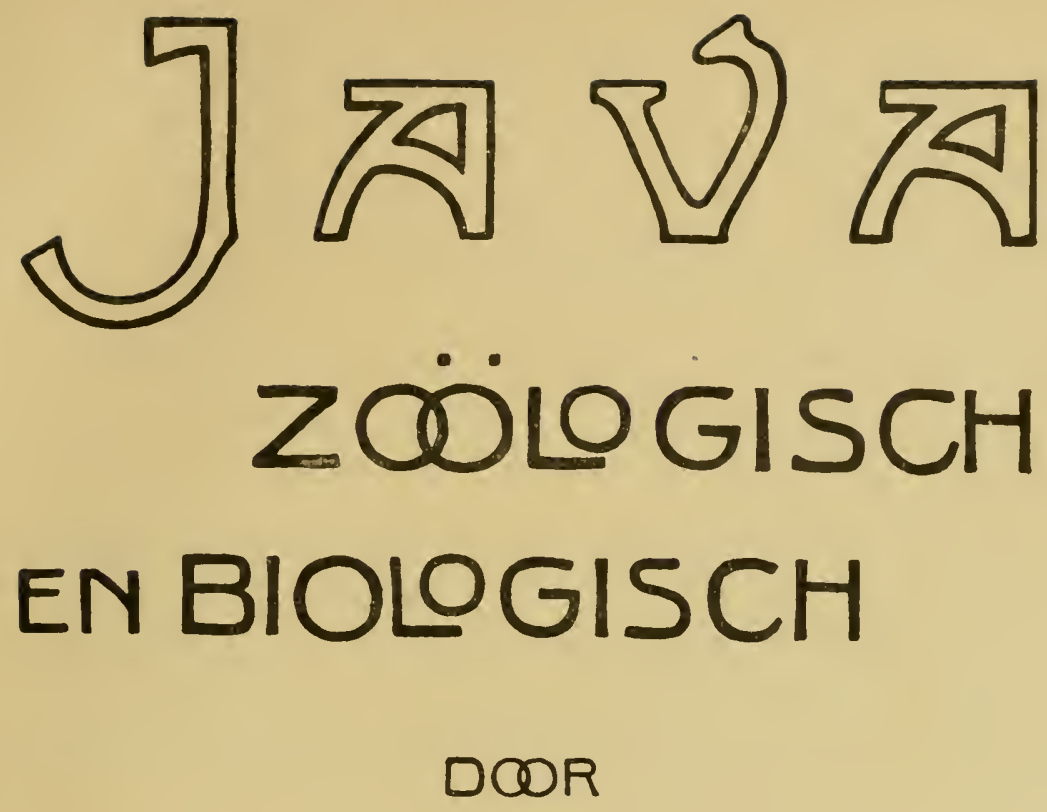

DRJ.C.KONINGSBERGER

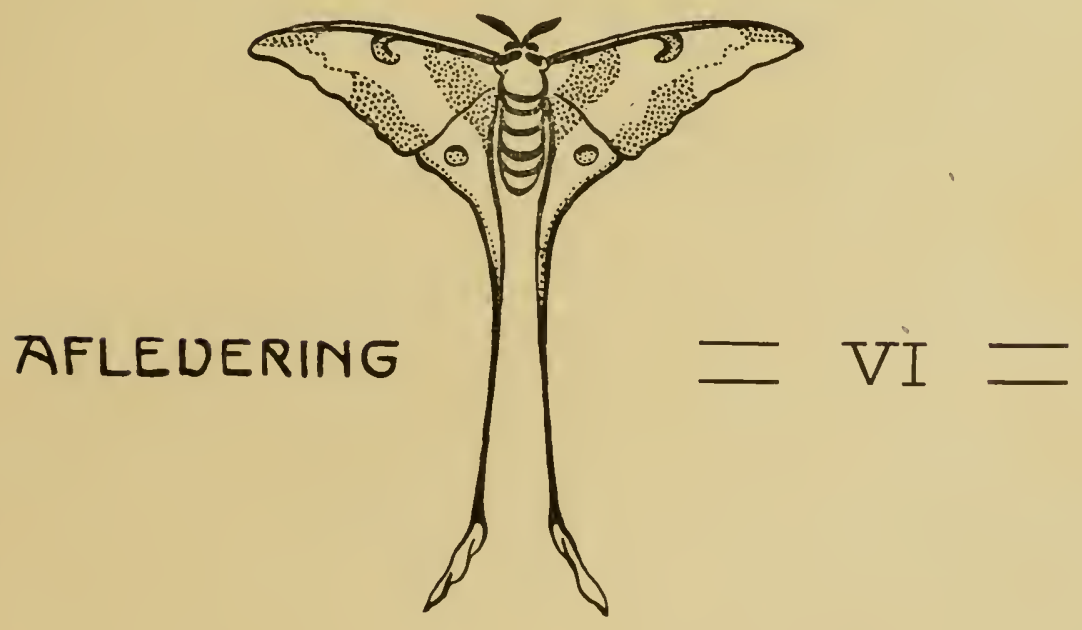

DRUKKERJ DEP. v. L. N. en H. BUITENZORG 1913.
Verkrijgbaar bij

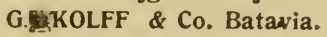

Prijs $f$ 1.- 



\section{I $\mathrm{NHOUD}$.}

\section{AFLEVERING I.}

pag.

VOORWOORD.

Hoofdstuk I. Algemeene samenstelling der Fauna van Java en hare wordingsgeschiedenis. De Hoofdgroepen. . . . . .

Hoofdstuk IT. Overgangen ran de eene groep in de andere. Molphologische gevolgen daalran. Voorbeelden van volmen, die in orergang zijn. Nachtelijke en diurne levenswijze. .

Hoofdstuk III. Inrloed ran jarargetijden, regen. wind en zonneschijn. Tergelijking met andere eilanden. -. . : .

\section{AEJ.EVERING II en III.}

Hoofdstuk IV. Kort overzicht der rerschillende gebieden. De Cultuurfauna bij uitnemendheid: de diervormen der grootere plaatsen . . . . . . . . . . . . . 51.

A. Zoogdieren . . . . . . . . . . 55.

B. Vogels. . . . . . . . . . . 60.

C. Kritpende ex Tweeslachtige Dieren. . . 76.

Hoofdste $V$. De Dielrormen der grootere plaatsen.

(Vervolg) . . . . . . . . . . . . . . . 90.

D. INSECTEN . . . . . . . . . . 90.

1. Orthoptera . . . . . . . . . . 90.

2. Neuroptera . . . . . . . . . . . 98.

‥ Rhynchota . . . . . . . . . 104.

4. Diptera . . . . . . . . . . . . 108.

Hoofdstuk VI. De Diervormen der grootere plaatsen.

(Vervolg). D. Ixsectex. (Vervolg) . . . . . . . . . 116.

э. Coleoptera . . . . . . . . . . . . 116.

6. Lepidoptera. . . . . . . . . . . . 127. 
HoofdSTUK VII. De Dielvormen der grootere plaatsen

pag.

(Vervolg). D. Insecten (Vervolg). . . . . . . . . 157.

7. Hymenoptera. . . . . . . . . 157.

8. Apterygota. . . . . . . . . . . 179.

Hoofdstuk VIII. De Diervormen der grootere plaatsen. (Vervolg) . . . . . . . . . . . . . . . . 180.

E. SCHORPIOENEN EN VERTANTE VORMEN . . 180.

F. Spinnen en Mijten. . . . . . . . 182.

G. Dutzendpouten. . . . . . . . . . 189

H. Kreeftachtige Dieren . . . . . . . 193.

I. WEeKDIEREN. . . . . . . . . . . . . 194.

K. TORMEN. . . . . . . . . . . . . . 195.

Hoofdstuk IX. De Fauna der dessa's. . . . . . . 198.

A. Dessa's IN Het OPEN VELD. . . . . . 199.

\section{AFLEVERING V.}

Hoofdstuk IX. De Fauna der dessa's (Vervolg).

A. DesSA'S IN HET OPEN YELD (Vervolg) . . . 205.

B. Dessa's in BoomriJke OMGeVing . . . . 212.

Hoofdstuk X. De Fauna der "dessa's. (Vervolg).

B. DessA's in BoomRtJKe OMGEVING. (Vervolg) • 227.

Hoofdstuk XI. De Sawahfauna . . . . . . . . 245.

\section{AFLETERING VI.}

Hoofdstuk XII. De Fauna van het Bouwland . . . . 272.

Hoofdstuk XIII. De Fauna van het Bouwland. (Vervolg) 295. 
microdisca) hier (') daar dit gebied zullen blijken te bewonen. wanneer; meer dan tot heden kon geschieden, in allerlei streken de plaatselijke fauna's aan een nader onderzoek zullen worden onderworpen.

De Kikvorschen rormen op humne beurt een aanzienlijk deel ran het roedsel ran rele Slangen. Tnorzooverre de reeds in Hoofdstuk IV besproken soorten dezel latste groep zich niet hoofdzakelijk op boomen of permanent onder den grond ophouden, zijn zij nigenoeg alle op de rijstrelden aan te treffen, terwijl hunne gelederen nog door een aantal andere rormen worden versterkt. Zoo trof ik eens in het laagland bij Pekalongan Simotes octolineatus in rij groot aantal aan, eene soort, die elders weder meer tot de hoogere streken beperkt schijnt. Xenopeltis unicolor, in West-Java onder der nam oraj bondol bekend en gemakkelijk aan zijn eigenaardig, glad en aal-achtig roorkomen te herkennen, Tropidomotus piscator, die bij rluchtige beschouwing licht met Simotes octolineatus wordt rerward, lipsadomorphus cynodon, die soms aanzieulijke afmetingen bereikt, Amblycephahs carinatus (o. leupeul) mogen hier rerder als niet zeldzame, algemeen verspreide vormen worden genoemd, terwijl Coluber radiatus (soms met den naam o. sapi adngeduid), Psammodynastes pulverulentus en Haplopeltura boa meer tot de hoogere streken beperkt schijnen te zijn en Macropistodon rhodomelas in de Oostelijke helft ran Jara meer dan in de Westelijke wordt aangetroffen.

Bijzonderheden uit het leven ran al deze dieren zijn ons feitelijk nog niet bekend. De meeste soorten ran slangen leiden waarschijnlijk een zwervend bestaan en trekken zich alleen in den partijd paarsgewijze terug in ontoegankelijke plaatsen, waar 
de eieren worden gelegd en bewakt. Eieren ran Kikrorschen vindt men op de sawah's betrekkelijk. zelden; ze zijn in die ondiepe waterlaag te reel aan allerlei schadelijk invloeden en rijanden blootgesteld en de dieren geven daarom de voorkeur aan plassen en aan langzaain stroomende riviergerleelten, waar ook de veiligheid der larven beter is rerzekerd.

Narrmate, de rijstplant groeit, trekt zij meerdere diervormen aan, waarvan een deel haar als voedsel, een ander deel als beschutting in het open veld gebruikt. De eerste categorie behoort voor het grootste gedeelte tot de insectenwereld en omvat een aantal vormen, die oeconomisch voor den mensch van aanzienlijke beteekenis zijn. Ook biologisch zijn vele elvan niet ran belang untuloot. Hierbij denk ik in de eerste plaats aan Nympluula depunctalis (staynalis), een klein rlinclertje van de familie der Pyralidae met satijnachtige, witte vleugels, voorzien van eenige lichtbruine streepjes en zrvarte stipjes, dat reeds terloops werd genoemd op pag. 153. Dit insect brengt zijn jeugd door op de pas uitgeplante savah's en is soms ook reeds op de kweekbedden te vinden. Uit de eieren, die door de wijfjes groepsgewijze op de jonge, teere rijstbladjes worden gelegd, ontwikkelen zich in weinige dagen kleine rupsen, die van clie blaadjes kleine stukjes afbijten en zich daarvan platte, kokervormige huisjes maken. Deze huisjes worclengevuld met een weinig water, dat nu en dan wordt ververscht en aan het dier de noodige zuurstof moet leveren. Want het leidt een amphibisch bestaan: terwijl het roorste gedeelte van het lichaam zich viijelijk in de lucht beweegt, is het achterste gedeelte op 
rerblijf in het water aangewezen en in rerband daarméde vool'zien ran eenige rijen van draadrormige. ten getale ran 2 tot 4 bij elkar geplaatste annhangsels. die phrsiologisch de rol ran kieuwen rerrullen. Bij duizendtallen is het soms op de sawah's te rinden en daar de rupsjes de hlaren zoodanig aanreten, dat slechts de opperhuid van ééne zijgde als een wit glinsterend vliesje aanwezig blijft, kan hunne aanwezigheid reeds op een afstand worden geconstiteerd. Ook den inlanders is de "witte zielste" (satil poctih) welbeliend, evenals de omstandigheid, dat men deze geneest, door de sawah eenige dagen droog te leggen. Merkwaardig is de wijze; waarop deze rups zich door het water beweegt, wanneer zij van de ééne rijstplant nar de andere wil verhuizen. Zoodla zij te water is gegaan, brengt zij het grootste gedeelte ran haar lichaam buiten het huisje en begint dan daarmede krachtig heen en weer te slingeren, waardoor zij in een tamelijk snelle voortbeweging kount. Eenmaal rolgroeid, verpopt zij zich in haar woning; die rooraf aan het onderste gedeelte van ern rijstplant wordt vastgesponnen.

De rlindertjes, die in hooge mate door kunstlirht worden aangelokt, zijn des aronds in onze woningen de boden, die ons melden, dat liet gerwas kolt gelenten is uitgeplant. Zij worden weldra gerolgd door een andere Pyralide, die langer tijd roor hare ontwikkeling tot rlinder noodig heeft, namelijk Schoenobius bipunctiferatis (pag. 152), waar'van de rups zeer spoedig na hare greboorte in de rijstplant binmendringt en eerst. als rolwassen insect redel daaruit te rourschijn komt. Dit binnendringen heeft plaats in het bovenste gedeelte ran den stengel, dwars door de bladscheden heen, waarna een onregelmatige gang wordt geboord. rie 
in lnet benedenste gerleeite eindigt en zich aldaar verwijdt in een ruimte, warim de poptoestand wordt dool'gebracht. In de secundaire stengels kan zich een rolgende, of wel een latel optredencle generatie van hetzelfde insect ontwikkelen, wat ten gerolge heeft, dat de rlindertjes op en bij de sawah's te rinden zijn, zoolang nog groene rijstplanten daarop roorkomen. Ditzelfde geldt roor een derde soort van Lichtmot, Cnaphalocrocis jolinalis, die ook nooit op de rijstrelden ontbreekt, maar in har optreden veel bescheidener en daardoor voor de plant minder gevarrlijk is. Hare rupsjes toch relgenoegen zich ermede, het borenste gedeelte der bladeren op te rollen tot een kokertje, dat hun tot verhlijfplaats dient en vanwaar zij zich na:1 naburige gedeelten van het blad begeven om met het bladmoes hum honger te stillen. Ze zijn daarbij steeds zoo verstandig, het blad niet zóódanig adn te tasten, dat de top daardoor zou verdrogen of afrallen.

Dergelijke kokervormige rerblijfplatsen zijn bij rupsen in het algemeen nogal in trek en het rijstblad leent zich bij uitnemendheid tot het vervaardigen ervan. Zoo is er geen sawah, waarop niet een zekeren dikwijls zeer groot-aantal Hesperidenrupsen is te rinden, die, vermoedelijk in verband met hun lichaamsgewicht, niet de toppen, maar het meer benedenwaarts gelegen gedeelte der bladeren beronen en de randen daarran met witachtige draden aan elkander spinnen. Ook de kapelletjes zetten zich ga:rine op de rijstplanten neder on zich in de zon te koesteren; het zijn voolal Pamphila augias, Hesperia philino, H. mathias en $H$. conjuncta, minder algemeen ook Pamphila dara.

Geheel vrij op de paddiblaren leeft daarentegen de 
frad groene, gehoornde rups van Melanitis leda (pag. 131), die door luar kleur de bescherming van een kokertje wel kan missen en slechts in het oog ralt, wanneer men hail in den ruegen morgen tegen de zon in ziet, omdat hare lichaam dan een donkere vlek op het verlichte blad reloor"zakt. Even openlijk vertoonen zich verschillende Borstelrupsen, o.a. die van Dasychira securis, maar dit schijnt hum, onbeschermd en in 't oog vallend als ze zijn, dikwijls slecht te bekomen: want zij zijn het, warran men, meer dall bij andere rupsen het geval is, dikwijls de overblijfselen aantreft, geheel bedekt met de cocons van kleine sluipwespen van de familie der Microgastridae.

Naast rupsen treden op de rijstrelden vooral Wantsen op den voorgrond. Algemeen vindt men hier Nezara viridula, Antestia histrio, Agonoscelis nubila, Podops vermiculatus en verwante soorten, die zich bij roorkeur op de buitenzijden der bladscheden neerzetten om daar het zachte, saprijke weefscl aan te boren; in oeconomische beteekenis worden zij allen echter verre overtroflen door de walang sangit, Leptocorisa acuta, die de halfrijpe korrels leegzuigt en daardoor zwart of donkerbruin doet verkleuren. Dit dier is een ware landplaag geworden in bijna alle rijstrerbouwende streken van tropisch Azië, wat voor een deel mag. worden toegeschreven aan de omstandigheid, rat het zoo goed als geen natumlijke vijanden heeft. De stinkklieren, die ten getale van twee par op de rugzijde van het achterlijf uitmonden, rormen hier blijkbaar een zeer werkzaam beschermingsmiddel; want zelfs de gulzigste tjitjak keert teleurgesteld terug, wanneer hij een waiang sangit heeft herkend 
in een bewegend roorwerp, dat aanrankelijk als een welkome prooi werd begroet.

De Homoptera zijn hier, zooals trouwens bij een grasachtig cultuurgewas is te verwachten, door allerlei kleine vormen van de families der Fulgoridae en vooral der Jassidae vertegenwoordigd. Deze treden soms in zoo grooten getale op, clat zij een ziekte veroorzaken van tamelijk ernstigen aard, waarbij de eene bladschede róór, de andere na, door de talrijke, steeds zuigende diertjes wordt gedood, totclat ten slotte ook de stengel zelf dit lot onder. gaat. Vooral de geslachten Delphax, Nephotettix en Deltocephalus treden dan op den voorgrond. Intusschen is deze ziekte vooral merkwaardig door het feit, dat zij bijna zonder uitzondering en in clen regel zeer spoedig door de natuur zelve wordt genezen. Een van de meest algemeene der Javaansche Lieveheersbeestjes namelijk, Coccinella arcuata, is buitengewoon belust op de jonge, nog ongevleugelde vormen van deze kleine Rhynchoten en wanneer nu de laatste tot een bijzonder sterke ontwikkeling naar getalsterkte komen, neemt ook, te humnen koste, de zijne zulk een raart, dat het evenwicht spoedig weder is hersteld. Of liever, het is in andere richting verbroken; want op zeker oogenblik is er een overmaat van Coccinellidue en de larven daarvan, die men dan hongerig op de rijstplanten ziet rondloopen en daar deze kerertjes door hun heldere kleuren wèl, de kleine Rhynchoten daarentegen op een aangetast reld zoo goed als niet in het oog vallen, beschourven de Javanen vrij algemeen coccinella arcuata als de oorzaak van de ziekte.

De hier genoemde, sa wahbewonende insecten; war'- 
adn nog een amtal omniroren, zovals kleine sprinkhanen, krekeltjes enz, zouden kumnen worden toegervegd, lokken slechts in geringe mate insectenetende vogels aan, waalschijnlijk omdat deze on de rijstrehlen geen behumlijke zitplaats vinden en zich eltoe moeten bepalen, in aangrenzende kampongranden, op) schuttingen en telegraafdraden en in aileenstaande boomen of den loer te zitten en in hun onmiddellijke omgeving telkens een kleinen uitval te doen. Orerigens hehouren zij tot de reeds besproken rormen der cultuurfauna: slechts waar de sawah's grenzen aan wildernissen, zooals in het kustgebied niet zelden voorkomt, vallen wel eens bijzondere waarnemingen te doen. Als zoodanig beschouw ik bijroorbeeld het geval van Chalcococcyx malayunus, een kleine, fraaie koekoeksoort, die een verre ran alledaagsche verschijning is en waarvan mij cens een aantal exemplaren werden gebracht, door een der verzamelaars geschoten op een sawah in het noorden van Bantam in de nabijheid van kustboschjes. De magen van deze dieren bleken gevuld te zijn met verschillende sawah-insecten, maar vor verreweg het grootste gedeelte met de zooeren genoemde Coccinellu arcuata. De vogels hadden hier blijkbaar hun gewone terrein verlaten voor een strooptocht in een aangrenzend gebied, vermoedelijk verlokt rloor de eenzame ligging daarvan. Ongetwijfeld doen dergelijke gevallen zich meermalen voor, mar zij worden natuurlijk slechts zelden opgemerkt. In dit bijzondere geval wordt tevens aangetoond, hoe gevariëerd het voedsel der koekoeken is. Deze soort schijnt trouwens allerlei insecten voor lief te nemen: want in de maag van een, in de nabijheic? van Bataria geschoten exemplaar beronden 
zich een paar exemplaren van de rupsenetende Vuurwants Dindymus rubiginosus.

Van de hoogere diervormen, die de rijstplant als voedsel gebruiken, moeten in de eerste plaats de Veldratten worden genoemd, het meest algemeen door de soort Mus rattus (pag. 56) vertegenwoordigd. Reeds op de kweekbedden treden deze dieren op, waar het kiemende zaad roor hen een gezochte spij,s uitmaakt; zij knabbelen voorts aan de basis der jonge planten, doch zijn natuurlijk het meest in hun element, wanneer de aren tot rijpheid komen. Hunne werkzaamheid openbaart zich het eerst in het midden der velden, omdat ze daar veiliger zijn dan aan de randen, maar ook deze vallen hun niet zelden ten offer. Overdag ziet men ze weinig; zij houden zich dan bij voorkeur schuil in hunne holen, die zich in de dijkjes of onder aangrenzende wegen en droge velden bevinden. De dijkjes worden dikwijls zóó doorwoeld, dat zij geen stand houden en, tot meerdere schade van het gewas, het water wegrloeit. Slechts waaj bepaalde slangen in groot aantal voorkomen, wordt hun bestaan bemoeielijkt. Het meest rerdienstelijk maakt zich in dit opzicht ongetwijfeld Python reticulatus (jay. 81), in wiens darmkanaal men soms een geheele serie van ratten kan aantreffen, waarvan de voorste pas is ingeslikt, de achterste reeds voor een aanzienlijk gedeeite is verteerd. Ook Varanus salvator (pag. 80) treedt hier op als bondgenoot van den mensch, maar toch minder geregeld dan de slangen.

In de treede plaats een aantal kleine vogels van de familie der Ploceidae, die in rerband daar. 
mede met den algemeenen naam ran "Kijstdiefjes" worden angeduid. Ontmoetten wij ze roor een deel reeds in een ander gebied (pag $(; 7)$, hier zijn ze eerst recht op hun plaats. Het zijn de priet (Uroloncha lencogastroides), de peking (Munia nisoria), de glatik: ( $M$. oryzivora), de bondols ( $M$. maja en $M$. ferruginea). de bondol itam ( $M$. atricapilla), de bondol. idjoe (Erythrura prasina) en de priet benggala (Sporaeginthus amandava). Laatstgenoemde soort-de inlandsche naam wijst erop-schijnt in vroeger jaren uit Vuor-Indië op Java te zijn ingevoerd; zij komt nog maar plaatselijk in grooten getale voor, vermoedelijk omdat ze met de anderen een zwaren strijd om het bestaan heeft te voeren. De voorlaatste is in de laaglanden minder algemeen dan in de hoogere streken, zooals in verschillende deelen ran de Preanger Regentschappen. Van de anderen zijn rooral de vier eerstgenoemde soorten over geheel Java verspreid. Zij mogen zich voor een deel voeden met de zaden ran willekeurige grassoorten, het liefst begeren zij zich in grootere of kleinere troepen naar de sawah's, wanneer het gewas aldaar aan het rijpen is. Niet alleen rerdwijnt dan een aanzienlijke hoeveelheid der rijstkorrels in hun hongerige masen, maar door hun lichamsgewicht knakken zij bovendien de halmen of werpen ze die tegen den grond of in het water. Vandaar; dat de inlanders zich op allerlei wijzen van deze ongenoode gasten trachten te ontdoen. Des aronds rangen zij ze in werpnetten, als de rogeltjes zich in struikgerras of hoog; rietachtig gras hebhen ter ruste begeren: orerdag probeeren zij ze te rerjagen door over de sawal's lange touwen ran hamboe te sjannen, die in een klein wachthuisje samenkomen en dadr door kinderen in be- 
weging worden gebracht, zoodra een koppel dieren ergens neerstrijkt.

Eindelijk moeten hier worden genoemd de echte Wevervogels (manjar's) van de geslachten Ploceus en Ploceëlla. Ook deze leven voor een aanzienlijk deel ran rijst, maar zijn, wat hun nestbouw betreft, zulke typische bewoners der suikerrietvelden, dat ze beter dáár ter sprake komen.

Veel natuurlijke vijanden hebben deze verschillende Ploceidae niet; een zeker aantal mag ten prooi vallen aan kleine, roovende zoogdieren of aan roofrogels, sommige wellicht ook aan slangen, maar over het algemeen kumnen zij zich tamelijk ongestoord ontwikkelen. Slechts één hunner belagers moet voor dit gebied nog afzonderlijk worden genoemd, namelijk de Vogelspin Selenocosmia (Mygale), javanensis. Deze grootste der op Java voorkomende spinnensoorten, die door de sterke beharing van lichaam en pooten nog aanzienlijker van afmetingen lijkt, dan ze in werkelijkheid is, graaft haar holen in de dijkjes der rijstvelden en loert uit den ingang daarvan op de vogeltjes, die zich, geen kwaad vermoedend, in de nabijheid mochten wagen. Op het gunstige oogenblik, d.w.z., wanneer het vogeltje haar den rug toekeert, neent de spin haar kans waar. Gelukt het haar, zóó te springen, dat ze haar slachtoffer dadelijk met de pooten kan omvatten en derhalve het uitslaan der vleugels beletten, dan heeft ze haar doel bereikt. Want dan kan ze met kracht de zware voorkaken in den rug doen dringen en in, beide wonden het gift uitstorten, dat op de aangevallene een snelle, paralyseerende werking schijnt te hebben. 
Wij keeren thans terug tot de diervormen, die slechts in indirect rerband met de rijstjuant op de sawah's leren en welken het, zij het bij sommige ouk onder beschutting der planten, in hoofdzaak is te doen om liet water en de bewoners darran. Een geheele reeks ran rogels heeft hier de revue t.e passefren: zij behooren roor verreweg het grootste gedeelte tot de orde der Waadrogels, die hier natumlijk bijzondel gunstige condities vinden. Dit laatste betreft rooral de kleinere vormen, die zich bij naderend gevar tusschen de planten kumnen verbergen of door hun geringe afmetingen reeds zonder meer verborgen zijn: de grootere soorten rinden het hier niet rustig en reilig genoeg en ran deze kan men slechts Ardea (Phoyx) manillensis een enkele maal in dit gebied waarnemen. Daarbij komt nog, dat in de streken, waar de sawahbouw zijn grootste ontwikkeling heeft bereikt en nagenoeg alle terreinen in beslag neemt, geen ander geboomte roorkomt dan dat der dessa's, dat roor de meeste der hier broedende soorten geen nestplaats naar hun zin oplevert. Zooals wij vroeger (pag. 75) reeds zagen, nemen echter enkele soorten genoegen daamede, ja, nestelen zelfs in de boomen der grootere plạatsen, zoodat zij ook in het zoeken naar roedsel in 's menschen nabijheid allicht geen geraar zien. Dat dit geraar niettemin bestaat, geroelen rooral de Hercdias-soorten, op welke, ter wille van het gevederte en rooral van de egretten, in sommigestreken zóó reelvuldig wordt gejaagd, dat zij die langzamerhand vermijden en zich elders terugtrekken, waar men ze voorloopig met rrede laat. Het aantal op Java roorkomende soorten van dit geslacht bedraagt drie, nl. Herodias alba, H. garzetta (= Gazetta nigripes) 
en H. (Mesophoyx) intermedia, warvan de eerste de grootste, de tweede de kleinste is, terwijl zij orerigens en rooral buiten den paartijd in hun egaal wit vederkleed zooveel overeenkomst vertoonen, dat ze op eenigen afstand niet van elkaar zijn te onderscheiden. Overigens zijn zij op de rijstvelden niet zulk een vaste verschijning aIs Bubulcuscoromandus, die met een gelijken inlandschen naam (koendoel) wordt aangeduid, maar zich door een meer gedrongen gestalte van de Herodias-soorten onderscheidt en gedurende een vrij groot gedeelte van het jaar is te herkenmen aan de oranjebruine kleur op kop, nek, hals en rug.

De kleinere soorten van Reigers, die algemeen onder den naam blekok bekend staan, zijn hier het meest algemeen vertegenwoordigd door Ardeola speciosu, die in den paartijd inderdaad op zulk een soortnaam aanspraak kan maken, terwijl ran de kleinste soorten, als kokkokan aangeduid, de fraai bruine Ardetta cinnamomea het veelvuldigst wordt gezien. Intusschen is ook Ardetta sinensis in het geheel niet zeldzaam, maar het is uiterst moeilijk, zich van de talrijkheid van deze kleine reigersoorten eene voorstelling te maken, daar ze geheel tusschen de rijstplanten verdwijnen en slechts bij ernstig gevaar opvliegen. Ook van hun levenswijze zijn nog weinig bijzonderheden bekend, zooals dit trouwens bij de meeste der Javaansche. Waadrogels het geval is. Hun voedsel bestaat, zeer in het algemeen gesproken, uit de dieren, die zij in het water en in den modderigen bodem vinden, maar het schijnt wel, dat vele soorten aan een bepaald soort van voedsel de voorkeur geven, zonder daarom het andere geheel uit te sluiten. Jets dergelijks ligt 
tronwens roor de hand. dial bij zulk een dichte rogelherolking de onderlinge concurrentie anders te sinot zou worden.

T'erwijl de Ibidac en de Ciconidae door hun ainzienlijke afmetingen geen typische beroners ran dit gedeelte van het cultumigebied kumnen zijn, vinden de snippen, en wel nagenoeg uitsluitend Gallinago stenura (blèkek), hier in de maanden van hun verblijf op Java een waal dorado, althans roor zouverre zij geen slachtoffers worten ran de jacht, die op vrij groote schaal op hen wordt uitgeoefend, zoowel met schietgeweer als met netten. Deze gunstige omstandigheden blijken wel het best uit de toename ran hun lichaamsgewicht, aangaande hetwelk de volgende cijfers ter mijner beschikking staan *). Bij hun aankomst, in de maand October of iets later, wegen zij van 90 tot 120 gram: bij hun vertrek, omstreeks einde Maart, wegen de lichtste 120 , de zraarste 170 gram, een toename derhalve van gemiddeld to percent in een rijftal maanden. Het zou zel:y ran belang zijn te weten, hoeveel van deze toename weder verloren gaat op de terugreis naar de noordelijke landen, war zij broeden, maar het blijkt in allen gevalle, dat zij die reis onder uitnemende condities aanvangen en het is wel waarschijnlijk, dat er nog een voordeelig overschot zal zijn, om hen door den zorgrollen tijd ran het broeden en het grootbrengen der jongen heen te helpen.

Het schijnt, dat de Europeesche Watersnip, Gal-

*) Deze en meerdere gegevens heb ik te danken aan den Heer J. Ol.ivier. Oud-off. N. I. L. te Meester Cornelis, die mij een aantal zeer waardevolle ainteekeningen deed toekomen op mijn werken over de Zoogdieren en de Togels ran Java, met rergunning, daar. van bij latere publicaties gebruik te maken. wat thans met erkentelijklieid geschiedt. 
linago gallinago haar winterreis ook een enkele maal tot Java uitstrekt: als hooge uitzondering is zij een enkele maal tusschen de stemura-exemplaren aangetroffen.

Van de Ruiters, de Strandloopers, de Gruto's en de rerdere naaste rerwanten der Snippen komen verschillende, algemeen onder de namen tiril en trinil bekende soorten eveneens soms in grooten getale op de sawah's roor. Hoewel het eigenlijke terrein dezer vormen meer in de nabijheid der zee is gelegen, trekken zij niet zelden rer het binnenland in, gelijk omgekeerd de snippen in geenen deele aan de sawah's zijn gebonden, maar ook andere waterrijke terreinen voor lief nemen.

Ook de groep de Plevieren levert een hoogst algemeenen bewoner ran dit gebied, speciaal wat de laaglanden betreft, in Glareola orientalis, onder den inlandschen naam terè bekend. Deze wintergast wijkt echter door zijn gerorkten staart en zijn zeer lange vleugels nogal van het gewone type ran de Plevieren af en wordt naar de genoemde kenmerken en zijn daarmede verband houdende wijze van vliegen gewoonlijk met den welgekozen naam van Zwaluwplevier aangeduid. Ook begeeft hij zich zelden in het water, maar zoekt zijn roedsel op de drogere gedeelten en op de dijkjes, terwijl hij ereneens op afgeougst bouwland is te vinden.

Van de echte Plevieren moet voor dit gebied nog worden genoemd de troelek of lioewil, Charadrius fulvus, in de omstreken van Batavia als "dikkop" bekend. Vnor het overige zijn er nog tal van Waadrogels, die men wel eens op de sawah's kan aantreffen, maar die orer het algemeen toch meer thuis be- 
hooren in de waterrijke streken van het kustgebied en roorts cok in meer binnenwaarts gelegen en zelfs in hoogere streken, wamneer hodem en plantengroei hun daar slechts gunstig zijn. Verreweg de meeste ran deze zijn trekrogels, die den kouden winter ran het Noorden ontrluchten en roor wie het, wat de temperatuur van hun tijdelijk rerblijf aangaat, op een paar graden meer of minder ten slotte niet. aanko!nt.

In de streken, waal, in wisseling met den rijsthouw, op de sawah's vischteelt wordt gedreven en roorts op de pas geïnundeerde velden, waal zich raak kleine vischjes in het bevloeiingswater berinden, rinden verschillende soorten ran [Jsvogels een ruim bestaan. Het zijn vooral de kleinere soorten, die van het geslacht Alcerlo, die hier optreden en ran welke $A$. meninting, althans beneden 2000 roet, wel voor de meest algemeene mag worden gehouden. A. ispida, dezelfde soort, die in ons raderland wordt aalsgetroffen, wordt ook roor Jara opgegeven, maal werd nooit met zekerheid door mij aangetroffen; op eenigen afstand is ze bijna niet ran de vorige te onderscheiden. A. euryzona schijnt meel tot de hoogere streken beperkt te zijn en ook gaarne aan riviertjes te huizen; daarentegen is A. beryllina, hoerel rooral een kustrorm en gemakkelijk te herkennen aan de kleur, welke aan die van Halcyon chloris (pag. 6.5) herinnert, ook in dit gebied plaatselijk zeer algemeen. Ook de, cloor har kleur geheel van de Alcedo's afwijkende Ceyx innominata mag hier worden genoemd; ik nam dit rogeltje meermalen waal op sawah's beneden Buitenzorg, waar het zeer in het oog viel door de bruinroode kleur der boven- 
deelen, die, rooral wanneer zij door de zon worden beschenen, een zeer fraaien, lilakleurigen gloed rertoonen.

Wanneer het gewas zijn rijpheid nadert, het bevloeiingswater langzamerhand is weggeloopen en de velden een goudgele kleur beginnen aan te nemen. dan verdwijnt het grootste gedeelte van de bevolking, waarvan in de vorige bladzijden een kort overzicht werd gegeren. En wanneer, iets later, ook het oogsten is afgeloopen en de rerdroogde stoppels deels nog in onregelmatige plukjes overeind staan, deels door het branden zwartrerkoolde plekken vormen, dan herinnert bijna niets meer aan het intense leven en de veelzijdige bedrijvigheid van eenige maanden tevoren. Slechts enkele Rietzangers nemen dan het verlaten terrein in bezit en brengen nog een weinig levendigheid aan, door zich nu en dan al zingende in de lucht te verheffen en zwevend weder neer te strijken. Het is in de eerste plaats de grootste der Javaansche Sylviidae, Megalurus palustris (tjitjaliorek), die men alsclan, hoewel niet zeer algemeen, op de gewezen sawah kan aantreffen, zoekend naar de weinige sprinkhanen en krekeltjes, die nog van rroeger zijn overgebleven of door enkele spaarzame nieuwe uitlooper's der rijstplant zijn aangelokt. Talrijker zijn de zooveel kleinere Cisticola's, vooral C. cisticola, die zich met groote vlugheid tusschen de rerdroogde halmen beweegt en, in vereeniging met Prinia blythi, ereneens de laatste hand legt aan de zuivering van het terrien van de eenmaal zoo rijke insectenberolking.

En wanneer ten slotte een enkele Veldrat zich $n o g$ waagt in de thans onbeschutte omgering; ter 
wille van eenige weinige korrels, die, het nalezen niet waard, aan de halmen zijn overgebleven, dan trekt zij spoedig de aandacht van den slanken Elamus hypolencus, een Woụw, dien men door zijn klemren en zijn wijze ran rliegen roor een meeuw zou kunnen houden en die zoowel in dit. als in het thans te bespreken gebied, een niet zeldzame en bijzonder sierlijke verschijning is. 


\section{HOOFDSTUK XII.}

\section{De Fauna van het Bouwland.}

Voor wie Java van nabij kent, laat het zich hooren, dat dit gebied minder scherp is omlijnd, wat zijn fauna betreft, dan de terreinen, waarmede wij ons tot nu toe bezig hielden. In het bijzonder betreft dit de Gewervelde Dieren, die, in hooge mate over het vermogen om zich te verplaatsen beschikken, en dus geen vaste bewoners behoeven te zijn van een omgeving, die hun zoo weinig schuilplaatsen biedt als een stuk grond, dat, beplant met een éénof anderhalfjarig gewas, voortdurend verzorging en toezicht van de zijde van den landbouwer vereischt. Aan de andere zijde kan die omgeving roor hen zóóveel aanlokkends hebben, dat ze er gaarne tijdelijk vertoeven en er bijgevolg beter dan in hun eigenlijke woonplaats zijn waar te nemen. Veel hangt ook hier natuurlijk af van de aangrenzende terreinen; zijn deze geheel tot territorium van den mensch geworden, dan kan men er kwalijk andere hoogere dieren verwachten dan die van de cultuurfauna in engeren zin. Waar echter het bouwland grenst aan, of ligt in de nabijheid van bosschen en wildernissen, staat het bloot aan de invasies van wilde zwijnen, apen, herten en zelfs van wilde runderen en neushoorndieren, die zich aan het loof of aan de wcrtels der planten te goed doen. Tusschen deze twee uitersten ligt de zeer algemeene toestand, dat diersoorten als 
stekelvarkens, rasi's en loewatis hier roorkomen; kortom, ran de Zoogdieren kunnen rrijwel alle herbirore rolmen ran .Java elkander in dit gebied ont moeten.

In mindere mate geldt dit voor de Vogels, bij welke rooreerst de vegetariërs en de omnivoren het meer op zaden en rruchten, dan op andere plantendeelen hebben roorzien en, in de tweede plaats, de bosch en wildernis bewonende rormen zich maar zelden in het open veld wagen.

Dat roorts de aard van het rerboumde gewas van veel invloed is op de hoogere vormen der fauna, behoeft wel nauwelijks te worden gezegri. Zoo is bijroorbeeld Corvus enca, de gagak of engkak, dien men den Javaanschen dorpskiaai zou kunnen noemen, in tegenstelling met den gaok, Corvus macrorhynchus, dien wij reeds in de groote steden ontmoetten (pag. 75), een even onwelkome als algemeene gast op de relden, wanneer verschillende soorten van katjang, inzonderheid Arachis hypogaea (katjang tanah), Voandzeia subterranea (katjang bogor; en Glycine soja (katjang kedele) hun rijpheid naderen. Speciaal echter tijdens het oogsten ziet men ze soms bij geheele troepen, die met de grootste brutaliteit de werkende landlieden op den roet volgen, rich de maag vullen met hetgeen ze kunnen bemachtigen en tegen den arond met tragen vleugelslag hun dikwijls ver velwijderde rustplaatsen opzoeken. Zoo bezitten roorts de aanplantingen van gewassen met meelrijke wortels, als cassave (Manihot utilissima), of met voedzame knollen als oebi (Dioscorea-soorten) en, in de bergstreken, aardappelen. een bijzondere aantrekkingskracht voor de Wilde Zwijnen (Sus vittatus en Sus verrucosus), die er soms geducht kunnen huishouden. 
De losse grond en de beschutting der planten lokken verder verschillende vogelsoorten, die hun voedsel uitsluitend op den bodem zoeken, zooals Turnix pugnax (pag. 242) en het kleine Kwarteltje Exalfactoria lineata (pepiko), die hier overdag gaarne komen fourageeren, terwijl de randen der velden een geliefkoosde verblijfplaats zijn voor een aantal andere, die veel van een open terrein houden, maar toch gaarne een veilige retraite in hun nabijheid hebben. Een van de meest algemeene van laatstbedoelde is wel Pratincola caprata, een Vliegenvanger, die in West-Java algemeen bekend is onder den naam singsèwan, in Oost-Java onder dien van koetjita batoe en die geroegelijk kan doorgaan voor een kleine uitgave van den gewonen koetjita van Middenen Oost-Java, Copsychus amoenus, waaraan hij ook in zijn bewegingen doet denken. Deze Pratincola koint zoowel in de hoogere als in de lagere streken voor, maar ik zag haar nergens in zoo grooten getale als in het vlakke land bewesten Sidoardjo, waar elk bouwveld er eenige herbergde. Een andere vaste bewoner van deze terreinen, alsmede van de afgeoogste sawah's, is de Javaansche Leeuwerik, Mirafra javanica (brandjangan, manoek apoeng), die geheel de allures heeft van zijn welbekenden, Hollandschen verwant, maar minder fraai zingt. Minder algemeen zijn daarentegen de Pieper Anthus rufulus en de Timeliide Drymocataphus capistratus. Laatstgenoemde is een tamelijk schuwe vogel, die, evenals vele andere soorten der dusgenaamde "Miervogels", hoofdzakelijk op en nabij den grond leeft en zich, bij naderend gevaar, zóó hoog op de pooten kan oprichten, dat hij op een klein Steltloopertje gelijkt. In sommige streken staat hij onder den naam 
kantjilan bekend, wat rermorelelijk verband hoult, zoowel met zijn kleur, welke an die van een Dwerghertje (konljil) herinnert, als met de buitengewone snelheid, waarmede hij, evenals vele zijner verwanten, kin loopen.

Waal de omgeving ran het bouwland geschilite rust- en rerbliffplaatsen aanbiedt, wordt het ouk door verschillende Roofvogels als jachtterrein gebruikt. Behalre vele der reeds vroeger besproken soorten kunnen wij hier aantreffen Accipiter virgatus, een sperwer, die zich hoofdzakelijk met kleine rogeltjes voedt en gaarne in het open veld, hier en boven de rijpe rijstvelden jaagt: Astur soloensis, die een groote voorliefde heeft roor Sprinkhanen, waarvan voolal de maïsvelden en de riettuinen hem zulke welgedane exemplaren kunnnen opleveren: Falco papuanus, die meer in de hoogere streken thuis behoort, maar in den regentijd niet zelden afdaalt naar het laagland, waar hij spoedig de aandacht trekt van icder, die geen vreemdeling is in de vogelwereld, door de huitengewoon lange vleugels, die in de rust ver over den staart reiken en hem een bijzonder sierlijke en gemakkelijke vlucht geven, zelfs in die mate, dat het hem wel eens gelukt, vliegende Zivaluwen te bemachtigen.

Wat eindelijk de Sląngen betreft, moet roor dit gebied in het bijzonder worden genoend Ancistrodon rhodostoma, de gevaarlijke, hoogst giftige oelar lěma, die plaatselijk zeer algemeen kan optreden en een zekere roorliefcle roor cassare-aamplantingen schijnt te bezitten. Met de reeds rroeger besproken Naja tripudiuns. val. sputatrix mag deze Viperide, die met 
haar breeden, driehoekigen kop, het rrijkorte, dikke lichaam en den korten, snel versmalden staart een voorkomen heeft, dat in terugstootendheid geheel met de valsche, loerende oogen harmonieert, reilig worden beschouwd als de soort, die hier ten aanzien ran den mensch de meeste zonden op haar geweten heeft. De beet harer lange gifttanden, die in de rust achterwaarts onder een plooi van de mondslijmhuid liggen teruggeslagen, is in vele gevallen doodelijk. maar heeft roor het minst een lerenslange rerminking ran het gebeten lichaamsdeel, uiteraard veelal een been, ten gevolge. In tegenstelling met de meeste andere Slangen, neemt deze bij naderend gevaar niet de vlucht, maar neemt een rerdedigende houding ann, die, wanneer het geraar haar werkelijk ernstig roorkomt, zeer spoedig in een aanvallende beweging overgaat. Intusschen maakt ze, zoocia zij onraad bespeurt, een eigenardig geluid, dat relen inlanders wel bekend is en hun tot tijdige warschuwing dient.

Le insectenwereld heeft roor dit gebied, in zijn gelneel beschourd, in de eerste plaats een aantal vormen aall te wijzen, die hier steeds, en soms meer dan elder's, op den roorgrond treclen; in de tweede plaats een aantal andere, die min of meer karakteristiek erroor zijn.

Tot de eerste mag men rekenen een groote rerscheidenheid van Veldsprinkhanen, Sabelsprinkhanen en Krekels, die temirlden ran het veelal welig groeiende gewas een uitnemend verblijf vinden. Het meest trekken de Acridium-soorten (melunocorne, luteicorne, aeruginosum. roseum enz.) de aandacht, 
daar zij bij de narlering ran den mensch gewonnlijk oprliegen en door hun aanzienlijke afmetingen den indruk maken ran groene rogels. Ook le wijze, wallop ze, meestal reeds op korten afstanil, al zwerende neerstrijken, doet daaraan denken, maar het glinsteren der achtervleugels in den zonneschijn rerraadt weldra hun ware natuur. In aanmerking nemende het dikwijls rrij groote aantal dezer raatzuchtige dieren, verbaast men zich wel eens orer de betrekkelijk geringe schade, die ze aanrichten, evenals het wel eens berreemding wekt, dat in cen land, waar zooreel soorten ran Sprinkhamen roorkomen, eigenlijke sprinkhamenplagen, zooals uit rele andere streken bekend zijn, nooit zijn waargenomen. Het eenige geval, dat mij is bekend geworden en dat eenigszins aan zulk een plaag herinnerde, deed zich roor in 1s97, wial het was slechts een flauwe afschadnwing ran hetgeen andere werelddeelen soms te zien geren en kwam in hoofdzaak neer op een sterke rermeerdering, in bepadde gedeelten ran Midden-en Oost.Java, waarbij het eigenlijke trekken, dat juist ron de echt sprinkhanenplagen zoo karakteristiek is, slechts in zeer beperkte mate en over afstanden ran niet meer dan honderdtallen ran meters plaats had. De oolzaak ran dezen, voor Java zeer verblijdenden rrijdom der hedoelde plagen ligt rermoedelijk in de omstandigheid, dat el gedurencle het greheele jaar voor deze dieren roldonde roedsel is te vinden en er bijgevolg roor hen geen aanleiding bestaat, uit hun gewone doen te komen, in casu zich tot grnote; rondtrekkende troepen te vereenigen. Zulke vereenigingen toch. die in de insectentrereld en trouwens bij de dieren in het alsemeen verre ran zeldzaam zijn, schijnen rooral 
plaats te hebben op grond ran minder gunstige levensomstandigheden en raar nu de laatste reinig of niets te wenschen overlaten, blijven ze achterwege.

Tan de kleinere Teldsprinkhanen zijn de Attractomorpha-soorten (psittacina, crenulata e.a.) zeer talrijk en gemakkelijk herkenbaar aan den -kegelvormigen liop, terwijl rerder de geslachten Oxya, Epacromia, Trilophidia, Tryxalis en vele andere door een groote rerscheidenheid ran soorten zijn rertegen woordigd.

De Sabelsprinkhanen treden in aanzienlijk mindere mate op den roorgrond, daar deze over het alg'emeen meer bewoners van boomachtige gewassen zijn. Toch komt men hier wel eens Pseudophyllus-soorten tegen met fraaie, volkomen bladrormige voorvleugels, alsmede-en deze is rrij algemeen-Elimaea chloris, herkenbaar aan de nar boren gerichte legboor. Bij dikbladige gewassen ziet men niet zelden de eieren dezer dieren, netjes op een rij gelegd in een, in den bladrand gezaagde spleet. Cok het geslacht Mecopoda is hier door verschillende, grijsbruin gekleurde soorten rertegenvoordigd, waarvan $M$. elongata rel de meest algemeene is.

Tan de Krekels bemerkt men overdag weinig, daar zij zich alsdan schuil houden in den lossen bodem. Dat ze hiel echter in grooten getale aallwezig zijn, wordt bewezen door het gezang; dat ze-rooral in de arondschemering, róór het uitrliegen, doen hooren, alsmede door de sporen, die hun rraatzucht, rooral in jonge aanplantingen, achterlat. Het woord "gezang" is roor sommige soorten wel wat euphemistisch gekozen: soms is het een aanhoudend schril en scherp gefluit, terwijl het bij de Gryllotalpa-soorten, die hier bijzonder reelvuldig zijn en waarran rroeger (pag. 9S) reeds 
een rer kleinere werd genoemd, dikwijls in een suort ran onderandsch geloei dreigt te ontarden.

Naist Orthoptera herbergt dit genied in het algemeen reel Diptera, zonder dat deze aan een bepaald gewas de roorkeur schijnen te geren; het is blijkbar de zonnige omgeving; die hen aantrekt. Toor zooverre deze dieren niet leven ran roof, schịnen ze in den volwassen toestand met zeer weinig terreden te zijn. Een weinig water, afkomstig ran dauw of ran regell. een weinig detritus op de blaren is hun roldoende. Van hunne levensgeschiedenis weten wij, met uitzondering ran de Parasietrliegen, nog zeer weinig. Slechts ran sommige soorten ran de geslachten Daus en Bactrocera kennen wij de larven, die in vleezige, saprijke rruchten leven, naar deze fraaie, levendig met geel geteekende rliegjes zijn daarom toch niet talrijker op velden, waal bijr. tomaten worden relbourd, dan op andere, war voor hunne larven niets is te halen. Ouk talrijke andere dan de genvemde Trypetinae komen hier roor; soorten van Rioxa, Ptilona, Trypeta en andere geslachten, roor het meerencleel gekenmerkt door donkere, lichtgestippelde vleugels. die ze, onafhankelijk ran elkaar, ondel het loojen en soms ook tijdens het stilzitten, beurtelings op den l'ug leggen en zijwarts uitsteken, als gold het 't geren van signalen. Tan de rerwante familie der Ortalinue kan men hier vrij algemeen aantreffen Platystomu punctiplena, die zich roodanig houdt, o.a. door de uiteinden der grijsachtige vleugels orer het achterlijfsuiteinde naar beneden te buigen, dat men haal op het eerste gezicht houdt voor een kleine Curculionide.

Waar Bladluizen op de geteelde gewassen rourkomen, rertoonen zich de Surphiclae natururlijk in 
grosten getale. Sommige grootere vormen, zoorls Syiphus aegrotus, Helophilus pilipes en H. bengalensis zijn reeds in de rlucht te herkennen, wanneer zij zich in de lucht zwevende houden; andere algemeene soorten, zooals Megaspis errans, $M$. zonatus, Eristalis splendens, hebben een wildere vlucht, welke aan die der Calliphora's herinnert, terwijl Graptomyza longirotris l'ustig op de planten rondsluipt, zoekend naar een geschikte plaats voor haar nakomelingschap. De bloedzuigervormige larven kan men veelvuldig tusschen de luizen waalnemen; soms leven ze er geheel onbedekt, madr dikwijls plakken zij zich de leeggezogen huidjes op het licham, totdat ze geheel als in een dichten mantel zijn gehuld.

Een andere biologische groep vormen hier de Parasietrliegen, rool het meerendeel Tachinidae van de geslachten Exorista, Crossocosmia, Masicera, Taciina en vele andere. Zij zwerven, met de algemeene Nuscide Rlinia discolor, onrustig rond en weten zelfs rupsen te vinden, die zich in een opgerold bladstuk plegen te verschuilen. Ongeloofelijk is de snelheid, waarmede ze hun eieren deponeeren op de huid ran hun slachtoffer, steeds op een weeke plaats tusschen een par lichaamsgeledingen, vanwaar de lar'ven zich nad binnen boren en hum rernielingswerk begimnen, dat gewoonlijk in weinige dagen wordt voltooid. In den aanvang schijnen de parasieten zich uitsluitend te voenten met de reservestoffien, die de lups roor had poptoestand op zijde legt en de adngevallene ondervindt dan naturlijk weinig hinder ervan. Later gaat het ten koste van haar functionneerende organen, madr ook dan is het verwonderlijk, hoe weinig de rups uitwendig te zien geeft, welk een vernielingsproces in haar binnenste plaats 
heeft. Zoo kreekte ik eens een l'uls ran Anticyicu combusta, die tamelijk algemeen op' suikerriet en mais voorkomt, zonder dat ik wist of kon bemerken, dat zij door parasietvliegen was geïnfecteerco op zekelen morgen riel ze even gretig als gewoonlijk aan op het versche roedsel, dat haar werd gegeven, maar een par ur later was ran haar niet meer orer dan een zeer dun huidje, terwijl een twaalftal Tachinidenlarren in het kweekkastje bezig waren, een geschikte gelegenheid te zoeken om zich te verpoppen.

Aan Roofvliegen (Asilidae) is dit gebied niet zeer rijk, waarschijnlijk omdat de concurentie met de Libellen hum te zwaar ralt. Slechts de zeer algemeene cultuurvorm Asilus melanurus vliegt ook hier rond, terwijl ran verwante groepen hier nog mogen worden genoemd de, aan har kleur gemakkelijk kenbare Leptis (Chrysospila) ferruginea en rooral een aantal fraaie, goudgroen glanzende Psilopus-soorten, die, nadr het mij roorkomt, aan de aanplintingen van suikerriet boven elke andere omgering de roorkeur geven, zonder dat het duidelijk is, waaraan die roorkeur is te danken.

Tan de Vlinders zijn in dit grebied rerreweg liet best rertegenwoordigd de Noctuidac, meer in liet bijzonder de Trifinae. Dit laat zich trourens houren : want over de geheele wereld is het bourbland de geliefliooscle verhlijfplaats ran alsat tot de biologische groep der Aardrupsen behoort en zou meu werdas weinig van deze ditren ziet, het nachtelijk duistel loet ze in grooten getale boven den grond verschijntru. Als omnirore rormen mogen hier worklen genoemd talrijke soorten van de geslichten Agrotis, Leucania, 
Hadena, Nonagria e.a., terwịl Prodenia littoralis zich meer in de richting der tabaksplanten heeft gespecialiseerd, waarin zij-gelijk op Deli het geval is gewrorden - ongetwijfeld zou zijn gevolgd door Heliothis armigera, wanneer deze laatste het hier op Java niet nog behagelijker rond op de maisvelden, waar jonge stengeldeelen en het malsche weefsel van rijpende kolven haar alles bieden wat ze begeert, namelijk rijkelijk voedsel en roldoende weefsel om zich, zooals haar geliefkoosrle gerwoonte is, halverwege daarin te boren.

Karakteristiek roor dit gebied is de rijkdom aan Graafivespen van de groep der Sphegidae, roor zooverre het betreft de vormen, die in den grond nestelen. Ook dit ligt intusschen in den ard der zaak: de veelvuldig omgewerkte bodem heeft hier langzamerhand een structuur gekregen, die hem gemakkelijk toegankelijk maakt voor dieren, welker lichaamsbouw niet door bijzondere vormingen dicteert, dat hij op graven is ingericht.

De krachtigste en grootste der hier bedoelde Graafwespen zijn Sphex argentatus en $S$ curulentus. Men ziet deze zenuwachtige dieren steeds in groote bedrijvigheid; nu eens vliegen ze onrustig van de eene plek naar de andere, dan weder leggen ze een korten afstand te voet af, telkens even ophoudend on met verwoeden ijvel aan het graven te galan, zoodat, bij drogen grond, kleine stofwolkjes ervan opvliegen. Het is alsof 's werelds welzijn afhangt van het resultaat, dat toch bijna altijd nihil is, want na eenige seconden gaan ze weer rerder. Fomen ze een kleine opening in den bodem tegen, dan verdwijnen ze onmiddellijk daarin, in de hoop, 
aim het nitcinde el'viln een krekel of dergelijk insect. te vinden. Is dit inclerdiald het geval, dan heeft in het dnistel ren rerwoed gevecht pliats, dat gewoonlijk daarmede eimligt: lat de a angevallene van de (traafwesp een steek ontrangt, die hem roor zijn veriere levensdagen het bewustzijn ontrieemt. In de onmidellijke nabijheid ran den rerslagene wordt dan een ei gedeponeerd, zoodat de uitkomende larve dalelijk kan beginnen aan het wildbraad, dat roor harl' geheele jeugd moet dienen. Het schijnt namelijk, dat in dergelijke gevallen de sphex geen rigen nest graaft, wat trouwens ork geheel overbodig zou zijn; maal wanneer zij boven den grond met goed gerolg een prooi, steeds een Grylide, overvalt; dan is het noodzakelijk, deze op te hergen. Zij gaat dan met meer rolharding dau daar straks ath het graren, tenzij ze zoo gelukkig is, in to mabijheid een opening ran roldoende diepte te rinden, warin ze har slichtufter kim binnensleepen. Dit laatste gaat dikwijls met groote bezwiren gepaard, want de Krekel is soms twee of driemaal zoo groot als zij zalve en het is merkwandig om garle te slaan, tot welke, naal rerhouding enorme klachtsinspanning het rlugge en sierlijke dier in stalt is.

(reheel hetzelfile geven de verwante geslichten Tachytes. Larra en Liris te zien, waarran de soorten Larr, maura en Liris anrata de meest algemeene zijn, doch door hun kleinere afmetingen vallen deze, die ereneens op Gryllidue jagen, minder in het oog. Het geslacht Cerceris daarentegen, dat in roorkumen meer aan de reeds vroeger (pag. 170) hesproken Icaria's herinnert, jaagt op Eladkerertjes, warran vele culturrolmen ook in dit gebied algemeen rimliomen. 
Waar een gewas bloemen draagt, komen natuurlijk de Anthophila in grooten getale erop af. Het aantal der soorten is echter vrij gering: Apis indica en, in, meer afgelegen en houtrijke streken, Apis dorsata, verder Anthophora zonata, Nomia strigata en plaatselijk de kleine, maar fraai geteekende Ceratina hieroglyphica zijn wel de meest gewone verschijningen, waaraan, als parasietische vorm bij de Anthophora's, kan worden toegevoegd Crocisa emarginatu, die dadelijk opvalt door de afwijkende (zilverachtig blauwe) kleur der teekeningen op het overigens zwarte lichaam.

De overige insecten van het bouwland staan voor een zóó aanzienlijk deel in nauw verband met het geteelde gewas, dat zij heter aan de hand dáálvan worclen besproken, rvaarbij eerst de voornaamste der zoogenaamde tweede gewassen zullen worden behandeld.

KATJANG-SOORTEN.

De groote relschuidenheid ran Leguminosen, die onder bovenstaanilen naam algemeen worden aangeplant en waarvan de roornaamste zijn k. kedeleh (Soja hispidu of Glycine soja), k. tjina of k. tanah (Arachis hypoyaea), k. Bogor (Tounizeia subterranea), k. pandjang (Vigna sinensis of $T$. cutjang), k. idjo (Pliastolus radiatus of $P h$. mungo) en k. kolo of kratok (Phaseolus lunatus), heeft een tamelijk uniforme insectenberolking; die, wat Lepidoptera betreft, hoofdzakelijk uit Arctiidae en Lymantriidae bestaat. De harige Beerrupsen van Creulonotus interruptus en $C$. lactineus, Phissama transiens, Spilosoma maculifascia en S. strigatulum zijn hier schering en inslag; evenals 
de Borstelrupsen ran Dasychiramendosa en I). horsfieldi, Laeliu suffuse, Lymantrice-soorten, Euproct is bimaculnta, $E$. digromma en E. virgunculu, die, hoewel alle ran tamelijk polyrore natum; het malsche blad der Leguminosen blijkbaar gaarne eten. Ook Hypsa complana en H. alciphron, Argina cribraria en A. argus komen hier reel roor.

Meer karakteristiek rool de katjangrelden zijn eenige sourten van tamelijk groote Langwantsen (Lygaerdae), warran Anoplocnemis (Mictis) grossipes de reelvuldigste is, die plaatselijk wordt vervangen of vergezeld door Mictis fulvicornis, Physomerus culcar, Ph. parvulus en vermoedelijk nog wel meerdere soorten van deze groep van dof-lederachtige, donker grijsbruine insecten. Zij hebben alle in hooge mate de eigenschap, bij aanraking of andere stoornis de welbekende, ranzige wantsenlucht te rerspteiden, terwijl de larren, zoodıa zij zich bedreigd achten, zich verdedigen door de vloeistof, die deze lucht ran zich geeft, met kracht te spuiten uit eene parige opening, die zich nabij het achtereinde van het abdomen hevindt. Dit is ongetwijfeld een werkzaam rerdedigingsmindel tegen insectirore rijanden, rooral, omdat zij met de toepassing erran zeer vlug zijn en daarom is het wel verwonderlijk, dat de rolwassen dieren niet erorer beschikien, aangezien bij hen de bedoelde opening door de vleugels is bardekt. IIon ziet het trourvens in de insectenwereld dikwijls, dat de larren heter beschut zijn dan de volwassen rlieren, een verschijnsel, dat op het eerste gezicht een ietwat zonderlingen indruk makt. Immers, zoo is men geneigd te rragen, waarom wordt zooveel zorg besteed aan het groot brengen, terwijl de dieren, eenmaal volwassen, in veel mindere mate bescherming genieten? T'ot antwoord op deze rraag 
zou men op twee zaken kunnen wijzen. primo, dat de bestaanszekeiheid eener diersoort grooter wordt. naarmate meer indiriduen den rolwassen toestand bereiken: randaar de bescherming. Secundo, dat. duor de tal. rijkheid der nakomelingschap (eieren), een betrekkelijk gering adntal rolwassen individuen ruim roldoende is om het roortbestaan der soort te waarborgen: daarom is in dien toestand de bescherming minder noodzakelijk.

Behalre deze Langwantsen rindt men in de katjangaanplantingen algemeen kleine, glimmend zrarte schildwantsen ran het geslacht Biachyplatys ran de familie der Scutelleridar, bij rvelke het schild nagenoeg het geheele achterlijf bedekt en derharre een weinig moet worden opgelicht, wanneer de dieren hun rlengels roor het gebruik, voor den dag moeten halen". Deze uitulukking klinkt wellicht rreemd, maar dat de dieren deze beweging, evenals het weder op. bergen, als een bezigheid ran eenige beteekenis beschouren, zou men zoo opmaken uit de omstandigheid, dat zij. zoodra ze hij stoornis uit hun géwoonlijk rrij indolenten toestand ontwaken, beginnen met zich te laten rallen, instede ran weg te rliegen, of, na éénmaal de rleugels te hebben gebruikt, ze roorloopig naist het lichaam laten hangen om dezelfde reden, waarom een ruiter zijn jarid niet afzadelt, wanneer hij het rooruitzicht heeft, orer een krartiertje zijn rit te moeten rerrolgen.

Zijn ook deze wantsen door stinkklieren beschermd. een andere berroner ran dit gebied reet zich or, geheel andere rijze tegen rerrolging te rrijwaren. ook wederom alléén in den larralen toestand. De bedoelde is Aspidomorliha mitituris. een zeer in het oog rallende Gaside. zoomel door den ronden rorm, 


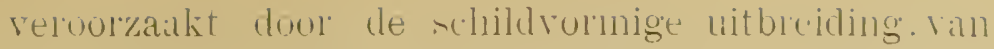
pronotum en elytra. als duol hada heldere klemen en teekeningen. De lichaamsvolm del larven vall dit kerertje beantwoordt am dien der Chrysumeliden in het algemeen, maar langs den geheelen lichaamsrand bevindt zich een nitstaande klans van harde, puntige uitsteckiels. dir on humne beurt dorens dragens. Tu zou men zoo zeggen. dat deze berrapening al bescherming genoeg rerleende: honderde soorten ran Blarkererlarren. die open en bluot op blaren leven. moeten het doen zondel deze en komen el wok. Tiettemin berindt zich bij de Aspidmmoiphu-larve boven de anale opening nog een livit, stomp nitsteeksel, dat roor-en achterwalts kan worden bewogen en aan dit uitsteeksel nu worden rastgeplakt niet alleen de huidjes, die hij de rerschillende rervellingen worden afgeworpen. maar ook de uitwerpselen, die dadalan ten slotte zrarte. hij rergrooting gezien. shoerrormige haren rormen. Het aldu- gevormale geheel doet zioh rums als een slurdige pluim en deze wordt nu. dour het bedoelde uitsterksel naar roren te richten. gebruikt om het lichaam te bedekken en aan het oug ran een mogelijken rerrolger te onttrektien.

Wij noemden hier de soort At militaris. omdat deze de meest algemeene is in dit gebied: men kan el intusschen ook Aspidumorpha amabitis en A. assimilis aantreffen. met geheel orereenkonstige larren, en zelfs soorten ran het relwante geslacht Coptocycla, maal deze laatste zijn nog slechts gedeeltelijk tot le cultumfiauna orergegan. Wij zullen ze liter in een meel oorspronkelijke omgering atantreff'rn. 
VAIS.

De maisvelflen, die tijdens het latere gedeelte van de rijpingsperiode der vruchten een tamelijk dor en onbervoond aanzien hebben, zijn rooral tijdens den bloei van het gewas een concentratiepunt van zeer rijk insectenleven. Op de blaren kumnen wij de Hesperiden-rupsen teruginden, die we reeds bij de rijst ontmoetten en die zich hier met een stukje omgeslagen bladrand als woning moeten vergenoegen. Bovendien treffen wij hier dikwijls aan de fraaie rupsen van Dreata petola, die, wanneer zij nogiong zijn, in troepjes bijeen aan de onderzijde der blaren zitten, terwijl zij zich op lateren leeftijd verspreiden. Oprallend is het verschil tusschen de jonge en de volgroeide rupsen van dezen Spinner. De eerste zijn in hoofdzaak geelgroen en vertoonen smalle, zwarte ringen, die op den rug breeder zijı dan op zijde. Met elke vervelling wordt echter de harige, 'zwarte ringstreep breeder, maar tevens korter en er volmen zich smalle, nieuwe strepen tusschen de oude. Wanneer eindelijk de rups har laatste vervelling heeft volbracht, zijn de vroegere ringen samengetrokken tot breede, dichtbehaarde dwarsstrepen op den rug; smal omzoomd door geelgroene lijnen. De tallijke, zwarte haren worden later door de rups gebruikt om el de cocon ran te rervaaldigen, die er als een vormlooze, verkoolde massa uitziet.

Ook verschillende Wantsen komen hiel vrij constant voor. Naast de Gramineeën-bewonende Nezara viridula en $N$. griseipennis kan men hier soms in grooten getale aantreffen de kleine, bruinzwarte, fraai met geel geteekende Antestia histrio en vool's $M e$ - 
garhynchus truncatus, een Pentatomide. lie dour haar slanken bour etnigsains een overgang tot de Lygaeiden vormt. Een andere soort ran hetzelfule geslacht, M. rostratus, is wok wel eens in dit gebied te rinden, maar zij is nog geen raste berwoonster ervall en houdt zich liever op in de grassen langs de bosch. randen.

De genoemde insectenvormen worden in talrijkheid vaak verre overtroffen door een kleine, glinsterend bruinzwarte Coccinellide, Verania afflicta, kenbaar aan cen klein, helder geelbruin plekje an beide landen van het pronotum. Deze diertjes zijn rooral te vinden op de mannelijke bloempluimen: zij loopen daar ijverig heen en weer, vliegen even op, wanneer men ze stoort, maar zetten zich dadelijk weder op een naburige !lads neer. Blijkbar roeden zij zich met het zachte weefsel der helmdraden, die ze eerst doorknabbelen, zoodat de helmknop komt te rallen. en daarna gedeeltelijk opeten. Tandaar dat de blaren nabij hum basis met de afgebeten helmknoljessoms als bestrooid rijn.

\section{Katoen.}

Bij de bespreking rer insecten, die op de warve (Hibiscus tiliacus) zijn te rinden (jag: 212), werd er reeds op gerrezen, hoe sommige rormen een bepaalde roorliefde aan den dag leggen rool planten ran de familie der Malvacene, die zich in het algemeen toch niet door bijzondere bestanddeelen onderscheiden. Het sterkst rindt men die roorkur guprononceerd bij enkele Wantsen. Waarran toen de twee meest algemeent rormen werden genvemd. De ééne daarran, de scutelleride Tectucoris cyanipes, 
die in den volwassen toestand op de geheele horenzijcle geelbruin is, bezit larven, dit door has helderroode en goudgroene kleuren almede tot die fraaiste insecten behooren en de gewoonte hebben, tijdens hare jeugd in dichte kringen rondom de jonge takken te zitten. Dit is hun blijkbaar bijgebleven ran de omstandigheden, waronder zij het levenshicht hebben aanschouwd, want ook de eieren rormen dergelijke ringen. Voor de planten is deze grewoonte ruïneus, daar de tak afsterft boven de plaats, waar zooreel honderde kleine zuigsnuiten in het bastweefsel zijn doorgedrongen.

Orerigens schijnt het, dat de larvale kleuren ook velen volwassen exemplaren na de laatste rervelling nog bijblijren, soms gedurende vrij langen tijd, zoodat zij alsdan den rerzamelaar nog in dien toestand in handen komen.

De tweede de genoemde Wantsen, de Pyrrhocoride Dysdercus cingulatus (königii), is nog reel algemeener dan de rorige, matar leeft, ook in jeugdigen toestand, meer verspreid en parsgewijze, waarbij zij zich giarne ophoudt in de nabijheid der rijpende vruchten en zich roedt met de sappen van den vruchtwand. Zij heeft een opperrlakkige. mar toch zeer bedriegelijke gelijkenis met een andere Turrwants, namelijk Dindymus rubiginosus, hier op Java vonral door de variëteit hypogastrica vertegenwoordigd. In levenswijze wijken beide vormen echter zeer van elkander af, want deze Dindymus leeft ran roof op andere insecten, voornamelijk rupsen, welken ze haar krachtigen zuigsnuit in den rug steekt, om ze daarna in triomf weg te dragen en op een rustig plekje te verorberen.

op rle katoenplant komen ruorts een groot aantal 
soorten ran Blankevertjes rour, die "reneens vroegrer. reeds werden remeld en welks oprleden op gelijlie wijze de aandacht trekt, als bij de waroe het geval was. 'Trots liet oprallende daarran, doen zij in den grond der zaak toch minder kwaal dan een parr rupsen, waarvan de ééne, Heliothis armigera, reeds bij cle algemeene beschrijving ran dit gebied ter sprake kwanr. Zoo wij hier deze soort nogmatals noemen, dan is het om erop te wijzen, hoe zij, die op) Deli roolat de tabak aintast en op Jara aan mais de roorkelir geeft boven tabak un katoen, in Amerika en elders (zij is rrijwel cosmopoliet) haar liefde speciaal bij de katoenplant heeft geplaatst en de jonge rruchten op de bij hiar gebruikelijke wijze relnielt. Wel een bewijs, dat dezelfde diersoort volstrekt niet oreral hetzelfde hehoeft te doen, maar "sich in biologisch opzicht kan differentiëeren, ook zonder diat daartoe een uitwendige noodzakelijkheid bestaat, daal zoowel op Java als in Amerika alle drie plantensoorten naast elkaal worden rerbouwd. De specialiseering op Deli kan men desnoods nog toeschrijven aan de kun:-tmatige alleenheerschappij, die men aldaur orer anzienlijke uitgestrektheden aan de tabaksplant heeft gegeven.

Is dus Heliothis armigera op de katoenvelden ran Jara niet meel dan een , occasional", een tamelijk vaste bervinel is de rups ran Earias fabia, een rlindertje, dat rroeger tot de Noctuidae werd gerekend, maar later naar de familie der Arotiidae is verhuisd. Als men zijn naturlijke rerwantschaj alleen naar de levenswijze der rups zou willen heoordeelen, was men vroeger dichter hij de waalheid dan thans: de laatste toch heeft ongereer dezelfde wijze van optreden als die van Holiothis armigera en boort in re zichte, 
groene weefsels ran stengeltollen en jonge vruchtel, madr verandert minder dikwijls ran woonplaat. Het schijnt wel. dat de nitbreiding van dit insect, dat in rroeger jaren ol, Jara nooit ran zich heeft doel? spreken, hier met die der katoencultum gelijker tred heeft gehouden en dat deze diersoort derhalre gedurende liet laatste tiental jaren onder anzienlijh verbeterde omstandigherlen is gekomen.

\section{SULAIATEAE.}

Van deze familie worden hier algemeen rerhouwd verschillende rariëteiten van terong (solamm melongena): tjabeh (spadnsche Pejel. Copsicum anmunmi) en tomaat (Lycopersirum esculentum), waaraan, rool rele bergstreken, kan worden tuegeroegd de aaritalluel (Srolunmm tuberosum), terivijl ook de tabak (Nicotianu trbacum) tot dezelfide familie lehoolt: maar: wegens. de platselijk groute uitgebreidheid harer cultur. afzonderlijk zal rom ben besproken. temeer; dar bij haar niet de dierrormm roorkomen, die roor de viel eerstgememde plantensoorten typisch zijn.

Wet dit laatste hobhen wij rooral het oog op het foccinelliden-geslacht Epilachna, dat geheel den gewomen habitus der Liereheersheestjes heeft, daarom door velen rool carniroor wordt gehouden, madr in werkelijkheid slecht plantenetende rormen omrat. die het op lara ruoral ol de genoemde Solaneeün, in aanzienlijk. mindere mate of eenige Komkommerachtige gewassen (Cururbitaceae) hebben vonzien. Tall het genoemde geslacht. lat door het nogal doffe roorkomen der bovendeelen ran de carnivore, rouri. bunine Liereheersheestjes is te onderscheiden, komen? hier algemeen ile sorten trrita. pytho en pusillanima 
vol, die hoofizakelijk velshillen in het aathal en le platsing der zwarte vlekjes op de dekschilden. Daral echter deze velijes dikwijls niet aanwezig zijn in het aantal, dat roor de soort als normad wordt opgegeren, op het ééne dekschild raak tallijker zijn dan op het andere en eindelijk een bedenkelijke neiging rertoonen om met elkander tot grootere pleklien samen te rloeien, is het dikwijls uiterst moeilijk na te gaan, met welke soort men heeft te (loen. ()ok de larven en de langwerpige eieren, die in hoopjes op de blaren worden gelegd en wel in de houding, wadran Couumbs een groot deel ran zijn roem heeft te danken, vertoonen bij de verschillende soorten een groote, onderlinge gelijkenis. De eerste zijn langwerpig, geelgroen ran kleur en ran talrijke, gestekelde, in overlangsche rijen geplaatste dorens roorzien, zoodit ze eenige gelijkenis rertconen, madr dan zeer in het klein, met de geraarlijke Slakrupsen van bijr. het genus Parasa

ln de tweerle plaats is in deze Solaneeën-aanplantingen, maar bij de terong in aanzienlijk meeriere mate dan bij do andere, algemeen het genus Coptosoma ran de familie der Scutelleridae aanwezig en het veelrulidigt rertegen wondigd door de soort cribrarium. Het is merkwaldig dat deze diertjes, waarran de huofilkleur licht groenachtig bruin is, erin geslaagd ziju, als rij vaste wvomplaats een plintensoort in beslag te nemen, die, zonals de terong, op lle plaats, waar ze zich ineestal bevinden, d.w.\%. op de onflerzijde der blaren, een achtergrond kan aanhieden, waaltegen ze hijna niet zijn te onderscheiden. Vandiall dan ouk, naar alle waarschijnlijkheid, de roorliefde voor (leze solanee buren de andere, waalop ze naturlijk in minder reilige condities rerkeeren. 
De overige "tweede gewassen" leveren weinig stof roor een afzonderlijke bespreking. De soorten, die worden aangekweekt ter wille van volumineuze, meelrijke onderaardsche deelen, zooals cassave (Manihot utilissima), bataten (Convolvulus batatas), oebie Dioscorea-soorten) e.a. geven daarin soms talrijke kolonies te zien van Cylas formicarius, welke levendig gekleurde Snuitkever in gedaante nadert tot de Brenthidae en in alle stadiën van ontwikkeling in zulke knollen en wortels is te vinden. Op djarak (Ricinus communis) vindt men verder niet zelden de harige rupsen van Trabala vishnu (pag. 145) en de kale, maar fraai gekleurde rupsen van Ophiusa melicerte, die, evenals die van Ophiusa serva, waaraan ze ten nauwste ver. want zijn, gaarne melksaphoudende blaren schijnen te eten; beide soorten treden althans nu en dan ook in zeer grooten getale op in de Palaquium-aanplantingen te Tjipetir. 


\title{
HOOFDSTUK XIII.
}

\section{De Fauna van het Bouwland.}

\author{
(Verrolg).
}

TABAK.

De uitgestrektheid gronds, die op Java jaarlijks met tabak wordt beplant, is zóó aanzienlijk, dat het in geenen deele is te rerwonderen, dat zich in de insectenwereld allengs eenige rormen hebben afgezonderd, die wel niet uitsluitend, maar toch rerreweg het meest in die aanplantingen worden gevonden. Waar zij zich staande houden gedurende de perioden, waarin geen tabak te velde staat, is een, nog niet roor alle opgehelderde zaak. Speciaal betreft dit een lileine 'l'ineide, Lita solanella (tabacella), die in den larralen toestand bij de tabak hoogst eigenaardige verminkingen veroorzaakt, waarvan de meest in het oog rallende aanleiding heeft gegeren tot den naam "omo mĕteng", in het Hollandsch gewoonlijk door "dikbuikziekte" weergegeven. Het optreden dezer larve verloopt namelijk, in zijn eenvoudigsten vorm, op de rolgende wijze. De rrouwelijke vlinder legt een ei tegen een van de jongere bladeren en wel in de rorkrormige rertakking van een der zijnerven. Zij beschadigt daarbij het weefsel en doet daardoor een prikkel ontstaan, die oorzaak is, dat het gedeelte ran het blad, dat ran de beschadig- 
de nerf en de verdere vertakkingen daarvan zijn voedsel ontvangt, niet op de normale wijze uitgroeit. De bladoppervlakte wordt op die plaats ongelijk en de bladrand vertoont na korten tijd een inham, waaraan de aanwezigheid van het rupsje kan worden herkend. Dit laatste baant zich een weg in het sappige. buiten den raatbundel gelegen weefsel ra!n de bladnerf en boort daarin in de richting ran de hoofdnerf verder, een uiterst klein, maar tuch zeer duidelijk en soms reeds van buiten waarneembar kanaaltje nalatend. Tan de hoofdnerf komt de rups in den bladsteel en vandaar in den top ran den stengel. Hier aangekomen, begint zij meer om zich heen te vreten. malakt een tamelijk groote, meer of minder in gangen rertakte holte en doet op die plaats de buikachtige opzwelling ran den stengel ontstaan, waarnaar de gevolgen van haar optreden worden genoemd. Na korten tijd is de rups rolwassen; zij rreet alsdan eene opening naar buiten, maar laat de opperhuid van den stengel aanwezig. Daardour ontstaat een rond, zeer doorschijnend plekje, dat later moet dienen om het uitkomende vlindertje een gemakkelijken uitweg naar buiten te rerleenen. Hoewel hetzelfde insect elders ook is wargenomen in de knollen van aardappelplanten, kunnen deze haar hier te lande kwalijk een verblijfplaats aanbieden gedurende de maanden, warin geen tabak is te vinden, aangezien de terreinen. waarop beide plantensoorten worden verbouwd, daartoe te ver van elkander liggen. Vermuedelijk leidt dus deze Lita, in een betrekkelijk gering aantal exemplaren, tijdelijk een rerborgen bestaan in een geheel andere plantensuort, daal het rrij onaannemelijk is, dat zij gedurende zón langen tijd in den toestand ran ei of 


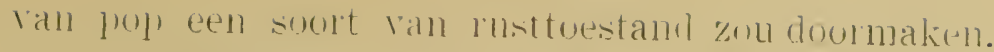
\%ulke toxitandem toch komen in de tropen reme van algenteen rool en worden ook dall nog veelal door huitengersons omstandigherlen, zooals groote dloogte (rgl. lag. .27) reroorzaakt. In het nornale gatat. ol' lava althans, het insectenlerencontinu ran gestacht tot geslacht doul: de erine grenelatie moge. door lle eenigrzins rerschillende omstandigheden, vool haal lerenscrelus wat mex of wat minder tijd in beslag memen dan de andere. groote perioden van stilstand. als in de gematigde luchtstreken, zijn hiel slechts hij nitzondering war to nemen.

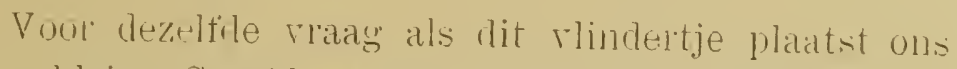
een kleine Capside ran het geslacht Leptotennu die zelden op de tabaksielilen onthlest en soms in ontelbair aantal ol) de plinten is te rinclen. in hot bijzoniler up de bovenste gerleelter daaran. Waal het insect ziroh met groote rlugheid ovel de klerelig.

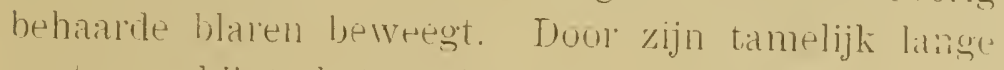

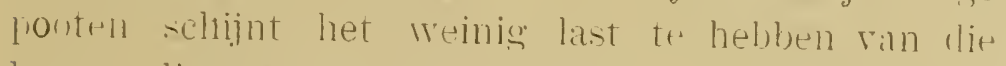

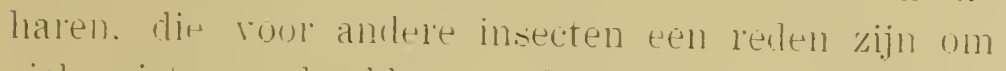
zicls niet op de blalen taltbans op de hovenste. sterkst beluadrde) en de howgere stongeldeelen vall

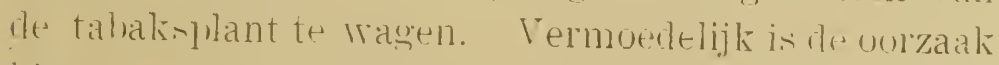
hieran, rat het knoprormiges sterk oliehoudencte miteinde lan de laden rij annaking aftbreekt en dat

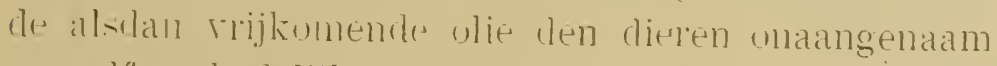
tll \%elfs sclladtelijk. ja. ill sommnge gevallen noodlottig is. Het laatste o.a. bij liet hoogst algemeens. zwatbruine miertje Inlichoderus bituberrululus. Ik hel, likwijls waalgenumen. lat. Wanneer deze miclsuort up rem sterk helaral tahaksblad terecht bumst.

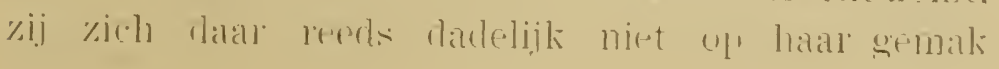


bevindt. Blijkbaal wordt ze in har bewegingen belemmerd en zij tracht zich daarom met alle kricht uit deze, haal hoogst onaangename omgering te verwijderen. Gelukt het hait, den bladrand te bereiken, dan laat zij zich dadelijk vallen; gelukt haal dit niet, dan sterft ze na eenige minuten onder sterk convulsieve verschijnselen, die op een dood cloor verstikking wijzen, vermoedelijk veroorzakt, doordat de olie der haren in de ademhalingsopeningen ran het achterlijf dringt en deze verstopt doet raken. of wij hier inderdaad met een verdedigingsmiddel der tabaksplant tegen ongewenschte gasten hebben te doen, is echter nog een open v'radg. Men zou zelfs geneigd zijn, die ontkennend te beantwoorden, omdat andere insecten, ook dezulke, die de plant reel meer kwaat doen dan de genoemsde miersoort, ongestraft tusschen de hiren kunnen verblijien of zich daartusschen bewegen. Het eerste bijv. zien wij bij de, op tabak zeer algemeene, groene Bladluis, die van het afbreken der haren geen list heeft, omdat zij zich zoo goed als nooit beweegt. Het tweede bij de l'upsen, die op en van de blaren leven en zelf eenigszins behaard zijn, warrdoor vermoedelijk de olie minder tot hadr huid doordringt. Wat deze Bladluis aungaat, ralt nog op te merken, dat ik haal nooit vergezeld zag van mieren, die anders bij de Aphidae zelden of nonit ontbreken. Na het aangaande de Dolichoderus-soort medegedeelde, is cleze afwezigheid begrijpelijk, maar aan den anderen kant heeft het zoete afscheidingsproduct der luizen voor de mieren zooveel aantrekkelijks, dat cnkele soorten, die loor het bezit van lange pooten eenigszins in het voordeel zijn, er toch nog iets op geronden hebben, om zich althans van een gedeelte 
van deze lekkernij mester te maken. De meest ilgemeane der hier beloelde is de voweger (pag. 16i1) reeds genounde Plugiolepis longipes. Deze nu kan men dikwijls op de tabaksplinten watrnemen, malat vooral op de lagere bladeren, die door allerlei invloeden reeds een aanzienlijk (leel van humne beharing hebben verloren. Eene reis nar de bovenste deelen der plant, waar zich de meeste Bladluizen berinden, durven deze mieren blijkbaar niet aan, rooral ook, omoat ze dan den dichtbehaarden stengél moeten passeeren en daarom wachten ze beneden tencoudig den afvallenden honigdauw op.

Behalve de reeds in het algemeen roor luet bouwland genoemde rupsen kan men hier vrij reelvuldig aantreffen de ongemeen fraai gekleurde rupsen der beide Doodshoofdrlinders Acherontia lachesis en $A$. styx, alsmede de rupsjes der Pylalide Botys marginalis, die zich gewoonlijk, in kleine troepjes bij elkaal, onder een gemeenschappelijk spinsel aan de onderzijde der bladeren ophouden. Eindelijk moet hier het geslacht Piusia worden senoemd, waarvan de soorten signata en eriosoma vaak zeer algemeen zijn, terwijl ook nu en dan hier optreedt de rups ran de fraaie Plusia orichalcea, die, wanneer ze des avonds als vlindertje door het lamplicht wordt aangelokt, met haar grootendeels goudglanzende roorvleugels een schitterend effect makkt.

Voegt men aan liet borenstaande nog toe, lat de tabaksaanplantingen een dorado schijnen te zijn voor de Tenebrioniden Holoniara pices:ens, Opatrum depressum, O. acutangulum, O. truncatum en hunne ritnaaldachtige larven, dan heeft men een vrij volledig beeld van hetgeen hier in faunistisch opzicht valt waar te nemen. 
Liggen de velden der Europeesche tabaksondernemingen grootendeels in een gebied, dat met groote kampongs is doorzaaid, zoodat allerlei vogels van de kampongfauna er nog wel eens vallen waar te nemen en eenige levendigheid aanbrengen, ander's is het met het reusachtige tabaksgebied der inlandsche bevolking in de Residentie Kedoe, meer bepaaldelijk met de treek, die zich, bezuiden de spoorlijn, tot een hoogte van circa 4000 voet tegen de noordelijk hellingen ran Sindoro en Soembing uitstrekt. Volgt men van Parakan den stijgenden weg, die naar het, op 4500 voet hoogte gelegen zadel tusschen deze beide bergen ruert, dan ziet men, zoover het oog reikt, bijna niets anders dan de terrasgewijze aangelegde velden, met hier en daar kleine nederzettingen der bevolking ertusschen. Nagenoeg geen enkele boom verbreekt het eentonige van dit landschap, dat aan de bovenzijde is begrensd door de vrijwel volmaakt rechte benedenlijn van den reboisatiegordel. Vandaar een troostelooze armoede aan hoogere diervormen; een enkele Sturnopastor waagt zich nog in deze eenzaamheid, hier en daar een waadvogeltje op vochtige gedeelten, maar over het algemeen is de indruk die van een gebied, dat door den mensch even volledig in beslag is genomen als een dichtberolkte achterbuurt eener groote stad.

\section{SUIKER.}

Van weinig tropische cultuurgewassen is, dank zij de onderzoekingen ran Kobus, Zehrtner, Arendsen Hein, rax Deventer e.a., de fauna zoo goed bekend als die ran het suikerriet op Jara. Zenst- 
NER *) publiceerde in 1597 een beredeneerd overzicht ran de dierrormen, die men destijds als schadelijk roor het riet haw leeren kennen en kwam tot een londerdtal soorten, ivelk aantal men sedert nog met eenige indere heeft kunnen rermeerderen. Voegt men daarbij nu nog de nuttige rormen, dan komt men zeker tot een 1.j0-tal diersoorten, die met hut suikerriet in oeconomische betrekking staan.

Wie de anplantingen te roet of per voertuig rombij gaat. ziet daarvan weinig of niets: men moet zich inderdaad de varmte diarbinnen getroosten, wil men ran dezen rijkrom ook maar het voornaamste en meest up den voorgrond tredende raarnemien. Van' het optreden van Zoodieren ziet men gewoonlijk slechts de sporen, die echter roor elk type nogal karakteristiek zijn. Zoo is de vreterij der Knaagdieren, hier hoofdzakelijk door Ratten en een enkele maal ook door Siurus notatus (jag. 200) rertegenwoordigd, gemakkelijk te herkennen aan de omstandigheid, dat de stengels slechts zijn aangerreten tusschen de knoopen, die, bij zulk een overvloed van roedsel, den dieren waarschijnlijk te luard zijn. Zijn ook de knoopen ditngevreten, dan kan men el vrij zeker ran zijn; dat Wilde Varkens (Sus vittatus en S. verrucosus) aan het werk zijn geweest, welker opitreden zich borendien pleegt te openbaren in het omselliggen van het riet en het omgewoeld zijn van den bodem, dit latste als gerolg ran het zoeken naar engerlingen en wormen.

Een eigenaaldige bescludiging veroorzaakt de loewak (Paradoxurus hermaphroditus, pag. 57), die slechts dmune rietstengels aantast, door daarin op

*) Mededectingen van het Kroefstution Uost-Java. Nieuwe serie, No. 37 
eenige hoogte boven den grond te bijten en ze vervolgens zóó te wring’sn, dat het suikerhoudende sap in zijn bok vloeit. Door deze manoeuvre worden de aangetaste stengels in een aantal orerlangsche vezalbuntels gespleten, die zich later wel grootendeels weder tegen elkaar leggen, maar toch niet meer onderling kunnen vergrozien, zoodat het riet de toəgebrachte beschadiging zeer duidelijk blijft vertoonen.

De reeds vroeger (pag. 264) terloops genoemde Wevervogels en inzonderheid de soort Ploceus manjar, treden in de suikerriet-aanplantingen soms op in een aantal, dat vele duizendtallen kan bedragen en op een wijze, die, hoe onaangenaam overigens roor den planter, biologisch zeer interessant is. Vaste bewoners kunnen zij er natuurlijk niet zijn; ze verschijnen er tegen het voorjaar, wanneer in de omgeving der riettuinen in de lagere streken de rijst begint te rijpen en dus voorloopig op een roldoende hoeveelheid voedsel kan worden gerekend. Spoedig komen paring en nestbouw atan de orde en het is deze laatste, die vooral merkwardig is, zoowel door den vorm en den omvang der nesten, als door de wijze, waarop (leze worden opgehangen *). Vandiar dat een riettuin, waar zich een kolonie van Wevervogels heeft gevestigd. waar het gewas zeer is gehavend, doordat het de materialen voor den nestbouw heeft moeten leveren en waar de korfrormige nesten aan een paar elkaar kruisende en dikwijls geheel kàal geplukte hoofdnerven zijn opgehangen, een zeer curieuzen a anblik oplevert. Elk nest op

"). Een uitvoerige beschrijving van een en ander is gegeren door Zehntner in: Mededeelingen van het Proefstation Oost-Java. 'T'weede Serie, No. 46. 
zich zelf is een knap stuk werk en bestaat nit een broerholte en een korteren of langeren, ronden gang; die daartoe van buiten toegang verleent. Op de grens tusschen ging en holte is een hooge, ronde drempel, waardoor de laatste nog meer liet karaktel' ran een afzonderijk kamertje rerkrijgt. De gang, die zich van buiten roordost als een tuitrormig aanhangsel ran het nest, is buitenwarts schuin naar beneden gericht, zoodat de hinnenruimte ran het nest rolkomen tegen weer en wind is beschermd. Het pleit in hooge mate roor het intellect der Wererrogels, dat zij deze inrichting ran het nest steeds weten door te roeren, ongeacht de verschillende omstandigheden, waarmede zij bij den aanvang ran den bouw, in het bijzonder ten aanzien ran de situatie der ophangpunten, hehben te maken.

Trots den omrangrijken arbeid en de rele zorgen. dan het bouwen der nesten rerbonden, worden deze slechts éémmaal gebruikt. Zijn in Mei en Juni de jongen van het eerste broedsel uitgerlogen, dan worden de nesten verlaten: ze heginnen een r.r. waarloosd roorkomen te krijgen, worden donker ran kleur en rallen dikwijls op den grond of hangen uit elkaar. Spoedig beginnen nu de nijrere diestjus opnieus, want er wordt tweemaal gebroed. Zijn ook de jongen van het tweede hroedsel grootgebracht, dan verdwijnt langzamerhand de geheele kolonie. De dieren verspreiden zich, om in den regel het volgend jaar naal dezelfde nestplaatsen terug te kesren.

Het bovenstaande betreft meer in het bijzonder Ploceus manjar; de reel minder algemeene Ploceëlla javanensis, die soortgelijke nesten bouwt, schijnt niut de neiging te hebben, zich tot talrijke koloniën te rer- 
eenigen en in het algemeen nog weinig op verblijf in het cultumrgebied gesteld te zijn. Wel is zij even verzot op rijst als de andere soort, doch roor haar nestbouw geeft zij de voorkeur aan eenzame en boomrijke terreinen. Beide soorten staan algemeen bekend onder der inlandschen naam manjar, terwijl de fraaiere mannetjes wel eens als manjar kembang van de meer eenvoudige wijfjes worden onderscheiden.

De gewone kampongspecht Dendrocopus analis (pag. 74) komt ook wel eens in de riettuinen en zal dat oorspronkelijk wel hebben gedaan ter wille van de talrijke borende larven, die het suikerriet herbergt. Langzamerhand heeft hij echter zooveel smaak gekregen in het zoete weefsel der stengels, dat hij thans het riet alleen dàrom wel cens schijnt aan te tasten. Er zijn op Java trouwens meer spechten van een gemengd diëet en het is zeer goed mogelijk, dat ook deze, speciaal bij het, openhameren en daardoor "nolens volens" proeven van smakelijke vruchten, op dergelijke wijze ertoe zijn gekomen, hun uitsluitend carnivore gewoonten vaarwel te zeg'gen.

Tot de Insecten, die in riettuinen dadelijk onze aandacht trekken, behonren weder de talrijk Psilopus. soorten en voorts de blauwgrijze Fulguride Phenice maculosa, die zich gewoonlijk aan de onderzijde der bladeren ophoudt en gekenmerkt is door de zeer lange voorvleugels, die niet op het lichram rusten, maar steeds zóó opgericht zijn, dat het diertje zich voordoet als een $V$.

Bladluizen en Schildluizen vinden hier eveneens een goed verblijf. Van de eerste familie zijn de meest algemeene vertegenwordigers de witte Oregma 
lamigera en de groene Aphis sacchari, die beide in hooge mate tot de vorming ran roetdauw aanleiding. geven. Vin de Coccidae zijn het een aantal soorten van de geslachten Chionaspis, Aspicliotus, Juctylopius e.a., die deels op de blaren, deels op de stengels roorkomen, terwijl afzonderlijk melding moet worden gemaakt ran het geslacht Aleurodes, dat de zoogenaamde Mottenschildluizen omvit, dikwijls tot den rang eener afzonderlijke familie verheven. In het bijzonder is Aleurodes horgi in dit gebied een zeer algemeen insect, dat niet nalat de andacht te trekken, o.a. door de ringrormige eihoopjes, vanwar de larven zich langzamerhand verspreiden, steeds in den vorm van ledige huidjes de sporen van hun verblijf nalatend. Deze huidjes, alsmede die, waaruit ten slotte de rolwassen diertjes met hun grijsgerlekte, breede roorrleugels teroorschijn komen, vormen met de wasachtige afscheidingsproducten der laven grijze korsten, die op humne beurt wedel het atuzijn geren aan een schimmelregetatie ran dikwijls aanzienlijken omrang.

Bij de talrijlie parasieten dezer op het suikerriet levende Plantenluizen zullen wij niet stilstaan; zij rormen een wereld op zich zelf, waarin de onderzoekingen ran ZEHxTrer ons hebben binnengeleid en hare waarneming rereischt heel wat meer dan een oppervlakkig bezoek. Slechts een tweetal Coccinclliclae moge hier worden genoemd, Caria dilutata en Synonycha grandis, die beide, waar ze anwezig zijn, door har bijzondere grootte onmiddellijk in het oog vallen.

Een groep ran larven, die bij het suikerriet duor den bouw ran het blad op den roorgrond kunnen 
treden, zijn de zoogenaamde mineerlarven, die zich tusschen beide opperhuiden ophouden en zich met het bladmoes voeden. Drie ervan behooren, voor zooverre zij in dit gebied vourkomen, tot de kevers, ééne is een rupsje. Van ce kevers is Hispella wakkeri, een gedoornde Hispide, over geheel Java verspreid; de larvengang begint op het punt, waar het moederdier een eitje in het bladweefsel heeft gelegd en is over zijn geheele lengte tamelijk breed. Daardoor onderscheidt hij zich van die der beide andere keverlarfjes, Asphanisticus krügeri, die in West-, en A. consanguineus, die in Oost-Java voorkomt. Bij deze kleine Buprestiden toch zijn de gangen over ongeveer de helft hunner lengte zeer smal, weinig meer dan lijnvormig, om zich eerst daarna te verbreeden. Bij het rupsje eindelijk, de larve van Cosmopteryx pallifasciella van de familie der Tineidae, begint de gang eveneens smal, maar de verbreeding heeft eerder en meer geleidelijk plaats, terwijl aan het begin van den gang, in de opperhuid der onderzijde, steeds een paar kleine, ronde openingen zijn war te nemen, die gewoonlijk door boormeel zijn verstopt. Bovendien is de Aphanisticus-gang steeds te herkenren aan een klein, bruin, hol kapje bij het begin, dat daar door het moederdier tot bescherming van het ei is aangebracht.

Ook de stengel van het liet leent zich bij uitnemendheid rool de huisvesting van boorders. Een viertal daarvan, de stengelboorder (Diatraea striatalis), de Witte Boorder (Scirpophaga intacta), de Gele Boorder (Chilo infuscatellus) en de Grauwe Boorder (Graptolitha schistaceana) is van algemeene bekendheid en twee ervan verraden hunne aanwezigheid in het riet reeds door de sporen humer werkzaamheid in den 


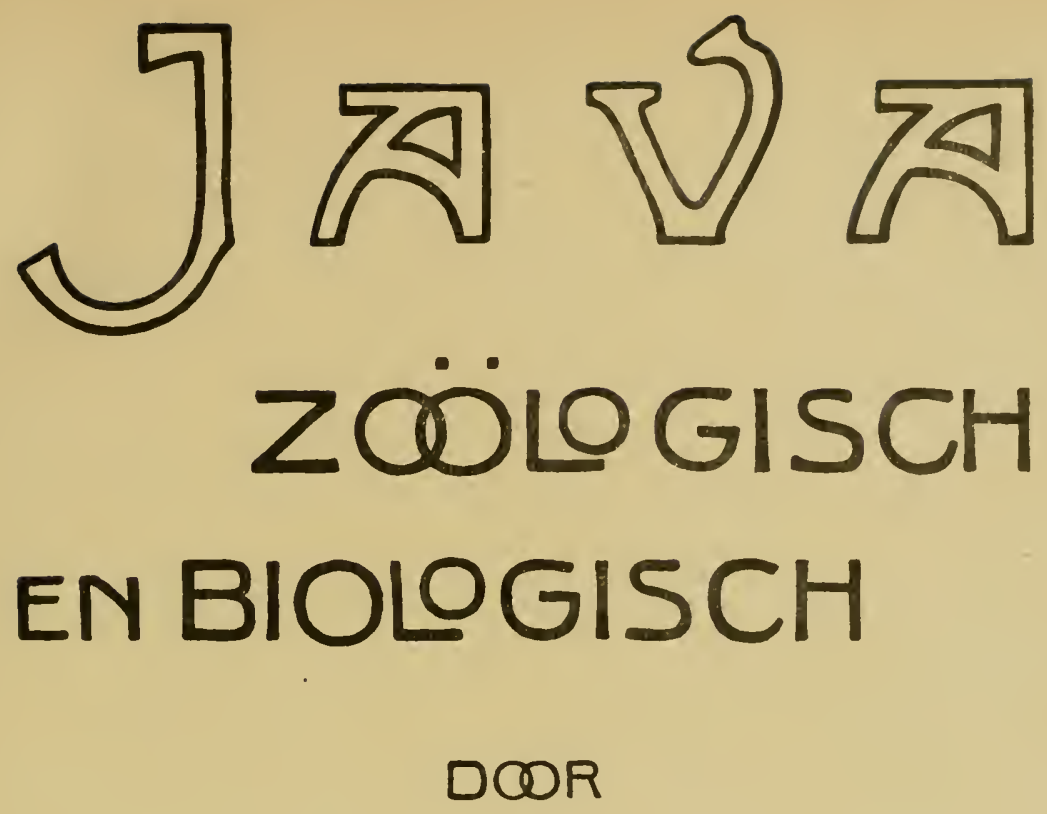

\section{DR.J.C.KONINGSBERGER}

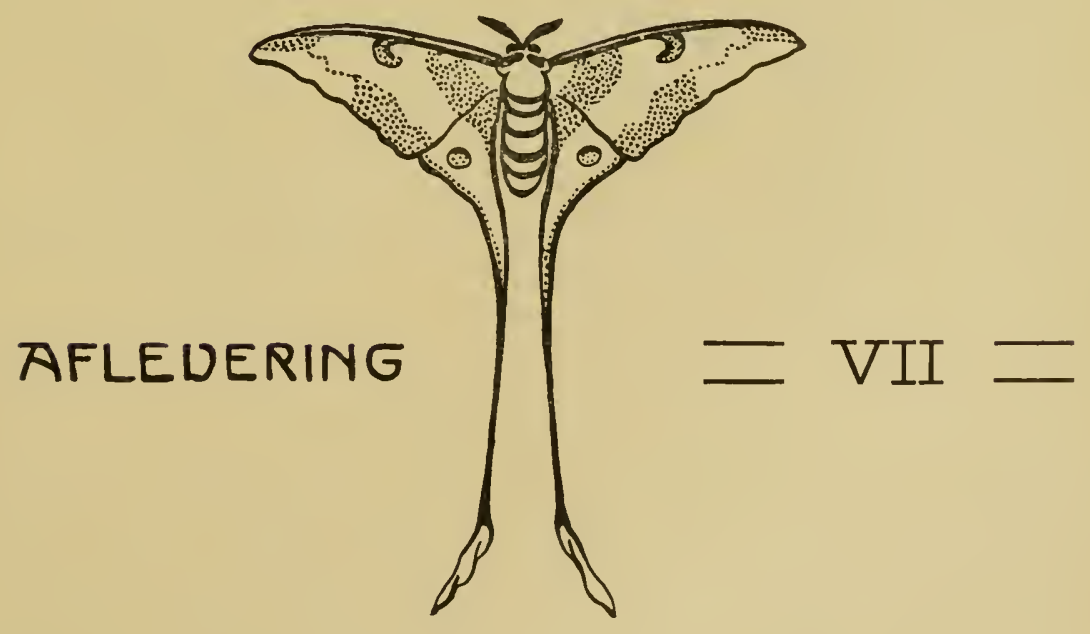

DRUKKERIJ DEP. v. L. N. en H. BUITENZORG 1913.
Verkrijgbaar bij

G. KOLFF \& Co. Batavia.

Prijs f 1.- 



\section{N HOUD.}

\section{AFLEVERING I}

Vookwoord. Algemeene samenstelling der Fauna van Java en hare wordingsgeschiedenis. De Hutdgroepen. . . . .

Hoofdstuk II. Overgangon van de eene groep in de andere. Morphologische gerolgen Uial'vall. Toorbeelden van volmen, die in overgang zijn. Nachtelịke en diume levenswijze.

Hoofdstuk III. Invloed var, argetiden, regen, wind en zonneschijn. Tergelijking met andere cilancien. . . .

pag.

\section{AEJEVERING II en III.}

Hoofdstuk IV. Kort overzicht der verschillende gebieden. De Cultuurfauna bij uitnemendheid: de dierrormen der grootere plaatsen . . . . . . . . . . . . . . . .

A. ZoogdiereN . . . . . . . . . 55.

B. Vogels. . . . . . . . . . . 60.

C. Kruipende en Tweeslachtige Dieren. . . 76.

Hoofdste $V$. De Dierrormen der grootere plaatsen.

Vervolg) . . . . . . . . . 90.

D. INSECteN . . . . . . . . 90.

1. Orthoptera . . . . . . . . . . 90.

2. Neuroptera . . . . . . . . . . . . 98.

3. Rhynchota. . . . . . . . . . 104.

4. Diptera . . . . . . . . . . 108.

Hoofdstuk VI. De Diervormen der grootere plaatsen.

(Vervolg). D. Ixsecten. (Vervolg) . . . . . . . . . 116.

ว. Coleoptera . . . . . . . . . . . 116.

6. Lepidoptera. . . . . . . . . . . . 127.

\section{AFLEVERING IV.}

Houfdstuk VII. De Diervolmen der grootere plaatsen

(Vervolg). D. IxsecteN (Vervolg). . . . . . . . . 157.

7. Hymenoptera. . . . . . . . . 157.

8. Apterygota. . . . . . . . . . . 179. 
Hoofdstuk VIII. De Diervormen der grootere plaatsen.

(Vervolg) . . . . . . . . . . . . 180.

E. Schorpioenen en Veritante VorMen : : 180.

F. Spinnen en MiJten. . . . . . . . 182.

G. DUIZENDPOOTEN. . . . . . . . . . . 189

H. Kreeftachtige Dieren . . . . . . . 193.

I. WEEKDIEREN. . . . . . . . . . . . 194.

K. WORMEN. . . . . . . . . . . 195.

Hoofdstuk IX. De Fauna der dessa's. . . . . . . 198.

A. DESSA'S IN HET' OPEN TELD . . . . . 199.

\section{AFLEVERING V.}

Hoofdstuk IX. De Fauna der dessa's (Vervolg).

A. Dessa's IN HET OPEN veld (Vervolg) . . . 205.

B. Dessa's in BOOMRIJKE OMgeving . . . . 212.

Hoofdstuk X. De Fauna der dessa's. (Vervolg).

B. Dessa's in Boomrijke omgeving. (Vervolg) . 227.

Hoofdstuk XI. De Sawahfauna . . . . . . . 245.

\section{AFLEVERING VI.}

Hoofdstuk XII. De Fauna van het Bourvland . . . . 272. Hoofdstuk XIII. De Fauna van het Bouwland. (Vervolg) 295.

\section{AFLEVERING VII.}

Hoofdstuk XIV. De Fanna van Braakliggend Land en Weidevelden ... . . . . . . .

Hoofdstur Xं. De Fauna van het Gebied der Overjarige Cultuurgewassen . . . . . . . . . . . . . 322. DJATIBOSSCHEN KOFFIE EN SchaduWBoomen . 327.

Hoofdstuk XVI. De Fauna van het Gebied der Overjarige Cultuurgewassen (Vervolg). . . . . . . . . . . 351. CACAO. . . . . . . . . . 351. 
jongsten larventoestand. Zoo begeven zich de Stengelboorders onmiddellijk na hunne geboorte naar de jonge, nog opgerolde blaren, waal ze op talrijke plaatsen het bladmoes afschaven. Hierdoor ontstaan witachtige vlekjes, die niet anters zijn dan de overgebleven opperhuid van de onderzijde der bladeren en een vrij zekere aanwijzing van de aanwezigheid ran Diatraea-rupsen. De Witte Boorders doorboren den bundel der nog opgerolde, jonge blaren in dwarse lichting, zoodat, wanneer de blaren zich hebben ontrold, daarin dwarsgeplaatste rijen van kleine gaatjes zichtbaar zijn. De beide andere der genoemde Borders laten niet zulke kenteekenen na en humne aanwezigheid kan daarom eerst worden geconstateerd, wanneer het grootste gedeelte van hun larvale leven reeds achter den rug ligt. Er doen zich alsdan opdrogingsverschijnselen der jonge bladkokers voor, welke verdroging bij den Gelen Boorder dadelijk den geheelen koker omvat, bij den Grauwen Boorder eerst het jongste ontrolde blad betreft.

De rupsen, die bij het suikerriet alleen de bladeren beschadigen, zijn roor het meerendeel oude bekenden, die wij reeds bij de rijst en de mais ontmoetten (zooals Melanitis leda, de Hesperia's en Dreata petola) of roor het bouwland in het algemeen noemden (Borstelrupsen, Aardrupsen). Nieuw zijn de Sphingide Leucophlebia lineata, die niet zeer dikwijls, maar dan in grooten getale optreedt, Anticyra (Phalera) combusta en de Pyralide Cnaphalocrocis bifurcalis, die zich van een paar naburige bladtoppen een verblijf spint en dit gebruikt als uitgangspunt voor tamelijk onschuldige rooftochten, die slechts hier en daar een gedeelte van het bladmoes gelden. 
De Coleoptera zijn, behalve door de reeds genoemde mineerlarven, door een zeer beperkt aantal soorten vertegenwoordigd. De meest bekende van deze is wel Apogonia destructor, een klein Bladsprietig kevertje, welks larven zich aan de wortels van het riet te goed doen, terwijl de imagines zich het liefst ophouden in de boomachtige Leguminosen, zooals toeri (Sesbania grandiflora), klampis (Acacia tomentosa, var. chrysocoma), kelor wono (Sesbania aegyptiaca) en tamarinde (Tamarindus indica), die veelvuldig in de omgeving der tuinen ziju te vinden en zelfs dikwijls langs de randen zijn aangeplant. Bij dit insect treffen wij voor het eerst een langdurigen rusttoestand aan. De zeer gedetailleerde onderzoekingen van ZEHNTNER hebben namelijk aangetoond, dat de kevertjes, die in October en vooral in November tevoorschijn komen, alsdan hunne eieren in de riettuinen leggen. De larven, die zich uit deze eieren ontwikkelen, worden in Maart tot een volgende generatie van kevertjes, die tot in Mei rondvliegen en zich dan in den, bodem verbergen, om aldaar gedurende den drogen tijd een rusttoestand, vergelijkbaar met de winterrust van gematigde luchtstreken, door te brengen. Door de regens van den volgenden Westmoesson worden - ze daaruit opgewekt. Zooals wij later zullen zien, komt een dergelijke toestand bij meerdere kevers van dezelfde familie voor; dat hij door de langdurige droogte van den Oostmoesson wordt veroorzaakt, is op te maken uit de omstandigheid, dat bij een abnormaal regenrijken Oostmoesson steeds veel Apogonia's rondvliegen en dat hij in West-Java, waar droge perioden van eenige maanden lengte zelden voorkomen, in evenredig mindere mate wordt aan getroffen. 


\section{HOOFDSTUK XIV.}

\section{De Fauna van Braakliggend Land en Weidevelden.}

In een dichtherolkt land als Java zijn natuurlijk in de lagere streken niet reel terreinen van eenigszins brukbaren aard, die niet roor het een of ander worden gebezigrd. Onder braakliggend land wordt hier dan ook verstaan het geheel ran die gronden in het cultuurgebied, dit niet geregeld aan grondbewerking en beplanting worden onderworpen, mar. die daarom volstrekt nog niet onproductief behoeven te zijn. Zij kunnen de bevolking van brandhout, in gunstige gevallen soms van hout voor woningbouw voorzien: waar veel arènpalmen (Arenga sacharifera) erop voorkomen, levert de exploitatie dezer boomen een bron van inkomsten. Men vindt er dikwijls ook allerlei andere boomen, die een of ander product leveren en eindelijk dienen ze als plaatsen, waar het vee na gedanen arbeid een heenkomen vindt. Zelfs wilal zij met Lantana en, in streken boven 1000-2000 voet met krinjoe (Eupatorium pallescens) ketjoeboeng (Datura alba) en dergelijke gewassen zijn begroeid, zijn er altijd nog wel grazende huisdieren, die daartusschen iets van hunne gading: vinden.

Hier en daill zijn de bedoelde terreinen van vrij groote uitgestrektheid en daarom mogen ze, nok faunistisch, als een afzonderlijk gebied worden be- 
schouwd, al was het daarbij alleen maar om de armoede aan eigen diervormen van eenigszins opvallend karakter, waardoor ze zich in het algemeen kenmerken. Men kan hier. mijlen ver loopen, zonder iets ander's tegen te komen dan enkele ran de meest gewone vormen der cultuurfauna en zelfs de bloemen van de Lantana's, die om hun alledaagschheid niet worden gewaardeerd, maar toch inderdaad een bijzondere kleurenpracht kunnen vertoonen, vermogen bijna geen andere insecten te lokken, dan dic ons reeds van de vroeger besproken terreinen bekend kunnen zijn.

Toch zijn er daaronder, roor wie de bijzondere omstandigheden van dit gebied een groote-aantrekkelijkheid schijnen te hebben, zoodat wij ze hier in grooter aantal dan elders ontmoeten. Hierbij denk ik o.a. aan vele kleine Rhopalocera; Lycaeniden, kleine Hesperiden, Terias-soorten zijn hier overvloedig: te vinden en van beide eerstgenoemde families zou men hier al een geheele verzameling bij elkaar kunnen brengen. Waar grasvlakten praedomineeren, vindt men verder in groot aantal verschillende Junoniasoorten, waarbij wij aan de, vroeger (pag. 132) reeds genoemde soorten nog $J$. wallacei kunnen toevoegen.

Voorzooverre dit gebied in de nabijheid der kampongs ligt, vloeit het natuurlijk ineen met de reeds vroeger besproken omgeving daarvan, waarbij men de eerste de beste grasvlakte van eenige beteekenis wel als buitengrens van die omgeving kan beschouwen. Hier toch wordt het grazende rund van de ééne zijde gevolgd door verschillende soorten van Spreeuwen en Buchanga's, terwijl van den anderen kant soms Steltloopers, inzonderheid Herodias-soorten, komen aanzetten, om te azen op de wormen, die door 
den plompen tred der buffels uit den vaak drassigen bodem teroorschijn komen. Hier roegt zich bij de bedoelde Spreeuwen plaatselijk de witte Graculipica melanoptera, die, schuwer van aard dan Acridotheres en Sturnopastor, aan het stille, onbebouwde gebied de roorkeur geeft.

Naarmate men zich verder van de kampongs verwijdert, wordt voor zulke dieren het terrein gunstiger en wanneer het door een rijkere regetatie aan de dierenwereld mar iets betere levensomstandigheden aanbood, zou het faunistisch ongetwijfeld beter berolkt zijn. Thans herbergt het niet meer dan eenige minimumlijders, warronder ik in de voornaamste plaats zou willen rangschikken de Javaansche Haas (Lepus nigricollis), die hoofdzakelijk leeft van wildgroeiende kruiden, waaronder babadottan of bandottan (Hyptis suaveolens), en bajam merah (Amaranthus gangeticus) een voorname plaats innemen (OLivier). In tegenstelling toch met vele andere Knaagdieren, waagt zij zich zelden of nooit in de aanplantingen der bevolking en houdt zich bij voorkeur op in de struikwildernissen van dit gebied. Haar verspreidingsgebied op Java is bovendien beperkt, rermoedelijk niet alleen tot West-Java, maar ook dáár nog tot de streek, die ten Westen wordt begrensd door de Tjikandi, ten Oosten door de Tjitaroem en wellicht zelfs door de Bekassi-rivier en ten Zuiden door de bergenreeks, waarvan Salak, Gedeh en Pangerango de voornaamste toppen zijn. Deze zeer geringe ver'spreiding concordeert met de onderstelling, dat Lepus nigricollis hier indertijd, zou zijn ingevoerd. Blijkbaar heeft ze hier dan niet zulke gunstige omstandigheden aangetroffen als haal verwant, het Konijn, in Australië. De mogelijkheid 
blijft natuurlijk bestaan, dat ook elders op Java dan in het genoemde gedeelte hazen voorkomen, maar de gegevens, waarmede ik mijn eigen waarnemingen over deze diersoort kon aanvullen en waaronder die ran den Heer OLivier de belangrijkste zijn, luiden vrijwel éénstemming.

De tegenstelling, in dit gebied, tusschen gedeelten, die door den mensch nog druk worden bezocht en andere, die afgelegen en eenzaam zijn, openbaart zich ook in de Duiven, met name in de Turturidae.

Voor de gewone perkoetoet, Geopelia striata, die tot de cultuurfauna bij uitnemendheid behoort, maakt het weinig uit, of zij zich in de eerste of in de laatste hevindt. De tekoekoer, Turtur tigrinus, neemt reeds

1. meerdere voorzorgen in acht en houdt zich slechts daar op, waar ze met rust wordt gelaten. Zoodra dit niet het geval is, trekt zij zich naar stillere plaatsen terug. Veel schuwer nog is de deroek, Turtur bitor. quatus, die de nabijheid van druk bewoonde buurten zorgvuldig vermijdt.

Aangaande de levenswijze van deze drie Duiven stelde de Heer OLIviER eenige aanteekeningen te mijner beschikking, warran ik geen beter gebruik weet te maken, dan ze hier grootendeels te laten volgen.

"De verschillende soorten van Tortelduiven zijn meer veld-, dan boomvogels, in zoover, dat zij bij voorkeur laveien (hun voødsel zoeken) op open, vlakke terreinen, hetzij op droge, onbebouwde of pas gesneden rijstrelden, hetzij op grasvlakten; de laatste in het bijzonder, indien zij hier en daar, doch niet te dicht, begroeid zijn met tjenté-struiken (Lantana camara). 
Narmate de zon stijgt, zoeken zij de boomen op, doch indien ergens op het vlakke reld een poel met stilstaand water ligt, als karbouwenwed in gebruik, dan vindt men aan de randen hiervan op het heetste gedeelte ran den dag bijna altijd verscheidene koppels van de drie, in het wild levende soorten ran 'Turturidae. Het eigenaardige hierbij is, dat men de duiven ook ve] aantreft in de nabijheid ran andere wateren (meertjes bijr.), doch dat zij toch een speciale voorliefde schijnen te hebben voor de bovenbedoelde poelen. Of dit verband houdt met het aldaar veelvuldig aanwezig zijn van karbouwen, dan wel met den rorm dier plassen, die aan de randen zeer ondiep zijn en geleidelijk in het omliggend terrein overgaan, waardoor zij wellicht bijzonder geschikt zijn als drinkplaats voor de vogels, heb ik niet kunnen uitmaken.

Van de drie het meest gesteld op geboomte gedurende de middaguren is de deroek, die betrekkelijk vroeg in den morgen het vlakke veld reeds verlaat (behoudens het hierboven medegedeelde omtrent karbouwenpoelen) en dan bij tusschempoozen haar weinig gekunsteld, eenigszins somber geluid doet hooren. Daarna rolgt de tekoekoer, die eerst de boomen opzoekt, als het reeds goed heet begint te worden en omstreeks den middag de eerste tonen laat hooren van haar gekoer, dat vroolijker klinkt dan dat van de deroek en bij de verschillende individuen geheel anders is. Degene, die na den welbekenden roep, waaraan de vogel zijn naam dankt, tot driemaal toe een toon laat hooren, klinkend als "koek", staat in hoog aanzien bij de inlanders, die voor het bezit van zoo'n vogel gaarne hooge sommen besteden. Wanneer deze eigenschap gepaard gaat 
met nog een andere eigenaardigheid in het geluid of met de eene of andere afwijking van de gewone, bevedering (bijv. albinisme, dat ivel eens roorkont), dan ontkont het dier moeielijk aan een heiligrerklaring. Het geldt dan voor onkwetsbaar; het geweer zal dan eer in de hand des jagers springen, dan ook maar één veertje van de phenomenale duif deren.

In het algemeen is de tekoekoer een vogel, witaraan liet bijgeloof van $d \in n$ bruinen broeder allerlei bovennatuurlijke krachten toeschrijft. Haar bezit, evenals dat van de perkoetoet, brengt geluk aan.

Om ten slotte omtrent de gewoonten van de laatstgenoemde iets mede te deelen, zij hier vermeld, dat zij zich het minst van de drie om zonnewarmte schijnt te bekommeren. Wel is waar vliegt ook zij heel vaak hoog in een boom, om er haal aaldigen, vroolijken slag te doen hooren, doch ook vindt men haar op alle uren van den dag op den grond. 'Tegen de koele namiddaguren komen de twee andere soorten ook weer naar beneden om te laveien. Den nacht brengen alle drie soorten in het geboomte door, alwaar zij ook nestelen".

Ook de Papegaaiduiven (Treronidae), reeds vroeger (pag. 73) genoemd, komen in dit gebied voor, wanneer het maar voldoende geboomte bevat. "Vee] schuwer nog dan de tamelijk wantrouwige deroek zijn alle soorten van Papegaaiduiven, die ook meer geprononceerde boomvogels zijn en, in onderscheid met de hoofdzakelijk zaadetende Tortelduiven, zoo goed als uitsluitend frugivoor. Zij zijn verzot op allerlei besachtige vruchtjes, mits goed rijp, zooals die van de waringin (Ficus benjamina), de woeni 
(Antidesma bunias), de kandri (Bridelia lanceolata) enz. Heel rroeg in den morgen en tamelijk laat in den namiddag komen zij ook wel uit het hooge geboomte naar beneden, om zich te goed te doen aan de vruchtjes van sommige struikgervassen, waaronder de tjenté, misschien ook om te drinken, hoewel zij daaraan wegens hun levenswijze minder behoefte zullen hebben dan de, droge zaden verorberende tortels. De rest van den dag zoeken zij hoog opgaand hout, bij voorkeur in de eenzaamheid, zooals bijv. inlandsche begraafplaatsen (OLIvier)".

De laatste duif, die voor dit gebied moet worden genoemd, is de delimoekan (Chalcophaps indica), een als kooivogel om zijn fraai gevederte in hoog aanzien staande soort, die echter niet zeer algemeen is. $\mathrm{Zij}$ is in mindere mate dan eenige andere soort boombewoonsters en houdt zich het liefst op tusschen struikgewas en gras van een paar voet hoogte, zooals alang-alang.

Men vindt verder in dit gebied, voornamelijk onder de beschutting van kreupelhout, een tweetal Waadrogels, die men hier a priori niet zou verwachten, maar die er garme de warmere uren van den dag doorbrengen, dikwijls op aanzienlijken afstand van hun eigenlijke terrein. De eerste van dit tweetal is Gorsachius melanolophus, de eenige echte Roerdomp van Jara, die onder den inlandschen naam valangliada bekend staat en merkwaardig is door het groote verschil in vederkleed, dat er bestaat tusschen de oudere dieren en de jongen, ook wanneer deze laatste reeds geheel de allures van volwassen exemplaren hebben verkregen. Deze Roerdomp is een nachtrogel, in zooverre, dat hij gedurende de duisternis zijn 
grootste activiteit. ontwikkelt; maar, zooals bij meerdere dieren van een dergelijke levenswijze (o.a. ook bij den reeds vroeger genoemden Nachtreiger Nycticorax griseus, pag. 76) het geval schijnt te zijn, heeft hij weinig behoefte aan een langdurige rust en is ook gedurende een aanzienlijk gedeelte van den dag op de been. Zoo kan men hem soms midden op den dag waarnemen, terwijl hij zich schuw door het lage hout beweegt, waalin hij half droomend, half wakend den dag doorbrengt.

De tweede der bedoelde Waadvogels is het zeer algemeene Waterhoentje Amaurornis phoenicura, bekend onder de inlandsche namen terkoewak (mal.), kakiarèwan (soend.), sribombok (jav.) e.a. Hoewel van huis uit een liefhebber eener waterrijke omgeving, schijnt deze vogel het toch ook zeer goed op drogere terreinen te kunnen stellen. In Deli is hij bijvoorbeeld zeer algemeen op de uitgestrekte terreinen, die aldaar na het afoogsten der tabak en den, dikwijls daarop volgenden rijstbouw, gedurende ettelijke jaren braak blijven liggen en zich alsdan met een eigenaardige, savannen-achtige vegetatie bedekken. Evenzoo gevoelt hij zich geheel thuis op het brakkliggend land in Java en daar hij van nature niet zeer schuw is, ziet men hem daar niet zelden vlak vóór zich de wegen of de voetpaden oversteken en, opgeschrikt door de stoornis, onder luid geroep in het kreupelhout verdwijnen.

Het vee, dat op deze terreinen zijn voedsel moet zoeken, heeft, vooral op de zonnige gedeelten, nogal van bloedzuigende Dipterc te lijden. Is dit op zich zelf voor de dieren reeds hinderlijk, de zaak neemt 
vaak een veel ernstigrer karakter aan, waar de steek van sommige dezer insecten gepaard gaat met de uitstorting van speeksel, dat ziektekiemen bevat. In het bijzonder heb ik hier het oog op de plasmodiën, die de welbekende surrah reroorzaken en tot het geslacht Trypanosoma ran de Protozoën-proep der Flagellata behooren. Onze kennis van de vliegen, in welker lichaam deze kleine organismen een deel van hun levenscyclus doorbrengen en die derhalve in staat zijn, de ziekte over te brengen, is, wat Java betreft, nog zeer verre van volledig. Wij weten nog niet veel meer, dan dat de welbekende en zeer ver verspreide Stomoxys calcitrans hier een belangrijke rol moet spelen, daarin waarschijnlijk ter zijde gestaan door andere Muscidae ran nog minder oprallend voorkomen, zooals Hclematobia exigua. Voorts rust een zware verdenking op de Tabaniden-geslachten Tabanus (soorten: rubidus, brunneus, striatus, brunnipennis e.a.), Chrysops (soolten: dispar, fasciatus, translucens, rufitarsis) en Haematopota (soorten: javana, irrorata, lumulata e.a.), maar over het algemeen zullen nog zeer omvangrijke en vooral veel plaatselijke onderzoekingen noodig zijn, róódat ook hier de zoülogische wetenschap in het belang van den veestapel (latgene zal hebben gepraesteerd, waartoe zij reeds elders in staat is gebleken.

Geheel hetzelfule gellt ten aanzien van de Teken (Ixodidae), waarran Rhipicephalus australis hier de meest algemeene vorm is. Naar alle waarschijnlijkheid speelt deze soort hier de hoofdrol bij de verspreiding van een andere Flagellat, Piroplusmu bigeminum, die de Texaskoorts reroolzaakt. Met opzet wordt hier gesproken van verspreiding en niet van overbreinging, omdat het mij niet waarschijnlijk voorkomt, dat 
een vrouwelijke teek, die zich eenmaal gedurende een zeer langdurig verblijf op haar gastheer heeft volgezogen en daarna heeft losgelaten om met haar belangrijkste functie, het leggen der talrijke eieren, te beginnen, na afloop van die bezigheid andermaal zoul gaan zuigen. Veeleer houd ik het ervoor, dat zij alsdan met het leven heeft afgerekend. De jongen echter, door de moeder met Piroplasma's bedeeld, verspreiden zich in alle richtingen, zoeken en vinden nieuwe gastheeren en brengen daardoor de ziektekiemen verder. In hoeverre Rhipicephalus australis in dit bedrijf alléén staat, is eveneens nog een open vraag; het is geenszins onmogelijk, dat nog andere soorten van hetzelfde geslacht haar daarbij helpen, ja zelfs, dat vormen als Amblyomma testudinarium, waarvan de volgezogen wijfjes soms reusachtige afmetingen verkrijgen, ten deze nog iets op haar geweten hebben.

Ten slotte spelen in dit gebied de Spinnen een belangrijke rol, vooral in zooverre zij aan de grasvlakte een eigenaardig aanzien kunnen verleenen. Ik heb hier speciaal op het oog de groep der Netspinnen (Retitelariae), waarvan wij het geslacht Theridion wel als type mogen beschouwen. Deze dieren leven op den grond en bedekken het gras over een oppervlakte van een paar vierkante Decimeter met een tamelijk dicht spinsel, in welks nabijheid zij zich verbergen en afwachten, wat het toeval hun aan buit zal bezorgen. Op het midden van den dag zijn deze spinsels zoo goed als onzichtbaar, maar in de morgenuren zijn zij bedekt met duizende kleine dauwdruppeltjes en wanneer zij dan door de nog schuin opvallende zonnestralen worden beschenen, 
doen zij zich als witte, zijde-achtige sluiers voor. Eerst dan ziet men, hoe talrijk ze zijn en hoe aanzienlijk het aantal spinnen is in dit gebied; de geheele grond is er soms letterlijk mede bedekt, een verschijnsel, dat men ook, en wel het gemakkelijkst, kan waarnemen op de, met gras bedekte hellingen der spoordijken.

Het doel, waarmede deze netten worden gespreid, is rooral het bemachtigen van de kleinere soorten van Sprinkhanen, die in het gras overvloedig voorkomen. Komt zulk een insect met zijn pooten op het net terecht, dan raakt hij daarin spoedig verward, vooral met de stekels ran de achtelpooten. Dit is voor de spin het oogenblik, om uit haar hoekje teroorschijn te komen, echter nog niet daclelijk voor den aanval. Eerst worden namelijk de pooten van den Sprinkhaan door een aantal nieuwe draden nog steviger omsponnen; zelfs het lichaam wordt veiligheidshalve aan dezelfde bewerking onderworpen en eindelijk, als de prooi volkomen weerloos is gemaakt en slechts de geleding tusschen kop en rug nog een weinig kan bewegen, onvangt hij juist op die plek een beet, waaraan hij binnen weinige oogenblikken sterft.

Het spinsel der. Retitelariae kan intusschen ook voor grootere dieren gevaar opleveren, namelijk voor de grazende runderen en geiten, wanneer deze het in eenigszins aanmerkelijke hoeveelheid met het gras naar binnen krijgen. De draden hechten zich dan aan het slijmvlies van keelholte, slokdarm en maag, waardoor verschijnselen als braken en hoesten optreden, die men aanvankelijk geneigd is aan geheel andere oorzaken, bijv. het eten van vergiftige planten, toe te schrijven. 
Het geslacht Lathrodectus van dezelfde groep wordt in de literatuur wel voor Java opgegeven, doch ik heb daarvan nooit vertegenwoordigers in handen gehad. Sommige daartoe behoorende soorten zijn overigens zeer gemakkelijk herkenbaar; ze zijn geheel dofzwart, met een overlangsche, scharlaken roode streep op de bovenzijde, en veelal een dergelijke, maar minder duidelijke streep op de onderzijde van het massieve, tamelijk ronde achterlijf. De aldus gekleurde dieren zijn, wellicht juist in verband met hun voorkomen, in vele streken zeer gevreesd, zelfs in die mate (bijv. op Timor), dat aan hun beet een doodelijke werking op menschen, en op grootere dieren, zooals paarden en runderen, wordt toegeschreven.

Ook Aardspinnen (Territelariae) komen in dit gebied tamelijk veelvuldig voor, in het bijzonder de . kleinere soorten, die tot de geslachten Calommata, Cteniza e.a. behooren. Hun taktiek komt overeen met die van hun grootere verwanten van het geslacht Selenocosmia (pag. 264), maar hun verblijf is van kunstiger constructie. Zoo maken de Calommata's een gang van een par Decimeter lengte in den grond, terwijl zij daarin een langwerpig, peperhuisvormig spinsel vervaardigen, dat men in zijn geheel uit den bodem kan trekken. Boven den grond zet dit spinsel zich een kleine eindje roort en eindigt dan in een tamelijk nauwe opening, waarachter de bewoonster geduldig op een voorbijkomend insect of ander klein dier zit te loeren. De Cteniza-soorten maken een dergelijk verblijf, maar sluiten dit van boven af door middel van een valdeurtje, dat zij eveneens zelf vervaardigen van zandkorrels of andere partikels, door hun spinsel tot een tamelijk 
stevig geheel vereenigd. Dit deurtje nu staat op een kier, die de bewoonster in staat stelt een oogje in het zeil te houden en het oogenblik voor een uitval af te wachten. 


\section{HOOFDSTUK XV.}

\section{De Fauna van het Gebied der Overjarige Cultuurgewassen.}

Bovenstaande titel is slechts kortheidshalve gekozen: er kan hier natuurlijk evenmin sprake zijn van ééne fauna als van één gebied. In de eerste plaats treedt als factor van groote beteekenis op het verbouwde gewas zelf, in verband met de diervormen, waarmede het in rechtstreeksche oeconomische relatie staat. In de tweede plaats is van grooten invloed de habitus, dien dat gewas door zijn aard aanneemt of waarin het langs kunsmatigen weg door den mensch wordt gehouden. In de derde plaats maakt het een groot verschil, of men te doen heeft met een cultuurwijze mèt, of met eine zonder schaduwboomen of boomen, die (zooals kapok) èn tot tempering van het licht, èn om hun product worden tusschengeplant.

Wij zullen daarom de verschillende overjarige culturen afzonderlijk hebben te beschouwen.

\section{Djatibosschen.}

Weliswaar draagt een aanzienlijk gedeelte van de, met djati (teak, Tectona grandis) begroeide terreinen op Java een ourspronkelijk karakter, maar het aangeplante gedeelte heeft reeds zulk een omvang verkregen, en wordt jaarlijks znodanig uitgebreid, dat wij den djatiboom wel onder de cultuurgewassen mo- 
gen rukenen. Tot in de tweede helft ran de rorige eeuw voorwerp van een even onoordeelkundige als onverantwoordelijke exploitatie, die weinig beter was dan een stelselmatige rernieling, beslaan die terreinen, dank zij beter beheer en bijplanting, thans nog een oppervlakte van ongeveer 700.000 Hectaren, derhalve meer dan de prorinciën Gelderland en Utrecht samen. De grootste complexen strekken zich uit benoorden en bezuiden een denkbeeldige, 250 Kilometer lange lijn, die Semarang met Soerabaja verbindt; in het bijzonder is de Residentie Rembang het djatiland bij uitnemendheid. In het bekende werk van wijlen den Inspecteur van het Boschrvezen J. W. H. Cornes, „De Djattibosschen op Java, hunne natuur, verspreiding, geschiedenis en exploitatie", in 1881 te Batavia verschenen, worden ook aan de fauna dezer wouden eenige bladzijden gewijd. Reeds dáár wordt erop gewezen, dat die fauna zeer arm is; het armst, war de bosschen zich mijlen ver in onafgebroken eentonigheid uitstrekken, iets rijker, waar ze afwisselen met opengekapte gedeelten, die soms ten deele door tijdelijke nederzettingen der bevolking in primitieve cultuur zijn genomen, maar ten slotte veelal weder zijn begroeid met alang-alang en allerlei heester-en boomachtige gewassen en slingerplanten. Dergelijke, dikwijls zeer uitgestrekte plekken zijn dan de eigenlijke verblijfplaatsen van vele grootere diersoorten, die zich echter op hun zwerftochten ook in het djatibosch s.s. begeven. Zij behooren, floristisch zoorvel als faunistisch, tot de tweede groep der Graswildernissen, zooals wij die op pag. 53 hebben aangeduid en onderscheiden zich daarvan slechts door de, naar alle zijden gelijke omgeving. 
De armoede van de fauna der djatiwouden wordt wel in de eerste plaats veroorzaakt door de omstandigheid, dat de djatiboom zelf, in vergelijking met vele andere planten en speciaal met het meerendeel der cultuurgewassen, slechts zeer weinig parasieten heeft. Het sterk riekende, olieachtige hout is bij de houtborende larven niet bijzonder in trek en herbergt slechts enkele, in hunne levenswijze nog onvoldoend bekende larven van de geslachten Aegosoma en Stromatium van de familie der Cerambycidae, alsmede, maar gelukkig niet zeer algemeen, de rups van de groote Cosside Duomitus ceramicus. Ook het blad oefent, vooral in ouderen toestand, slechts weinig aantrekkingskracht uit op phytophage insecten en de rupsen ran de, ook op Java voorkomende Pyralide Pyrausta machoeralis, die in Britsch-Indië dikwijls in grooten getale op de djati leven, heb ik hier slechts sporadisch erop aangetroffen. CoRDEs beschrijft in zijn bovengenoemd werk „een donkergrijze of zwarte rups, behoorende tot het geslacht Tortrix, die zich, veelal reeds kort na het ontluiken, met het celweefsel van de bladeren der djatiboomen voedt.... Zij scheiden kleverige draden af, die vooral des morgens allerwege aan de bladeren hangen, zich aan de kleederen hechten en daarop vlekken achterlaten. Men zou ze met de bekende herfstdraden der koude luchtstreken kunnen vergelijken. In weinige dagen tijds kunnen deze rupsen over groote uitgestrektheden de bladeren vernielen, waarbij het geraamte van het blad geheel, als een witachtig weefsel, overblijft." Een verschijnsel als het laatstbeschrevene heb ik slechts eenmaal waargenomen, en wel sporende door de djattibosschen in het noordelijk gedeelte der Residentie Madioen, zoodat er geen gelegenheid was voor nadere waar- 
neming, die mij wel noodig voorkomt, ook ten aanzien van hetgeen de schrijver mededeelt betreffende de vlinders. "Gewoonlijk vliegen deze vlinders dadelijk in noordelijke richting naar de streken langs de kust, alwar zij op allerlei bloemen azen, warna zij dan in zwermen weder naar het binnenland trekken om op de djatiboomen hare eieren te leggen en daarna spoedig sterven. Vooral bij avond vertoonen zich groote zwermen van die kleine kapellen." Voor een Tortricide klinkt een en ander niet zeer waarschijnlijk; ik ben echter nooit in de gelegenheid geweest, de toedracht der zaak na te gaan en bepaal mij dus ertoe, de aandacht op haar te vestigen.

Een andere bladvretende rups, die door Condes niet wordt genoemd, maar dikwijls in groot aantal op de djati is te vinden, is die ran de Noctuide Hyblaea puera. Dit vlindertje is, o.a. aan de oranje vlekken op de achtervleugels, zóó gemakkelijk herkenbaar, dat het vermoeden voor de hand ligt, dat het zich eerst in de laatste jaren op de djati heeft geworpen; want het zou anders aan een zoo ijverig waarnemer stellig niet zijn ontgaan. Een dergelijke overgang is zeer goed denkbaar; (le geliefkoosde voedsterplanten toch van deze rups zijn, zoowel hier als in andere streken (o.a. Voor-Indië), Bignoniaceae. Deze familie nu is ook in de djatibosschen vertegenwoordigd, vooral door Oroxylum (Calosanthes) indicum (een niet zeer hoogen, aldaar verspreid groeienden boom met ineterlange, platte vruchten, die dan reusachtige peulen doen denken) en de overgang, hetzij wregens gebrek aan roedsel, hetzij bij toeval, op de djati, die tot een nogal verwante plantenfamilie (Verbenuceae) behoort, is in het geheel niet onwaarschijnlijk. 
De overige insecten, die mij van de djati bekend zijn, dragen een polyvoor karakter en zijn bovendien niet talrijk; geen wonder dus, dat, waar het hoofdgewas een zoo schrale basis aanbiedt, het geheele biologische complex der djatibosschen een overeenkomstige armoede aan diervormen vertoont. De opsomming der grootere dieren, door Cordes (l.c. pag. 101-110) voor de djatibosschen gegeven, bevat dan ook overwegend meer soorten, die men er zelden of soms tegenkomt, dan die er talrijk zijn. Zoo noemt hij van de Zoogdieren als uiterst zelden: Wilde Runderen (Bos sundaicus) en Wilde Honden (Cyon rutilans); als zelden: Herten (Cervus russa), Kidangs (Cervulus muntjak), Kantjils (Tragulus javanicus) en, in verband daarmede, Tijgers (Felis tigris); als iets talrijker: Wilde $\mathrm{Zwijnen}$ (Sus vittatus en Sus verrucosus), de Apensoorten Macacus cynomolgus (monjet, kètèk, koenjoek) en Semnopithecus pyrrhus (loetoeng, boedeng, kowi) en, wederom in verband met de beide laatste, Panters (Felis pardus). Geen van deze dieren is echter voor dit gebied voldoende karakteristiek, om hier nader te worden besproken.

Hetzelfde geldt van de niet zeer talrijke vogelsoorten, die men hier tegenkomt. Het meerendeel behoort tot vormen, die wij reeds elders ontmoetten. Een enkele maal, in afgelegen gedeelten, houdt de Pauw (Pavo muticus) zich hier op, maar ook deze hoort meer thuis in de secundaire wildernissen dan in het eigenlijke djatibosch, waar hij zich, in den drogen tijd, gaarne in de kale boomen neerzet. Alles samengenomen, geldt nog thans-en wellicht zelfs in meerdere mate dan voorheen - de conclusie van CoRDES: „in het algemeen bespeurt men echter in de djatibosschen uiterst weinig van het dierlijk 
leven. Zelden komen rogels of zoogdieren zoo talrijk voor, dat daardoor werkelijk leven of stoffeering in het landschap wordt gebracht. De diepe stilte, die er heerscht, wordt slechts verbroken door menschelijke bedrijvigheid".

\section{Koffie en Schaduwboomen.}

De uitgestrekte, aaneengesloten Javakoffie-aanplantingen, zooals die zich, een twintigtal jaren geleden, in de bergstreken van Midden-en Oost-Java mijlenver uitstrekten onder de schaduw der dadapboomen (Erythrina lithosperma en variëteiten), zijn -voor een niet onbelangrijk deel verdwenen, om plaats te maken voor andere cultuurgewassen, voor een ander deel vervangen door uitgebreide aanplantingen van Coffea robusta, die vooral in de Oostelijkste Residentiën en dikwijls op geen of zeer geringe hoogte boven zee zijn te vinden. Ook de terreinen, waal koffie, hetzij als zoogenaamde catch-crop, hetzij als blijvend gewas, in vereeniging met andere culturen voorkomt, beslaan thans een grootere oppervlakte dan vroeger. Voor de onderstaande beschrijving zullen wij echter als uitgangspunt nemen de eerstbedoelde terreinen, zooals ze o. a. nog in grooten getale in de omstreken van Malang zijn te vinden.

Ook hier is de eerste indruk in geenen deele die van tropischen rijkdom aan diervormen, maar een nadere kennismaking leidt tot andere inzichten, vooral, wanneer men die aanplantingen in verschillende seizoenen heeft leeren kennen, waarbij de regentijd, zooals in den aard der zaak ligt, heel wat meer verscheidenheid heeft aan te bieden dan de droge Oostmoesson. Toch biedt ook de laatste eigen- 
aardige verschijnselen aan. In het bijzonder denk ik hier aan verschillende Lichtmotten van het geslacht Agathodes, vooral A. modicalis en de iets grootere A. caliginosalis, welker rupsen, die op de dadap leven, bij roorkeur in den drogen tijd optreden. Zij worden door de planters van Coffea arabica niet ongaarne gezien, daar hun optreden in zoo grooten getale pleegt plaats te hebben, dat er dikwijls geen blaadje aan de schaduwboomen overblijft en de zonneschijn derhalve virjelijk kan toetreden tot, en een gunstigen invloed uitoefenen op de vruchten, die alsdan in het laatste gedeelte der rijpingsperiode verkeeren. Overigens levert een koffietuin, waarvan de dadap zivaar door Agathodes-rupsen is aangetast, een eigenaardigen aanblik op door het kale geboomte, dat zich verheft uit de fraaie groene onderlaag, die door. de koffieboomen wordt gevormd, terwijl overal "herfstdraden" hangen met ontelbale rupsen, die nieuw voedsel zoeken, of een plaats, waar zij zich kunnen verpoppen.

De Oostmoesson is ook bij uitnemendheid de tijd voor de loewak-koffie; want zooals reeds op pag. 57 werd medegedeeld, is de loewak (Paradoxurus hermaphroditus), trots zijn roofzuchtigen en tamelijk bloeddorstigen aard, een groot liefhebber van geheel of bijna rijpe koffiebessen. waarvan hij slecht schil en vruchtvleesch verteert. De ziden, de eigenlijke „koffieboonen” derhalve, verlaten het lichaam geheel "gepulpt" en zijn, tot de bekende hoopjes rereenigd, dikwijls in groote hoeveelheid in de aanplantingen te vinden. Het zijn niet alleen de zuinige planters, die de, op deze wijze bereide koffie als een deel van hun oogst beschouwen, maar er zijn er ook, die ze bij roorkeur voor eigen gebruik bestemmen, 
aangezien ze zich in smakk gunstig zou onderscheiden.

Over het algemeen echter is de Oostmoesson in deze gedleelten ran Java een periode ran kalmte op op het gebied van dierlijk leven, aan welke eerst door de najaarsregens een einde wordt gemakt. Een nieuwe uitloop ran de dadap trekt dan niet zelden dadelijk een ander geslacht ran Lichtmotten aan, tamelijk nauw verwant aan Agathodes, maar in levenswijze geheel verschillend. Het is Terastia, in dit gebied hoofdzakelijk door de soorten egialialis en meticulosalis rertegen woordigd, welker rupsen naar hun wijze van optreden behooren tot een biologische groep, welke men die der semi-boorders zou kunnen noemen en waartoe ook de vroeger (pag. 282 en 291) besproken rups van Heliothis armigera kan worden gerekend. Want terwijl zij zich voor een deel met bladmoes voeden (en, zoo noodig, ook uitsluitend daarvan kunnen leven), maken ze van tijd tot tijd een meer of minder diepen gang in jonge twijgen of ander zacht en saprijk weefsel. Hierdoor vernielen zij de aangetaste plantendeelen meestal totaal, terwijl in het geval van deze Terastia's dikwijls van de dool hen gedoode toppen een diepgaande verrotting van het merg uitgaat. In den regel weet de dadap zich van zulk een aanval weder te herstellen, gelijk in het algemeen aall dezen boom een groote taaiheid en een merkwaardig regeneratie-vermogen moeten worden toegekend. $\mathrm{Er}$ is misschien geen andere boom, waaraan de insectenwereld op zoo hevige mate zijn krachten beproeft; want behalve de reeds genoemde zijn er nog een aantal andere parasieten, waarvan sommige vrijwel constant aanwezig zijn. De meest geduchte daarvan zijn wel de larven van 
Batocera hector (pag. 126), die, hoewel ze ook leven in de takken en stammen van nootmuskaat (Myristica fragans), kapok (Eriodendron anfractuosum), kajoe koeda (Odina gummifer $a$ ) en andere, op Java algemeen aangeplante boomsoorten, toch aan het hout van dadap de voorkeur schijnen te geven. Vandaar, dat men in dit gebied de volwassen kevers veelvuldig aantreft; zij zitten overdag rustig tegen de takken, knabbelen wel een weinig aan den bast, maar doen overigens niet veel kwaad en zijn een geliefkoosde prooi voor rondzwervende kraaien. Deze maken gewoonlijk een luid misbaar, wanneer ze er een hebben ontdekt en voeren een soort van kannibaalschen vreugdedans uit, voordat zij den kever grijpen. Er volgt dan een even hevige als ongelijke strijd, waarvan het einde niet zelden is, dat de kever nog een gedeelte van zijn lichaam, namelijk kop en thorax (maar den laatste van de vleugels beroofd) weet te redden, doch natuurlijk weldra aan de verminking bezwijkt en dan een prooi wordt van mieren en andere opruimers van overblijfselen ran dierlijken aard. Als men nu bedenkt, dat de larven dezer Batocera vingergroot worden en dat één enkele boom soms een vrij groot aantal ervan herbergt, dan staat men inderdaad verbaasd erover, dat hij niet alleen nog in leven is, maar er dikwijls nog vrij welvarend uitziet. Slechts éénmaal heb ik waargenomen, dat een dadapboom door ééne larve was gedood, maar hier was de schuldige de reusachtige larve van den Atlaskever (Chalcosoma atla.s), een boschinsect, dat in een naburige aanplanting was verdwaald. De boom was aangetast even beneden den grond en het engerling-achtige dier, vermuedelijk wel de grootste insectenlarve van Java, had 
hem ter hoogte van den wortelhals rrijwel geheel uitgehold.

Zelden ontbreekt roorts op de dadap een kleine, geel groenachtige Jasside van het geslacht Typhlocyba, die in aantal vergoedt, wat ze in afmetingen te kort komt. Bij duizenden vliegen deze diertjes soms op, wanneer men een aangetasten tak schudt, maar bijna op hetzelfde oogenblik zetten zij zich weder op haar gewone rustplaats, de onclerzijde der bladeren in de nabijheid der nerven. Bij de koffieplanters algemeen bekend onder den naam "dadapvliegje", geeft deze diersoort aan de bladeren een herfstachtig roorkomen. De laatste verbleeken eerst ondel den invloed der ontelbare wondjes, die over hatr geheele ondervlakte worden toegebracht; darrna worden ze bruin, verdrogen en vallen af.

Een andere Rhynchote is minder-algemeen, mar kan zich nu en dan in ongeloofelijke hoeveelheden op de dadap vertoonen. De bedoelde is een rij groote Schildwants, Cyclopelta obscura, die rooral in West Java huist, terwijl het feit, dat zij in verschillende bergstreken der Preanger Regentschappen met den afzonderlijkén niam lapi pihi wordt aangeduid, reeds bewijst, dat zij zelfs de aandacht der inlanders heeft getrokken. Het voor den boom meest ruïneuze van haren molus operandi komt overeen met dat van meerdere andere Wantsen (o.ג. Tectocoris cyanipes, pag. 2S9), namelijk het bij elkaar blijven der jonge larven, wardoor ringvormige baststukken worden vernield en de daarboven gelegen takgedeelten gedood. Ik heb wel eens jonge aanplantingen gezien, waarin alles wat boven de koffie uitstak, geheel was afgestorren en waar de dieren, bij gebrek aan beter, 
genoodzaakt waren, hun krachten aan de koffie te beproeven. Dat bekwam hun echter slecht en daardoor verdwenen ze op even geheimzinnige wijze, als ze waren gekomen. In het optreden toch ran zulke enorme hoeveelheden exemplaren eener diersoort, waarvan men onder gewone omstandigheden naurelijks iets bemerkt, is nog veel duisters. Men kan in het algemeen spreken van verbreking ran het evenwicht in de natuur, maar de oorzaken, die tot die verbreking leiden en die, welke het erenwicht weder herstellen, laten zich slechts zelden met eenige zekerheid aanwijzen, de laatste niteraard iets gemakkelijker dan de eerste, die gewoonlijk reeds hebben uitgewerkt vóórdat het geheele verschijnsel onze aandacht trekt. De koffiecultuur heeft op dit gebied een aantal interessante roorbeelden aan te wijzen, waarvan het meest bekende wordt geleverd door Oreta extensa, een nachtvlindertje van de familie der Drepanulidae, waarvan de rups in Midden- en in OostJava, althans in de koffiestreken, algemeen onder den naam oelar tjèlèng (varkensrups) bekend staat, wellicht vanwege het staartrormige achtereinde ran het abdomen, dat bovenwaarts is gekruld. Dit insert behoorde oorspronkelijk natuurlijk thuis in de bosschen, die, vooral voorheen, de koffie- aanplantingen zoo nauw omgrensden en de rupsen voedden zich aldaar met de blaren van Ixora-en Pavetta-soorten van de familie der Rubiaceae. Toen echter de mensch de onvoorzichtigheid beging, in de onmiddellijke nabijheid groote uitgestrektheden met een andere soort van dezelfde familie te gaan beplanten, bleren de gevolgen niet achterwege. Een in den aanvang wellicht niet meer dan toevallige invasie bracht deze Oreta in omstandigheden, die roor hare ontwikkeling zoo onge- 
meen gunstig waren - op schadelijke insecten werd in de gouden dagen der koffiecultum nog niet reel acht geslagen -, dat aanvankelijk niets in staat was, aan haar vermenigvuldiging paal en perk te stellen. Gedurende vele jaren heeft, zij daardoor roor deze cultuu een elnstig gevaar opgeleverd, maar de oorzaken van het verdwijnen daarvan laten zich met even groote zekerheid aanwijzen als die van het ontstaan. Een vrij groote Sluipwesp namelijk, Theronia (Pimpla) concinna, heeft zich op de Oreta-rupsen gervorpen, in deze op hare beurt een gelegenheid tot vrijwel ongelimiteerde vermenigruldiging gevonden en ten slotte weinig minder dan haar ondergang berverkt. En zoo ik hier nog een tweerle oorzaak mag noemen, die den mensch in zijn kwaliteit van animal erectum, bipedum, bimanum (de diagnose ran Lixnaeus) binnen het kader van dit boek brengt, dan was die gelegen in de, destijds (ik spreek van een twintig jaren geleden) ook bij de planters in de tropen langzamerhand veldwinnende overtuiging, dat men zelfs hier wel eens iets tegen de vijanden ran zijn gewas moet ondernemen. Na het repressiere optreden der zuoeren genoemde Theronia's bleef echter weinig anders vrer dan het nemen ran praeventieve maatregelen en deze bestonden hier en daar in het uitloven van een niet onaanzienlijke premie voor de eerste l'ups, die in elke maand zou worden aangebracht. Hierbij had men echter geen rekening gehouden met het bestaan van rerschillende rassen bij de soort Homo sapiens en terwijl nu het ééne ras den strijd tegen Oreta extensa op krachtige wijze meende aan te binden, maakte het andere de larren daarvan op de meest bedriegelijke wijze na van gekauwde tabak. 
Een ander voorbeeld van het, in dit gebied, plotseling in sterke mate op den voorgrond treden eener diersoort werd, in ander verband, reeds genoemd in het Tweede Hoofdstuk (pag 26) en wordt nu en dan geleverd duor de kleine, gele Piëride Terias hecabe. Hier ligt de oorzaak minder duidelijk voor ons. De rupsen van dit Kapelletje eten gaarne de blaadjes van Albizzia moluccana, A. stipulata en andere Leguminosen, waarvan vooral de eerste in West-Java veel als schaduwboom werd aangeplant. Dit zou, op gelijke wijze als bij Oreta extensa, haar sterke vermenigvuldiging kunnen verklaren, wanneer die slechts éénmaal had plaats gehad, maar het bedoelde geval heeft zich bij deze diersoort herhaaldelijk voorgedaan en daarbij moeten dus invloeden in het spel zijn geweest, die zich niet zoo gemakkelijk laten aanwijzen. Overigens schijnt het evenwichtsherstel ook hier weder plaats te hebben door de werkzaamheid van een Sluipwesp en wel een Chalcis-soort, waarvan men de talrijkheid ten opzichte der vlindertjes zeer gemakkelijk kan nagaan. De verpopping dezer Terias heeft namelijk, in perioden als de bedoelde, plaats in lange rijen langs takken en kaalgevreten bladnerven, waaraan na het uitkomen der volwassen insecten, vlinders zoowel als parasieten, de leege pophuiden nog langen tijd aanwezig blịjen en door de wijze, waarop ze zịn opengegaan (de wespen maken een ronde opening aan één der zijden), duidelijk aangeven, welke hun laatste inhoud was.

Wij hebben nog even terug te komen op de dadap, die ook voor verschillende Coccidae een geliefkoosde verblijfplaats is. Vele daarvan zijn omnivoor en roepen hier gelijke verschijnselen in het leven als elders; een paar echter vereischen afzonderlijke 
aandacht. In de eerste plaats de, roor een Schildluis bijzonder groote Pulvinaria maxima, die niet alleen zelve een lengte van één cil. kan bereiken, maar bovendien eierzakken voortbrengt, helderwit van kleur en langwerpig van rorm, die tot $2 \mathrm{cM}$. lang kumnen worden en reeds op een afstand zichtbaar zijn. In de tweede plats. Aspidiotus pustulans, die op takken en stammen pokachtige opzwellingen veroorzaakt, in het midden waarvan de luis, in een ondiepe inzinking ligt ingebed. Eindelijk Lecanium tenebricophilum, die, zooals de soortnaam aanduidt, in het duister leeft en wel in het inwendige ran takjes, die door andere insecten (o. a. Terastia's) zijn uitgehold, maar daardoor nog niet zijn gedood. Zij leven daar in gezelschap van talrijke mieren, zijn bruin, halfkogelrormig en moeten reeds, hetzij zelfstandig, hetzij door de mieren aangedragen, als larven in hun verblijfplaats zijn gekomen, daar de gaatjes, die men in de takken waarneemt, reel te klein zijn om den rolwassen luizen doorgang te rerleenen.

Vele der op de dadap levende Schildluizen verraden hume aanwezigheid reeds door den roetdauw, dien ze ook op de koffieboomen veroorzaken. Dezen laatsten ontbreekt het echter in geenen deele aan eigen bewoners, die lietzelfde doen en daarvan is Lecanium viride de meest algemeene. Hoewel polyroor van nature, heeft deze Schildluis een groote voorliefde voor verschillende koffiesoorten en bewoont de aanplantingen niet zelden over aanzienlijke uitgestrektheden, waarbij ze een samengesteld biologisch geheel in het leven roept. Plantaardige en dierlijke parasieten volgen hadr op den roet. Nu eens vinden wij hadr 
omkransd door eell fijn kleed van witte schimmeldraden van nog onbekende, systematische plaats, die straalsgewijze onder haar schild te roorschijn komen en de bladoppervlakte rondom har begroeien; dan weder valt ze ten offer aan een andere schimmelplant, die haar, zooals een Aschersonic- soort, in een vormlooze, roode massa verandert, of, zooals eene Empusa, achtereenvolgens wit, grijs en zwart maakt. Sluipwespjes van het geslacht Encyrtıs, nauwelijks een mM. groot, maar toch in het oog vallend door het heldergele schildje, bewegen zich ijverig op de blaren der door Lecanium viride bewoonde boomen. In elke luis wordt slechts één ei gelegd, daar het kleine lichaam voor niet meer dan één larve tot voedsel zou kunnen strekken. Heeft deze straks haar vollen wasdom bereikt, dan rerpopt zij zich onder het schild van haar gastheer. Weldra schijnt dan het zich ontwikkelende, donker gekleurde lichaam van de wesp door het schild heen en iets later wijst een klein, rond gaatje daarin de plaits aan, waal de parasiet is uitgevlogen.

Sneller dan door deze inwendige parasieten, worden de luizen gedecimeerd door allerlei carnivore insecten. Daar zijn in de eerste plaats allerlei Coccinellidat de kleine Thea cincta, de roode Chilomenes sexmaculata, Chilocorus melanophthalmus e. a., allen ran den gewonen habitus der Lieveheersbeestjes, die hiel met hun larven een ruim bestaan vinden madr, naar het mij voorkomt, het in roofzucht afleggen tegen den staalblauwen Orcus janthinus, die, in samenwerking met zijn lichtgroene, van fijn vertakte stekeltjes voorziene larven, hier in oeconomisch opzicht wel de grootste rol speelt.

In de tweede plaats zien wij de bloedzuigervor- 
mige larven van allerlei Syrphidae zich tusschen de luizen bewegen. Sommige soorten oefenen hun rooversbedrijf open en bloot nit, andere bedekken ziclı het lichaam met de leeggezogen huiden hunner slachtoffers en stellen zich op die wijze terens een omhulsel roor de verpopping samen. Een der meest algemeene vormen is hier Helophilus pilipes, maar ook het gestacht Syıphus is hier door vele soolten van allerlei grootte vertegenwoordigd, reeds als verschillend te onderscheiden, als ze zich in den zomneschijn zwerende houden. Eindelijk de Gaasiliegen, welker aanwezigheid reeds wordt aangeduid door de eieren, die ook hier op de, bij het geslacht Chrysopa en zijn verwanten gebruikelijke wijze, op fijne, rvitglinsterende draden worden geplaatst. Soortnamen vallen hiel nog niet te noemen, want weinig insectengroepen zijn op .Tava-en trouwens ook elders-door de entomologen zoo weinig bestudeerd als deze.

Niettegenstaande dit heirleger van vijanden, dat men het best op een zonnigen morgen in den regentijd voltallig bijeen kan vinden, weet Lecanium viride zich hardnekkig staande te houden. Beter dan de grootere, hoog'gewelfde, bruine Lecanium hemisphaericum en dan rerschillende Ichnaspis- en Diaspissoorten, die zich hier nu en dan vertoonen, beter zelfs dan de geduchte Icerya purchasi, die hier ook reeds een enkele maal heeft gedreigd, houdt zij in dit gebied de eer harer familie op.

Bladluizen zijn in dit gebied niet ran reel beteekenis en ook Wantsen spelen, met uitzondering van de reeds genoemde Cyclopelta obscura, een ondergeschikte rol. Pentatoma plebeja vindt men nu en 
dan zuigend aan de rijpende bessen en aan de jonge takjes, welker merg ten. gevolge daarvan een roodachtige kleur verkrijgt. Interessantel is, hetgeen sommige Dalpada-soorten, vooral $D$. versicolor, te zien geven. Ook deze Wantsen zuigen aan de jonge, nog groene of althans nog groenachtige takken en veroorzaken daarop overlangsche, zwarte strepen. Maar bovendien schijnt de speekselachtige vloeistof, die zij vóór en tijdens het zuigen in de plant brengen, op die takken een zeer giftige werking te hebben. Men ziet deze alsdan spoedig verwelken, verkleuren, diarna verdrogen en ten slotte zwart worden, zoodat ze er als verkoold uitzien. Kort vóór dit laatste stadium vertoonen ze bovendien een zóó groote gelijkenis met een der phasen der djamoer oepasziekte (door Corticium javanicum veroorzaakt), dat men zich hier gemakkelijk in de oorzaak van het rerschijnsel zou vergissen.

Een der verschijnselen, die in dit gebied ook den minst zoölogisch onderlegden bezoeker opvallen, zijn de glinsterende gangen, die vooral op het blad der Javakoffie zichtbaal zijn en gemaakt worden door de larven van een klein vliegje van het geslacht Oscinis. Deze graven, door het bovenste gedeelte van het bladmoes weg te vreten, onder de epidermis een breeden, platten gang, die sterk gekronkeld is, dikwijls in zich zelf terugkeert en eindigt in een verbreed gedeelte, waar de verpopping plaats heeft. Evenals bij de mineerende rups van Phyllocnistis minutella, die wij vroeger (pag. 155) bij de Citrussoorten ontmoetten, wordt ook hier dikwijls gedacht aan de nagelaten sporen eener slak. Overigens is deze Oscinis vrijwel het eenige Dipteron, "dat hier 
eenigszins op den voorgrond treedt; bijna alle overige soorten, die hier als gerroon vallen waar te nemen, zijn vormen der cultuurfauna, die men ook elders kan tegenkomen. Slechts eenige groote Bombylidae zullen straks in ander verband ter sprake komen.

De rupsen, die men naast de reeds besproken soorten in dit gebied kan aantreffen, zijn vele, maar een groot aantal ervan is van tamelijk omnivore natuur. Spanrlipsen zijn ook hier zeldzaam, maar toch niet meer in die mate als in de oudere cultuurstreken. Zoo ontmoet men hier o.a. Hyposidra talaca en $H$. infixaria als rormen, die blijkbaar bezig zijn in de cultuurfauna over te gaan. Op de dadap treden nu en dan in groot aantal op de kleine rups ran Striglina scitaria, een Thyridide, die, door het bewonen van een, eerst half losgebeten en daarna opgerold gedeelte van de bladischijf een gemakkelijk te herkennen gast is; de groote, logge rups van den Atlasvlinder (pag. 140), waarvan een paar exemplaren in één nacht een boom kunnen kaalvreten; de fraaie rupsen van Hypolimnas misippus (pag. 133), waarran men de rlinders dicht bij den grond in den zonneschijn kan zien spelen. In de koffietakken is een zeer gewone gast de nonol, de roode rups van Zeuzera coffecae, die in jongen toestand haar aanwezigheid rerraadt door het rerwelkte uiteinde ran het takje, waarin zij zich bevindt, terwijl later een dikkere tak, dien ze ria den stam pleegt te bereiken, gewoonlijk afbreekt op de plaats, waar de nitvliegopening wordt gemaakt en de ledige pophuid nog een tijdlang zichtbaar blijft. De Liberia-koffie is roorts een nogal geliefkoosde verblijfplaats voor de Psychide Eumeta variegata, terwijl eindelijk, in het 
bijzonder op Java-koffie, eenige Slakrupsen vrij veelvuldig voorkomen, vooral Parasa bicolor, met den inlandschen naam oelar sệ̣̂t aangeduid en terecht gevreesd om de hoogst pijnlijke gervaarwording, die men bij de geringste aanraking met haar stekelige haren ondervindt. Het is zelfs voorgekomen, dat het werkrolk weigerde voor het binnenhalen ran den oogst tuinen in te gaan, waarin deze dieren op dat oogenblik voorkwamen, aangezien men bij het plukken natuurlijk zeer licht met handen of armen ermede in aanraking zou komen.

Van de, in dit gebied algemeen roorkomende kerers werd hierboven reeds Batozera hector genoemd. Een andere Boktor, Xystrocera festiva, komt meer voor in de aanplantingen in West-Java en in het algemeen dáár, waar Albizzia als schaduwboom wordt gebruikt, voor welken boom zijn larren een zeer geprononceerde voorliefde hebben. Van deze keversoort vindt men soms volwassen, maar zeer weekhuidige exemplaren in gangen, die geen directen uitgang naar buiten hebben en het lijkt mij niet onmogelijk, dat hier het paren en het voorbrengen van een nieuwe generatie wel eens plaats hebben, zonder dat de volwassen dieren het zonlicht aanschouwen. Een tweede, eveneens zeer algemeene bewoner der $A l$ bizzia-stammen is de larre der Buprestide Chrysochroa fulminans, die echter eerst op lateren leeftijd in het hout doordringen en geruimen tijd ter hoogte van het cambium vertoeven, waar zij zich aan de weeke, jongste lagen van het hout te goed doen. Op die plaatsen sterft de bast niet zelden over groote uitgestrektheden af, droogt op, krult binnenwaaits om en valt eindelijk af, waarbij dan duidelijk de 
openingen zichtbaar worden, waardoor de reeds rij groote larven naar binnen, in het hout, zijn gedrongen. Maar vóór het binnendringen vallen ze niet zelden ten prooi aan Spechten, inzonderheid aan de fraaie Tiga javanensis (platok bawang), die met de lerenswijze dezer Chrysochroa-larven blijkbaar goed bekend is en welker eigenaardig gehamer in de, met Albizzia beschaduwde aanplantingen een zeer gewoon geluid is. Intusschen houdt ook deze specht zich in geenen deele steeds even getrouw aan het diëet, dat roor hare familie als normaal wordt aangenomen, maar waarop (wij zagen het reeds vroeger) nogal uitzonderingen schijnen te bestaan. Feitelijk eet zij alles, wat ran dierlijken aard binnen haar bereik komt. Zoo rond ik bij rerschillende gelegenheden in haar maag niet alleen overblijfselen van Schorpioentjes, Oorwurmen, Kakkerlakken en dergelijke dieren, die zij nog wel onder een of anderen bast of in opengehamerd, dood of rottend hout kan hebben geronden, maar bovendien groote Mieren, cocons van Vlinders, pas uitgekomen Tliegen en Kerer's en zelfs rupsen, wat er wel op wijst, dat zij allerlei roedsel roor lief neemt, ook, wanneer ze niet op de gebruikelijke wijze ervoor behoeft te werken.

Het is hier de plats om met een enkel woord terug te komen op het, reeds in het Derde Hoofdstuk (pag. 40) genoemde verschijnsel ran het periodiek in grooten getale optreden van Bladsprietige Kevers, aangezien dienangaande in dit gebied meer warnemingen werden verricht dan elders. Borendien doet het zich hier - th dan speciaal op de terreinen in Oost-Jara, die wij als uitgangspunt dezer beschrijving atannamen- in zeer sterke mate roor. 
Aan het einde toch van den dikwijls langen Oostmoesson, wanneer de eerste regens in den bodem doordringen, doen deze aldaar een heirleger van Lamellicornia uit den poptoestand ontwaken, die zich weldra in de aanplantingen verspreiden en zich bij voorkeur met het malsche dadapblad voeden. Het zijn vooral de grootere vormen, die een jaar of langer voor hun ontwikkeling tot volwassen insect noodig hebben, welke zich dan vertoonen: Anomala jurinei, $A$. chalcites, $A$. aerea e.a; de grootere suorten van Lachnosterna, Haplidia en Ancylonycha; Exopholis hypoleuca, Lepidiota stigma en Tricholepis grandis, alle reeds op pag. 122 genoemd als cultuu vormen bij uitnemendheid. Men kan deze dieren soms bij honderdtallen van een enkelen dadaptak schudden en behoeft zich niet erover te verwonderen, dat zij weldra, in den bodem, het aanzijn geven aan een nakomelingschap van engerlingen, zóó talrijk, dat de welstand der aamplantingen daardoor niet zelden ernstig wordt bedreigd. Want veel natuurlijke vijanden hebben deze larven op Java niet; ziekten, door Isaria, Botrytis, Cordiceps en dergelijke parasietische schimmels veroorzaakt, werden hier tot dusverre niet of slechts sporadisch waargenomen, terwijl ze door hunne levenswijze buiten het bereik blijren van Sluipwespen en Tachinidae. Er is mij slechts ééne Wespensoort bekend, die ze aanvalt, nl. de Graafwesp Elis lindenii (pag. 167). Deze weet in haar onderaardsch verblijf door te dringen en daar een ei te deponeeren, waaruit zich een larve ontwikkelt, die den geparalyseerden engerling te lijf gaat en langzamerhand verorbert. Maar op hare beurt valt de wespenlarve nu en dan ten prooi aan een parasiet van de tweede orde, de made van 
Exoprosopu tuntalus, een groote donkergekleurde Bombylide, die men, evenals een parr rerwante rormen, niet zelden in snelle, stoere vlucht dicht bij den grond door de tuinen ziet zweven, blijkbaar op jacht ten bate harer nakomelingschap. Het is mij echter nooit gelukt wadr te nemen, hoe zij haar eieren krijgt op de plaats, waar zij ze hebben wil; slechts het opkrveeken van toevallig verkregen materiaal heeft mij tot de kennis van het bovenstaande gebracht, terwijl, wat de Wespen betreft, het wel waarschijnlijk is, dat ook andere Elis-soorten en soorten van het nauwverwante geslacht Scolia hun larven ten koste van engerlingen een bestaan bezorgen.

In koffietuinen, waarin, in den vorm van stronken en rottende stammen, nog veel overblijfselen van het rroegere bosch aanwezig zijn, treft men in den bodem dikwijls vrij ruime, ronde gaten aan, waarin zich groote, zwarte, glinsterende kerers van het geslacht Passalus ophouden; men vindt ook niet zelden overblijfselen van de doode dieren. Daar de engerlingvormige larven der Passalidae zich vrijwel uitsluitend met rottend hout voeden, komen deze kevers natuurlijk minder veelvuldig of in het geheel niet voor op terreinen, die reeds lang in cultuur zijn geweest.

Hetzelfde geldt van de Lucanidae, die in dit gebied vooral zijn vertegenwoordigd dool Aegus acuminatus, in mindere matedoor Odontolabisbellicosus, Eurytruchelus bucephalus, Hexarthrius rhinoceros, Dorcus parryi en andere, algemeen bekende volmen van de Javaansche fauna, voor welke eigenlijk weinig aanleiding bestaat om het bosch te verlaten, aangezien ze daar steeds, 
zoowel voor zich als voor hunne larven, uitnemende levenscondities aantreffen.

Andere rormen van Kevers, dan die in het bovenstaande werden besproken, treden in de koffie-aanplantingen niet of zelden op den voorgrond. Aan de bladeren knabbelen nu en dan allerlei Chrysomelidae, terwijl de bladranden dikwijls beschadigd worden door Curculionidae, zooals Myllocerus isabellinus, Hypomeces curtus, Rhinoscapha amicta e.a. meer of minder gewone vormen. Bovendien kan men hier en daar de werkzaamheid constateeren van Bastkevertjes, waarvan vooral Robusta-koffie nogal eens te lijden heeft en waarbij zich weder het op pag. 21 terloops genoemde geval voordoet, dat men, in een vrij kleine holte, in de dunnere takken gemaakt, alle ontwikkelingstoestanden van het insect, in dit geval Xyleborus coffeae, bij elkander kan aantreffen.

Eindelijk ziet men nu en dan de jonge takeinden verwelkt of afgestorven door de werkzaamheid der overigens nuttige, of althans niet schadelijke larven van Cicindeliden van de Collyris-groep, die zich daarin een zeer langwerpige holte boren en voor de opening. erran op vorbijwandelende insecten zitten te loeren. Deze, roor Roofkevers tot dusverre vrijwel op zich zelf staande handelwijze is waal'genomen bij Collyris emarginata, C. tuberculata en Tricondyla cyanea, maar het is niet onwaarschijnlijk, dat nog meer soorten uit dezelfde groep in haar jeugd een overeenkomstige levenswijze hebben, waarbij ze natuurlijk even goed andere planten tot woonplaats kunnen kiezen. 
Het in de voorgande bladzijden geschetste, biologische geheel ontleent, zooals rool de hand ligt. een aanzienlijk deel ran rijn vrij samengesteld karakter aan de omstandigheid, dat meer dan ééne plantensoort op hetzelfde terrein wordt gekweekt en waar schaduwboomen boven andere cultuurgewassen dan koffie worden gebezigd, kan men derhalre soortgelijke toestanden antrefien, zonder dat daarop later in dit werk zal worden teruggekomen. Hebben wij ons echter tot dusverre bijna uitsluitend met de insecten in dergelijke beschaduwde aanplantingen opgehouden; ook andere diergroepen vereischen een oogenblik onze aimdacht.

Zoo zijn zeer karakteristiek ervoor de vele Doornspinnetjes, die er, bij voorkeur ongeveer op manshoogte, hun rebben uitspannen. Vooral de kort en middelmatig lang gedoornde Gasteracantha- soorten (leucomeluena, brevispina, praetextata, roseolimbata e.a.) treden hier niet zelden in hinderlijke mate op.

Van de Zoogdieren kan hier, naast den reeds besproken Paradoxurus hermaphroditus, in de eerste plaats vorden genoemd de rassi (dèdès in West-Java, Viverricula malaccensis), door de afwisselende, zrvarte en lichtgrijze lingen van den staart reeds op een afstand ran den loevoak te onderscheiden. Ook dit roofdier is voor een deel planteneter en maakt zich wél eens schuldig aan het afvreten ran rijpe koffievruchten, maar toch in veel mindere mate dan zijn verwant, terwijl hij verder niet alleen op warm. bloedige dieren jacht maakt, mar ook genoegen neemt met groote insecten en insectenlarren.

Dat grootere Rooflieren, zelfs Tijgers, de oudere aamplantingen, vooral de eenzame en afgelegen gedeelten erran, wel eens onveilig maken, is een be- 
kend feit. Evenzoo, dat ze daarheen worden gelokt door Herten, Dwergherten en Wilde Zwijnen, die er op hunne beurt iets van hunne gading kunnen vinden, de beide eersten in het hoog opschietende gras van afgeschreven plekken, de laatsten in de rette enger. lingen en aardwormen in den bodem. Maar deze allen zijn toch niet meer dan zwerver's, evenals de Apen, die zich vaak aan de jonge dadapblaren te goed doen. Vaste bewoners kunnen slechts zijn eunige kleinere diervormen, waartoe o.a. de Tupaja's (toepai) behooren. Deze sierlijke, op kleine Eekhoorns gelijkende Insecteneters zijn in dit gebied geen zeldzame verschijning; men ziet ze dikwijls op de takken der koffieboomen loopen, roortdurend in levendige beweging alle hoekjes en gaatjes doorsnuffelend, waarbij ze nu en dan hun schel geroep doen hooren, waaraan rermoedelijk de Soendaneesche naam kètiès is ontleend. Tupaja javanica is hier de meest algemeene soort, T. ferruginea, iets grooter van stuk, is minder veelruldig. Ook hun diëet is van gemengden aard en het is wederom de rijpe koffiebes, die een deel ervan uitmaakt, ja, hen wellicht ertoe heeft gebracht de boschranden, waarin ze feitelijk nog thuis behooren, voor een deel te verlaten en hun geluk in het cultuurgebied te beproeven.

Een andere, kleine Zoogdierrorm, die zich nog: slechts nu en dan in de eenzame gedeelten dezer aanplantingen waagt, is de zonderlinge Hylomys suillus, die tot de familie der Egels wordt gebracht. mar, zooals door zijn soortnaam reeds wordt aangeduid, eenige overeenkomst met een varkentje rertoont.

Echter in duodecimo, want zijn totale lengte is niet meer dan $14-15$ cil., terwijl de lengte van het dunne, kale staritje niet meer dan één cM. bedraagt. Het 
zijn zoowel de habitus ran het dier in het algemeen, als, in het bijzonder, de verlengde, aan het uiteinde een weinig opwaarts gebogen neus, die deze gelijkenis in het leven roepen. Overigens is deze Hylomys in hoofdzaak een bewoner van laag geboomte en struiken, waarop hij in de jacht op allerlei insecten een bestaan vindt.

Ook de Vogelwereld geeft hier eenige vormen te zien, die wij elders nog niet ontmoetten. Twee ervan trekken reeds door hun stemgeluid van verre onze aandacht: Trachycomus ochrocephalus en Cyanops lineata, beide ook als kooivogels welbekend onder de namen resp. van tjitjarawah en boeltok. De eerste is een van de beste zangers van Java, met een vol en krachtig geluid. Weliswaar heeft hij het bosch nog niet geheel vaarwel gezegd, maar men mag wel aannemen, dat hij den overgang tot de cultuurfauna grootendeels reeds achter den rug heeft. Deze aansluiting aan den mensch is hem echter slecht bekomen; want zijn hooge waarde als zangrogel heeft hem van diens zijcle aan zulk een vervolging blootgesteld, dat hij hier en daar viijwel is uitgeroeid.

Den tweede heb ik nooit in het bosch gehoord, steeds erbuiten en hier en daar zóó aanhoudend en in zóó groot aantal, dat men den dieren gaarne eens een tijdlang het stilzwijgen zou opleggen. Het gewone geroep, waaraan de naam boeltok is ontleend, is nog wel an te hooren, maar moeielijker voor's menschen geduld te dragen is zijn, langdurig, gerekt, rollend gefluit, dat eenigszins gelijkt op het van verre gehoorde gefluit van een locomotief en wordt gevolgd door het, met korte tusschenpoozen kortelijk, maar soms in het oneindige, herhalen van den denzelfden 
toon, een gewoonte, die trouwens den meesten Bardvogels eigen is. Als kooivogel is hij overigens, o a. door zijn eigenaardige bewegingen, rooral die van kop en hals, alsmede door de gewoonte, liefst in een stuk bamboestengel van een paar Decimeter lengte te slapen, wel de observatie waard; als bestanddeel der fauna is hij vooral karakteristiek roor aanplantingen met opgaand geboomte en dan in het bijzonder in de streken boven $1000-1200$ voet.

Als vogels, die de aandacht trekken door hun fraai vederkleed, kunnen voor deze aanplantingen, wanneer ze niet te ver van de bosschen zijn verwijderd, worden genoemd de beide Pericocrotus-soorten miniatus en exsul, waarvan de laatste tot aanzienlijk lager streken afdaalt dan de eerste. Deze Rupsvogels (Campophagidae) vallen des te meer in het oog, omdat zij de gewoonte hebben, in dikwijls vrij talrijke koppels rond te trekken en daarbij voortdurend een zacht, meesachtig: gepiep te doen hooren. $P$. miniatus, voor een deel zwart met hier en daar een indigoblauwen weerschijn, voor het overig'e schitterend vermilloenrood, komt in laatstgenoemde kleur orereen met de bloemen ran de dadap, waartusschen de koppels zich gararne bewegen. $P$. exsul, waar de mannetjes op de niet zwart gekleurde deelen helder oranje, de wijfjes citroengeel zijn, levert een niet minder fraai gezicht op, wanneer de dieren met vlugge bewegingen in het geboomte hun voedsel zoeken. Beide soorten verkeeren in den toestand van overgang; dien hun vroeger (pag. 238) besproken verwant Pericocrotus peregrinus reeds geheel achter zich heeft en waarin de soort exsul aan miniatus weder een aanzienlijk eind schijnt vóól te zijn. 
Een fraaie rogel, die zich in dit gebied en ook in de daarin rerspreide kampongs ophoudt, is voorts Microtarsus melanocephalus, een groen en zwart gekleurde Ixodide, die gemakkelijk is te herkennen aan den afgezonden staart en de zeer verlengde, bovenste staartdekveeren. Hij is veel algemeener dan M. chalcocephalus, bij welken alle deelen, die bij de eerste soort groen zijn, een teere, blaıwgrijze kleur hebben. Overigens is de kleurverdeeling bij beide soorten zoo geheel dezelfde, dat men de ééne bijna voor eene variëteit van de andere zou kunnen houden.

Een vorm, die noch door geluid, noch door roorkomen de aandacht trekt, is de kleine Prionopide Hemipus obscurus, die in kleine troepjes rondtrekt, zich weinig bekommert over de hoogte boven zee, wanneer die de 3000 roet maar niet te boven gaat en evenmin kieskeurig is op zijn jachtterrein, wanneer dit hem slechts niet te dicht bij den mensch brengt. In zijn bewegingen, in zijn geheele wijze van doen, is deze Hemipus echter nogal opvallend. Van allerlei andere typen (mees, klauwier, rliegenvanger en zelfs huningzuiger) heeft bij iets en dit concordeert met de moeilijkheden, die de systematici hebben ondervonden, toen ze hem achtereenvolgens bij rerschillende fimilies onder dak wilden brengen. Totdat men eindelijk op den practischen inval is gekomen, hem met eenige andere vormen, waarmede men evenmin raad wist en wadran wij er later nog een paar zullen tegenkomen, tot eene afzonderlijke familie te vereenigen.

De overige vogels, die men in dit gebied kan ontmoeten, zijn alle reeds rroeger besproken; enkele 
$-350-$

zwervers uitgezonderd, die beter later, bij de fauna der bosschen en boschranden zullen ter sprake komen. 


\title{
HOOFDSTUK XVI.
}

\section{De Fauna van het Gebied der Overjarige Cultuurgewassen.}

\author{
(Vervolg) \\ Cacao.
}

De fauna der cacao-aanplantingen sluit zich zoowel door de wijze, waarop de cultuur wordt geedreven, als door de terreinen, waarop ze plaats heeft, zóó nauw aan de vorige aan, dat hier slechts de diervormen behoeven te worden besproken, die door hun levenswijze aan de cacaoplant zelve zijn gebonden en niet bijzonder talrijk zijn. Sommige ervan spelen echter, zooals bekend is, oeconomisch een zeer groote rol, bijv. Gracilaria cramerella, het Cacaomotje, welks rupsen zich in de vruchten boren en talrijke gangen en ruimten in het vruchtvleesch maken. Vele der rijpende zaden worden daardoor van het moederlijk weefsel geïsoleerd, krijgen geen toevoer van voedsel meer en sterven af. Zij gaan dan in een gedeeltelijke rotting over, maar drogen ten slotte uit, zoodat men een aangetaste vrucht, reeds door haar te schudden, als zoodanig kan herkennen. Uitwendig bemerkt men derhalve van de aanwezigheid der rupsen niets, maar zoodra ze volgroeid zijn, verlaten ze haar verblijf en verpoppen zich, 't zij aan de onderzijde der bladeren, 't zij tusschen de oneffenheden van vruchtschil of 
van stam, onder een geelbruin, zijde-achtig spinsel, dat nogal in het oog valt. Veel duidelijker en opvallender treedt de aanwezigheid der Capsidae van het geslacht Helopeltis aan den dag, wanneer deze, wat ze bij voorkeur doen, zich op de jonge, nog groene en dus nog weinig verhoute takjes hebben geworpen. De blaren zelf worden hier niet aangetast, maar ten gerolge der rerwondingen, die aan het takje zijn toegebracht, rerwelken ze en vallen weinige dagen later af, waarbij dan het inmiddels verdorde takje aan de plant blijft zitten. Dezelfde Wantsen tisten ook de vruchten aan, maar de sporen ran hun optreden vallen dan veel minder in het oog, terwijl ook de plant niet zulke ruïneuze gerolgen ervan ondervindt. Jonge vruchten kunnen weliswaar door talrijke Helopeltis-steken tot afsterven en afrallen worden gebracht, maar de plant brengt ze gewoonlijk in zóó grooten getale voort, dat toch niet alle tot rijpheid kunnen worden gebracht; oudere vruchten, met hun dikke, saprijke schil, reageeren niet anders erop dan door het vormen van de bekende zwarte vlekjes, gerolg van het plaatselijk afsterven van de buitenste weefsellagen.

Borende keverlarven, in hoofdzaak Cerambyciden, spelen ook hier een rrij belangrijke rol. De meest algemeene is die van Glenea novemguttata, een Boktorretje, dat zelfs de, in de grootere bevollingscentra verspreid voorkomende cacaoboomen pleegt te volgen en welks larven verblijf houden tusschen den bast en het hout, om eerst tegen de rerpoppingsperiode in dit laatste door te dringen en daar een korten, naar boven gerichten gang te maken. Ook de reeds vroeger (pag. 126) genoemde vormen Epepeotes luscus en 
Pelargoderus bipunctatus komen in dit gebied voor, alsmede Prannetha melamra. warrvan de larven, in rottenden bast en afgestorren kolven, meer een saplophang bestan leiden; voolts Monohammus fistulator, wairvan de larre aan cacao nog de voorkeur schijnt te geren boven koffie, waarin ik haar slechts een enkele maal aantruf. De meest energieke boolder is hier echter, reeds op grond ran zijn afmetingen, de larre ran Catoxantha bicolor, de grootste Buprestide van Java. Bij deze diersoort schijnt zich weder de tegenstelling: in klimaat, tusschen het IVestelijke en het overige gedeelte van Jara te doen gevoelen. ZeHNTNer toch, aan wiens onderzockingen men ook op dit gebied reel verplicht is, gewaagt voor Midden-Java van het uitkomen der kevers hourdzakelijli in Janurri, en ran eene, met dien termijn in verband staande lerenswijze der larven. In West-Jara daarentegen heb ik van een dergelijke regelmaat nooit iets waalgenomen. Wat de larven zelve aangaat, deze behooren almede tot het grootste, dat de insectenwereld op Java heeft aan te wijzen, daar een lengte van $15 \mathrm{cM}$. en een breedte over den thorax ran' $2 \mathrm{cM}$. volstrekt geen zeldzaamheid zijn en, wanneer men de boorgangen ziet, die deze dieren in de cacastammen maken, verwondert men zich in het geheel niet erorer, dat een parr hunner een volvassen boom kunnen dooden. Blijkbaar houden ze van ruimte in hun verblijf, want zelfs het boormeel wordt, door afzonderlijk daartoe vervaardigde openingen, eluit verwijklerd, een handelwijze, waardoor ze tevens hunne aanwezigheid rerraden.

Waar de Lamellicorniu, die de, ook hier reelvuldige engerlingen produceeren, in het rorige gebied het hoofdgervas vrijwel onaangeroerd lieten en zich 
tot het loof der schaduwboomen bepaalden, treden ze hier ook op de blaren der cacaoboomen op en laten daaraan de sporen hunner vratzucht achter, die roor de verschillende soorten dikwijls karakteristiek zijn en voor een deel werden afgebeeld door Docters ran Leeuwer *). Aan de reeds vroeger (pag. 342 ) genoemde soorten en geslachten dezer bij uitmemendheid vormenrijke familie kunnen voor dit gebied nog worden toegevoegd Adoretus umbrosus, Serica javana en S. pulchella, Brahmina pumila, Anomala anchoralis en verschillende, moeielijk van elkander te onderscheiden Apogonia-soorten. Vooral de kleinere vormen zijn in den volwassen toestand liefhebbers van zonneschijn en, in verband daarmede, zullen wij ze later weder ontmoeten in het gebied der theeaanplantingen, waar de zon steeds vrijen toegang heeft.

De Lepidoptera zijn in dit gebied slechts matig vertegenwoordigd. Zeuzera coffeae, in geenen deele gebonden aan de plant, vaaraan ze haar soortnaam ontleent, treedt ook hier soms in vrij groot aantal op, gelijk men haar eveneens kan aantreffen in thee, Erythroxylon coca en zelfs in Dammarboomen (Dammara alba). Voor bladvretende rupsen schijnt het eenigszins stugge cacaoblad weinig aantrekkelijks te hebben; slechts de rupsen der Psychidae, met hun uitermate trage stofwisseling en daarmede verbandhoudenden, langen levensduur, zijn hier rijk vertegenwoordigd en eveneens dool Docters raN LEEUweN meer in bijzonderheden nagegaan **). Men vindt

*) Bespreking van enkele Bladsprietige Kevers, welke schade doen aan de cacaobladeren. Cultuurgids 1909, Tweede Gedeelte, Afl. No. 12.

$\left.{ }^{* *}\right)$ 1. u. Jaargang 1909, Tweede Gedeelte, Afl. No. 11. 

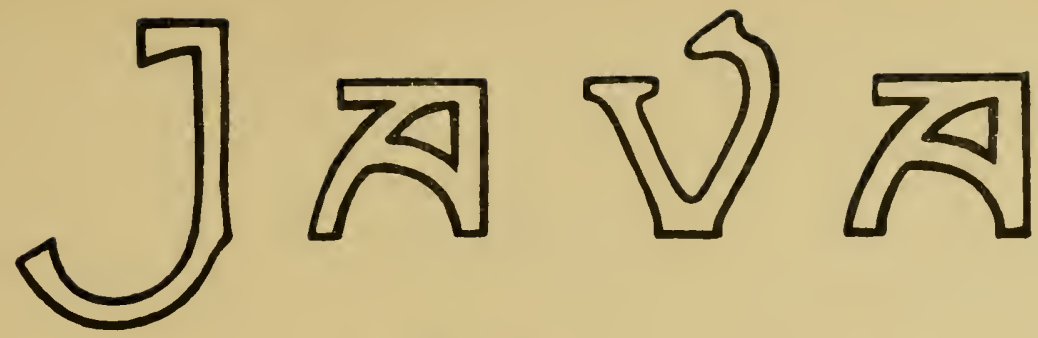

\section{Zஸ்டOGISCH}

\section{EN BIOLOGISCH}

DOR

DRJ.C.KONINGSBERGER

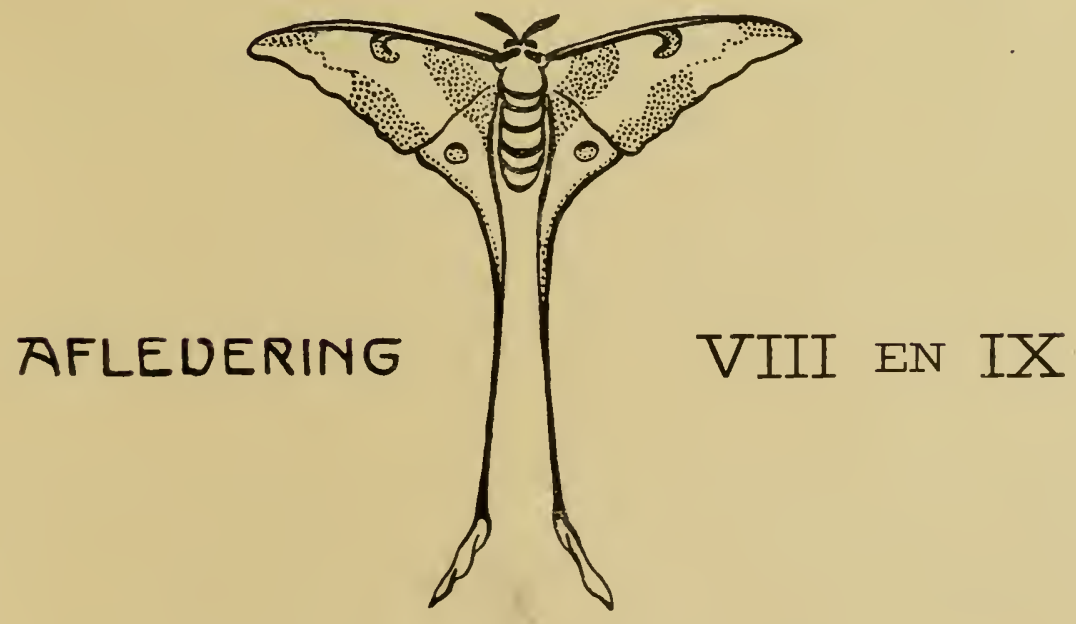





\title{
I N HO U D.
}

\author{
AFLEVERING I.
}

Hoofdstuk I Algemeene samenstelling der Fauna van Java en hare wordingsgeschiedenis. De Hoofdgroepen... . . . .

Hoofdstuk II. Overgangen van de eene groep in de andere. Morphologische gevolgen daarvan. Voorbeelden van vormen, die in overgang zijn. Nachtelijke en diurne levenswijze.

Hoofdstuk III. Invloed van jaargetijden, regen, wind en zonneschijn. Vergelịking met andere eilanden. . . . . 37.

pag.

5.

22.

37.

AEJJEVERING II en III.

Hoofdstuk IV. Kort overzicht der verschillende gebieden. De Cultuurfauna bij uitnemendheid: de diervormen der grootere plaatsen . . . . . . . . . . . . . 51

A. Zoogdieren . . . . . . . . . . . . 55.

B. Vogels. . . . . . . . . . . . 60.

C. Kruipende en Tweeslachtige Dieren. . . 76.

Hoofdstuk $V$. De Dierrormen der grootere plaatsen.

Vervolg) . . . . . . . . . . . . . . . . 90.

D. Insecten . . . . . . . . . . 90.

1. Orthoptera . . . . . . . . . . 90.

2. Neuroptera . . . . . . . . . . . . 98.

3. Rhynchota . . . . . . . . . 104.

4. Diptera . . . . . . . . . . . . 108 .

Hoofdstuk VI. De Diervormen der grootere plaatsen.

(Vervolg). D. Insecten. (Vervolg) . . . . . . . . . 116.

๖. Coleoptera . . . . . . . . . . . . 116.

6. Lepidoptera. . . . . . . . . . . 127.

\section{AFLEVERING IV.}

Houfdstuk VII. De Dielvormen der grootere plaatsen

pag.

(Vervolg). D. Ixsecten (Verrolg). . . . . . . . . . . 157.

7. Hymenoptera. . . . . . . . . 157.

8. Apterygota. . . . . . . . . . . 179. 
Hoofdstuk VIII. De Diervormen der grootere plaatsen. (Virvolg) . . . . . . . . 180

E. Suhorpioenen en Veriwante Vormen . . 180.

F. Spinnen en MiJtey. . . . . . . . . 182.

G DUIZENDPOOTEN. . . . . . . . 189

H. Kreeftachtige Dieren . . . . . 193.

I. WeERDIEREN. . . . . . . . . . . 194.

K WORMEN

Hoofdstuk IX. De Fauna der dessa's . . . . . 198.

A. Dessa's in het open veld . . . . . . 199.

\section{AFLEVERING V.}

Hoofdstuk IX. De Fiuna der dessa's (Verrolg).

A. Dessa's IN HET OPEN Veld (Vervolg) . . 205.

B. Dessa's in BOOMRIJKE OMGEVING . . . 212.

Hoofdstuk $X$. De Fauna der dessa's. (Vervolg)

B Dessa's in BoonriJKe omgeVING. (Vervolg) . 227.

Hoofdstuk XI De Sawahfauna. . . . . 245.

\section{AFLEVERING VI.}

Hoofdstuk XII. De Fauna van het Bouwland . . . 272.

Hoofdstur XIII. De Fauna van het Bouwland. (Vervolg) 295.

AFLEVERING VII.

Hoofdstuk XIV. De Fimna van Braakliggend Land en

Weidevelden $\dot{\mathrm{X}} \mathrm{r}$. De Fauna van het Gebied der Overjarige Cultuurgewassen . . . . . . . . . . . . . . . . DJATIBosSCHE. . . . . . . . . . . . . 322. KOFFIE EN SCHADUWboomen . . . . . . 327.

Hoofdstur XVI. De Fauna van het Gebied der Overjarige Cultuurgewassen (Vervolgl. . . . . . . . . . 351.

CACAO. . . . . . . . . . . 351.

AFLEVERING VIII en IX.

Thee. . . . . . . . . . . . . . . 355.

KlNA. . . . . . . . . . . . 363. 
Hevea en andere, RUBber PROdUCEerende Ge-

IVASSEN. PALARUIUMT.

368.

Hoofdstuk XVII. De Zoetwaterfauna en de Detritusfauna van het Cultuurgebied. . . . . . . . . . . . . 373

ZOOGDIEREN . . . . . . . . . . . . . . 374.

Kruipende en Tweeslachtige Dieren. . . 374.

VISSCHEN . . . . . . . . . . . . 380.

Gelede Dieren. . . . . . . . . . 399.

WEEKDIEREN . . . . . . . . . . . . . . 404.

Wormen en andere Lagere Dieren. . . . 406.

De Detritusfauna van het Cultudrgebied. . 408.

Hoofdstuk XVIII. De Fauna der Graswildernissen. . . 414. 

hiel zoowel de gladde, langwerpig-peperhuisvormige en alleen uit spinsel bestaande huisjes van Heijlaertsiaen Animula-suorter, als de, eenigszins slordig met stukjes blad bekleede verblijven van Eumetu layardi en Lamera cana en de, reeds van vroeger (pag. 3:39) bekende, met stokjes en afreknabbelde stukjes blad. nerf bekleede huisjes van Eumeta variegata (crameri). Het merkwardigst en sierlijkst van vorm zijn echter die ran het geslacht Pagodia, die zijn opgebouwd uit ronde bladstukjes, die van voren naar achteren toe (ten aanzien van het lichaam van de rups gerekend) kleiner worden, spiraalsgewijze en terens dakpansgewijze zijn gerangschikt en aan het geheele rerblijf inderdaad eenigszins het aanzien eener miniatuur-pagode verleenen.

Zelden ontbrekende bewoners van dit gebied zijn eindelijk verschillende Dactylopius-soorten, die in de oneffenheden van de schil der vruchten een uitgezocht verblijf vinden, in lset bijzonder nabij den korten steel, waar ze in den regel door allerlei soorten van Mieren ijrerig worden bezocht.

\section{Thee.}

De thee-aanplantingen van West-Java vormen een uitgyestrekt gebied, dat zoülogisch en voolaal ten aanzien rer hoogere dieren, geheel afwijkt van de laatstbesproken terreinen. Een niet meer dan milnshoug, dikivijls zelfs nog lager gehouden culturugewas, dicht opeengeplant in een omgering, die gewoonlijk zooveel mogelijk van andere planten wordt gezuiverd, kan uit den aard der zaak weinig anders te zien geven dan zijn speciale gasten en daarnaast een aantal liefhebbers van licht en lucht, van ruimte en zonnesihijn.

Dit vindt in de eerste plaats zijn uitdrukking in 
de avifauna, waarin de Zwaluwen, als luchtbewoner's bij uitnemendheid, steeds op den voorgrond treden. Met dikwijls ongeloofelijke snelheid scheren zij vlak over de heesters, volgen ze cle glooiingen van het terrein of verdwijnen ze, bij het oversteken van een ravijn, even snel uit het gezicht als ze daarin zijn gekomen. Veelal heeft men nauwelijks den tijd on te zien, of 't een Gierzwaluw of een Huiszwaluw was, die voorbijschoot. Beide families zijn hier ruim vertegenwoordigd, de laatste vooral dour de groote Hirundo striolata, de eerste door alle vormen, die reeds vroeger werden besproken (pag. 70 en 71), alsmede door Micropus pacificus en Chelydon dasypus, welke laatste soort althans door BARTELS in rrij groot aantal op den Gedeh werd waargenomen, waar de dieren vermoedelijk op den doortrek waren.

Na het vallen der duisternis hoort men in de theetuinen niet zelden het geroep der Cuprimulgus- soolten, die zich overdag schuil houden in aangrenzende wildernissen, in on bebouwde rarijntjes en, in oudere tuinen, zelfs onder de theeheesters en die na zonsondergang hun jacht beginnen. Zij hebben het daarbij vooral gemunt op kevers, waarran zij, op gunstige aronden, een aantal kunnen verorberen, welker gezamenlijk gewicht bij het hunne niet ver ten achter staat. Dezelfde voorliefde vinden wij bij Eurystomus orientalis, die zich vooral tegen en gedurende de avondschemering laat zien. Overdag houdt hij zich in reiliger omgeving, liefst zelfs in bosschen op, maar zoodra de bedrijrigheid van den dag een einde heeft genomen, plaatst hij zich garlue, aan den rand der aanplantingen, op een kalen tak, die hem een goed orerzicht over de omgering aanbiedt en warrop hij niet alleen na elken uitval weder 
trug keert, maar dikwijls een geregelde, dagelijksche velschijning is ran zoodinig opvallend roorkomen, lat hij in de Preanger zelt's met ren rasten naam (bébiali) wordt aangeduid.

T'ot de gewone verschijningen in dit gebied behooren rerder Lanius bentet, die dnor zijn eenvoudig, mar. niet onaardig stemgeluid spoedig de aandacht trekt; Artamus leucongaster (pag. 23S), die dikwijls dezelfde rijze van jagen als Eurystomus orientalis in praktijk brengt; Pratincola caprata (pag. 274), die ook hier de. vroeger roor har genoemde levensroorwarden ten volle aanwezig vindt. In den Westmoesson, de wintermaanden van het noorden, rinden hier borendien talrijke Kwikstaarten een rrorlijk en zonnig verblijf. Het zijn Motacilla flava en $M$. melanope, warran vooral de eerste in grooten getale herwaarts komt. Men ziet deze sierlijlse rogeltjes gewoonlijk in kleine troepjes rondtrekken, dikwijls neerstrijken en, zonder bijzondere schuwheid te toonen, met den wandelaar toch steeds een behoorlijken afstand houden. De onhebouwde ravijntjes eindelijk bieden niet zelden een goed en veilig rerblijf aals Pycnonotus bimaculatus, dadelijk te herkennen als een nauren verwant del roeger (pag. 61 en 239) besproken soorten ran hetzelfde geslacht, maar, o. a. door de beide oranje bundels ran korte, rechtop staande reertjes achter de neusgaten, sierlijker ran roorkomen en borendien begaafd met een niet onaardigen zang; alsmede aan Megalurus pulustris (pag. 270), die zich intusschen ook wel in de open tuimen waagt, gelijk rij hem rloeger op de afgeoogste rijstvelden ontmoetten. Hoog in de lucht zwevende Roofrogels maken eveneens een deel uit ran het fammistisch heeld. dat deze omgering te zien geeft: de nabijheid 
der bosschen verklaart gemakkelijk hunne aanwezigheid en de open gesteldheid van het terrein doet ze hier meer in het oog vallen dan elders, maar meestal vliegen zij zóó hoog, dat aan herkennen niet valt te denken. Veel is er voor hen in de theetuinen niet te halen; want de zooeven genoemde rogels lokken hen niet hierheen, kleine zoogdieren zijn hier ook vrij schaarsch en een van de weinige vormen, die zich overdag vertoonen, doet hun bovendien concurrentie aan. Ik bedoel hiermede Herpestes javanicus, (ganggarangan), een klein, maar buitengewoon bloeddorstig en brutaal roofdiertje, dat men nu en dan, in sommige streken zelfs vrij dikvijls, door de tuinen ziet hollen. Het is in geenen deele tot dit gebied beperkt, komt zelfs in het geheele cultuurgebied (buiten de grootere plaatsen) vall het zeestrand tot hoog in het gebergte voor, maar geeft zich nergens zoo bloot als hier, waar zijn zwerftochten, ran de eene kampong naar de andere, hem meestal onrermijdelijk. door de aanplantingen voeren. Zijn vermetelheid is van dien aard, dat hij ook overdag in de onmiddellijke nabijheid van menschelijke woningen hoenders en eenden aanvalt en tracht mede te sleepen.

De insectenwereld dezer aanplantingen hangt glootendeels nauw met de theeplant zelve samen en is niet zeer rijk aan vormen. Enkele erran zijn echter voor dit gebied nogal karakteristiek. Als zoodanig moet hier in de eerste plaats worden genoemd het geslacht Ricania van de familie der Fulgoridae, waarvan vooral de soort atrata hier zeer algemeen, fuliginosa minder veelvuldig optreedt. Door den vorm en de kleur der rleugels en door de wijze, waarop de laatste worden gedragen, zien velen 
deze insecten voor kleine vlindertjes aan, maar wie ze tracht te grijpen, bemerkt aan de springende beweging, waarmede ze hun vlucht beginnen, dat men hitr met iets anders heeft te doen. Gewoon lijk zitten ze rustig tegen de jonge takjes, met welker sappen zij zich voeden en bij nadering van eenig gevaar trachten zij eerst zich aan de afgewende zijde van het takje te verschuiles, een ware struisvogel-politiek, daar ze, wegens humne grootte, door die beweging niet minder zichtbaar worden. Wordt het gevaar hun te groot, dan vliegen ze weg.

Andere, voor dit gebied kenmerkende verschijningen zijn de vele Cicindela's, die men vooral gedurende de warmere uren van den voormiddag in grooten getale kan aantreffen op droge, zandige paden en hellingen, welke alsdan in den zonneschijn liggen te blakeren. Het name zijn Cicindela discreta, $C$. vi luata, C. minuta en C. analis hier algemeen. Net de, bij deze dieren gebruikelijke rlugheid bewegen zij zich over den grond, deels loopend, deels vliegend, soms heide bewegingen tegelijk makend. Naar zoodra de zon zich achter een wolk verbergt, is het met hun levendigheid gedaan en wanneer de regen dreigt, is er geen spoor nueer van hen te zien.

In de derde plaats een paar rupsen, die hier met groote voorliefde vertoeven: die van het geslacht Belippa en die ran Stauropus alternus. De Brlipparupsen behooren tot de soorten laleana, lohor en albiguttata; vooral Belippa laleana treedt soms in zeer grooten getale op. Hun voorkomen is geheel afwijkend van dat van andere Slakrupsen, daar de dorens en de brandharen geheel ontbreken, daarentegen het geheele lichaam, met uitzondering ran de buikzijde, 
is omhuld door een dikke, half doorschijnende, korrelig-glasachtige huid, waarin, op regelmatige rijen, gelerstirjes zijn waar te nemen.

Overigens is de kleur der dieren zon rolmaakt gelijk aan die van het theeblad, dat men ze zeer gemakkelijk over het hoofd ziet. De cocons, die gewoonlijk worden gemaakt in een daartoe gesponnen plooi van het blad, zijn bolvormig, slechts op de aanhechtingsplaatsen een weinig afgeplat, krijtachtig wit van kleur en springen npen langs een volkomen zuiver cirkeltje, waardoor het orercenkomstige segment als een dekseltje wordt opgetild. Slechts op ééne plaats blijft een soort van scharnier aanwezig. De uitkomende vlindertjes blijven een tijdlang aan één of aan beide achterpooten hangen en hebben dan de dichte beschubbing geheel uitstaand, zoodat zij in die houding vrijwel onherkenhaar zijn en het meest op een dicht, wollig coconnetje gelijken.

De rups van Stauropus alternus heeft den welbekenden, aan het geheele genus eigen rorm. Daar zij in de rusthouding kop en thorax opgericht houdt en met de lange pooten van het derde thoracaalsegment een beweging maakt, welke herinnert aan de aan de heweging, die een hoog steigerend pard met de roorbeenen te zien geeft, hebben de Soendaneezen haar den naam hileud koeda gegeven.

In de vierde en voornaamste plaats geeft in dit gebied het, reeds bij de cacao genoemde Capsidengeslacht Helopeltis blijk van zijne aanwezigheid, waarbij de soort antonii verreweg de meest algemeene is, theivora meer tot de lagere streken beperkt schijnt. De modus operandi dezer dieren is bekend; al zuigende brengen zij aan de jonge takjes en blaadjes talrijke steken toe, waardoor even zoovele, aanvankelijk 
lichtbruine, later donkerbruine tot zwarte plekjes ontstan, die ten slotte ertoe leiden, dat de jonge uitloop verschrompelt, verdort en verdroogt. Die verdroging strekt zich echter niet uit tot de plaals, waar, in het inwendige der takjes en gewoonlijk ten getale van twee bij elkaar, de langwerpige en naar verhouding zeer groote eieren worden gelegd, die uitwendig hare aanwezigheid door een fijn, witglinsterend, harrormig aanhangsel verraden. Hoevel de wijfjes van een legboor zijn voorzien, die bij $H$. antonii in de rust naal voren, bij $H$. theivora naar achteren wordt gedragen, moet men zich toch eenigszins rerbazen over de krachtspraestatie, wartoe deze teere diertjes blijkhaal bij het leggen der eieren in stiat zijn.

De werkzaamheid dezer insecten bereikt har hoogtepunt in de vroege morgenuren. Wanneer de zon stijgt, trekken zij zich naar de beschaduwde deelen der heesters terug, om in de latere namiddaguren weder voor den dag te komen. Vliegen doen ze weinig, als wisten ze, dat dit, met het oog op de vele Zivaluwen, hun ondergang zou beteekenen. Ook voor het overige stadn zij, trots de iveinig beschermende omgeving, warin ze leven, aan weinig gevaren bloot; hoogstens vallen enkele aan een verdwalde Mantis of dergelijken roover ten prooi.

Aan de genoemde rormen kunnen nog worden toegevoegd de P'sychidat, die hier in niet minder rerscheidenheid optreden dan in het vorige gebied, terwijl ten aanzien van een aantal kleine Lamellicormia, die men niet zelden aan de bladeren vindt knabbelen en waarvan hier Popilia biguttata, Serica javana en $S$. pulchella de meest algemeene zijn, nog 
valt op te merken, dat zij, hij droogte van eenigszins langen duur, zich gaarne in den grond verbergen en dan een lusttoestand doormiken. Deze slaap duurt echtel niet zoo lang als die van Apogonia destructor in de omgeving van het suikerriet; de diertjes dringen ook niet zeer diep in den grond en worden uit hun rust opgewekt door de eerstkomende regenbui, die zelden langer dan een vier-of vijftal weken op zich laat wachten. Van de genoemde kevertjes is Popilia biguttata voor de thee-aanplantingen wel de meest karakteristieke, hoewel zij het naar getalsterkte tegen de Serica's aflegt.

Als insectenvormen, welker aanwezigheid, in vrij gronten getale, voor zooverre bekend is, geen rechtstreeksch verband houdt met de theeplant, moeten de Tipulidae, in het bijzonder de groep der Longipalpi worden genoemd. Vooral de Tipula-soorten ran middelmatige grootte, zooals T' umbrina en. T. pedata, Pachyrhina fasciata, Ctenophora's, in het bijzonder $C$. (Pselliophora) ardens en $C$. (P.) compedita, zijn hier schering en inslag. Vanwaar ze komen en waarom ze hier blijkbaar gaarne vertoeven, zijn nog open vragen. Het is niet onmogelijk, dat ze hun larventoestand doorbrengen in de vochtige omgeving van onbebourde ravijnen of naburige bosschen en door den zonneschijn herwaarts worden gelokt. Zooveel is zeker, dat de wind, die over deze open aanplantingen vrij spel heeft en daarvan dikwijls een ruim gebruik maakt, hen in het minst niet deert en dat zij in den regel ook weinig moeite duen, zich ertegen te beschutten, zelfs al worden ze op de lange pooten vrij onzacht heen en weel geslingerd.

Ten slotte een enkel woord orer een parr soorten 
van Mijten, die niet zelden in zoo grooten getale op de theeheesters roorkomen, dat het uiterlijk en vooral de kleur der aanplantingen reeds hunne aanwezigheid rerraden. Eene ervan, Tetranychus bioculatus, werd reeds roeger (pag. 43) genoemd; zij leeft rooral op de bovenzijde der oudere bladeren, die op de plekken, waar de dieren tot koloniën zijn opeengehoopt, een roodachtige tint aamnemen. Deze diersoort, dezelfde als de "red spider" van Britsch Indië, komt rooral op de lager gelegen ondernemingen roor. Hoogerop wordt zij grootendeels vervangen door Brevipalpus obovatus van dezelfde familie der Trombidiidae, die vooral op de onderzijde der bladeren leeft, maar overigens ook op alle, vooral jonge deelen der planten is te vinden. Ter onderscheiding van de rorige, die als "roode Mijt" bekend staat, wordt deze soort gewoonlijk met den naam "oranje Mijt” aangeduid, niet alleen omdat de kleur der dieren zelve in het oranje-achtige loopt, maar ook om de gelijksoortige tint, die zij aan de, door haar bewoonde planten verleent. Voorts ondervindt zij in veel mindere mate den invloed der weersgesteldheid, in het bijzonder dien van zware regenbuien, omdat de meeste individuen daartegen beveiligd zijn en dit heeft wederom ten gevolge, dat Brevipalpus in veel meerdere mate dan Tetranychus den stempel zijner aanwezigheid op deze omgering kan drukken. Bij een zeer talrijk en langdurig optreden soms in die mate, dat de planten een groot deel der bladeren laten rallen en zelfs tot afsterven kunnen worden gebracht.

KINA.

Wanneer wij roor een oogenblik de diervormen 
buiten beschouwing laten, welker aanwezigheid op rekening van de nabijheid der bergwouden moet worden gesteld, dan is de fauna der kinaplantsoenen tamelijk arm. De Lepidoptera zijn nog het best vertegenwoordigd, in de eerste plaats door een adntal groote rupsen, waarvan wij die van Attacus allas hier niet voor de eerste maal ontmoeten. Dit gulzige, zeer polyvore insect kan hier echter optreden in een aantal, dat ontrustbarend wordt, maar gewoonlijk niet nalaat, de aandacht te trekken van verschillende vogelsoorten, inzonderheid Kraaien, van welke laatste slechts één exemplaar zijn rreugdegekras over het ontdekken van den rijken maaltijd behoeft aan te heffen, om binnen korten tijd alle soortgenooten uit de buurt om zich heen te zien.

Twee andere groote rupsen, die het speciaal op de kina voorzien hebben, behooren tot de familie der Lasiocampidae. Het zijn Metanastria hyrtaca en Odonestis plagifera, in de Preanger Regentschappen welbekend onder de inlandsche namen hileud boegbroeg en hileud sinanangkeup en aan hunne wijze van beharing te herkennen als verwanten van Suma concolor (pag. 145), de Lasiocampide der grootere plaatsen.

De vierde groote rups van dit gebied is die van de Sphingide Daphnis hypothous (hileud setetaroe), die reeds vroeger (pag. 139) als een sporadische bewoner van sommige Rubiaceae werd genoemd, maar in deze omgering niet zelden in zeer groot aantal optreedt en met de beide bovengenoemde Lasiocampidae tot de ernstige plagen der kinakultuur behoort.

Als vorm van geringer afmetingen roegt zich daarbij de rups van Euproctis flexuosa (hileud merang) van de familie der Borstelrupsrlinders, die in jeug- 
digen tostand in groote truepen bij elkiar roorkomt, terwijl eindelijk he rups ran de Pyralide Glyphodes (Pachyarches) psittacalis in de oudere plantsoenen op soortgelijke wijze optreedt als de Agathodes-soorten (pag. 328) in de dadal, en ook Psychidae, inzonderheid Eumeia variegata, hier in geenen deele ont,meken.

Walal de aimplantingen nog niet gesloten zijn, valt ook hier dikwijls het optreden van het Capsidengeslacht IIelopeltis waal te nemen; zijn de boomen ouder, dan manifesteeren deze diertjes zich op minder duidelijke en vooral op minder schadelijke wijze. Voorts treft men hier vele der reeds in dit en in het vorige Hoofdstuk genoemde Lamellicomia en hunne larven aan, terwijl als in dit gebied algemeene Curculionidae mogen worden genoemd Dermatodes costatus, D. punctulatus en Pluytoscaspha triangularis. Plaatselijk treedt nu en dan eene Apoderus-soort op eigenaardige wijze op, door namelijk van bladmateriaal een kokerrormig huisje te maken, dat sterk herinnert aan de welbekenda huisjes der Europeesche Ryuchites betulcti. Voegt men nu aan het bovenstainde een aantal omnirore insecten toe, die geen afzonderlijke vermelding meer behoeven, dan zijn daarmede de gewone gasten der kinaboomen vrijwel alle genoemd. Voolal in ouclere tuinen doet echter het kalakter van beschaduwde aanplanting zich selden en kin men alle, daarvoor rroeger genoemde diervormen terugrinden. Voor de hooger gelegen kinatuinen moeten daaraan nog een paar vogelsoorten worden toegevoegd, die zich zelden of nooit beneden $t$ tot 5000 vnet zeehoogte vertoonen. Eene daarvan is het kleine Meesje Psaltria exilis, het kleinste rogeltje van Java en nog grootendeels een busch- 
bewoner, die in koppels van twintig tot dertig stuks tochten makkt door naburige aanplantingen. De diertjes, welker aanwezigheid men vooral bemerkt aan het fijne, piepende geluid, dat ze, als vele Meezen, voortdurend doen hooren, leggen een buitengewone bewegelijkheid aan den dag. Ze zitten letterlijk geen seconde op dezelfde plaats en de geheele troep trekt in den regel met groote snelheid voort, als vertrouwde ze de omgeving nog niet al te best.

Eveneens tot de hoogere streken beperkt, maar reeds in mindere mate vreesachtig, is cle blauwe Vliegenvanger Stoparola indigo, die aan een fraai voorkomen een aardig stemgeluid part. Hij verwijdert zich niet gaarne ver van het bosch, maar gedraagt zich daarbuiten overigens tamelijk rustig en zit dikwijls geruimen tijc op eenzelfde, nogal onbeschutte plaats, waar hij door zijn gevederte zeer in het oog valt. Nog twee andere Muscicapidae kunnen hier worden genoemd: de kleine Muscicapula melanolenca, die zich bij voorkeur tusschen het gebladerte schuil houdt, doch slechts even zichtbaar behoeft te worden, om aan de witte strepen over zijn zwart vederkleed te worden herkend, en Culicicapa ceylonensis, een vogeltje, dat noch door zijn, in hoofdzaak groenachtig vederkleed, noch door geluid of bewegingen de aandacht trekt.

Aan de nabijheid van het bosch is voorts nu en dan de aanwezigheid te danken van een Rupsvogels, die veel grooter, maar ook veel minder sierlijk is dan zijn, ook hier niet zeldzame familiegenoot Perico. crotus miniatus (pag. 348), namelijk Artamides larvatus, een aschgrijzen vogel, die door de zwarte kleur van de teugels en het gedeelte rondom de oogen een buitengewoon somber en nadenkend uiterlijk heeft en wiens 
voedsel weliswaar hoofdzalielijk uit insecten, maal voor een deel ook uit vluchten bestaat. Wil hij zich aan dit gemengde diëet houden, dan is het ook roor hem zark, zich niet te ver ran het bosch te verwijderen, daar in de kinatuinen aan vruchten niet veel is te halen.

Ook wat de Zoogdieren betreft, komen wij hier, althans op de hooger gelegen aanplantingen, in het verspreidingsgebied van een boschrorm, die onder beschutting van het nachtelijk duister dikwijls het cultuurgebied bezoekt en daar de sporen van zijn werkzaamheid achterlaat. De bedoelde rorm is de Stinkdas Mydaus meliceps, als sigoeng (soend.) of teledoe (jav.) welbekend. Dit kleine Roofdier voedt zich voornamelijk met wormen en insectenlarven, die hij in den grond aantreft en daaruit opgraaft met de krachtige graafklauwen, waarvan in het bijzonder de voorpooten zijn voorzien. In sommige streken is hij zeer algemeen, gelijk de talrijke omgewoelde plekken in den grond kunnen getuigen. Hierbij mag echter niet over het hoofd worden gezien; dat vok Wilde Varkens en de, in het geheele cultuurgebied verspreide Helictis orientalis (pag. 34) op dergelijke wijze hun roedsel zoeken. Maar deze laten niet dat andere spoor na, waarnaar de sigoeng kan worden gedetermineerd, namelijk de intense: muskusachtige lucht, waaraan hij zijn Hollandschen naam ontleent, en die afkomstig is van klieren, die aan weerszijden nabij de anale opening uitmonden. Reeds bij de geringste verontrusting worden deze klieren in werking gezet. Zij verspreiden wel den hevigsten en meest doordringenden stank, die mij bekend is en die nog dagen lang blijft hangen aan de roorwerpen, waaraan 
hị zich heeft medegedeeld. Men kan zich roorstellen, dat gevoelige personen ervan flauw vallen; mijn persoonlijke ervaring is die van duizeligheid en bemoeielijking der ademhaling. Ook honden, die in dit opzicht anders voor geen klein geruchtje vervaard zijn, trachten zich op allerlei wijzen, zooals door zich in het gras te rollen, ervan te ontdoen.

\section{Hevea en ANDERe, RUbBer PROdUCEerende} gewassen. Palaquium.

De rubbercultuur heeft, biologisch gesproken, op Java nog geen geschiedenis van eenige beteekenis achter den rug en zij is nog niet voldoende lang in de gelegenheid geweest; om zich uit hare omgering reeds een eigen fauna te selecteeren. De toekornst zal hier ongetwijfeld nog veel nieuws aanbrengen, vooral waar; zooals o.a. in de omstreken van Bandjar, die omgeving bestact uit laaggelegen, moerassige bosschen met een rijke fauna, die nog nooit haar krachten aan eenig cultuurgewas heeft beprofd.

Een en ander geldt natuurlijk in de minste mate roor de karet (Ficus elastica), ten eerste, omdat (leze boom hier inheemsch is en ten tweede, omdat reeds rij oude aamplantingen ervan bestaan, terwijl het verder in het algemeen, in oeconomischen zin gesproken, een voordeel zal blijken, dat men te doen heeft met melksaphoudende planten, waarvan, welke overigens de physiologische functie van het melksap zij, niet kin worden ontkend, dat zij door vele phytophage dieren worden vermeden of slechts bij gebrek aan beter aangetast. Gevallen van wat de Duitschers "gegentheilige Anpassung" noemen en waarvan bekende voorbeelden zịjn de Ezel, die bij voorkeur 
de blaren der Distels eet, en de rups van de Europeesche Sphinx euphorbice, die zich uitsluitend met de groene deelen ran de Wolfsmelk roedt, zullen, bij do ruime voedselkeuze in een tropische ongering, wel tot de uitzonderingen blijven behooren. Dat zij echter niet als uitgesloten mogen worden beschouwd, bewijst wel de omstandigheid, dat een, van huis uit bladvretende Landslak van het geslacht Parmarion zich hier en daar reeds in grooten getale op de Hevea heeft geworpen, de jonge, groene deelen daarvan danvreet en het uitrloeiende melksap met graagte opzuigt.

Waar de rubber produceerende gewassen worden verbouwd op oude cultuurterreinen, die vrceger met iets anders waren beplant, leveren zij, van zoölogisch standpunt bezien, nog iveinig bijzonders op. De stammen en dikkere takken van Ficus elastica zijn een geliefkoosde verblijfplaats van de larven van Batocera-soorten, inzonderheid van Butocera albofasciata, waarvan men de, bij het leven schitterend gekleurde kevers soms rustig op de blaren rindt zitten. Vourts van een aantal andere Boktorren, waaronder de eveneens reeds vroeger (pag. 353) genoemde Monohammus fistulator, alsmede Epicedia maculatrix.

Aan de bladranden vindt men niet zelden beschadigingen, die bovendien door gestold melksap zijn rerontreinigd en reroorzaakt. worden, 't zij door' Abirus picipes, een donkere, koperachtig bruine Chrysomelide, 't zij door verschillende Locustidae, die, vooral in den jongen, nog ongevleugelden toestand, nogal gaarne op de groote bladeren ran de karet schijnen te vertoeven, dewijl ze daar gelegenheid 
hebben, hun geliefkoosden rusttoestand aan te nemen, warrbij ze zoowel de zeer lange sprieten, als de eveneens lange achterpooten giheel gestrekt houden (rgl. pag. 97).

Overigens valt het harde blad, naar begrijpelijk is, niet bijzonder in den smaak van insecten, zoodat men ook weinig rupsen erop aintreft. Een paar Spinnertjes, Ocinara dilectula en 0 . signifera, die, wanneer zij de vrije keuze hehben, liever van het zachtere blad van den waringin (Ficus benjamina, pag. 142) leven, komen nu en clan in rrij groot aantal erop voor, doch nooit in die mate als op laatstgenoemden boom. Sporadisch vindt men nu en dan eenige lupsen van de Pyralide Glyphodes bivitralis tusschen een paar jonge blaren, die ze langs de geheele oppervlakte tegen elkaar spinnen, terwijl eindelijk de rups van de fraaie Hypsa cgens hier niet zelden voorkomt.

Op Hevea brasiliensis is de oogst voor den zoöloog nog schraler; hier moet hij zich voorloopig tevreden stellen met eenige omnivore vormen, die het veelal bij een eerste poging tot vestiging laten en elders een beter heenkomen zoeken. Daarentegen heeft de, overigens niet veelvuldig aangeplante Funtumia (Kickxia) elastica dadelijk een specialen gast gevonden in Glyphodes unionulis, die reeds meer dan eens een poging tot cultuur van dit gervas heeft verijdeld.

Waar echter-en dit is vooral met Hevea brasiliensis het geval-voor de rubbercultuur nieuwe, veelal laaggelegen, woeste terreinen werden ontgonnen, heeft de fauna daarvan zich niet zonder meer goedschiks laten verdrijven. Dáál wor'den de jonge aanplantingen bezocht en dikwijls vernield door 
Herten, Dwergherten, Wilde Zwijnen en zelfs hier en daar duor Wilde Runderen. Dáá treden ook dik wijls de Termieten op hun meest typische wijze op, nam.lijk dooi het bouwen van manshouge heuvels, zooals men die op Java in andere gebieden zelden aantreft. Geen wonder; want deze dieren, die vooral in het warme klimaat der laaglanden thuis behooren, werden bij het ontginnen niet verdreven. Zij hebben zich slechts voor korten tijd in den bodem teruggetrokken en zien nu weldra de kans schoon, aan hun lust tot bouwen den vrijen teugel te vieren, reelal slechts indirect ten nadeele van het gewas, dat, roor zooverre tot heden de ervaring heeft geleerd, slechts door ééne soort, Coptotermes gestroi, rechtstreeks wordt aangetast. Ik acht het intusschen niet onmogelijk, dat eerlang, wanneer de hoeveelheid doode, plantaardige stof, die op dergelijke, nieuw ontgonnen terreinen in groote hoeveelheid in den grond is gebleven, zal zijn opgeteerd, de Hevea-plant het ook van de zijde van andere soorten zal hebben te ontgelden.

Terwijl de audere rubberplanten (Castilloa eiastica, Manihot glaziovii enz.) nog geen stof tot bijzondere opmerkingen leveren, moet een enkel woord worden gewijd aan de Palaquium anplantingen te Tjipetir in de Preanger Regentschappen. Reeds vroeger (pag. 294) werden voor deze hoomen een paar niet zeldzame, dikwijls in grooten getale optredende gasten genoemd; deze worden echter in algemeenheid verre overschaduwd door een andere diersoort, die men hier veilig met den naam van stamgast mag betitelen. Het is Rhodoneura myrtaea, van de kleine 
familie der Thyrididae. De oorspronkelijke voedsterplant van de rups heb ik nooit kunnen ontdekken; hoewel ik de meeste, op Java wild en gecultiveerd voorkomende planten van dezelfde familie, die der Sapotaceae, daarop heb onderzocht; ook het rlindertje heb ik slechts éénmaal in een andere omgeving verzameld en wel in een gehéél andere, namelijk in den Botanischen Bergtuin te Tjibodas, op 4500 voet boven zee, waar het des avonds op het lamplicht afkwam. Hoe het zij, deze diersoort heeft zich ran den aanvang met het nieuw ingevoerde gervas vereenzelvigd op een wijze, waarvan mij geen tweede voorbeeld bekend is. Ook de manier van optreden der rups in nogal karakteristiek. In haar jeugd woont zij tusschen de jongste blaadjes, waaraan weldra een derde wordt vastgesponnen. Zij voedt zich dan met een gedeelte van het bladmoes en verontreinigt hare verblijfplaats in hooge mate met haar uitwerpselen. Na eenigen tijd begeeft zij zich naar een ouder blad, gewoonlijk het in leeftijd volgende, rouwt en spint dit overlang's samen en zet daar hare werkzaamheid voort. Wordt ook cleze verblijfplaats haar te onrein, dan verwijdert zij zich door een ronde opening in het laatstbedoelde blad te vreten. Is zij dan tevens volgroeid, dan verpopt ze zich tusschen bladafval op, of in de borenste lagen van den grond; zoo niet, dan tast ze eerst nog één of meer oudere blaren aan. Door deze wijze van optreden doet zij de uiteinden der takken afsterven en wanneer een jonge zij-uitloop hetzelfde lot ondergiat, wordt, onder rorming van een heksenbezemachtig geheel, de groei der boomen op zeer typische wijze belemmerd. 


\section{HOOFDSTUK XVII.}

\section{De Zoetwaterfauna en de Detritusfauna van het Cultuurgebied.}

De meeste rivieren van Java zijn bergstroomen, die, vooral in regenrijke perioden, zooveel zwevende bestanddeelen mederoeren, dat het water een bruine kleur en dikwijls zelfs een drabbig roorkomen hezit. Erg aanlokkelijk moet, naar onze schatting; het verblijf daarin voor de dierenwereld niet zijn en hiermede houdt waarschijnlijk verband de reeds vroeger (pag. 2.53) vermelde omstandigheid, dat vele kleinere vormen, welker lerensfunctiën door de vele verontreinigingen zouden worden bemoeielijkt, hier ontbreken, of slechts aanwezig zijn op de plialsen, waar de condities iets gunstiger zijn. Als zulke platsen beschouw ik de gedeelten met een gering verral, wilal derhalve reel bezinking platats heeft, de hier en daar te vinden, rustige kreekjes langs de oevers en het stroomgebied in vele hooger gelegen streken, waas het water dikwijls reel helderder is. Toos de grotere rormen daarentegen schijnt de gencemde trestand van het water geen bezwaar op televeren, $j i x$, in rele gevallen zelfs een gunstige factor te zijn, inzociverre dieren, die van roof leven, minder gemakkelijk of in het geheel niet zichtbaar zijn en andere, die aan reel verrolging bloot staan, zich betel kunnen schuil houden. 


\section{ZOOGDIEREN.}

De Roofdieren zijn hier zeer algemeen vertegenwoordigd door Lutra leptonyx (soend: sero, jav: welingsang, mal: andjing ajer), een ottersoort, die zich van verwante vormen onderscheidt door de zeer geringe ontwikkeling der klauwen, maar overigens geheel van hetzelfde type is en zoovel in rivieren, als bij stilstaande wateren van eenigen omvang wordt aangetroffen.

Hij woont in holen, die in de oevers worden uitgegraven en, behalve een opening boven de waterlijn, meestal ook daarbeneden een uitgang hebben, zoodat het dier bij naderend gevaar, naar gelang van omstandigheden, in verschillende richtingen kan vluchten. In den regel vindt men de otters in kleine troepen bij elkaar, die nu en dan formeele drijfjachten houden op visch, waarbij, gelijk ook bij vele andere Roofdieren het geral is, wanneer de bloeddorst zich ran hen meester maakt, ook na het verzadigen van den honger een aantal slachtoffers uit louter moordlust wordt afgemaakt. Bij die jachten leggen de Otters een groote behendigheid aan den dag en daar zij borendien gemakkelijk tembaar en zeer leerzaam van aard zijn, worden ze in sommige streken op de wijze van jachthonden op de visscherij afgericht.

Het is niet onmogelijk, dat op Java, naast Lutra leptonyx, nog een andere vorm moet worden onder. scheiden, doch dienaangaande bestaat nog geen voldoende zekerheid.

\section{Kruipende en Tweeslachtige Dierex.}

Van de Reptilia zijn alle orden in de rivieren ran Java vertegenwoordigd. Nabij de mondingen houdt zich Crocodilus porosus op, dikwijls in zóó groot 
aantal, dat de dieren een blijvend gevarar opleveren voor de bevolking, die zich, hetzij uit on roorzichtigheid aan hun aanvallen blootstelt, hetzij door het uitgeoefende bedrijf, inzonderheid dat der risscherij, nood. zilielijkelwijze in hun areaal moet wagen. Waar de gesteldheid ran het terrein zulks toelaat, gaan de Krokodillen re rivieren soms vrij rer op, den atdrijrenden afval, rooral lijken ran grootere dieren, tegemoet. Want hoe aggressief ze ook zijn tegenover l'vende dieren, die binnen hun bereik komen, toch schijnen ze nog een voorliefde te hebben roor lichamen, die reeds in staat van ontbinding verkeeren en als opruimers daarvan valt hun een zekere verdienste niet te ontzeggen.

Zooals bekend is, bereiken de Krokodillen soms reusachtige afmetingen; lengten van jen 6 Meter schijnen niet tot de uitzonderingen te behooren. In de verzameling alhier bevindt zich een schedel, waarbij de afstand ran het róoreinde tot het punt midden tusschen beide oogen $56 \mathrm{cM}$. berlraagt. Bij een opgezet exemplaar ran 372 cM. lengte bedraagt die afstand 37 c.I. Als men nu aanneemt, dat op lateren leeftijd de verhoudingen der afmetingen niet meer aan reel veranderingen onderhevig zijn, komt men voor het exemplaar, waarvan de becloelde schedel afkomstig is, tot een totale lichaamslengte van 5,60 Meter.

Aangaande den leeftijd, dien zulke dieren hebben bereikt, kan men slechts gissingen wagen, maar wanneer men bedenkt, dat de groei ran koudbloedige dieren, vooral op lateren leeftijd, slechts uiterst langzaam plaats heeft, dan zou het mij in geenen deele verwonderen, als de riviermondingen van Java nog Krokodillen herbergden, die .Tax Pieterszoon Koex hier aan land zagen stappen. 
De wijfjes leggen de eieren, die wit van kleur, ellipsoid van vorm en ongeveer $8 \mathrm{cM}$. lang zijn, op ee'n verborgen plek tusschen de oavervegetatie en maken dailtoe een soort van nest, waarop van ouderlijke zijde steeds een oogje wordt gehouden. De uitkomende jongen gelijken reeds dadelijk op de ouder's, maar de snuit is zeer liort in vergelijking met den omvang van den schedel, zoodat de kop, van terzijde gezien, gelijkt up dien van een eend.

Of, nadst het geslacht Crocodilus, ook dat der Gavialen (Tomistoma) op Java voorliomt, is een, nog niet met zekerheid heantwoorde vraag. Naast den gewonen inlandschen naam hoeaja bestaat een tweede, betjokkok, die volgens sommige inlanders een andere dierswort zou betreffen. Het is echter, trots herhaalde pogingen, nooit gelukt een exemplaar van die diersoort machtig te worden. Waar Tomistoma schlegelii op Sumatra en Borneo wordt geronden, zou in haar vonkomen op Java niets bevreemdends liggen.

Van cle orde der Hagedissen treft men in de rivieren zeer veelvuldig aan den reeds vroeger (pag. 80) hesproken minjawak (Varanus salvator), die eveneens gaarne voedsel schijnt te nuttigen, dat reeds in ontbinding rerkeert. Hoewel men hem natuulijk niet tot de eigenlijke waterbewoners kan rekenen, voelt hij zich toch in het natte element bijzoncier op zijn plaats en kan, als het erop aankomt zich te verschuilen, geruimen tijd onder water doorbrengen. Ook bij het jacht maken op visschen komt die eigenschap hem goed te pas. Buiten het water houdt hij zich op, voor zooverre hij geen rooftnchten te land onderneemt, in de talrijke holen, die zich in de, raak hooge en steile oever's hevinden en waarin 
hij als gezelschap kan aantreffen Python reticulatus (pag. 81), die in nog mindere mate waterbewoner is, maar toch zooveel voorliefde voor de onmiddellijke nabijheid van grootere of kleinere rivieren aan den dag legt, dat men hem bij le fauna diarran niet onvermeld mag laten.

Daarentegen komen slerhts zelden buiten het water de rertegenwoordigers van de vierde orde der Reptielen, de Schildpadden, waarvan in het zoete water van Java de meest algemeene vertegenwoordiger is Trionyx cartilagineus. Voor deze dieren is inderdaad de trcebele gesteldheid van het water een bijzonder" gunstige factor, die hen in stat stelt, zich staande te houden in de nabijheid ran den mensch, aan wiens aandacht zij daardoor ontgaan. Nen kan er zeker van zijn, clat, bij de ongelukkige neiging der inlanders, elk dier te clooden, dat zij op hun weg ontmoeten, deze Schildpadden reeds lang zouden zijn uitgeroeid, wanneer ze niet de kunst rerstonden, van de bedoelde omstandigheid zoo goed mogelijk partij te trekken. Dat zij intusschen niet louter voor hun genoegen in het rerborgene leren, mag men wel opmaken uit de omstandigheid, dat zị, wanneer de kans zich daartoe aanbiedt, gaar'ne een rustig ongenblik aan de oppervlakte doorbrengen. In het bijzonder tegen de arondschemering, wanneer alom kalmte heerscht en zij zich onbespied wanen, ziet men ze op daartoe geschikte plaatsen in alle stilte aan de oppervlakte komen. Slechts een gedeelte van den kop steekt boren het water uit, soms ork een gedeelte van het rugschild, maar dat ligt blijkbaar niet eens in de bedoeling: want gewoonlijk verdwijnt het weder spoedig, terwijl een weinig geritsel voldoendellis, on 
het geheele dier weder in de diepte te doen verdwijnen.

De afmetingen, die deze diersoort bereikt, zijn eveneens aanzienlijk en het lichaamsgewicht is daarbij zeer groot. Exemplaren, warvan het rugschild, over de welving gemeten, een lengte heeft vin 50 cM., worden slechts met moeite door rier man gedragen.

De verwante soort Trionyx subplanus, door de mindere welving van het rugschild gemakkelijk van de vorige to onderscheiden, is minder algemeen.

Beide soorten die in West-Java onder den nadm koeja bekend staan, leven deels van plantaardig, deels van dierlijk voedsel. Bij het verslinden van hun prooi leggen ze een buitengewone wreedheid aan den dag. Zij zijn daarbij namelijk vrijwel uitsluitend dangervezen op den klachtigen, maar niet zeer grooten bek. Hebben zij nu een voorbijzwemmend dier, een visch, een kikvorsch of wat ook, gegrepen, dan zetten zij de voorpooten schrap tegen hun prooi en scheuren stukken daaraf met zulke snelle bewegingen ran den kop, dat ze hem feitelijk geen oogenblik lsslaten.

De echte Zoetwaterschildpadderi (Emydae) wagen zich meer buiten het water dan de Trionyx-soorten en zijn orer het algemeen zeldzamer. Het meest treft men nog ian Cyclemys (Cuora) amboinensis, minder Cyclemys dhor en Damonia subtrijuga, die alle in afmetingen verre bij oudere Trionyx exemplaren ten achter staan. Slechts zelden toch ziet men individuen, we'lker rugschild een lengte bereikt ran $20 \mathrm{cM}$. of meel. Het is niet onmogelijk, dat hun mindere algemeenheid een gevolg is van hun mindere schuwheid, waardoor zij, vooral op hun tochten buiten het water, meer in het oog vallen en hijgevolg meer aan vervolging zijn blootgesteld. Hun roedsel is meer van 
dierlijken aard, warrbij fle ernmaal met den bek gegrepen prooi eveneens niet meer wordt losgelaten.

Landschildpadden (Testudo en verwante geslachten) zijn ran Java niet bekend.

'Terwijl wij van de volwassen Batrachiërs reeds vroeger ettelijke vormen ontmoetten, moet hier met een enkel wonrd melding worden gemaakt van de larven, die zoowel in stilstaande als in snelstroomende wateren dikwijls in groot aantal zijn te vinden. Orer het algemeen beantwoorden zij aan het gewone type, maar bij sommige soorten vinden wij een bijzondere adaptatie aan het oponthoud in een melium, warin zij zich niet zonder deze op de gewenschte wijze zouden kunnen staande houden. T'erwijl toch de meeste soorten, die in heken en rivieren leven, aldaar de l'ustige plekken bewonen en zich dikwijls onder de beschutting van steenen en andere voorwerpen plaatsen, zijn er enkele vormen, die de kracht van den snellen stoom weerstand weten te bieden en daartoe in staat worden gesteld door een zuignap aan de onderzijde van het lichaam, warmede zij zich o.d. aan steenen vasthouden. Deze adaptatie is "simple comme bonjour”, maar het merkwaardige is rooral, dat nu eens (bijv. bij Ranu jerboal de zuignap een afzonderlijk organan is, lat achter de mondopening is gelegen, dan weder 10.a hij Bufo asper *)) door den mond zelven wordt gerormd; wel een bewijs, dat, wanneer in de natuur een bepaald doel moet worden bereikt, geen verlegenheid behoeft te hestaan on de wijze, waarop dit moet plaats liebben, en lat ook hier meerdere wegen van gelijke perfectie tot hetzelfde doel kunnen leiden.

") Vol. Vas Kampex. Beitrag zur Kenntniss der Amphinbienlarven des 'ndischen Archipels in Tat. Tijdschr. voor N. I. Deel 69, pag. 25. 


\section{VISSCHEN.}

De vischfauna der binnenwateren van Java is nog zeer onvoldoende bekend. Een van de oorzaken daarvan ligt in het ontbreken van een geregeld visscherijbedrijf. Wel. heeft, in de Preanger Regentschappen zelfs op groote schaal, vischteelt op sawah's plaats, hier en daar ook in vijvers, *) maar deze teelt betreft slechts een paar soorten, waarbij goudvisch verreweg de voolnaamste plaats inneemt. Voor het overige wordt slechts te hooi en te gras gevischt, soms uit tijdverdrijf,. soms om een bijverdienste te hebhen en in beide gevallen met zeer elementaire hulpmiddelen. Waar aldus niet orer eenige ervaring kan worden beschikt, zooals die in den loop der jaren door elk bedrijf wordt opgedaan, is het onmogelijk, anders dan door stelselnatig verzanelen, een inzicht te krijgen in het voorkomen en de rerspreiding del verschillende vischsoosten. Maar zulk verzamelwerk neemt meer tijd in beslag dan daaraan tot heden kon worden besteed. Want het is met de visschen een geheel andere zaak dan bijr. met vogels en vlinders. Voor waarnemingen betreffende de laatste kan men elk oogenblik gebruiken, ook al is op dat moment de hoofdbezigheid een andere, maar voor die betreffende de visschen moet men langeren tijd ter platse vertoeven, over allerlei hulpmiddelen beschikken en borendien nog, het noodig'e geluk hebben.

Het aantal soorten van zoetwatervisschen bedraagt op Java, naar schatting, tusschen 150 en 200. Hierbij komt nu nog een zestigtal soorten van zeeen brakwatervisschen, die de ririeren soms vrij ver

*) De vischvijvers nabij de kust blijven hier nog buiten beschouwing. 
opzwemmen, maar die men natuurlijk niet tot de echte zoetwaterfauna kan rekenen. Van de laatste leveren verreweg het grootste contingent de Karperachtigen met ruim 60, en de Meervallen met ruim 30 soorten. Ook de Grondels en de Labyrinthvisschen zijn, zooals wij hieronder zullen zien, rrij goed vertegenwoordigd.

De Kraakbeenige Visschen kunnen hier buiten beschouwing blijven; zij behooren in zee tehuis, al zwemmen ook sommige Zaagvisschen (Pristis-soortell) en sommige Roggen (inzonderheid Trygon-soorten) het zoete water wel eens een eindweegs in.

1)e Familie der Aalachtigen (Muraenidac) is in de binnenwateren vertegenwoordigd door het geslacht Anguilla en wel door de soorten $A$. siclat, $A$ mauritianc en $A$. bicolor. De naam van eerstgenoemde, de meest algemeene, is ontleend aan den gelijkluidenden Javaanschen naam, die overigens ook aan de beide andere soorten wordt gegeven. De Naleische naam is moa, terwijl in de Soendaneesche streken de jongere exemplaren als laraq, de oudere als loebing worden aangeduid. In de grootere plaatsen worden ze wel onder den naam ikan paling verkucht. Zooals ook van hum Hollandsche rerwanten bekend is, vertoeven ze gaarne in den modder, terwijl ze geruimen tijd buiten het watel kunnen leven, wat hun te pas komt, wamneer ze van het eene water narr het andere willen rerhuizen. Verblijf in een beperkte hoereelheid helder water. bijv. in een legenbak, is hun blijkbaal onaangenaam: is de laded hun te hoog om eruit te springen, dan vervallen ze in een toestand van lethalgie en brengen lan dagen achtereen bewegingloos door in een nagenoeg verticale houding. 
Het geslacht Muraena, dat zich van Anguilla o.a. onderscheidt door het ontbreken der borstvinnen, is meer marien, evenals het geslacht Ophichthys, dat gekenmerkt is door een vrijen (d.w.z. niet door een verticale vin omzoomden) staart. Echter is rooral Ophichthys loro niet afkeering van zoet water, zoodat deze sonrt soms nog vrij ver van zee wordt bemachtigd.

Van de zeer naverwante familie der Symbranchidae, die eveneens aalvormig zijn en zich kenmerken dool de samenvloeiing der beide uitwendige kieu wopeningen tot ééne rentrale opening; is een hoogst algemeen verspreide vertegenwoordiger Monopterus javanensis, onder den naam beloet of weloet bekend. Meer nog: dan de echte palingsoorten heeft dit dier neiging om zich in modderigen grond te verbergen en toont daarbij een merkwaardig uithoudingsvermogen ten aanzien van watergebrek. Dikwijls komen de beloets met het bevloeingswater op de rijstvelden terecht, waar zij zich dan vrij diep in den grond verbergen en niet zelden eerst bij een rolgende grondbewerking voor den dag komen. "Worden er-zoo schrijft de voormalige Adjunct-Inspecteur van den Inlandschen Landbouw H. DE BIE *)-tijdens het omspitten van de sawah beloets buitgemaakt, dan hoult de sawahbewerker die zoolang in een korfje of ben van eigenaardig gebroken rorm, hetwelk aan een touwtje om het iniddel wordt gedragen. Veelal echter hangt de vangst aan risten aan een bamboe touwtje over den zonnehoed, waardoor zij in de zon wordt gedroogd". De beloet komt zoowel in de laag. landen als in de hoogere streken voor; zelfs in den

\footnotetext{
$\left.{ }^{*}\right)$ De Teelt van Zoetwatervisch in de Preanger Regentschappen Buitenzorg, 1909. pag. 35.
} 
vijver ran den Bergtuin tt 'l'jibodas, op 4500 roet boven zee, is hij een riste hewoner.

Een tweede rorm van dezelfde familie, Symbranchus bongalensis, schijnt daarentegen meer tot de lagere streken beperkt te zijn. Hij komt o.a. Wel eens voor in de moerasboschjes, rvarin de kiray-palmen (Metroxylon-snorten) groeien en waarin het water veelal tamelijk helder is. Heeft het dier zich nu, zooals zijn gewoonte is, roor het grootste gedeelte in den molderigen bodem ingegraven, dan markt de groenachtige, platte staart eenigszins den indruk van een uitlooper van zulk een palm en naar die gelijkenis hoort men deze soort soms met den naam poetjoek hiray aanduiden.

De verschillende soorten der heide genuemde families rertoonen in den regel weinig sprekende kleuren, mar deze zijn wel eenigszins veranderlijk naar gelang der omgering. In helder water treden groen en olijfbruin reel meer op den voorgrond, terwijl een verblijf in troebel water en in modder grauwachtig zwarte tinten reroorzaakt. In de eigenschap, geruimen tijd zonder of slechts met een mininım ran water te kunıen leven, staan ze in geenen deele alleen. Wij treffen die bij meerdere rormen uit verschillende families aan. Sommige worden dartoe in staat gesteld door het vermogen, in de kieuwruimte een roldoenden roorraad water mede te nemen, andere bezitten boven of achter de kieuwrumten luchtzakken, in welker wanden een deel ran het bloed circuleert, dat alclus in aamraking worclt gebracht met lucht, die rechtstreeks uit de atmosfeer wordt opgenomen. Het laatste treffen wij o.a. aan bij sommige Situridue (Meervallen), zuoals bij het geslacht Clarius, warran verschillende snorten hier 
onder den naam ikan lèlèh bekend staan. Hier zijn de bedoelde zakken zelfs boomvormig vertakt, waarbij de vertakkingen eindigen in kleine blaasjes, zoodat het geheele orgaan een klierachtig uiterlijk heeft.

Van de bedoelde Clarias-soorten is verreweg de meest bekende $C$. batrachus (magur). De andere zijn C. teysmanni, die vooral in de hoogere streken schijnt thuis te behooren, C. nieuhofi, die in de omstreken van Batavia nogal algemeen is en aldaar $i$. lindi wordt genoemd en eindelijk C. melanoderma, die minder veelvuldig wordt angetroffen. Als bijna alle Siluridae, zijn zij in het bezit van soms zeer lange, draadvormige aanhangsels nabij de mondopening, bij dit geslacht acht in aantal, welke baarddraden verband houden met het verblijf in troebel en zelfs modiderig water, waarvoor ook bij deze familie een groote voorliefde wordt aangetroffen. De oogen kunnen in zulk een omgeving slechts geringe diensten bewijzen en worden hier gedeeltelijk vervangen door de bedoelde draden, die als tastapparaat fungeeren.

Een andere welbekende Siluride is de ikan djambal (Pangasius djambal), die over geheel Java algemeen verspreid voorkomt, door de inlandsche bevolking veel als voedsel wordt gebruikt, speciaal in gedroogden toestand, en door haar als een der beste vischsoorten van het zoete water wordt beschouwd.

Voorts kunnen hier worden genoemd: Callichrous bimaculatus, een fraaie zilverachtige visch met een rooden gloed over de bovendeelen, een zwarte vlek aan weerszijden boven de borstvin en een slechts weinig ontwikkelde rugvin. Zij wordt, evenals verschillende soorten van het naverwante geslacht Cryptopterus (waar de rugrin slechts door een draadvormig nitsteeksel is vertegen woordigd) met den naam 
ikon limpoh of limpok angeduid. Lais hexanema, in de Preanger Regentschappen ikan lais genoemd; Wallago attu, in Bitavia ikan tjangoep, die soms zeel. groote afmetingen bereikt.

Het geslacht Macrones is in de hinnenwateren hethet meest vertegenwoordigd dool de soort nemurus (mal. ikan bawon, soend. senggal), die meer benedenwaarts voor een groot deel wordt rerrangen dool. M. gulio. De laatste strekt haar verspreidingsgebied ork uit over het brakke water der ririermondingen en wordt daar dikwijls in grooten getale gevangen. Evenals eenige andere, in hoofdzaak marine Siluridae o.a. Arius caelatus en Ketengus typus, draagt zij den Maleischen naam ikan manjoeng.

Van de .kleinere soorten dezer familie, die zich dikwijls door een fraai voorkomen onderscheiden, kan in de eerste plaats worden genoemd Glyptosternum platypogon, die nogal algemeen voorkomt, en roorts het geslacht Acrochordonichthys, wadrvan de rerschillende soorten een meer plaatselijke verspreiding schijnen te hebben. Al deze kleinere soorten, die, althans in West-Java, onder den gemeenschappelijken naam ikan lièlièl bekend staan, behooren meer in de bergstreken thuis. Slechts in regenrijke tijden worden zij niet zelden door den stroom naar de benedenstreken medegevoerd, tenzij, zooals o.a. bij Glyptosternum het geval is, het bezit ran een zuignap hen in staat stelt, zich staande te houden.

Eindelijk zij hier nog vermeld Bagarius bagarims, een rorm, die soms een lengte ran $1 \frac{1}{2}-2$ Meter bereikt en zich vooral in de breedere en diepere gedeelten der rivieren ophoudt. Deze soort is niet zeer algemeen en o.a. gekenmerkt door de, aan de basis rerbreede baarddraden ran de hovenlip. 
In West-Java stat ze onder den naam lika bekend.

Bij de meeste Siluridae zijn ò le rugrin, of de borstrinnen, en in vele gevallen beide, van een stekel voorzien, die als verderligingswapen dienst doet en bij onzachte aanraking herige pijn veroorzaakt. Aan een bepilalde giftklier behoeft hier niet te worden gedar:ht; het is de huidafscheiding ran het dier zelve, die in een wonde als giftstof (en dikwijls zeer hevig) werkt.

De familie der Karperachtigen (Cyprinidae) overtreft hier in vormenrijkdom nog verre de rorige; wij zullen ons echter ook bij har moeten bepalen tot een vluchtige vermelding der meer algeneese vormen. In tegenstelling met de Situridae, zijn de Cyprinidae liefhebbers van helder water; slechts de kleine onderfamilie der Cobiticlae maakt hierop een uitzondering. Want zooals de Hollandsche naam Modderkruipers reeds voldoende aangeeft, houden deze, dikwijls zeer kleine vischjes zich op in water met een lossen, modderigen bodem en men behoef ze daarom niet te zoeken in wateren, waar de bodem een harde gesteldheid heeft. Deze levenswijze opunbart zich veder in een uitwendig kenmerk, de aanwezigheid, rondom de inondopening, van 6-s tastorganen, die hier echter slechts van geringe lengte zijn, daarentegen naar roren gericht. worden gedragen. Betrekkelijk lang zijn ze (rooral die aan de bovenlip) bij het geslacht Botia, op Java vertegenwoordigd door de soort hymenophysa, die de, rool een Cobitide nogal aanzienlijke afmeting van is cM. kan bereiken en yemakkelijk herkenbaal is aan de talrijke snalle, frai blauwe dwarsbanden over het lichaam. Van de overige Cobitidce van Java 
mogen hier als algemeen worden genoemd Nema. chilus fascialus, van $4-\$$, en Lepidocephalichthys hasseltii, ran niet meer dan $3-4$ cM. lengte. 'Trots deze geringe afmetingen, worden de diertjes, die onder de inlandsche namen djelèr en serowot bekend staan, dikwijls nog gevangen, vooral door vrouwen en kinderen, en als toespijs bij de rijst genuttigd.

Ook het geslacht Homaloptera neemt eenigszins een afzonderlijke positie in, zoowel door den algemeenen, rooral vóor de rugrin afgeplatten lichadmsrorm, waardool het nog aan de Siluridae herinnert, als rool de platsing van de mondopening aan de onderzijde ran den kop. Zoowel deze platsing, als de ainwezigheid van soortgelijke, maar kleinere baardharen als bij de Cobitidae worden aangetroffen, wijzen, hoewel dienaangadnde nog iveinig met zekelheid hekend is, op een levensivijze in of nabij den bodem van het water. De grootste en fraaiste soort ran dit geslacht is Homulopter paionina, die haal naam ontleent aan een overlangsche rij ran zes pauroogachtige rlekken op der rug. Zij is terens de meest algemeene, hoewel ook le kleinere $H$. wassinliii en de zeer langwerpige $H$. ophiolepis niet zeldzaam zijn. Alle houlen zich bij voorkeur op in streken van bergachtigen aard.

Bị de echte Cymmindac zijn de lladromige tastorganen rondom de mondopening ò geheel afwezig; of klein in aantal (2) of 4 ) en gering van afmeting. Datarentegen vertoonen lippen en kaken soms reldikkingen en aangloeingen, dis wel is wair als hulpapparaat bij het zuigen aan allerlei voorwerpen litenst doen, doch raarbij terens rermoedelijk ran sensnrische heteekenis zijn. Bij sommige senera 
komen ze menigvuldiger en duidelijker roor dan bij andere; zoo zijn ze rooral bij Tylognathus en Labeo goed ontwikkeld. Van het eerste geslacht zijn de meest algemeene soorten T. falcifer (mal. lehat; soend. oedjah) en T. hispidus; het tweede is platatselijk sterk rertegenwoordigd door L. chrysophekadion, die soms een halven Meter lang wordt en een zeer donkere lichaamskleur bezit, echter verlevendigd door een groenachtig, soms zelfs goudgroen vlekje op elke schub. Bovendien is deze soort, evenals de verwante L.ery. thropterus, die vooral in de bergstreken roorkonit, gekenmerkt door een groot aantal poriën over het geheele gedeelte ran den kop, dat róór de oogen ligt.

Een algemeen verspreide vorm van deze groep van Cypriniden is verder de santran, Barbichthys laevis, bij welke echter de bedoelde organen in reel mindere mate zijn ontwikkeld, evenals bij Osteochilus hasseltii, die nog reel algemeener is en, evenals vele der bovengennemde en bovendien nog een aantal andere soorten, in West.Java met den naam nilem wordt aangeduid. Orer het algemeen zijn echter de hier opgegevèn inlandsche namen niet zeer vast en hoogstens plaatselijk van eenige warde; de feitelijke toestand is, dat de meeste inlander's wel eenige en soms zelfs vrij veel namen van visschen in hun hoofd hehben, doch slechts ongeréér weten, op welke soorten en groepen deze namen betrekking hebhen. Zelfs de rischhandelaren te Batavia, bij wie men in de eerste plaats eenige meerdere kennis zou rerwachten, duiden alle bovengenoemde Cyprinidae met den algemeenen naam wadon goenoeng aan, daarmede een voudig. te kennen gevende, dat zij ze wel herkennen als verwanten ran de wadon (verschillende ook nabij Batavia roorkomende Burbus-soorten), maar zich 
overigens het hoofd niet wenschen te breken over deze, uit het binnenland (de bergen) aangevoerde soorten.

Alrorens over te gadn tot de rermelding van eenige soorten van het laatstgenoemde, uiterst vormenrijke geslacht Barbus, moeten hier twee algemeen bekende vischsoorten worden genoemd, die, vooral door Chineezen, uit noordelijker streken zijn ingevoerd, namelijk de Karper en de Goudrisch. De eerste (Cyprimus carpio) is hier en daar verwilderd en wordt niet zelden, soms in zeer groote exemplaren, in rivieren en plassen aangetroffen. 'Toen, in 1911, de grwote vijrel' in 's Lands Plantentuin geheel moest worden schoongemaakt en daartoe geclurende eenige dagen drooggelegd, kwamen eenige reusachtige Karper's voor den dag, die zich daar rustig hadden ontwikkeld in het rijftiental jaren, dat sedert een vorigen dergelijken schoommaak was reloopen. Ze werden drol de werklieden ikan tambra genoemd en staan. ouk rlders onder dier naam bekend, hoewel de eigenlijke iliun tambru een Barbus-soort is, warmede zij esnige gelijkenis vertoonen. Het is niet onwarschijnlijk, dat de Kinperteelt rroeger hier te lande ran neer beteekenis is gerveest dan thans, maar dat zij langzamerhand is rervangen door de Goudvischteelt, die reel gemakkelijker is en spoediger resultaten oplerert. De Goudrisch (Carassius auratus), van den Karper dadelijk te onder'scheiden door de afwezigheid der baarddraden, wordt sinds ongereer jo jaar in West-Jara, en inzonderheid in sommige gerleelten der Preanger Regentschappen, op groote schaal geteeld. zoowel in vijrel's (en dan soms in gezelschap ran eenige andere Cyprinidae), als vooral 
op de sawah's. Zooals bekend is, bestaan ran haar een groot aantal, dikwijls zeer sierlijk gevormde en fraai gekleurde cultuurvariëteiten, doch deze kunnen hier buiten beschouwing blijven; wat men hier teelt, is de oorspronkelijke soort, waarbij hoogstens kleurverschillen, loopende tusschen de bekende goudkleur en verschillende nuancen van grijs, zijn waar te nemen. Zij staat hier algemeen bekend onder den naam ikan mas en speelt in de genoemde streken een vrij groote rol als volksvoedsel en liandelswaar.

Het geslacht Barbus is op Java door een vijfentwintigtal soorten rertegenwoordigd, waarvan sommige eveneens als roedsel roor de inlandsche bevolking niet zonder beteekenis zijn en in verband daarmede een vasten inlandschen naam hebben van iets meer dan plaatselijke waarde. Dit is in de eerste plaats het geral met de reeds genoemde ikan tambra (Barbus tambra), die even groote afmetingen kan bereiken als de Karper, van welken zij zich o.a. door de zeer groote schubben onderscheidt. In dit laatste kenmerk, alsmede in de, voor Cyprini dae rrij sterke ontwikkeling der baarddraden, reseenigt zij een paar verwante soorten rondom zich, waarvan hier mogen worden genoemd $B$. soro, waarvan de wetenschappelijke naam aan den Soendaneeschen is ontleend en B. tambroides, die zich op hare beurt onderscheidt door den gecompliceerden, gelobden bouw der lippen.

Een tweede bekende rorm is de $i$. hampal ( $B$. hampal), die eveneens een vrij aanzienlijke grootte bereikt, hoewel niet in die mate als de $i$ tambra, terwijl als derde kan worden genoemd de reel kleinere (hoogstens vingerlange) beunteur (B. maculatus), die rermoedelijk wel als de meest algemeene 
Cyprinide ran Jara mag worden beschouwd. Speelt zij, door haar geringe afmetingen, oeconomisch een niet meel dan bescheiden rol, in biologisch opzicht bieat ze een interessante bijzonderheid aan, door gastrijleid te rerleenen aan een Isopode van de familie der Vischpissebedden (Cymothoüdae), welke dieren in de Preanger Regentschappen onder den naam soengkeat bekend staan.

De hier bedoelde soort, Ichthyoxenus jellinghausii. zwemt gedurende een gedeelte van het larrale leven rrij rond en in die periode vallen rele aan visschen ten prooi, ook aan de beunteur, die daardoor blijk geeft, niet zoo bijzondel op zijn aanstaanden gast te zijn gesteld. Deze doet van zijn kant alle moeite, het begeerde logis te reroreren. „Zoodra de visch roelt, dat een jonge soengkeat zich aan zijn lichaam heeft rastgegrepen, schiet hị snel rooruit, waarschịnlijk met het doel, de parasiet van zich af te krijgen, hetgeen ook meestentijds gelukt. Heeft de soengkeat zich echter rastgehecht achter een der bolst-of buikvinnen, dan helpt dat snelle rooruitschieten natuurlijk niet, daar hij dan door de rinnen vast tegen hot lichaam ran de risch wordt gediukt. Ik geloof, dat de gaten, warrdoor de soengkeat in de visch is gedrongen, juist dáárom bijna zonder uitzondering achiter de vinnen zijn gelegen (Ouwens *). De berloelde gaten ontstaan oj de plek, waar het de parasiet gelukt, zich staande te houden: zij geren toegang: tot een zakrormig verblijf, dat niet in verdere cre. meenschap staat met eenig inwendig orgaan ran den gastheer, zoodat hier slechts inwoning, geen kost wordt verleend. Den laatste neemt de Isoporle

*) Nog iets over Ichthyoxenus jellinghumsii. Herklots, door P. A. Ouwexs in Nat. Tijdsclur. voor Ned. Indie, Leel 67, ['ag. 29. 
blijkbaar uit het omringende, haar vrijelijk toestroomende water op. Gelijk ook bij vele verwante volmen het geval is, maakt de volwassen soengkeat eerst een mannelijke, daarna een vrouwelijke periode door. Eerst gedurende de laatste restigt zij zich voor goed en is dadrtoe zelfs verplicht door den toenemenden lichaamsomrang, die het haar onmogelijk zou maken, zich door de opening heen te werken, gelijk in den mannelijken toestand, en kort daarvóór, mede met het oog op de paring, nog plaats heeft. Eveneens in overeenstemming met hetgeen bij rele andere Crustaceeën is wargenomen, kunnen de dieren, wanneer zij gedurende de ontwikkelingsperiode der eieren, die hier in een broedzak worden bewaard, als roedsel worden gebruikt, gevaar voor vergiftiging opleveren. Gevallen daarvan hebben zich meermalen voorgedaan, wanneer, bij de bereiding van beunteur tot een of ander culinair product, uit onachtzaamheid aangetaste exemplaren mede werden bereid.

Rondom Barbus maculatus groepeeren zich een aantal andere soorten, die wel ecns tot een afzonderlijk geslacht (Puntius) ermede worden vereenigd en war. van eveneens zeer algemeen zịn $B$. lateristriga, gekenmerkt door een hoogen róórug, B. obtusirostris, $B$. gonionotus (vrij algemeen met den inlandschen naam tawes aangeduid), B. rubripennis, B. bramoides (mal. wadon) e. a.

Te Bataria maakt men over het algemeen weinig verschil tusschen de Barbus-soorten en duidt ze met de namen wadon en lawak aan; in Midden-en Oost-Java heeten zij wridder, welke laatste naam aldaar ook wordt gegeren aan de kleine, maar fraaie Cyprinide Rasbora argyrotaenia (die in West-Java onder den rrij vasten naam parai bekend staat), 
aan Dangila curieri (soend. tiworo) en an de slanke Ciossochilus oblongus (soencl. djèdjèt), allen vormen, die in de meeste rivieren en soms in groot atantal kunnen worden aangetroffen.

'len slotte zij nog rermeld het Cypriniden-geslacht Chela, dat zich onderscheidt door de hooge ligging vall den mond, die daardoor eenigszins naar boren is gericht en bij de meest voorkomende soort, $C$. anomalurus, zelfs in het verlengde ran de ruglijn ligt.

De Familie der Haringen (Clupeidue) omvat slechts marine vormen, van welke echter sommige nu en dan in groote troepen de rivieren opzwemmen en aldaal dan tijdelijk een aanzienlijk bestanddeel ran de fauna uitmaken. Hier te lande is dit rooral het geval met een paar soorten ran het geslacht En graulis, verwanten derhalre van de Ansjovis, met name E. melanochir en $E$. tri, heide onder den inlandschen naam itian teri welbekend.

De kleine familie der Notopteridae is hier rertegeworrigd door de soorten kapirat en chitala ran het zoetwatergenus Notopterus, dat o.a. gekenmerkt is door den spits toeloopenden staalt, welks vin met de anaalvin tot één g'eheel is versmolten en, vooral wat eerstgenoemde soort betreft, het groote verschil tusschen de fijne beschubbing van het lichaam en de reel grovere van den kop. Van $N$. kapirat, aldus nitar den inlandschen naam genoemd, komen soms exemplaren van j0 tot 60 c.I. lengte roor.

Van de Cyprinodontidae is de kleine Haplochilus panchax op Java hoogst algemeen. Zij is het best bekend onder den inlandschen nam itun kiupalu tima, 
ontleend aan een, als wit metaal glinsterend plekje op den kop (dat echtel niet bij alle individuen eren duidelijk is) en behoort tot een groep van kleine risschen, aan welke ten groote beteekenis wordt toegeschreven in verband wet het verdelgen van muggenlarven. Het brengen van deze rischjes in stilstaand water, waarin zij niet ran nature roorkomen, is inderdaad wel aan te bevelen, maar het is natumlijk nog veel beter, zooveel mogelijk te zurgen, dat er geen stilstaand water is, ook en vooral niet in die geringe hoeveelheden, waarin zelfs deze kleine Haplochilus niet zou kunnen bestaan. Haar grootste lengte bedraagt nauwelijks $6 \mathrm{cM}$; een verwante, maal meer zeldzame soort, $H$. javanicus, brengt het zelfs niet verder dan 4 cM.

De op Java in het zoetwater voorkomende Scomberesocidue staan allen onder den naam djoelong-djoelong bekend en zijn hoofdzakelijk zeedieren, die zich gedeeltelijk aan het verblijf in zoet water hebben geaccomodeerd. De grootste ervan is Belone stiongylur $\alpha$, warlvan in den benedenstroom en de mondingen der rivieren soms exemplaren van een halven meter lengte worden lemachtigd. Bij haar zijn beide kaken tot een langen, krokodilachtigen bek verlengd en hierdoor onderscheidt het geslacht Belone zich van Hemiramphus, waarbij slechts de onclerkaak zeel lingr en prienvorming is en door het dier, dat daarbij een bijna rerticale hourling aanneemt, garrne in den molder wordt gestoken. In liet binnenland is zeer algemeen Hemiramphus fluciatilis, die, zooals de soortnaam aanduidt, slechts ran het zoete water bekend is en zelfs hoog in het grobergte roorkomt. In de lagele streken komen vor $H$. cmblymus, eveneens 
in hoofdzak een zoetwatervorm, alsmede $H$. dispar en $H$. buffonis, die beide meer in zee thuis behooren.

De familie der Percidae (Baarzen) speelt op. Java op culinair gebied een belangrijker rol dan faunistisch, in zooverre verschillende soorten, zooals de kakap (Lates calcarifer), de kakap merah (Lutjanus annularis) en de hrapoe (Serranus-sourten) behooren tot de beste tafelrisschen, die de omringende zeeën opleveren. In het zoete water is zij slechts zeer spararzaam rertegenwoordigd, met nane door een paar soorten vau het geslacht Dules, die in geen opzicht van bijzon:tere beteekenis zijn.

Van de s'quamipinnes is de groep der dikwijls grillig gerormde en schel gekleurde Chaetodontina in de rivieren slechts vertegenwoordigd door Scato. phagus argus (ikan kipar), die echter niet veel hooger gaat dan de mundingen. Daarentegen treft men Toxotes jaculator tot ver in het binnenland aan, terwijl de gewoonte ran deze visch, insecten, die zich in de nabijheid van het water ophouden, te bemachtigen door ze te "schieten" met een paar druppels water. die met rrij veel kracht uit de mondopening worden verwijderd, ook den inlanders welbekend is. Ze staat in verband daamede algemeen als ilian suempit bekend.

'Tijdelijke hezoekers van den benedenloop der rivieren zijn verder eenige rertegenwoordigers ran verwante, kleine families, o.a. Catopra fusciata (fam. Nandidue), Polynemus tetradactylus (ikan koero. fam. Polynemidae), Corvina miles (fam. Sciaenidac) en Trichiurus glossodon (ikan lajoer, fam. Trichiuridae), terwijl van te familie der Carangidae vooral ver- 
schillende Equula-soorten (ikan pepèrèk) zich soms vrij ver landwaarts in begeren.

Hoewel, zooals vroeger reeds werd opgemerkt, het aantal soorten van de familie der Gobiidae in de binnenwateren van Java aanzienlijk is, weten wij van hunne verspreiding nog minder dan bij andere groepen het geval is. Als voedsel staan zij niet hoog aangeschreven, noch bij de Europeanen, noch bij de inlanders, die hen vrij algemeen met de namen ikan belosso of bossolk en $i$. poentang aanduiden. Het geslacht Gobius telt, naast eenige zoetwatervormen (o.d. Gobius pleurostigma, G. belosso, G.tambujon) een aantal andere, die zoowel in zee, als in de rivieren roorkomen. Van de laatste is Gobius giuris een van de meest voorkomende vormen. Het geslacht Sicydium, een zoetwatergenus, dat door een parr kleine soorten is vertegenwoordigd, geeft evenmin aanleiding tot bijzondere opmerkingen, terwijl het roorkomen der Eleotris-soorten, die weder over zoet en zout water zijn verspreid, roldoende wordt aangeduid door den soortnaam van ééne harer, ophiocephalus, en den (plałtselijken) inlandschen naam ilan gaboes laoet (vgl. hieronder bij Ophiocephalidae). Een algeheelen slang. of liever alalachtigen habitus treffen wij aan bij Amblyopus graculis en Trypanchen vagina, die roomamelijk het zoute en het brakke water bewonen en, zooals hun lichaảmsvorm reeds doet rermoeden, een groote roorliefde roor modder aan den dag leggen.

be eigenaardig gebouwde Mastacembelidae, die in hun lichaamsvorm ereneens aan Alen herinneren. zijn op Java door de heide geslachten Rhynchobdella 
en Mastacembelus rertegenwoordigd. Rhynchobdella aculcutu, kenbaar aan een iantal oogvormige vlekken langs de basis van de rugvin, is meer beperkt tot de nabijheid der zee. warr zij zich, bij voorkeur in ondiep water, in den modder ophoudt; de Mastacembelus-soorten maculatus en unicolor zijn daarentegen echte zoetwatervormen, die tot vrij hoog boven zee roorkomen, maar overigens wederom dezelfde voorliefde voor een weeken bodem bezitten.

Eveneens echte zoetwatervisschen zijn de ophiocephalidae, hier algemeen ondel den naam ikan gaboes bekend. Het zijn hevige roofdieren, die aan de vischteelt veel nadeel kunnen toebrengen, maal ter wille van hun goed vleesch dikwijls op hunne beurt in vijvers worden gehouden, waal men soms reusachtige exemplaren ziet rondziremmen. De meest gewone soorten zijn Ophiocephalus striatus en O.gachua; minder veelvuldig is 0 . lucius (i. gaboes tjina). Alle hebben het vermogen, langen tijd buiten het water te kunnen doorbrengen en wanneer ze in de rijrers, warin ze worden geteeld, niet voldoende van roedsel worden voorzien, lerert een tochtje over het laind, op zoek naar een heter verbliff, volstrekt geen bezwaar op, wanneer de oever's van den rijres maar van dien aard zijn, rat zij daartegen kummen opkinipen.

Ook de Labyrinthvisschen (Labyrinthici) behooren in het zoete water thuis. De meest bekende daarvan is wel de goeramih (Osphromenus olfax), die tot de beste zoetwatervischen van Jara behourt en veelvuldig wordt geteeld. Zeer algemeen rijn wh 0 . striatus en O. trichrpterus, maar deze zijn gewornlijk van te geringe afmetingen, om als tafelvisch ennige 
waarde te hebben; gedroogd komen ze onder den naam ikan sepat in den handel en zijn dien rorm voor de inlandsche bevolking een welbekende toespijs bij de rijst.

Het vermogen, zich buiten het water op te houden, ook bij deze familie algemeen, treedt het duidelijkst aan den dag bij de Klimbaars (Anabas scandens), die, zooals bekend is, zich zelfs op takken nabij het water kan bewagen en aldaar jacht maakt op insecten. Zij bewoont zoowel de hoogere als de lagere gedeelten der rivieren, is niet zeldzaam, en komt soms in grooten getale bij elkaar voor, zooals ook het geval is met de kleine Betta's (B. pugnax en B. trifasciata), die eenigs. zins aan de Haplochilus-soorten herinneren.

De Mugilidae behoeven hier slechts terloops te worden genoemd. Zij zijn in hoofdzaak bewoners der zee, die echter, vooral in jengdigen toestand, de rivieren soms vrij rer en in groote scholen opzwem. men. De meest bekende der Mugil-soorten, die in de rivieren van Java zijn wargenomen, is de ilian belanak (Mugil planiceps).

Het is waarschijnlijk niet van algemeene bekendheid, dat in de rivieren van Java Platvisschen (Pleuronectidae) voorkomen. Niet alleen zijn het de Cynoglossus. soorten potous en oxyrhynchus, alsmede Synaptura commersoniana (alle als ikan lida bekend), die de rivieren opzwemmen, maar laatstgenoemd geslacht telt zelfs meer dan ééne soort, die uitsluitend van het zoete en hoogstens ook het brakke water bekend is en van welke op Jara S. leucorhyncha wordt aangetroffen. Ook de Zeenaalden (Syngnathidae) dragen hun naam niet met volkomen juistheid. Syngnathus spicifer komt tot ver binnen 
het stroomgebied ran vele rivieren roor en het verwante geslacht Doryichthys heeft één uitsluitenden zoetwaterrorm aan te wijzen (D. caudatus), terwijl een andere $(D$. brachyurus) ran zoet en brak water bekend is. Biologisch zijn de Zeenaalden merkwardig door de zorg, die de mannetjes aan de eieren besteden: zij dragen deze bij zich in een, uitwendig. nauwelijks zichtbaar zakje, warin de eieren door huidplooien worden heschermd en dat bij Syngnathus in de staartstreek, bij Doryichthys in de abdominaal: streek is gelegen. Bekend is hun eigenaardige wijze van zwemmen, in een bijna verticale houding, waarbij de rourtherveging hoofdzakelijk door de kleine rugrin tot stand wordt gebracht.

De Plectognathi eindelijk zijn hier ruimschoots vertegenwooldigd door het geslacht T'etrodon van de familie der Gymnodontidae, waarvan verschillende soorten onder den inlandschen naam ikan boentak (met verschillende toevoegingen nar gelang der soort) bekend staan. Een zuivere zoetwatervorm is T. leiurus, in zoet en brak water komen roor $T$. patocu en T. fluviatulis, terwijl T. sceleratus, T. lunaris en T. oblongus zeevormen zijn, die ook in de rivieren kunnell worden a angetroffen. De meeste soorten hebben het rermogen, het van nature reeds ronde lichaam nog aanzienlijk op te blazen, dool elastische aanhangsels ran het darmkandal met lucht te vullen. Loor deze manoeurre wordt hun soortgelijk gewicht geringer; ze komen dan aan de oppervlakte te drijien, met de buikzijde naar boren gekeerd.

\section{Gelent: Dierex.}

Zooals reeds rroeger (pag. 25.3) werd opgemerkt. zijn kleine Crustaceeën in het zoete water ran Jara 
uiterst schaarsch in velgelijking met hetgeen bijv. West-Europa te zien geeft. Copepoda, Ostracoda en Phyllopoda ziet men hier zelden of nooit en dan nog alleen in plassen van tenigen omvang. Dezelfde erraring werd reeds opgedaan door Max IVEBer gedurende zijn reizen in Nederlandsch Indië in 1888 en 1889; zij was ook die ran KR $\mathrm{R}$ EPELIN, die in 1904 gedurende eenige mianden op Java verzamelde en zijn bijzondere andacht aan de kleinele dierrormen van het zoete water wijdde. Slechts in de groote meren van Sumatra trof eerstgenoemde Entomostraca in aantal van beteekenis aan ${ }^{*}$ ), maar ook hier was het aantal soorten gering, terwijl latstgenoemde slechts twee soorten van Ostracoda aantrof, die-beide nieuw bleken en het aantal der van Java bekende soorten dier orde nog slechts op zes brachten. Daarentegen is, wederom in tegenstelling met het, zooeven ter vergelijking aangehaalde, West-Europa, het aantal Decapoda ianzienlijk. zoodat, in haar geheel beschouwd, de Crustaceeën-fauna van het zoete water hier een rolslagen ander karakter vertoont dan ginds. Dit ralt des te sterker op, wanneer men aan het borenstaande nog toeroegt, dat ook de Amphipoda en Isopoda hier niet, zooals in Europa, door echte znetwatervormen, maar bijna uitsluitend door rormen ran marinen vorsprong zijn rertegenwoordigd. Echter spelen ook deze beide groepen hier in het zoete water een zó bescheiden rol, dat wij ze, na hetgeen vroeger aangaande Ichthyoxenus je:linghausii werd medegedeeld, thans stilzwijgend kunnen voorbijgaan, om later, hoog in de bergwouden, nig een interessante Amphipode ain te treffen.

*) Vgl. Die Süssuaser-Crustareen des Indischen Archipels ron VAX Wreber, in Zool Erg. viner Reise in Vierlerländisch Ust-Indien, 3d. II, yag. 528 . 
Van de Decupoda werd rroeger reeds Atya moluc. censis als de meest algemeene der zoetwaterkrabben genoemd. Als andere Brachyura kunnen wij hier noemen Ocypoda cordimana, Sesarma nodulifera, Parutelphusa convexu en $P$. tridentata, die roomamelijk in de lagere streken voorkomen, om in de hoogere gedeelten ran het culturrgebied en daarboren te worden vervangen door Telphusa granulata, Geotelphusa kïhlii e. i.

Van de Macrura treedt rooral het garnalengeslacht Palaemon met de soorten dispar, lar, elegans en pilimamus op den voorgrond, terwijl van Caridina slechts de somt laevis ran Java bekend is.

Summid summarum geldt roor Javi in het bijzonder; wat Max Weber (l. c. pag. 5:34-543) roor de zoetwater-Crustaceeënfauna van geheel Indië in het algemeen aantoonde: een groote schaarschte aan kleinere rormen, speciaal Entomostraca, die elders ran oudsher in het zoete water den boventoon roeren en. rermoedelijk als gerolg daarran, een gelegenheid tot invasie ran marine rolmen, die daar ran ruimschoots hebben gehruik gemaakt en dat nog heden ten dage doen.

Orer de insectenfauna van dit gebied kumnen wij kort zijn na hetgeen bij de hespreking der Sawah. fauna reeds over de waterberwonende insecten werd gezegd. Waar de gesteldheid ran het water zich ertoe leent, vindt men hier dezelfcle rormen terug; waal het bestaan der laatste door den snellen stroom onmogelijk word gemakat, zijn verschillende Hydrometridae in hun element, in het bijzonder de grootere romen zooals Gerris fluxiorum, G. fossarum en Ptiln- 
mera laticaudatu, die met bewonderenswardige rolharding den geheelen dag tegen den stroom oproeien, zonder daarbij feitelijk van plaats te veranderen. De kleinere soorten geren mee: de voorkeur aan langZaam stroomend water en aan de rustige hoekjes, die men in de bergstroompjes overal tusschen de steenen dantreft. Daal rindt men relschillende soorten van het geslacht Metrocoris, alsmede de fraai roode Perittopıs (/ufus?) en andere, ongerleugelde vormen, die zich, op de wijze der Draaikevers, marl in rustiger tempo, op de oppervlakte van het water bewegen, terwijl eindelijk zeer algemeen is de kleine, slanke, niet meer dan lijnvormige Hydrometru vittata die, wanneer men niet te ver ran eenig water rerwijderd woont, des aronds dikwijls door het lamplicht wordt binnengelokt.

Sommige insecten, die, althans in den volwassen tuestand en voor zooverre wij weten, niets met watel hebben uit te staan, hechten toch aan de onmiddellijke nabijheid daarvan. Dit is in de eerste plaats het geval met een groot aantal Diptera, warran hier slechts genoemd zij het geslacht Diopsis, merkwaardig door de platsing der nogen, die zich aan het uiteinde van lange, steelrormige uitgroeiingen van den kop bevinden en bij enkele soorten van elkander zijn rerwijderd op een afstand, die minstens aan de lengte van luet lichaam gelijk is. De meest algemeene soort is Diopsis vittatus, die de gewoonte heeft, op eenigszins beschaduwde plaatsen in dansende zwermen boren strompjes en waterleidingen te zweven. 'Treft de insectenverzamelaar zulk een zwerm ian, dan kan hij de dieren bij dozijnen bemachtigen, maar heeft hij dit geluk niet, dan kan hij dagen en 
weken lang zoeken, zonder één enkel exemplaar tegen te komen. Iets dergelijks is hier met veel diersoorten het geval, inzonderheid met insecten, en daarom is het meestal zoo uiterst moeielijk, te voldoen aan de veelvuldige aanvragen, uit Europa en elders, om toezending van materiaal van bepaalde soorten. De aanviagers, met de toestanden hier te lande onbekend, stellen zich voor, dat men hier die soorten maar voor het grijpen heeft; zij bedenken niet, dat de kans op het dadelijk verkrijgen van het gevraagde soms weinig grooter is dan die op het vangen van Meikevers in een kouden Decembernacht.

Naast Vliegen zijn verschillende soorten van Wespen, vooral Graafwespen, hier aan te treffen, maar hier ligt de oorzaak hunner aanwezigheid voor de hand: de hellende oevers bieden hun een gunstig terrein vor het uitgraven der nesten. Zeer algemeen is hier Stizus pusillus, die jacht'maakt op kleine $H_{0}$. moptera; minder veelvuldig de fraaie Bembex borrei, die haar jongen met Vliegen grootbrengt. Terwijl de eerste verplicht is, aangrenzende bouwlanden en grasvelden tot jachtterrein te kiezen, kan de tweede dichter bij huis blijven; want de vele bovenbedoelde Vliegen, die gaarne in den zonneschijn spelen op de boven het water uitstekende steenen der rivierbedding, leveren haar ruimschoots materiaal.

Van de levenswijze der talrijke larven van Neuroptera, die getuigen o.a. de duizenden van Ephemeridae, die ons des aronds soms lastig vallen) in grooten getale hun dagen in het veelal troebele water der cultuurstreken moeten doorbrengen, is nog niets bekend. Zóóveel is zeker, dat aan de voorliefde 
voor helder water, welke deze insecten in de gematigde luchtstreken kenmerkt, hier in den regel niet kan worden voldaan en dat een, meer dan oppervlakkige waarneming noodig is, om eenig spoor der bedoelde larven te ontdekken.

Terwijl vele Schorpioenen en Duizendpooten, van huis uit vochtlievende dieren, zich gaarne in de nabijheid van rivieren en plassen ophouden, herbergen vooral de laatste nog vrij talrijke vertegenwoordigers van de familie der Hydrachnidae (Watermijten), die deels vrij rondzwemmen, deels zich vasthechten aan grootere dieren en alsdan een soms greheel, soms gedeeltelijk parasietisch leven leiden. Zoo is het bekende geslacht Atax ook hier op Mollusken verteg'enwoordigd, terwijl de vroeger (pag. 250) besproken larven der verschillende Waterkevers soms talrijke koloniën van Hydrachna's en verwante vormen met zich ronddragen.

\section{WEEKDIEREN.}

Net den grooten rijkdom aan Visschen vormt de betrekkelijke armoede aan Zoetwatermollusken een groot contrast. Armoede althans aan verscheidenheid van vormen; want het aantal individuen is bij sommige soorten.soms zéér groot. Ik denk hierbij in het bijzonder aan het reeds vroeger (pag. 194) rermelde, vormenrijke geslacht Melania, dat hier boven alle andere dell boventoon voert en o.a. ruim vertegenwoordigd is door de soorten tuberculata, scabra en testudinaria. Van deze dieren wemelt het sorns in de open waterleidingen, ook in de groote centra der bevolking, en in stilstaande wateren. Het 
is raarbij oprallend, dat de veelal donker gekleurde, soms uitwendig geheel zwarte, peperhuisvormige woningen zelden geheel gaaf zijn; vooral aan het spitse uiteinde zijn dikwijls gaatjes waar te nemen en soms is dit uiteinde geheel verdwenen. Hier zijn waarschijnlijk allerlei uitwendige invloeden in het spel, zooals natuurlijke slijtage (want rlit uiteinde is het oudste gedeelte van de schelp), uitlooging door het water, beschadiging door andere, verwante volmen.

Tegenover deze Melaniidae treden de andere families van Slakken verre op den achtergrond. Slechts de Waterlongslakken (Limnaeidae) hebben een paar algemeen voorkomende vormen aan te wijzen, waarvan hier Limnaea javana (met vele valiëteiten) en de platte Planorbis compressus mogen worden genoemd. Ook van de echte Moerasslaken (Paludinidae) komt Vivipara javanica tamelijk algemeen voor, maal voor het overige levert het zoete water in het algemeen geen Gastropoden in opvallend aantal op.

Met de Bivalven is het op dergelijke wijze gesteld: tegenover het sterk op den roorglond treden van het genus Corbicula, van de familie der Cyrcnidae, een opvillende schallschte aan andere vormen, in het bijzonder aan Unionidae, die elders vaak zulk een groote rol spelen. De algemeenheid der Corbicula's blijk1, evenals die der Melania's, wel het hest uit de talrijkheid der schelpen en de fragmenten daarran in het grint, dat uit de ondiepe beddingen der rivieren wordt opgehaald en waarin men vooral de soorten sulcatr, ducalis en javanica aantreft. In West.Java staan ze algemeen onder den naam remies bekend; de inlanders eten ze gaarne, gelijk ook het geval is met de veel grootere Batissa-soorten, 
die echter minder algemeen zijn, en de nog grootere Cyrena's.

\section{Wormen en ANdere Lagere Dieren.}

Van de echte Wormen behoeven hier slechts de Bloedzuigers te worden vermeld. Terwijl de Rhynchobdellidae nog wel eens, in gewoonlijk kleine exemplaren, zijn te vinden in de kieuwholten van Visschen en Krabben, bewegen vele Gnathubdellidae zich bij voorkeur rrijelijk rond, zoodat men ze, waar de helderheid van het water dit toelaat, soms met slang. vormige bewegingen kan zien rondzwemmen. Zij hechten zich gaarne aan badende, warmbloedige dieren, maar vallen ook wel jonge visschen aan, die ze dan gedeeltelijk afkluiven, liefst langs het meest vleeschrijke gedeelte der flanken, als gevolg waarvan men de slachtoffers wel eens met gedeeltelijk blootliggenden ruggegraat zich ronddrijven. De meest geduchte dezer parasieten behooren tot het geslacht Poecilobdella waarvan $P$. granulosa en $P$. javanica hier wel als de meest algemeene mogen worden beschouwd. Beide soorten bereiken soms aanzienlijke afmetingen; exemplaren ran 10-12 cMr. lengte zijn zeer gewoon.

Bryozoa zijn hier in stilstaand zoet water zeer reelvuldig, maar systematisch nog onvoldoende bekend. Eigenaardig is, dat ook hier geregeld statoblasten worden gemaakt, welke vormingen mell in Europa steeds in verband heeft gebracht met het bestaan der, voor diervormen als deze, hoogst ongunstige wintermaanden. Daar een dergelijke adaptatie hier geheel overbodig is, moet den statoblasten toch nog een andere beteekenis worden toegekend, die wellicht 
met de verspreiding der soorten verband houdt. De groeiplaatsen der Bryozou zijn de\%elfde als elders, maar zij zijn hier gewoonlijk in hooge mate met kleine Algen en allerlei detrituspartikels bedekt. Merkwardig is, in verband hiermede, de waarneming van Kraepelin *), die in een waterplas bij Tjitajam (benoorden Buitenzorg) eene Plumatella soort aantrof, bij welke iedere polypide nabij het mondgedeelte omgeven was door een krans van 8-12 gasten, van de groep der Raderdiertjes, wier kleine huisjes den indruk maakten van tentakels.

Zoutwatersponzen ontbreken op Java evenmin en komen zoowel in stroomend, als in stilstaand water voor. Aan wortels van drijvende en stengels van vastzittende waterplanten, aan steenen en in 't water staande booinstammen vindt men niet zelden een kleine, fraai groene soort, die ik voor Spongilla proliftrens houd. Een grootere, grijsachtige soort (S. alba ?) trof ik meermalen aan op steenen in rustige hoekjes van rivierbeddingen, waar het water tijd heeft om te bezinken. Verder vond Weber ${ }^{* *}$ ) eene Ephydatia-soort, door hem naar de vindplaits bogorensis genoemd, die over haar groeiplaats een dunne, rondachtige bedekking vornt van lichtgrijze kleur. Deze, en rermoedelijk ook andere, verwante soorten vallen het meest in het oog, wanneer ze in helder, stilstaand water groeien op doode, gezonken en daarna zwart geworden bladeren, waarop zij zich dan scherp afteekenen. Mar over het algemeen is ook ran de Spongillidae van Java nog zeer weinig bekend.

\footnotetext{
$\left.{ }^{*}\right)$ Eine Süsswasserbryozoë (Plumatelln) aus Java von K. KraepeliN. Witteilungen aus dem Naturhistorischen Museum, XXIII (1906).

$\left.{ }^{* *}\right)$ Zoologische Ergebnisse einer Reise in Nicd. Ost-Indien. Bd I, pag. 33.
} 
Wij kunnen dit zeer korte overzicht van de zoetwaterfauna van Java niet besluiten zonder den lezel onze rerontschuldiging te hebben anngeboden orer het feit, dat daarin meer sprake is geweest van hetgeeen wij niet, dan van hetgeen wij wel weten. De werkkring van den schrijver heeft echter steeds zooveel bemoeienis met de landfauna medegebracht, dat roor die van het water, die bovendien in vele opzichten zooveel tijdroovender is, weinig gelegenheid orerbleef en slechts nu en dan terloops eenige vluchtige waalmemingen konden worden gedian. Intusschen mocht een samenvatting van hetgeen ter zake bekend is, in dit werk m.i. niet ontbreken, hoe uiterst weinig het ook moge zijn in vergelijking met het groote onderzoekingsgebied, dat hier nog open ligt.

\section{De Detritus-Fauna van het Cultudrgebied.}

Verschillende oorzaken werken ertoe mede, dat, vooral in het cultuurgebied, de gezamenlijke afval ran planten-en dierenrijk veel minder omvangrijk is, dan men, in aanmerking nemende beider rijkdom, a priori zou verwachten. Een van die oorziken is de hooge temperatuur, die, gewoonlijk met een groot vochtigheidsgehalte der lucht gepard, op de ontleding van doode stoffen van beiderlei aard een zeer versnellenden invloed heeft. Hoe groot die invloed is, blijkt wel het best uit de geringe humusvorming in de oorspronkelijke bosschen van het tropische laagland, op welker bijna altijd vochtigen bodem de untleding zóó snel in haar werk gaat, dat het humusstadium als het ware wordt overgeslagen, of alchans zeer vluchtig doorgemaakt en de verdere 
ontledingsproducten in opgelosten toestand in den bodem verdwijnen. Hierbij voegt zich nu, wat de planten betreft, de iverkzaamheid van talrijke, in en van plantaardigen detritus levende insecten, waarbij in de eerste plaats moet worden gedacht aan de Termieten, die het opruimingswerk op groote schail verrichten en daardoor in belangrijke mate medewerken tot de bespoediging van den kringloop der stof in de tropen. Soortgelijk werk wordt ten admzien van den dierlijken detritus in hoofdzaak verricht door de Mieren, die daarbij eveneens door tal van andere, minder massaal optredende insecten worden terzijde gestaan.

Een derde oorzaak is gelegen in de dichtheid der bevolking en haar gewoonte, allen afval, zoudra deze door zijn omvang hinderlijk wordt, te verbranden. Mestvaalten kent men niet; een niet onaanzienlijke waride gaat dagelijks verloren en als rook de lucht in.

'Trots dit alles blijft er, vooral buiten de onmiddellijke omgering van den mensch, een roldoende hoeveelheid, inzonderheid plantaardige detritus aanwezig om een aantal diervormen te rereenigen tot een biologische groep, die zich daar méér dan ergens anders thuis voelt. Die groep wordt, in rerband met het hierboven in de eerste plaats opgemerkte, grooter, naarmate men in looger streken komt, met dien verstande, dat, plaatselijk verschillend, maar in het algemeen op 5000 tot 6000 voet zee hoogte, een optimum ran condities wordt bereikt, terwijl daarboren de lage temperatuur van het hooggebergte weder een daling veroorzaakt.

Wij zullen ons echter roorloopig bejalen tot het culturrgebied, dat grootendeels beneden 3000 roet 
is gelegen, en waar in den drogen tijd van detritusfauna aanzienlijk minder is te bemerken dan in het grootere gedeelte van het jaar, waarin de regen veelvuldig genoeg valt, om den afval voordurend vochtig te houden. De basis van het dierlijk leven wordt hier grootendeels gevormd door den ongeloofelijken rijkdom aan Dipterenlarven, die hier een saprophytisch bestaan leiden en waarvan het meerendeel behoort tot de veelal onianzienlijke, onderling slechts geringe verschillen vertoonende Muscidae, zooals wij die dagelijks, o. a. op de saprijke gedeelten ran vruchten op onze tafel, kunnen waarnemen. Deze larven, die, kwamen ze alle tot ontwikkeling, Java vrijwel onbewoonbaar zouden maken, dienen tot roedsel aan talrijke andere insecten en vooral insectenlarven, waarran in de eerste plaats een groot aantal tot de orde der Kevers behoort. Van de Carabidae, die hier zoowel in den jeugdigen als in den volwassen stiat verblijf houden, werden vroeger (pag. 116) reeds de soorten genoemd, die des avonds, dikwijls op het licht afkomen, wat in mindere mate het geval in met Chlaenius javanus, C. circumdatus, Catascopus elegans, Pericalus 4-maculatus, Physodera dejeani en de Orthogonius-soorten alternans en brunnilabris. Ook Staphylinidae zijn hier veelvuldig aan te treffen, van welke in dit gebied het geslacht Leptochirus vooral op den voorgrond treedt. Voorts allerlei larven van Weekhuidige Kevers, die in den regel zeer vraatzuchtige ronfdieren zijn en dikwijls het vermogen hebben, licht te verspreiden; Histeridae van de geslachten Hololepta, Platysoma e.a. en eindelijk die geheele bent van Microcoleoptera (Scydmaenidae enz.; zie pag. 119), waarvan de Javaansche vertegenwoordigers nog slechts zeer onvolledig bekend zijn. 
Naast deze Kevers treden kleine, veelal donker gekleurde Orthoptera, vooral Gryllidae, in grooten getale op. Van de laatste zijn de geslachten Gryllus, Loxoblemnus, Scleropterus e.a. hier rijk vertegenwoordigd, terwijl van de Lcrididae het geslacht Tettix en zijn verwanten hier ook algemeen voorkomen, doch meer in de onmiddellijke nabijheid van, dan in den afval. Ook van deze dieren leeft het meerendeel van roof, maar zij vallen op hunne beurt ten prooi aan talrijke Graafwespen van de genera Tachytes, Larra e.a., die hier onverpoosd rondloopen en rondvliegen, telkens onder het afgevallen blad verdwijnen en in den regel hun pogingen met goed gevolg zien bekroond.

Ook de Oorwurmen zijn in hoofdzaak detritusdieren, die deels een carnivore, deels een saprophage levenswijze hebben, welke laatste wij ook aantreffen bij een aantal larven van Bladsprietige Kevers, die hier in groote verscheidenheid zijn te vinden. Sommige van deze gaan op lateren leeftijd dieper in den grond en voeden zich alsdan met levende wortels; andere zijn blijvers, die hier gervoonlijk ook den poptoestand doormaken, zooals de groote, geheel aan het engerlingen-type beantwoordende larven van Oryctes rhinoceros (pag. 202), Xylotrupes gideon (pag. 121) en die van andere, kleinere Dynastidae.

Apterygota ziet men in de lagere streken slechts weinig; slechts ééne Lipurine komt er algemeen onder vochtig, afgevallen blad voor, namelijk de fraai roode Anura fortis.

De afgevallen, rottende bladmassa is voorts een 
geliefkoosde verblijfplaats voor allerlei Duizendpooten en Pissebedden. Van beide zijn de meest algemeene soorten van het cultuurgebied reeds vroeger (pag. 189-193) genoemd; van de eerste zijn het vooral de kleinere vormen, die wij hier terugvinden. Ook talrijke soorten van Spinnen vinden hier een ruim bestaan, maar zij onderscheiden zich niet door iets bijzonders, echter met ééne uitzondering. Deze betreft de Krabspin Platythomisus phryniformis, een van de fraaiste Spinnen van Java, die men hier eigenlijk niet zou verwachten; want er bestaat een opvallend scherpe tegenstelling tusschen de onaanzienlijke omgeving, warin zij zich ophoudt en haar ongemeen fraai uiterlijk. $Z i j$ is namelijk helder zwavelgeel van kleur, maar heeft op den cephalothorax vier kleine en op het achterlijf een zestal grootere, fraai staalblauwe vlekken, terwijl ook de uiteinden der pooten diezelfde kleur bezitten. Niettegenstaande dit zeer toonbare kleed vermijdt ze het volle daglicht en verschuilt zich angstvallig onder de bladeren. Wordt ze ontdekt, dan heft zij de beide voorste paren pooten omhoog en houdt die geruimen tijd in trillende beweging, vermoedelijk met het doel, den indringer vrees aan te jagen.

In organische overblijfselen van dierlijken aard treden vooral de Copridae op den voorgrond, waarvan de voornaamste cultuurvormen reeds op pag. 120 werden genoemd. Vele hunner hebben de gewoonte, zich na afloop van het larvale leven, door samendrukking der wanden van hun verblijf, een hardwandige kamer voor de verpopping te vervaardigen en in de daarbij aan den dag gelegde vaardigheid staat de groote Heliocopris bucephalus bovenaan. Deze maakt 
zich een bolvormige woning, die de afmetingen heef $t$ van een grooten aardappel en zóó hard is, dat men zich afvraagt, hoe de kever ten slotte eruit komt.

Merkwaardige is het ontbreken, in dit gebied, van Silphidae, die over het algemeen op Java zeldzaam, althans zeer plaatselijk, voorkomen. Niet onwaarschijnlijk houdt dit verband met het snelle verloop der ontbindingsprocessen in de lagere streken en met het aggressieve karakter van vele der andere diervormen, die hier gewoonlijk de rol van opruimers vervullen.

Een zeer bijzondere soort van detritus is de bodem van verschillende grotten, die door Vleermuizen, door Zwaluwen of door beide worden bewoond. Deze bodem zou bestaan uit de iitwerpselen dezer dieren, wanneer zich daarin niet dikwijls een Mijtenfauna ontwikkelde van zoodanigen omvang, dat de vallende excrementen vrijwel dadelijk worden verteerd. Bij het gaan door dergelijke grotten heeft men het gevoel, alsof men loopt door mul, grofkorrelig zand; men zakt tot de enkels in eene substantie, die bij nader onderzoek nagenoeg geheel blijkt te bestaan, uit doode en levende Mijten van vrij aanzienlijke afmetingen, die tot de groep der Uropodidac behooren, doch welker systematische plaats nog niet nader kon worden vastgesteld. 


\section{HOOFDSTUK XVIII.}

\section{De Fauna der Graswildernissen.}

Zooals reeds in het Eerste Hoofdstuls werd opgemerkt, beslaan de gezamenlijke grasivildernissen op Java een zeer alanzienlijke oppervlakte. Zij zijn deels van ouderen, deels van jongeren datum. In het eerste geval drigen ze wellicht een geheel oorspronkelijk karakter en bestonden in allen gevalle, vóórdat de tegenstelling tusschen cultuurgebied en wildernis haar huidige scherpte aannam. De plantensoorten, waaraan ze haar naam ontleenen, zijn alang-alang (Imperata arundinacea), glagah of kaso (Succharum spontaneum), glonggong (Sacharum arundinaceum), die alle over geheel Java voorkomen, terwijl plaatselijk andere hooggroeiende grassoorten hetzij zich bij deze komen voegen, hetzij zelf de alleenheerschappij voeren. In den regel is echter deze heer'schappij der grassen niet absoluut, want daargelaten, dat allerlei andere kruidachtige planten ertusschen kunnen worden aange troffen, waarvan de klimmende en windende vormen haar hier en daar wel eens overwoekeren, zijn vooral de oudere terreinen van dit gebied dikwijls tamelijk rijk aan alleenstaande of tot boschjes vereenigde, boomachtige gewassen, zooals ploso of pelasa (Butea monosperma), malaka (Pliyllanthus emblica), kesambi (Schleichera trijuga) e.a. Ook Bambusa-soorten komen verspreid ertusschen voor, terwijl ik eindelijk tot dit 
gebied ouk reken de grasrijke terremen, die aan de aanwezigheid van veelal alleenstaande, hooge wainierpalmen een eigenaardig karakter ontleenen en rie o.a. in de Preanger Regentschappen in het, allen jagers welbekende district Tjidammar, een groote uitgestrektheid beslaan. In West.Java is het hoofdzakelijk de gehang-palm (Corymha gebanga), die op het lanischap zijn stempel drukt, terwijl in Midden- en Oost-Java vooral de lontar (Borassus flabelliformis) en de sadang (Livistona rotundifolia) hun omgering beheerschen.

Het behoeft wel geen betoog, dat in dit gebied de fauna rijker is, naarmate de flora meer verscheidenheid van vormen aanbiedt. In de zuivere grasivildernissen is zij ongemeen arm; wat daar ruorkomt, is vok in die met gemengde vegetatie te rinden en behoeft geen afzonderlijke beschouwing, wanneer men voor elk der hieronder te bespreken diersoorten slechts de rraag beantwoordt, of haar levenswijze de aanwezigheid van boumachtige gewassen, om welke redenen ook, wenschelijk of noodzakelijk maakt. Ook de nitgestrektheir der wildernissen is uit den aard der zaak van grooten invloed, speciaal op de aanwezigheid van grootere dieren, welker verblijf alhier slechts van duurzamen aard kan zijn, wanneer zij er gelegenheid vinden, zich ver van 's menschen omgeving terug te trekken, zoodra daartoe aanleiding bestaat.

De hooge grasvegetatie levert in de eerste plaats een bij uitstek geschikt verblijf op voor kleinere Zoogdieren, die hier overdag volkomen veilig zijn. Viverricula malaccensis, Paradoxurus hermaphroditu., Herpestes javanirus, Helictis orientalis en andere, ons 
reeds van vroeger bekende, kleinere Roofdieren vertoeven hier gaarne om te rusten en te nestelen, terwijl ze el voor een deel ook hun voedscl vinden, o.a. in verschillende soorten van Ratten, die nog niet of slechts gedeeltelijk tot samenleven met den mensch zijn overgegaan. Als zoodanig mogen hier worden genoemd Mus (Epimys) neglectus en vooral Nesocia (Bandicota) setifera, welke laatste voor een Rat geweldige afmetingen kan bereiken. Van huis uit bewounster van dit gebied, schijnt deze soort in de overgangsperiode tot de cultuurfauna te verkeeren; want bij de pestbestrijding in Oost-Java en het daaraan verbonden verzamelen van Ratten, werden reeds talrijke exemplaren uit de naaste omgeving ran de kampongs en zelfs uit de huizen verkregen. Of, naast haar, een nog grontere soort valt te onderscheiden, die dan identiek zou zijn met de echte „Bandicoot-Rat" van Engelsch-Indië, meen ik voorloopig nog in het midden te moeten laten. De beantwoording van een dergelijke vraag moge eenvoudig lijken, de moeielijkheden, zich voldoende vergelijkingsmateriaal voor de lieantwoording ẹrvan te verschaffen, zijn ongemeen groot in een land, waar, hoeveel belangstelling in dergelijke zaken ook bij vele buitenstaanders worde aangetroffen, dezen meestal tijd en gelegenheid ontbreken, om de gewenschte en onmisbare medewerking te kunnen verleenen.

Een dergelijke omstandigheid doet zich voor bij een ander Roofdier van meer geduchten aard dan de reeds genoemde, dat in dit gebied voorkomt, namelijk den Wilden Hond, Cyon rutilans. Aangaande deze diersoort toch zijn onder jagers en onder andere personen, die door den aard van hun bedrijf veel in 
de wildernis vertoeven, de meest uiteenloopende beschouwingen gangbaar. Sommigen houden vast aan het bestaan van slechts ééne soort of variëteit; anderen-en deze vormen de meerderheid-rerklaren met beslistheid, twee vormen te kunnen onderscheiden, die vooral in grootte van elkaar verschillen; wederom anderen kennen er zelfs drie en stemmen in die opvatting met de meeste inlanders overcen. Bewijsstukken voor de beide latste opvattingen, in den vorm vian huiden of in welken ander'en vorm ook, heeft men mij echter nooit kunnen vertoonen en men bepaalde zich steeds tot een beroep op het bestaan der inlandsche namen, waarmede die onderstelde variëteiten worden aangeduid. In OostJava namelijk onderscheidt men, naar gelang der afmetingen, drie vormen, waarvan de grootste wordt aangeduid als wawar, de middelste als adjag en de kleinste als kèkè of kiki. In West-Java zijn de orereenkomstige namen lagog, adjag en oesang-èsang. De kwestie, waarom het hier gaat, werd reeds in 1596 behandeld door Kohlbrugat ${ }^{*}$ ) destijds geneesheer van het Sanatorium te 'Tosari, die, na te hebben medegedeeld, dat ook op het Tenggel-gebergte drie variëteiten worden onderscheiden, daarop laat volgen:

,In de Preanger kent men ook drie soorten en over deze mocht ik van den Heer Du PERror de volgende inlichtingen ontvangen, die mij roorkomen beslissend te zijn, al mochten andere jagers met het door den Heer Du PERron uitgesproken oordeel niet overeenstemmen.

"Gedurende mijn meer dan 16-jarig verblijf in de verschillende streken van de Preanger en bij mijne

*) Zoogdieren vau den Tengger in: Natuurkundig Tijdschrift voor. ied-Indië. Deel LV. pag. 261. 
herhaalde jachttochten naar de wildernissen aan de Zuidkust van dat gewest, heb ik dikwijls over verschillende soorten ran wilde honden door de Inlanders hooren spreken en heb ik voortdurend moeite gedaan, om van die verschillende soorten exemplaren machtig te worden. Ook de heeren vas Heeckeren en Kerkhoven, beiden woonachtig op de onderneming Sinagar in het Soekaboemische, en meer anderen, met wie ik jaagde, hebben diezelfde pogingen gedaan.

"In de Preanger spreken de Inlanders van drie soorten, n.l. van den lagog, volgens hen de grootste soort, welke alléén of hoogstens bij paren leeft, doch in kleur en levenswijze verder overeenkomt met den adjak, volgens hen iets kleiner, en levende in troepen van 4 tot 16 a 18 stuks en ten laatste den oesang.èsang, volgens hunne beschrijving eene soort ter grootte van eene kat, en steeds in troepen levende, welke de adjaks vergezellen en dezen dienen als speurders en jagers.

„Nimmer heeft één onzer van deze laatste sonrt één exemplaar te zien kunnen krijgen; ook waren de beschrijvingen der Inlanders aangaande de kleur en het uiterlijk roorkomen van dit dier zóó uiteenloopend en weinig aannemelijk, dat bij ons allen sterke twijfẹl bestaat, of één hunner het dier werkelijk gezien heeft en meenen wij, dat de verhalen en beschrijvingen eenvoudig berusten op het napraten van den eenen door den anderen.

„Alle door ons uitgeloofde premiën hebben ons nog nirnmer in het bezit doen komen van eenig voorwerp, zelfs niet van een huid of schedel van deze laatste soort; nooit heeft men ons iets anders gebracht of vertoond dan exemplaren van den ge- 
wonen udjak. Door het met walikambing vergiftigen del restes van door wilde honden verscheurde dieren, gelukte het den Heer KerkHoven in ongeveer 30 jaren meer dan 70 stuks vall deze dieren machtig te worden; ik zelf krees er op dezelfde wijze een tien- of twilalftal, maar wij troffen onder dit geheele aantal nimmer één oesang-ìsang aan.

"Wanneer de door ons vergiftigde dieren goed ontwikkelde, oude exemplaren waren, dan betitelden de Inlanders die met den naam van lagog; terwijl kleinere en jongere voorwerpen steeds door hen werden aangesproken met dien van adjag.

"Wij hebben echter tusschen die beide soorten nooit eenig verschil, except in ouderdom en in grootte kunnen waarnemen. Ik voor mij, en ik geloof met mij de meesten mijner jachtvrienden, ben dan ook overtuigd, dat er op Java slechts ééne soort van wilden hond, n.l. de adjag (Canis primaevus of rutilans) voorkomt en dat de overige, alleen bij de Inlanders bekende soorten, hun bestaan slechts ontleenen aan verschillen in grootte en uiterlijk, veroorzaakt door verschil in ouderdom en wellicht in levensomstandigheden van diezelfde soort" ".

Aan deze uitspraak kan ik nog toevoegen die van den Heer A. J. M. Ledeboer, een welbekend jager uit Java's Oosthoek, die mij schreef naar aanleiding van den kiki: "Heeft $U$ ooit een exemplaar of een vel van die kleine soort gezien? Ik doorkruis de busschen vali Oost-Java gedurende 16 jaar, d.i. ik makk gemiddeld vier tuchten van twintig dagen vel jaar en ben overal bekend. Steeds heb ik naar die beestjes gezocht, doch zelfs nimmer sporen erran gezien. Ik hoorde wel eens, dat ze in troepen roorkomen van wel vijftig stuks. Adjags heb ik 
gezien, soms alléén, de grootste troep bestond uit veertien stuks. I $k$ wil daarom niet beweren, dat die kleine hondjes niet bestaan, doch heb er een reis naar Buitenzorg voor over om eens ten vel te zien".

Ik geloof op grond van het bovenstaande, dat wij, zoolang degelijke bewijsstukken van het tegendeel ontbreken, moeten aannemen, dat op Java slechts één vorm van Cyon rutilans voorkomt, waarbij de mogelijkheid echter niet is uitgesloten, dat er kleine, plaatselijke verschillen bestaan, die intusschen meer verband zullen houden met kleur, dichtheid en lengte der beharing enz., dan met de afmetingen, welke laatste wel uitsluitend aan leeftijdsverschillen zullen zijn toe te schrijven.

De adjag, om hem bij zijn meest gebruikelijken naam te noemen, is van nature uiterst schuw en vermijdt zooveel mogelijk de nabijheid van den mensch. Verkeert bij echter in gevaar, of wordt hij door den honger gedreven, dan behoort hij tot de gevaarlijkste diersoorten, die de wildernis van Java oplevert. In den regel vindt hij voedsel genoeg, hetzij in hetgeen hij zelf bemachtigt, hetzij in de overblijfselen van de prooi van groote Roofdieren. Zooals nit het bovenstaande reeds bleek, leeft hij in den regel in troepen, die een zwervend bestaan leiden en op hun tochten niet alleen bosschen, maar ook de meer afgelegen en eenzame gedeelten ran het cultuurgebied bezoeken.

De groote Roofdieren zijn hier, tot een hoogte ran circa 4000 roet boven zee, vooral vertegenwoordigd door den Tijger (Felis tigris), wiens roorliefde roor graswildernissen men in verband heeft 
gebracht met de donkere strepen op het bruingele lichaam, door welke combinatie hij moeilijk zichtbaar zou zijn tusschen het dikwijls meer dan vingerdikke, hooge en onderaan geel gekleurde riet, derhalve onopgemerkt zijn prooi zou kunnen besluipen en op zijn beurt zich gemakkelijk aan de aandacht van vervolgers zou kunnen onttrekken. Soortgelijke redenen zouden de vorrkeur van den Panter (Felis pardus) voor het bosch verklaren, waar de zonnestralen, die door het gebladerte heendringen, een lichteffect terweeg brengen, dat concordeert met zijn gevlekte huid.

De Tijger zou geen waardig voorwerp van de jacht zijn, indien ook over hem niet een groot aantal verhalen in omloop waren, die grootendeels hun oorsprong vinden in den bril van den jager en de fantasie van den inlander. De omstandigheid, dat ook bij deze diersuort kleine individueele en plaatselijke verschillen bestaan en dat kleur en teekening met den leeftijd van het dier reranderen, heeft ook hier aanleiding gegeven tot de meening, lat er meer dan één vorn hestaat. Dit is echter niet het geval; ik veroorloof mij hier weder een aanhaling uit hetgeen de Heer Ledeboer mij ter zake mededeelde: „Ik schoot op Java en Bali 37 koningstijger's, warrvan ik de teekening del strepen nauwkeurig heb nagegaan, evenals de grondkleur van de huid. Voor Java is mijne ondervinding de rolgende: hoe ouder het dier, des te lichter de grondkleur, die bij oude dieren bepaald geel wordt, en hoe smaller de strepen. Bij zeer oude dieren gaan de strepen, die, van voren gezien, loopen ter weerszijden van de inplanting van den nek en even op den schouder naar beneden, zelfs over in stipjes. In de 
ligging der stepen merkte ik nooit eenig principiëel verschil op. Ik ging dit juist steeds nauwkeurig na, omdat de inlanders beweren, dat er twee soorten zijn".

Volledigheidshalve moge hiel ook volgen, hetgeen de schrijver zegt aangaande de exemplaren ran Bali: „De teekening der zwarte strepen van de tijgers op Bali is gelijk aan die van Java; echter zijn de strepen dikker en is het rood donkerder, bij bij jonge dieren bepaald roodbruin, bij oude exemplaren nog iets donkerder dan het rood van jonge dieren op Java. Ook zijn de tijgers van Bali kleiner dan die van Java; in ieder geval staan de maten van de elf dieren, die ik daar schoot, ver beneden die van Java".

In Oost-Java onderscheidt men, vermoedelijk naar de leeftijdsverschillen, een matjan yembong en een matjan loreng; in West-Java zijn de namen meong gedeh en meong santjang vrij zeker daarop gebaseerd, want met den eersten wordt aangeduid de grootste en gevaarlijkste vorm, gekenmerkt door een tlauw geelroode tint van de vacht en mindere ontwikkeling van de strepen, terwijl de tweede betrekking heeft op een kleineren vorm, met sterk ontwikkelde strepen en een meer levendig rood gekleurde racht.

Gewoonlijk leeft de Tijger in paren. Het aantal jongen, dat tegelijk wordt voortgebracht, bedraagt twee tot vijf; de jonge dieren blijven zeer lang l,ij de moeder. Evenals de meeste Zoogdieren, is de Tijger een nachtdier. Overdag - en vooral gedurende de warme uren - houdt hij rust en kiest daartoe steeds zooveel mogelijk dezelfde plek, in de schaduw van boschjes of boomgroepen. Eerst tegen het invallen 
van de duisternis gaat hij op roof uit en rerwijelert zich daarbij niet zellen tot op aanzienlijken afstand van zijn dagverblijf. Ziju roedsel bestaat hoofizakelijk uit Wilde Zwijnen, die in clit gebied gewoonlijk urervloedig roorkomen, en Herten, die hiel. plaatselijk evenmin zeldzaam zijn. Waar echtel de genoemde dieren schatarsch zijn, rergrijpt hij zich zonder schroum aan de paarden, runderen en geiten van de naastbijzijnde menschelijke nederzettingen. De mensch wordt eerst in de laatste plats aangerallen en dan nog vermoedelijk alleen door individuen, die, hetzij ivegens verwording, hetzij wegens ziekte of ouderdom, niet in staat zijn op de gewone wijze in hun levensonderhoud te voorzien.

Zooals zooeven reeds werd opgemerkt, komen in dit gebied Wilde Zwijnen reelvuldig voor; loewel ze, gelijk bekend is, in geenen deele ertoe beperkt zijn Als toevluchtsoord, en zelfs als rast rerlulijf, kunnen zij overigens moeielijk iets beters verlangen, rooral in streken, waar geen Tijgers roorkomen. Tan de heide soorten, die op Java inheemsch zijn. is sus viltatus (soend. bagong of banen; jav. tjètèng: mal. babi oetan) de meest algremeene; zij rariëert in verschillende kenmerken zoodanig, dat hier, neer dan bij Tijger's en bij Wilde Honden, aanleiding zou zijn, om aan het vestaan van meer dan ééne soort te denken, wanneer men niet met de toedracht der zaak bekend was. De bedoelde verschillen betreffen in de eerste plaats de dichtheid der haarbedekking, die tusschen sterk behaard en nagenoeg onbehaard kan uiteenloopen: in de tweede plaats de kleur der haren, die nu eens zwartachtig, dan weder bruin of geelbruin, bij sommige exemplaren zelfs roodbruin 
is: in de derde plaats de streep langs de zijden van den kop, die soms breed en wit is, soms in het geelachtige en bruinachtige overgat en dan, in verband met de kleur van het overige haarkleed, wel eens geheel verdwijnt of althans zeer onduidelijk wordt. Zoo bestaat er inderdaad een zeer groot verschil tusschen het donkere, griluwachtig zwarte dier, dat men in de binnenlanden vaak ziet, en het roodharige Strandvarken van de Zuidkust, warrvan reeds op pag. 20 sprake was.

De tweede soort, Sus verrucosus, die minder al. gemeen, maar toch verre van zeldzaam is, is dadelijk te herkennen aan de drie paar wratachtige uitwassen aan den kop, waaraan zij den Hollandschen naam Wratzwijn en den Soendaneeschen naam bagong gagadoengan heeft te danken. Bovendien zijn volwassen exemplaren grooter dan die dan Sus vittatus, terwijl de beharing in het algemeen veel dichter en de kam van stijve, opstaande haren op achterhoofd en nek krachtiger ontwikkeld is. De kleur der haren variëert ook hier zeer sterk, met zwart en geelbruin als uitersten; slechts de onderdeelen van den romp zijn, evenals de voorste gedeelten der voorpooten en schenkels, vrij constant geelachtig wit.

Beide soorten, maar vooral Sus vittatus, hebben een groote verticale verspreiding. Laatstgenoemde gevoelt zich in de warmste gedeelten van het laagland evenzeer thuis als in de koude der hoogere bergstreken. Het hangt er maar van af, aan welke temperatuur de dieren van jongsaf gewoon zijn; want groote tochten, 't zij in het algemeen, 't zij van de bergen naar de vlakte of omgekeerd, ondernemen de Wilde Zwijnen niet. Deze zijn ook overbodig bij dieren, die het, in het verduwen van voedsel van den meest 
uiteenloopenden ald, tot zulk een bijzondere hoogte hebben gebracht. Wat de zee aan afral op het strand werpt, wordt door de bewoners van de kuststreek even gaarne gegeten als bijvoorbeeld de Balanophora's in de hoogste streken van West-Java door de exemplaren, die zich aldaar in het hooggebergte ophouden. Overigens is Sus verrucosus moediger en wilder ran natuur, en daardoor gevaarlijker, dan Sus vittatus, die in het algemeen meer eene, in den regel weinig begeerde neiging tot aansluiting aan de omgeving van den mensch aan den dag legt.

Evenals de Wilde Zwijnen, vertoeven de Herten gaarne in dit gebied, rooral wanneer naburige bos. schen hun gelegenheid geven, zich in voorkomende gevallen van een veilige retraite te verzekeren. Van de Cervidae is Ceroulus muntjak (soend. mentjek; jav. sangsan; mal. kidang) verreweg de meest algemeene soort, die ook voorkomt, waal de wildernissen ran betrekkelijk geringen omrang zijn en die dikwijls aller. lei aanplantingen bezoekt ter wille van het loof en de jonge uitspruitsels. Gewoonlijk leeft deze soort in paren, die raak door een of twee jongen rergezeld worden. De dieren zijn echter uiterst schuw. zoodat men ze slechts te zien krijgt op ruime, open terreinen, bijv. wanneer zij zich in theetuinen wagen. Hun zintuigen, in het bijzonder reuk en gehoor, zijn echtel zoo uitnemend ontwikkeld, dat zij ook dan den verren toeschouwer spoedig hebben ontdekt en met groote snelheid in de wildernis verdwijnen. Hoe sierlijk van vormen en zacht van uiterlijk ook, is echtel de kidang van een tamelijk nijdige natuur: in het bijzonder zijn de rolwassen mannetjes gevaarlịk, door de hehendigheid en de klacht, warmede 
zij ran de groote, eenigszins buitenwarts gerichte hoektanden van de boventak gebruik maken.

De echte Herten, Cervus russa (soend. ocntjal; mal. en jar. mendjangan) zijn minder algemeen en meer tot wildernissen van aanzienlijken smvang beperkt. JusGHUHx verhadt nog van groote troepen van herten, door hem in sonmige hooge streken van jir va waal. genomen, doch dergelijke truepen behworen, zoo ze nog roorkomen, heden ten dage tot de gronte zeldzaamheden. Fraaie exemplaren berinden zich in den hertenkamp van het paleis te Buitenzorg, waar deze soort erhter verre in de minderheid is bij den witgerlekten Cervus axis ran Britsch Indië, die den (echter weinig meer dan half) gedomesticeerden staat blijkhar betel verdraggt en zich daarin ook rijkelijker vortplant. Dat ook de mannetjes van Cerus russa geen gering te schatten tegenstanders zijn, kan men daar, rooral in den bronstijd, dikwijls waarnemen.

Van de Dwergherten (Tragulidae) komt hier de welbekende kantjil (soend. peutjang), Tragulus javanicus, voor, doch dit kleine en sierlijke diertje vertoeft vooral gialne in de boomrijke gredeelten van dit gebied, terwijl het, meer dan de Cervidae, ook in de bosschen verhlijf houdt. Niet onwaarschijnlijk stait dit in verband met zijn gewoonte, bij naderend geraar zich liever schuil te houden, dan te trachten, door de vlucht eraan te ontkomen.

Ten slotte kunnen bij dit gebied ter sprake worden gebracht de beide grootste Zoogdieren ran Jara, de banteng (Bos sundaicus) en de baduk (Rhinoceros sundaicus), die zoowel hier, als in de oorspronkelijke bosschen voorkomen. Vooral de bantengs bezoeken de graswildernissen garme, ondat zij el overvloed 
ran voedsel vinden in de jonge blaren en de uitloopers der grove glissoorten; de Neushoorndieren bezoeken roolal de getleelten, die aan de bosschen grenzen, welke plekken rijk zijn aan groote, boomachtige kruiden van de geslachten Musa, Elettaria en dgl., watlatan zij boven grassen de voorkeur geven. Beide diersoorten komen zoowel in het laagland, als hoog in de bergstreken voor, maar hun aantal is, gelijk bij dieren van dergelijke afmetingen roor de hand ligt, slechts platatselijk van eenige beteekenis.

Voor de Rhinocerossen is het Zuidelijk en vooral het Zuidwestelijk gedeelte van West-Java in het algemeen en van de Residentie Bantam in het bijzonder nog het terrein bij uitnemendheid; de bantengs zijn algemeener verspreid, maar ook hun gebied wordt kleiner, naarmate meer terreinen in cultuur worden gebracht. Zoo waren, om een voorbeeld te noemen, nog slechts tien jaar geleden, de uitgestrekte, voor een groot deel moerassige wouden tusschen Bandjal en Maos een dorado vool deze licren. maar de bedoelde streek is in dien korten tijd geworilen tot een van cle belangrijliste centra del rubbercultum, met het gevolg, dat de bantengs wedel een gedeelte van hun verspreidingsgebied hebben moeten rerliezen.

Beide diersoorten zijn bij de Europeanen een geliefkoosrl voorwerp van de jacht op grof wild, terwijl zij ook bij de inlanders in eere staan, de banteng om zijn vleesch, dat zich uitnemend leent tot het maken van deng-rleng, de badat vooral om den hoorn en de snijtanden (speciaal den eersten), aan welke door hen zeer bijzondere krachten worden toegeschreven. Ook de huid vertegenwoordigr een 
aanzienlijke handelswaarde. Gelijk de meeste groote herbivoren, zijn zij van nature vreedzame dieren, welker groote schuwheid waarschijnlijk voor een deel moet worden gesteld op rekening van de vervolging, waaraan zij ten allen tijde zijn blootgesteld geweest. Slechts onder bepaalde omstandigheden, bijv. wanneer zij gewond zijn, of wanneer zij hun jongen moeten verdedigen, treden zij aanvallend op en zijn dan, zoowel door hur geweldige lichaamskracht, als door hun vlugheid hoogst gevaarlijke tegenstanders. Zelfs de Rhinoceros legt dan een vlugheid aan den dag, die men bij zulk een plomp dier niet zou verwachten.

Naar aanleiding vall verschillende der hierboven kortelijk besproken diersoorten moge het hier de plaats zijn, een paar bladzijden te wijden aan een onderwerp, dat natuurhistorisch ran groot belang is, namelijk:

\section{De Toekomst Der grootere, op Jara}

iN HET WILD LEVENDE ZOOGDIEREN.

Het is onvermijdelijk, dat bij de uitbreiding van de menschelijke maatschappij met haar landbouw, industrie, veeteelt enz. en bij de noodzakelijkheid, deze behoorlijk te beschermen, de natuur nu en dan in het gedrang komt. Dit treft de dieren in den regel meer dan de planten, die meestal lagere eischen aan ruimte stellen en zich dikwijls nog op allerlei kleine, onbenutte plekken weten staande te houden; het treft ze in meerdere mate, naarmate ze grootere uitgestrekheden gronds voor hun behoorlijke ontwikkeling noodig hebben. Op het vasteland heeft 
de expansie van den mensch ten gevolge, dat de opgejaagde diervormen zich naar elders terugtrekken, of zich concentreeren op plaatsen, waar zij nog voldoende levensomstandigheden vinden. Zoo hebben Wolven en Beren West-Europa reeds lang verlaten, terwijl de Wilde Zwijnen er nog slechts verspreid op gunstige plekken voorkomen. Erger is het gesteld op eilanden, waar de diervormen, welker bestaan in of nabij de menschelijke miatschappij op den duur onmogelijk is, onverbiddelijk tot ondergang zijn veroordeeld, tenzij bijzondere maatregelen in hun belang worden genomen.

Zoodinige maatregelen, die ten aanzien der grootere Zoogdieren van Java in de laatste tientallen van jaren steeds urgenter werden, zijn hier ten deele reeds. genomen en voor het overige in voorbereiding: Zij beoogen een tweeledig doel, primo de gedeeltelijke bescherming der bedoelde diervormen op alle plaatsen, waar ze voorkomen, secundo hunne onvoorwałrdelijke bescherming op daartoe aan te wijzen terreinen.

Het eerste wordt nagestreefd dool de ordonnintie van Staatsblad 1909 No. $49 \%$, die op 1 Juli 1910 in werking is getreden, roor geheel NederlandschIndië geldt en uitsluitend betrekking heeft op de Zoogdieren en de Vogels, die dool har in het algemeen worden beschermd, d.w.z, dat zij de jacht erop verbiedt. Echter wordt (Staatshlad 1909 No. 594) roor twee groepen een uitzondering gemaakt. De eerste groep omvat alle soorten, die uit oeconomisch oogpunt geen bescherming verdienen, dus de schadelijke, de lastige en de gevaarlijke vormen, voor welke men mag aannemen, dat in afzienbaren tijd geen gevaar voor uitroeiing bestaat, wanneer men, 
zooals de ordonnantie doet, de jacht erop geheel rrij laat. In deze groep zijn, wat de Zoogdieren van Java betreft, opgenomen de Apen, de Wilde Zwijnen, de Tijger, de Panter, de Loewak, de Wilde Honden, de Stinkdas, de Otter, de Eekhoorns, de Muizen en Ratten, het Stekelvarken, de Haas en de Kalong.

De tweede groep omvat diersoorten, voor welke de bescherming "hetzij geheel, hetzij ten deele, tijdelijk en onder telkens bepaaldelijk aan te geven roorwaarden, ten doel hebbende de uitroeiing van de betrekkelijke diersoorten tegen te gaan", kan worden opgeheven. Deze opheffing geschiedt door de Hoofden van Gewestelijk Bestuur, die desverkiezend, vooraf zoölogisch advies kunnen rragen, maar overigens geacht moeten worden, beter dan iemand anders op de hoogte te kunnen zijn of te worden gebracht ran hetgeen in verband met de plaatselijke omstandigheden het meest wenschelijk is. In deze groep zijn, voor Java, gebracht de Herten, de Dwergherten en de mannelijke Wilde Runderen.

Alle andere Zoogdieren op Java dan die ran deze beıde groepen zijn dus onvoorwaardelijk beschermd, tenzij er (Art. 4) sprake zij van het verzamelen roor wetenschappelijke, doeleinden, waarvoor speciale vergunning kan worden verleend, of (Art. 5) het vangen of dooden van dieren op de erven van woningen en besloten, omheinde terreinen, dat den bewoners of den bezitters ten allen tijde vrij staat. Men zou dus reeds in deze ordonnantie alléén een waarborg hebben tegen de uitroeiing, op Java, van welke Zoogdiersoort ook, indien aan haar op krachtige wijze de hand werd gehouden en indien de jacht, voor zooverre zij is of kan worden toegestaan, op behoorlijke wijze werd uitgeoefend. Aan deze beide voorwaarden worlt 
echtel niet roldaan. In afgelegen streken, en dat zijn natuurlijk juist de plaatsen, waar de dierrormen, die liet meest bescherming behoeven, zich bij roolkeur ophouden, is het toezicht op de nalering der urdommantie ten eenenmale onroldoende, zoodat clandestiene jagers daar geheel vrij spel hebben. Bovendien wordt door inlanders de jacht, ook roor zooverre zij geoorloofd is, uitgeoefend op een wijze, die in vele richtingen funeste gevolgen heeft. Zij ivordt namelijk roorafgegaan door het in brand steken, orel groote uitgestrektheden, van cle wildernissen, ten einde daarna des te gemakkelijkker alles te kunnen neerschieten, wat zich op de opengebrande terreinen vertont.

Meu behoeft nauwelijks te viagen, wat de grevolgen van deze methode zijn. Tal van kleinere Zoogdieren en van Vogels worden reeds door het branden gedood. I $k$ denk hier in het bijzonder aan Pauwen, Wilde Hoenders en andere vormen, die op of nabij den grond nestelen en wier nesten, eieren en jongen te gronde gaan. Boomen en struiken worden gedoud, alle opslag wordt vernield, naburige bosschen *) en aanplantingen worden niet zelden door liet rum aangetast. Het is een troostelooze rernieling ran hetgeen de natuur; dikwijls onder ongunstige omstandigheden van bodem en klimaat, heeft opgebouwd en de kaalgebrande vlakten en hellingen kunnen borendien niet zonder invloed blijren op regenral en andere meteorologische faktoren ran aangrenzende en rooral van lagere streken. Slechts de wortelstokken der grassen, diep in den grond rer-

*) Hier behoeft slechts te worden herinnerd aan de vele klachten. die jaarlijks door den Dienst van het Boschwezen worden genit; het totale verlies, door het branden ain s lands bosschen toegebracht, moet inderdaad een aanzienlijk bedrag vertegenwoordigen. 
borgen, blijven in leven en geven weldra het aanzijn aan magere scheuten, die door de verkoolde. bedekking van den hodem heendringen en de lokmiddelen zijn voor het wild, dat onder deze omstandigheden gemakkelijk kan worden gedood.

Het tweede der hierboven genoemde doeleinden kan worden bereikt door het stichten van natuurhistorische reserveterreinen, waarop alle jacht, onder welken vorm ook, is verboden. Zulke terreinen zijn op Java als door de natuur zelve aangewezen: zoowel in het uiterste Westen, als in het uiterste Oosten van zijn zuidkust loopt Java uit in een wild, bergachtig, boschrijk en onbewoond schiereiland, dat natuurhistorisch slechts voor "taboe" behoeft te worden verklaard, on het gestelde doel volledig. te bereiken. Het schiereiland Djoengkoelon in het Westen, slechts door een moerassige landtong van niet meer dan anderhalven kilometer breedte met Java verbonden, en het schiereiland Blambangan in het Oosten, iets minder gunstig, maar toch nog uitstekend gesitueerd, zijn ongetwijfeld de terreinen, waarop ten deze het oug moet zijn gericht. Beider uitgestrektheid is ruim voldoende, om ook voor de grootste diersoorten het roortbestaan op afdoende wijze te verzekeren, waarbij dan tevens ook voor de overige fauna en voor de flora hetzelfde wordt gewaarborgd.

De voor dit gebied meest karakteristieke Vogels zijn de Spoorkoekoeken (mal. boeboet, soend. doedoet), waarvan op Java drie soorten voorkomen. De meest algemeene van de drie is Centropus javanicus, een. niet zeer schuwe vogel, die zich dikwijls tot op korten afstand laat naderen en in deze omgeving. 
zoowel door ziju donkere kleur, als door zijn eigen. aardige bewegingen zeer in het oog valt. Daar namelijk de bovenste gedeelten van het rietachtige gras, waar hij de meeste kans heeft, zijn geliefkoosd voedsel (sprinkhanen) te vinden, niet krachtig genoeg zijn om hem op de gewone wijze te dragen, rust hij vaak met half uitgespreide vleugels op het gebladerte en werkt zich dan half springend, half vilegend vooruit. De beide andere soorten, Centropus sinensis en $C$. purpureus, veel grooter dan de rorige, zijn minder algemeen en schuwer van aard. Plaatselijk zijn ze echter niet zeldzaam, waarbij de laatstgenoemde, vooral in Oost-Java is te vinden. In levenswijze en allures komen ze overigens met $C$. javanicus overeen.

Behalve vele der voor vroegere terreinen reeds genoemde Roofvogels zijn hier een tweetal soorten waar te nemen, die men elder's zelden te zien krijgt. De ééne daarvan is de groote Maleische Ruigpootarend (Neopus malayensis), die met groote voorliefde de eierhoudende nesten van andere vogels leegplundert en deze hier betrekkelijk gemakkelijk kan ontdekken. wanneer hij langzaam boven de grasvlakten zweeft. Door zijn aanzienlijke afmetingen en vooral door zijn lange vleugels, is hij in de vlucht gemakkelijk van alle andere Roofvogels te onderscheiden en een paar ran deze dieren leveren, zooals men ze dikwijls samen kan waarnemen, in hun statige, mar daarom niet minder sierlijke bewegingen, een fraaien aanblik op. die in deze, overigens zoo eentonige en raak troostelooze omgering aangenaam aandoet. Hun vlucht is daar bij onvermoeid: men ziet ze nooit zich neelzetten um, op de wijze ran rele hunner rerwanten, ran een hoog vaarnemingspunt hun omgering te bespierlen. 
De tweede is juist de kleinste van alle Javaansche Roofvogels, namelijk de Dwergvalk of Muschralk, Microhierax fringillarius, die niet grooter is dan een koetilang (Pycnonotus aurigaster) en nagenoeg uitsluitend van insecten schijnt te leven. Slechts éénmaal trof ik in zijn maag kleine beentjes aan, die naar alle waarschijnlijkheid van een priet, een hondol of dergelijk vogeltje afkomstig waren; vour het overige bevatten de onderzochte magen steeds overblijfselen van insecten, vooral Sprinkhanen en Glazemakers. De laatste, die ook hier in onbeperkt aantal zijn te krijgen, nuttigt hij het liefst, terwijl ze hem tevens nog voor een ander doel van dienst zijn. Microhierax nestelt namelijk in de holten van boomstammen *) en inaakt zich daarin een zachte onderlaag van de vleugels dezer insecten, die zich daarvoor uitstekend leenen.

Eindelijk is voor dit gebier nogal karakteristiek Timelia pileata, zelfs in die mate, dat hij in WestJava met den naam manoek kaso wordt aangeduid. $\mathrm{Hij}$ is een van de weinige der overigens viij talrijke Timeliidae van Java, die zich boven de loor hen bewoonde vegetatie wagen. Want terwijl de meeste hunner, zooals wij later zullen zien, steeds op of zeer nabij den bodem blijven, ziet men deze soort niet zelden op het hoogste gedeelte ran een langen stengel zitten en daarbij tevens zijn hoogste lierl uitzingen.

Zoowel in het hooge gras zelf, als in de boomgroepen en boschjes, die verspreid erin voorkomen, treft men voorts dikwijls nesten en zelfs geheele koloniën van Wevervogels aan, terwijl ook de ver-

\footnotetext{
${ }^{*}$ II. Bartels, Zur Lebens-und Nistweise javanischer Vögel, in Journ. für Ornithologit, 1903, pag. 270
} 
schillende Munia's en hunne verwanten, vooral wanneer de wildernissen niet te ver van rijstvelden zijn selegen. er tegen den avond gaarne in groote troepen een goed heenkomen zoeken; men ziet wel eens alleenstaande boomen, die zóó overbeladen zijn met Rijstrogeltjes, dat de takken er zwaar door afhangen.

Dat voor Hoenderachtige Vogels terreinen als deze niet ongeschikt zijn, laat zich hooren, vooral wanneer naburige wildhout- en djattibosschen den dieren overdag gelegenheid geven on te gaan fourageeren onder het afgevallen blad. Naast de reeds vroeger genoemde Turnix pugnax (pag. 242) en Exalfactoria lineata (pag. 274) kunnen wij dan ook in dit gebied zoowel de wilde Hoendersoorten van Java als den Pauw aantreffen.

Eerstgenoemde zijn Gallus ferrugineus (soend. kasintoe, jav. bekiko) en Gallus varius (soend. tjangehger, jar. pitè wono), van welke beide men niet zelden verschillende eigenschappen in het pluimvee der kampongs terugvindt. Vooral in Oost-Java, op Madoera en op de eilanden in de nabijheid daarvan, wordt van kruisingsproducten met Gallus varius reel werk gemaikt, met nauwlieurige onderscheiding, ook in de benamingen, van de hoeveelheid "wild bloed", die zich in de geteelde individuen bevindt. Hoewel beide soorten soms naast elkaar roorkomen, mag men in het algemeen aannemen, dat $G$. varius meer in de lagere, $G$. ferrugineus meer in de hoogere streken voorkomt. Beider aard is schuw en wild, blijft dat ook in gevangenschap en verloochent zich gewoonlijk evenmin in de nakomelingschap, die door kruising met tamme huenders wordt verkregen.

De Pauw, Pavo muticus (mal. merak), komt slechts 
in de meer afgelegen gedeelten van dit gebied roor, terwijl zijn gewoonten hem tevens binden aan de aanwezigheid van hoog geboomte-hoewel soms genoegen wordt genomen met één enkelen buom --, waarin hij overdag een uitkijkplaats en des nachts een rustplaats kan vinden. Buitengewoon schuw vall aard als hij van nature is, en door de jacht wel in steeds meerdere mate zal worden, is hij zeer moeielijk te benaderen en men moet zich verbazen over de vindingrijkheid der inlanders, die in streken, waar Pauwen voorkomen, altijd nog wel kans zien, tegen een betrekkelijk geringe geldelijke belooning; een exemplaar aan te brengen. In onderscheid met Pavo cristatus, de soort, die in Europa algemeen bekend is, vertoont bij $P$. muticus het wijfje dergelijke metaalkleuren op het gevederte als het mannetje Terwijl de Gallus-soorten voor hun nestbouw soms groote hoeveelheden gevallen blad, takjes en aarde bij elkarr brengen en deze soms tot manshooge heuvels opstapelen, nestelt de Pauw met zeer weinig omslag op den grond of, maal slechts bij uitzondering, op een lagen, breeden, horizontaal groeienden tak.

Aan Slangen is dit gebied eenige rormen rijk, die wel niet uitsluitend hier voorkomen, maar er toch beter dan elders kunmen worden ter sprake gebracht. Een daarvan is de koperachtig glanzende, gevarlijke Viperide Lachesis punicea, welker verwantschap met den vroeger (pag. 275) besproken Ancistrodon rhodostoma ook door de Soendaneezen in den naam oraj lema goenoeng wordt neergelegd. Zij is veel algemeener dan L. graminea, de tweede soort van dit geslacht, die op Java en ook in dit gebied voorkomt en houdt zich garme op in het onderhout ran de 
boschijes, die met het hooge gras afwisselen, omdat zij aldail gelegenheid heeft, zich op geringe hoogte boven den grond om de takken te slingeren en tusschen het gebladerte verscholen, de komst van kleine, warmbloedige dieren af te wachten. Haar beet, hoewel minder gevaarlijk dan die van Ancistrodon, is van zeer ernstigen aard en daar zij bovendien zeer spoedig tot een plotselingen uitval uit haar schuilplaats overgaat, is het zaak, in deze omgeving steeds tegen haar op zijn hoede te zijn.

Een derde vorm is de omgemeen fraaie chrysopelea ornata, herkenbaar aan een reeks van heldere, goudachtig groene, eenigszins stervormige figuren over de ruglijn van het donkere lichaam. Zij is, hoewel van huis uit giftig, tegenover den mensch van tamelijk onschuldigen aard, al was het alleen, omdat haar afmetingen zelden van dien aard zijn, dat zij hem een beet zou kunnen toebrengen. Hetzelfde is het geval met de reeds vroeger (pag. 85) genoemde Doliophis intestinalis, die hier vrij veelvuldig voorkomt en eveneens door haar kleine mondopening weinig vat op grootere voorwerpen heeft.

Van de niet giftige soorten mogen hier genoemd worden Dendrophis formosa, die zich, evenals $D$. pictus (pag. 84) gaarne om allerlei voorwerpen heenslingert en Zamenis mucosus, die bij voorkeur de rochtige gedeeiten van dit gebied opzoekt en gemakkelijk is te herkennen als een verwant van den meer algemeenen $Z$. korros (pag. 83); voorts kan men hier nog een aantal kleinere vormen vinden, zooals Xenodon purpurascens, Oligodon subtorquatus e.a., maar het meerendeel dezer is niet aan een bepaald gebied gebonden en vindt in allerlei ornge- 
ving wel iets van zijn gading, alsmede de gelegenheid voor een rustige schuilplaats.

Verscheidenheid van Insekten behoeft men in dit gebied niet te zoeken, maar de groepen, die er optreden, doen dat in den regel in grooten getale. Reeds noemden wij de Libellen, waarvan het wel eens raadselachtig is, hoe ze hier aan den kost komen en zelfs, vanwaar ze afkomstig zijn. Want water, waarin zij toch den larventoestand moeten doorbrengen, is hier dikwijls ver te zoeken, zoodat men wel tot de gevolgtrekking moet komen, dat de volwassen dieren zich dikwijls ver verwijderen van de plats, waar ze hun jeugd doorbrachten. Wat het voedsel betreft, rereischt de ontwikkeling der meeste insekten, die hun tot prooi dienen, meestal ook meer vochtigheid, dan hier gewoonlijk is te vinden, zoodat het vermoeden roor de hand ligt, dat ze wel eens met een ledige maag hum nachtkwaltier betrekken. Tenzij de fortuin hun gunstig is en de avondschemering hun nog een maaltijd aan uitvliegende Mieren en Termieten bezorgt. Vooral aan Mieren toch zijn de graswildermissen rijk en al is het aantal der soorten niet zeer groot, er zijn daaronder, die, niet op menschelijke indringers gesteld, daarvan, al naar gelang van de wapenen, waarorer ze beschikken, door bijten of door steken ten duidelijkste blijk geven, wanneer men bij ongeluk met een hunner koloniën in aanraking komt.

Goed vertegenwoordigd zijn verder de Acrididae, zooals trouwens is te verwachten in eene regetatie, die hoofdzakelijk uit Gramineën bestaat. Maar ook hier is het aantal der individuen groot, dat der soorten gering, terwijl onder de laatste geen rormen voor- 
komen, die ons nog niet van vroeger besproken gebieden bekend kunnen zijn.

Voor het overige kan de insectenwereld hier niet. anders dan arm worden genoemd; de eentonige regetatie levert geen behoorlijke basis daarvoor en naast de zooeven genoemde Acrididae voeden zich slechts een aantal, veelal weinig in het oog vallende rupsen met de blaren of met andere deelen der grassen. Onaanzienlijke Lichtmotjes, voor verrerveg het meerendeel ran de groepen der Crambinae en Schoenobiinae, vliegen hier dikwijls rond, bij onze nadering uit hun dagrust opgeschrikt. Voor zooverre soorten van Dagvlinders hier algemeen zijn, munten ze evenmin uit door grootte of fraaiheid van voorkomen. Zoo - is hier bijr. zeer ruim vertegenwoordigd het geslacht Mycalesis ran de familie der Satyridae, in het bijzonder door de soorten horsfieldi, perseus en medus, welker rupsen op de alang-alang zijn te vinden. Voorts vliegen hier een aantal Hesperidae rond, waarran wij er vroeger reeds eenige bij het suikerriet, de mais en de rijst aantroffen, namelijk Pamphila augias en $P$. dara. Hesperia phitino, $H$. mathias en $H$. conjunctu (pag. 258). Hier vinden wij de exemplaren, die wat roedsel hetreft, aan "den eenroud der voorvaderen" zijn getrouw gebleren en hun bakermat niet hebben verlaten. Wij treffen ze hier aan in gezelschap van een aantal verwante vormen (zooals Hesperia toona, H. brunnea), bij welke die eenvoud tot heden regel is gebleven, alsmede van eenige andere soorten van dezelfde familie (zooals Matapa aria, M. Aruna en Suada swerga), die liel de dagen harer jeugd op de rerspreid roorkomencle bamboeplanten dorbrengen.

Ook ran een andere oude bekende, Mclanitıs leda 


\section{$-440-$}

(pag. 259), komen wij hier een aantal exemplaren tegen, die veelal rustig tegen de onderzijde der overhangende rietbladeren zitten en aldaar hun dagslaap genieten.

Het aantal rupsen, dat men waarneemt, is opvallend gering, maar hierbij moet men niet vergeten, dat één opvliegende Vlinder meer in het oog valt dan honderd stilzittende rupsen, en dat die van vele der bovengenoemde soorten bovendien nog de gewoonte hebben, zich in een kokervormig dichtgesponnen verblijf op te houden. 

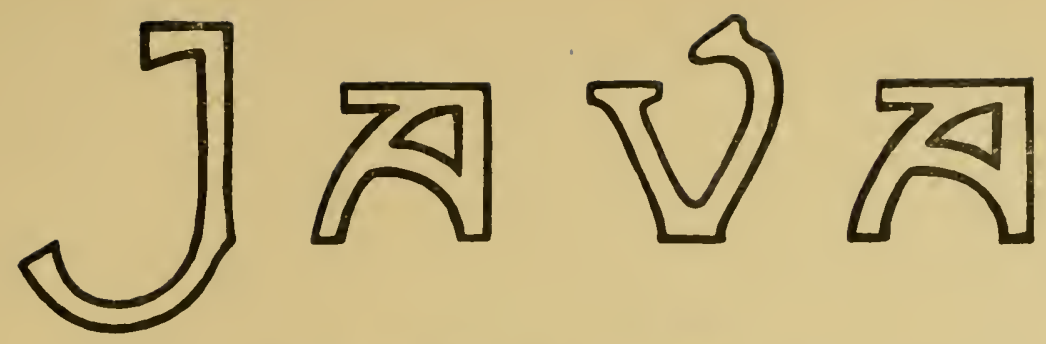

\section{ZÖLOGISCH}

\section{EN BIOLOGISCH}

DCOR

\section{DRJ.C.KONINGSBERGER}

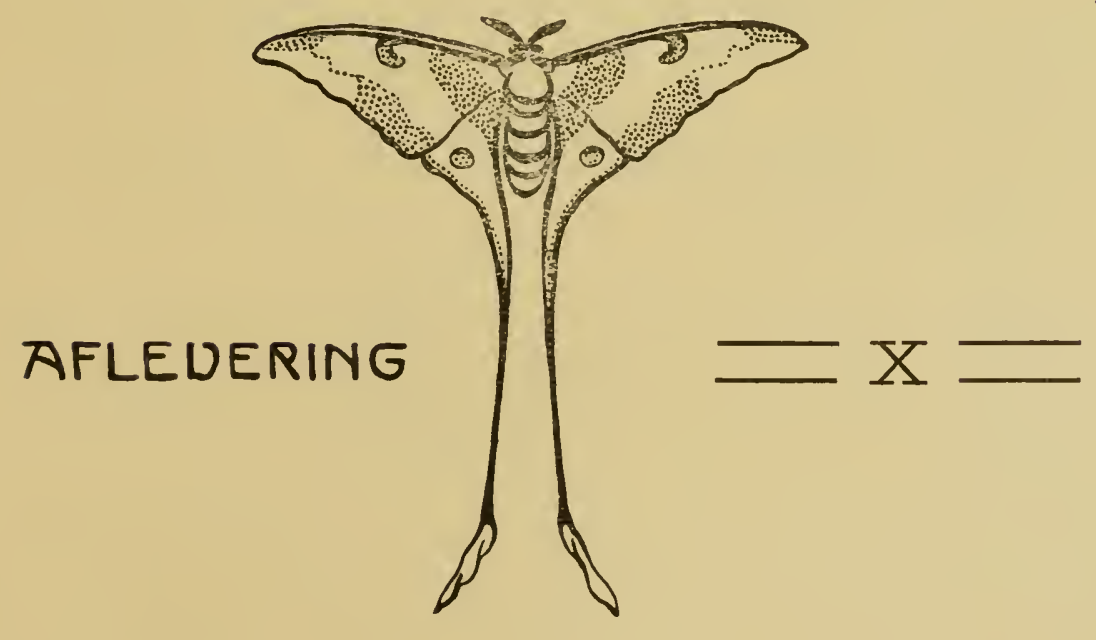

DRUKKERIJ DEP. v. L. N. en H. BUITENZORG 1914.
Verkrijgbaar bij

G. KOLFF \& Co. Batavia.

Prijs f 1.- 



\section{N HOU D.}

\section{AFLEVERING I.}

Voorwoord. ·. Algemeene samenstelling der Fauna van Java en hare wordingsgeschiedenis. De Hoofdgroepen. . . . . .

Hoofdstuk II. Overgangen van de eene groep in de andere. Morphologische gevolgen daalvan. Voorbeelden van vormen, die in overgang zijn. Nachtelijke en diurne levenswijze. .

Hoofdstuk III. Invloed van jaargetijden, regen, wind en zonneschijn. Vergelijking met andere eilanden.

pag.

1.

5.

22.

37.

\section{AFJ EVERING II en III.}

HoofDSTUK IV. Kort overzicht der verschillende gebieden. De Cultuurfauna bij uitnemendheid: de diervormen der grootere plaatsen .. . . . . . . . . . . . .

A. ZOOGDIEREN . . . . . . . . . . . . 55

B. Vogels. . . . . . . . . . . . . . 60.

C. Kruipende en Tweeslachtige Dieren. . . 76.

Hoofdstuk $V$. De Diervormen der grootere plaatsen. Velvolg)

D. INSECTEN $\cdot \cdot \cdot \cdot \cdot \cdot \cdot 90$

1. Orthoptera . . . . . . . . . . 90.

2. Neuroptera . . . . . . . . . . 98.

3. Rhynchota . . . . . . . . . . 104.

4. Diptera . . . . . . . . . 108.

Hoofdstuk VI De Diervormen der grootere plaatsen.

(Vervolg). D. Insecten. (Vervolg) . . . . . . . . . 116.

5. Coleoptera .. . . . . . . . 116.

6. Lepidoptera. . . . . . . . . . 127.

\section{AFLEVERING IV.}

Houfdstuk VII. De Diervolmen der grootere plaatsen

(Vervolg). D. Insecten (Vervolg). . . . . . . . . 157.

7. Hymenoptera. . . . . . . . . . 157.

S. Apterygota. . . . . . . . . . 179. 
Hoofdstuk VIII. De Diervormen der grootere plaatsen.

(Vervolg) . . . . . . . . . . . . . 180

E. SCHORPIOENEN EN VERWANTE VORMEN . . 180.

F. Spinnen en Mijten. . . . . . . . . 182.

G. Duizendpooten. . . . . . . . . . . . 189

H. Kreeftachtige Dieren . . . . . . . 193.

I. WEEKDIEREN. . . . . . . . . . . 194.

K. WORMen. . . . . . . 195.

Hoofdstuk IX. De Fauna der dessa's . . . . . 198.

A. Dessa's IN Het OPEN VELD . . . . . 199.

\section{AFLEVERING V.}

Hoofdstuk IX. De Fauna der dessa's (Vervolg).

A. DeSSA's IN HET OPEN VeLD (Vervolg) . . . 205.

B. Dessa's in boomrijke omgeving . . . . . 212.

Hoofdstuk $X$. De Fauna der dessa's. (Vervolg).

B. DeSSA's IN BOOMRIJKE OMGEVING. (Vervolg) . 227.

Hoofdstuk XI. De Sawahfauna . . . . . . . 245.

\section{AFLEVERING VI.}

HoofDSTUK XII. De Fauna van het Bouwland . . . . 272. Hoofdstuk XIII. De Fauna van het Bouwland. (Vervolg) 295.

\section{AFLEVERING VII.}

Hoofdstuk XIV. De Fauna van Braakliggend Land en Weidevelden $\dot{X} \dot{V}$. De Fauna van het Gebied der Overjarige Cultuurgewassen . . . . . . . . . . . . .

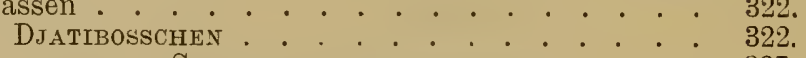
KOFFIE EN SChadUWBoomen $: \quad: \quad: \quad 327$.

Hoofdstur XVI. De Fauna van het Gebied der Overjarige Cultuurgewassen (Vervolg). . . . . . . . . . 351. CACAO. . . . . . . 351.

AFLEVERING VIII en IX.

THEE . . . . . . . . . . . . 355.

KINA . . . . . . . . . . 363. 
Hevea ex andere, RUbBer PROdUCEerENDE GEWASSEN. PalaquiUm.

368.

Hoofdstuk XVII. De Zoetwaterfauna en de Detritusfauna van het Cultuurgebied. . . . . . . . . . . . . 373.

ZOOGDIEREN . . . . . . . . . . . . 374.

Kruipende en Twe fislachtige Dieren. . . . 374.

VISSCHEN . . . . . . . . . . . . . . 380.

Gelede Dieren. . . . . . . . . . 399.

WEEKDIEREN . . . . . . . . . . . . . . 404.

Wormen en andere Lagere Dieren. . . . . 406.

De Detritusfaunavan het Cultuurgebied . . 408.

Hoofdstuk XVIII. De Fauna der Graswildernissen. . . 414.

\section{AFLEVERING $\mathrm{X}$.}

Hoofdstuk XIX. De Fauna van het Kustgebied. . . . 441.

I. RHIZOphoren - Gebied. . . . . . . . 443.

II. Strand EN DUinen. . . . . . . . . . 449.

III. RatwaH's. . . . . . . . . . . . 461.

Hoofnstuk XX. De Fauna der Boschranden. . . . . . 476. 



\section{HOOFDSTUK XIX.}

\section{De Fauna van het Kustgebied.}

Zooals reeds in het Eerste Hoofdstuk (pag. 7) werd opgemerkt, is de fauna van het kustgebied uit twee elementen opgebouwd: primo de vormen, die, van huis uit litoraal, bij de vorming van Java in zijn tegenwoordige gedaante langzamerhand van elders hierheen kwamen en daarbij eenvoudig de nieuw ontstaande kustlijnen hadden te volgen; secundo de bewoners van het laagland, die in de nadering en in de nabijheid der zee geen reden zagen, om zich meer naar binnenlandsche streken terug te trekken. Deze tweede groep heeft zich gaandeweg wederom in twee deelen gesplitst, waarvan men het eene met den naam van facultatieve kusthewoners kan bestempelen, torwijl het andere bestaat uit vormen, die zich dermate aan de nieuwe omstandigheden hebben geaccommodeerd, dat ze thans niet meer weg kunnen.

De facultatieve kustbewoners behoeven ons hier niet lang bezig te houden; het zijn cultuurvormen of boschvormen, al naar gelang het kustgebied aan de binnenzijde wordt begrensd door cultuurstreken of door wildernis. Hun al of niet aanwezig zijn wordt eenvoudig bepaald door de vradg, of de omstandigheden er naar hun gading zijn. Dat bijv, Lanius bentet hier gaarne in de ruigten en in de lage strandboschjes vertoeft, staat direct in verband 
met zijn algemeene voorliefde voor een heesterachtige vegetatie; de nabijheid der zee is hem daarbij geheel onverschillig.

Van veel meer belang zijn voor ons de diersoorten, die in den loop der tijden tot verplichte kustbewoners zijn geworden, waarbij ons natuurlijk in de eerste plaats de vraag interesseert, welke omstandigheden daartoe aanleiding hebben gegeven. Een antwoord daarop kan echter nog slechts in weinige gevallen worden gegeven. Zoo bijv. bij de groote Civetkat Felis viverrina, een Roofdier, dat over een groot deel van tropisch Azië is verspreid en over het algemeen gaarne in de nabijheid van moerassige of waterrijke plekken vertoeft. Hier op Java is zij echter slechts aangetroffen op het uiterste grensgebied ran den vasten wal, waar zij zich ophoudt in de moeielijk toegankelijke vloedbosschen en zich grootendeels voedt met visch. Om de laatste te bemachtigen, onderneemt zij dikwijls strooptochten over de sero's (staketsels), die door de inlandsche visschers langs een aanzienlijk gedeelte van de noordkust in ondiepe gedeelten der zee worden geplaatst en rooft haar voedsel dan uit de centrale vergaarkommen, waarin, bij een ruirne vangst, de visch zich ophoopt. Het aannemen van een dergelijke zeer speciale levenswijze heeft er blijkbaar toe geleid, dat Felis viverrinu op Jara slechts in dit gebied voorkomt.

Een ander voorbeeld treffen wij aan bij den ijsvo. gel Halcyon sanctus. Terwijl in het algemeen de Halcyon-soorten ware omnivoren zijn van een uiterst gulzige natuur, is $H$. sanctus tot een "Feinschmecker" geworden, die niet gaarne iets anders eet dan hetgeen zout en brak water hem aan-bepaalde kleine Crustaceëen kunnen opleveren. Vandaar, dat zijn 
voorkomen beperkt is tot dit gebied, waar de bedoelde diersoorten roor hem in groote hoeveelheden zijn te vinden; het verwende nageslacht kan eenroudig niet meer daarbuiten.

Bij sommige diersoorten kunnen wij de oorzaken met meer of minder waarschijnlijkheid vermoeden.

Bij de uiterst schuwe en daarom moeielijk verkrijgbare Muskaatduif Myristicivora bicolor (pag. 8) ligt het voor de hand, dat de vruchten van de eene of andere boomsoort van de kustflora haar tot voedsel zullen dienen, al heeft het onderzoek van eenige weinige magen dienaangaande nug geen nadere aanwijzingen kunnen geven. Bij andere daarentegen bestaan in het geheel geen aanwijzingen aangainde de oorzaken van hun uitsluitend voorkomen nabij de kust. Zoo bijv. bij den fraaien Honigzuiger chalcostetha insignis, voor velken wij meer landinwaarts even goed de noodige bestaansvoorwaarden aanwezig zouden achten. Toch komt hij daar niet voor, evenmin als de kleine Vliegenvanger Gerygone modiglianii, die in de standboschjes benoorden Batavia zeer veelvuldig is, overigens nergens op Java werd waargenomen, maar op Sumatra in de nabijheid van het Toba-meer werd geschoten, op meer dan 3000 roet hoogte boven zee. Blijkbaar hecht deze diersoort veel aan de nabijheid eener groote watervlakte, maal waarom zij clat doet, is vooralsnog een open vraag.

\section{Rhizophoren-Gebieis.}

Slechts bij laag water kan het gebied der Rhizophoren nog tot den vasten wal worden gerekend. Het geeft ons dan vooreerst een aantal diervormen 
te zien, die, voor zooverre zij zich op of nabij den grond ophouden, zeedieren zijn, die er geen bezwaar tegen hebben, eenigen tijd buiten hun eigenlijke element te vertoeven. Tot de meest bekende vormen hiervan behoort het visschengeslacht Periophthalmus, van de familie der Gobiidae, dat in dit gebied op geen enkel modderig plekje ontbreekt. Exemplaren van allerlei leeftijd zijn daar steeds waar te nemen, stil zittend, hetzij op den doorweekten, half vloeibaren bodem, hetzij - en met blijkbare voorliefde op de half horizontale wortels en doode takken, die overal daaruit steken. Zij houden zich onbewegelijk, maar zoodra zij bij onze nadering onraad bespeuren, schieten zij met ongeloofelijke snelheid naar het naastbijzijnde water en laten slechts voor een oogenblik een lijnvormig spoor in den weeken grond achter. De beweging en het zich vasthouden op het droge hebben hoofdzakelijk plaats door middel van de borstvinnen, die aan de basis van een krachtig complex van spieren zijn voorzien, waardoor deze organen in een veel grooter aantal richtingen bruikbaar zijn, dan in den regel het geval is. Soms steunt het dier er geheel op, waardoor het lichaam een half opgerichte houding aanneemt.

Een andere visch van dit gebied, die zich soms op het droge waagt, is de ikan kodok, Batrachus grunniens, maar deze is toch hoofdzakelijk een bewoner van den modder, wien de inlanders om de giftige eigenschappen zijner stekels liefst uit den weg gaan.

Krabben zijn hier natuurlijk in overvloed te vinden. Allerlei Paguridae strompelen hier rond, niet alleen op den bodem, maar ook op de wortels en soms 
zelfs op de takken der mangroveplanten. Andere Krabben houden zich half in den modder verscholen en trekken zich bij onze nadering terug met een knappend geluid, dat ongeveer klinkt als het geluid, dat wij met duim en voorvingers kunnen maken en dat hier op soortgelijke wijze, namelijk door het snel dichtslaan der scharen, wordt veroorzaakt. Verschijnt men plotseling voor een modderpoel, waarin zich vele dezer dieren hebben verscholen, dan wordt men onwillekeurig herinnerd aan het "afzetten" van het geweer bij een troepje recruten.

Waar rotsblokken of groote steenen zich boven den modder verheffen, wordt onze aandacht getrokken door de aanwezigheid daarop, beneden de hoogwaterlijn, van talrijke Chiton's en Patella's, die daarop verblijf houden in meer of minder diepe, komvormige inzinkingen, welker omtrek steeds met die van hun lichaam overeenkomt. Blijkbaar scheiden zij langs de buikzijde van het lichaam eene stof af, die het gesteente oplost en, al naar gelang van de samenstelling van dit laatste, diepere of minder diepe holten doet ontstaan. De dieren zijn als samengegroeid met hun verblijfplaats; gewoonlijk zijn ze slechts los te krijgen door een mes met kracht onder hun lichaam te brengen. Tegen vochtverlies door verdamping moeten ze uitnemend beschermd zijn; want eenige uren van zonnegloed, waaraan ze toch dagelijks zijn blootgesteld, deren hen in het geheel niet.

Kunnen wij deze Mollusken nog volledig tot de zeefauna rekenen, er zijn een aantal andere, met welke dat niet meer het geval is. Zelfs is het in geen enkele groep van het dierenrijk in zoo hooge mate tot de vorming van speciale brakwatervormen 
gekomen als bij de Weekdieren. Bij de Vischen had men het ook kunnen rerwachten, maar er zijn maar weinig soorten, die alleen van het brakke water bekend zijn; slechts de Zeenaalden vertoonen een zekere neiging in die richting.

Vele genera van Mollusken daarentegen zijn grootendeels echte brakwaterdieren geworden en het is merkwaardig, daarbij op te merken, hoe er allerlei graden van overgang bestaan. Talrijke Taenioglossa leveren daarvan een voorbeeld. Zoo is het geslacht Cerithium nog voor een deel marien, maar telt reeds een groot aantal soorten, die slechts aan modderige kusten worden gevonden (C. tuberculatum, corallinum, morum, variegatum enz.) en hoogstens het steeds natte gedeelte der mangrove-wildermissen binnendringen, waar zij zich dan dan de wurtels vasthouden. Het geslacht Potamides, dat men als den brakwatertegenhanger der vroeger (pag. 404) besproken Melania's zou kunnen beschouwen, is al iets meer geavanceerd, gaat verder binnenwaarts in het Rhizophorengebied, heeft geen bezwaar ertegen, zich bij zijn kruiptochten tegen de wortels soms boven de waterlijn te begeven en kan soms worden aangetroffen in een zone, waar het zoutgehalte van het water nog maar uiterst gering is ( $P$. ornatus, cingulatus, telescopium, sulcatus, palustris e.a.). De neiging om het natte elemet tijdelijk te verlaten, welke gepaard schijnt te gaan met die om zich landinwaarts te begeven, vinden wij nog duidelijker aan den dag tredend bij onze Alikruiken, de Littorina-soorten, die dikwijls is groot aantal zijn te vinden op de blaren van allerlei mangrove-planten. Van deze dieren is L. scabra wel een der meest algemeene; andere, op Java aangetroffen soorten zijn: L. carinifera, undulata, bullata, vilis e.a. 
Alle bovengenoemde, van de zeezijde afkomstige Slakken treffen $n u$ in dit gebied verwanten am, ran welke wij met groote waarschijniijkheid kunnen aannemen, dat zij van den anderen kant afkomstig zijn, namelijk van het zoete water of van het land. Het eerste is vermoedelijk het geval met sommige Rhipidoglossa, inzonderheid met het geslacht Neritina, dat hier door de soort crepidularia algemeen is vertegenwoordigd; hier moet dan een accommodatie hebben plaats gehad aan het verblijf in water met een, soms timelijk hoog zoutgehalte. Hetzelfde moet zijn geschied met sommige Pulmonata, voor zooverre zij bewoners van het zoete water waren, terwijl andere Longslakken, die van de landzijde in dit gebied zijn doorgedrongen en die hoofdzakelijk landbewoners waren, hier meer dan voorheen aan een tijdelijk verblijf onder water zijn blootgesteld. Accomodatie aan dit laatste moet hun trouwens niet zeer moeielijk zijn gevallen, daar het vermogen, zuurstof uit water op te nemell, velen hunner van oudsher eigen is.

Het zijn, van de Pulmonata, hoofdzakelijk vele der Auriculidae, die wij hier aantreffen. Het verst voortgegaan in de richting der zee is wel het geslacht Melampus, waarvan men verschillende soorten kan aantreffen aan de open kust, tegen steenen en op stukken hout. Daarentegen vindt men het Tijgeroortje (Cassidula auris-felis) $\in$ n andere Cassidula-soorten, alsmede de algemeene Pythia pantherina, het meest in de mangrove, zoowel op den zachtmodderigen grond als aan de wortels der boomen. Tot nog iets meer binnenwaarts gelegen terreinen beperkt zijn, in het algemeen, het Mydasoor en het Judasoor, Auricula mydae en $A$. judae, die de twee grootste der hier voorkomende "Oorslakken" zijn en die ook 
nog te vinden zijn op gedeelten der kustrawah's, waar het water van tijd tot tijd geheel zoet is.

Bij de Lamellibranchia staan wij voor geheel overeenkomstige verschijnselen: vereeniging, in de zone van het brakke water, van vormen van tweeërlei herkomst. Maar aangezien de tweekleppige Schelpdieren in den regel niet rrijwillig boven de oppervlakte van het water komen, vele soorten zich liefst diep in zand of modder ingraven, valt hunne aanwezigheid in veel mindere mate op. Van de familie der Oesters (Ostreidae) zien wij Ostrea cucullata zich in de richting van het brakke water begeven; in meerdere mate nog 0 . mytiloides, die in het rhizophorengebied tamelijk algemeen is en zich daar gaarne aan de wortels en zelfs aan het onderste gedeelte der stammen vasthecht, die ze hier en daar in dichte korsten bedekt. Van de Psammobiidae, die, zooals hun naam aanduidt, op den bodem leven, zijn ook verschillende vormen van het brakke water bekend, terwijl de Solenidae, in het Hollandsch gewoonlijk met den naam Gaperschelpen aangeduid, in verschillende geslachten (Solen, Siliqua, Cultellus e.a.) in den modder der mangrove zijn te vinden, waarin zij zich, evenals elders, diep ingraven. Aan de genoemde vormen sluiten zich nu van de landzijde verschillende Cyrenidae aan, die van daar meer of minder diep in de moerassen van het kustgebied, dikwijls soms tot in de zone der rhizophoren, binnendringen.

In het geboomte bewegen zich de IJsvogels van het kustgebied. Van het geslacht Alcedo kan men hier vooral de soort beryllina aantreffen, die echter ook het binnenland ingaat (pag. 269); het geslacht Hal- 
cyon is vooreerst vertegenwoordigd door de straks reeds genoemde $H$. sanctus, terwijl hier en daar, maal uitsluitend in boschrijke streken, H. coromandus valt waar te nemen. In grootte worden deze soorten alle verre overtroffen door Pelargopsis leucocephala (var. fraseri), die ook de minst schuve is, zich dikwijls tot zeer korten afstand laat naderen en een van de fraaiste en tevens meest eigenaardige rerschijningen is van dit gebied.

De overige diervormen, die men hier kan aantreffen, zijn òf echte zeebewoners, die hier buiten beschouving blijven, of vormen, die meer-of even goed-thuis behooren in een der beide volgende gebieden.

\section{Strand en Duinen.}

Slechts hier en daar vertoont het Javaansche strand een breedte, die eenigszins nabij komt aan hetgeen wij uit ons vaderland gewoon zijn; in den regel is het veel smaller. Ook de duinen zijn slechts kleine, zelden meer dan manshooge vormingen, die niet meer dan eenige weinige meters breedte beslaan. De zanderige bodem, waaruit zij zijn opgebouwd, zet zich echter soms nog viij ver binnenwarts voort en draagt de strandboschjes van een eigenaardig floristisch karakter, waarin tal van heesterachtige gewassen met hooger opgaand geboomte afwisselen.

Waar het strand een breedte ran eenige beteekenis beslaat, heeft het de meest uiteenloopende bewoners aan te wijzen. Hier het spoor ran een Krokodil, wiens logge lichaam een breede rore heeft achtergelaten, terwijl de infrukken der klauwen 
daarnaast duidelijk zichtbaar zijn. Ginds, aan den rand der duinvorming, een zanderige put, de plaats, waar een groote Zeeschildpad (Chelone mydas en Ch. imbricata) haar eieren in het zand heeft hegraven. Maar eromheen niet zelden de sporen van Wilde Zwijnen, die de eieren weder opgroeven en voor goede buit verklaarden. Schuwe, langpootige Krabben, welker lichaamskleur met die van het zand overeenkomt (genus Ocypoda e.a.) rennen in zulk een vaart al vluchtend langs ons heen, dat wij ze nauwelijks als zoodanig herkennen. Zij overtreffen in snelheid zelfs de talrijke Cicindela's (C. longipes, $C$. aurulenta e.a.), die hier leven van den afval der zee en eveneens buitengewoon schuw zijn. In het vochtige gedeelte zitten, verscholen in tallooze openingen in den bodem, Krabbetjes van allerlei kleur en gedaante op den loer. Sommige daarvan stellen zich tevreden met, zonder meer, een eenvoudig en hoogst tijdelijk verblijf te graven, dat door de eerstkomende golf weer grootendeels vervloeit; andere houden iets hooger verblijf, waar ze althans eenige uren buiten bereik van het water zijn en onder deze bevindt zich eene soort (van het genus Ocydromus), die het opgegraven zand in den vorm van ronde klompjes buiten de opening legt en ze rangschikt tot een eigenadrdige, 7 tot 9-stralige figuur, die door Morrs*) in verband is gebracht met het nog raadselachtige petrefact, waaraan de palaeontologen den naam Asterosoma radiciforme hebben gegeren. Wanneer men echter bij aanraking bemerkt, hoe uiterst los de samenhang der zandkorrels in deze klompjes is, dan komt dit verband mij twijfelachtig voor. Hoe het zij, men moet de volharding der dieren bewon.

*) H. Morix. Am Indischen Strand. Munchen, 1909. 
deren, die dag in, dag uit, den strijd tegen het water steeds met denzelfden ijrer opnieuw aanvariden en ons haast doen denken, dat de uitrlukking ,een gehengen als een garnaal" op biologische waarneming herust.

Een bijzondere, mar vooral plaatselijke verschijning aan het strand van Java is de Molukkenkreeft Limulus moluccanus. Hier en daar (o a. aan sommige gedeelten van de kust van Krawang) is deze diersoort hoogst algemeen en de wijfjes komen dan in grooten getale op het strand om hare talrijke eieren aldaar in het zand te begraven.

De strandboschjes zijn over het algemeen nogal rijk aan vogels, maar deze zijn bijna alle facultatieve bewoners van dit gebied, die wij reeds elder's ontmoetten. Als vormen, die hier karakteristiek zijn, noemden wij hierboven reeds Chalcostetha insignis en Gerygone modiglianii. Waar echter het kustgebied onmiddellijk grenst aan boschrijke wildernissen, vloeien de avifauna's van kust en van bosch geheel ineen en dalen de boschvormen af tot het zeestrand (pag. 20). Waar voorts een rotsige kust zich vrij steil boven een dikwijls niet meer dan lijnvormig strand verheft, spelen de Gielzwaluwen van het geslacht Collocalia een groote rol, in het bijzonder wanneer zich in de rotsen holen bevinden. Bekend zijn in dit opzicht o.a. de groote grotten te Karang Bollong aan de kust van Banjoemas. Hier, zoowel als elders, waar soortgelijke omstandigheden zich voordoen, leven zwaluwkolonies van een ongeloofelijke getalsterkte. Niet zelden wonen zij daar samen met bijna even talrijke Vleermuizen en men kan 
dan tijdens morgen-en avondschemering het interessante schouwspel bijwonen van een uitgaanden en een binnentrekkenden stroom van honderdduizenden van dieren, die elkaar aflossen in deze voor den mensch, in het bijzonder voor den Europeaan, gewoonlijk moeielijk toegankelijke verblijven. Voor een aanzienlijk procent, soms nagenoeg uitsluitend, bestaan deze zwaluwenkolonies uit Collocalia fuciphaga (pag. 7,), de soort, die de eetbare vogelnestjes oplevert, ter wille waarvan vele grotten worden geëxploiteerd door Chineezen, die ze, in den regel voor tamelijk langen termijn (drie tot vijf jaar) van de Regeering pachten. Het weinig minder dan halsbrekend werk van het verzamelen (zgn. plukken) der nesten heeft dan op geregelde tijden plaats door geroutineerde inlanders en wel in dier voege, dat van de vier jonge generaties, die jaarlijks door de zwaluwen in het leven worden geroepen, minstens ééne zich geheel ongehinderd kan untwikkelen. Komen de grootste dezer zwaluwengrotten langs het zeestrand voor, ook in het binnenland zijn ze niet zeldzaam, inzonderheid waar een waterrijke omgeving een voldoende hoereelheid kleine Diptera kan voortbrengen, die den vogels tot voedsel dienen. Naast Zwaluwen en Vleermuizen herbergen zij in den regel een aantal kleinere Roofdieren en vele Slangen, die hier op bijzonder gemakkelijke wijze aan den kost komen. Daarentegen is de Arthropodenfauna in het algemeen niét zoo rijk, als men a priori zou verwachten. Vaste bewoners der wanden zijn slechts eenige weekhuidige Gryllidae, bij welke de zeer lange sprieten vermoedelijk goed maken, wat de dieren aan gezichtsvermogen te kort komen, alsmede Psendoscorpionidae. Voor het overige huizen 
bijna alle Gelede Dieren in de guano, die den bolem dezer grotten dikwijls tot een aanzienlijke dikte bedekt. Wordt hier de alleenheerschappij niet gevoerd door Mijten (pag. 413), dan spelen deze toch steeds een rol ran beteekenis, waarbij zij dan worden terzijde gestaan door larven van Diptera, Tenebrioniden in alle stadiën van ontwikkeling, kleine Copriclae enz., terwijl JACoBson in een grot aan de Zuidkust, nabij Babakan, in grooten getale aintrof een soort van het geslacht Arixenia, dat nauw aan de Oorwurmen is rerwant, welke soort zich aldaar door een sterk geprononceerd kannibalisme onderscheidde *).

Aan Insecten zijn de Strandboschjes in het algemeen niet zeer rijk, maar er zijn een paar trouwe comparanten daaronder. Eene daarvan is de, onder den inlandschen naam rangrang bekende, roode Mier Oecophylla smaragdina (pag. 162), die haar soortnaam ontleent aan het groenachtige achterlijf der rolwas. sen, gevleugelde wijfjes. Men ziet de nesten ran deze soort dikwijls in de boomen hangen. Zij bestaan uit groote klompen ran bladeren, die vrij los aan elkander zijn gesponnen op zoodanige wijze, dat het verband tusschen blad en boom niet is verbroken. Zij blijven derhalve groen en bieden den dieren, hunnen eieren en larven een zeer zindelijk verblijf. Bij het aan elkander spinnen der bladeren wordt gebruik gemaakt van het spinvermogen der larren. De arbeidster neemt een van de laatste tusschen de kaken en beweegt haar als spoeltje heen en weer tusschen de beide plaatsen, die aan elkander beres-

\footnotetext{
*) Nedegedeeld in de Vergadering der Neciev-landsche Entomologische Vereeniging van 21 Januari 1912 (Verslag. pag. VII).
} 
tigd moeten worden, terwijl de larve haar spinklieren in werking stelt en bij elke beweging een, zich weldra samentrekkend draadje vormt; eene werkwijze, die bij meerdere vormen van de Camponotinae wordt gevolgd.

De rangrang is verder merkwaardig door het groote aantal insectenvormen, die zij ter wille van zoetachtige afscheidingsproducten patroniseert. Bij allerlei soorten ran Blad-en Schildluizen, bij jonge Homoptera van allerlei aard en zelfs bij sommige slakvormige Lycaenidenrupsjes kan men ze in grooten getale aantreffen, veelal bewegingloos wachtend op het oogenblik, waarop een droppel van het begeerde vocht zal verschijnen. Dit phlegmatische geduld staat in scherpe tegenstelling met het gedrag van de dieren, zoodra ze zich gestoord of bedreigd achten. Want alsdan loopen ze als bezetenen rond, de lange kaken zóóver opengesperd, dat ze in elkanders ver lengde komen te liggen, terwijl zij, hebben ze in hun paroxysme eenmaal iets vastgegrepen, zich liever in twee stukken laten trekken dan loslaten.

Een andere vaste bewoner van dit gehied is de Vlinder Danais chrysippus, wiens rupsen leven op de fraaie widoeri (Calotropis gigantea), die hier algemeen voorkomt. Ook hier is echter roor deze diersonet de nabijheid der zee geen factor van eenige betee. kenis; want waar, zooals in sommige bergstreken van Oost-Java, haar roedsterplant in een geheel andere omgeving behoorlijke bestaarısvoorwarden vindt, volgt zij haar overal. Ook de Pieride Thestias venilia houdt zich gaarne in de nabijheid der zee op.

Opvallend is hier verder nu en dan het groote aantal kleine Bijtjes (Melipona, Prosopis en verwante geslachten), wair deze zich rerzamelen rondom 
njamploeng-boomen (Calophyllum inophyllum), die door de eene of andere oorzaak schorswonden vertoonen. Uit deze wonden vloeit een gomachtige hars, die eenige handelswarde bezit, maar de pogingen, dit product in grootere hoeveelheren te verzamelen (de boomsourt is in dit gebied hoogst algemeen), hebben schipbreuk geleden op de concurrentie dezer kleine Hymenoptera, die den mensch bij het inzamelen steeds vóór waren en de harsachtige stof blijkbaar kennen als een prachtig materiaal voor den nestbouw

Veelvuldiger dan elder's zijn hier eindelijk groote Asilidae, zooals Philodicus javanus en Ommatius fulvus, waarvan men in dit gebied soms reusachtige exemplaren kan aantreffen. Deze stoere vliegers wagen zich ook boven de zee, evenals men dat hier van de Glazenmakers kan waarnemen en het telkens naar beneden schieten wijst erop, dat zij zich niet ontzien, kleine zeediertjes te bemachtigen op gelijke wijze, als waarop de roofrogels op hun prool in het water stooten.

Het roorbeeld, hun door de laatste gegeven, hebben ze trouwens dagelijks roor oogen; want aan Roofvogels is het kustgebied zeer rijk, al is het aantal der hier voorkomende soorten niet groot. Verreweg de meest algemeene vorm is Haliastur intermedius, reeds in 1784 door voN WuRMu beschreven als „de Kuikendief van het eiland Java”, hoewel de billijkheid gebiedt te erkennen, dat hij ten aanzien der hoenders tamelijk vrij uitgaat. Ook in het binnenland is deze fraaie Arend lang niet zeldzaam en zelfs in het hooge gebergte komt hij voor: met zijn helder bruin vederkleed en zijn witten kop levert hij een prachtigen aanblik op, rooral als men 
hem, bij nog laag staande zon en met een helderblauwe lucht als achtergrond ziet zweven. Zijn eigenlijke terrein is echter het kustgebied, waar hij in alle havens van Zuidelijk Azië de aandacht trekt van den nieuw aankomende, die zich erover verwondert, hier door Arenden de rol te zien vervullen, die in Noordelijker streken steeds door de Meeuwen en hun verwanten wordt gespeeld. Nobel is die rol in het algemeen niet voor een diersoort, zoo nauw geparenteerd aan den koning van zijn stam; het azen op den afval der schepen is met die verwantschap eigenlijk moeielijk overeen te brengen, maar de groote havenplaatsen hebben nu eenmaal talrijke parasieten onder hare bevolking en in zijn natuurlijke omgeving maakt deze Haliastur, zooals wij reeds opmerkten, een veel beteren indruk.

Zijn minder algemeene, grootere verwant Hali. aetus leucogaster heeft niet zulke gedeclasseerde exemplaren in zijn gezin en is altijd een fiere verschijning. Hetzij hij in breede kringen in de lucht zweeft en daarbij duidelijk het schitterend wit van cen grnot deel van zijn rederkleed laat zien, hetzij hij op een kalen tak of op een rotspunt zit te rusten, nooit wordt het "noblesse oblige" door hem uit het oog verloren, terwijl hij zich, hoewel in hoofdzaak vischeter, nu en dan nuttig maakt door het verdelgen van de hoogst giftige Zeeslangen (Enhydrinae), die zich gaarne aan de oppervlakte van het water ophouden.

De derde Arend van dit gebied is de Bastaardvischarend Polioaetus ichthyaetus, die in grootte tusschen de beide vorige stiat en den vrij constanten inlandschen naam doek draagt. Hij is minder fraai van voorkomen en door den grijzen kop gemakkelijk 
van de beide andere te onderscheiden, terwijl hij ook in het hinnentand bij watervlakten ran eenigen omvang wordt aangetroffen, wat met Haliactus leucogaster nooit het geval is.

De orerige vogels van dit gebied behooren alle tot de Waad-en de Zwemrogels en zijn roor een aanzien. lijk deel ook aan te treffen in het hierna te bespreken gebied der rawah's. Toch zijn er een aantal, die een speciale voorliefde hebben voor het open strand en daarvan moge, van de familie der Ardeidae, in de eerste plats worden genoemd de grijze Reiger Lepterodius sacer, wiens nest men niet zelden in de boomen der mangrove-vegetatie kan aantreffen. Hij is tamelijk schuw, maar toch lang niet in die mate als de Ciconiide Dissura episcopus, dien men zonder buitengewone voorzorgen niet kan naderen tot een afstand, kleiner dan een driehonderd meter. Zelfs op dien afstand gemakkelijk te herkennen door den witten hals, die scherp afsteekt tegen het overigens, van terzijde gezien, geheel zwarte verlerkleed (de naam episcopus is inderdaad niet slecht gekozen), zit hij gaarne op een stuk koraalsteen of ander roor. werp van geringe hoogte in de zone, waar de golven op het strand uitrloeien en kan daar soms uren lang onbervegelijk rerblijven, totdat een naderend praurtje of eenig rumoer op een, roor anker liggend schip hem doet verhuizen of geheel uit het gezicht verdwijnen.

De Strandloopers en hunne verwanten zijn op Java al even algemeen als ovelal elders op lut grensgebied tusschen land en zee. Tan de Tringidae zijn niet minder dan negen soorten hier warrgenomen (Tringa arenaria, minuta, subminuta, ruficollis, acuminata, sub- 
arquata, crassirostris, alpina en platyrhyncha), alle van zeer groote geographische verspreiding, sommige zelfs volledig cosmopoliet. Ze komen hoofdzakelijk in de maanden van den Westmoesson hierheen om de winterkoude van het Noorden te ontvluchten en dragen in het late najaar hoogstens nog eenige sporen van het fraaiere zomerkleed, die later geheel verdwijnen. Vandaar het ietwat eentonige voorkomen, dat ze hier steeds te zien geven en dat de determinatie soms zeer lastig maakt.

Geheel hetzelfde geldt van de Ruiters, hier door de Totanus-soorten glottis, hypoleucus, calidris, glareola en stagnatilis vertegenwoordigd, van welke vooral de beide laatstgenoemde gaarne ook aan plassen in het binnenland vertoeven. De meeste zijn ons reeds bekend uit ons vaderland, waar ze met de namen Tureluur ( $T$. calidris), Oeverlooper (T. hypoleucus) enz. worden aangeduid. Van de Strandlooper's zijn ze, ook op eenigen afstand, te herkennen door de meerdere grootte en door een flauwe opwaartsche buiging van den snavel, welk laatste kenmerk zich in veel sterkere mate vertoont bij de Gruto's, die hier, zoowel aan het strand als bij naburige poelen en moerassen, zijn vertegenwoordigd door Limusa limosa en $L$. novae-zeelandiae.

Ook de Wulpen zijn oude bekenden uit Holland, althans Numenius arquatus en N. phaeopus (de Gewone Wulp en de Regenwulp) Beide, alsmede Numenius cyanopus, bewonen hier hetzelfde gebied als de Gruto's en staan bij de inlander's bekend onder den naam gadjaün, die ontleend is aan den langen, sterk benedenwaarts gekromden bek, waarin zij een zekere gelijkenis met den snuit van een olifant meenen te moeten ontdekken. 
Van de Plevierachtigen moet hier in de eerste plaats, als bij voorkeur strandbewoner, Strepsilas interpres worden genoemd, in Holland als Steenlooper hekend. Dien naam verdient hij ook hier, waar men hem zeer veelvuldig op de, bij laag water droog loopende koraalriffen kan zien rondtrippelen, dikwijls in gezelschap van Aegialites dubia, Aeg. ruficapillus en andere soorten van echte Plevieren, van welke hij zich op een afstand door het ontbreken van den witten halskraag, en van nabij door het bezit van een achterteen onderscheidt.

De algemeene, reeds bij de Sawahfauna (pag. 268) genoemde Charadrius fulvus is ook een enkele maal op of nabij het zeestrand te rinden, maar hij wordt hier toch grootendeels vervangen door een grooteren verwant, namelijk Squatarola helvetica, die gewoonlijk met den inlandschen naam troelek besar wordt aangeduid.

De Zwaluwplevier Stiltia isabella komt hier soms ook in grooten getale voor. Zij komt niet uit het Noorden herwaarts, maar uit het Zuidoosten, namelijk uit Australië en is in verband daarmede vooral een Oostmoesson-verschijning, die zich in het late najaar tot groote troepen vereenigt, welke gezamelijk de terugreis naar de broedplaatsen ondernemen.

Van de Zwemvogels trekken hier in de eerste plaats de sierlijke Zeezwaluwen (Sternidae) de aandacht, waarvan een twaalftal soorten langs de kusten ran Java zijn waargenomen, die hoofdzakelijk tot de geslachten Sterna en Hydrochelidon behooren. Luchtbewoners bij uitnemendheid en bijna alle van een groote geographische verspreiding, zoeken zij hun voedsel al zwevende boven de golven, maar dat zij zich niet uitsluitend met "zeeproducten" roeden, 
bewijst wel de omstandigheid, dat ik in de maag van Sterna media eens een groot aantal volwassen gerleugelde wijfjes van de hierboven besproken Oecophylla smaragdina heb aangetroffen, terwijl enkele soorten zich ook wel naar de meer binnenwaarts gelegen rawah's begeven om aldaar te fourageeren.

Een schitterenden aanblik levert hier verder een koppel Rotspelikanen op, als die zich, in een bepaalde orde opgesteld, in groote kringen op geringe hoogte beweegt of soms nagenoeg stil staat in de lucht, met zwakke vleugelbeweging rustend op den wind. Verschillende soorten dezer Sulidae komen hier voor, waarvan, naar het schịnt, Sula piscator de meest gewone is. Echte Pelikanen krijgt men slecht op grooten aftand te zien; zij vertoeven, ongemeen schuw als ze zijn, bij voorkeur op lage zand-en koraalbanken, die een eindweegs in zee liggen.

De Fregatvogels eindelijk worden hier ook wel aangetroffen, maar zijn in zoo hooge mate zee-en luchtbewoners, dat zij nauwelijks meer tot de landfauna kunnen worden gerekend.

Tegen den avond kan men op vele plaatsen van het strand van Java's Noordkust getuige zijn van ongeloofelijke hoeveelheden kalongs (Pteropus edulis, pag. 225), die zich door het luchtruim bewegen. Vele daarvan houden overdag verblijf op de eilanden en gaan elken avond naar den vasten wal, om tegen den morgenstond weder terug te keeren. Doch waar het land zelf hun een geschikt dagverblijf aanbiedt, zooals hier en daar aan de steile, boschrijke kust. van Japara, daar komen ze soms roor in menigten, die, worden ze overdag door het een of ander on- 
gewoon roorval aan het vliegen gebracht, letterlijk de zon verduisteren.

\section{RAWAH'S.}

Zeer algemeen langs de Noordkust en in MiddenJava ook langs de Zuidkust, strekken zich grootere en kleinere, meer of minder sterk met een boschachtige regetatie bedekte moerassen uit, waarin het water, al naar gelang van het jaargetijde en van de min of meer onmiddellijke nabijheid der zee, een afwisselend routgehalte heeft, dat natuurlijk tot nul daalt, waar de moerassen worden gevormd door regen- en rivierwater, dat niet geregeld kan afvloeien. In deze rawah's bevinden zich dikwijls weer hoogere, steeds boven het waternivean liggende gedeelten en het laat zich daarom hooren, dat wij hier een gebied vóór ons hebben, waarin de levenscondities, zoowel voor de planten-; als voor de dierenwereld, een optimum bereiken. De hooge temperatuur van het laagland; een vochtige bodem en een rochtige atmosfeer; water, lucht en aarde als media om in te leven; het werkt hier alles mede om de meest gunstige roorwaarden te scheppen roor een coenobiose, die in rijkdom van vormen al het andere overtreft. Dat men zich hier in het kustgebied bevindt, is een factor van des te geringer beteekenis, naarmate het zoutgehalte ran het water daalt. Bij die daling verdwijnen een aantal planten en dieren van halophiel karakter, maar zij worden ran de landzijde door andere vervangen en de natuur van het overgangsgebied wordt er des te rijker om.

Zoo vinden wij in dit gebied in de eerste plaats een aanzienlijk gedeelte terug van de dierrormen, 
die in de Hoofdstukken XI en XVII voor het zoete water werden genoemd; in de tweede plaats een groot procent van de dieren van de kustfauna, die in de vorige bladzijden van dit Hoofdstuk reeds de revue passeerden. Waar voorts de moerassen boschrijk zijn, herbergen zij vele vertegenwoordigers van de later te bespreken boschfauna en eindelijk geven ze ons vele vormen te zien, die hier uitsluitend of bij voorkeur vertoeven. Het is uiteraard de laatste rubriek, die ons hier heeft bezig te houden.

Voor de avifauna hebben wij onze aandacht hoofdzakelijk weder te wijden aan de waterlievende vormen, welk praedicaat bij uitnemendheid van toepassing is op het Duikertje.Podiceps philippensis, een nauwen verwant van den Hollandschen Dodaars. Deze, als meliwies batoe (mal.) en titihan (jav.) bekende soort is hier standvogel en komt in de rawah's algemeen voor. Hare adaptatie aan het oponthoud op en in het water gaat zóóver, dat zij zich op het droge nog slechts ongemakkelijk en onzeker beweegt en in den loop der tijden ook den staart als een, niet meer noodig aanhangsel heeft afgeschaft. Bij naderend gevaar zoekt ze haar toevlucht onder water en weet zich daar in den regel aan de vervolging te onttrekken.

Voor Eenden is het hier een dorado. $\mathrm{Zij}_{\mathrm{j}} \mathrm{ijn}$ hier in de eerste plaats vertegenwoordigd door het geslacht Dendrocygna, dat zijn naam ontleent aan de omstandighied, dat het zijn nesten niet altija maakt op den grond, maar ook wel eens in het geboomte. $\mathrm{Nu}$ en dan wordt bovendien geen eigen nest vervaardigd, maar eenvoudig het verlaten nest van een andere vogelsoort in gebruik genomen. De 
beide Dendrocygna-soorten arcuata en javanica zijn voor de jagers op Java het waterwild bij uitnemendheid, algemeen met den naam meliwies aangeduid; vooral de eerste is hoogst algemeen, terwijl zij de gewoonte heeft, zich van tijd tot tijd te vereenigen tot groote troepen, die, bij voorkeur gedurende de duisternis, rondtrekken en een fluitend geluid maken, dat tot aanzienlijken afstand hoorbaar is.

Nettion gibberifrons komt in dit gebied evenzeer tamelijk veelvuldig voor en wordt wel met den naam meliwies vetan aangeduid (soend. benjoet), terwijl de kleine Nettopus coromandelianus als meliwies batoe bekend staat. De laatste komt ook wel op voor haar geschikte plaatsen in het binnenland voor, terwijl de eerste tot het kustgebied beperkt schijnt te zijn. Dat verder Querquedula circia haar wintertochten wel eens tot Jara uitstrekt, is langen tijd betwijfeld, doch werd in 1912 weder door BARTELs bevestigd gevonden.

Van de Aalscholvers is hier de petjoek (Phalacrocorax javanicus) de meest algemeene rorm. Hij leeft van visch, die hij al duikende bemachtigt en is tevens een uitnemende vlieger, die zich gaarne op boomen neerzet om uit te rusten. "In vaardigheid van vlieger en duiken wordt hij echter nog overtroffen door den Slanghalsvogel (Plotus melanogaster), als petjoek oelar bekend, die zich bovendien zeer ver in het binnenland begeeft en tot op aanzienlijke hoogte boven zee werd waargenomen. Een tijdlang geleden had een dezer merkwaardige vogels den grooten vijver in den Buitenzorgschen Plantentuin tot jachtterrein uitgekuzen en was daar in de stille uren van den morgen uitstekend waar te nemen. Wanneer 
hij zwemt, ziet men niets dan den kop en een gedeelte van den hals boven het water uitsteken. Men krijgt volmaakt den indruk, alsof een slang zich gedeeltelijk boven het water verheft. Plotseling verdwijnt het dier, om, soms na geruimen tijd, elders weder boven te komen. Heeft hij tijdens het duiken een visch bemachtigd, dan wordt deze in de lucht geworpen en met buitengewone behendigheid steeds zóó opgevangen, dat hij, met den kop naar voren, naal binnen glijdt. Het verlaten van het water schijnt den vogel nogal moeite te kosten, ten minste hij werkt eenige oogenblikken met vleugels en pooten beide, voordat hij rrij kan opvliegen. Maar, eenmaal in de lucht, blijkt hij een uitstekend vlieger te zijn, die als een roofvogel groote kringen beschrijft en zich eindelijk neerzet. Voor dit laatste had hij een vast plekje uitgekozen en wel den top van een hooge Auraucaria in den tuin van het paleis. Nauwelijks was hij daal gezeten, of de hals werd een weinig ingetrokken en de vleugels werden uitgespreid, zoodat hij dan volmaakt het voorkomen had van den adelail van het Pruisische rvapen. Steeds hield hij daarbij, vermoedelijk om zich te warmen en te drogen, zijn rug naar de zon gekeerd" *).

Naast vele der Waadrogels, die hierboven reeds vool het strand werden genoemd, kan men hier een aantal andere aantreffen, die zich gaarne in een ietwat beschutte omgering ophouden. Dit is o.a. het geval met Porphyrio calvus, den mandar (mal.) of peloeng (jav.), een vogel, die meer door fraaiheid van kleuren dan sierlijkheid van vormen uitmunt

') De Vogels van Java en hunne oeconomische beteekenis, Deel II, pag. 78 . 
en gewoonlijk met den Hollandschen naam Purperkoet wordt adngeduid. De korte, maar hooge bek en de breede, scharlakenroode, aan de achterzijde vierkante voorhoofdsplaat geven hem een dom uiterlijk; de zeer lange teenen wijzen erop, dat hij zich, mits snel loopende, ook over groote, drijvende bladeren van waterplanten kan bewegen. In dit opzicht legt hij het echter: verre af tegen de beide Parra's van dit gebied, Metopidius indicus en Hydrophasianus chirurgus, bij welke de uiteinden der nagels zelfs buiten de horizontale projectie ran het lichaam vallen.

Eerstgenoemde is de meest algemeene ran de twee en wordt, vermoedelijk om zijn fraai vederkleed, in de omstreken van Batavia met den naam pengantenan aangeduid; middenteen en achterteen bereiken hier een lengte van $10 \mathrm{cM}$. De tweede verschijnt hier gewoonlijk slechts in een eenvoudig vederkleed, d.w.z. zondel den trapsgewijze verlengden staart, dien ze hoofdzakelijk slechts draagt gedurende den, in Noordelijker streken doorgebrachten partijd en waarvan bij de, hier overwinterende exemplaren in den regel niet meer dan een afgesleten overblijfsel aanwezig is.

De eenige Kievitsoort van Java, Lobivanellus cucullatus, is eveneens tot de nabijheid der zee beperkt; har zeer lange beenen doen haar, op eenigen afstand gezien, in habitus met de Parra's overeenkomen, maar zoowel teenen als bek zijn veel korter, terwijl de laatste gedeeltelijk bedekt wordt dunr de geel witte huidlellen, die naar beneden langs den roorkant der wangen afhangen en hovenwaarts elkaar op de rugzijde van den snavel ontmoeten. Naar het stemgeluid draagt deze soort den inlandschen naam beberèk.

Van ongeveer dezelfde grootte en dezelfde rer- 
houding tusschen lichaamsgrootte en lengte der pooten als de Parra's, zijn de buitengewoon fijn gebouwde Himantopus-scorten leucocephalus en candidus, die in dit gebied, maar ook wel aan plassen in het binnenland voorkomen. Het sneeuw witte vederkleed met de zwarte vleugels en den zwarten mantel, de lange, teere, fraai roode pooten en de dunne, lange, flauw opwaarts gebogen snavel maken deze dieren tot een ongemeen sierlijke verschijning, die in het geheel niet overeenkomt met hetgeen men zich bij de Hollandsche benaming Kluiten ervan voorstelt, zelfs niet, waar dit geslacht door den naam Steltkluiten van andere, minder langpootige geslachten wordt onderscheiden.

Wij komen thans tot de Waterhoentjes, Ralletjes en consorten, die voor het meerendeel ook in het binnenland zijn aan te treffen, wanneer de omstandigheden er naar hun zin zijn, maar die toch hier beter dan elders kunnen worden ter sprake gebracht. Vorral in dat gedeelte van het gebied der kustmoerassen, war het brakke water langzamerhand in zoet water overgaat, zijn ze soms zeer algemeen en talrijk. Reeds rroeger (pag. 316) zagen wij, dat één der Waterhoentjes, namelijk Amaurornis phoe. nicura, zijn voorliefde voor waterrijke terreinen wel eens laat varen. Met de twee andere vertegenwoordigers van dezelfde familie (Gallinulidae) schịnt dat in mindere mate roor te komen, maar deze zijn schuwer en minder algemeen, zoodat van hun gewoonten minder bekend is. De ééne, Gallinula clulo ropus (mal. tjamperlali), vertoeft gaarne in een dicht begroeide omgeving; de andere, Gallicrex cinerea, is slechts een winterbezoeker van Java, die in Noorde- 
lijker str ken thuis behoort. Borendien heeft zij neiging tot een nachtelijke lerenswijze en ralt door hatr grijs rederkleed orerdag zeer reinig in het oog.

De Rallen zijn aanzienlijk kleiner dan de Watelhoentjes en naar verhouding iets hooger op de pooten, waardoor ze nog veel sneller in hun bewegingen zijn. Zij loopen diarbij zoo goed als onhoorbar en weten zich ook, wanneer dat in hun kraam te pas komt, uitnemend schuil te houlen. De inlandsche naam tikosan, waaronder ze algemeen bekend staan, houdt rermoedelijk met een en ander verband; zij doen in dit opzicht inderdaad aan muizen denken. Van de zes soorten, die ran Java bekend zijn, zijn $H y$ potaenidia striata, Rallina fasciata en Limnobaetus fuscus verreweg de meest gewone.

Ook het, aan de Rallen nauw verwante Porceleinhoentje Poliolimnas cinereus hoort in dit gebied thuis. In levenswijze, allures enz. komt het geheel met de eerste overeen en het wordt daarom ook met denzelfden inlandschen naam aangeduid.

Werden de Snippen in het algemeen reeds vroeger (pag. 267) besproken, een afzonderlijk woord moet nog worden gewijd aan Rostratula capensis (blètièk boelan, blètièk liembang), van welke thans boven allen twijfel is verheren, dat zij op Java ook broedt. En dat niet alleen incidenteel, zooals wel eens bij enkele achterblijvers eener trekvogelsoort gebeurt, maar in grooten getale, gelijk in Juni 1912 door den Heer OLivier werd geconstateerd in de nabijheid van Meestel Cornelis, waal hij op een uiterst drassig en moeielijk toegankelijk terrein een groot aantal dezer „Goulsnippen” neste- 
lend aantrof. Het schijnt derhalve, dat deze diersoort, die zich overigens, evenals de Gallinago's, op allerlei waterrijke terreinen vertoont, zich in den broedtijd naar meer afgelegen, eenzame en goed beschutte plekken terugtrekt.

Voor de grootere Waadvogels zijn, met uitzondering van een par vroeger genoemde vormen, de rawah's van het kustgebied het terrein bij uitnemendheid; schuw als ze bijna zonder uitzondering zijn, vinden ze hier ò de eenzaamheid, òf een verblijf met veel gelegenheid om zich schuil te houden en in den regel beide.

Waagt, zooals wij rroeger zagen, Phoyx manillensis zich nog wel eens in het cultuurgebied, de beide Ardea-soorten cinerea en sumatrana houden zich liever aan het verblijf in de wildernissen. Eerstgenoemde is dezelfde soort, die ook is ons vaderland voorkomt; de exemplaren, die in de wintermaanden herwaarts komen, zijn vermoedelijk afkomstig uit China en noordelijker gelegen landen.

Van de Ibidae is Ibis melanocephala, naar het schijnt, algemeener dan Plegadis falcinellus. Borendien vertoeft de laatste hier slechts korten tijd, terwijl de eerste hier langer blijft en volgens Vorderman zelfs gedurende het geheele jaar in de rawah's in de omstreken van Batavia is te vinden. Hun gekromde bek maakt ze, ook in de vlucht, gemakkelijk herkenbaar, terwijl het vederkleed van Ibis melanocephala van dien aard is (kop en hals zwart, het overige vederkleek geheel wit), dat ververwarring met de andere, in hoofdzaak glanzend bruine soort (met zwarte rleugels) niet mogelijk is.

Wat vorm ran den bek betreft, maakt Tantalus 
cinereus (mal. walangkada) een overgangsvorm uit tusschen de Ibissen en de Ooievaars. Ook deze Stultooper met een min of meer eigenwijs voorkomen is plaatselijk in het geheel niet zeldzaam.

De echte Ooievadrs ran het geslacht Ciconia strekken hun wintertochten niet tot Java uit. De reeds bij de strandfauna genoemde Dissura episcopus komt hun in rorm en allures nog het meest nabij, maar overigens worden ze hier vervangen door twee Leptoptilus-soorten, waalvan $L$. javanicus onder den naam bango algemeen bekend is. Beide onderscheiden zich dool het ontbreken van veeren op kop en hals, wat hun een hoogst eigenaardig voorkomen geeft, dat bij de bango nog wordt verhoogd door een zrvakke poging om, door middel van een bundel van haarvormige veeren op het achterhoofd, nog eenige gratie aan te brengen. 'Terwijl L. clubius, die herkenbaar is aan het bezit van een kropzak onder aan het naakte gedeelte van den hals, op Java vrij zeldzaam is, komt de andere, iets kleinere soort, hier in tamelijk groot aantal voor. Haar algemeene bekendheid heeft zij te danken aan de omstandigheid, dat zij in den gevangen staat zeer gemakkelijk tot den rang van semi-huisdiel opklimt en van de, haar alsdan geschonken rrijheid geen al te ongepast gebruik maakt. Op den grond is de verschijning der bango's niet zeer gracieus, maar in de lucht zwevende, in groote kringen en dikwijls op aanzienlijke hoogte, maken zij een statigen indruk.

'Ten slotte moeten nog een par kleine Reigersoorten worden genoemd, die eveneens in het kustgebied meer dan elders roorkomen. Twee daarvan behooren tot de zoogenaamde Woudaapjes, op de 
sawah's door het geslacht Ardetta (pag. 266), hier door het geslacht Butorides vertegenwoordigd. Het zijn $B$. javanica en $B$. stagnatilis, beide dieren van een half nachtelijke levenswijze, die zich oveldag slechts vertoonen, wanneer zij door het een of ander zijn opgejaagd. Ook hun vederkleed is van dien aard, dat zij in eene hegroeide omgeving niet gemakkelijk in het oog rallen. De maleische naam kokokkan laut duidt aan, dat ook de inlanders met hunne voorliefde voor de nabijheid der zee bekend zijn.

De derde is Dupetor flavicollis, een nogal fraai geteekende Ralreiger, in dit gebied de trgenhanger van zijn verwant Ardeola speciosa in meer gecultiveerde streken en evenals deze met den inlandschen naam blekok aangeduid. Ook deze soort nadert in lerenswijze tot de Nachtreiger's.

Van de overige vogelsoorten, die voor het kustgebied karakteristiek zijn, werd yroeger reeds melding gemaakt; wij kunnen daaraan nog toevoegen, dat de fraai grijze Spreeuw Sturnia sturnina (mal. moentjang) zich gaarne troepsgewijze ophoudt in open terreinen aan de binnenzijde ervan, terwijl zij in het binnenland neer rerspreid voorkomt.

Aan Slangen zijn de rawah's eveneens rijk en daal het meerendeel dezer dieren tamelijk onverschillig is tegenover temperatuur en omgeving, kan men hier een aanzienlijk deel tegenkomen van de voimen, die voor vroegere gebieden reeds werden genoemd. Daaraan sluiten zich hier eenige soorten aan, die bijzonder waterlievend zijn en waarvan enkele in hunne verspreiding tot het kustgebied beperkt zijn. 
Daartoe kan men in de eerste plaats rekenen Acrochordus jaranicus, een van de meest lethargische dieren, die op Jara roorkomen. Het is een slang, die rrij aanzienlijke afmetingen bereikt; exemplaren ter dikte van een pols en ter lengte van twee tot drie Meter zijn zeer gewoon. In den regel houdt zij zich in het water op, maar elk ander verblijf, wilarin men hasr plidatst, een kist, een hok, een mand of wat ook, is haar even welkom; zij doet althans ran het tegendeel niet blijken en wanneer men har aan het staartgedeelte opneemt, blijft ze rustig in min of meer sierlijke kronkels hangen en doet niet de minste moeite om ran houding te veranderen. De chagrijnachtige huid is, rooral bij oudere exemplaren, reel te wijd voor het lichaam en ligt er: als een ruime zak om heen; vandaar de nlandsche naam oelar karoeng. In het Zoülogisch Museum werden jaren lang een paar groote exemplaren in leren gehouden, samen met een jongen Gaviaal (Tomistomu schlegelii), die, ook in zijn bewegingen, zijn contubernaals volkomen als "quantité négligeable" behandelde; nooit echter heb ik de laatste door eenige beweging zien verraden, dat die, in onze oogen dikwijls hinderlijke geringschatting hen in eenig opzicht aandeed. Een paar malen werden eenige jongen ter wereld gebracht (de eieren ontwikkelen zich geheel in het lichaam der moeder), maar deze dieren hadden rolkomen een "aartje naar hun vaartje”, vonden het blijkbaar niet eenmaal de moeite waard in het leven te blijven, deden althans niet de geringste moeite daartoe en stierven na eenige dagen, zonder. dat de moeder naar hen had omgezien en rermoedelijk ook, zonder dat van hun bestaan iets tot hun eigen besef was doorgedrongen. 
Een tweede, minder ongevaarlijke bewoner van dit gebied is Cerberus rhynchops, die, naar zijne physionomie te oordeelen, zijn geslachtsnaam met eere dradg. Intusschen heeft de mensch ook van deze slang weinig gevaar te vreezen, evenals van de verwante, reeds vroeger (pag. 85) genoemde Homalopsis buccata, die, als groot liefhebster van water, ook hier veel voorkomt, dikwijls half in den drassigen bodem ingegraven, zoodat slechts een enkele winding ran haar lichaam zichtbaar is en haar aanwezigheid verraadt. Ook deze soort is van zulk een bedaarde natuur, dat ik meermalen bijwoonde, dat inlanders die ééne winding beetpakten en het dier met kracht uit den grond trokken, zonder dat het daarin aanleiding vond om iets anders te doen, dan bij wijze van voorloopige bedreiging den bek te openen. Door eene insnoering achter den kop herinneren Cerberus en Homalopsis anders eenigszins aan Viperiden en zien er op het eerste gezicht gevaarlijk genoeg uit.

Veel minder algemeen is vermuedelijk Chersydris granulatus, die in kleur en teekening min of meer aan de Zeeslangen doet denken; ook Hypsirhina plumbea en Simotes fasciolatus zijn geen alledaagsche verschijningen, maar moeten toch vooral in dit gebied worden gezocht.

Twee soorten, die men liefst uit den weg giat, zijn Naja bungarus en Python molurus. De eerste, die overigens ook in het binnenland wordt gevonden, is een der meest gevaarlijke en aggressieve giftslangen van Java en trouwens van alle landen, waar zij voorkomt. Opmerkelijk is haar verschillend uiterlijk op jeugdigen en op volwassen leeftijd. In jongen toestand is zij fraai donkerblauw ol) de bovenzijde, met 
een aantal geelwitte divarsstrepen, die een sterk convexe zijde naal roren hebben gekeerd. Langzamerhand gaat de blauwe kleur in een donkergrijze over en de dwarsstrepen worden minder duidelijk. Oude dieren zijn tamelijk licht grijs, terwijl alsdan van de witte strepen nog slechts overblijfselen aanwezig zijn in den vorm van ver uit elkaar liggende, lichte plekken. Dergelijke exemplaren bereiken afmetingen, welke nabij komen aan die van een Python van middelbare grootte.

Python molurus is bij uitnemendhied een bewoner ran boschrijke rawah's. Van geheel andere natuur dan $P$. reticulatus, gaat hij zeer spoedig tot een aanval over. Terwijl de laatste in gevangenschap weinig ander's dan een onverstoorbare rust geniet, is de eerste steeds op zijn hoede en houdt den hals dadelijk in den welbekenden S-rorm tot een uitval gereed. In de rrije natuur heeft hij de gewoonte, in het geboomte te hangen, den staart ergens in de hoogte stevig om een tak geslagen, het lichaam naar beneden afhangend, zóó, dat de kop zich tamelijk dicht boven den grond bevindt. In die houding wacht hij het oogenblik af, waarop een roorbijloopend dier als prooi kan worden gegrepen. In de rawah's tusschen Bandjar en Maos heeft, tijdens de groote ontginningen roor de rubbercultuur aldaar, ook menige inlander een geduchte beet van deze slang in arm of been gehad; want men ziet hem nauwelijks, omdat het grijsbruine lichaam, hoe levendig en fraai ook geteekend, wanneer men het dier afzonderlijk ziet, in het gervirwar van takken en lianen der wildernis zoo goed als onzichtbaar is.

Aan hetgeen bij de bespreking der zoetwaterfauna 
aangaande de Schildpadden werd gezegd (pag. 377 -379 ) kunnen wij voor dit gebied nog toeroegen, dat hier, in verband met de geringe vervolging, waaraan de dieren zijn blootgesteld, soms reusachtige exemplaren voorkomen en dat, eenigen tijd geleden, uit de moerassen van Tandjong Priok een exemplaar ran de, nog niet van Java bekende Pelochelys cantoris werd verkregen, dat een lengte van 129 en een breedte van 74 cM. had. Dat ook de Varanidae zich hier uitnemend op hun plaats gevoelen, behoeft wel geen betoog. De Batrachidae treden hier daarentegen zeer op den achtergrond, daar zij over het algemeen, zoowel in de volwassen als in den larvalen toestand, liefst elk water vermijden, dat brak is of van tijd tot tijd kan worden. Vandaar, dat zij weder talrijk optreden in de zuivere zoetwater-moerassen, die een weinig meer landinwaarts zijn gelegen.

Bij de bespreking der Visschen van het zoete water zijn tevens reeds een aantal vormen genoemd, die, hoewel van huis uit bewoners van de zee, zich dikwijls stroomopwarts begeven of, met de zee, het brakke water van riviermondingen, kreeken, kustmoerassen enz. bewonen. Het laat zich hooren, dat er behalve de genoemde soorten, nog een aantal andere zijn, met welke dit het geval is en dat dit aantal grooter wordt, naarmate men de zee nadert. Het zou echter geen zin hebben, in een werk over de landfauna al deze vertegenwoordigers van de zeefauna op te noemen, temeer daar eenige volledigheid toch niet zou zijn te bereiken, aangezien van het meerendeel der Visschen levenswijze en gerwoonten nog volslagen onbekend zijn. Ééne soort magechter niet onvermeld blijven, namelijk de bandeng (Chanos 
chunos, familie Chupeidae), eene in het kustgebied van Java oeconomisch zeer belangrijke verschijning, ondat zij daar door den mensch wordt aangekweekt. Deze teelt heeft plaats in de tambaks, rechthoekige vischvijver's, die uitsluitend langs de lage en rlakke Noordkust worden aangetroffen en aldaar een gezamenlijke oppervlakte beslaan van ruim 50.000 Hectaren. Zij worden kunstmatig aangelegd, waarbij natuurlijk zooreel mogelijk wordt partij getrokken van de natuurlijke gesteldheid van den bodem, bestaande terreininzinkingen enz. De bandeng wordt, in bepaalde tijden van het jaar, in zeer jeugdigen toestand in de nabijheid der kust in zee gevangen en in enorme hoeveelheden in de rijrer's geplant. De latste zijn natuurlijk verzamelplaatsen van alle diersoorten van dit gebied, die op visch azen en, voor zooverre zij zelf niet in het water leven, geen bezwaar ertegen hebben, zich in een veelal open, onbeschutte omgeving te wagen.

Voor de Weekdieren kunnen wij verwijzen naar hetgeen diarover bij het Rhizophorengebied werd medegedeeld. Het water van dit laatste en dat der rawah's loopt dikwijls in elkiar, zoodat hier geen grens van eenige scherpte is te maken. Het hangt geheel van plaatselijke omstandigheden af, of de Molluskenfauna meer een marien, of meer een zoet. water-karakter draagt. 


\section{HOOFDSTUK $\mathbf{X X}$.}

\section{De Fauna der Boschranden.}

Daar de fauna der boschranden een derivaat is van de boschfauna, zou menallicht verwachten, haar na de laatste te zien besproken. Dat van deze, voor de hand liggende volgorde wordt afgeweken, vindt hoofdzakelijk zijn oorzaak in de omstandigheid, dat hier onder boschranden wordt verstaan de smalle zone, die zich op alle gebergten uitstrekt langs den bovenrand van het cultuurgebied, door welks uitbreiding de oorspronkelijke fauna binnen de boschgrenzen werd teruggeduwd. Daar voorts in het tegenwoordige tijdstip verreweg de meeste, voor landbouw geschikte terreinen op Java voor dat doel in gebruik zijn genomen, is dit proces van terugdringen der fauna grootendeels afgeloopen. De hoogte boven zee, tot op welke het heeft plaats gehad, loopt nogal uiteen en is afhankelijk geweest van factoren als boschreserve, algemeene helling van het terrein, dichtheid der bevolking en dgl., maar over het algemeen ligt de bedoelde zone tusschen 3000 en 6000 voet boven zee, met een zeer globaal gemiddelde derhalve van 4500 voet. $\mathrm{Nu}$ is de boschfauna binnen de genoemde grenzen wel niet op verschillende hoogten en overal geheel dezelfde, maar bijzonder groote verschillen doen zich daarin toch niet voor. Vandaar, dat zich een algemeene boschrandfauna heeft ontwikkeld, die op 3000 voet zeehoogte wel 
eenige diervormen heeft aan te wijzen, die men op 6000 roet niet aantreft en omgekeerd, maar toch over het algemeen een tamelijk homogeen karakter rertoont.

$\mathrm{Er}$ is nog een tweede reden, van zuiver practischen aard, waarom wij de boschraudfauna vooraf en onafhankelijk van de boschfauna bespreken. Menigeen toch, die slechts tijdelijk op Java vertoeft en zich daarbij eenigszins van de algemeen voorkomende dierrormen op de hoogte wil stellen, komt wèl in aanraking met de eerste en niet, of in veel mindere mate, met de laatste, die borendien roor den waarnemer zooveel moeielijker toegankelijk is.

'Twee oorzaken hebben ertoe medegewerkt, dat aan den rand van het oorspronkelijke bosch een afzonderlijke coenobiose, een biologisch geheel van vrij aanzienlijken omvang, zich heeft gerormd. De eerste is de zeer begrijpelijke onwil bij vele diervormen, zich binnen nieuwe en engere grenzen te laten terugdringen, omdat daardoor dikwijls nieuwe levenscondities worden geschapen en in allen gevalle een verzwaring van den strijd om het bestaan plaats lieeft. Vandaar bij vele der betrokken diersoorten een neiging tot expansie, die aanleiding geeft tot zwerftochten in het cultururgebied, die niet zelden het karakter aannemen van strooptochten en in den loop der jaren dikivijls zijn gevolgd door een ${ }_{s}$ blijvende vestiging ten koste van den mensch, zijn veestapel, zijn pluimgedierte en zijn landbouwgewassen (vgl. pag. 12 en vgl.)

De tweede oorzaak is de aanwezigheid, langs de boschranden, van veel licht. „Wie de oorspronkelijke tropische natuur wil zien in al haar rijkdom aan 
leven en schoonheid" - zoo schreef ik in $1907^{*}$ ) - "hij dringe niet door in het, door veelheid van boomen vaak onzichtbare bosch, maar blijve erbuiten en zette zich neer aan den rand. Want de innerlijke drang naar licht en lucht, naar weldoende warmte en opwekkenden zonneschijn, die zich bij het meerendeel der hooger georganiseerde, levende wezens openbaart, diijft ook deze met kracht daalheen". Laatstbedoelde oorzaak heeft ook tengevolge, dat de fauna der boschranden niet uitsluitend is beperkt tot de zone, waar het bosch overgaat in het gecultiveerde gebied (of in graswildernissen). „Een open plek midden in het bosch, een breede uitkapping, een roetpad langs een steile helling; het is alles om het eren, wanneer maar laaggroeiende planten zich met hoogere kunnen vermengen, wanneer er maar zonneschijn genoeg is, om beider bloemen zich te doen ontplooien tot een rijken maaltijd voor tallooze diervormen, op een groen kleed van even rijk patroon".

Hier denken wij het eerst aan de Dagvlinders, die door dezen maaltijd worden aangelokt. In het gedeelte der vegetatie, waar gras en bloeiende kruiden nog den boventoon voeren, houdt een groote verscheidenheid van de kleinere soorten der Satyridae, zich op. De geslachten Mycalesis, Debis, Lethe en Ypthima zijn hier rijk vertegenwoordigd, terwijl vooral in het hoogere gedeelte van dit gebied, de vrijwel cosmopolitische Vanessa cardui (fam. Nymphalidae) dikwijls door haar algemeenheid de aandacht trekt. Van de grootere Satyridae vliegt hier Neorina chrishna, echter niet op de warmere uren van den dag, als wanneer zij zich schuil houdt. Zij is echter

*) Zoölogische Wandelingen te Tjibodas. TErsuannia, 1907. 
minder lichtschuw dan rele andere vertegenwoordiger's der beide genoemde families, die daarom dit terrein vermijden en zich liever binnen het bosch ophouden.

Ook de beide Papilio soorten peranthus en arjuna houden zich bij roorkeur nabij den grond op. Het liefst zetten zij zich op natte, modderige plekken; met half geopende rleugels blijven zij soms langen tijd op dezelfde plaats zitten en geven dan den toeschouwer de gelegenheid, hun fraai kleed te bewonderen, waarvan vooral de goudgroene rlekken en de gelijkkleurige bepoedering op de bovunzijde der vleugels de aandacht trekken. Soms zijn de dieren zúó verdiept in het opzuigen ran vocht uit den bodem, dat ze zich met de hand laten grijpen. Plaatselijk hoogst algemeen is hier ook de Elycinide Telchinia violae (?), die in habitus min of meer aan een Cyclosic herinnert, maar door den vorm der sprieten dadelijk als een Dagrlinder is te herkennen.

Terwijl Lycaenidae en Hesperidae hier even talrijk zijn als oreral elders op laagbloeiende planten en fraaie Euploca's, waaronder wij hier onder meer de soorten radamanthus (diocletianus), lencostictos en eyndhovii kunnen opmerken, met kalmen vleugelslag rondvliegen, zoodat de donker paarschblauwe gedeelten op de borenzijde der mannetjes duidelijk zichtbaar zijn, bewegen fraaie Charaxes-snorten zich in het hoogere gedeelte van het onderhout. Het meest algemeen zijn hier (maar plaatselijk bestaan natuurlijk allerlei verschillen) Charaxes schreibersi en Ch. jalysus, die ook hier bij de vrijage hetzelfde spelletje te zien geven, dat op pag. 133 voor den cultuurrorm van dit genus werd beschreven. Andere zonlicht lievende Nymphalidae zijn hier: allerlei Euthalia's, de fraaie Symphaedra dirtea, waarvan de mannetjes 
zoowel door geringere grootte als door kleur en teekening van de wijfjes rerschillen en waarvan men dikwijls talrijke exemplaren bijeen kan vinden op afgevallen, rottende vruchten. Voorts bonte Cethosia's, de reeds vroeger genoemde Hypolimnassoorten, nu en dan een teere Cyrestis enz. enz.

Het geslacht Pieris is hier vooral door de soorten paulina, panda en pundione vertegen woordigd. Piepers *) vermeldt, dat hij laatstgenoemde soort dikwijls in grooten getale waarnam op den Poentjak, den op circa 4500 voet boven zee gelegen bergpas, die over het Megamendoeng-gebergte ran de Residentie Batavia naar de Preanger Regentschappen voert. De dieren zetten zich daal gaarne neer op den weg, op de natte plekken, die er door de, aldaar gewoonlijk eenige minuten rustende paarden worden veroorzaakt. Hoewel deze observatie reeds ran minstens vijf en twintig jaren her dateert, kan men, gelijk inij met meerdere dergelijke waarnemingen van ouderen datum is gebleken, heden ten dage nog volkomen hetzelfde waarnemen.

Veul opvallender dan de genoemde soorten is echter Pieris (Appias) nero, die door haar oranje roode kleur en haar vlugge bewegingen zeer de aandacht trekt.

Voegen wij nu aan het bovenstaande toe, dat ook de meeste Rhopalocera van het aangrenzende cultuurgebied hun zwerftochten garne over de bloemenrijke boschranden uitstrekken, dan laat het zich

$\left.{ }^{*}\right)$ The Rhopalocera of Java, by M. C Piepers and P. C. T. Snellen. The Hague, Martinus NiJHoFf. Dit rijk en uitnemend geillustrecrde, maar daardoor tamelijk kostbare werk zii allen vlinderliefhebbers aanberolen. Tan de zes deelen, waruit het zal bestaan, verschenen er reeds drie, die behandelen $1^{\circ}$ de Pieridae, $2^{\circ}$ de Hesperidae, $3^{\circ} \mathrm{de}$ Danaidae. Satyridae, Ragadidae en Elymniadxe De prijs dezer drie deeien is resp. Gld. 18, 25 en 37.50. 
hooren, dat de lepidopteroloog hier een waar dorado kan aantreffen.

Ditzelfde geldt trouwens voor den entomoloog in het algemeen. Zoo zijn hier ook van de Hymenoptera tal ran rormen aanwezig, die wij elders nog niet ontmoetten, terwijl wij tevens vele oude bekenden kunnen tegenkomen. Als een verwant der Eumenes-soorten herkennen wij hiel dadelijk den donkerblauwen Zethus cyanopterus, gekenmerkt door den, op de bovenzijde afgeplatten, fijn geribden achterlijfssteel. Meer nog dan het insect zelf, inter'sseert ons zijn nest, dat wel naar het Eumenes-type is gebouwd, maar zich uitrending roordoet als een onregelmatig gevormde pijnappel of dergelijke Coniferenrucht. Het is namelijk niet uitsluitend van aarde vervaldigd, maar roor een groot deel ook van harde bladstukjes, die aan den rand eenigszins afgekauwd en vrij regelmatig, schubrormig zijn gerangschikt, terwijl zij aan de onderzijde een soort ran rozet vormen. Soms ziet men, dat het nest, dat, tot 7 cellen bevat. tegen afsijpelend water is beveiligd, doordat Jovenaan, d.w.z. aan het ondereinde van den steel, waaraan het hangt, eenige hladstukjes tot een soort ran uitstekend en aan ééne zijde tuitvormig uitloopend dak zijn vereenigd en het is merkwaardig, daarbij op te merken, dat zulk een beveiliging alleen is aangebracht bij de nesten, die door hun plaatsing ran langdurig ifsijpelend water last kunnen hebben.

Andere opvallende Hymenoptera ran dit gebied zijn de paarsch-blauwe Macromeris splendida, een Graafwesp, die met Spinnen fourageert en zelfs de grootere soorten daarvan met succes te lijf gaat, 
alsmede de Salius-soorten, die bij de keuze van het voedsel voor hunne jongen minder exclusief zijn en daartoe ook op Blattidae en andere Orthoptera jacht maken. Vooral Salius bipartitus en S. verticalis zijn hier gewoon; minder algemeen is de groote S. ducalis, herkenbaar aan een paar zilverachtige vlekken op de donkere voorvleugels. In afmetingen leggen de genoemde vormen het nog af tegen Scolia procer, waarvan vooral het wijfje soms een bijzondere grootte bereikt. De schitterende, goudgele vlekken op het metaalachtig blauwe lichaam maken deze soort even gemakkelijk herkenbaar, als haar bijzondere verbolgenheid op den mensch, die haar pad kruist en om wien ze in zeer langwerpige kringen rondvliegt, in 't voorbijgaan telkens een aanval beproevend.

Van de Anthophila zien wij (behalve echte Hommels, die nagenoeg uitsluitend boven \pm 3500 roet voorkomen en meer in het bosch thuis behooren) een groot aantal Megachile's. Vooral $M$. heteroptera is een boschrandvorm, maar ook de soorten semivestita, melampyga, disjuncta en bicolor vliegen hier rond, terwijl hun aanwezigheid bovendien duidelijk wordt aangetoond door de welbekende verminkingen, die ze aan allerlei bladeren toebrengen.

Coleoptera zonder tal zijn hier verder op blaren en bloemen te vinden. Zooals voor de hand ligt, hebben de Chrysomelidae de overhand. Deze zijn hier niet alleen te vinden in honderde vormen, die aan het normale Bladkevertype beantwoorden (zooals de geslachten Lema, Crioceris, Clytra, Diapromorpha, Aspidolopha e.a.), maar ook in alle andere typen dezer vormenrijke groep. Noemen wij daarvan in 
cle eerste plaats de schitterende Sagra's, herkenbaar aan hun aanzienlijke afmetingen, hun metaalachtige kleuren en hun eigenaardige achterpooten met sterk verdikte, bij de mannetjes van sterige doornuitsteeksels voorziene dijen. Slechts van de soort S. buqueti zijn mij de larven bekend; deze trof ik eens aan, maar reeds bezig zich te relpoppen, in den weinig meer dan vingerdikken stengel van een liaan, die op de plaats, waar de dieren blijkbaar hun larventoestand hadden doorgebracht, knolvormige, in elkander versmeltende gallen ter grootte van amandelen ver. toonde.

In de tweede plaats de groep der Hispidae, waarvan de ongestekelde vormen hier rooral zijn vertegenwoordigd door de geslachten Botryonopa en Anisodera, welke soorten bevatten, die voor Hispidae bijzonder groot zijn. Van Botryonopa sanguinea zijn mij geen andere bijzonderheden bekend, dan dat zij zich voedt met de blaren van palmen en daardoor, in de laagste gedeelten van dit gebied, wel eens op de cocospalmen der dessa's terecht komt. Eene Anisodera-soort van nagenoeg dezelfde afmetingen heeft het vooral voorzien op de blaren van Zingiberaceae, in het bijzonder op die der grootere soorten, die algemeen langs de boschranden voorkomen. Zij gebruikt deze blaren niet alleen tot voedsel, maar ook tot woonplaats gedurende de paringsperiode en het moet worden erkend, dat haar keuze slechter kon zijn. Zoodra het, aanvankelijk tot potlooddikte opgerolde, jonge blad zich aan het uiteinde een weinig begint te ontplooien, begeeft het jonge paar zich in dit peperhuisvormig verblijf en dringt daarin zóó diep door, dat het tegen alle schadelijke invloeden van buiten volkomen is beveiligd. Het oponthoud 
in dit uitnemende logis kan vele dagen duren en gedurende dien tijd dient een gedeelte der wanden den gasten tot voedsel. Maar bij het knabbelen aan het opgerolde blad worden de versçhillende lagen van het peperhuis aangevreten en, wanneer het blad zich dan later ontrolt, vertoont het cle dwarsgeplaatste rij van gaatjes, die men bij deze planten zoo algemeen aantreft. Er is hier nog een tweede keversoort, die met dit comfortabele logis hekend is, namelijk de Calandride Sphenocsrynus seminudus, door haar langwerpigen vorm eveneens zeer geschikt om het te bewonen, maar deze soort vreet niet aan het blad.

Gestekelde Hispidae verraden hier evenzeer hunne tegenwoordigheid, maar bij deze zijn het vooral de larven, die aan allerlei blaren, vooral van groote grasachtige gewassen, de sporen van hun vraatzucht in den vorm van mijngangen achterlaten. De volwassen diertjes zitten overdag veelal rustig op beschutte plaatsen en vallen daardoor minder in het oog. Het zijn vooral de meestal zwarte Hispa's en Hispella's, die men hier aantreft; minder algemeen zijn de Platypria's, die door hun platte, zeer verbreede uitsteeksels bijna even breed als lang zijn.

In de derde plaats de Cassidinae, kevertjes, van welker pracht men zich slechts een voorstelling kan maken, wanneer men ze op een zonnigen morgen in hun natuurlijke omgeving heeft waargenomen. De algemeen verspreide cultuurvorm van deze groep, Aspidomorpha militaris (pag. 286), is reeds een fraai insect, maar het wordt verre in de schaduw gesteld door wat men hier te zien krijgt en waartoe hetzelfde genus in de soorten amabilis en assimilis reeds een bijdrage levert. Het fraaist zijn echter de soorten 
van het geslacht Coptocycla, namelijk scalaris, punctata en catenata, die hier vrij algemeen en dikwijls in groot aantal zijn te rinden; deze diertjes schitteren als diamanten in de stralen der morgenzon, die ze met hun gewelffe, met goudgroen geteekende schilden en de half doorschijnende randen daarvan, naar alle richtingen weerkatsen.

Fraai zijn ook vele metaalglanzende Eumolpinae; namen als Scelodonta nitidula en Nodostoma cieneomicans spreken reeds daarvan. Noemen wij verder slechts de helder staalblauwe Corynodes-soorten en de geslachten Colaspoides, Chrysolampra, Abirus (vgl. pag. 369), Colasposoma, Aulexis en Apolepis om den lezer eenig denkbeeld te geven van hetgeen deze omgeving den verzamelaar aanbiedt, die hier ran Bladkevers in meer beperkten zin, bovendien een aantal opvallend gekleurde of geteekende vormen als Sphenoraia javana, Aulacophora batesi, Podontia affinis, Phyllocharis undulata e.a. kan aantreffen.

De Solunum- soorten, die dikwijls tusschen het struikgewas cler boschranden groeien, lokken veelal herbivore Coccinellidae van het vroeger (pag. 292) reeds besproken genus Epilachna aan, terwijl ook car'nivore Lieveheersbeestjes hier in groot aantal voorkomen. Behalve een aantal oude bekenden zien wij hier o.a. Verania lineata, Coelophora inaequalis, C. deficiens, Panomoea pardalina, alle min of meer ijverig in de weer op zoek naar Phytophthires, die hier in veel geringer verscheidemheid aanwezig zijn, dan men a priori zou verwachten. Vandaar, dat vele hunner zich dikwijls moeten tevreden stellen met jonge Homoptera, die hier veel orervloediger zijn, vooral in de kleinere soorten. 
Als laatste vormen van Kevers, die hier plaatselijk dikwijls in sterke mate op den voorgrond treden, mogen hier worden genoemd het geslacht Hoplia van de familie der Melolonthidae en de groep der Collyridae. Het eerste omvat een aantal kleine, maar door dof- vergulde teekeningen op prothorax en dekschilden zeer sierlijke kevertjes, die men gewoonlijk aantreft, knabbelend aan bladranden. De laatste bewegen zich met ongeloofelijke snelheid over kruiden en heesters en zijn daardoor op het eerste gezicht moeielijk te herkennen. Maar een weinig geduld bewijst ook hier goede diensten; men herkent dan, behalve de reeds vroeger voor aangrenzende aanplantingen genoemde vormen (pag. 344): Collyris horsfieldi, C. tuberculata en de kleine, groene, C. arnoldi.

Werd aangaande de Plantenluizen zooeven reeds opgemerkt, dat ze hier niet bijzonder talrijk zijn, andere groepen van Rhynchoten vragen des te meer onze iutudacht. Natuurlijk hebben wij in de eerste plaats de vormen te verwachten, welker uiterlijk wijst op voorliefde voor veel licht. Daartoe mag vooral worden gerekend het Wantsengeslacht Chrysocoris en zijn verwanten, sshitterende dieren van een goudgroen glanzende, dikwijls nog met een purperen gloed overtogen kleur, waarop, in regelmatige verspreiding, zwarte vlekken van allerlei vorm zichtbaar zijn.

Ook deze dieren moet men levend gezien hebben om de juiste voorstelling te hebben van de pracht, die ze ten toon spreiden; de exemplaren in de verzamelingen geven daarvan niet het geringste denk- 
beeld en slechts die, welke in een oplossing ran formaldehyde worden beward, behouden een gedeelte van den glans.

Een eveneens fraaie Scutelleride is hiel Cantao occllatus, die men gewoonlijk in kleine troepen aantreft, terwijl van de Pentatomidae voor dit gebied mogen worden vermeld: het geslacht Dalpada met virj talrijke, nogal op elkaar gelijkende soorten; Paracritheus trimaculatus, met zeer sterk ontwikkelde, puntig eindigende, schouderuitsteeksels en een groote, gele vlek in elk der drie hoekpunten van 'het schildje; Antestia anchora, bij welke men met eenigen goeden wil wel een roode ankervormige figuur op het zwarte schildje kan opmerken; Eurydema pulchrum, die op de vorige gelijkt, maar minder druk is geteekend; Cinxia limbata, tamelijk groot van stuk, maar stemmig van gewaad in haar zwarte jurk met roode biesjes; Menida formosa, met een werkelijk ankervormig figuurtje op het uiteinde van het scutellum; Audinetia spinosa, die hier en daar wel eens op de kapokboomen van aangrenzende kampongs overgaat. Van de grootere vormen is Catacanthus aurantius hier tamelijk algemeen, evenals Eusthenes robustus, waarvan de mannetjes gekenmerkt zijn door zwaal gedoornde en sterk verdikte dijen der achterpooten en Pycanum amethystinum, die, dikwijls ook diep in het bosch, op lianen van het geslacht Uncaria is te vinden. Noemen wij eindelijk nog het geslacht Megymenum, waarvan de verschillende soorten den indruk maken, alsof ze van hevig rerroest ijzer zijn gemaakt en Diplorhinus furcatus, die gemakkelijk is te herkennen ain het platte, diep ingesneden, horizontale uitsteeksel aan den kop, dan zijn met het bovenstaande 
toch nog niet meer dan de meest in het oog vallende Schildwantsen vermeld.

Een overeenkomstigen rijkdum aan vormen vertoonen hier de Capsidae en de kleinere Lygaeidae; voor de eerste mag men dit gebied zelfs beschouwen als het terrein bij uitnemendheid, daar ze zoowel in het cultuurgebied als in het bosch tamelijk schaar'sch zijn. Van het noemen van namen moet ik mij hier nog onthouden, ook wat laatstgenoemde betreft, daar de Javaansche vormen nog slechts zeer lacunair zijn onderzocht.

De grootere Lygaeidae komen, voor zooverre ze niet in de cultuurfauna zijn overgegaan, meer in het bosch, dan langs de randen voor; hun veelal donker bruingrijze kleuren wijzen ook niet voorliefde voor veel licht. Ook de Reduviidae zijn hier slechts matig vertegenwoordigd.

Dat het hier wemelt van Diptera, behoeft nauwelijks vermelding. Ook van deze vliegen de kleinere soorten voor een aanzienlijk deel nog onbeschreven rond; men vindt daaronder het fraaiste, het fijnste, het teerste, dat de natuur kan voortbrengen. In een verscheidenheid, wadivar men zich bijna geen denkbeeld kan maken, wanneer men het niet met eigen oogen heeft aanschouwd, komen hier de sierlijkste vliegjes voor. Bij de ééne soort is het 't lichaam, dat door eleganten vorm en metaalachtige pantsering de aandacht trekt, bij een andere zijn het de vleugels, die verwonderlijk schoone tinten vertoonen. Maar het gaat met deze diertjes als met teere plantendeelen: zoodra de turgor eruit is, die de verschillende deelen op spanning en in den juisten stand houdt, is het 
mooi eraf. Geen opgezet exemplaar, hoe zorgruldig ook geprepareerd, is meer dan een flauwe afschaduwing van het levende insect.

Van de grootere vormen treden hier o. a. veel Trypetinen op, dikwijls door hun gevlekte vleugels te onderscheiden (geslachten Rioxa, Tephritis, Trypeta e. a.) Ze zijn in het algemeen traag in hunne bewegingen en wandelen langzaan over bladeren en bloemen, daarbij den éénen vleugel dikwijls geheel zonder eenig verband met den ander bewegend. Geheel ander's gedragen zich vele Dolichopodidae (o. a. vele soorten van het genus Psilopus), die zóó hard loopen, dat zij den indruk maken van te glijden, of de talrijke Syrphidae, die zich schijnhaar onbervegelijk in de lucht staande houden, de vleugels onzichtbaar door de snelle beweging, het helder gekleurde lichaam blinkend in den zonneschijn. Enkele Syrphidae hebben het voorkomen en de wijze van beweging van Wespen: Ceria javana houdt men bijvoorbeeld gemakkelijk voor een kleine Eumenes of soortgelijke Graafwesp; vele Bacha-soorten gelijken op Icaria's.

Veelvuldig zijn hier eindelijk de Calobatidae, waarbij ook hier dezelfde eigenaardigheden zijn op te merken, die voor de vormen der cultuurfauna (pag. 114) reeds werden vermeld:

Bijzondere vermelding verdient roor dit gebied een plaatselijk zeer algemeene Springstaart van het geslacht Entomobrya, waarschijnlijk E. longicornis, niet alleen, omdat het dier de, voor een Poduri aanzienlijke lichaamsgrootte van $5 \mathrm{~m} . \mathrm{m}$. kan bereiken, naar vooral om de bijzondere levenswijze, waardoor het zich van zijn verwanten onderscheidt. 'T'erwijl toch de laatste in den regel detritus-dieren zijn, die 
in het verborgene leven en het licht schuwen, leeft deze soort open en bloot op bladeren en legt zelfs voorliefde voor fellen zonneschijn aan den dag. Het is helder bleekgroen van kleur, draagt zijn vork vrijwel onzichtbaar tegen de buikzijde van het lichaam naar voren geslagen en houdt de lange sprieten in een boog naar boven en ter zijde uitgestrekt. Wanneer het stil zit, vertoont het een bedriegelijke gelijkenis met een of andere groene Capside, maar wanneer men het wil grijpen, verraadt het onmiddellijk zijn ware natuur door met een krachtigen sprong te verdwijnen.

De rijkdom aan vliegende insecten heeft natuurlijk een overeenkomstigen rijkdom aan Spinnen ten gevolge. Alsof ook deze groep niet voor andere wil onderdoen, komt ook zij hier met haar fraaiste vormen voor den dag. Daartoe mag men ongetwijfeld rekenen de Argyopesoorten (cremulata, catenata, bifasciata e.a.), die hun webben bij voorkeur maken eenige meters boven den grond, uitgespannen tusschen een paar overhangende takken boven het gebladerte der lagere vegetatie. Zit het dier toevallig met den rug naar ons toegekeerd, dan kan men de gouden teekening bewonderen, die in banden en andere figuren is aangebracht op het breede, langs den rand eenigszins gekartelde achterlijf, terwijl de paarsgewijze uitgestoken pooten (zóó, dat de vier paren samen een kruis vormen) afwisselend donkere en fraai roodbruine banden vertoonen.

Van het geslacht Gasteracantha kunnen wij hier niet alleen verschillende oude bekenden aantreffen (pag. 345), maar ook een merkwaardigen vorm, dien wij nog niet ontmoetten, namelijk $G$. arcuata, ge- 
kenmerkt door de bijzondere ontwikkeling van de twee zijdelingsche stekels, die zóo lang en daarbij zóódanig gebogen zijn, dat ze samen een hoogen, bijna gesloten boog boven het lichaam vormen. Blijkbaar heeft men hier met een geval van hypertelie te doen; de korte en de matig lange stekels, die wij bij de overige Doornspinnen aantreffen, zijn ongetwijfeld zeer nuttige rormingen, die de dieren tegen menigen aanval zullen vrijwaren. Hier echter is het doel voorbijgestreefd en wat oorspronkelijk nuttig was, is door te sterke ontwikkeling nutteloos en zelfs geraarlijk geworden; want bij de lange uitsteeksels aangerat, is het dier volkomen weerloos.

Aanzienlijk beter toegerust tot den strijd om het bestaan, die hier echter voor Spinnen niet bijzonder zivaar behoeft te zijn, is de Krabspin Pandercetes decipiens, eene soort, die on redenen, welke aan onze waarneming nog ontgdan, bijzonder veel bescherming schijnt noodig te hebben, want ondanks haar uitnemende toerusting is zij zeldzaam. De laatste bestaat daarin, dat let dier op lichaam, pooten en palpen is bedekt met grijsachtig witte, tamelijk onregelmatig gerormde, platte aanhangsels van epidermalen oorsprong, die de meest bedriegelijke gelijkenis vertoonen met de lobbige randen van de vele Korstmossen, die alom op takken en bladeren zijn te vinden. Zet het dier zich nu, zooals zijn gewoonte is, plat en met uitgestrekte pooten tegen of op zulk een tak of blad, dan is het inderdaad, zoowel door vijand als door prooi, ommogelijk ran zijn omgeving te onderscheiden; het levert een van de meest frappante voorbeelden van beschermende gelijkenis, die men op Java kan aantreffen. 
De vlugge Springspinnetjes, ook hier door een groot aantal dikwijls fraaie en soms metaalachtig glanzende soorten vertegenwoordigd, drijven den spot met alles wat naar beschermde gelijkenis zweemt Onbezorgd springen ze rond over bloemen en blaren, maar het is niet onmogelijk, dat zij die luchthartigheid dikwijls duur moeten betalen. Want zij hebben een geduchten vervolger in Atthopyga eximia, den eenigen, maar algemeen verspreiden en dikwijls zeer talrijken, metaalkleurigen Honigzuiger der hoogere streken op Java, wiens bewegingen men hier uitnemend kan bespieden. Het blijkt daarbij, dat hij zich slechts bij hooge noodzakelijkheid in de lucht zwevende houdt; ongemeen lenig gymnast als hij is, weet hij zich aan de stelen der of van nature, of door zijn lichaamsgewicht afhangende bloemen wel zóó vast te houden, dat hij, lichaam en hals rekkend zoover slechts mogelijk is, over den rand der kroon daarbinnen kan kijken en oppikken wat van zijn gading is.

Wij zijn hierdoor als vanzelf gekomen op de avifauna van dit gebied, die eveneens een groot aantal vormen heeft aan te wịzen, waarvan wij echter reeds een deel in de aangrenzende aanplantingen ontmoetten. Dit was o.a. het geval met de Pericocrotus- en Microtarsus soorten, Hemipus obscurus, Eurystomus orientalis, Pycnonotus bimaculatus, Psaltria exilis, Stoparola indigo, Muscicapula melanoleuca, C'ulicicapa ceylonensis, Artamides larvatus e.a., die hier dikwijls „schering en inslag” zijn. Karakteristiek voor deze omgeving is verder het geluid van twee Baardvogels: Cyanops armillaris en Chotorhea corvina; geblinddoekt zou men haar daaraan herkennen. De 


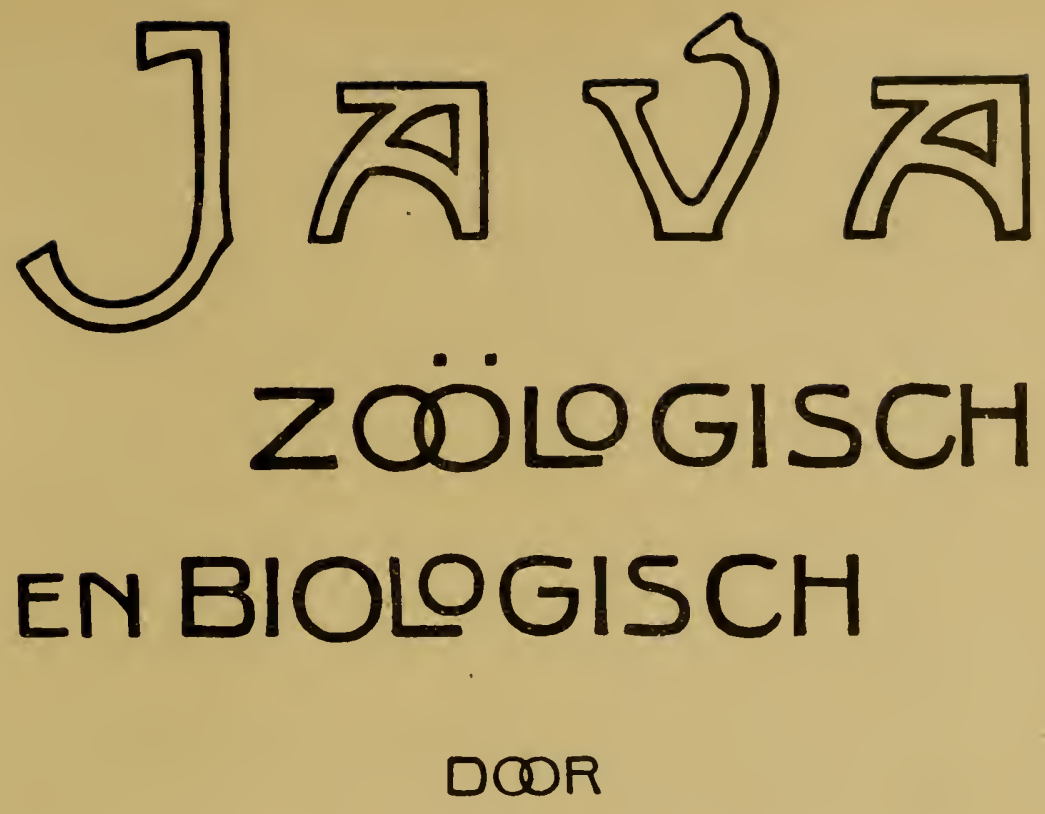

\section{DRJ.C.KONINGSBERGER}

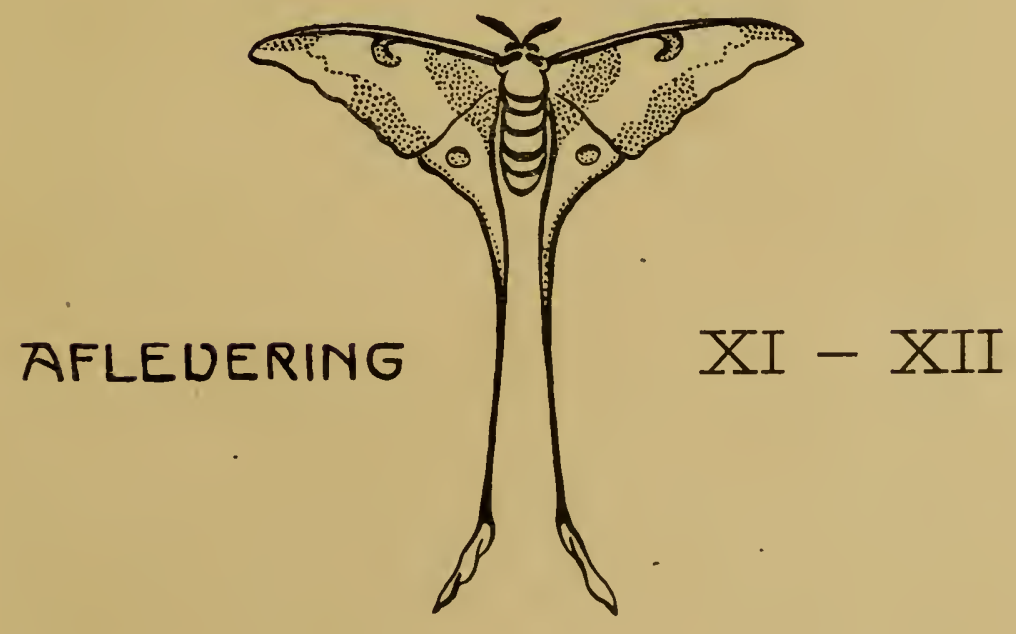

DRUKKERIJ DEP. v. L. N. en H.

BUITENZORG 1915.
Verkrijgbaar bij

G. KOLFF \& Co., Batavia.

Prijs f 2.- 


$$
\text { - }
$$


eerste is de tegenhanger van den reeds vroeger (pag. 347 ) besproken boeltok (Cyanops lineata), die het bosch geheel heeft verlaten. Hij is even vervelend om op den duul aan te hooren, even hardnekkig in zijn geroep. Geen middagwarmte, voor zooverre daarvan op deze hoogte mag worden gesproken, geen wolken, die de toppen van het geboomte omhullen en aan het landschap een voorkomen ván trieste eenzaamheid geven, zijn in staat om hem tot zwijgen te brengen. Ook is hij voor een boschvogel niet schuw; zonder bezwaar zet hij zich in 's menschen nabijheid op een kalen tak en begint onmiddelijk met zijn gervep, onverstoorbaar als de afslager bij een publieke verkooping. De tweede is schuwer van aard en komt zelden in de lagere gedeelten van het geboomte; ook weerklinkt zijn stem minder aanhoudend en langdurig. Zijn naaste verwant op Java is Chotorhea javensis. Bij dit geslacht vermijden echter de beide soorten elkander op andere wijze dan bij Cyanops. Hier geen tegenstelling tusschen een vorm van het cultuurgebied en een boschvorm, maar tusschen een vorm der hoogere en een der lagere streken, in welke laatste het geluid van $C h$. javensis eveneens een zekere aanwijzing is, dat men zich in de nabijheid van het bosch bevindt.

De beo (Mainatus javanensis) begint op Java tamelijk zeldzaam te worden. Waar hị nog voorkomt, vindt men hem bij voorkeur lang's den rand der bosschen, waar hij zijn nest maakt in zeer hooge, zich boven het omgevende hout verheffende en daardoor tamelijk geïsoleerde boomkruinen. De jacht, die voortdurend op zijn jongen wordt gemaakt, heeft hem tot zulke ontoegankelijke nestplatsen zijn toevlucht doen zoeken. 
Men staat overigens verbaasd over de vermetelheid, waarmede sommige inlanders hem zelfs nog in deze schuilplaatsen weten te beștoken, waarbij het-beklimmen der dikwijls gladde en loodrechte gedeelten der boomstammen plaats heeft met behulp van lange bamboestengels, evenwijdig aan de stammen geplaatst en daarmede verbonden door dwarse latjes, die als sporten voor dezen primitieven ladder dienst doen. Dergelijke klimtoestellen kon men vroeger in het (thans verdwenen) bosch van Waleri, aan de Noordkust der Res. Pekalongan, in vrij grooten getale aantreffen; ze droegen daar zelfs een vrij permanent karakter.

Staat de beo als kuoivogel in hooge eer wegens zijn aanleg tot het aanleeren van allerlei geluiden en gezegden, in de vrije natuur geeft hij weinig bijzonders te zien en te hooren. Waar hij, zooals op Sumatra nog op vele plaatsen het geval is, in grooten getale voorkomt, wordt zijn eentonig fluitend geroep, dat door den inlandschen naam boeroeng "tjioeng" vrij goed wordt weergegeven, zelfs vervelend en hinderlijk.

Een andere luidıuchtige bewoner van dit gebied is Pomatorhinus montanus, waarover reeds vroeger (pag. 29) uitvoerig is gesproken. Maar deze gunt zich. den tijd niet om ons te vervelen, daar hij in grootere of kleinere troepen, soms ook paarsgewijze rondtrekt. Zulke troepen komen plotseling onder voortdurend geroep aanzetten, houden zich eenige minuten, zeer druk en gewichtig doende, aan of eren buiten den rand van het bosch op en verdwijnen dan weder even snel, als ze kwamen. Zij leveren in deze wijze van optreden een scherpe tegenstelling met 
de beide Malkoha's van Java, die eveneens gaarne liet bosch voor een poosje verlaten om in naburig geboomte naar voedsel te zoeken. Het zijn Rhinococcyx curvirostris en Zanclostomus javanicus, beide nauwe verwanten van de vroeger (pag. 432) besproken Spoorkoekoeken, waaraan ze in habitus en bewegingen dadelijk herinneren. Hun donker gevederte is echter reel fraaier. Vooral de eerste is weinig schuw. Gewoonlijk treft men ze in paren aan, die zeer op hun gemak rondtrekken en daarbij slechts zelden hun stemgeluid doen hooren. Haast hebben ze zelden of nooit; ze houden zich soms een geheelen voolmiddag in denzelfden boom op, waarbij ze dikwijls liıngen tijd stil zitten, domweg vór zich uitkijkend en de lange staart slap afhangend. Wordt hun aandacht dool iets in de nabijheid getrokken, ditn springen ze tamelijk handig en vlug op een naderbij gelegen tak, maar als het dan blijkt, niets bijzonders te zijn, dan blijven ze ook dàl stil zitten. Is het echtel iets ran hun gading (vooral fraaie, metaalachtig glanzende kevers eten zij gaarne), dan geven zij duor een kort, dof klokkend geluid hunne tevredenheid te kennell. In West-Java zijn zij algemeen ondel den naam lontrok bekend, terwijl ze ook dikwijls worden aangeduid als boeboet kembang, waardoor hun verwantschap met de Spoorkoeken wordt aangegeven.

Vau de Duiven houden zich vooral de Kaneelduiven (Macrıpygidıe) hier op, die, loewel nog boschbewoners, een duidelijke neiging aan den dag legrgen om de banden met de wildernis losser te maken. Zij wagen zich wiij ver nat buiten, komen wel in de buurt van kampongs en vertoeven zelfs niet zelden in tamelijk open terreinen, warl de vruchten 
van allerlei struiken hun tot voedsel strekken. Tegen den avond trekken zij zich echter weder terug in het bosch, waar hun silhouet gemakkelijk herkenbaar is aan den tamelijk langen, recht naar achteren gehouden staart. Er komen op Java drie soorten van deze familie voor, alle van het geslacht Macropygia, namelijk $M$. leptogrammica, $M$. emiliana en $M$. ruficeps.

De beide eerstgenoemde zijn plaatselijk soms zeer algemeen en talrijk; de derde soort ziet men minder dikwijls, maar zij valt door haar geringere grootte ook niet zon in het oog. Naar het stemgeluid worden zij door de inlanders als boeroeng oewoek, naar de kleur als boeroeng oentjal aangeduid.

Voor het overige kunnen de boschranden ons nog een aantal vogelsoorten te zien of te hooren geven, die minder typisch ervoor zijn dan de bovengenoemde, deels omdat men ze door hun schuwheid moeielijker te zien krijgt en deels omdat ze ook dikwijls elders voorkomen. Dit laatste is 0 . a. het geval met Stuchyris thoracica, een tamelijk groote Timeliide, die gemakkelijk herkenbaar is aan een witte krop, een zwarte keel en een overigens bruin vederkleed; met Chalcococcyx basalis, een kleinen Koekoek, van welken de meest geliefkoosde verblijfplaats, zoo hij er een heeft, mij nog niet bekend is, daar ik hem in biologisch zeer uiteenloopende terreinen waarnam; met Acrocephalus orientalis, waarschijnlijk slechts een winterbezoeker, die het hier met de omgeving zoo nauw niet neemt; eindelijk met Loriculus pusillus, de seriendiet, die, veel meer boschvogel gebleven dan zijn verwant, de bèttèt (pag. 232), toch ook wel in boomrijke, bewoonde streken voorkomt.

De omstandigheid dat, hetzij als begrenzing der 
naburige aanplantingen, hetzij om andere redenen, in den regel een meer of minder primitiest weg; soms niet meer dan een smal voetpad, langs de boschranden voert en dat deze weg ook gaarne door grootere Zoogdieren wordt gebruikt, is oorzaak, lat men hier dikwijls Herten, Wilde Zwijnen en zelfs grootere Ruofdieren kan waarnemen. Deze kunnen hier echter buiten verdere beschouwing blijven. Van de kleinere Znogdieren, die vroeger, hij de boomachtige aamplantingen, werden besproken, kan men hier eveneens alle vormen tegenkomen. l)aaraan moet thans een tweetal suorten worden toegevoegd, die den boschrand nooit of hoogst zelden verlaten, maar waarvan de ééne, een Eekhoorensoort, het daglicht en zelfs de naijheid van menschen in geenen deele schuwt. De bedoelde is Sciurus insignis, ongeveer van de grootte van de badjing (pag. 200) en dadelijk te herkennen aan de drie zwarte, overlangsche strepen over den fraili bruinen rug. Van deze sierlijke diertjes ziet men dikwijls paren zich al spelende in de lagere gedeelten van het geboomte voortbewegen. In de kruinen wagen zij zich echter nooit en het schijnt, dat zij hun voedsel uitsluitend vinden op den grond of in het onderhout en de struiken.

De tweede is Arctogale leucotis, een klein Roofdier van het locwak-type, dat zich voor een aanzienlijk deel met rijpe boschvruchten pleegt te voeden. Zijn verwantschap met den loewak is zóó groot, clat hij vrveger daarmede, als Paradoxurus trivirgatus, in één geslacht werd vereenigd. De algemeene huidkleur is van een fraai bruin, op de bovendeelen donkerder dan op de buikzijde, terwijl over den rug drie donkere, overlangsche strepen verloopen, die soms in vlekken zijn opgelost en soms geheel moeten ont- 
breken. In hooge mate nachtdier, houdt hij zich overdag schuil in holten van boomstammen en der. gelijke plaatsen en slechts het toeval doet nu en dan een exemplaar ontdekken.

De bovenbedoelde wegen langs de randen der bosschen geven ons vok gelegenheid tot liet waarnemen van Slangen, die zich niet zelden in den zonneschijn liggen te koesteren, iets, dat hun, voor zooverre ze geen boomslangen zijn, in bosschen en gras- of struikwildernissen minder gemakkelijk valt. Gegeven de betrekkelijke onverschilligheid der slangen voor hunne omgeving, kunnen wij hier een aantal der rroeger besproken vormen tegenkomen: er zijn echter rerschillende soorten, die een besliste roorliefde roor hoogere streken ( 2 tot 4 duizend roet) aan den dag leggen en wok niet veel van de nabijheid van den mensch moeten hebben, al komen zij daarin toevallig wel eens terecht. Als zoodanig mogen hier worden genoemd Doliophis bivirgatus, ven fraai, van boven donkergrijs tot zwart giftslangetje met een fijne, roode, overlangsche lijn terzijde van het lichadm en rooden kop, staart en buikzijde; Xenodermus javanicus, uiterst sierlijk van voorkomen, met een sterke tegenstelling tusschen de groote buikschilden en de fijnbeschubde flanken van liet lichaam, en met overlangsche rijen van verdikte schubben over den rug; Hypsirhina enhydris, metaalachtig grijs van boven, witachtig op de onderdeelen en om het geheele lichaam overlangs, donker gestreept; Tropidonotus chrysargus, van boven bruinachtig grijs, met teekeningen die eenigszins herinneren aan die vall Chrysopelea ornata (pag. 437) en een donkere vlek op de zijdelingsche uiteinden der witachtige buikschilden; Dryophis fasciolatus (?), 
een even typische boomslang als de vroeger (pag. 85) genwemde D. prasinus en eveneens met een donkere huid die bij de minste uitzetting van het lichaam tussuhen de uiteenwijkende schilden voor den dag komt: Dipsadomorphu. drapiczii, van den algemeenen hahitus vall het genus, met donkerc dwarsstrepen aan weerszijglen van den rug en een rij van lichte, gedeeltelijk zwart-onzumde rlekken langs den onderrand der flanken: Coluber tricolor; groenachtig geelbruin op de onderdeelen, bruinachtig op de bovencleelen, met een zivarte streep over het oog. die zich achterwaarts eenige centimeters voortzet.

Van grooter verticale verspreiding is Polyodontophis geminatus, met twee roodbruine strepen over den zwarten tot doukergrijzen rug, waardoor deze soort aan Sinotes octolineutus (pag. 255) herinnert, waarvan zij echter door den bruinen (soms weder in tweeën gedeelden) nekband is te onderscheiden. Een gevaarlijke gast is voorts de variëteit lencodira van Naja tripudians, die zich door de witachtige kleur aan de onderzijde ran kop en hals (op de laatste met twee zijdelingsche, donkere rlekken) van de meer algemeene en reeds rroeger (pag. 82) besproken variëteit sputatrix onderscheidt, maar overigens in allures en wijze van aanvallen en verdedigen geheel daarmede overeenstemt. Eindelijk zij nog vermeld Cylindrophis melanotus, die dezelfde verborgen levenswijze en ook geheel denzelfden plompen habitus heeft als zijn vroeger (pag: 82) genoemde verwant C. rufus, maar minder in bewoonde buurten schijnt roor te komen, evenals zulks het geval is met een paar, onmiddellijk als zoodanig te herkennen Calamaria-soorten, die tot heden slechts in de hoogere streken zijn aangetroffen. 


\section{HOOFDSTUK XXI.}

\section{De Boschfauna in het algemeen.}

Hoewel in de vorige hoofdstukken niet meer is gegeven dan een algemeen overzicht van de fauna's der verschillende besproken gebieden, zal het zonder meer duidelijk zijn, dat de oerfauna, die wij op pag. 10 onderscheidden, tijdens de historische ontwikkeling van Java uit haar gelederen héél wat vormen heeft zien verdwijnen, vóórdat haar restant zich kon groepeeren tot de coenobiose, die wij thans als de meest oorspronkelijke van.Java hebben te beschouwen, namelijk de boschfauna. Men zou kunnen zeggen, dat de oerfauna een reusachtig zuiveringsproces heeft ondergaan en dat er een garde is overgebleven, waarop het bosch met vrij groote zekerheid kan rekenen, tl komen nog voortdurend gevallen van desertie voor en al zullen die zich ook in de toekomst ongetwijfeld blijven voordoen. Met deze "garde" zullen wij ons thans hebben bezig te houden.

$\mathrm{Er}$ is niemand, en in de eerste plaats geen natuuronder'zoeker, die zich kan onttrekken aan den indruk, dat een tropisch bosch een organisch geheel is van zeer bijzonderen, men mag bijna zeggen van geheel éénigen aard. Het is eerder één organisme van uiterst samengestelden bouw, dan een opcenhooping van individuen, die zelfstandig naast elkander voortleven. Ja, vele van die individuen kunnen zelfs niet 
onafhankelijk van de andere bestaan, of, wannéér ze het kunnen, dan zijn ze dikwijls zich zelf niet meer. Plant een woudboom in het open veld en - zoo hij daar wil gedijen - is het toch niet dezelfde boom, zooals men dien kent uit het bosch.

Hiermede is volstrekt niet gezegd, dat de omstandigheden in het bosch voor de plantaardige en dierlijke organismen aldaar zoo bijzonder gunstig zouden zijn; veeleer is het tegendeel dikwijls het geval. Het is een harde strijd, die daar moet worden gestreden, maar die voortdurende strijd geeft training en harding, yeeft, als wij het zoo eens mogen uitdrukken, een grevoel van eigenwaarde en trots. Bied aan iemand, die met hart en ziel werkman is, zooals zijn vader en zijn grootvader het vóor hem waren, en zooals hij hoopt, dat zijn kinderen het na hem zullen zijn, bied dien man een behoorlijk inkomen aan op voorwaarde van een dolce far niente en hij zal het trotsch afwijzen. Zoo weigert ook het echte bosch-organisme zich buiten het woud te vestigen, al zijn de omstandigheden van voeding, licht en lucht er dikwijls oneindig veel gunstiger. De bezetting van ledige plekken in de nabijheid toont dit ten duidelijkste aan. Het zijn geen boschplanten en boschdieren, die daar komen, maar vreemde indringers en gelukzoekers, de heffe van flora en fauna; het trotsche bosch-org:unisme "verwildert” niet; zijn gelederen zijn in den loop der eeuwen grootendeels gezuiverd valn alle vormen, lie daartoe neiging hebben vertoond.

El zijn een groot aantal dielvormen voor welke het feit, dat zij in het oorspronkelijke woud leven, zoozeer hoofdzak is, rat de andere factoren, inzonder- 
heid de klimatologische, daarbij vergeleken, van geen of hoogstens ondergeschikte beteekenis zijn. Wij vinden dezulke zoowel onder de lagere, als onder de hoogere dieren en voorzeker niet het minst onder de laatste. Zoo zijn er van de vier Apensoorten van Java twee, die zoowel in de heete laaglanden, voor zooverre daar nog bosschen zijn, als in de bergwouden tot op vrij aanzienlijke hoogte voorkomen, namelijk Macacus cynomolgus en Semnopithecus maurus.

De eerste (m. monjet; s. koenjoek; jav. kĕtěk) is wel de meest algemeene van de twee en komt hier en daar ook veelvuldig voor in de mangrove-bosschen langs de kust. Van de tweede (m. loetoeng, jav. boedeng), die normaliter zwart is, komt, vooral in het Oosten van Java, een roodbruine vorm voor, die vroeger als een afzonderlijke soort onder den naam Semnopithecus pyrrhus is beschreven. Deze vorm omvat echter de individuen, die levenslang, of althans veel langer dan gewoonlijk, de veel lichtere kleur van het jeugdkleed hebben behouden. De haren der jonge dieren zijn namelijk steeds roodachtig goudgeel en vertoonen slechts over de dorsale middellijn zwarte uiteinden. Eer'st langzamerhand breidt zich het zwart over de geheele vacht uit, met uitzondering dan van den bedoelden pyrrhus-vorm. Hoewel de loetoeng tot in zeer hooge streken voorkomt en door KoHLBRUGGe in het Tengger-gebergte zelfs op 7500 voet boven zee werd waargenomen, schijnt hij toch in het alge. meen aan warmere streken de voorkeur te geven, een voorliefde, die hij volgens BüтtiKofer *) ook op Borneo vertoont.

Een ander Zoogdier, dat zich weinig aan de tem-

$\left.{ }^{*}\right)$ Notes Leyden museum, XIX, pag. 38 . 
peratuur laat gelegen liggen en daarbij bij voorkeur, hoewel niet uitsluitend, in het bosch vertoeft, is de rroeger (pag. 426) reeds genoemde kantjil, Tragulus javanicus, terwijl de Panter (Felis pardus) eveneens een, over hooge en lage streken verspreide woudbewoner is. Zooals bekend is, bestaat van den Panter een zwarte rorm, die vroeger eveneens als een af\%onderlijke soort (Felis melas) is beschreven. Men vindt echter in hetzelfde nest wel eens een zwart jong tusschen de normale en wanneer men de huid van een zwart volwassen individu bij verschillend invallend licht bekijkt, kan men nu en dan zeer duinelijk dezelfde vleksgewijze teekening waarnemen als bij de normaal gekleurde dieren. Ook naar de grootte van het lichaam, naar de grondkleur van de vacht en naar de grootte en de meer of minder dichte plaatsing der vlekken kan men bij den Panter een drietal rormen onderscheiden, die door de soendaneezen zelfs als meong malangbong (de grootste), meong toetoel en meong keroed (de kleinste) worden onderscheiden. Het staat echter nog niet rast, in hueverre deze vormen constant zijn of in hoeverre zij in verband staan met woonplaats, klimaat. roedsel enz. De zwarte vorm wordt in West-Java algemeen met de namen meong loembang en meong hideung aangeduid.

Sporen van den Panter vond ik tot bij Kandang Badak, in het zadel tusschen Pangerango en G. Gedeh, op een hoogte van ruim 7000 voet.

Van de Vogels zijn in de eerste plaats de Neushoornvogels (Bucerotidae) echte boschbewoners, die door hun grootte en hun eigenaardig voorkomen 
volkomen passen in een oorspronkelijke, min of meer woeste omgeving. Zij zijn op Java vertegenwoordigd dool drie soorten: Buceros sylvestris (rangkok), Rhytidoceros undulatus (djoelan) en Anthracoceros convexus (kangkareng), die hier alle drie naast elkaar vuorkomen, elders elkander min of meer schijnen uit te sluiten. Hunne aanwezigheid verraadt zich reeds op danzienlijken afstand door het eigenaardige piepende en krakende geluid, dat zij bij het vliegen veroorzaken, welk geluid schijnt te worden veroorzaakt, doordat de lucht met kracht tusschen de basale gedeelten der slagpennen wordt doorgedreven, welke hier niet door de onderste vleugeldekveeren worden bedekt. Een soort van onwelluidende Aeolusharp, die den indruk maakt, alsof een nieuwe mand met zwaren inhoud door eenige dragers wordt vervoerd. Bekend is bij deze rogels de opsluiting van het wijfje gedurende den broedtijd, als wanneer zij in de nestholte (gewoonlijk in de holte van een boomstam) door het mannetje wordt ingemetseld, terwijl zij hare vrijheid niet herkrijgt, vóóldat de jongen zich zelfstandig kunnen bewegen.

Echte boschbewoners zijn voorts de meeste Spechten (Picidae) van Java. Van de 15 soorten, waardoor deze familie hier is vertegenwoordigd, zijn er niet min. der dan 12, die men zelden of nooit buiten het bosch ontmoet. Van de levenswijze dezer boschspechten weet men nog maar zeer weinig, maar zóóveel is zeker, dat zij lang niet alle hun voedsel steeds zoeken op de wijze, die voor deze familie vrij algemeen als typisch wordt aangenomen. Daarop wijst vooral het onderzoek van verschillende maaginhouden. Zoo werden in de maag van Gecinus vittatus gevonden kevers, vliegen en gevlengelde 
mieren, in die van Gecinus puniceus vooral mieren. Bij Chrysophlegma mentale en Thriponax javensis zijn zelfs overblijfselen van vruchten aangetroffen. Chrysocolaptes strictus, Chr. validus en Hemicercus concretus bevatten daarentegen steeds insectenoverblijfselen, die wijzen op het zoeken naal voedsel in boomstammen, levende zoowel als rermolmde. Neemt men hierbij in aanmerking; wat vroeger (pag. 341) over de levenswijze van Tiga javanensis rerd opgemerkt, dan blijkt, dat de levenswijze der Spechten op Jara nogal gedifferentiëerd is, temeer, waar Micropternus brachyurus, blijkens de onderzochte magen. zich uitsluitend met den inhoud ran mierennesten schijnt te roeden. De wijze van nestelen van rleze soort is op Java nog niet bekend, maar het is niet onmogelijk, dat zij overeenkomt met die eener verwante soort in Britsch Indië, die eenvoudig de papierachtige nesten eener Mier van let geslacht Crematogaster in beslag neemt, daarin het noodige "vertimmert" en de wettige bewoner's verjaagt en vermoedelijk voor een deel opeet. Men heeft zelfs waargenomen, dat de Mieren het niet vernielde gedeelte van het nest bleven bewonen, in welk geval de broedende vogel al bijzonder gemakkelijk aan voedsel voor zich en later ook roor zijn jongen zou kunnen komen.

Evenals de Ṡpechten. hebben ook de Vliegenvangers in liet algemeen zeer weinig neiging aan den dag gelegd om in de culturfauna over te gaan. Slechts met een drietal is dit rolledig het geval geweest, een paar andere (pag. 236) zoeken in het cultuurgebied de meest afgelegen gedeelten op en wederom een drietal andere (pag. 366) wagen zich wel eens buiten het bosch op kleine strooptochten. Er 
blijft echter nog ruim een dozijn soorten over, die in de bosschen leven; daar deze echter in verticale richting een meer beperkte verspreiding hebben, dan, voor zooverre thans bekend is, met de Spechten het geval schijnt te zijn, kan het meerendeel ervan later nog ter sprake worden gebracht.

De Vorkstaarten (Henicuridae), reeds op pag. 10 terloops genoemd, moeten in het geheel niets van de nabijheid van den mensch hebben, maar stellen overigens geen andere, bijzondere eischen dan helder water en een boschrijke omgering. Vandaar, dat men ze zoowel in lagere als in hoogere streken, aantreft. Twee vormen komen op Java voor, t.w. de grootere Henicurus leschenaulti en de kleinere Hydrocychla velata, beide uiterst sierlijke dieren, die men het best te zien krijgt door zich in een rerborgen hoek nabij een bergstroompje neer te zetten. Zij bewegen zich met buitengewone vlugheid over de steenen, die boven het bruisende en schuimende water uitsteken en maken, wanneer ze toevallig door een zonnestraal worden beschenen, den indruk, alsof ze van half doorschijnend glas waren gemaakt.

Van de Timeliidae geldt hetzelfde als van de Spechten en van de Vliegenvangers: een overvloed van boschvormen tegenover slechts een paar vormen in de cultuurfauna. Het moet worden erkend, dat de levenswijze van verreweg de meeste vertegenwoordigers dezer familie hen bij uitnemendheid in het bosch op hun plaats doet zijn. Vlugge loopers, minder goede vliegers, als ze zijn, houden zij zich bijna voortdurend op of zeer nabij den grond op. Onderhout en kruidachtige planten verleenen hun 
daarbij niet minder beschutting dan hum, in den regel zeer eenvoudig vederkleed. Hoewel eenige soorten ook in de lagere streken voorkomen, hourlt het meerendeel zich op in bosschen van middel. matige hoogte boven zee, zoodat ze diair het best ter sprake komen.

Er zijn verder een aantal afzonderlijke soorten, die lier moeten worden genoemd. $\% 00$ is Oriolus xanthonotus van de bosschen in het laagland tot die, welke op $t$ i 5000 voet boven zee zijn gelegen, de parallelvorm van Oriolus maculatus (pag. 64), een cultuurorm bij uitnemendheid. Evenzoo is Batrachostomus javensis in het bosch de tegenhanger van de Caprimulgus- soorten (pag. 231) daarbuiten.

Het Dwergspechtje Sasia abnormis, dat in zijn levenswijze minder overeenkomst met de echte Spechten vertoont dan in zijn lichaamsbouw, is eveneens een vorm van groote verticale verspreiding. De maaginhouden van meerdere exemplaren heboen het waarschijnlijk gemaakt, dat het zich voedt met vrij levende, hoogstens bladrollende rupsen en niet met houtborende larven. Het is overigens van een zoo nietig diertje ook niet te verwachten, dat het in staat zou zijn, de laatste in hun verblijf op te sporen. Zijn gewone houding is ook niet klimmend, maal zittend.

Wanneer ik hier verder Cissa thalassina noem, dan is dat, omdat men dezen luidruchtigen boschbewoner een zeer enkele maal in laaggelegen bosschen tegenkoint. Zijn eigenlijke gebied ligt echter meel tusschen 2000 en 6000 voet. Hetzelfde geldt van Carpophaga aenea, welke Muskaatduif zich eveneens wel eens in de lagere streken vertoont. 
Wat eindelijk de Roofvogels betreft, daarvan heeft men in het algemeen de Dagrnofrogels meer om en buiten, dan in het bosch te zoeken; verreweg de meeste kwamen dan ook bij de cultuurfauna reeds ten sprake. Slechts voor Uilen is het getemperde licht van het woud een aantrekkelijke omstandig heid. Behalve Phodilus badius. die vermoedelijk in den overgangstoestand naar de cultuurfauna is (pag. 221), kan men hier aantreffen Ninox borneensis, Glaucidium castanopterum en vooral Syrnium sinense, waaruit blijkt, dat het vooral de Katuilen zijn, die aan de wildernis zijn getrouw gebleren.

Slangen ziet men in de bosschen weinig. Slechts in de laaglanden, waar de bosschen het karakter van rawah's vertoonen, komen ze vrij veelvuldig voor (zie pag. 470-473). Hoogerop worden ze vervangen door Lacertiliën en Batrachiër's, die later zullen ter sprake komen. Thans zij slechts opgemerkt, dat ten aanzien van beide laatstgenoemde groepen, voor zooverre hun boschvormen betı eft, een duidelijk verschil in verticale verspreiding is war te nemen tusschen de breedere Noordelijke, en de smallere Zuidelijke strook, waarin Java door de reeks zijner vulkanen wordt verdeeld. Een verschil, dat verband houdt met de omstandigheid, dat de homogeniteit der omgeving in de Zuidelijke strook in vele opzichten zooveel grooter is dan in de andere. Zij is minder bevolkt en daardoor minder in cultuur gebracht; de bosschen dalen op vele plaatsen nog af tot aan de kust. Het klimaat staat er meer dan in het breede, Noordelijke gedeelte, onder den onmiddelijken invlued van de zee en is daardoor minder rijk aan sterke afwisselingen, altemaal zaken, 
die ertoe hebben geleid, dat vele diervormen zich aldaar minder dan elders in de hoogere streken hebben teruggetrokken.

De Insectenwereld der bosschen vertoont in hooge mate het zeer bijzondere karakter, waarop in den aanvang van dit hoofdstuk werd gewezen. Het is in den loop der jaren menigmaal voorgekomen, dat $i k$, ergens in de nabijheid van het bosch vertoerende, aan een inlander had opgedragen, aldaar te gaan verzamelen en dat de man, het gemakkelijker of veiliger oordeelend, zich niet in de wildernis te wagen, zijn opdracht elders ging uitvoeren. De aard van het verzamelde verried dat steeds onmiddelijk; er was inderdaad geen ontkennen aan. Boschvormen en cultuurvormen zijn hier te scherp van elkander gescheiden, dan dat een dergelijke poging tot misleiding eenig succes zou kunnen hebben. Bovendien is het hier niet alleen een kwestie van dier-soorten; in vele gerallen zijn het geslachten, families, zelfs systematische eenheden van nog hooger orde, ran welke met zekerheid kan worden gezegd, dat ze geheel of roor een overwegend deel uit het ééne, of nit het andere gebied afkomstig zijn.

Een van de meest sprekende voorbeelden hiervan levert de groote groep der Eu-neuroptera, waarvan bijna alle Mecoptera en verreweg het meerendeel der Planipennia zuivere boschvormen zijn. Wat aan enkele soorten van Mierenleeuwen en Gaasvliegen in de cultuurfauna is overgegaan, is niet meer dan een fractie vian het geheel, dat op Java voorkomt, en bevat bovendien juist de vormen, die aldaar door eenvoud van voorkomen, door afwezigheid van alles, 
dat in bijzondere mate de aandacht zou kunnen trekken, volkomen op hun plaats zijn. Het minder eenroudige, het door vorm en kleur opvallende, het bizarre, dat alles is in het bosch gebleven. De Ascalaphiden met hun lange, knodsvormige sprieten zweven er gaarne boven de bergstroompjes; de Mantispa's, in habitus sterk aan kleine Mantis-soorten herinnerend, de Panorpa's, met hun verlengde snuiten en slanke, gekromde achterlijven, aan het uiteinde van een forceps voorzien, het zijn altegader vormen, die in de oorspronkelijke natuur thuis behooren en vaarvan het opvallende zijn hoogtepunt bereikt in vormen als Leptopanorpa, die volkomen den indruk maakt, alsof hị met zịn eigen, bovenmatig lang abdomen eigenlijk zelf geen raad weet.

Een ander voorbeeld leveren de Glazenmakers (Odonata), waarvan reeds op pag. 247 de voornaamste cultuurvormen werden genoemd, onder vermelding van de omstandigheid, dat ééne van de drie families, die der Agrionidae, zoo goed als niet in de cultuurfauna is overgegan. Inderdaad, zoolang men den boschrand en de aangrenzende terreinen volgt, is men omgeven door dozijnen van alledaagsche Libellulidae en Aeschnidae, maar zoodra men door de bedding van een bergstroompje het bosch eenige meters ver ingaat, staat men op de eerste de beste, goed verlichte plek voor de fraaie Vestalis lugens en andere Agrionidae (Euphaea variegata, Psilocnemis marginipes, Agriocnemis incisa), die hun vaak wonderlijk fraai gekleurde vleugels en abdomina in den zonneschijn laten schitteren. Zij worden daarbij in hun vlugge bewegingen op bedriegelijke wijze nagebootst door de fijne en elegante Papilionide Leptocircus, van welken in dit verband tegelijk even 
melding kan worden gemaakt en dien men op het erste gezicht zeer zekel niet als een nauwen verwant der statige Ridderkapellen herkent. Met hun grootendeels doorschijnende voorrleugels, hun naar achteren in lange stadrten verlengde achtervleugels vertoonen deze vlindertjes een geheel ander type van insect, waaraan de soortnaam van één hunner, libelluloides, niet zonder recht is ontleend.

De zoveven genoemde, doorschijnende, glazige rleugels herinneren aan een andere familie van Vlinders, die op Java eveneens weinig anders dan. hoschrormen bevat. namelijk die der Sesiidae. Uit, de cultuurfauna is mij slechts een enkele vorm bekend, eene Aegeria-soort, die in den larvalen toestand zich ophoudt in de schillen van cacaokolven, die door Helopeltis zijn aangetast 1) en derhalve het, bosch voor naburige arnplantingen heeft verlaten. Voor het overige ontmoette ik deze, dikwijls zeer fraai grekleurde vlindertjes nooit anders dan in het bosch, waar zij de gewoonte hebbell, dicht boven den grond rond te vliegen, waarbij ze zich in onregelmatige kringen bewegen en ten slotte hijna niet van plaats veranderen. Opmerking verdient hierbij, dat van de zeer naverwante familie der Syntomidae (pag. 143) juist weer een vrij gloot aantal snorten in de cultuurfauna is overgegaan.

Ook de Hymenoptera vertoonen verschillende groepen van grooteren en kleineren omvang, die aan het bosch verre de voorkeur geven boven elke andere omgeving. Ik denk hier in de eerste plaats aan de Wesp Polistes hebraeus, die stellig mag worden beschouwd

1). Beschreven door Docters vaN LEeUwen in de "Cultuurgids" 1910, Treede gedeelte. Afl. No. 4. 
als een van de diersoorten, die zich het minst aan de temperatuur hunner woonplats laten gelegen liggen. Zij is verre van algemeen, maar de weinige exemplaren, die ik in den loop der jaren verkreeg, loopen, wat vindplaats betreft, uiteen tusschen de kustbosschen bij Tandjong Priok en de hoogste gedeelten van den Pangerango, ruim 9000 voet boven zee.

Als voorbeeld van een genus, dat in zijn geheel tot de boschfauna moet worden gerekend, moge het vormenrijke geslacht Mutilla worden genoemd, waarvan men de ongevleugelde wijfjes dikwijls tusschen het afgevallen blad op den bodem ziet rondloopen, de mannetjes daarentegen slechts zelden te zien krijgt, omdat zij zich hoog boven ons bereik, bij de bloeiende kruinen van het geboomte ophouden. Ook de later nog te bespreken Hommels (geslacht Bombus) kunnen hier voorloopig worden vermeld.

Verder zij een afzonderlijk woord gewijd aan de galvormende Wespen (Cynipidae en verwanten), die op Java, in het algemeen gesproken, „schitteren door afwezigheid."

Was dit reeds lang mijn indruk, het wordt door Docters van LeEuwen met cijfers aangetuond in zijn laatste publicatie over de gallen van Java *). Van de 500 gallen, door dezen onderzoeker in samenwerking met zijn echtgenoote beschreven, komen slechts 15 op rekening van Hymenoptera, een uiterst gering aantal, wanneer men daarmede bijvoorbeeld eens vergelijkt, wat een klein land als Nederland in dit opzicht te zien geeft. Het onderzoek heeft zich echter niet uitgestrekt tot den bijzonderen vorm van gallen, dien de vruchten van het vormenrijke geslacht

*) Bulletin àu Jardin Botanique de Buitenzorg. II Sẻrie, No 15. een vervolg op de publicaties, die in de noot op pag. 162 zijn genoemd. 
Ficus ons te zien geven en men krijgt den indruk, dat de bedoelde insecten op Java daarop al hun krachten hebben geconcentreerd.

Wanneer men in het bosch "vruchten" van Fucussoorten openmaakt, die nagenoeg rijp zijn, zal men de inwendige holte niet zelden bewoond vinden door wat men op het eerste gezicht vour verschillende soorten van kleine insecten houdt. In sommige gevallen is inderdaad meer dan ééne soort aanwezig, maar in den regel ziet men vóó zich kleine Wespjes, die ran een kortere of langere legboor zijn roorzien (derhalve vrouwelijke individuen) en mierachtige, ongevleugelde insecten, die min of meer hulpbehoevend rondstrompelen en van welke het onderzoek heeft uitgewezen, dat zij de bijbehoorende mannetjes zijn. Al deze diertjes hebben zich ontwikkeld in kleine gallen, gevormd door telkens één rrouwelijk bloempje, dat derhalve zijn bestemming volledig heeft gemist en een insect, in plaats van een zaadje heeft voortgebracht

Over de, nog verre van opgehelderde, beteekenis van deze insecten voor de plant zullen wij ons hier niet in beschouwingen verdiepen. Volstaan moge worden met de mededeelingen, dat in de verschillende "vijgrruchten" van Java (er komen hier ruim 80 Ficus-soorten voor) een geheele verzameling van kleine Hymenoptera valt te maken, die men met den collectiefnaam "vijgeninsecten" kan bestempelen. Vooral de mannetjes daarvan vertoonen een geheel abuormalen bouw, terwijl de wijfjes zijn roorzien van een legboor, bij sommige soorten ter lengte van een naald, terwijl de lichaamslengte niet meer dan $3-4 \mathrm{mM}$. bedraagt. Zulk een diertje is zóó licht, dat de leegboor, bij het uiteinde aangevat, niet een- 
maal doorbuigt. Aan den anderen kant heeft het insect het vermogen, zijn legboor zóóver te buigen, dat het uiteinde nabij het achtereinde van zijn abdomen komt te liggen, en haar in die houding in den wand van een jonge vijgvrucht te doen binnendringen. Deze „langstaartige" diertjes toch zijn weer parasieten van de "inquilinen". zooals de oorspronkelijke bewoners der galbloemjes worden genoemd en daar er voor hen met hun lange boor niet aan te denken valt, op de gewone wijze (nl. tusschen de schubben door, die de opening afsluiten) in de binnenruimte te komen, waarin zich de bloempjes bevinden, zijn zij wel verplicht, hun slachtoffer's via recta, dwars door den wand der vijgvrucht heen, te bereiken. Het verlaten van het verblijf valt den volwassen dieren later niet moeielijk, daar, na het rijpen, bij het orificium (de door schubben afgesloten opening) door het van stand veranderen, het uitvallen en zoo noodig, het losknagen der schubben een opening van voldoende ruimte wordt gevormd, om allen gevleugelden bewoonsters, inquilinen zoowel als hun parasieten, de gelegenheid tot ontsnappen te geven. De mannetjes der inquilinen blijven binnen de afgevallen vijgvrucht nog eenigen tijd in leven, maar na de bevruchting der wijfjes, die vóór het uitvliegen plaats heeft, is hun levenstaak ten einde.

Aangaande de systematische plaats dezer vijgeninquilinen verkeert men nog eenigszins in het onzekere. Sommigen rekenen ze tot de Cynipidae, anderen tot de Chalcididae; wederom anderen plaatsen ze in de onmiddellijke nabijheid van laatstgenoemde familie als Blastophagidae, welke naarn is ontleend aan den geslachtsnaam der soort Blastophag a grossorum, die bij de gewone Europeesche Vijg in Italië en Griekenland een rol speelt. 
Wat de Formicidae aangaat, moet de bekentenis wolden afgelegd, dat wij aangaande de bosch bewonende soorten en humne levenswijze nog minder weten dan aangaande de soorten, die in onze naaste omgeving leven en waarvan de meest, algemeene vormen vroeger (pag. 157 - 162) werden genoemd. Zelfs de vraag, in hoeverre er een scherpe grens tusschen beide groepen bestatat, kan nog niet voldoende worden beantwoord, hoewel het viststaat, dat eenige soorten beirle gebieden bewonen. zooals de reeds meermalen genoemde rangrang (Oecophylla smaragdina). Ook is het een bekende zaak, dat men in woningen, die zich nabij het bosch of in jonge ontginningen bevinden, dikivịls oneindig meer last heeft van de invasies van allerlei Mieren, dan in meer bewoonde streken. Feitelijk mag men echter op Java in dit opzicht van groot geluk spreken. Wanneer men de verhalen leest van betrouwbare waarnemers in Britsch Indië en in de Molukken, om van andere tropische landen niet te spreken, betreffende den overlast, dien men aldaal, ook in de grootere plaatsen, dikwijls van deze insecten ondervindt, dan heeft men hier geen reden tot klagen, waal een weinig toezicht, mitis het slechts voortdurend zij, ons vrijwel op afdoende wijze tegen deze plaag beschermt.

In de bosschen treedt vooral de groep der Myrmicinae op den voorgrond, dadelijk herkenbaar aan de twee gelerlingen van den achterlijfssteel, waardoor het, ablomen ten aanzien van den thorax een groote bewegelijkheid bezit. Van die bewegelijkheid maken sommige soorten gebruik op een wijze, die een min of meer komischen indruk maakt. Zoo is er een Aphaenogaster-soort, die men gewoonlijk in lange colonnes, van drie tot vier dieren breedte, ziet mar- 
cheeren en die de gewoonte heeft, het achterlijf benedenwaarts naar voren te slaan en derhalve tusschen de pooten te dragen. Van ons standpunt bekeken, lijkt deze wijze van loopen zeer ongemakkelijk, maar de dieren denken daar blijkbaar anders over; het is hun normale gang, dien men het best kan waarnemen, wanneer men ze tegen het licht ziet, bijv. marcheerende op den tak van een slingerplant.

Andere Myrmicinae, inzonderheid sommige soorten van het geslacht Crematogaster, slaan het abdomen bovenwaarts naal voren en leggen het derhalve op de rugzijde van den thorax, maar gewoonlijk doen zij dat eerst onder den invloed van de eene of andere emotie, vermoedelijk als eene bedreiging.

Komen geslachten als Phidole, Phidologiton, Sima e.a. in de grootere plaatsen, sommige zelfs in onze woningen wel eens voor, zoo schijnen zij toch in de wildernis een hoogere maatschappelijke ontwikkeling te bereiken, deels naar getalsterk te en déels naar rijkdiom van ontwikkelingsvormen. Dit laatste geldt o.a. vooral voor Phidologiton, welk geslacht zeer polymorphe soorten telt, daar (behalve werksters in verschillende grootte) ook een soldatenkaste optreedt, die eveneens rerschillende rangen kent, welker distinctieven echter slechts bestaan in verschil van afmetingen. De kleinste en tevens dapperste soldaten hebben ongeveer de dubbele grootte der werksters, de grootste zijn ongeveer vijfmaal zoo groot. Ontmoet men in het bosch een colonne van zulk een diersoort, dan kan men gewoonlijk alle vormen daarin aantreffen, waarbij onmiddellijk de aandacht wordt getrokken door de luie, indolente wijze, waarop de grootere soldaten met den troep medesukkelen. 
Zij bewegen zich traag en langzaam voort, waarbij zij meestal omstuwd zijn door een groot aantal der gewone werkmiertjes. Het is, alsof ze door deze worden gesteund en geleid; eenige kracht schijnt er vall hen niet uit te gaan.

"Men heeft zich reeds dikwijls verdiept in de beteekenis dezer Gulliver's, echter zonder tot een bevredigende oplossing te komen. Een Engelsch natumronderzoeker vergelijkt ze met de staatsie-olifanten, die in Britsch-Indische optochten medewandelen, om aan de zaak meer luister bij te zetten. Een andere, blijkbaar meer practisch aangelegde zoon van Albion, heeft de onderstelling uitgesproken. dat ze op staatskosten door de mieren worden onderhouden, om, in oogenblikken van gevaar, als afleiders daarvan dienst te doen. Wanneer namelijk het nest door een insecten-etenden vogel wordt ontdekt, zoo redeneert hij, zullen deze groote dieren het eerst in het oog vallen en ivorden opgegeten, terwijl de andere alsdan tijd hebben voor de vlucht" 1).

Wat hiervan zij, ik heb deze groote individuen nooit aangetroffen in de nesten, die ik van dit en verwante geslachten meermalen te Buitenzorg waarnam, éénmaal zelfs in een lade van mijn schrijftafel, die langen tijd ongeopend was gebleven. In den regel waren dan slechts eenige kleinere soldaten aanwezig, die hun plicht op meer martiale wijze opvatten.

Het bovengenoemde geslacht Sima is niet polymorph, maar treedt soms in zeer groote maatschappijen op, die het liefst in omgevallen, reeds zeer vermolmde boomstammen huizen. Zet men zich bij ongeluk op zulk een boomstam neer, dan heeft men groote kinns,

1) "Zoölogische Wandelingen te Tjibodas": Teysmannia 19(5T 
eenige zeer pijnlijke steken in de zitdeelen te krijgen: want de soorten van dit geslacht, vooral de grootere. zijn zeer aggressief en maken dadelijk gebruik van hun angel. Zelfs het zoeken met een pincet in hun nesten moet met groote omzichtigheid plaats hebben, want het gladde metaal is voor hen geen beletsel om het bij honderden te beklimmen.

Veel verdraagzamer zijn de Myrmicaria-soorten, die gewoonlijk in den grond nestelen en welker nesten hunne aanwezigheid verraden door de kleine zandkratertjes, die aan de uitgangen worden opgeworpen en die men vooral op de voetpaden dikwijls kan waarnemen. De verborgen levenswijze van dit geslacht is oorzaak, dat het zich zonder mueite ook in de nabijheid van den mensch kan staande houden.

Het behoeft wel geen betoog, dat ook de groep der Camponotinae in de bosschen ruimschuots is vertegenwoordigd, maar zij treedt in den regel niet in die mate op den voorgrond als de vorige. Het zijn vooral de Polyrhachis-soorten, die de aandacht trekken door de bewapening van den thorax en den achterlijfssteel met allerlei, dikwijls grillig gevormde dorens en stekels, terwijl een roodbruine Camponotus-soort niet zelden optreedt als voorvechtster van de boschfauna in menschelijke woningen, die nabij het bosch zijn gelegen en het alsdan den bewoners wel eens hoogst onaangenaam en lastig kan maken.

Dorylinae en Ponerinae ziet men in de bosschen veel minder dan erbuiten. De eerste, omdat zij diep in den grond leven en slechts de mannetjes ervan gedurende de duisternis vliegen, de tweede, omdat zij meer verspreid dan in groote maatschappijen leven en tegenover de overwegende meerderheid der andere groepen eenigszins in het niet verzinken. 
Van de Dolichoderinae, die slechts bij nauwkeuriger beschouwing van de Camponotinae zijn te onderscheiden, zullen wij later nog een bijzonderen vorm tegenkomen.

'Tot de boschlievende insectenvormen moeten eindelijk een aantal vertegenwoordigers van de Vlinderfamilie der Nymphalidae worden gerekend, waarvan sommige een aanzienlijke verticale verspreiding hebben, andere meer tot bepaalde hoogten beperkt zijn; sommige de donkerste gedeelten van het woud opzoeken, andere de open gedeelten, vooral de nabijlheid der bergriviertjes.

Een boschvorm bij uitnemendheid is, in vele bergstreken, Clerome arcesilaus, die overeenkomstige gewoonten heeft als Cyllo leda (pag. 131), maar de kunst, zich onzichtbaal te plaatsen, in nog veel hooger mate meester is. Bij een wandeling door het bosch ziet men het dier sonıs plotseling vóór zich ver'schijnen, een oogenblik langs zeer onregelmatige lijnen vliegen en zich dan op het afgevallen blad zóódanig neerzetten, dat hij volmaakt onzichtbaar is, waartoe in de eerste plaats de kleur van de onderzijde der rleugels medewerkt. Maar bovendien plaatst hij zich bij voorkeur met het achterlijf naar den wandelaar gekeerd, die hem dan, door de stijf samengeklapte vleugels, in het geheel niet meer ziet. Jaugt men hem een paar maal achtereen op, dan trekt hij zich op de donkerste en dichtst begroeide plekken terug.

Minder lichtschuw in Kallima paralekta, een van de klassieke voorbeelden van "mimicry", met de bekende teekening van een verdroogd blad, inclusive de nerven, op de onderzijde der vleugels in den rusttoestand. Ook deze vlinder zou volkomen on- 
opgemerkt blijven, als hij maar rustig bleef zitten; blijkbaar echter durft ook hij het daarop niet te laten aankomen. Want bij onze nadering neent hij de vlucht en is dan dadelijk te herkennen aan het fraaie blauw op de bovenzijde dor vleugels en den roodbruinen band over de voorrleugels.

Dergelijk fraai blauw, dikwijls met een violetten gloed overtogen, treft men bij meerdere soorten van groote Nymphalidae aan, zooals bij Terinos clarissa, Thaumantis odana en Zeuxidia luxeri, vormen, die gaarne in de nabijheid der riviertjes vertoeven en die men vooral in perioden van groote droogte gemakkelijk te zien krijgt, omdat zij dan samenkomen nabij de gedeelten der beddingen, waar nog een weinig water is te vinden. Zoo heb ik den grootsten rijkdom aan groote en fraaie vlinders, dien ik ooit bij elkaar zag, aangetroffen aan het einde van een langdurigen Oostmoesson in de woeste bosschen nabij Java's Eerste Punt (Z. W. Bantam). De nagenoeg uitgedroogde bedding van een klein riviertje vormde daar een toegangsweg van het strand landinwaarts en elke natte plek was aldaar het vereenigingspunt van allerlei vormen, die men onder gewone omstandigheden slechts zelden te zien krijgt. Zelfs het bruine, drabbige, zilte water nabij de monding bleek op deze dieren nog een groote aantrekkingskracht uit te oefenen, maar toch viel weder op te merken, dat geen enkele zich ooit buiten de beschutting van het geboomte waagde.

Andere groote Nymphalidae, die in dit verband mogen worden genoemd, zijn Amathusia dilucida, Zeuxidia doubledayi, Z. arnethystus, Discophora sondaica, Ammonia decora, Prothoe angelica, terwijl de fraaie T'enaris horsfieldii, dadelijk te herkennen aan de twee 
donkere, in het midden een zilverwit stipje restooncude, olanje omzoomde oogrlekken op elken achterrleugel, meer een liefhebber is vall zonneschijn en vooral de open gedeelten opzoekt. Daar kan men hem aantreffen in gezelschap ran Dichorragia nesimachus, Euripus halitherses, Stibochia coresia en andere algemeene rormen, zooals de fralaie en groote; in vleugelvorm aan Papilio's herinnerende Parhhenos gambrisius, de oranjebruine Cynthia deione en de, rool het meerendeel eveneens gekleurde Cirrochroa's.

El zal in de bosschen van Java nog heel wat moeten worden verzameld in alle deelen van het eiland en op allerlei hoogten boven zee, voordat men zich eenige voorstelling zal kunnen maken van de horizontale en de verticale verspreiding der aldaar meer op den voorgrond tredende insectenvormen. Wat de verticale verspreiding aangad, vindt men den grootsten rijkdom niet in de koudere en hoogere, maar evenmin in de laagste en warmste streken; ik zou geneigd zijn, liet maximum te zoeken tusschen 1500 en 3000 voet boven zee en dan nog ineer in het regenrijke Westen, dan in het Oosten met zijn langdurigen drogen tijd, die aan de ontwikkeling van het insectenleven tot vollen, tropischen rijkdom een niet onbelangrijken hinderpaal in den weg legt. 


\section{HOOFDSTUK XXII.}

\section{De Boschfauna der lagere streken. $(0-2500$ voet $)$}

Zooals reeds vroeger werd opgemerkt, dragen de bosschen, die ongeveer op gelijk niveau liggen met de zee, dikwijls het karakter van rawah's, zoodat, voor zooverre hun fauna met dit karakter in verband staat, naal de bladz. $4 \vdots 1$ tot 475 kan worden verwezen. De diervormen, die thans ter sprake moeten komen, zijn de echte boschdieren, voor welke de gesteldheid van den bodem geheel of voor het grootste gedeelte onverschillig is.

Dit is bij uitstek het geval bij boomenbewonende dieren, zooals Nycticebus tardigradus, de lori of koekang (s. moeka), een klein Zougdier van de orde der Halfapen, dat in de bosschen der warmere streken in het geheel niet zeldzaam is, maar als nachtdier natuurlijk slechts zelden wordt gezien. Overdag in een toestand van diepe rust verzonken, komt de lori eerst tegen de avondschemering in beweging en beweegt zich dan langzaam en behoedzaam door het geboomte. Zijn voedsel is grootendeels van plantaardigen aard, maar op zijn nachtelijke sluiptochten vangt hij ook wel insecten of plundert vogelnesten om de eieren of de jonge dieren. Te oordeelen nar de bewegingen, die men hem soms ziet maken, moet hij over groote spierkracht en lenigheid beschikken, die in het bijzonder spreken uit de lang- 
zaamheid, warmede die bewegingen worden uitgevoerd.

Het Spookdiertje (Tarsius spectrum) vindt men in cle zoölogische literatuur ook meermalen vool Java vermeld. Indien het hier werkelijk voorkomt, zal men het, te oordeelen naar zijn voorkomen op Banka en Borneo, eveneens in dit gebied moeten zoeken. Ik heb echter nooit een exemplaar gezien, waarvan werkelijk vaststond. dat het van Java afkomstig was.

De bientoerong (Arctitis binturong) is tot heden ook voornamelijk beneden 2500 voet zeehoogte aangetroffen. Het is een Roofdier van deels katachtigen, deels beerachtigen habitus, dat in het bezit is van een langen, rolronden, dik beharden staart, die vooral door de jonge dieren als grijporgaan wordt gebruikt. De kleur van de vacht is in den regel zeer donker, soms bijna zwart, maar de uiteinden der haren zijn in vele gevallen grijs en van de lengte dezer grijze gedeelten hangt de totale kleur van het dier in hooge mate af. De witte rand der ooren is ook niet steerls in gelijke mate ontwikkeld. Het schijnt, dat de bientoerong voor een groot deel van vruchten ,leeft en in Oost-Java veel menigruldiger is dan in het Westen.

De reeds vroeger (pag. 419) genoemde Heer LEDEBoER schreef mij over deze diersoort het volgende: "Hier in het Djembersche heb ik tweemaal een bientorrong geschoten: beide malen hevatte de maag niets anders dan vruchten van den boeloe-boum*). Eenmaal zag ik een exemplari. dat geschoten was ten Zuiden ran de spoorhalte Kempit. In Djember

-) Met dezen naam worden verschillende Fıcus-soorten aangeduid, gewoonlijk met een nadere toovoeging tot verdere onderscheiding der soort. 
en Banjoewangi hebben de inlanders geen naam ervoor. Het vorige jaar was ik op de Zuidoostelijke helling van den Semeroe, op ongeveer 1500 voet boven zee, en hoorde daar bij het ondergaan van de zon van alle kanten een langgerekt geschreeuw, als é-oe klinkend, met de oe héél lang gerekt. Ik vroeg de inlanders, wat voor een dier dat was en zij noemden het een baong. [k schoot er een, terwij] het schreeuwde, uit een waringin en het bleek een bientoerong te zijn. Speciaal in die buurt komen ze veel voor."

Het lijkt mij wel waarschijnlijk, dat de bientoerong nu en dan genoodzaakt is, de bosschen te verlaten, wanneer het voedsel daar schaarsch is, en dat hij op zijn zwerftochten dan de vruchtdragende Ficus. boomen in de nabijheid der kampongs bezoekt, in welker takken hij zich overdag gemakkelijk kan schuil houden.

Een derde Zoogdier van dit gebied, dat grootendeels op de boomen leeft, is de Roode Boschrat Pitechir melanurus. In de bosschen der Djampangs, bezuiden Soekaboemi, waar veel voor het Zoölogisch Museum alhier is verzameld, schijnt deze soort geen zeldzame verschijning te zijn. Wellicht is dit ook elders het geval; aan de, vooral op de bovendeelen bruinroode vacht en den zwartachtigen, kalen staart is zij gemakkelijk genoeg herkenbaar.

Onder de Vogels, die zich vooral of uitsluitend in de lager gelegen bosschen ophouden, zijn er een paar, die door hun stemgeluid zeer de aandacht trekken. en daardoor gemakkelijk herkenbaar zijn. 
Eéne ervan is Platylophus galericulatus, die het meest veelvuldig tusschen 1500 en 2500 voet zeehoogte voorkomt en wiens geroep aan het blaten van een geit doet denken. De Maleische en Soedaneesche namen boeroeng kambing en manoek mbè zijn daaraan ontleend. Deze gaai-achtige vogel, die, met uitzondering van een witten, halvemaanvormigen kraag, een geheel zwart vederkleed bezit, is ook naar het uiterlijk gemakkelijk te kennen door de verlenging der voorhoofdsveeren, die een kuif vormen, waarvan de achterste veeren soms $7-8 \mathrm{cM}$. lang zijn en een weinig naal buiten zijn gekromd. Het dier is in het geheel niet schuw en, gelijk vele gaai- en eksterachtige vogels, zeer nieuwsgierig, zoodat hị den wandelaar in het bosch soms langen tijd volgt, daarbij echter steeds een behoorlijken afstand bewarend.

Een ander geroep brengen wij dadelijk thuis als dat van een Baardvogel; het herimnert aan dat van Xantholaema rosec (pag. 66), maar is reel scheller. De vogel, die het voortbrengt, is trouwens een nauwe verwant ervan, namelijk Xantholaema australis, en tevens zijn tegenhanger in het bosch. Ook bij dit geslacht van Baardvogels vertoonen de twee soorten, die op Java voorkomen, evenals bij Chotorhea en bij Cyanops, een duidelijk uitgesproken neiging, elkanders gebied zoo volkomen mogelijk te vermijden.

Andere vogelsoorten vallen hier op door hun fraai gevederte. Daartoe mag in de eerste plaats worden gerekend Dissemurus paradiseus, var. platurus, in dit gebied de tegenhanger van den, voor hooger gelegen bosschen later te noemen Bhringa remifer. Het vederkleed van Dissemurus is geheel zwart, maar door een staalblauwen, metaalachtigen gloed zeer fraai. Het grootste sieraad van het dier is echter de staart, 
waarvan de buitenste pennen ongereer de dubbele lengte hebben van de andere, in het midden een versmalde vlag vertoonen en orer liet achterste gedeelte eenigszins schroefvormig zijn gedraaid. Deze Drongo is veel minder schuw en zeldzaam dan Terpsiphone affinis, de fraaiste Vliegenvanger van Java, dien men maar zeer zelden en dan nog alleen in de meest afgelegen bosschen te zien krijgt, waar hij zich met ongeloofelijke snelheid en vlugheid tusschen het dichte gewirwar der takken beweegt. Ook hier is de staart weder het voornaamste sieraad; het middelste paar staartpennen is namelijk sterk verlengd, hangt sierlijk gebogen achterwaarts en maakt ook onder het vliegen een bijzonder effect. Intusschen is ook het overige vederkleed fraai; de blauwzwarte, gekuifde kop, de helderblauwe huid om het oog en de eveneens gekleurde snavel steken scherp af tegen het witte gevederte van den romp. Een en ander betreft echter slechts het mannetje; het wijfje heeft een veel eenvoudiger en, met uitzondering van den zwarten kop, in hoofdzaak bruin vederkleed, zonder verlengde staartveeren. Het is eenigszins vreemd, dat dit dier op Java zoo zeldzaam is; in de laaggelegen bosschen van Sumatra is hij veel algemeener en Vorderman trof hem zelfs op Billiton in vrij groot aantal aan. Hij werd daar, naar deze mededeelt, door kinderen met lijmstokjes gevangen, wat er wel op wijst, dat hij op dit kleme eiland, onder den drang de omstandigheden, een deel van zijn groote schuwheid heeft moeten afleggen.

De IJsvogel Carcineutes pulchellus behoort, zooals trouwens de soortnaam reeds aanduidt, eveneens tot deze rubriek. Door de keuze van zijn voedsel, dat grootendeels uit insecten bestaat, is hij niet aan de 
nabijheid van water gebonden en hij is eigenlijk de eenige vertegenwoordiger zijner familie op Java, die tot de echte boschvogels moet worden gerekend. Tevens de eenige, bij welken een duidelijk verschil tusschen het voorkomen der mannetjes en dat der wijfjes bestaat, in zooverre de donkere, dwarsgestreepte teekening op het gevederte der bovendeelen bij de eerste een blauweı, bij de laatste een bruinen ondergrond heeft.

Sierlijke vogeltjes zijn verder de beide Rubigulasoorten dispar en squamata van de familie der Ixodidae, waarvan de eerste als koetilan mas bekend staat. Deze naam is ontleend aan de goudgele kleur van borst en buik, die op keel en kin overyaat in vurig helderrood, welke kleur op hare beurt fraai afsteekt tegen het metaalachtig blauwzwarte vall den zwak gekuifden kop. Rubigula squamata heeft minder sprekende kleuren, madr is dadelijk te herkennen aan de witte, harige omzooming der vederen van dé borst, waardoor deze een grofgeschubd voorkomen heeft. Beide soorten zijn in vele laaggelegen bosschen de, dikwijls tallijke tegenhangers-van de Pycnonotussoorten aurigaster en analis in onze cultuurfauna. Op dergelijke wijze wordt de, in bebouwde, maal boomrijke streken niet zeldzame Pitta cyanura (pag. 241) hier vervangen door Pitta muelleri, die dezelfde levenswijze heeft als eerstgenoemde en in zijn omgeving al bijzonder moeielijk in het oog valt. De zwarte kop en de, in hoofdzaak en voor zooverre zichtbaar, groenachtige kleur der bovendeelen maken het dier zoo goed als onzichtbaar tusschen de zwarte, rottende plantendeelen, die in warme bosschen den grond bedekken en waartusschen allerlei versch afgevallen, groene plantendeelen verspreid liggen. 
Als laatste vorm van deze rubriek zị genoemd Irene turcosa, waarvan het mannetje in fraaiheid van gevederte stellig wel de kroon spant boven alle vogels van Java. Geheel fluweelachtig zwart van kleed, wordt zijn voorkomen verlevendigd door een breeden band van schitterend helder, ultramarijn, blauw, die op den kop begint, zich over nek, mantel, een deel der vleugeldekveeren en den rug voortzet en op de bovenste staartdekveeren eindigt. Ook de staartdekveeren der onderzijde hebben die kleur. Op Java is deze soort schaarsch. Van WestJava ken ik geen exemplaren, maar in Midden-Java komt zij op de hellingen van het Moeriah.gebergte en van den Merapi voor, terwijl zij ook in de bosschen van Banjoewangi is waargenomen. Op Borneo schijnt zij echter veel algemeener te zijn, te oordeelen naar de talrijke exemplaren, die in de aldaar bijeengebrachte verzamelingen voorkomen, terwijl VORDERMAN haar ook op Billiton in grooten getale waarnam. Feitelijk mag voor de verschillende, hier genoemde streken niet van volkomen dezelfde diersoort worden gesproken (er zijn kleine verschillen), maar het algemeen voorkomen der dieren is zóó overeenstemmend, dat wij ons hier deze kleine ketterij meenen te mogen veroorloven.

Aan Duiven zijn de lagere bosschen in het algemeen minder rijk dan de hoogere. Noemde ik hierboven (pag. 507) reeds den pergum (Carpophaga aenea) als wel eens naar dit gebied afdwalend, maar beter hoogerop te huis, als meer vaste bewoner kan hier worden genoemd de fraaie Goudduif Caloenas nicobarica, die echter zeldzaam is en, voor zooverre mij bekend, slechts in de bosschen van Zuid-Bantam is aangetroffen. 
Ook de fraaie, groote Papegaaiduif Butreron capellet schijnt zich bij voorkeur in de warmere streken op te houden, terwijl Ptilopus jambu hier en in het volgende gebied de tegenhanger is van het Jufferduifje der cultuurstreken Pt. melanocephalus. Opmerking verdient, dat van de genoemde Duiven, die op den vasten wal van Java soms schaarsch of althans moeielijk te vinden zijn, op de omringende, nabijgelegen en veelal met oorspronkelijk bosch bedekte koraaleilanden dikwijls talrijke exemplaren zijn aan te treffen. Zelfs Carpophaga aenea schijnt hier het warme klimaat geheel te vergeten ter wille van het rustige ell ongestoorde verblijf, dat deze onbewoonde en bekoorlijke stukjes grond haar kunnen aanbieden.

Voor het overige komen in dit gebied typisch een aantal vogelsoorten voor, die in geen enkel opzicht bijzonder de aandacht trekken, maal die nittemin hier kortelijk moeten worden vermeld. De kleine, blauivzwarte Koek koek Chalcococcyx xunthorhynchus, kenbaar aan den fraai gelen snavel, waaraan zijn soortnaam is ontleend, is één daarvan. Waar zijn verwanten basalis (pag. 496) en vooral malayanus (pag. 261) neiging tot aansluiting aan de cultuurfauna vertoonen en ook in hun voedselkeuze een bijzondere richting hebben ingeslagen, is hij zoowel aan het bosch, als aan het normale dieët van zijn stam getrouw gebleven. Het eerste geldt ook van den Honigzuiger Arachnothera armata, die een bedriegelijke gelijkenis met $A$ longirostris (pag. 230) vertoont en zoowel in dit gebied, als iets hoogerop, de boschvorm van dit geslacht is gebleken. Deze soort werd, eenige jaren geleden, voor het eerst door den Heer BARTELs, op ongeveer 3000 voet boven zee, in het bosch op 
den Pangerango aangetroffen. Later bracht mijn jager een paar exemplaren mede van Bandjar, waar hij ze eveneens in het (destijds aldaar nog alom voorkomende) bosch had geschoten. Overigens is het niet onbegrijpelijk, dat deze soort op Java eerst zoo laat werd ontdekt; want men moet al over een zeer scherpen blik en een groote kennis van vormen beschikken om, in het veelal dichte groen, deze soort van longirostris te onderscheiden. Waarschijnlijk hebben de vroegere verzamelaars haar daarom over het hoofd gezien, want de jacht in deze terreinen is in den regel zóó bezwaarlijk, dat men er zich liever niet ophoudt met diervormen, die men elders veel gemakkelijker meent te kunnen krijgen.

Van de Bastaard-Honigzuigers, in het cultuurgebied zoo algemeen door Dicaeum flammeum (pag. 63) vertegenwoordigd, is hier Dicaeum chrysorrheum de boschvorm, die in de tairijke en daaronder vaak fraaibloemige Loranthus-soorten van het woud een ruim bestaan vindt.

Dat ook echte insecten-eters hier geen gebrek behoeven te lijden, behoeft wel geen betoog. Speciale boschvormen van de lagere streken zijn vooral de Prionopide Tephrodornis virgatus, die in habitus aan een Klauwiertje herinnert; Pachycephala grisola, die gewoonlijk tot de Klauwieren wordt gerekend, maar veel allures van een Muscicapide vertoont, en de echte Vliegenvangers Philentoma velatum en Rhinomyias baliensis, de eerste een blauwgrijze vogel met een zwarten sluier over het gelaat en een bruinen hals, de tweede olijfbruin van boven, wit van onderen, met een breeden, okerkleurigen band dwars over den krop.

Van de Timeliiden is vooral Malacopterum lepido- 
cephalum in lagere streken aangetroffen. Naar de onderzochte maaginhouden te oordeelen, houdt deze soort zich minder voortdurend nabij den grond op dan haar verwanten, die over het algemeen in hooger gelegen streken hun hoogste ontwikkeling naar soorten en individuen bereiken.

Ten slotte moeten voor dit gebied nog twee vogels worden genoemd, waarvan ééne, de patrijs Arboricola orientalis, tot heden slechts van Oost-Java bekend is. Zij is nauw verwant aan den later te bespreken Arb. javanica, als poejoe gong-gong welbekend en in vele bergstreken van West-Java zeer algemeen. De tweede is Asarcornis scutulata, een zeer schuwe en vermoedelijk daarom tot de zeldzame diersoorten gerekende Eend, die aan haar omgeving, behalve het karakter van rawah, ook dat van dicht en eenzaam woud als eisch stelt.

Van de Vlinders der lagere bosschen zijn bij de bespreking der Nymphalidae in het vorige Hoofdstuk reeds een aantal genoemd. Wij kunnen daaraan toevoegen, als meer in het bijzonder in dit gebied thuis behoorend, het geslacht Hestia van de familie der Danaidae, op Java vertegenwoordigd door de beide soorten belia en lynceus, waarvan de eerste tot WestJava schijnt beperkt te zijn en ook de tweede in de Westelijke helft van het eiland reelvuldiger is dan in de Oostelijke. Beide zijn, met hun groote, lichttot donkergrijze, half doorschijnende, zwart gevlekte vleugels, hoogst sierlijke dieren, bij welke de natuur weder eens heeft willen probeeren, hoever zij haar goede gaven kon overdrijven, zonder de begunstigden het bestaan al te lastig of zelfs onmogelijk te maken. 
De enorme oppervlakte der vleugels staat in geenerlei verhouding tot het teere lichaam en als men de dieren ziet vliegen, krijgt men volkomen den indruk, dat het geheel op goed geluk gaat, dat zij geen behoorlijk stuur over zich zelf hebben en dat het "meer geluk dan wijsheid" is, wanneer ze arriveeren op de plaats, waar ze heen wilden. Zulke dieren moeten boschdieren zijn; in de min of meer geordende maatschappij daar buiten, in het "geregelde huishouden" der cultumrfauna is voor hen geen plaats, zij zouden zich daar niet staande kunnen houden. Zelfs hun miniatuur-uitgave Ideopsis gaura, die vroeger wel eens tot hetzelfde geslacht werd gerekend, heeft hiermede zooveel moeite, dat haar, hier en daar ondernomen, proefnemingen om in de cultuurfauna over te gaan, nog slechts met zeer twijfelachtigen uitslag zijn bekroond.

De in de cultuurfauna algemeene Terias hecabe en T. sari (pag. 135) vinden hier hun tegenhangers in de soorten harina, die veel minder, en tilaha, die veel meer zwart op de vleugels heeft dan beide eerstgenoemde. De Pieride Nepheronia valeria, waarvan bij de mannetjes het wit op de bovenzijde der vleugels een licht blauwgroene tint vertoont, stelt krachtige pogingen in het werk om het bosch te verlaten en is daarin plaatselijk reeds geslaagd.

Ook van de Kevers treden in de lager gelegen bosschen een aantal vormen meer dan elders op den voorgrond. Werd op pag. 125 Apoderus melanopterus genoemd als een vorm der cultuurfauna, de ware zetel van dit genus is de wildernis, die nog slechts door zijn meest eenvoudigen vertegenwoordiger is verlaten. Want de fraai geteekende $A$. notatus en 
de gestekelde $A$. hystrix zijn daarbuiten niet te vinlen, evenmin als $A$. cygneus, die zijn naam ontleent aan de buitengewoon lange, halsvormige verlenging ran dell kop.

De groote Elateride Alaus lacteus is eveneens een echt boschinsect, dat meesterlijk gebruik weet te maken van zijn kleur en teekening om zich verdekt op te stelleu. Deze kever plaatst zich namelijk bij voorkeur tegen een, met Korstmossen bedekten boomstam en is dan, van boven gezien, niet vall zijn omgeving te onderscheiden. Hij ralt slechts in het oog; wanneer men hem, ran terzijde, als eene verhevenheid ziet, terwijl hij ook alweder de gewoonte heeft, bij naderend gevaar op te vliegen. In dit opzicht gedraagt zich veel verstandiger de Carambycide Coptops lichenea, wiens soortnaam voldoende aangeeft, dat hij zich op gelijke wijze aan het oog van zijn belagers kan onttrekken en die steeds rustig blijft zitten.

Geheel anders is het gesteld met twee andere Boktorren, die vooral in dit gebied voorkomen, namelijk Thysia tricincta en Dejanira quadripunctata, beide ongemeen fiaai van voorkomen, waarvan rooral de eerste, die men gewoonlijk in kleine troepen bij elkaar aantreft, eerder al het mogelijke doet om de aandacht te trekken. De purperen kleur van het geheele dier, de zwarte, harig-fluweelachtige strooken over de dekschilden, de sierlijke pluimen aan de geledingsplaatsen der; wijd uitstaand gehouden sprieten, doen hem reeds op een afstand in het oog vallen. Ook de tweede soort ziet men, in haar roodbruine, fluweelen jurk, niet licht. over het hoofd.

Goed vertegenwoordigd zijn hier verder de Anthothribidae, die zich opwaalts ook nog in een gedeelte 
van het volgende gebied uitstrekken en van welke feitelijk slechts de kleine, onaanzienlijke Araeocerus fasciculatus (pag. 125) in de cultuurfauna is overgegaan (wellicht hier van elder's is ingevoerd). Met name mogen hier worden genoemd Xylinades wester. manni en de kleinere $X$. rugosus, de geslachten Acorynus, Sintor en Otidognathus, en eindelijk de groote Mecocerus gazella, die zijn naim ontleent aan de afmetingen der dunne, draadvormige sprieten, die bij sommige exemplaren vier maal de lengte van het lichaam hebben en een buitengewoon sterke prikkelbaarheid vertoonen.

Een van de fraaiste kevers der Javaansche fauna, Chrysochroa buqueti, kan men hier eveneens aantreffen; het vermoeden bestaat, dat deze zijn larventoestand doorbrengt in een der boomachtige Leguminosen, die hier in groot aantal zijn te vinden. Om zich een voorstelling te kunnen maken van de pracht van dit dier, moet men het levend hebben gezien; want zoowel het ivoorwit der dekschilden als de vlammend roode kleur langs de randen van den prothorax verliezen na den dood spoedig een groot deel rall hun helderheid.

Een meer bescheiden rol spelen hier de Mordellidae, herkenbaar aan de scherppuntige, achterwaartsche verlenging van het achterlijf. Evenals een aantal Languridae, treft men ze tamelijk veelvuldig op bladeren en bloemen aan. Zoo ook verschillende soorten van Snuitkevers uit de verwantschap van het geslacht Colobodes, die bij nadere beschouwing raak zeer sierlijk blijken te zijn geteekend en gekleurd, maar op het eerste gezicht den indruk maken van een tamelijk vormloos klompje, waarin men zich zelfs met kop- en achtereinde gemakkelijk vergist, aan- 
gezien de kop, zooals in het algemeen bij de groep. der Cryptorhynchidae, volledig kan worden opgeborgen.

Verder zij hier genoemd het vrijwel op zich zelf staande geslacht Atractocerus, dat gewoonlijk tot de kleine familie der Lymexylonidae wordt gebracht, maar door de nagenoeg geheel gereduceerde dekschilden en den slanken rorm aan de Staphylinidae, herinnert, waarvan het zich echter onderscheidt, doordat de achtervleugels waaiervormig boven het achterlijf liggen opgerouwen. Opvallend is verder de groote lengte van het achterlijf. De kevers van dit geslacht zijn vaal bruingele nachtdieren, die ook wel eens in bewoonde buurten voorkomen, ell aangaande welker levenswijze nog niets bekend is. Zij komen met vrij veel geraas op het licht af, waarbij het lange achterlijf tamelijk slap afhangt. Ik heb eens bij de lamp een zwanger vrouwelijk exemplaar verkregen, dat des nachts een groot aantal langwerpigspoelvormige eieren heeft gelegd tusschen de lagen filtreerpapier, waarmede de bodem van haar gevangenis was belegd Uit de bewegingen van het achterlijf viel op te maken, dat het dier de eieren tusschen, en niet op de voorwerpen wilde leggen. De larfjes, die een tamelijk grooten, chitineuzen kop hadden, boorden zich in een stuk dood hout, dat ik daartoe binnen hun bereik had gelegd, maar stierven, nadat zij daarin halverwege waren verdwenen. Blijkbaar was dit voor hen niet het juiste milieu.

In de hoogere gedeelten van dit gebied treden de Tenebrionidae en hun ver'wanten nogal op den voorgrond. Tot de laatste reken ik o. a. de groote, bruine tot bruingrijze Trictenotoma's, insecten, die men om hun sprieten en andere kenmerken ook wel bij de Cerambycidae heeft geplaatst. Voorts de Cistelidae, van welke 
men hier vooral de geslachten Cistelomorphu en Allecula kan tegenkomen; de Lagriidae, een zeer uniforme groep, welker boschvormen in voorkomen geheel met de vormen der cultuurfauna overeen komen. De eigenlijke Tenebrionidae zijn in de eerste plats vertegenwooldigd door de groote, dofzwarte Nyctobates-suorten impressa en valgus, die men dikwijls in troepen bij elkaar aantreft; verder door fraai gesculpteerde vormen als Strongylium ambiguum en door soorten, die door kleur, of door glans, of door beide in het oog vallen, zooals verschillende vertegenwoordigers der geslachten Encyalesthus en Ceropria, alsmede de plaatselijk zeer algemeene Eucyrtus splendens.

De merkwaardige insecten, die algeneen onder den naam van "Wandelende Bladen" en "Wandelende 'Takken" bekend zijn, treft men eveneens vooral in bosschen van 1500 tot 2500 voet zeehoogte aan, terwijl laatstgenoemde zich bovenwaarts in een aantal, allengs kleinere en meer eenvoudige vormen voortzetten.

Er zijn op Java twee soorten van "Wandelende Bladen", die beide tot het geslacht Phyllium behooren, namelijk $P h$. pulchrifolium en $P h$. siccifolium-Hun normale kleur is bladgroen, maar van de eerste treft men niet zelden exemplaren aan, die "herfsttinten" vertoonen en uiteenloopen tusschen tamelijk helier geel en bruinachtig rood, maar dan steeds met de eigenaardige, donkere, onregelmatige teekeningen, welke in zoo hooge mate bijdragen tot hun gelijkenis op blaren, die tengevolge van ouderdom aan het verkleuren zijn. Zonder nog genoegen te nemen met de eenvoudige verklaring van een mijner inlandsche verzamelaars: "doeloe daoen, abis djadi binatang" *),

\footnotetext{
*) "vroeger was het een blad, daarna is het een dier geworden".
} 
zullen wij ons hier niet verdiepen in de vele, maar tot heden tumelijk onvuchtbare beschouwingen van teleologisch aard, wartoe deze insecten in den loop der laatste dertig jaren aanleiding hebben gegeven en alleen erop wijzen, dat wij hier staan voor één van die gevallen, warin de plastische kracht der natuur is gekomen tot een herhaling van vormen, die reeds elders zijn bereikt. Deze g'evallen zijn te merkwaardiger; naarmate de levende wezens, die ze vertoonen, verder van elkander af staan (en daarom is het voorbeeld, dat het geslacht Phyllium ons level't, zeker een van de meest frappante), maar overigens zijn zij in het geheel niet zeldzaam. Men denke bijvoorbeeld eens aan de "pauwoog-teekening", eene comininatie en rangschikking van kleuren, die bij allerlei dierrormen (rogels, visschen, vlinders, lagere dierens) is te vinden en waarvan men bijna zou kunuen zeggen, dat zij door de natum met zekere voorliefde wordt aangebracht. Voorts aan de overeenkomst in algemeenen habitus tusschen het Crustaceeên-geslacht Squilla en het Orthopteren-genus Mantis; dan de bedriegelijke gelijkenis van een Kikvorsch van het geslacht Polypedutes (pag. 88), wanneer hij zich in den rusttuestand bevindt, met de eigenaardige, tegen stammen en takken aangedrukte blarleren van sommige klimplanten van de geslachten Dischidia en Conchophyllum van de familie der Asclepiadaceae; aan de gelijkenis, die het Dipterengeslacht Celyphus (pag. 115) door de grvote ontwikkeling van het scutellum heeft verkregen met een wants van de familie der Scutelleridae en zelfs met een Coccinelide, bij welke de halve bolvorm van het lichaam niet door het schildje, maar vooral door de voorvleugels wordt veroorzaakt. 
De larven der beide Phyllium-soorten zijn bedeeld met dergelijke herfsttinten als waarvan hierboren sprake was. In onderscheid met de volwassen dieren, die tamelijk traag in hun bewegingen zijn, loopen zij, met opwaarts gebogen abdomen, vlug en levendig rond. Langzamerhand gaat, met uitzondering van de bovenbedoelde individuen, hun kleul in heldergroen over; wij staan hier dus, wat het levenslang. blijven der kleur van het jeugdige dier betreft, voor een dergelijk geval als bij Semnopithecus pyrrhus (pag. 502).

Van de "Wandelende Takken" is op Java Cyphocrania goliath de merkwaardigste vorm. Bij deze diersoort zijn mannelijke exemplaren nog veel schaarscher dan bij Phyllium. Het schijnt zelfs, dat parthe nogenese hier regel is en dat slechts nu en dan, met tusschenpoozen van eenige jaren, mannelijke individuen optreden. Even merkwaardig als de dieren zelf, is, bij beide geslachten, de lange duur van den eitoestand, die bij Phyllium pulchrifolium gemiddeld honderd dagen bedraagt.

Terwijl wij in het volgende Hoofdstuk nog gelegenheid zullen hebben te wijzen op enkele andere gerallen van wat men dikwijls, en niet zelden terecht, beschermende gelijkenis noemt, moge voor dit gebied ten slotte nog melding worden gemaakt van de zoogenaamde mierenplanten Hydnophytum myrmicarum en Myrmecodia echinata, beide epiphytische Rubiaceae, die in sommige laaggelegen bosschen niet zeldzaam zijn. Het zijn gewassen van kruidachtigentot heesterachtigen groei, welker takken ontspringen uit één groot, knolachtig orgaan, welk laatste inwendig een stelsel van gangen en holten vertoont, die dnor- 
kleine, ronde openingen met de buitenwereld in verbinding staan en door mieren, vooral de Dolichoderine Iridomyrmex myrmecodiae, worden bewoond. Men heeft langen tijd gemeend, hier te doen te hebben met een geval van mutualisme, waarin de mieren, ter vergoeding van het verleende onderdak, den planten in een of ander opzicht een tegendienst zouden bewijzen. Het is echter nooit gelukt, eenige aanwijzing te vinden aangaande datgene, waarin die tegendienst zou kunnen bestaan, zoodat wij wel moeten aannemen, dat ook in dit geval de mieren niet anders doen, dan wat zij in de tropen nergens kunmen laten, namelijk alle hoekjes en gaatjes opzoeken en tot verblijfplaats inrichten. 


\section{HOOFDSTUK XXIII.}

\section{De Boschfauna van $2500-5000$ voet boven zee.}

\section{A. Gewervelde Dieren.}

Te oordeelen naar den rijkdom - der fauna, moeten binnen de bovengenoemde grenzen de levensvoorwaarden in het algemeen bijzonder gunstig zijn. Het nog tamelijk warme klimaat, het slechts bij uitzondering optreden van perioden van langdurige droogte en de vormenrijke flora werken daartoe ongetwijfeld in de voornaamste plaats mede. Vandaar dat men, naast de vroeger besproken, algemeene boschvormen, hier een aantal nieuwe diersoorten kan ontmoeten, dat mij-de schatting is natuurlijk uiterst moeielijk-grooter voorkomt dan het geheel, waarvan in het rorige Hoofdstuk een overzicht werd gegeven.

De Apensoorten van Java komen hier op hun volle getalsterkte door het optreden van Hylobates leuciscus en Semnopithecus mitratus. De eerste, de eenige Gibbon vall Java, algemeen onder de namen Wauwau (mal.) en oa (soend.) bekend, is geen liefhebber van het warme laagland, maar evenmin van het koudere gelleelte der bergstreken, zoodat hij in zijn verspreiding nauwelijks den bovengrens van dit gebied 
bereikt. Hij leeft in troepen, die dikwijls een vrij aanzienlijke getalsterkte bereiken en welker concerten tot grooten afstand hoorbaar zijn. Het samenspel in deze concerten is niet zoo goed en zoo geregeld als bij Hylobates syndactylus, (den siamang) op Sumatra, maar het is er toch verre vandaan, dat de dieren maar in het wilde erop los schreeuwen, zooals dat bijroorbeeld bij een troep kraaien het geval is. Een zeer muzikaal aangelegde, Belgische missionaris, die langen tijd op Nieuw Guinea had vertoefd, heeft mij eens een navolging voorgezongen van de nachtelijke „zanguitvoeringen” der Papoea's aldaar, waarin zóóveel overeenkomst met het zangerige geroep van een troep Gibbons viel te bespeuren, dat het aan weinig twijfel onderhevig kan zijn, of wij hebben bij deze, verstandelijk het hoogst staande dieren te doen met een eerste poging om zich tot samenwerking op muzikaal gebied te vereenigen. Rhythmus, voorgaan en volgen, invallen op bepaalde oogenblikken, dat alles is bij de Gibbons onmiskenbaar waar te nemen. Ook in ander opzicht vertoonen zij een hoogen graad van ontwikkeling; het ontbreken van den staart en de opgerichte gang wijzen hun, in niet mindere mate dan het intellect, dat $z i j$ in gerangen staat aan den dag leggen, een plaats aan in de onmiddellijke nabijheid van den mensch.

Semnopithecus mitratus, de soerili, is een echte. bewoner der bergwouden, die zich bij voorkeur in het hoogere gedeelte van dit gebied ophoudt. Ook hij leeft in troepen, welker geroep zich echter bepaalt tot een schel en ordeloos geschreeuw. Over het algemeen is echter de soerili niet zeer luidruchtig; daarbij is hij tamelijk schuw van aard en buitengewoon vlug in zijn bewegingen. Op den grond 
beweegt hij zich echter niet zeer handig en vermoedelijk daarom waagt hij zich zelden buiten het geboomte.

De Eekhoorns zijn hier vertegenwoordigd door de grootste en door de kleinste soort van Java, t.w. door Sciurus bicolor en Sc. melanotis. Op plaatsen, waar hij in den regel niet aan vervolging is bloot. gesteld, is Sciurus bicolor, de djerellang of djelarang, niet zeer schuw. Men kan hem daar gemakkelijk met een tooneelkijker gedurende geruimen tijd waarnemen, terwijl hij zich vrij langzaam en traag door de hoogere gedeelte van het geboomte beweegt of zich, met den fraaien, breeden staart half gekruld afhangend, rustig op een tak neerzet om eenig verkregen voedsel te verorberen. Maar zoodra men op eenigszins luidruchtige wijze zijn nabijheid te kennen geeft, verdwijnt hij met groote vlugheid, onder het maken van enorme sprongen van den eenen tak op den anderen.

Sciurus melanotis is een zeer kleine soort, die, met inbegrip van den staart, hoogstens 18 cM. lengte bereikt en vooral kenbaar is aan een witte streep, die aan beide zijden van den kop onder de oogen en de ooren verloopt en bij den schouder plotseling. eindigt. Door haar geringe afmetingen valt zij natuurlijk weinig in het oog, maar overigens is zij niet zeldzaam.

De Vleermuizen nemen aanzienlijk in getalsterkte af, naarmate men hooger in het gebergte komt, wat verband houdt met de mindere veelvuldigheid aldaar van uitvliegende insectenzwermen. Van de Vleermuizen, die van plantaardig voedsel leven, moge 
hier worden vermeld Eonycteris spelaea, van welke soort BARTELs ontdekte, dat zij zich gaarne met stuifmeel voedt ${ }^{*}$ ). Hij nam haar waar, in aanzienlijken getale rondvliegend om bloeiende Agave-planter, warabij de dieren zich telkens voor een oogenblik op de bloemen neerzetten en later de maag geheel met stuifmeel gevuld bleken te hebben. $\mathrm{Nu}$ had men zich reeds lang afgevraagd, waartoe bij deze soort (en bij de verwante Carponycteris minima) de buitengewoon lange, met borstel- en haakvormige papillen bedekte tong zou hebben dienst te doen; de bovengenoemde waarneming maakt het meer dan waarschijnlijk, dat wij hier hebben te doen met een werktuig om bloemen van hun stuifmeel te kunnen berooven, ook wanneer dit laatste minder gemakkelijk toegankelijk is.

Aan Vogels zijn de bosschen op deze hoogte ongemeen rijk. Statige Roofvogels, ons roor het meerendeel reeds van elders bekend, ziet men hier hoven de ravijnen zweven of op een hoogen, kalen tak dikwijls uren lang rusten. Een verschijning; nog niet elders ontmoet, is (naast de friaie, maar zeldzame lophotriorchis kieneri) de groote Edelvalk Falco ernesti, die zich maar zeer zelden in lagere streken vertoont en het liefst in de hoogere bergwouden verblijf houdt, waar hij jacht maakt op Boschhoenders, Arboricola's en dgl. Zijn verspreidingsgebied begint op ongeveer 3000 voet boven zee en zet zich tot de hoogste zone van het gebergte voort, waar in het bijzonder Arboricola javanica soms in groote koppels is te vinden.

Het geslacht Dicaeum van de Bastaard-Honigzuigers wordt op deze hoogte vooral vertegenwoordigd door

") Bulletin du Département de l' Agriculture aux Indes Neérlandaises, No. 20, pag. 13. 
de soort sanguinolentum, fraaier gekleurd dan zijn verwant $D$. flammeum uit de cultuurfauna (pag. 63), maar minder fraai dan zijn familiegenoot Prionochilus percussus, die zijn soortnaam ontleent aan een helderroode vlek op de borst, als was hij daar met een scherp voorwerp doorstoken. Zware concurrentie schijnen deze beide boschbewoners, wat voedsel betreft, elkander niet aan te doen. Want terwijl de eerste, getrouw aan het diëet van zijn familie, zich voedt met de vruchten van woekerplanten als Loranthus en Viscum, maakt de laatste, althans voor een deel, jacht op allerlei insecten.

Dergelijke afwijkende levenswijzen, wij zagen het o. a. ook bij de Spechten, zijn in het geheel geen zellzaamheid. Zij betreffen niet alleen de keuze van het voedsel, maar soms ook de wijze, waarop dit wordt bemachtigd. Zoo deelde de Heer Bartels mij mede, dat de, door hem ontdekte Caprimulgus bartelsi, die in de bosschen van den G. Gedeh tusschen 3000 en 6000 voet zeehoogte niet zeldzaam bleek te zijn, in voedselkeuze wel met de andere Geitenmelkers overeenkomt, maar in zijn wijze van jagen veeleer aan een Dicrurus doet denken. Zoo voedt zich verder de Klauwier Laniellus leucogrammicus, in dit gebied een zeer gewone verschijning, voor een deel met vruchten en hetzelfde geldt van zijn familiegenoot Ptererythrius aenobarbus, die hier eveneens niet zeldzaam is. De omstandigheid, dat vruchten (en in het algemeen plantaardig voedsel) hier gemakkelijk en vooral in grooter hoeveelheid zijn te verkrijgen, moet, naar het mij voorkomt, op het ontstaan van dergelijke afwijkingen wel van invloed zijn geweest. Trots den grooten rijkdom aan insecten en andere dierlijke organismen hunner omgeving, be- 
vatten de magen der echte carnivoren onder de rogels dikwijls zóó weinig, dat men zich afvraagt, hoe ze daarvan eigenlijk kunnen bestaan. Kieskeurig zijn zij in het algemeen niet, zoaals voldoende blijkt uit de verscheidenheid, die de maaginhouden bij verschillende individuen van dezelfde soort, of die welgevulde magen van enkele individuen te zien geren. Traag in het zoeken zijn zij evenmin; want zij zijn den geheelen dag bezig. Men moet dus wel aannemen, dat het verkrijgen van een ruime hoeveelheid voedsel den dieren minder gemakkelijk valt, dan men zou meenen en de overgang, van verschillende soorten, tot een half plantaardig dieët is daardoor gemakkelijk verklaarbaar. De neiging tot dien overgang moet echter aanwezig zijn en waar wij die aantreffen bij Ptererythrius aenobarbus, ontbreekt zij blijkbaar weder geheel bij de naverwante, fraaie Pt. flaviscapis, in wiens maag ik nooit iets van plantaardigen aard, maar steeds uitsluitend overblijfselen van de meest uiteenloopende insecten aantrof. Ook deze soort hoort in dit gebied thuis; beide komen nog in het volgende voor en Pt. flaviscapis nam ik zelfs in het hooggebergte waar.

Voorts moet die overgang roor een deel ook worden gesteld op rekening van de groote concurrentie, die de insectenetende vogels elkander hier aandoen. Een gulzige slokop als Cissa thalassina makt het bijvoorbeeld zijn lotgenooten niet gemakkelijk. Deze luidruchtige veelvrat, die hier in troepen of, in sommige jaargetijden, paarsgewijze algemeen voorkoint, verslindt vrijwel alles, wat hij van dierlijken aard tegen komt en is in dit opzicht op éen lijn te stellen met Halcyon chloris (pag. 65). Intusschen moet hem de eer worden gelaten, dat hij door zijn 
luid, schel en aanhoudend geroep, waaraan de inlandsche naam èkkèk-geling is ontleend, aanzienlijk medewerkt tot opvroolijking van het bosch en dat hij door de kleur van zijn vederkleed, zijn bek en zijn pooten tot een van de fraaiste vogels van Java moet worden gerekend.

Even luidruchtig, maar veel schuwer, is hier Garrulax rufifrons van de familie der Garrulacidae, die wel eens met den Hollandschen naam Spotlijsters wordt aangeduid. Ook deze soort trekt dikwijls in groote troepen rond, die op verren afstand hoorbaar zijn en in welker geschreeuw men met een weinig goeden wil eenige gelijkenis met een schel en spottend gelach kan opmaken. De inlanders in West-Java vinden meer gelijkenis erin met het gehinnik van een paard en noemen hem daarom manoek koeda. Eenige jaren geleden werd een twaalftal dezer dieren door een inlander uit de bergstreken aan het Zoölogisch Musseum alhier te koop aangeboden. Hoe de man ze levend in handen had gekregen, heb ik niet kunnen uitvorschen. Zij hadden zich, in hun wildheid en schuwheid, in hun primitieve gevangenis tot bloedens toe stukgerlogen, werden uit medelijden gekocht en daarna losgelaten. Gedurende een drietal dagen kon men hun geroep in den Plantentuin hooren, maar daarna waren ze, vermoedelijk naal veiliger en koeler streken, verdwenen.

Een tamelijk algemeene insecteneter van dit gebied is verder de fraaie, zwarte, maar met een groenen glans bedekte Bhringa remifer, die in deze streken den vroeger (pag. 525) besproken Dissemurus vervangt en zich door een dergelijk sieraad onderscheidt. Ook hier bestaat dit in de twee buitenste staartpennen, welker schachten bij deze soort zeer zijn verlengd 
en alleen aan de uiteinden vlaggen dragen, die onder de vlucht achter het dier aanwapperen en hem bijzonder gemakkelijk herkenbaar maken. Ook zijn niet onaardige zang verraadt dikwijls zijne aanwezigheid, die zich in den regel niet hooger dan de bovengrens van dit gebied uitstrekt.

Veel hooger gaat de echte Vliegenvanger Rhipidura phoenicura, dien men reeds bij den eersten aanblik herkent als een nauwen verwant van onzen gewonen Vliegenvanger der cultuurstreken $R h$. javanica. In levenswijze, in bewegingen, zelfs in stemgeluid stemt hij daarmede volkomen overeen, maar de bruine staart, in zijn waaiervormige uitspreiding steeds goed zichthaar, doet hem dadelijk ervan onderscheiden. Dezt soort is een van de meest algemeene boschvogels op ongeveer 3000 voet en daarboven, waar zij tot meer dan 7000 voet zeehoogte voorkomt. Geen der talrijke andere Vliegenvangers is zóó algemeen of treedt in ander opzicht zóó op den voorgrond. Van Alseonax latirostris, die hier ook verre van zeldzaam is, zou men, gelet op den breeden en platten snavel, a priori aannemen, dat hij ook zijn voedsel voornamelijk in de vlucht bemachtigt en derhalve door zijn bewegelijkheid nogal in het oog moest vallell. Dit is echter niet het geval en de uitkomsten van het maagonderzoek stemmen daarmede overeen; het roedsel bleek voor een groot gedeelte te bestaan uit insecten, die men gewoonlijk stilzittend aantreft.

Boven 3000 voet komen wij langzamerhand in het gebied van de Lijsterachtigen, die in de cultuurfauna slechts door een gering aantal soorten bleken te zijn vertegenwooldigd. Daar ik hier meer het oog heb op wat men naar levenswijze, aard der bewegingen 
en algemeen voorkomen als Lijsterachtigen zou kunnen samenvatten, mogen hier in de eerste plaats worden genoemd de beide Beeklijsters Myiophoneus cyaneus en $M$. flavirostris, de laatste, tevens de grootste van de twee, aldus genoemd naar zijn helder gelen snavel, overigens beide glanzend blauwzwart van vederkleed. Tegen het vallen van den avond wagen deze Beeklijsters zich wel eens buiten het bosch, weliswaar niet in open terreinen, maar in de nabijheid van beekjes langs eenzame, beschaduwde wegen en men behoeft ze dan maar in hun bedrijvigheid bij het zoeken naar voedsel waar te nemen, om dadelijk aan den gewonen Hollandschen Merel te worden herinnerd. In het bosch zelf krijgt men ze minder gemakkelijk gedurende langeren tijd te zien; slechtseen goed verborgen observatieplaats in de nabijheid van een bergstroompje stelt daartoe in staat.

Terwijl de Merula's nog veel hoogerop thuis behooren, zijn de andere echte Lijsters hier vertegen woordigd door Oreocichla horsfieldi, in hoofdzaak bruinachtig van kleur, welke nogal zeldzame soort zich eveneens gaarne in de nabijheid van stroomend water ophoudt; door Zoöthera andromedae, welker voedselkeuze ook al wijst op veelvuldig rerblijf nabij den grond en door de beide Geocichla's sibirica en interpres. Van deze is de eerste niet meer dan een wintergast, die echter nogal in groot aantal hierheen schijnt te komen; een korte, witte streep aan weerszijden ran den kop en het overigens grijze vederkleed maken hem gemakkelijk herkenbaar. De tweede soort is, voor zooverre bekend, geen trekvogel, maar zij is tot dusverle zoo weinig aangetroffen, dat aangaande haar verspreiding en levenswijze niets naders bekend is.

Aan de Lijsters sluiten zich een paar andere vormen 
nog zeer gereedelijk aan, namelijk de Prionopide Cochoa azurea en de Rupsvogel Lalage fimbriata. De eerste draagt zijn soortnaam met eere en is een fraaie boschvogel, in wiens maag uitsluitend vruchten werden gevonden, waaronder ook de blauwe besachtige vruchten, die, bij planten van de meest uiteenloopende verwantschap, in het onderhout der bosschen op deze hoogte zoo algemeen voorkomen, niet zelden het intensiefst gekleurd, waar het minste licht dooldringt *).

Lalage fimbriata is een blauwachtig donkergrijze boschvogel, iets grooter dan zijn verwant $L$. terat (pag. 75) uit de cultuurfauna en bij de wijfjes gekenmerkt door een fijne, dwars loopende streping van het gevederte op de borst. In tegenstelling met laatstgenvemde, die een eenzelvige natuur schijnt te hebben, komt men L. fimbriata niet zelden in kleine troepjes tegen, die gezamenlijk rondtrekken op zoek naar rupsen en kleine sprinkhanen.

Hier moge tevens worden genoemd Oriolus cruentus, dien snen, om zijn kleur en zijn afmetingen, in het bosch zeer gemakkelịk voor een lijsterachtigen rogel aanziet. Want in tegenstelling met de andere Wielewalen vin Java is zijn geheele vederkleed zwart, met een zwakken, blauwachtigen gloed. Slechts over de borst loopt een karmijnroode streep, terwijl zich een plekje van dezelfde kleur buiten op elken vleugel bevindt. In zijn bewegingen is hij veel rustiger dan de Lijsters; elke sprong, die hij doet, makt den indruk van behoorlijk te zijn overdacht. Zijn stemgeluid is mij niet bekend; iets, dat op het gefluit van onzen gewonen Wielewaal (O. maculatus)

") Van deze omstandigheid maak ik hier opzettelijk melding, omdat men in de literatuur niet zelden de meening vindt uitgesproken, dat anthocyaan, bij de meeste dezer vruchten het kleurend bestanddeel, de plantendeolen tegen te sterk licht moet beschermen. iets, wararan hier allerminst behoefte bestaat. 
gelijkt, heb ik in het bosch nooit gehoord. Zijn voedsel is van gemengden aard.

De Timeliidae zijn hier, als echte boschvogels, goed vertegenwoordigd; het onderhout is juist op deze hoogte boven zee voor hen bijzonder geschikt. Men hoort ze intusschen meer dan men ze ziet. Een kort, bij de meeste éénsylbig geluid verraadt in den regel hunne nabijheid, maar men moet eenig geduld hebben en zich zeer rustig houden, vóórdat men ze te zien krijgt. Zelfs dan is het uiterst moeielijk, de soort te herkennen, want hun verderkleed biedt weinig bijzondere kenteekenen aan. Slechts Cyanoderma melanothorax kan men vrij gemakkelijk onder scheiden aan de drie zwarte vlekken, die samen een onderbroken, halven cirkel vormen rondom de flauw geelachtig witte keel; de Mixornis-soorten desnoods nog aan de donkere schachtstreepjes op de, dikwijls tamelijk heldergele borstveeren. Maar de soorten van het geslacht Turdinus, Notodela diana, Alcippe solitaria e.a. zijn op het terrein zelf en bij het gedempte licht, dat daar heerscht, niet thuis te brengen. Laat ik daaraan toevoegen, dat zulks onder veel gunstiger omstandigheden ook niet steeds gemakkelijk valt.

Het voedsel der Timeliidae bestaat uit nagenoeg alles, wat zij nabij den grond aan gedierte aanwezig vinden. Slakjes en wormen worden even gaarne genuttigd als insecten. Slechts Alcippe solitaria eet ook vruchten en zaden, terwijl de overige bestanddeelen der onderzochte maginhouden het vermoeden wettigen, dat deze soort zich in mindere mate dan de meeste andere Timeliidae nabij den grond ophoudt.

Wordt deze familie in het algemeen gekenmerkt door lange pooten en een korten staart, wij vinden 
deze kenmerken nog meer op den voorgrond treden bij de kleine Oligura superciliaris, die zich ook in levenswijze nauw aan de Timeliidae aansluit en in dit gebied tamelijk veelvuldig kan worden aangetroffen, als men hem en zijn manieren maar eenmaal kent. Hij is een grappige, kleine verschijning, bijna zonder staart en met zeer lange pooten, die, als hij zich hoog opricht, voor een miniatuur-reigertje zou kunnen doorgaan. Om zich bij naderend gevaar te verbergen, makkt hij aanvankelijk een duikende beweging en houdt zich doodstil, maar in den regel zet hij het spoedig daarna op een loopen, waarbij hij zich, alvorens op te vliegen, met de snelheid van een muis voortheweegt en reeds daardoor al heel spoedig uit het gezicht is.

Uit dezelfde verwantschap en eveneens zeer karig met een staart hedeeld, is Pneupyga rufa, die er eenigszins schubbig uitziet, doordat over een groot deel van het vederkleed de veeren met een andere dan de grondkleur gezoomd zijn. De staart bestaat, evenals bij het Hollandsche Winterkoninkje, uit een aantal korte, opstaande veertjes, die zóó dicht bij elkander zijn ingeplant, dat ze elkaar nagenoeg geheel bedekken. Ook deze soort houdt zich gaarne nabij den grond op en nuttigt gaarne kleine Weekdieren; voor zooverre mijne ervaring reikt, is zij minder algemeen dan de vorige, maar het kan natuurlijk zeer goed wezen, dat er bosschen zijn, waar juist het omgekeerde het geval is.

Echte Rietzangers behoeft men in de bosschen uiteraard niet te zoeken. Cettia montana heb ik slechts éénmaal waargenomen en wel in een, met hoog gras (Saccharum en dgl.) begroeide, voormalige 
uitkapping nabij de watervallen van 'Tjibeureum, op ongeveer 5000 voet boven zee. Prinia polychroa, in dit gebied de tegenhanger onzer gewone en zeel algemeene Prinia familiaris (pag. 64), lijkt mij een heel eind op weg om het bosch vaarwel te zeggen. Zij is veel minder bewegelijk en luidruchtig dan laatstgenoemde en houdt zich, naar het mij voorkomt, meer buiten dan in het bosch op.

Een aardige en vroolijke verschijning is Hemixus virescens, een op de bovendeelen olijfgroene Ixodide, die op de lichtgrijze borst zeer in het oogvallende, donkere, groenachtige zoomen op de veeren vertoont. $\mathrm{Hij}$ is zeer algemeen en verraadt zijn nabijheid door een tweesylbig, schel groep, dat volkomen gelijkt op dat van den Europeeschen Vink (Fringilla coelebs).

'Tamelijk algemeen is hier ook de Boomklever Sitta azurea, dien men dadelijk herkent door zijn overeenkomst met Sitta frontalis (pag. 75). In tegenstelling met den laatste, dien men steeds in paren aantreft, trekt deze soort in kleine troepen rond.

Over het algemeen speelt, vooral in de hoogere gedeelten ran dit gebied, het rondtrekken van rogels in troepen een groote rol, en dat niet in koppels van ééne soort, maar in luidruchtige benden, waarin men soms wel een dozijn soorten kan onderscheiden. Men kan hier soms langen tijd loopen, zonder dat de aandacht in bijzondere mate door vogels wordt getrokken, maar niet zelden komt dan onder luid geroep en gefluit op eenmaal zulk een troep aanzetten, waarbij men dan oogen te kort heeft om te onderscheiden, uit welke soorten zij bestaat. Want veel tijd gunnen de dieren den waarnemer niet, vooral wanneer hij door zijn kleeding of door de plaats, waar hị zich bevindt, gemakkelijk in het 
oog valt. Ik acht het volstrekt niet onmogelijk, dat dergelijke troepen hun ontstaan hebhen te danken aan iets dergelijks als het imponeerend gevoel van grootsche eenzaamheid, dat ook den mensch in deze dichte, dikwijls slechts spaarzaam verlichte wouden dikwijls berangt. Bijzondere gevaren zijn er hier voor de rogels niet; integendeel, zij zijn hier veel veiliger dan in open terreinen, maar toch kan het zijn, lat de verlatenheid hen drukt en dat zij daarom het gezelschap zoeken, niet alleen van soortgenooten, maar ook van andere, die onder dezelfde omstandigheden verkeeren.

De neiging daartoe bestaat echter niet bij alle. Alleen, of hoogstens bij paren, treft-men, behalıe vele der boven reeds besproken soorten, de 'Trogon's aan, de sierlijke Harpactes orescios en Hapalarpactes reinwarciti, klimvogels door de plaatsing der teenen, maar overigens van gelijke beweging als bijv. sommige langstartige Duiven, die eveneens, wanneer ze stil zitten en langs de takken loopen, de staartveeren angstvallig in het verlengde van het lichaam houclen, in onderscheid met rormen als de Spoorkoekoeken, die ze steeds slap laten afhangen. Beide soorten komen in het benedenste gedeelte ran dit gebied naast elkander voor, maar vandaar zet het verspreidingsgebied van eerstgenoemde zich vooral benedenwaarts, dat van de laatste vooral nar boven voort.

Eurylaemus javanicus is daarentegen weder van een meer gezellige natuur, hoewel ik nooit waarnam, dat hij zich ook bij andere soorten aansluit. Hij is trouwens in het algemeen geen alledaagsche verschijning, doch waar hij voorkomt, verraadt hij bij zonnige weersgesteldheid zijne anwezigheid door een tamelijk welluidenden zang. 
Een typisch geluid roor de bosschen op deze hoogte is, gedurende het grootste deel van het.jaar, het krachtige geroep van den Koekoek Cuculus poliochephrlus. Het klinkt als "sét-koeng-koeng", maar de eerste syllabe is dikwijls slechts zóó flauw hoorbaar, dat men geen oogenblik aarzelt, in de beide laatste een groote overeenkomst met het geroep van den Hollandschen Koekoek, Cuculus canorus, te ontdekken en den vogel, die het geluid voortbrengt, op het genus te determineeren. Waar hij aanwezig is, hoort men hein den geheelen dag, van den vroegsten morgen tot laat in de avondschemering.

Ten slotte moeten nog de Duiven van dit gebied ter sprake komen. Reeds noensden wij hierhoren (pag. 529) Ptilopus jambu als vertegenwoordiger der Jufferduiven maar meer dan deze trekken hier de Carpophaga's de aandacht, niet alleen door hun stemgeluid, maar ook door het geraas, dat ze maken, wanneer zij in de onmiddellijke nabijheid opvliegen. Vooral Carpophaga aenea, de pergum (mal.), kadantja (s.) of gedoewo (j.) laat den mensch tot op korten afstand naderen en jaagt hem dan door zijn plotseling opvliegen soms een schrik op het lijf. Hij is de grootste der Javaansche Duiven en om zijn smakelijk vleesch een geliefkoosd voorwerp van de jacht. Die goede smaak wordt echter weleens bedorven door het voedsel, dat hij gebruikt. Ik herinner mij een geval, waarin de dieren eenvoudig oneetbaar waren door een sterken en bitteren citroensmaak, die bij onderzoek bleek te zijn veroorzaakt, doordat zij zich hadden te goed gedaan aan de vruchten van Litsea citrata, een hier en daar in het gebergte nogal veelvuldig voorkomenden boom van de familie der Lauraceae, die in alle deelen, maar vooral juist 
in de vruchten, een groote hoeveelheid aetherische olie bevat.

'Terwijl Carpophaga lacernulata veel minder algemeen is dan $C$. aenea, treedt het geslacht Sphenocercus vall de Papegaaiduiven hier nogal op den voorgrond. Met de reeds genoemde Butreron capellei (pag. 529) vertegenwoordigt het deze familie in de bosschen, terwijl de Osmotreron's in de cultuurfauna zijn over. gegaan. Van de twee Javaansche soorten oxyurus en korthalsi komt de eerste, die dadelijk is te herkeunen aan de puntige verlenging van het middelste paar staartpennen, nog wel eens in lager gelegen terreinen voor, terwijl zij ook algemeener schijnt te zijn dan de tweede.

Van de Reptiliën behoeven voor dit en de hooger gelegen terreinen de Slangen ons niet meer bezig te houden. In de bergwouden ontmoet men ze betrek. kelijk weinig en dan zijn let nog steeds vormen, die ons reeds van andere gebieden bekend kunnen zijn. Daarentegen zijn de bosschen tamelijk rijk aan Hagedisachtige dieren, al is het aantal soorten daarvan niet bijzonder groot.

De Bosch-Geckonide bij uitnemendheid is Gymno. dactylus marmoratus, die, in een verzameling op spiritus staand, den indruk maakt van vrij levendig te zijn geteekend, maar in het bosch, tusschen het verdrougde blad en op de, vaak met Korstmossen begroeide stammen en takken tamelijk lastig zichtbaar is.

Van de Agamidae treft men zeer algemeen de beide Gonyocephalus-soorten chamaeleontinus en kuhli aan, de laatste met een iets hooger verspreidingsgebied dan de eerste. De geslachtsnaam is bijzonder gelukkig gekozen, wanneer hij althans aan het Grieksche 
woold gonos (hoek) is ontleend, want de kop is inderdaad zeer hoekig en scherpkantig; rooral de rand boven het oog is opvallend en bij kuhlii nog sterker ontwikkeld dan bij chamaeleontinus. Het aantal schubben op de rugzijde, die door een bijzonder sterke ontwikkeling (en in den regel door een lichtere kleur) zich van de nor:nale schubben onderscheiden, is bij kuhlii ook iets grooter. Daarentegen is de kam op de rugzijde bij haar iets kleiner dan bij de andere, terwijl haar buikschubben gekield zijn.

Beide soorten houden zich overdag rustig en schijnen dan in een half slapenden toestand te verkeeren. Men kan ze althans gemakkelijk naderen. Tegen de avondschemering komen ze meer in actie en men hoort dan voortdurend hun schel, fluitend geroep, dat tot diep in den nacht roortduurt en waarbij zij elkander steeds beantwoorden.

Van de Scincidae is de fraai geteekende, bruinachtige en zeer slanke Lygosoma temminckii de bosch-en bergvorm bij uitnemendheid, die men bijna overal in dit gebied in groot aantal kan waarnemen. Minder algemeen is Mabuia rugifera, die hier in de plaats treedt van $M$. multifasciata (pag. 80), terwijl Ablepharus peroni nog zeldzamer is en in de laatste jaren slechts eenmaal (door Ourvexs) op het plateau van Pengalengan werd verkregen.

'Terwijl over de larven der Batrachiërs, ook van dit gebied, reeds vroeger (pag. 379) met een enkel woord werd gesproken, moeten thans nog eenige der volwassen rormen ter sprake komen, die in de bergstreken thuis behooren.

Een echt boschdier, door zijn voorkomen volmaakt 
aan zijn omgeving geaccomodeerd, is Megalophrys montana van de familie der Pelobatidae. Het is bijna niet mogelijk, dezen Kikvorsch, wanneer hij stil zit, van de verdorde en verkleurde bladeren op den bodem te onderscheiden. Dit is te merkwaardiger, omdat kleur en teekening der bovendeelen bij de verschillende individuen zeel uiteenloopen; het is zelfs moeielijk, twee geheel gelijke exemplaren te vinden. Terwijl de jongen zeer schuw zijn, zijn de oudere dieren gekenmerkt door een zeer phlegmatische natuur; men kan ze, evenals sommige Padden, opnemen, bekijken en weder neerzetten. zonder dat ze bijzondere moeite doen um zich aan dit onderzoek te onttrekken. Misschien heeft de ervaring, zoo bij dieren van deze ontwikkelingshoogte al iets van dien aard bestaat, hen geleerd, dat zij des te veiliger zijn, naarmate zij zich rustiger houden.

Megalophrys hasselti, de tweede soort van Java, is niet zoo talrijk, maal tevens minder tot de bergstreken beperkt. Aan de Zuidelijke hellingen vall het gebergte daalt zij zelfs tot de nabijheid der zee af (vgl. bladz. 508) en het komt mij voor, dat haal verspreiding, evenals die ran meerdere diersoorten, rooral wordt beheerscht door de vraag; of er helder stroomend water aanwezig is, met roldoende gelegenheid om zich op te houden in schuilloeken, waar zij van den stroom geen last hebben. Want daar de larven van dit geslacht geen zuigapparaat hebben om zich vast te houden, kunnen zij zich niet aan de kracht van den stroom blootstellen, zonder gevaal van te worden medegesleept.

De Engystomatidae zijn hier vertegenwoordigd door het geslacht Microhyla en vooral door de soort achatina, een kleinen Kikvorsch van een welgedaan voor- 
komen en een tamelijk lichte en neutrale lichaamskleur, die onderbroken wordt door een, niet altijd even sterk ontwikkelde, donkere streep, die achter elken voorpoot begint en langs de zijde van den romp achterwaarts verloopt. In tegenstelling met de Megalophrys-soorten, die in den volwassen toestand volslagen landdieren zijn, wagen de Microhyla's zich niet ver van het water.

Een formeel landdier is, in den volwassen toestand, ook de kleine pad Bufo cruentatus, dien men in de hooggelegen bosschen dikwijls op de, met mos en allerlei lagere planten begroeide boomstammen aantreft. Hij is gekenmerkt door heldere, zwavelgele en karmijnroode vlekken op de bovenzijde en ten nauwste verwant aan den minder algemeenen Bufo borbonicus, die langere achterpooten heeft.

De eigenlijke Kikvorschen (Ranidae) zijn hier in de eerste plaats vertegen woordigd door eenige Ranasoorten, waarvan Rana kuhlii wel de meest algemeene en de grootste is. Zij is in den regel te herkennen aan de donkergemarmerde teekening op kin en keel. Rana chalconota, slanker van bouw en met een gouden gloed over de bovendeelen, is eveneens zeer algemeen en nauw verwant aan $R$. jerboa, die zich vooral door de langere achterpooten van haar onderscheidt. Minder algemeen is de slanke, overlangs bruin gestreepte Rana javanica. Van de Ixalus-soorten, die alle maar een paar duim lang zijn, is Ixalus aurifasciatus, in de bergbosschen van West-Java alhans, niet zeldzaam. Deze soort ontleent haar naam aan een helder gelen band tusschen de oogen, waardoor zij gemakkelijk is te onderscheiden van de lichtgeel gestippelde Ixalus flavosignatus.

Het geslacht Polypedates eindelijk is in de berg- 
$-559-$

streken vertegenwoordigd door de soort javanus, die zich door de minder ontwikkelde zwemvliezen van de vroeger (pag. 88) besproken $P$. reinwardti onderscheidt. 


\section{HOOFDSTUK XXIV.}

\section{De Boschfauna van $2500-5000$ voet boven zee.}

B. Ongewervelde Dieren.

Het laat zich hooren, dat in de vochtige atmosfeer der bosschen Slakken goed kunnen bestaan. Het meest vallen, door hun afmetingen, de Cyclostomatidae in het oog, die, niettegenstaande de zooeven vermelde, gunstige omstandigheid uitnemend bestand zijn tegen watergebrek en, na het afsluiten van hun huisje, weken en zelfs maanden lang aan uitdroging weerstand kunnen bieden. De dieren kunnen zonder bijzondere voorzorgsmaatregelen, in een doos met mos of houtwol, de reis naar Europa maken. Van de grootere soorten wordt door de inlanders beweerd, dit zij gedurende de duisternis een schel klinkend geluid maken en voor het bedoelde geluid, dat men bij bosschen op deze hoogte elken avond hoort, heb ik nooit een andere herkomst kunnen aanwijzen, maar zekerheid heb ik dienaangaande nog niet kunnen verkrijgen. Zeker is, dat ze in gevangenschap geen geluid doen hooren. Een van de meest gewone soorten dezer groep is Cyclophorus perdix.

Van de Zonitidae treft men hier het ons reeds van vroeger (pag. 369) bekende geslacht Parmarion 
aan, alsmede Nanina, Trochonanina, Sitala e.a. Ook de Helicidae zijn hier, o.a. door een aantal Helixsoorten, goed rertegenwoordigd, maar toch kan men niet zeggen, dat eenige groep de Cyclostomatidae in beteekenis voor de physionomie der fauna eenigermate nabij komt.

De wereld der Insecten heeft in dit gebied een overweldigenden rijkdom van vormen aan te wijzen waarin, naar het nij voorkomt, de Kevers wel een hoofdrol spelen, voor zooverre het de dieren betreft, die zich onmiddellijk aan ons oog vertoonen. Het zou geen zin hebben. lange lijsten te geven van hetgeen hier kan worden bijeengebracht en wij zullen ons ertoe bepalen, te wijzen op die groepen, die in dit gebied een aanzienlijk deel van hun krachten hebben geconcentreerd en er dus meer dan elders op den voorgrond treden.

Daartoe mag, wat de Kever's betreft, vooreerst worden gorekend de familie der Brenthidae, waarvan wij in het cultuurgebied geen enkelen vertegenwoordiger aantroffen. Hier ontmoeten wij niet zelden het paradestuk der familie, den grooten Eutrachelus temminckii, rondstrompelend tusschen het afgevallen blarl of op de bodemvegetatie. Vooral de mannetjes trekken onze aandacht door hunne afmetingen en door de sterke ontrikkeiing der kaken, geplatst op het vorkvormige, platte uiteinde van den langen snuit, aan welken laatsten, iets vóór het midden, de lange, draadvormige sprieten zijn ingeplant; eindelijk door de verdikte, met een korten stekel gewapende dijen. Dit laatste vertoonen de, over het algemeen veel kleinere wijfjes ook, die meer 
een normalen, zij het ook zeer langen Curculionidensnuit hebben.

Een andere rorm van dit gebied is Agriorrhynchus borrei, veel kleiner dan de vorige en waarvan de mannetjes een korten, maar zeer sterk rerbreeden snuit hebben, terwijl als kleinere en soms zeer algemeene rormen ran het gewone Brenthidentype mogen worden genoemd Prophthalmus-, Megacerus, Cerobates-en Miolispa-soorten. Eenigszins afwijkend van vorm zijn daarentegen Diurus forcipatus, Cediocera tristis en eenige andere, meer zeldzame vormen, bij welke de algemeene rerlenging in de lengte-as van het lichaam nog veel meer op den voorgrond treedt, zoodat men soms met weinig meer dan lijnvormige dieren te doen krijgt. Bij de beide, met name genoemde soorten werkt daartoe ook nog mede een lang en dun, staartrormig aanhangsel der dekschilden, dat soms de lengte van het lichaam evenaart. Bovendien hebben deze dieren meer de kleur van de doode en vermolniende boomstammen, waarop zij zich bij voorkeur ophouden en waarin zij ook hun jeugd hebben doorgebracht.

Een tweede familie van Kevers, die hier talrijker vertegenwoordigers telt dan elders, is die der Cerambycidae. Naast ver'schillende grijsbruine Batocera's, dadelịk te herkennen als nauwe verwanten van de soorten, die wij vroeger in de cultuurfauna leerden kennen, ontmoeten wij hier den schitterenden boschvorin Batocera octomaculata, tegenhanger van $B$. albofasciata (pag. 369), maar met grootere en meer: regelmatige, scharlakenroode vlekken op de dekschilden. Uit dezelfde verwantschap is Apriona flavescens, die ook nog aan het bosch getrouw is gebleven.

Kenbaar aan twee stevige, eenigszins naar achteren 
omgebogen stekels aan elke zijde van den prothorax is de donker bruinzwarte Ancyloprotus javanus, die nog vall de grootte der Batocera's is, terwijl de slanke, doffe, grijsachtig bruine Aegosoma marginale de aandacht trekt door het groote verschil in afnetingen, dat men bij de verschillende individuen kan opmerken. Een verschijnsel, dat men vrij algemeen waarneemt bij insecten, welker larven in hout boren, omdat de laatste zich daarin maar zeer moeielijk kunnen verplaatsen en afhankelijk zijn ran den voedselrijkdom der plekken, waar het toeval ze heeft gebracht.

'Tot de meer zeldzame soorten behuoren Pachylocerus pilosus, die van boven gezien, de gedaante van een Curculionide heeft en gekenmerkt is door korte, snoervormige sprieten, Himantocera plumosa, die haar sooltnaam ontleent aan de haarbundels op de sprieten en Agelasta irroratu, die van haar bruinachtig grijze kleuren en teekeningen weder garne gebruikt maakt om zich op een soortgelijk gekleurden achtergrond schuil te houden. Dadrentegen treden de geslachten Cacia, Gnoma, Praonetha, Sphenura, Glenea e. a. ons in een groot aantal soorten en dikwijls ook in een grout dantal individuen tegemoet, waarvan hier in het bijzonder mogen worden vermeld de fraaie, blauwe, wit gevlekte en gestreepte Sphenura picta, de donkere, achter op den prothorax witgeringde S. funerula (met bovendien een witte vlek op elk der dekschilden), de donkerbruine, fraai met orarje geteekende Glenea lineosa en de helder roodbruine Glenea ochracea. Plaatselijk kan ook de groote, donkerbruin met geelbruin in talrijke vlekjes en overlangsche streepjes geteekende Anammus dejeani zeel talıijk zijn en dan de aandacht trekken door de 
buitengewone lengte der sprieten, welke soms driemaal die van het lichaam bedraagt. De fraaie Eustathes splendida nadert in algemeen voorkomen al eenigszins tot de Chrysomeliden en valt vooral in het oog door den glanzenden, metaal- achtig blauwen band over de basale helft der lichtbruine dekschilden.

Een van de Keverfamilies, welker vertegenwoordigers zich bij uitnemendheid in dit gebied en in de lagere gedeelten van het volgende ophouden, is die der Cetoniidae. Bij verschillende soorten doet zich hier het verschijnsel voor, dat men ze jaren lang tevergeefs kan zoeken en dan op eenmaal en zeer plaatselijk voor een grooten rijkdom van individuen komt te staan, die blijkbaar gezamenlijk op een klein plekje grond den meerjargen larventoestand hebben doorgebracht, ook als volwassen dieren bij elkaar blijven en op hunne beurt een nieuwe generatie onder dezelfde oinstandigheden zullen plaatsen. Zoo bezit het Zoölogisch Museum alhier een geheele serie exemplaren van de fraaie Diceros petelii, die alle op hetzelfde oogenblik en op dezelfde plaats werden verzameld, terwijl vóór noch na dien tijd ooit één exemplaal werd verkregen. Hetzelfde is het geval met de bronskleurige Mycteristes rhinophyllus. Ook de Chalcothea-soorten huizen nogal bij elkaar, terwijl ditarentegen de groote, bruizwarte, lichtbruin gevlekte Clerota budda meer op zich zelve leeft. Ook Rhomborrhina gigantea, en de groote Agestrata- soorten treft men gewoonlijk slechts in weinige exemplaren bij elkander aan.

Het meest algemeen en het rijkst vertegenwoordigd zijn de geslachten Clinteria, Macronota, Protaetia en Glycyphana, waarvan men, zoowel verspreid als tot troepen vereenigd, allerlei, in den regel fraai 
gekleurde en levendig geteekende soorten in dit gebied kan aantreffen. Clinteria atra, Macronota regia, egregia, monacha en variegata, Protaetia acuminata, Glycyphana torquata en albomaculata behooren daarbij tot de meest gewone vormen.

Terwijl van de Buprestidae het geslacht Belionota hier de meest algemeene en tevens boschvorm gebleven representant is, treft men van Cantharidae in dit gebied nog wel de bonte Mylabris pustulata en een paar, op echte Spaansche Vliegen gelijkende Epicauta-soorten aan, maar deze dieren zijn, zonder nog voorliefde voor bepaalde terreinen aan den dag te leggen, reeds voor een groot deel in de cultuurfituna overgegaan.

De Curculionidae zijn, zooals te verwachten is, in dit gebied zeer rijk vertegenwoordigd en vooral het geslacht Alcides treedt met talrijke soorten en individuen op de voorgrond (A. dejeani, sulcatulus, reticulatus, chiliarchus e.a). Daarnaast zijn Episomus chlorostigma, Eugnathus viridanus en verschillende Hylobius-soorten zeer algemeen. Als "gidsvorm" voor dit gebied zou, in vele bosschen, Oxyrhynch"s latcralis kunnen worden beschouwd.

Van de groep Calandrinae moet in de eerste plaats Lithorhynchus myrmidon worden genoemd, wiens larven voorkomen in de zachtere weefsels der betrekkelijk weinige Palmsoorten der bosschen en die derhalve zeldzamer wordt, naarmate ook deze gewassen hoogerop schaarscher worden. Sphenophorus sericans is hier de tegenhanger van S. planipennis (pag. 209) van het cultuurgebied, samen met Cosmopolites sordidus, die in onderscheid met zijn gedrag in andere streken, hier op Java nagenoeg niet in de cultuurfauna optreedt. 
Van het geslacht Cercidocerus is de grootere soort bipunctatus minder algemeen dan securifer, wiens eigenaardige sprieten met "het best bij meeldraden van Lilium kan vergelijken. De kleine, tamelijk platte Cossonus ephippiger vertoont eenige gelijkenis met sommige vormen der ongestekelde Hispidae, wat vermoedelijk verband houdt met zijn neiging, zich tusschen dicht op elkaar gedrukte plantendeelen in te dringen.

Terwijl het gros der Carabidae zich in den detritus ophoudt, leven enkele meer levendig gekleurde vormen op bladeren en bloemen, waar wij, onder meer, verschillende soorten van de geslachten Catascopus, Calleida, Trigonotoma, Physodera enz. kunnen aantreffen.

Nog een tweetal Keverfamilies moeten hier worden vermeld, die men a priori kan verwachten in een gebied, dat zoo vochtig is en daarbij zoo rijk aan schimmels van de familie der Polyporeae, die velen hunner representanten tot voedsel strekken: de Endo mychidae en de Erotylidae.

Van de eerste is Amphisternus hamatus, gekenmerkt door wratachtige, gladde verhevenheden op de dekschilden wel de meest algemeene tegenhanger van den vroeger (pag. 127) genoemden Eumorphus marginatus. Maal ook Eumorphus quadrinotatus is verre van zeldzaam en wij kunnen hier nog een aantal andere soorten tegenkomen, bij welke de heldere oranje kleur, in deze familie voor de vlekken zoo algemeen, de bovenhand heeft gekregen over het sombere zwart of blauwzwart (bijv. Cymbachus pulchellus) en die daarom een ietwat vreemden indruk maken in het onaanzienlijke milieu, waarin men ze gewoonlijk aantreft. 
Van de Erotylidae bevatten de geslachten Encaustes en Triplatoma vooral de grootere vormen, waarvan Encaustes cruenta en Triplatoma c-notata tamelijk algemeen zijn. Men vindt deze dieren zoowel op de genoemde schimmels, als op vochtige, rottende boomstammen. Van het geslacht Episcapha zijn de soorten glabra en quadrimaculata het meest algemeen; de eerste is door zijn meerdere grootte, zijn glimmend voorkomen en de grootere, oranjebruine vlekken op de dekschilden gemakkelijk van de tweede te onderscheiden. Minder algemeen is Aulacochilus quadripustulatus. Vele dezer Erotylidae leven rooral in den larventoestand in groote troepen bij elkaar en zitten dan aan de onderzijde en op de stelen der Polyporeae en dergelijke schimmelplanten. Zij geven daar wel eens aanleiding tot galachtige vormingen, waarin dan tevens de poptoestand wordt doorgebracht.

Nauw velwant aan deze familie, dikwijls zelfs erin opgenomen, is het geslacht Helota, waarvan de meeste soorten door hun metaalachtige groene kleur en de groote hardheid van hun pantser aan Buprestiden doen denken. Maar het karakter der sprieten verraadt hen spoedig, terwijl meestal ook de oranje vlekken op de voorvleugels niet ontbreken. De gewone vorm op Java is $H$. vigorsi, die men soms op wonde, vochtige plekken van boomstammen kan aantreffen, maar die zich gaarne schuil houdt achter bladscheden en in dergelijke hoekjes. Eenigszins afwijkend van het gewone type is de kleine $H$. semifulva, oranjebruin van kleur, maar metaalachtig blauw op den kop en het achterste gedeelte der dekschilden. 
Van de Dagvinders trekken ook in dit gebied de Nymphalidae het meest de aandacht; Clerome acresilaus zou men in vele bosschen zelfs als "gidsvorm" kunnen beschouwen. Maar daarbij treft men ook vertegenwoordigers van andere families aan, die tot de bosch- en bergvormen moeten worden gerekend. Zoo bijv. Euploea gamelia; Danais albata, die het liefst dicht bij den grond over de boschpaden vliegt; Elymnias casiphone, gemakkelijk als een verwant van vroeger besproken vormen te herkennen en hoogerop vervangen door de meer grijsachtige $E$. ceryx, die op deze hoogte, met haar schaarschte aan palmen, langzamerhand moeite begint te krijgen om aan den kost te komen en daarom niet zeer algemeen is.

Van het geslacht Delias (Thyca) is vooral D. crithoe een vorm der hoogere streken, in de rust gemakkelijk herkenbaar aan de roode kleur op de basis der gele, zwartgerande achtervleugels.

Aan overvloed van Heterocera ontbreekt het hier al evenmin, maar deze onttrekken zich overdag grootendeels aan de waarneming, terwijl de woningen, waarin ze des avonds zouden kunnen binnenvliegen, in den regel te ver van het bosch verwijderd zijn, om hen in grooten getale te lokken. Daarbij komt nog, dat van vele families, die juist hier het best zijn vertegenwoordigd, zooals de Geometridae en de Zygaenidae, de meeste vormen niet of zelden op het licht afkomen.

Dit laatste is wel met de Sphingidae het geval, die bovendien door hun krachtige vlucht in staat zijn, doelbewust groote afstanden af te leggen. Zoo kunnen wij hier de dof-grijsbruine Polyptychus dyras waarnemen, alsmede Acosmeryz ancea, Ambulyx se- 
mifervens en Pseudosphinx discistriga. Meer typisch vool dit gebied is echter de groep der Macroglossinae, die in lagere streken niet, of althans sporadisch voorkomen, in het bijzonder voor zooverre de vormen betreft, die ons onmiddellijk aan Europeesche soorten herinneren. Onder de anderen bevindt zich een interessimte vorm, die ook in de warmere laaglanden voorkomt, maal op Java niet algemeen is, namelijk Cephonodes hylas, een groenachtige Macroglossine met nagenoeg geheel doorschijnende vleugels en een fraai roode kleur op het derde en vierde segment van het achterlijf. Zij is een boschvorm, die zich nu en dan zeer sterk vermenigvuldigt en dan tot emigreeren overgaat, waarbij zij natuurlijk op het aangrenzende cultuurgebied is aangewezen. Zulk een uitval heeft zich op Java, voor zooverre mij bekend is, slechts tweemaal voorgedaan, ééns in Midden-, en ééus in Oost-Java. Beide malen zijn eenige koffieaanplantingen het kind der, overigens niet zeer hooge rekening geworden. Op Malakka en op Sumatra doet zich bij deze diersoort hetzelfde verschijnsel voor, maal haal verschijnen in het cultuurgebied is tot heden steeds van tijdelijken aard gebleven.

Van de Zygaenidae is Pompelon subcyanea hier een tamelijk gewone vorm, evenals Cyclosia papilionaris, die ook tot lagere streken afdaalt, en Histia libelluloides, welker soortnaam niet gelukkig is gekozen, daar niet de minste gelijkenis met een Libellulide valt waar te nemen. Ook de fraaie Amesia sangui. flua en de schitterende Milleria intercisa zijn niet zeldzaam. Voor het overige zijn de grootere Zygaenidae verre van algemeen: in de kleinere daarentegen bestaat een groote verscheidenheid van vormen, waarop wij hier echter niet nader zullen ingaan. 
De Hypsidae zijn, zooals wij vroeger (pag. 146) reeds zagen, grootendeels in de cultumfauna overgegaan; slechts Hypsa marmorea en Euplocia membliaria zijn vormen van de wildernis gebleven. Ook het meerendeel der Arctiidae heeft het bosch verlaten, maar deze familie is daar toch nog vrij goed rertegenwoordigd o.a. door een paar Alpheea-soorten, door de fraaie Areas galactina en door de, nogal zeldzame Pelochyta astrea, terwijl ook tairijke Cyanasoorten, met hun roode bandjes en donkere stipjes op het witte lichaam en de witte vleugels, wel sterk aan die van het cultuurgebied herinneren, doch bij nadere beschouwing daarran toch geheel blijken te verschillen. Overigens levert de onderfamilie der Lithosiinae, waartoe laatstgenoemd geslacht behoort, ook hier een rijken oogst aan allerlei kleinere vormen.

Het geslacht Eusemia, van de familie der Agaristidae, dat groote en zeer in het oog vallende vormen omvat, die voor een aanzienlijk deel tot de boschvormen behooren, is in de hoogere streken vooral door de soort maculatrix verfegenwoordigd, een van de kleurenrijkste insecten, die men hier kan aantreffen; want terwijl de grondkleur van lichaam en vleugels fluweelachtig zwart is, zijn daarop, zoowel op bovenals onderzijde, witte, gele, oranjeroode en azuurblauwe gedeelten aan te treffen en dat, zonder aan den totaalindruk door overlading afbreuk te doen. Ook Zalissa transiens, een vorm van twijfelachtige verwantschap, maar die gewoonlijk in dezelfde familie wordt gerangschikt, komt hier voor en trekt rooral de aandacht door de meerdere grootte der individuen, vergeleken bij die, welke men in het laagland aantreft. Exemplaren van Buitenzorg hebben een 
vlengelspanning ran gemiddeld $36 \mathrm{mM}$., van Tjibodas van $5(;) \mathrm{m} M$.

Over de Noctuidae kunnen wij kort zijn. Hun aantal is hier, zovals nauwelijks behoeft te worden gezegd, zeer adnzienlijk, maar zij spelen volstrekt niet die groote rol als in de cultuurfauna (pag. $147-$ 151). Hierbij dient weder in aanmerking te worden genomen de minder gunstige gelegenheid tot waarneming, waarop hierboven reeds werd gewezen; het is hest mogelijk, dat onze opinie geheel anders zou worden, als men eens eenige maanden midden in het bosch een huis bewoonde, dat des avonds goed verlicht werd. Mijn ervaring te Tjibodas, war het wonnhuis vlak bij den rand van het bosch staat, wijst daarop echter nog niet. Hoe het zij, er zijn een aantal echte Uilen, die tot de boschfauna moeten worlen gerekend en waarvan hier, als grootere vormen, mogen worden genoemd Apsarasa radians, die haar naam ontleent aan de groote, blauwzwarte vlek, die een aanzienlijk deel van den geelwitten voorvleugel bedekt en in alle richtingen stralen uitzendt, die tot den vleugelrand doorloopen, de sombere Iontha umbrina, te herkennen aan een groote, zwarte anaalpluim en de verlengde hoeken der achtervleugels, en Phyllodes consobrina, een van de grootste Noctuiden van Java, die op de bovenzijde der achtervleugels de kleuren der Nederlandsche vlag vertoont. Ook Arcte coerulea mag men, naar het mij voorkomt, nog wel tot de boschvormen rekenen, evenals vele Trigonodes-soorten, terwijl ook het geslacht Ophideres (pag. 149) e. a. het bosch nog lang niet geheel hebben verlaten.

Bijzonder talrijk zijn voorts in dit gebied de Focillinae en de Deltoidinae, maar deze beide groepen 
omvatten geen vormen, die in eenige opzicht de aandacht trekken. Hoogstens zouden wij een uitzondering kunnen maken voor een Mastigophorus-soort, die ik overigens slechts een paar maal des avonds waarnam, en die opvalt door de enorme ontwikkeling der palpen, waarvan het eerste lid ver vóór den kop uitsteekt, terwijl het tweede lid achterwaarts is gericht en boven den kop komt te liggen, en het derde plat is en een langen haarbundel draagt, die tot boven het achterlijf reikt.

Terwijl van de Uraniidae, naast verschillende andere, een langgestaarte Urapteroides valt waar te nemen, zijn de Geometridae hier door een zeer groot aantal vormen vertegenwoordigd. Zooals wij vroeger reeds opmerkten, is deze Vlinderfamilie in hooge mate het bosch blijven bewonen, zonder dat het mogelijk is, daarvoor een bepaalde oorzaak aan te wijzen. Verreweg de meeste soorten zijn echter van bescheiden afmetingen en evenzeer bescheiden van voorkomen, hoewel vele, als men ze levend vóór zich ziet, een heel wat beter figuur maken dan in de verzamelingen; hier geldt hetzelfde als op pag. 488 voor de Vliegen werd opgemerkt. Overdag houden de meeste zich stil en zitten dan tegen boomstammen of tegen de onderzijde van bladeren. Slechts enkele vliegen overdag rond. Van de grootere vormen mogen hier worden genoemd Thinopteryx crocoptera, Elphos hymenaria en vooral de fraaie en kleurijke Euschema mititaris en E. minervaria, verder soorten van Hypochrosis, Biston, Amblychia, Pseudoterpna e. a. terwijl door fraaiheid en fijnheid van teekening vormen als Trygodes divisaria en Maxates-soorten uitmunten. Milionea zonea, die in voorkomen de mooiste Zygaenidae nog achter zich 
laat en in de bosschen van Sumatra en Borneo vrij algemeen schijnt te zijn, heb ik op Java nooit waargenomen.

De Rhynchota zijn hier door de Pentatomidae niet zoo ruim rertegenwoordigd als atan de randen der bosschen, doch men vergete niet, dat de insecten fauna ran de kruinen der boomen zich voor een groot deel aan onze waarneming onttrekt. Wat wij in het onderhout waarnemen, zijn vooral donker gekleurde vormen, wien het is aan te zien, dat ze liever in dit getemperde licht, dan in den zonneschijn vertoeven. Van dezulken is Aspongopus ochreus zeker wel een der meest typische vormen. De groote Tesseratoma javanica is iets glimmender, maar overigens van dezelfde, weinig sprekende, bruingele kleur. Een derde vorm, die den indruk maakt, alsof zijn kleur het na de laatste vervelling niet meer der moeite wadrd vond, voor zulk een matige belichting nog voor den dag te komen, of wel, alsof zijn kleur door etiolpering weer was verdwenen, is Priassus spiniger. De genoemde vormen roeden zich met plantensappen, maar er zijn hier onder de Pentatomidae ook roovers, die vooral op rupsen jacht maken. Een van de meest geduchte daarvan is de breedgeschouderde Placosternum taurus, die zich niet ontziet rupsen aan te vallen, die stellig zes maal zijn eigen lichaamsgewicht hebben. Ook deze soort is van een bruinachtige kleur met gemarmerde teekeningen, die volkomen past bij vochtige boomschors en afgevallen blad. Iets eleganter van vorm en levendiger van voorkomen (door twee gele, ovale vlekken aan de basis van het scutellum) is Canthecona rufescens, 
eveneens een varnivoor, wiens beide schouder's in harde scherpe doorns uitloopen.

Van de Lygaeidae is vooral de groep der Coreinae hier ruim vertegenwoordigd. Ook bij deze dieren is dof bruinachtig grijs de overheerschende kleur en daardoor passen zij geheel in humne omgeving. De meeste zijn tamelijk groot van stuk en lederachtig van huid. De grootste is Prionolomia heros, die soms een lichaamslengte van $35 \mathrm{mM}$. hereikt en geken. merkt is door een sterk ontwikkelde; langs de zijranden getande verbreeding van den rand van het pronotum; de mannetjes bovendien door een sterke verdikking van de dijen en een bladvormige verbreeding van de tibiae der achterpooten. Evenals met vele zijner verwanten het geval is, vindt men dit insect gewoonlijk in troepen bij elkaar, die zoowel uit volwassen, als uit jonge, ongevleugelde individuen bestaan, waarbij de laatste in den regel ook hier zeer spoedig overgaan tot de toepassing van het verdedigingsmiddel, dat op pag. 285 werd besproken.

Minder geducht uitziende vürmen van dezelfile groep zijn hier Pendulinus laminatus, soms met meer, soms met minder rood op de basale gedeelten der voorvleugels; Homoeocerus angulatus en $H$. albiguttulus, die in kleur meer tot de walang-sangit naderen en waalvan de laatste gekenmerkt is door een lichte stip op elk der voorvleugels, ongeveer in het midden; Notobitus meleagris, groot, met lange dorens aan de dijen der achterpooten; Colpura obscura en Leptoglossus membranaceus, beide dofzwart en in levenswijze reeds naderend tot de detritusfauna; Acanthocoris scubrator, die een overgang vormt tot de kleinere soorten; Alydus linearis (van de grootte van een 
walang sangit en dikwijls daarvoor aangezien), die in overgang tot de cultuurfauna verkeert. Een meer zeldzame vorm eindelijk is Dalader planiventris, een van de grootere soorten, die gekenmerkt is door groote, naar voren gezichte verbreedingen van het pronotum, door een platte verbreeding van het achterlijf, waardoor dit laatste bijna cirkelvormig wordt en door een bladvormige verbreeding van het voorlaatste lid der sprieten; door een algemeene neiging, derhalve, van het integument $\mathrm{m}$ in de breedte uit te groeien.

De kleinere Lygacidae behooren voor een aanzienlijk deel tot de detritusfauna en vertoonen daarvan ook uiterlijk alle kenmerken. Slechts eenige vormen, die wat levendiger gekleurd zijn, zooals Lygaeus hospes, geven zich meer bloot en zijn op takken en blaren te vinden. Zij vertoonen in hun kleuren en de verdeeling daarvan groote overeenkomst met Vuurwantsen (Pyrrhocoridae), die hier ook door een paar, spoedig in het oog vallende soorten zijn vertegenwoordigd. Zwart met rood in verschillende tinten zijn hier rrijwel het eenige kleurenmateriaal, waarmede de natuur aan het werk is geweest; vandaar, dat een zekere eentonigheid in deze groep van insecten niet valt te ontkennen. De grootere Vuurwantsen van dit gebied zijn Physopelta gutta en $A n$ tilochus nigripes; van de kleinere is Euscopus rufipes het levendigst geteekend.

Voor de Roofwantsen zijn de bosschen het terrein bij uitnemendheid, dat vooral in de bovenste gedeelten van het vorige begint en zich tot ongeveer 5000 voet hoogte uitstrekt. Wel is waar zijn verspreid ook in het hoogere gedeelte van het cultuurgebied verschillende soorten aan te treffen en zijn andere, 
zooals de, op den thorax nijdig gestekelde Canthesancus trimaculatus meer in de lagere busschen thuis, de echte Reduviidae vindt men toch het meest op eerst. genoemde terreinen. De vaalbruine, langwerpige vormen, zooals Thodelmus falleni, Sastrapada flava en Oncocephalus squalidus, verraden door hun kleur reeds, dat men ze niet bij voorkeur in het felle zonlicht moet zoeken. Vele der andere vertoonen dikwijls heldere en fraaie kleuren, en daarin spannen Eulyes amoena en de Ectrychotes-soorten wel de kroon, maar toch vindt men ook deze meer in de beschaduwde gedeelten der bosschen, dan langs de schel verlichte randen; wellicht brengt hun rooversbedrijf dat mede. Wederom andere zijn door de natuur zóó toegerust, of takelen zich zelf zóó toe, dat zij bijna onzichtbaar zijn in de omgeving, waarin zij zich bij voorkeur ophouden; het eerste vertoont een Centrocnemis-soort, die geheel met oneffenheden; wratjes en stekeltjes is bezet en door haar vale, bruingrijze kleur hier overal we] een veiligen achtergrond vindt; het tweede kunnen wij waarnemen bij de jonge exemplaren ran Acanthaspis flavoraria,die zich zelf geheel met zandkorrels en allerlei kleine partikels omhullen en in dien toestand alleen aan de sprieten als een Reduviide zijn te herkennen. Deze dieren leveren wel een der meest saillante voorbeelden van heschermende gelijkenis, die op Java zijn te vinden en dat zij daarvan een behoorlijk gebruik weten te maken, bleek mij bij exemplaren, die ik in gevangenschap hield en die dadelijk roerloos stil zaten, zoodra er eenig gevaar naderde. In dien toestand zijn ze voor iemand, die met hunne aanwezigheid niet bekend is, niet als levende organismen te herkennen. Bij de laatste vervelling wordt echter het zanderige jasje voor goed 
afgelegd en het volwassen insect gaat verder zijn levensweg met open vizier. In dien latsten toestand gelijkt het sterk op Velitra imbropicta. ereneens rij algemeen in lit gebied, maal niet in het bezit ran de doornige uitsteeksels aan de beide achterste hoeken van het pronotum.

Het geslacht Sminthocoris, waarvan men hier de sourten singularis, pictus en rufus adntreft, trekt de aandacht donl den buitengewoon platten vorm ran het lichaam. Hoewel vrij groote insecten, zijn zij weinig dikker lan carton en de tamelijk algemeene rufius spant in dit opzicht wel de kroon. Deze lichaamsrorm wijst, zooals roor de hand ligt, op de plautsen, waal ze hun prooi zoeken, namelijk onder losse baststukken vall boomen en dgl. Daardoor behooren deze insecten al min of meer tot de detritusfauna en zij vormen een overgang naar de naverwante groep der Piratinae, die wij geheel daartoe mogen rekenen en die later nog ter sprake zal komen.

In andere richting voert het geslacht Tiarodes, dat zijn naam ontleent aan den vorm van den kop en hiel door de soort versicolor is vertegenwoordigd, naar de groej van grootere en levendiger gekleurde Roofwantsen, waarvan hierboven reeds een paar werden genoemd. Van het geslacht Ectrychotes is de soort violaceus verreweg de ineest algemeene, terwijl de bruinachtige, als vernist uitziende Pristhevarna (Ectinoderus) bipunctata, te herkennen aan een wit plekje op elken voorvleugel, wel de grootste Roofwants van Java is (ruim $30 \mathrm{mM}$. lichaamslengte). Intusschen bereiken ook sommige exemplaren van Eulyes amoena wel eens die lengte. Deze fraaie soort vertoont op een lakroode algemeene kleur een aantal metaalachtig donkerblauwe gedeelten, waarvan 
wel het meest opvalt de rij van ronde vlekken op de vliezige, zijdelingsche randen van het achterlijf. Zij knmt gewoonlijk in kleine troepjes voor, die geen bijzonder roofzuchtigen indruk maken en zelfs de vraag wel eens doen rijzen, warrvan de dieren eigenlijk leven.

Het geslacht Sycanus, hier o.a. dool S. collaris vertegenwoordigd, is gekenmerkt door een langen hals, terwijl de nogal zeldzame Yolinus sufflatus, naast dit kenmerk een eigenaardige, blazige, diep ingesneden zwelling van den achterlijfsrand vertoont. De overige Reduviiden dezer groep, die men hier nog in grooten getale kan tegenkomen, geven geen aanleiding tot bijzondere opmerkingen, zoodat nog slechts met een enkel woord moet worden melding gemaakt van een paar langwerpige vormen der Euagoras-groep, waarvan sommige Euagoras-soorten sterk aan walang-sangits doen denken, Endochus nigricornis en vooral Isyndus heros een veel gevaarlijkel voorkomen hebben.

Moge het hovenstaande al eenig denkbeeld geven van den Rhynchoten-rijkdom der bosschen, toch treedt die rijkdom eerst recht aan den dag bij de Homoptera. Dat leert ons in de eerste plaats de vallende avond, wanneer de Cicaden hun "gezang" beginnen, ons uit de grootere plaitsen eenigszins bekend door het gekrijsch van Dundubia mannifera (pag. 105). Hier is het een ware ketelmuziek, die wij te hooren krijgen, zonder evenwel, anders dan door een gunstig toeval, iets te kunnen waarnemen van de dieren, die haar voortbrengen. Want zij zitten tegen de dichtbegroeide boomstammen of in het gewirwar der takken, waar ze uiterst moeielijk 
zijn te ontclekken. Bovendien zivijgen zij, zoodra ze eenig onrad bemerken en, kont men nader, dan ziju ze met bliksemsnelheid verdwenen. Wij kunnen dus slechts vermoeden, dat de zwardere geluiden vall de grootere soorten afkomstig zijn. Zoo is er een geluid, dat klinkt als het slaan op ecn aambeeld, op eenigen afstand gehoord, en clat ik zou willen toeschrijven aan een der Pomponia-sourten, die wel tot de allergrootste rormen van deze groep behooren. Madl het kan ook afkomstig zijn van de fraaie Tosena fusciata, die een lichamslengte ran 55--60 mM. heeft en te herkennen is aan de dofzwarte, roodgeaderde vleugels, waarover, even als orel den thorax, een helder groene dwarsband loopt. Ook de breedkoppige soorten van het geslacht Cryptotympana, bij hetwelk de oogen zelfs buiten de zijlijnen van den thorax uitsteken, of die van de geslachten Platylornia en Meimuna, die meer aan het gewone tengèrret-type beantwoorden, moeten roor een krachtig aandeel in het algemeene concert worden verantwoordelijk gesteld. Een van de grappigste geluiden is dat van de, nog al bont geteekende Platypleurı nobilis, die zijn soortnaam stellig niet aan zijn gezang heeft te danken. Het klinkt, alsof een stuk kinderspeelgoed met een hoogst onaangenaam, krassend geluid werd opgewonden. Nu zou men daarmede nog vrede kumnen hebben, wanneer het afloopen iets bijzonder liefelijks te hooren gaf. Maar dit laatste bestaat uit een reeks van krijschende klanken, die, zoo mogelijk, het gehoororgaan nog ondangenamer aandoen dan de eerste reeks. Het geheel is inderdaad lachwekkend ran leelijkheid.

De meer bescheiden partijen worden vermoedelijk gespeeld door Purana- en Leptosaltria- suorten, als- 
mede door de zeer algemeene Huechys incarnata, die druk met rood is geteekend, maar vooral gekenmerkt is door de roodachtig grijze, dofzwart geaderde en gezoomde roorvleugels.

In tegenstelling met dezen rijkdom aan Cicaden, is Java arm dan zongendamde Lantaarndragers. Van het geslacht Fulgoru, dat de grootere vormen omrat, komt de soort oculata hier voor, terwijl het geslacht Pyrops is vertegenwoordigd door de bleekgroene $P$. dohrni. Beide vertoonen het groote, naar voren gerichte en eenigszins bovenwaarts gebogen, abnormaal groote uitsteeksel aan den kop, dat nuet den naam "lantaarn" wordt bestempeld, maar geen lichtgevend rermogen bezit. Zelfs heeft men in het algemeen nooit eenige functie voor dit zonderlinge orgaan kunnen aanwijzen en wij zullen vermoedelijk niet ver van de waarheid zijn door aan te nemen, dat men hier heeft te doen met een geval van zoogenaamde hypertelie, die in de tropische natuur zoo menigmaal voorkomt.

Van de verwante geslachten, die geen zoodanig orgaan bezitten, kan hier Aphana worden genoemd, waarvan de soort farinosa op Java wel de meest gewone is. Dit roodachtige insect heeft zijn soortnaam te danken aan de witte, wasachtige stof, die een groot deel van lichaam en vleugels bedekt, bij vele Homopteren van deze afdeeling voorkomt, maar. hier zeer sterk opvalt. Bij andere Aphana-soorten van Java, zooals pulchella en atomaria, vindt men haar in veel mindere mate.

Het geslacht Thessitus, gekenmerkt door een verbreeding van het kopgedeelte onder de oogen, geeft ons een paar soorten te zien, waarvan ééne den naam mortuifolia draagt, die haar voorkomen vol- 
doende aangeeft. De andere soort, Th. insignis, vertoont weder die eigenaardige, Lichenen-achtige kleur en teekening, die wij in onze onmiddelijke omgeving bij Dehaania femorata, kunnen waarnemen (pag. 96) en die door de natuur dikwijls wordtaangewend, wanneer zij een beschermende gelijkenis in het leven wil roepen. Bij de bedoelde Thessitus. soort wordt deze gelijkenis dikwijls bedorven door de overvloedige wasafscheiding aan het uiteinde van het abdomen, die als witte vlokken tusschen en onder de vleugels door te voorschijn kumt en juist weder de aandacht op het dier restigt: maar men moet hierbij niet vergeten, dat de bescherming niet tegen den mensch in het leven is geroepen, maar tegen vogels en hagedissen, die in zulk een pluizige en wollige massa rermoedelijk weinig aanlokkends vinden, gesteld al, dat hunne aandacht daardoor in gelijke mate wordt getrokken als de onze. Dat intusschen vogels, wanneer zij eenmaal hebben ontdekt, dat er goed voedsel onder schuilt, geen bezwaar ertegen hebben, deze wasachtige stof op den koop toe mede te eten, bewijst wel het op pag. 233 ten aanzien van een Cuculus sonnerati medegedeelde. Deze Flatidae, wilarvan de vroeger (pag. 215) besproken Poeciloptera stollii gevoegelijk als type kan worden beschouwd, leven in hun jeugd gewoonlijk in groote troepen bij elkaar en nu behoeft de nabijheid van een hongerigen vogel onder zulk een troep maar eenige beweging te brengen, om de aanwezigheid van een overvloedigen maaltijd te verraden.

Systematisch sluiten zij zich nauw aan de zooeven besproken vormen aan en zij zijn in de bosschen in groot aantal te vinden. Vele soorten herinneren 
in hun habitus weder sterk aan Nachtvlindertjes. Van de grootere vormen mogen hier worden genoemd Copsyrna maculata, met witte, grijs geteekende voorvleugels, Colobesthes falcata, bij welke de rose-achtig lichtbruine voorvleugels aan den achterhoek in een verlengde punt uitloopen en die een der grootste Flatidae van Java is (vleugelspanning tot $60 \mathrm{mM}$ ); Bythopsyrna circulata, met isabella-gele vourvleugels, zwartgerand en met nog twee donkere, sterk gebogen banden over het middengedeelte; eindelijk verschillende bruinachtige, soms nagenoeg ongeteekende Phromna-soorten.

Van de Membracidae verdient het geslacht Centrotus en zijn verwanten de dandacht, waarvan wij vroeger (pag. 106) reeds een paar eenvoudige vormen hebben ontmoet. De bijzonderheid dezer insecten is gelegen in het pronotum, dat dikwijls de zonderlingste en meest bizarre uitgroeiingen vertoont. In hun eenvoudigsten vorm doen zij zich voor als een parr horens (vandaar een soortnaam als taurus) en een tamelijk recht, achterwaarts gericht uitsteeksel, dat boven het achterlijf ligt, maar bij de talrijke soorten doen zich allerlei wijzigingen en complicaties van vormen bij deze uitgroeiingen voor, die deze groep tot een van de meest interessante der Rhynchoten maken. Op die bijzonderheden zullen wij hier echter niet ingaan. Volstaan moge worden met de vermelding van het feit, dat de bosschen wederom het grootste contingent ervan leveren.

De grootere soorten der Cercopidae behooren voor een aanzienlijk deel tot het geslacht Cosmocarta en zijn eveneens boschdieren, hoewel men ook buiten de bosschen wel eens verdwaalde exemplaren aantreft. Kenbaar aan het groote, veelal glimmende en 
dikwijls breedgerande pronotum, vrijwel het eenige, dat in de rust van het lichaam zichtbaar is, vertoonen zij op de groote voorvleugels niet zelden fraai gekleurde banden en vlekken op een, gewoonlijk donkeren, soms zelfs glimmend zwarten achtergrond. Soortnamen als nigripennis, tricolor, octopunctata en flavifascia, waarmede de meer algemeen voorkomende rol'men van Java zijn bestempeld, duiden dit voldoende aan.

Ook zoogenaamde Schuimdiertjes (geslacht Aphrophora e. a.) komen hier voor, maal geven hezelfde te zien als overal elders. Bovendien behooren zij tot de kleinere vormen, die hier in het algemeen buiten beschouwing moeten blijven. Zoo zijn wij ook de vormenrijke groep der Delphacinae stilzwijgend voorbijgegaan en zullen hetzelfde doen met de Jassidae, eene familie van Rhynchoten van ongeloofelijken vormenrijkdom, ook en vooral in dit gebied. Zich daarin eenigermate thuis te gevoelen, vereischt de speciale studię van weinig minder dan een menschenleeftijd. Slechts het geslacht Tettigoniella zij hier met name genoemd, omdat het een paar soorten bevat van iets meerdere grootte, waarvan de lakroode, op kop en pronotum zwart gestippelde $T$. ferruginea in dit gebied de meest algemeene is.

Terwijl de Diptera der hooger gelegen bosschen nog in een volgend Hoofdstuk ter sprake zullen komen, voor de Neuroptera naar het vroeger (pag. 509) medegedeelde moge worden verwezen, overigens eerstgenoemde orde, evenals die del Hymenoptera en der Orthoptera in de detritusfauna nog een groote rol zal blijken te spelen, moeten nog een paar 
woorden worden gewijd aan de groepen der Locustidae en der Mantidae van laatstgenoemde orde.

Vooral de eerste behoort tot de insectengroepen, waarbij de natuur, op een vrij eenvoudig patroon, met haar kleuren- en vormenmateriaal een oneindige verscheidenheid in het leven heeft geroepen. Zal niemand eenige moeite ermede hebben, zelfs de grilligst gevormde en wonderlijkst geteekende Locustide dadelijk als zoodanig te herkennen, er bestaan ten aanzien vooral van prothorax, voorvleugels en legboor een aantal vormen, dat men, door het ontmoeten van steeds nieuwe, voor onuitputtelijk zou kunnen houden. Bij den thorax bestaan ze in verbreedingen, uitgroeiingen, dorens, stekels en randen van allerlei samenstelling; bij de voorvleugels zijn het, naast de verschillende geluid-apparaten, vooral kleur en teekening, die onze aandacht trekken. Hier meenen wij een normaal, groen blad vóór ons te hebben, ginds lijkt het verdroogd of verdord. Hier is het als met krijt bestoven, elders vertoont het fraaie, oogvormige teekeningen, wederom elders meenen wij met vlekjes te doen te hehben, die door bladschimmels zijn veloorzaakt. De legboor is nu eens bijzonder groot, dan weder normaal van lengte of zelfs klein; nu eens gelijkt zij op een breed zwaard, dan eens op eels speer, een kris, een kapmes of wat niet al. Een der meest bekende en tevens een der merkwaardigste vormen dezer groep is wel de siment salak, zooals hij door de Soendaneezen wordt genoemd, Megalodon ensifer, een, niet het minst door zijn dikken, met een stekel bewapenden kop, inderdaad monsterachtig uitziend dier, waarvan de mannetjes als "vechtkrekels" in hooge eere staan en dikwijls tegen grof geld worden verhandeld. 
Van de Mantidae moet men de meest bizarle vormen meer op andere eilanden ran den Archipel zoeken, madr toch geven de bosschen van Jara nog een groote verscheidenheid van rormen te zien, die, wat thorax, kleur en teekening betreft, eenigszins parallel loopen met hetgeen wij zooeven voor de Locustidae mededeelden. Bij den prothorax zijn het vooral verbreedingen en bladrormige uitgroeiingen, die optreden, zelden stekels of een andere bewapening. Het nabootsen van verdorde blaren is hiel (o.a. hij het genus Deroplatys) nog rolkomener, terwịl wij (o.a. bij Mantis bumeisteri) ook rveder de, reeds. meermalen besproken, nabootsing ran Korstmossen aantreffen.

Terwijl de Spinnen, voor zooverre zij niet onder het afgevallen blad en elders in het verborgene leven, veelal het meest aan de boschranden zijn te vinden, waar wij reeds eenige erran bespraken en zich voorts in de hoogere, beter verlichte gedeelten van het geboomte aan onze waarneming onttrekken, wordt onze aandacht hier in den regel spoedig gevestigd op de Hooiwagens, die in de cultuurfauna volkomen ontbreken. Zij zijn hiel op Java echte boschdieren, die gewoonlijk tegen de dicht begroeide stammen zijn te vinden, maal zich ook 'garme in kleine troepen opstellen in schuilhoekjes ran allerlei aard, waar zij tegen den regen beveiligd zijn. Worden ze daar gestoord, dan is het een waal "sallve qui peut", waarbij men zich erover verbaast, dat elk dier zijn acht lange pooten zoo gauw uit de algemeene verwarring weet te redden. Vooral het geslacht Gagrella van de familie der Phalangoidae 
is hier door verschillende soorten vertegenwoordigd, die van een stevig, doornachtig uitsteeksel op het rugschild zijn voorzien en dikwijls ongemeen lange pooten hebben. Zoo bereikt het tweede paar pooten van Gagrella celerrima (vulcanica), die een lichaamslengte heeft van 3-4 mM., een lengte van ruim $10 \mathrm{cM}$. 


\section{HOOFDSTUK XXV.}

\section{De Boschfauna van $5000-7500$ voet boven zee.}

Er behoeft wel nauwelijks op gewezen te worden, dat, gegeven de formatie van Java, de totale uitgestrektheid der gebieden met groote snelheid afneemt, naarmate wij ons hooger boven het niveau der zee begeven. Wanneer men de verschillende gedeelten van het gebied, dat ons in dit Hoofdstuk zal hebben bezig te houden, naast elkander kon leggen, zouden zij vermoedelijk geen grooter oppervlakte beslaan dan die van een der kleinere Residenties. Deze uitgestrektheid zou misschien nog wel groot genoeg zijn om een fauna te herbergen, even rijk als die van het vorige gebied, wanneer de verschillende stukken werkelijk, en sinds een vroeg geologisch oogenblik, één geheel hadden gevormd. Maar het tegendeel is waar; het gebied is niet alleen versnipperd, maal bovendien van geologisch jongen datum. Dez: drie zaken, de kleinheid, de versnippering en de geringe ouderdom, maken het zonder meer begrijpelijk, dat wij hier komen te staan voor eene fauna, die het in rijkdom zeer verre aflegt tegen die der terreinen beneden 5000 voet. Hierbij komt nog, dat in Midden- en in Oost-Java de bovengrens van het echte tropische woud, met zijn rijke, gemengde flora, dikwijls aanzienlijk lager ligt dan in het vochtige Westen, zoodat de dierenwereld, welker bestaan toch 
in laatster instantie op de plantenwereld is gebaseerd, aldaar zooveel minder gelegenheid tot een veelzijdige ontwikkeling heeft gehad.

Op een hoogst belangrijke vraag kan helaas in dit werk nog geen volledig antwoord worden gegeven, namelijk deze: in hoeverre is de omstandigheid, dat op elk der afzonderlijk liggende terreincomplexen van dit gebied zich op eigen gelegenheid, onafhankelijk van de andere, een fauna heeft moeten vormen, op de huidige samenstelling van die plaatselijke fauna's van invloed geveest? Voor zooverre de grootere diervormen aangaat (en voor zooverre wij weten!) bestaat er een tamelijk groote, onderlinge overeenkomst in die samenstelling, maar wat de kleinere betreft, bevinden wij ons nog op een "terra incognita", waarover eerst onderzoekingen van toekomstige en wellicht nog ver verwijderde jaren het noodige licht zullen hebben te verspreiden. Intusschen is in die richting reeds een eerste schrede gezet, welke doet vermoeden, dat ook ten aanzien der kleinere diervormen die uniformiteit nog wel zal medevallen. Ik heb hier het oog op de interessante "Studien über südostasiatische Dipteren", die gedurende de laatste jaren door den Amsterdamschen hoogleeraar DE MEYERE in het Tijdschrift voor Entomologie zijn verschenen en die gebaseerd zijn op materiaal, dat ook uit verschillende, ver uiteenliggende gedeelten van dit gehied afkomtig is (Tosari, G. Oengaran, Diëng-plateau, G. Gedeh e. a. plaatsen). Uit deze publicaties blijkt, zoowel uit nieuwe vindplaatsen van reeds beschreven soorten, als uit de vindplaatsen van nieuwe soorten, dat in de verschillende, afzonderlijk liggende stukken van dit gebied in vele gevallen dezelfde soorten werden aangetroffen. Wanneer men 
nu bedenkt, dat het hier gaat om vliegjes ran slechts eenige Millimeters grootte, waarin zulk een rijkdom en verscheidenheid van vormen heerscht, dat men zich wel eens afvraagt, of de beschrijring en de bewerking ervan geen "onbegonnen werk” zijn, dan is het niet teveel gewaagd, de onderstelling uit te spreken, dat, in het algemeen, in de verschillende hooggelegen deelen van Java in den loop der laatste geologische perioden, onder tamelijk gelijke omstandigheden, faunistisch ook tamelijk gelijke toestanden zijn ontstaan.

Vele grootere Zoogdieren, zooals Wilde Runderen, Tijgers, Panters, Herten, Wilde Zwijnen enz, houden zich nog boven 5000 voet op of strekken, bij roedselschaarschte in lagere streken, hun tochten hierheen uit. De eenige eigen vorm van dit gehied is Prionodon gracilis, een zeer slank en fraai geteekend Roofdier, dit in voorkomen en levenswijze (voor zooverle men dazrvan iets weet) een plaats inneent tusschen de Echte Katten en de Civetkatten en dat meer in de Oostelijke, dan in de Westelijke helft ran Java schijnt roor te komen. In oudere werken vindt men roor dit dier de Javaansche namen linsang en deloendoeng opgegeven. Voor zooverre ik uit meer recente gegevens heb kunnen opmaken, mij verschaft door personen, die, te oordeelen naar de beschrijving, die zij ervan gaven, deze soort hebben waargenomen, is het een nachtdier, dat zich in moeielijk toegankelijke plaatsen, zooals bij steile en rotsachtige rivierbeddingen, ophoudt. Voor hen, die wellicht nog eens tot het doen van verdere wairnemingen in de gelegenheid zullen komen, volge hier een korte beschrijring. 
Kleur in hoofdzaak geelachtig wit; over den nek loopen donkere, langwerpige, overlangsche strepen, over den rug langwerpige, dwarse vlekken. Talrijke donkere vlekken vertoonen zich voorts op de zijden van het lichaam en op de buitenzijde der pooten, waar ze allengs kleiner worden. De staart heeft de kleur van het lichaam, maar vertoont 5 of 6 donkere ringen. Lengte van kop en lichaam $30-35$ cM., van den staart $25-30 \mathrm{cM}$.

Ook van de Vogels, die wij in de algemeene bespreking der boschfauna (Hoofstuk XXI) noemden, alsmede van de soorten, die wij in het vorige gebied ontmoetten, kunnen wij hier nog een aantal tegenkomen, maar over het algemeen wordt de avifauna toch armer, naarmate men hooger stijgt. Het bosch wordt stiller, het gevoel van eenzaamheid grooter. Reeds vroeg in den morgen pakken gewoonlijk de wolken zich samen en jagen de nevels door het geboomte. Wel is waar breekt nu en dan een zonnestraal door, soms voor langeren tijd, maar men is gedurende het grootste deel van het jaar nooit zeker ervan, dat het volgende oogenblik geen stortbui zal brengen. Den psychologischen invloed van een en ander schijnen de dieren even goed te ondervinden als de mensch; er is iets onzekers in hun opgewektheid en wat men aan gezang van vogels hoort, is haastig en wordt even plotseling afgebroken, als het begint. Wie, die de bosschen op deze hoogte bezocht, kent niet dien onzichtbaren zanger op den grond, die zijn statig lied begint op het oogenblik, waarop hij bijna gevaar loopt, onder den voet te geraken en die zich al zingende verwijdert, zonder dat het in den regel gelukt, hem tusschen de dichte plantenbedekking 
ran den bodem te zien te krijgen? Maar ook hij maakt zijn lied naar ons idée niet af; men verwacht nog iets, maar het is blijkbaar afgeloopen. Zooals zijn manier van doen reeds doet vermoeden, behoort deze zanger tot de Timeliidae; het is Brachypteryx montana, donker, blauwachtig zwart in het mannelijk, grauwachtign bruin in het vrouwelijk geslacht. Zijn gezang kan kwalijk een uiting zijn van opgewektheid; bijna zonder uitzondering heft hij het aan, wanneer hij zich eenigszins bedreigd moet achten. Hoe het zi], hij brengt eenige afleiding in de stilte dezer omgering en daarroor moeten wij hem al lankbaal zijn. In het gebergte van West-Java is hij gewoon, in de bosschen van den G. Gedeh en den Pangerango zelfs algemeen. Op den G. Semeroe heb ik hem ook gehoord, maar het geluid kivam mij niet geheel hetzelfde voor; wellicht was hier een andere, verwante Timeliide aan het woord.

Een tweede, voor ons nieuwe verschijning in de hoogere bergstreken is Zosterops fallax. Wanneer ooit een soortnam met volle recht is toegekend, dan is het zeker deze. De ornitholoog, die hem toekende, had slechts het oog op zịn bouw en zijn gevederde: had hij het dier in de rrije natuur waargenomen, hij had allicht den superlarief gekozen. Want ook in zijn manieren heeft deze vogel niets van de andere Zosterops.soorten ran Java (pag. 240). Hij is luidruchtig, trekt veelal paarsgewijze rond, zoekt niet het hoogere gedeelte van het geboomte en is, misschien door onbekendheid met den mensch, in het geheel niet schuw. Mijn eerste ontmoeting met deze soort was ergens in het dichte onderhout op den G. Gedeh, waar twee exemplaren zich op manshoogte zóó dicht voor mij neerzetten, dat ik 
ze met de hand had kunnen grijpen. Ten bewijze van de juistheid van den soortnaam zij hier medegedeeld, dat ik ze voor een Aegithina-soort hield en mij geruimen tijd bezig hield met de vraag, welke soort, van dat geslacht in deze omgeving zou kunnen voorkomen, totdat het mij op eenmaal inviel: de Brilrogel zonder bril, Zosterops fallax!

Van de Vliegenvangers houdt Rhipidura phoenicura ons in vrij groot aantal en tot zeer hoog in het gebergte gezelschap; men hoort telkens zijn driesylbig geroep. Vele andere, kleinere soorten der familie verdwijnen langzamerhand, om te worden vervangen door de Cryptolopha's, op Java door drie soorten vertegenwoordigd, waarvan de ééne hier, de andere ginds in aantal schijnt te praedomineeren: trivirgata, grammiceps en schwaneri. De eerste, die van boven olijfgroen, van onderen geelachtig groen is, ontleent haar soortnaam van drie olijfgroene strepen over den zwarten kop. De tweede heeft een helder roodbruinen kop, een witten stuit, twee evenwijdige, gele bandjes over den vleugel en de onderdeelen wit. De derde is van boven donker grijsachtig, van onderen flauw citroengeel, met uitzondering van kin en hals, die, evenals een superciliairstreep, wit zijn.

Voorts herbergt dit gebied een Fringillide, namelijk Chlorura hyperythra. Volgens waarnemingen van VORDERMAiN en van BARTELS leeft deze soort in kleine koppels in de hoogere gedeelten van het geboomte. $\mathrm{Zij}$ is van boven grasgroen, van onderen kaneelachitig bruin, terwijl de mannetjes op het voorhoofd fluweelachtig zwart, op den bovenkop fraai indigoblauw zijn gekleurd.

Het voorkomen van Duiven op deze hoogte hangt natuurlijk ten nauwste samen met de begroeiing 
van het terrein. In het algemeen kan men zeggen, dat zij even hoog stijgen als het gemengde bosch, wiarbij hun roorkomen aldaal op een bepalald tijdstip, afhangt van het al of niet aanwezig zijn van eetbare vruchten. Vooral de Jufferduiven gaan zeel hoog en ééne daarvan, Ptilopus roseicollis komt zelfs bij vourkeur in dit gebied voor:

De poejoe gonggong, Arboricola iavanica, die reeds vroeger (pag. 531) terloops werd genoemd, komt vooral in grooten getale roor in het bovenste gedeelte van dit gebied, waar het bosch ijlel en minder hoogstammig wordt en waar stukken betrekkelijk vlak terrein zijn te vinden. Zoo hoort men hem den geheelen dag en ran alle kanten in het zadel tusschen den Pangerango en den G. Gedeh, dat op circa 7000 voet boren zee is gelegen. In dergelijke onbewounde en eenzame oorden zijn de dieren veilig, terwijl in lagere en gemak. kelijker te bereiken streken druk op hen wordt gejaagd terwille van het vleesch, dat uitstekend van smaak is en ran dat van de Europeesche Patrijs herinnert.

Daar is hier nog een tweede vogel, die, ware hij minder zeldzaam, stellig ook een geliefkoosd voorwerp van de jacht zou zijn, namelijk de Boschsnip Scolopax saturata, die, volgens waarnemingen van BARTELs, ook wel eens tot 4000 voet afdaalt, maar dan in zeer vochtige en dichtbegroeide plekken der wouden. Zij is op meerdere bergen van Jara aangetroffen, maar overigens slechts bekend ran het Arfakgebergte op Nieuw Guinea, een verspreidingsgebied derhalve, hetwelk herinnert aan dat van de bekende, fraaibloemige Primula imperialis, waarvan eveneens tot heden geen bevredigende verklaring kon worden gegeven.

Een van de meest opvallende verschijselen, die de Insectenwereld op een hoogte van ongeveer 5000 
voet hoven zee te zien geeft (hier iets hooger, ginds iets lager), is het plotseling optreden van Hommels, die in de lagere streken ten eenenmale ontbreken en aldaar don' de Hontbijen (pag. 174) worden rervangen. In het grensgebied komen ze naast elkaar voor, met dien verstande, dat de weinige Xylocopa's, die op deze hoogte nog te vinden zijn, nooit in het bosch komen, terwijl de Hommels in het bosch wonen en zich slechts voor het bezoeken van bloemen diarbuiten begeven. Er is mij van Java slechts ééne soort bekend, namelijk Bombus rufipes, bij welke echter het rood der pooten grootendeels duor de dichte, zwarte beharing geheel wordt verborgen, zoodat men haar wel als eene variëteit obscuripes heeft onderscheiden. Zij komt algemeen in drie grootten voor: de grootste afmetingen bereiken de wijfjes, iets kleiner zijn de mannetjes en nogkleiner de arbeidsters. Alle zijn geheel zwart en sterk zwart behaard, zoodat de gele stuifmeelklompjes, die de arbeidsters en soms ook de wijfjes op de schenen samenpakken, door hun kleur reeds op een afstand, en zelfs in de vlucht, duidelijk waarneembaar zijn. Van eenige periodiciteit in de ontwikkeling dezer dieren heb ik op Java nooit iets bemerkt; men vindt, ze gedurende het geheele jaar in een vrij gelijk aantal. Zij nestelen in den grond, het liefst aan de oevers van beekjes, maar overigens ook elders. Hun natuur is zeer goedaardig en zelfs bij hinderlijke stoornis bepalen zij zich tot een brommende demonstratie.

Onder de overige Hymenoptera van dit gebied vallen ons nu en dan blauwe Bladwespen op, die volkomen op de Europeesche Hylotoma's gelijken, doch dergelijke dieren zijn zelfs hier zeldzaam en hun rupsachtige larven heb ik nog nooit gevonden. 
Aan Dipteru is hier allerminst gebrek, maar vormen, die door humue afmetingen bijzonder in het oog vallen, zijn hier schaalsch en van de overige weet men nog maar zeer weinig. Een moeielijk te schatten, maar ongetwijfeld zeer aanzienlijk procent vliegt hier nog onbeschreven rond, zooals uit het volgende kan blijken. In 1911 maakte ik een tocht van vier dagen naar de, boren 5000 voet gelegen gedeelten van den Pangerango en den G. Gedeh, waarbij ook aan de Diptera.zooveel mogelijk aandacht werd gewijd en, onder meer, een aantal Syrphidae werden verkregen, die later aan den Dipteroloog Prof. DE MEIJERE te Amsterdam werden gezonden, door wien ze sedert zijn bewerkt in diens bovengenoemde "Studien über sïdostasiatische Dipteren". Van de 11 soorten van Syrphidae, welke deze kleine verzameling bleek te bevatten, waren slechts twee reeds van elders beschreven, acht waren geheel nieuw en ééne werd als nieuwe variëtiet aan een reeds beschreven soort toegevoegd. Wanneer men nu bedenkt, dat deze Syrphidae door hun kleuren en afmetingen hier nog tot de meest in het oog vallende Insecten behooren, die derhalve door verzamelaars in het algemeen nog eerder dan andere rormen worden verkregen, dan behoeft men wel niet te vragen, hoe het gesteld is met onze kennis van de kleinere insectenvormen der hoogere bergstreken in het algemeen.

De grootere vormen zijn in hoofdzaak een opwaartsche voortzetting van die van het vorige gebied, waarbij men, al stijgende, den éénen iets eerder, den anderen iets later van het tooneel ziet verdwijnen, zonder door andere te worden vervangen. 


\section{HOOFDSTUK XXVI.}

\section{De Detritus-fauna der Bosschen.}

Zooals ivij, bij de bespreking der Detritus-fauna van het Cultuurgebied (pag. 408) reeds gelegenheid hadden op te merken, zijn de warmere streken volstrekt niet de plaatsen, waar dit gedeelte van de dierenwereld zijn hoogste en vormenrijkste ontwikkeling vertoont. Door de hooge temperatuur gaat de ontleding der doode stof zóó snel in haar werk, en door de werkzaamheid van diervormen als Termieten wordt een aanzienlijk deel van die stoffen bovendien zóó spoedig opgeruimd, dat voor de ontwikkeling van een gecompliceerde fauna, warvan de bestanddeelen in onderlingen, biologischen samenhang staan, feitelijk niet voldoende tijd overblijft. Anders wordt het, wanneer men, al stijgende, de grens der tropische warmte overschrijdt en op terreinen komt, waar de gemiddelde temperatuur niet meer dan 15 tot 20 Centigraden bedraagt, met slechts zeer geringe schommelingen in haar jaarlijksch verloop. Dáár heeft-ik bepaal mij nu tot de bosscheneen langzaam verloopend ontledingsproces plaats, dat gevoed wordt door den onafgebroken en overvloedigen afval der rijke flora en begunstigd door de noodige hoeveelheid vocht. Bovendien wurden de, zooeven bedoelde, snelle opruimers hier schaarsch, wat vooral van invloed is op de verrotting en vermolming van meer massieve plantendeelen, zooals 
afgebroken takken en omgevallen stammen, die hier soms vele jaren noodig hebben om te verdwijnen.

In de volgende bladzijden zal worden getracht een overzicht te geven van de detritus-fauna, zooals zij zich op haar rijkst voordoet en vooral op een hoogte van circa 5000 voet is te vinden. De lezer moge dan bedenken, dat zij zoowel in benedenwartsche richting (om de genoemde redenen), als in bovenwaartsche) om de lage temperatuur en den geringeren afval) in rijkdom aan vormen en individuen afneemt. Daaraan zi.j toegevoegd, dat ik bijna al mijn waarnemingen over dit onderwerp verrichtte in de bergwouden van den G. Gedeh, maar dat meer vluchtige en terloops ingestelde waarnemingen elders steeds tot vrijwel gelijke resultaten hebben geleid.

Het komt mij voor, dat ook hier de grondlaag van het dierlijk leven bestaat uit Dipterenlarven, die zich rechtstreeks met den detritus en zijn sappen voeden. Maar in dit laatste rinden zij hier veel meer concurrentie dan in de Cultuurfauna, met name van de zijde van kleine Slakjes, alsmede van Wormen, van welke men sommige fraai gekleurde Planariën dikwijls opgerold, maar overigens open en bloot, op een vochtig, rottend blad kan zien liggen. Voor het meerendeel behooren deze dieren tot het ons reeds van vroeger bekende geslacht Bipalium, dat zich kenmerkt door een duidelijk van het lichaam te onderscheiden kop, die bij de meeste soorten den vorm eener halve maan heeft. Bij andere, in den regel kleinere en daardoor minder in het oog rallende soorten (van de geslachten Geoplana e. a.), die door hun slijmerig voorkomen echter dadelijk als Planariën zijn te herkennen, loopt het lichaam aan beide einden versmald uit en is het kopgedeelte slechts bij nauw- 
keurige waarneming aan de aanwezigheid van twee of meer oogvlekken te onderscheiden.

Laten deze dieren den wandelaar volkomen met rust, hetzelfde kan niet worden gezegd van een andere groep van Wormen, die in den detritus dikwijls maar al te rijk naar onzen zin is vertegenwoordigd, namelijk de Bloedzuigers. Het is wel aan te nemen, dat het meerendeel hunner zich onder normale omstandigheden voedt met willekeurig vocht, dat organische resten bevat (zooals wij dat 0 . a. ook moeten aannemen van de millioenen Muggen, die in de mangrove- vegetatie leven), om de eenvoudige reden, dat ze niets anders tot hun beschikking hebben. Daarom moet men zich verbazen over de buitengewone vindingrijkheid, die ze aan den dag leggen om te kunnen profiteeren van de gelegenheid tot een beteren maaltijd, wanneer die zich onverwacht en in den regel niet langer dan gedurende eenige seconden voordoet. Vooral in regenrijke tijden zijn de bosschen rijk aan kleine vertegenwoordigers van het geslacht Haemadipsa van de familie der Herpobdellidae en het is alsdan bijna niet mogelijk, een tocht door het bosch te maken, zonder door deze dieren te worden aangevallen. Gewoonlijk houden zij zich onder het afgevallen blad op, maar een enkele maal vindt men ze ook wel eens op natte takken en bladeren van het onderhout, waarheen zij zich "op hoop van zegen" hebben begeven. Komt die zegen in den vorm van een passeerenden homo sapiens, dan kan men er zeker van zijn, dat de Bloedzuiger op het juiste oogenblik zijn sprong weet te nemen, maar even zeker weten de dieren den voorhijganger ten slotte te vinden, wanneer diens voet slechts een oogenblik wordt neergezet in de nabijheid van 
hun verblijfplatts op den grond. De reukzin, in het algemeen de speurzin van deze Bloedzuigers moet ongel wofelijk hoog ontwikkeld zijn: want de moeielijkheid begint voor hen feitelijk pas, wanneer zij zich onopgemerkt op de buitenzijde der kleeren bevinden en een doorgang moeten zoeken naar de huid ran hun niets rermoedenden gistheer. Deze moeielijkheid weten zij echter in den regel glansrijk te orerwinnen en men staat dikwijls verbaasd erover, hoe zij in den dooltof ran kousen, laarzen, hroek en puttee's nog een weg hebben weten te rinden. Veel hinder verorzaken zij intusschen in den regel niet; tegen den tijd, waarop zij zich hebben volgezogen en het van den omvang van een lucifer tot dien van een potlood hebben gebracht, begint het geina akte wondje jeuk te reloorzaken en daardoor eerst wordt de schuldige ontdekt.

Een derde groep van Wormen, die in dit gebied goed zijn rertegenwoordigd, zijn de Lumbriciden en rall deze verdient vooral de aandacht Perichaeta musica, die haal soortnaam ontleent aan het geluid, dat zij, op nog niet verklaarde wijze, kan voortbrengen. Vermoedelijk wordt het reroorzaakt door onderlinge wrijving der talrijke lichaamsringen bij de sterke inkrimping en uitrekking van het lichaam, waartoe deze dieren, evenals alle Regenwormen, het vermogen bezitten. Meer nog trekt dit dier de aandacht door de reusachtige afmetingen, die oude exemplaren kumnen bereiken en waardoor zij op het eerste oogenblik den indruk maken van Slangen, wanneer men ze tusschen het afgevallen blad ziet schuifelen. Meermalen nam ik individuen van 40 tot $50 \mathrm{cM}$. waar. Volgens de inlanders zouden de jonge exemplaren dezer diersoort zijn te vinden in 
de groote pollen der pakoe kedaka (Asplenium nidus) die men in de bosschen allerwege als epiphyten in in het geboomte aantreft en die steeds groote hoereel- . heden zelf gevormde en opgevangen detritus bevatten. Het is waar, dat men daarin niet zelden Lumbriciden aantreft, doch voor zooverre ik die onderzocht, waren het steeds exemplaren van kleinere vormen, die vermoedelijk door tusschenkomst van vogels daar waren terecht gekomen. Het kan namelijk licht gebeuren, dat de helft van een buitgemaakten Regenworm, waaraan zich een clitellum met bevruchte eieren bevindt, aldaar onopgegeten blijft liggen of tusschen de blaren van zulk een varen weet te ontsnappen.

Echte detritus-dieren zijn hier ook de Duizendpooten, van welke men hier alle geslachten, en voor een deel ook dezelfde soorten, kan terugvinden, die reeds bij de Cultuurfauna (pag. 189) werden genoemd. Het meerendeel ervan houdt zich op nabij of op den grond, maar vele grootere Polydesmidae loopen gaarne tegen natte boomstammen en zijn dan tusschen de fijne, mosachtige vegetatie, die zich gewoonlijk daarop bevindt, zeer in het oog vallend. Vele der kleinere vormen zijn vooral in en op rottende boomstammen te vinden. Wij kunnen hier weder het verschijnsel waarnemen, dat het bij dieren, die gedurende hun geheelen levenscyclus in het verborgene leven, zooals het meerendeel der kleinere Myriapoden, in veel mindere mate dan bij andere, tot een scherpe scheiding tusschen vormen der wildernis en vormen van het cultuurgebied is gekomen. Die groote Polydesmidae ziet men bijroorbeeld zelden of nooit buiten het bosch; van de kleinere vormen hebben beide terreinen zelfs meerdere soorten gemeen. 
Om dezelfde reden komen wij hier ook van de Schorpioenen vele oude hekenden tegen, wanneer wij ons de moeite geren, ze in hun schuilhoeken, bij voorkeur langs de randen der beekjes, te gaan opspeuren. Aan de rroeger (pag. 181) genoemde vormen kunnen wij rool dit gebied nog toeroegen Chaerilus variegatus, die zich door een meer gedrongen bouw ran andere Schorpioenen ran dezelfde lichaams.

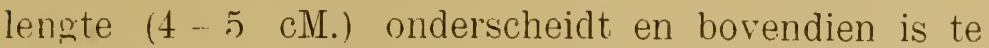
herkennen aan de lichte kleur tusschen de praeabdominale geledingen, waaraan hij trouwens zijn soortnaam ontleent. Ook de Phrynichidae, die zich in soortgelijke schuilplaatsen als de Schorpioenen ophouden, hehooren bij uitnemendheid in dit gebied thuis. Inzonderheid levert Phrynichus phipsoni hier zeer groote exemplaren, bij welke de zweepvormige uiteinden van het voorste paar pooten soms een lengte van 12 cM. bereiken. Deze aanhangsels, die de dieren met groote zorgruldigheid ongedeerd door de beperkte ruimten, waarin zij zich gewoonlijk bewegen, weten mede te voeren, doen, zooals hun voorkomen reeds doet vermoeden, als tastorganen dienst. De oogen, die, ten getale ran acht gewoonlijk behoorlijk ontwikkeld, aanwezig zijn, kunnen uit den aard der zaak eerst goede diensten bewijzen, wanneer het dier, door zijn tastorganen op de aanwezigheid van een prooi opmerkzaam gemaakt, uit zijn schuilplaats teroorschijn komt. Er zijn echter ook Phrynichidae met gereduceerde gezichtsorganen, die derhalve geheel of gedeeltelijk op hun tastorganen zijn aangewezen.

Een zeer merkwaardig detritus dier is de Amphipode, waarop reeds vroeger (pag. 400) werd gezinspeeld. Bị mịn onderzoekingen orer dit deel der 
fauna, die voornamelijk in den vrij drogen (maar in de bosschen toch altijd nog voldoende rochtigen) Oostmoesson van 1913 plaats hadden, werd mijn aandacht al zeer spoedig getrokken door betrekkelijk groote dieren, die overal tusschen het afgevallen blad in grooten getale aanwezig waren, maar op de wijze van Vlooien zóó snel weg sprongen (en dan in den regel spoorloos verdwenen waren), dat ze op het terrein zelf uiterst moeielijk te bemachtigen bleken. Het viel echter niet moeielijk, een voldoende aantal ervan te verkrijgen in een hoogwandigen, glazen bak, waarin snel een paar handen vol afgevallen blaren met de medekomende aarde en verderen detritus werden geworpen. Eenigszins tot mijn verbazing bleek deze diersoort eene Amphipode te zijn, en geheel overeen te komen met de beschrijving van Orchestia parvispinosa, door MAX WEBER in 1888 in dezelfde streek "onder steenen en vermolmend hout" aangetroffen ${ }^{*}$ ). Het bestaan dezer diersoort was mij uit die beschrijving wel bekend, maar ik had inderdaad niet verwacht, dat zij in de fauna van het afgevallen blad, ook op de droogste plekken, een eerste viool zou blijken te spelen. De dieren zijn in levenden toestand donker grondkleurig bruin, maar nemen in spiritus reeds na eenige oogenblikken een fraaie, zalmkleurige tint aan.

De Isopoda treden hier iets meer op den voorgrond dan in het cultuurgebied, maar spelen toch nog een tamelijk bescheiden rol. Van het reeds op pag. 194 genoemde geslacht Philoscia is de soort pallida hier de meest gewone.

${ }^{*}$ Zoologische Ergebnisse einer Reise in N. O. I.; Bd. II. pag. 566 . 
$\mathrm{Na}$ de Orchestia's trekken in het afgevallen blad de Apterygotu vooral onze aandacht, omdat zij eveneens door groote, springende soorten zijn vertegenwoordigd. Deze verkrijgt men zeer gemakkelijk, door op het te onderzoeken terrein hier en daar eenige vellen wit papier neer te leggen en dan de blaren met de handen om te woelen. Een aantal komt dan bij hun sprong op die papieren terecht en blijft daar rustig genoeg zitten, om onder een klein glazen buisje te worden gevangen. Vooral een paar Lepidocyrtus-soorten zijn zeer algemeen en talrijk; ze zijn tamelijk groot (met inbegrip van den springstaart ongeveer $6 \mathrm{mM}$.), maar lijken, vooral op het witte papier gezien, nog veel grooter, doordat ze geheel bedekt zijn op opstaande, harige schubben, die ze bij conserveering in alcohol bijna geheel verliezen, maar die aan het levende dier een zeer bijzonder aanzien verleenen. Evenals de Entomobryasoort, waarvan sprake was op pag. 489 , houdt men deze dieren op het eerste gezicht voor geheel iets ander's, dan ze in werkelijkheid zijn.

De Rhynchota zijn in de detritus-fauna vertegenwoordigd door een vrij groot aantal geheel zwarte, of althans donker gekleurde Lygaeidae en Reduviidae van middelmatige tot kleine afmeting. Zoowel verspreid op den grond, als onder de schors en in het vergane hout van afgestorven boomen en gevallen, rottende stammen kan men ze in groote verscheidenheid aantreffen. Van de Lygaeiden mogen hier worden genoemd Lygaeus hospes, die voor deze omgeving nog tamelijk druk met rood is gekleurd; Graptostethus servus; Pamera annulicornis; Bochrus poecilopterus, zeer plat van lichaamsbouw en met 
ongemeen zwaar gebouwde achterpooten, die hem relmoedelijk in staat stellen, zich met kracht in allerlei spleten te dringen; eindelijk verschillende Pachymerus- en Eucosmetus-soorten, waarbij er zijn, die, wellicht slechts ter verdediging, ook den mensch gevoelige steken kunnen toebrengen. Van de kleine, naverwante familie der Aradidue kan men hier den dofzwarten korstigen, eveneens tamelijk platten Brachyrhynchus orientalis soms in grooten getale aantreffen.

Van de Reduviiden zijn het, zooals vioeger reeds werd opgemerkt, vooral de Piratinae, die tot de detritus-fauna behooren: Pirates affinis en andere soorten van hetzelfde geslacht, Cleptocoris atromaculatus en Sirthenea flavipes zijn hier wel de meest opvallende roovers, die men vaak tusschen het natte blad en op rottende boomstammen aan het fourageeren vindt.

Van de Orthoptera vallen hier in de eerste plaats de Blattidae te noemen. Eerst, hier bemerkt men, dat deze familie toch nog andere vormen heeft aan te wijzen, dan die ons uit het dagelijksch leven en steeds in ongunstigen zin bekend zijn. Daar zijn er; die men, zoowel door hun kleur, als door hun lichaamsbouw, dadelijk als nauwe verwanten onzer Huiskakkerlakken herkent, en andere, die zich vooral door kleur en teekening daarvan onderscheiden en door beide in hun omgeving moeielijk te onderscheiden zijn. Geslachten als Pseudophoraspis, Epilampra en vooral Morphna leveren daarvan goede voorbeelden. Maar er zijn er ook, die in algemeen voorkrmen afwijken van de bovenbedoelde vormen, zooals de groote, diklijvige en zeer harde Panesthia aethiops, die eenige overeenkomst met een Passalide vertoont. 
Eindelijk vindt men in het bosch ook tal van soorten, die in hct vrouwelijk geslacht ongevleugeld zijn en van deze is de merkwardigste vorm zeker wel de l'uwe, leerachtige Catara minor, die, als men pooten en sprieten buiten beschouwing laat, aan een $Z e$ phronia doet denken.

Onaanzienlijke Gryllidae zijn hier voorts te kust en te keur te vinden, maar bieden minder verscheidenheid in roorkomen aan dan de eveneens talrijke Tetrigidae, die naar alle zijden wegspringen, wanneer men slechts het gevallen blad met den voet omwoelt. Evenals bij de Centrotus-groep der Homoptera, is hier het pronotum in zijn verschillende vormen een van de hoofdoorzaken der verscheidenheid. Bij alle soorten is het sterk naar achteren verlengd, zoodat het geheele lichaam eenigermate erdoor wordt beschermd, maar bovendien vertoont het allerlei uitsteeksels en uitgloeiingen, die aan sommige soolten een vreemd voorkomen verleenen.

De grootere Gryllidae treft men niet op, mar soms tamelijk diep in den lossen buschgrond aan, waar ze tegen den avond hun eentonig, soms snerpend, soms brommend lied aanheffen. Het is hier al $\in$ ven moeielijk, on niet te zeggen ondoenlijk, als bij de Cicaden, om na te gaan, welk geluid een bepaalde soort voortbrengt, maar men mag wel aannemen, dat de $z$ waarste basstem in het arondconcert wordt aangeheven door Gryllus orientalis (?), een krekel, die door zijn afmetingen en voorkomen tot het afzichtelijke nadert.

Eindelijk de Forficulidae, van welke men hier de grootere en vooral de, van een grooten forceps voorziene vormen te zien krijgt, zooals Eparchus insignis en E. tenellus, Pygidicrana marmoricrura en 
P. pallidipennis, alsmede Echinosoma sumatranum, die van een meer gedrongen gedaante is dan de eerstgenoemde vorinen, slechts een kleinen forceps heeft, maar te herkennen is aan de korte, dikke borstels en de tamelijk lange, geelachtige haren, waarmede het geheele lichaam is bezet. De functie van den forceps is mij steeds even duister gebleven als die van het "gewei" der Lucanidae, van den tang van Xylotrupes en meer dergelijke vormingen, die er wel gevaarlijk en geducht uitzien, maar overigens nog minder kwaad kunnen uitrichten dan een staatsiedegen, daar ze voor de dragers nooit een oorzaak tot struikelen kunnen worden.

De Coleoptera hebben in de detritus-fauna een paar zeer merkwaardige vormen aan te wijzen en wel in de eerste plaats de Carabide Mormolyce phyllodes, een der paradestukken van kevercollecties. Terwijl de larven, die zich in de spleten en andere schuilhoeken van rottende boomstammen ophouden (SHelford nam ze op Borneo waar in holten tusschen deze stammen en de daarop groeiende Polyporeeën), vrijwel aan het gewone type der familie beantwoorden, zijn de imagines gekenmerkt door een zeer plat lichaam, een langen hals, een ongeveer even langen, verbreeden en langs de zijden gedoornden prothorax en zeer groote, op de zijden en naar achteren bladvormig uitgegroeide dekschilden. Voegt men daarbij nog de lange, draadvormige sprieten en de zeer lange, dunne pooten, dan kan men zich voorstellen, welken vreemden indruk dit dier moet hebben gemaakt op den natuuronderzoeker, die het voor het eerst in handen kreeg. Zelfs waar men de aanwezigheid van het dier verwacht, geeft het nog eenige emotie, 
wanneer men het, bij het moeizaam omkeeren van een groot stuk rottend hout, plotseling vóor zich ziet. Die emotie schijnt intusschen wederkeerig te zijn; want het dier blijft een oogenblik als verstijfd van schrik zitten, maar neemt daarna de vlucht, zoo snel als zijn lange pooten hem maar dragen kunnen.

Evenals Mormolyce, komt de bekende "larve van PERTY" het menigvuldigst voor in bosschen van geringe tot middelmatige hoogte boven zee; zij houdt zich eveneens het liefst op aan de onderzijde van rottend hout, maar wandelt ook wel eens vrij daarop rond. Naar alle waarschijnlijkheid behon't zij tot het geslacht Lamprophorus van de familie der Lam. pyridae, maal aangezien het volwassen mannetje nog niet bekend is en het volwassen wijfje geheel den vorm der larve behoudt, bestaat dienaangaande nog geen zekerheid. Een van de bijzonderheden van deze zwarte, met bruin geteekende, platte en fraai gelede dieren, die ons onwillekeurig aan Trilobieten doen denken 1), is wel de aanwezigheid van een vleezige schijf, die uit de anale opening te voorschijn komt en bij het loopen als "naschuiver" dienst doet. Merkwaardig zijn verder de korte, vleezige sprieten, die uit twee schuin naar voren gerichte openingen worden uitgestulpt en aan het uiteinde eene onregelmatig afgebroken, dunne chitinebekleeding, alsmede eenige zintuigharen dragen. De volwassen wijfjes bezitten geen naschuiver, doch vertoonen aan den achterrand der voorlatste geleding van het abdomen een heuvelvormige verhevenheid, die door vijf papillen is omgeven en nog tot het laatste lichaamssegment behoort. Tusschen deze papillen komen de eieren te

1) Vgl. mijn opstel over deze dieren in „De Tropische Natuur”, Deel I, pag. 17 . 
voorschijn, die ook zonder voorafgaande paring in vrij groot aantal (gemiddeld 60) en afzonderlijk worden gelegd, maar alsdan niet uitkomen. Uit de omstandigheid, dat bij talrijke kweekproeven, die door anderen en mij met deze dieren werden genomen, nooit mannetjes werden verkregen, moet men wel opmaken, dat de laatste tamelijk gering in aantal zijn. Onder de Javaansche Lampyridae, in het Museum alhier aanwezig, is geen enkele soort aanwezig, die, wat afmetingen - betreft, bij de groote, vrouwelijke dieren zou passen. Mijn vermoeden aangaande het genus berust op exemplaren van Sumatra.

Behalve de beide besproken Kevervormen herbergt, zooals wel nauwelijks behoeft te worden gezegd, de plantaardige detritus een heirleger van veelal kleinere Carabidae, alsmede van Staphylinidae. Scydmaenidae, enz. enz., maar het ligt niet op onzen weg, daarop nader in te gaan.

Overblijfselen van dierlijken aard vindt men slechts zeer weinig en daarmede houdt wel verband de zeldzaamheid van Silphidae (Aaskevers) op Java; wall in de natuur op andere wijze voor de opruiming van het afgestorvene wordt gezorgd, vindt de Doodgraver geen bestaan. Slechts éénmaal heb ik eenige exemplaren van deze familie gezien, die in de nabijheid eener hooggelegen onderneming waren gevonden. Zij gaven mij den indruk, tot het geslacht Necrophorus te behooren, geleken althans sterk op den Hollandschen $N$. vespillo. Er zijn echter gedeelten van het dierlijk lichaam, zooals beenderen en hoeven, die langeren tijd blijven liggen, en daaronder vindt men wel eens Trox costatus van de familie der Coprophaga, terwijl onder de uitwerpselen 
van grootere Zoogdieren, die hier overigens ook niet veelvuldig zijn, behalve de gewone Ontophagus. en Copris-soorten, wel eens fiaai blauwe vertegenwooldiger's van het geslacht Saprinus van de familie der Histeridae zijn aan te treffen.

Zooals hierboven reeds werd opgemerkt, zijn larven van Diptera in ongeloofelijke hoeveelheid en ver. scheidenheid in den vochtigen detritus op den bodem en elders te vinden en het behoeft daarom niet te verwonderen, dat de volwassen vormen in overeen. komstigen overvloed aanwezig zijn. 'Toch schijnen de Diptera - en waarschijnlijk ook de meeste andere insecten van dit gebied-tijdens den toestand van larve of van pop te worden gedecimeerd op een wijze en tot een percentage, waarvan men vioeger niet het geringste vermoeden had. Dit is mij gebleken bij-de onderzoekingen, die ik in 1913 in dit gebied instelde.

Daal het mij namelijk was opgevallen, dat men, ook op zonnige plekken, betrekkelijk zoo weinig vliegende, insecten kon waarnemen, terwijl ze er toch in groot aantal moesten zijn, besloot ik eenș een methode van verzamelen toe te passen, waarbij minder werd gelet op den ongeschonden toestand van het verzamelde, dan op de hoeveelheid ervan. Die manier bestond in het heen en weer zwaaien, even boven den grond, van een insecten-net met vrij diepen zak, en daarbij langzaam roortloopen: Het net moet daarbij zóó snel worden bewogen en voortdurend zóó worden gekeerd, dat de kans van ontsnappen voor de gevangen dieren zoo gering mogelijk wordt. Na eenige minuten verzamelens werd het net plotseling gesloten, door het een halven slag on te slaan, en de buit naar huis gebracht. 
Daarna werd een groote glazen stolp horizontaal gelegd, met het gesloten einde naar een venster, en het net geopend voor de onderzijde gehouden. Alles wat nog vliegen kan, begeeft zich alsdan snel naar het licht. Reeds de eerste maal was het resultaat verrassend. Het aantal geheel of nagenoeg ongeschonden insecten, dat in de stolp kwam, bleek ruim 400 te bedragen en de rest in het net, die erg beschadigd of reeds gestorven was, ruim 1000 . Het verzamelen had nog geen tien minuten geduurd. De geheele buit bleek voor meer dan $90 \%$ uit Diptera en Hymenoptera te bestaan en wel in ongeveer gelijke hoeveelheid. Het overige waren Kevertjes, allerlei kleine Lang-en Rnofwantsen, Tetrigidae, een paal Orchestia's enz. enz. Het meest trof mij natuurlijk die rijkdom aan Hymenoptera; want de Diptera had ik verwacht. In een ongeloofelijke verscheidenheid van vormen bleken Evaniide, Braconidae, Ichneumonidae, Proctotrupidae, in één woord alles wat tot de groote biologische groep der Sluipwespen en vooral tot de kleinere vormen daarvan moet worden gerekend, in het verzamelde.aanwezig te zijn.

Op deze wijze werd een aanzienlijke hoeveelheid materiaal verkregen, waarvan, onder mededeeling van de wijze waarop en de plaats, waar het was bijeengebracht, de Diptera werden gezonden aan Prof. DE MeiJere te Amsterdam, de Hymenoptera aan den Engelschen entomoloog Claude Morley, die duor zijn bewerking van de Ichneumonidae in de "Fauna of British India" geacht mocht worden, het verzamelde het best te kunnen beoordeelen. Onder opmerking, dat de bewerking van een zoo omvangrijk en grootendeels onbekend materiaal eerst zeer geleidelijk zou 
kunnen plaats hebben, schreef laatstgenoemde onder ineer in zijn antwoord: "they are quite a revelation to me for (though I had suspected that collectors mainly took the larger and more conspicuous kinds) I had no idea that these minute and obscure species were so numerous in Java and consequently probably in India".

Aan het antwoord ran Prof. DE MeiJere moge het volgende worden ontleend, waardoor de lezer van de meest bevoegde zijde wordt ingelicht omtrent de hoofdtrekken der samenstelling van wat zich aan Diptera in den detritus bevindt:

"De samenstelling van het materiaal doet denken aan wat men bij ons op beschaduwde, niet bepaald vochtige plekken vangt. Van Cecidomyiden is er slechts één enkel exemplaar; van Mycetophyliden eenige Sciara's en verschillende andere soorten, meest in enkele exemplaren. In warme streken van Java is deze familie schaarsch. Verder zijn er een paar Simulium's, een parl Ceratopogon's, een Culex en een kleine Tipulide. De Stratiomyiden zijn door ééne soort vertegenwoordigd, de Empiden eveneens (eene Tachydromia, in talrijke exemplaren). Dolichopodiden zijn er vrij veel, verscheidene soorten, echter geen Psilopus, welk genus op Java overigens zoo talrijk is vertegenwoordigd. Van Phoriden zijn er ook verscheidene soorten. Asiliden, Bombyliiden, Srrphiden enz. zijn er niet bij. Van Calyptraten vind ik er verscheidene Anthomyiden en een Tachinide onder. Van de familie der Acalyptraten zijn de Borborinen het best vertegenwoordigd; het genus Limosina levert door zijn aantal exemplaren de hoofdmassa vall het gehecle materiaal; vooral een kleine soort met donkere vleugels is talrijk. Overigens zijn er ook rrij wat 
$-612-$

Drosophiliden, enkele Sapromyziden, een Ortaline, 2 Chloropiden en ook een Heteroneuride in éen exemplaar onder." 


\section{HOOFDSTUK XXVII.}

\section{De Fauna van het Hooggebergte.}

De gezamenlijke oppervlakte, die op Java in beslag wordt genomen door terreinen boven 7500 voet zeehoogte, is slechts zeer gering in vergelijking met het geheel en bedraagt vermoedelijk niet meer dan $1 / 100$ percent daarvan. Bovendien zijn in Midden-en Oost-Java nog aanzienlijke gedeelten ervan zonder vegetatie van beteekenis, zoodat ook de dierenwereld aldaar vrijwel geheel ontbreekt.

Wanneer men de zoogenaamde vierde zône van JuNGHUHN heeft bereikt, die samenvalt met hetgeen wij hier als hooggebergte hebben aangeduid, worden in de eerste plaats de grootere dieren schaarsch. De dagen zijn voorbij, waarin, zooals JunghuHs nog weet te verhalen, groote kudden Herten in de tjemarabosschen op de hoogere gedeelten van den Ardjoeno rondzwierren ell Neushoorndieren zich op meerdere bergtoppen hun vaste wegen baanden. Plaatsnamen als Kandang badak (het zadel tusschen den Pangerango en den G. Gedeh, op 7500 voet zeehoogte) hebben nog slechts historische beteekenis. Van de grootere Roofdieren, inzonderheid van den Tijger, gaat het verhaal, dat zij zich, wanneer zij zich zeer ziek gevoelen of hun einde voelen naderen, naar de hoogste gedeelten van het gebergte begeren, om dààr rustig te sterven. Wilde Zwijnen komen hier nog roor, wanneer er voor hen maar iets te 
eten valt, zooals de Balanophora's in het hooggebergte van West-Java (pag. 425).

Slechts één Zoogdier is in zijn voorkomen tot dit gebied beperkt, althans nooit elders waargenomen, namelijk een Wezel, Mustela flavigula. In andere gedeelten van zijn verspreidingsgebied, bijv. op Sumatra, komt dit dier in veel lager gelegen streken voor, doch iets dergelijks is met meerdere diersoorten het geval en moet wel grootendeels op rekeuing worden geschreven van het lange tijdperk, gedurende hetwelk Java reeds tamelijk dicht bevolkt en bebouwd is geweest en van den onmiskenbaren afkeer, dien sommige diersoorten van den mensch schijnen te hebben. Salomon Mulder vertelt in zijn verhan deling "Over de Zoogdieren van den Indischen Archipel", dat hij op zijn vele tochten over Jara dezen Wezel slechts tweemaal ontmoette, "de eerste reis ongeveer ter hoogte van 1500 ellen boven het zeerlak, op den berg Tangkoeban Prahoe, waar twee individuen op de naakte steerien, langs den rand van den grooten krater diens vulkaans rondsprongen; en de tweede reis, onder genoegzaam dezelfde omstandigheden, in de nabijheid des vuurhaards van den berg Gedé, op een hoogte van ruim 2500 ellen."

Het is mij nooit gelukt, een exemplaar van deze diersoort te zien, hoewel ik bij het bezoeken van beide plekken wel eenige hoop daarop had, in verband met hetgeen op pag. 480 werd opgemerkt ten aanzien van Pieris pandione op den Poentjak. Die hoop werd bovendien nog verlevendigd door een andere waarneming op den kraterrand van den G. Gedeh. JunghuHN vertelt namelijk, dat hij bij het bereiken van dien krater aldaar een paar exemplaren van den Lijster Merula javanica zag l'ondhuppelen, eene 
diersoort, die eveneens tot dit gebied is beperkt. Dat was omstreeks 1860 . 'Toen ik, ongeveer j0 jaar later, na den $G$. Gedeh van den Westzijde te hebben beklommen, buiten het kreupelhout kwam en vij plotseling voor de steile, hier en daar loodrechte binnenhelling van den geweldigen krater stond, was het eerste, dat ik daar zag, op weinige Meters aftand, eveneens een par van deze Lijsters, die zich op uitspringende r'otsstukken aan Vaccinium-vruchtjes te goed deden.

Oorspronkelijk werd deze vogelsoort van het hooggebrigte, die op verschillende bergtoppen van West- en Midden-Java is wargenomen, onder den naam Merula javanica beschreven. Er bleken echter kleine verschillen te bestaan, die aanleiding ertoe gaven, dat de vorm ran West- Java als Merula fumida werd onderscheiden van die van Midden- Java, voor welken de naam $M$. javanica behouden bleef. Nu werd in 1886 door den Engelschen reiziger WhiteHEAd in Oost-Jara, hoog in het Tengger-gebergte, een derde rorm rerkregen, die zich onderscheidt door de lichtere kleur van den kop en den naam Merula whiteheadi ontring. Het komt mij roor (en daarom maak ik speciaal melding ran deze drie, overigens onderling zeer nauw verwante soorten), dat wij hier staan roor een geval, dat den invloed van het isolement op de hoogste gedeelten der gebergten, die door uitgestrekte vlakten van elkander zijn gescheiden, op zeer instructieve wijze aantoont en waaruit wij tevens kunnen leeren, hoe een diersoort zich in meerdere soorten kan splitsen. Want het kan bijna niet worden betwijfeld, dat deze drie Merula-soorten een gemeenschappelijken stamvorm hebben gehad in een tijdperk, dat geologisch nog maar kort achter 
ons ligt en dat de verschillen, die zij thans vertoonen, eerst na hun isoleering op afzonderlijke bergtoppen zijn opgetreden. Tevens mogen wij, als deze onderstelling juist is, in dit g'eval een aanwijzing zien, dat dergelijke verschillen niet altijd door uitwendige factoren in het leven behoeven te worden geroepen; want de omstandigheden, waaronder deze drie soorten leven, loopen al heel weinig uiteen. Veeleer denkt men aan een innerlijke neiging tot verandering; waalvan de uitingen genivelleerd zouden zijn geworden, wanneer de dieren in één gebied bij elkdar waren gebleven, maar thans tot standvastige verschillen hebben geleid.

Volgens vroegere waarnemers moet in dit gebied ook een Eend, Ancs superciliosa, roorkomen, en wel in het bijzonder bij de kratermeertjes, die hier en daar op de hoogste gedeelten der rulkanen zijn te vinden. Het verspreidingsgebied dezer diersoort lig't Oostelijk van Java en strekt zich uit tot over het vasteland van Australië; het is zeer goed mogelijk, dat enkele individuen hun tochten wel eens Westelijk, tot Java, uitstrekken en dan de hoogste streken opzoeken. Het museum alhier bezit een paar exemplaren, van Celebes, die verzameld werden in het bergland boven Paloppo. Overigens is de avifauna van dit gebied niet rijk. Zosterops fallax en Pycnonotus bimaculatus vergezellen ons tot de hoogste punten; Rhipidura phoenicura Ptererythrius flaviscapis, Brachypteryx montana en Sphenocercus oxyurus nam ik tot ruim 8000 voet zeehoogte waar. Een kleine Siphia-soort, naar den ontdekker Siphia vordermanni genoemd, komt voor in de hoogste gedeelten van den G. Gedeh. Enkele Zwaluwen scheren langs de kale hellingen der kraterranden en nu en dan vertoont 
zich $n 0 g$ een Roofvogel. Stasiasticus montis, een kleine Rietranger, is wargenomen op het hoogste gedeelte van den Ardjoeno.

Het moet echter worden erkend, clat dit geried nog maar zeer onvolledig is onderzocht en dat mogelijkerwijze aan bovenstaande opsomming later nog: vele namen zullen zijn toe te voegen. De biologische exploratie van deze terreinen levert echter zooreel bezwaren op ran allerlei aard en is daarbij zóó kostbaar, tot onze kennis ervan niet anders dan zeer. langzaam kan vooruitgaan.

Kruipende en Tweeslachtige Dieren ziet men niet meer, hoewel ik overtuigd ben, dat de laatste zich toch nog wel zullen ophouden op een terrein als de Aloen-Aloen van den G. Gedeh, een groote, halfcirkelvormige vallei, die gevormd wordt door den buitenwand van den huidigen krater en een veel wijderen, bijna even hoogen klaterwand ran reel ouderen datum. Door het midden dier vallei stroomt een helder beekje, dat de oorsprong is van een der rivieren, die naar het Zuiden stroomen en langs welks kanten, evenals langs die der Hollandsche slooten, Boterbloemen (Ranunculus javanicus en $R$. diffusus) groeien, die ons onwillekeurig aan de nabijheid ran kwakende Kikvorschen doen denken.

Wat Insecten betreft, is de rijkdom der bergtoppen aan Vliegen opvallend, inzonderheid war het terrein bedekt is met de bloemenrijke kruiden en heester's van het hooggebergte, waaronder veelal de groenachtig witte Anuphulis-soorten en kleine Ericaceae de hoofdrol spelen. Zij zijn daar bepaald in hinderlijk groot aantal aanwezig en even lastig te verdrijven als hun Hollandsche verwanten op een zonnig plekje op de heide. Eene Calliphora-soort, door de Meisere 
als var. javanica van $C$. fulviceps beschreven, speelt er hier en daar een hoofdrol met een ruig uitziende Tachinide, wadrvan wij echter tevergeefs naar den gastheer zoeken. Ortalinen zijn er tamelijk talrijk, terwijl ook het geslacht Syrphus goed is vertegenwoordigd. Vele dezer Vliegen zijn uiterst teer van bouw en drijven alzoo den spot met de theorie, dat zij zich op dergelijke, aan hevige luchtstroomingen blootgestelde terreinen niet kunnen staande houden. Echter vond RoEPKE op het hoogste gedeelte van G. Gedeh in zeer talrijke exemplaren een Sciarasoort, die zich meer volgens deze theorie gedroeg. De mannetjes toch vlogen niet, maar liepen als mieren over den bodem rond, met de vleugels in trillende beweging en blijkbaar op zoek van de veel minder talrijke wijfjes, welker vleugels tot een prar onbruikbare aanhangsels bleken gereduceerd te zijn ${ }^{*}$.)

Voor het overige zijn er maar weinig insecten, die dadelijk onze dandacht trekken. Van de $H y$ menoptera treffen wij de Hommels en een paar Wespen tot op de toppen van het gehergte aan; de aanwezigheid van Polistes hebraeus in dit gebied werd reeds vioeger (pag j11) vermeld. Vlinders zich men nagenoeg niet. Een parr kleine iycaenidae en Hes. peridae houden ons gezelschap tot aan de bovenglens der vegetatie en op het hoogste, kale gedeelte van den kraterrand van de G. Gedeh bemachtigde ik eens een eenzaam rondvliegend exemplaar van Vanessa cardui. Intusschen lijdt het geen twijfel, dat ook dit gebied een aantal vormen herbergt, en daaronder vermoedelijk zeer belangwekkende, die eerst door lintere onderzoekingen aan het licht zullen wordeu gebracht.

") - Vgl. DE MeIJeRe in „Tijdschrift voor Entomologie" Deel 56, pag. 320 


\section{Alphabetisch Register der Dierennamen.}

Aalachtigen, :381.

Aaltjes, 195.

Aardspinnen, 320.

Aardwormen, 196.

Aaskevers, 608 .

Abacetus, 116 .

A birus, 485 .

-picipes, 369.

Ablepharus peroni, 556.

Acanthaspis flavoraria, 576 .

Acanthocoris scabrator, 574.

Acanthodrilidae, 197.

Acanthogenius distactus, 116.

Acarina, 188.

Accipiter virgatus, 275.

Acherontia lachesis, 299.

- styx, 299.

A contia transversa, 148.

Acontiinae, 148.

Acorinus, 534 .

Acosmeryx ancea, 568.

Acrididae, 95, +11, 438.

Acridium, 95.

-aeruginosum, 276.

-luteicorne, 276.

-melanocorne, 276.

-roseum, 276.

Acridotheres, 311.

-javanicus, 69.

Acrocephalus orientalis, 496.

Acrochordonichthys, 385.

Acrochordus jaranicus, 471.
Acropteris striataria, 151.

Actias maenas, $1+1$.

Adjag, +17 .

Adoretus umbrosus, 122,354 .

A egeria, 511.

Aegialites dubia, 459.

-ruficapillus, 459.

Aegithina scapularis, 61.

A egosoma, 324.

- marginale, 563.

Aegus acuminatus, 27, 34:3.

A emene, 147.

Aenictus, 159.

Aeschniclae, 247, 510.

Aethopyga eximia, 492.

-mystacalis, 230.

- siparaja, 230.

Agaristidae, 570 .

Agathodes, 328.

-caliginosalis. 154, 328.

-modicalis, 328.

-ostensalis, 154.

Agamidae, 555.

Agelasta irrorata. 563.

Agestrata, 564 .

Agonista endoleuca, 149.

Agonoscelis nubila, 107, 259.

Agrilus armatus, 122.

Agrionidae, 247, 510.

Agriocnemis incisa, 510 .

Agriorrhynchus borrei, 562.

Agrotis. 147, 281. 
Alaus lacteus, 533.

Alcedo beryllina, 269, 448.

-euryzona, 269.

-ispida, 269.

-meninting, 269.

Alcides chiliarchus, 565.

-dejeani, 565.

-reticulatus, 565.

- sulcatulus, 565.

Alcippe solitaria, 550 .

Aleurodes bergi, 305.

Allecula, 536.

Alphaea, 570.

Alseonax latirostris, 547 .

Alydus linearis, 574.

Amarygmus, 124.

Amathusia dilucida, 520.

-phiclippus, 65, 132, 205.

Amaurornis phoenicura, 316, 466.

Amblycephalus carinatus, 255.

Amblychia, 572.

Amblyomma sublaeve, 224.

-testudinarium, 318.

Amblyopus gracilis, 396.

Amblyteles, 163.

Ambulyx semifervens, 568.

Amesia sanguiflua, 569.

Ammonia decora, 520.

Ammophila clava, 166.

- variabilis, 166.

Amphidromus, 195.

Amphipoda, 400, 601.

Amphisternus hamatus, 566 .

Ampulex, 164.

Anabas scandens, 398.

Anaciaeschna taitensis, 247.

Anamnus dejeani, 563.

Anas superciliosa, 616.

Ancistrodon rhodostoma, 275.
Ancylonycha, 122, 342 .

Ancyloprotus javanus, 563 .

andjing ajer, 374 .

-tanah, 98.

Andrena, 172.

Anguilla bicolor, 381 .

-.. mauritiana, 381.

-sidat, 381.

Anguillulidae, 195.

Animula, 355.

Anisodera, 483.

Anomala, 40 .

-aerea, 122, 342.

-anchoralis, 354 .

-chalcites 122, 342.

-jurinei, 342.

-ypsilon, 121.

Anopheles, 108, 109.

Anoplocnemis grossipes, 285.

Antestia anchora, 487.

-histrio, 107, 259, 288.

Antheraea paphia, 141.

Anthomyidae, 114, 611 .

Anthophila, 284, 482 .

Anthophora zonata, 172, 284.

Anthothreptes malaccensis,

-phoenicotis, 229.

Anthothribidae, 533.

Anthracoceros convexus, 504 .

Anthribidae, 125.

Anthus rufulus, 274 .

Anticyra combusta, 281, 307.

Antilochus nigripes, 575.

Anura fortis, 41:.

Apen, 502.

Aphaenogaster, 515.

Aphana atomaria, 580.

-farinosa, 580 .

-pulchella, 580 . 
Aphanisticus consanguineus, Ardea sumatrana, 468

-krë̈geri, :306.

306. Ardeidae, 457.

Aphidae, 105.

Aphis sacchari, 30.).

Aphodius marginellus, 120.

A phrophola, 583.

A pidae, 174.

Apis indica, $17 \mathrm{~s}$.

-mellifica, 178.

- dorsata, 284.

-indica, 284 .

Apoderus, 365.

-cygneus, 533.

-hystrix 533.

-melanopterus, 125, 532.

-notatus, 532.

Apogonia, 121, 354 .

-destructor, 308.

Apolepis, 485.

Appias, 480.

Apriona flavescens, 562 .

Apsarasa radians, 571 .

Apterygota, 179, 411, 603.

Arachnothera affinis, 230.

-armata, 529.

-longirostris, 230, 529,

Araneus dehaanii, 187.

-laglaizei, 187.

-moluccensis, 187.

Aradidae, 604.

Araeocerus fasciculatus, 125.

Arboricola javanica, 531, 593.

-orientalis. 531.

Arcte coerulea, 517.

Arctiidae, 146, 284, 570.

Arctitis binturong, 523.

Arctogale leucotis, 497.

Ardea cinerea, 468.

-manillensis, 265.

Ardeola speciosa, $2 t i t i$.

Ardetta cinnamomea, 206t.

- sintelisis, ¿266.

Areas galactina, 570,

Argina argus, 285.

-cribraria, 147, 285.

Argyope, 187.

- bifasciata, 490.

- catenata, 490.

- crenulata, 490.

Arius caela.tus, 385.

Arixenia, 453.

Armadillo murinus, 194.

Artamides larvatus, $366,492$.

Artamus leucogaster 238, 357.

Asarcornis scutulata, 531.

Ascalaphiden, 510.

Asilidae, 113, 254, 281, 455,

611.

Asilus melanurus, 281.

Aspidiotus, 305.

-pustulans, 335.

Aspidolopha, 482.

-amabilis, 287, 484.

-assimilis, 287, 484.

-militaris, 287.

Aspongopus ochreus 573.

Asterosoma radiciforme, 450 .

Astur soloensis, 275.

-trivirgatus, 219.

Atax, 404.

Athyma, 133.

Atlaskever, 330.

Atlasvlinder, 140, 339.

Atmodes marmorea, 126.

Atractocerus, 535.

Attacus atlas, 140, 339, 364 .

-ricini, 141. 
Attelabus bispinosus, 125.

Attidae, 63.

Attractomorpha, 95.

- crenulata, 278.

-psittacina, 278.

Atya, 253.

-moluccensis, 254, 401.

Audinetia, spinosa, 487.

Aulacochilus quadripustula- tus, 567.

Aulacodes, 153.

Aulacophora batesi, 485 .

-flavomarginata, 126.

-quinqueplaginata, 126.

Aulexis, 485.

Auriculidae, 447.

Auricula judae, 447.

-mydae, 447.
Baardvogels, 65, 492.

Baarzen, 395.

babi oetan, 423.

Bacha, 489.

Bactrocera, 279.

badak, 426 .

badjing, 58 .

Bagarius bagarius, 385 .

bagong, 423.

- gagadoengan, 424.

bandeng, 474.

Bandicota, 416.

banen, 423 .

bangbara, 174 .

bango, 469 .

banteng, 246, 426 .

baong, 524.

Barbichthys laevis, 388 .

Barbus, 388, 390.

Barbus bramoides, 392.

-gonionotus, 394.

-hampal, 290.

-lateristriga, 392.

-maculatus, 390

-obtusirostris, 392.

-rubripennis, 392.

- soro, 390.

-tambra, 390.

-tambroides, 390.

\section{B.}

Bastaard-vischarend, 456.

Bastkevers, 216, 344.

Batissa, 405.

batjokkok, 376 .

Batocera octomaculata, 562.

-albofasciata, 26, 369.

-hector, 126, 215, 330.

Batrachidae, 474.

Batrachostomus javensis, 34,

507.

Batrachus grumniens, 444 .

bèbèak, 357.

beberèk, 465 .

Behangersbijen, 173.

bekiko, 435.

Belionota, 565.

Belippa albigutatta, 359.

-laleana, 359.

-lohor, 359.

beloet, 382 .

Belone strongylura, 394.

Belostoma indicum, 108, 252.

Belostomatidae, 252.

Bembex borrei, 403.

Benhamia, 197.

benjoet, 463 .

beo, 493 .

Betta pugnax, 398.

-trifasciata, 398. 
bettet, 2:3:.

beunteur, 390.

Bibionidae, 111.

bido, 22:3.

bientjarong, 64 .

bientoerong, 523.

bioel, 34, 218.

Bipalium, 66, 197, 597.

Biston, 572.

Bivalven, 405 .

Bhringa remifer, 234, 525, 546.

Bijen, 172.

Bijeneters, 228.

Bladluis (op tabak), 298.

Bladluizen, 105.

-(op suikerriet). 304 .

Bladsprietige Kevers, 40.

Bladvogels, 238.

Bladwespen, 16\%.

Blastophaga grossorum, 514.

Blaștophagidae, 514.

Blatta orientalis, 91.

-rhombifolia, 91.

Blattidae, 90, 164, 604 .

blèkèk, 267.

- boelan, 467.

-kembang, 467.

blekok, 266, 470 .

Bloedzuigers, 406, 598.

Boarmia, 151.

Bochrus poecilopterus, 603.

boeaja, 376 .

boeboek, 124 .

boeboet, 432 .

-kembang, 495.

boedeng, 326, 502.

boeèk, 60 .

boeltok, 347 .

boeroeng engkoet-engkoet, 66 .

-kambing, 525. boeroeng kijas, 62 .

-kopi, 29.

- oentjal, 496.

- oewoek, 496.

-paok, 241.

-tepèkong, 70 .

-tjabeh, 63.

-tjioeng, 404.

Bombus, 50, 512.

-rufipes, 594.

Bombylidae, 113, 339, 34:3, 611 .

Bombyx, waringi, 142.

bondol, 263.

-idjoe, 263 .

-itam, 263.

Boomklevers, 75 .

Boorders (in suikerriet), 306.

Bootsmannetjes, 251.

Borborinae, 611.

Borstelrupsen, 146, 259.

Bos bubalus, 246 .

—sundaicus, 246, 326, 426.

Boschkat, 218.

Boschrat (roode), 524.

Bostrychidae, 124.

Botia hymenophyse, 386.

Botryonopa sanguinea, 483.

Botys marginalis, 299.

Brachartona catoxantha, 204.

Brachyplatys, 286.

Brachypteryx montana, ว91,

616.

Brachyrhynchus orientalis,

604.

Brachytrupes achatinus, 98.

Brachyura, 401.

Braconidae, 163, 610.

Brahmina pumila, 354 .

brandjangan, 274.

Brenthidae, 294, 561. 
Brevipalpus obovatus, 363.

Brilvogels, 240.

Bronthispa, 204.

Bryophila, 148.

Bryozoa, 406.

Bubo orientalis, 34, 220.

Bubulcus coromandus, 266.

Buceros sylvestris, 504.

Bucerotidae, 503.

Buchanga, 71, 234, 310.

-cinerea, 72.

-longa, 72.

Bufo asper, s7, 379.

-biporcatus, 87.
Bufo borbonicus, 558.

-cruentatus, 558.

-melanostictus, 87.

Buisspinnen, 186.

Bungarus candidus, 82.

-fasciatus, 82.

Buprestidae, 122.

Butastur liventer, 223.

Buthus cyaneus, 180.

Butorides, javanica, 469.

-stagnatilis, 469.

Butreron capellei, 529, 555.

Bythopsyrna circulata, 582. cacaomot, 351.

Cacia, 126, 5633.

Cacomantis merulinus 74, 233.

-sepulchralis, 233.

-sonneratii, 233.

Calamaria, 499.

-linnei, 82.

-multimaculata, 82.

- reticulata, 82.

- tesselata, 82.

Calandra granaria, 125.

-oryzae, 125.

Calandrinae, 565.

Calleida, 566.

Calliphora, 112. 280.

-fulviceps, var. javanica, 618 .

Calichrous bimaculatus, 384 .

Callula baleata, 89 .

—pulchra, 89.

Callyna jugaria, 148.

Calobata albitarsis, 114.

Calobatidae, 114, 489.

Caloenas nicobariaca, 528.
Calogramma festiva, 147.

Calommata, 320.

Calornis chalybea, 69 .

Calotes cristatellus, 79.

-jubatus, 79.

Calpe minuticornis, 150.

Calymnia panopus, 139.

Camponotus, 161, 518.

Camponotinae, 160, 518.

Campophagidae, 348, 366.

Cantao ocellatus, 487.

Cantharidae, 565.

Canthecona rufescens, 573.

Canthesancus trimaculatus,

Caprimulgidae, 34.

Caprimulgus, 356.

一affinis, 231.

- bartelsi, 231, 544.

jotaka, 231.

-macrurus, 231.

Caprinia conchylalis, 153.

Capnodes, 151. 
Capsidae, 47, 297, 352, 488. Carabidae, 116, 410, 566, 608. Carangidae, 395.

Carassius auratus, 389.

Carcineutes pulchellus; 526.

Cardiophorus carduelis, 122.

- javanus, 122.

Carea subtilis, 211.

Caria dilatata, 305.

Caridina, $2 \overline{3}$.

-laevis, 401.

Carponycteris minima, 543.

Carpophagaaenea, 507,528, 554 .

-lacernulata, 555.

Carpophilus hemipterus, 119.

Cassidae, 286.

Cassidinae, 484.

Cassidula auris-felis, 447.

Catacanthus aurantius, 487.

Cataclysta, 153.

Catageus, 182.

Catara minor, 605.

Catascopus, 566.

-elegans, 410.

Catephia acronyctoides, 149.

Catharsius molossus, 120.

Catopra fasciata, 395.

Catopsilia catilla, 136.

-crocale, 27, 136.

-seylla, 136.

Catoxantha bicolor, 353.

Cecidomyidae, 254, 611.

Cediocera tristis, 562.

Celyphus obtectus, $115,537$.

Centrocnemis, 576.

Centropus javanicus, 432.

-purpureus, 433.

- sinensis, 433.

Centrotus, 106, 582.

-cornutus, 106.
Centrotus dama, 106.

Cephonodes hylas, 569.

Cerambycidae, 12ti, 324, 352, 562.

Ceratina hieroglyphica, 284.

Ceratopogon, $110,611$.

Cerberus rhynchops, 472.

Cerceris, 283.

Cerchneis occidentalis, 219.

Cercidocerus bipunctatus, 566 .

- securifer, 566 .

Cercopidae, 582.

Cercotmetus, 253.

Ceria javana, 489.

Cerithium corallinum, 446.

-morum, 446.

-tuberculatum, 446 .

- variegatum, 446.

Cerivoula picta, 209.

Cerobates, 562.

Cerophysa nodicornis, 126.

Ceropria, 123, 536.

Cervidae, 425.

Cervina miles, 395,

Cervulus muntjak, 326, 425.

Cervus russa, 326, 426.

Cethosia, 480.

Cetonidae, 50, 120, 564.

Cettia montana, 551.

Ceyx innominata, 269.

Chaerilus variegatus, 601 .

Chaerocampa alecto: 138 .

- butus, 138.

-lucasi, 138, 139.

-mydon, 138.

-oldenlandiae, 138.

- silhetensis, 138.

-theylia, 138.

—vigil, 138

Chaetodontina, 395. 
Chalcis, 334.

Chalcididae, 163, 514.

Chalcococcyx basalis, 496.

-malayanus, 261.

-xanthorhynchus, 529.

Chalcolampra violaceipennis,

212.

Chalcophabs indica, 315 .

Chalcosia thallo, 144.

Chalcosidae, 144.

Chalcosoma atlas, 3:30.

Chalcostetha insignis, 443,451 .

Chalcothea, 564.

Chanos-chanos, 474 .

Charadrius fulvus, 268, 459.

Charaxes athamas, 133.

-jalysus, 479.

-schreibersi, 479.

Chela anomalurus, 393.

Chelifer, 182.

Cheliferae, 182.

Chelone imbricata, 450.

-mydas, 450.

Chelonethidae, 182.

Chelydon dasypus, 356.

Chersydris granulatus, 472 .

Chilo, 152.

-infuscatellus, 306.

Chilocorus melanophthalmus,

Chilognatha, 192.

Chilomenes sexmaculata, 336.

Chilopoda, 189,

Chionaspis, 305.

Chiropodomys anna, 201.

-gliroides, 33, 201.

Chiton, 445.

Chlaenius bihamatus, 116.

- circumdatus, 410.

-javanus, 410 .
Chloropidae, 612.

Chloropsis nigricollis, 239.

-viridis, 239.

Chlorura hyperythra, 592.

Chotorhea corvina, 492.

-javensis, 493.

Chrysididae, 163.

Chrysis, 163.

Chrysochroa buqueti, 534.

-fulminans, 122340.

Chrysocolaptes strictus, 505 .

-validus, 505.

Chrysocoris, 486.

Chrysolampra, 485.

Chrysomelidae, ว0, 126, 211, $344,482$.

Chrysopa, 337.

Chrysopelea ornata, 437, 498.

Chrysophlegma mentale, 505.

Chrysopila, 281.

Chrysops dispar, 113, 317.

-fasciatus, 113, 317.

-rufitarsis, 317.

-translucelis, 317.

Cicindela analis, 359 .

- aurulenta, 450 .

-discreta, 359.

-longipes, 450.

-minuta, 359.

- viduata, 359.

Cicindelidae, $46,116$.

Ciconidae, 267, 457.

Cimex lectularius, 107.

Cinnyris hasselti, 228.

-pectoralis, 63, 228.

Cinxia limbata, 487.

Cirrochroa, 521.

Cirrohrista fumipalpis, 152.

Cissa thalassina, 507, 545 .

Cistelidae, 535. 
Cistelomorpha, 536.

Cisticola, 270.

- cisticola, 270.

Citigradae, 185.

Cittocincla tricolor, $23 \bar{r}$.

Cladocera, 253.

Clarias batrachus, 384.

-lindi, 384.

- magur, 3S4.

- melanoderma, $3 \$ 4$.

-nieuhofi, 384.

-teysmanni. 384.

Claterna cidonia, 150 .

Cleonus, 125.

Cleptocoris atromaculatus,

604.

Clerome arcesilaus, 519, 568.

Clerota budda, 564 .

-atra, 565.

Clupeidae, 393, 474.

Clytanthus annularis, 209.

Clytra, 482.

Cnaphalocrocis bifurcalis, 307 .

-jolinalis, 153, 258.

Cobitidae, 386.

Coccidae, 104, 126, 305, 334.

Coccinella arcuata, 260.

Coccinellidae, 126, 260, 292.

$305,336,485$.

Coccystes coromandus, 234.

Cochoa azurea, 549.

Coelioxys, 173.

Coelophora, deficiens, 485 .

-inaequalis, 485.

Colaspoides, 126, 485.

Colasposoma, 485 .

Coleoptera, 116, 482.

Collocalia, 451.

-fuciphaga, 71, 452.

-linchii, 71.
Collyridae, 486.

Collyris, $116,344$.

-arnoldi, +86 .

-emarginata, 344.

-horsfieldi, 486.

-tuberculata, :344, 486.

Colobesthes falcata, 582 .

Colobodes, 5.34.

Colpura obscura, 574.

Coluber melanurus, 84 .

-oxycephalus, 84 .

-radiatus, 255

-tricolor, 499.

Columba litoralis, $\triangleleft$.

Conocephalinae, 96.

Conorhinus rubrofasciatus, 107

-sanguisugus, 108.

Conosia, 111.

Copepoda, 253, 400.

Copridae, $+12,453$.

Copris punctulatus, 120.

—sulcicollis, 120.

Coprophaga, 120.

Copsychus amoenus, 62.

-musicus, 62.

Copsyrna, 215.

- maculata, 582.

Coptocycla, 287.

- catenata, 485.

-punctata, 485.

-scalaris, 485.

Coptops lichenea, 533.

Coptosoma cribrarium, 293.

Coptotermes gestroi, 37.

Corbicula, 194, 405.

-ducalis, 405 .

-javanica, 405.

- sulcata, 405.

Coreinae, 574.

Corixa, 25]. 
Corixidae, 108, 251.

Corvus enca, 273.

- macrorhynchus, 75, 273.

Corynodes, 485.

Cosmocarta flavifascia, 583.

-nigripennis, 583.

-octopunctata, 583.

-tricolor, 583.

Cosmophila erosa, 148.

Cosmopolites sordidus, 565.

Cosmopteryx pallifasciella, 306.

Cossonus ephippiger, 566.

Crambinae, 152, 439.

Crambus, 152.

Creotonotus interruptus, 147 , 284.

-lactineus, 147, 284.

Crematogaster, 505, 516.

Cricula trifenestrata, 75, 141.

Criniger gularis, 239.

Crioceris, 482.

Crocidura, 33.

-murina, 58.

Crocisa emarginata, 284.

Crocodilus porosus, 374.

Crossochilus oblongus, 393 .

Crossocosmia, 280.

- sericariae. 113.

Crustacea, 193, 253, 399.

Crypsirhina varians, 241.

Cryptodesmus, 193.

Cryptolopha granmiceps, 592.

- schwaneri, 592.

-trivirgata, 592.

Cryptopterus, 394.

Cryptorhynchidae, 535 .

Cryptorhynchus, 9.

-mangiferae, 125, 214.

Cryptotympana, 579 .
Cryptus, 136.

Cteniza, 320.

Ctenophora ardens, 362 .

- compedita, 362.

Cucujidae, 119.

Cuculus, 232.

-poliocephalus, 554.

Culex, 109.

Culicicapa ceylonensis, 366,

Culicidae, 108, 248.

492.

Culicoides, 110.

Cultellus, 448 .

Cuora, 378.

Cupha erymanthis, 132,

Curculionidae, 125, 344, 365,

565.

Cyana, 147, 570 .

Cyanoderma melanothorax,

550.

Cyanops armillaris, 492 .

-lineata, 347.

Cybister simibis, 249.

Cyclemys dhor, 378.

-amboinensis, 378.

Cyclodes omma, 149.

Cyclopelta obscura, 331 .

Cyclophorus perdix, 560 .

Cyclosia papilionaris, 569.

Cyclostomatidae, 560.

Cylas formicarius, 294.

Cylindrophis melanotus, 499 .

-rufus, 82.

Cyllo leda, 41, 307.

Cymbachus pulchellus; 566 .

Cymothoidae, 391.

Cynipidae, 162, 512, 514.

Cynoglossus oxyrhynchus, 398.

-potous, 398. 
Cynopterus brachyotis, 58.

-marginatus, 58 .

Cynthia deione, 521.

Cyon rutilans, 326, 416 .

Cyphocrania goliath, 538 .

Cyprinidae, 386.

Dactylopius, 305, 355.

-adonidum, 104.

-longifilis, 104.

Dacus, 115, 279.

dadapvliegje, 331 .

Dagvlinders, 478.

Dalader planiventris, 574 .

Dalpada, 487.

—versicolor, 333.

Damonia subtrijuga, 378 .

Danaidae, 130, 531 .

Danais albata, 568.

-aspasia, var: crocea, 131.

—chrysippus, 4 54.

- genutia, 131.

-juventa, 131.

-melaneus, 131.

Dangila cuvieri, 393.

Daphnis hypothous, 139, 364.

-nerii 139.

Dasychira, 146.

-horsfeldi, 285.

-mendosa, 285.

Debis, 478.

Decapoda, 401.

dèdès, 345 .

Dehaania femorata, 96.

Deiopeia pulchella, 147.

Dejanira quadripunetata, 533.

Delias belisama, 134.

-crithoe, 568.

- egialea, 136.

- hyparete, 136.
Cyprinodontidae, 393.

Cyprinus carpio, 389.

Cypselus subfurcatus, 70.

Cyrena, 406.

Cyrenidae, 405, 448.

Cyrestis, 480 .

D.

delimoekan, 31 j.

deloendoeng, 589.

Delphacinae, 583.

Delphax, 260.

Deltocephalus, 260.

Deltoidinae, 150, 571.

Dendrocopus analis, 74, 235.

304.

Dendrocygna arcuata, 463.

-javanica, 463.

Dendrophis forınosus, 437.

-pictus, 84.

Dermatodes, 125.

- costatus, 365.

-punctulatus, 365.

Desmestidae, 119.

deroek, 312, 313.

Deroplatys, 585 .

Diacamma, 160.

Diapromorpha, 482.

Diaspis, 337.

Diatraea striatalis, 306.

Dicaeum chrysorrheum, 530.

-rubrum, 63.

-sanguinolentum, 544.

Diceros petelii, 564 .

Dichorragia nesimachus, 521. dikkop, 268.

Dindymus rubiginosus, 262.

-var. hypogastrica, 290.

Dineutes australis, 117, 250.

Dinoderus, 124.

Diopsis, 402. 
Diopsis vittatus, 402.

Diplax, 247.

Diploptera, 167.

Diplorhinus furcatus, 487.

Dipsadomorphus cynodon, 255.

-dendrophilus, 85.

-drapiezii, 499.

-multimaculatus, 85.

Diptera, 108, 279, 316, 402, 488, 595, 610 .

Discophora celinde, 65, 132,

-sundaica, 520.

20 อั.

Dissemurus paradiseus, var. platurus, 525 .

Dissura episcopus, $45 \overline{7}, 469$.

Diurus forcipatus, 562 .

djalak, 68.

djantiengan, 63 .

djèdjèt, 393.

djelarang, 542 .

djelèr, 387.

djerellang, 542 .

djoelan, 504.

djoelong-djoelong 394 .

djok-djok, 61 .

doedoet, 432 .

doek, 456.

doewa, 82.

Doleschallia bisaltide, 133 .

Dolichoderinae, 519.

Dolichoderus bituberculatus, 107, 297.

Dolichopodidae, 113, 489, 611.
Doliophis bivirgatus, 498.

-intestinalis, 85, 437.

Doodshoofdvlinders, 299.

Doornspinnen, 345.

Doratodesmus, 193.

Doreus parryi, 343.

Dorylinae, 158, 518 .

Doryichthys brachyurus, 399.

-caudatus, 399.

Dorylus, 158.

Draaikerers, 250.

Dreata petola, 288, 307.

-udiana, 142.

Drepanulidae, 143, 332.

Drosophilidae, 612.

Drymocataphus capistratus 10 ,

274.

Dryophis fasciolatus, 498.

-prasinus, ๖5, 499.

Dudusa, 143.

Duikertje, 462,

Duiven, 73, 312.

Duizendpooten, 189, 412,600 .

Dules, 395,

Dundubia mannifera, 105.

Dupetor flavicollis, 470 .

Dynastidae, 120, 411 .

Dysdercus cingulatus, 212, 290.

-königii, 290.

Dytiscidae, 117, 249.

Dwergherten, 326, 426.

Dwergspecht, 507.

Dwergvalk, 424.
Earias fabia, 291.

Echinosoma sumatranum, 606.

Ectinoderus, 577.

Ectornomyrmex astutus, 160.

\section{E.}

Ectrychotes, 576, 577.

-violaceus, 577.

Edentata, 22:3.

Eekhoorns (vliegende), 202. 
Eenden, 46:.

Egnasia, 151.

ekkek-geling, 5 +6.

Elanus hypoleucus, 271.

Elateridae, 122.

Eleotris ophiocephalus, 396.

Eligma narcissus, 147.

Elimaea chloris, 278.

Elis lindenii, 167, 342.

-rubromaculata, 167.

- thoracica, 167.

-tristis, 167.

Elphos hymenaria, 572.

Elymnias casiphone, 568 .

- ceryx, 568.

-lais, 132.

-undularis, 13:.

Empydae, 611.

Emydae, 378.

Encaustes cruenta, 567.

Encyalesthus, 536.

Encyrtus, 336.

Endochus nigricornis, 578.

Endom ychidae, 127, 566.

engkak, 273.

Engraulis melanochir, 393.

- tri, 393.

Engystomatidae, 557.

Enhydrinae, 456.

Entomobrya longicornıs, 489.

Entomostraca, 400.

Eonycteris spelaea, 543.

Epacromia, 278.

Eparchus insignis, 605.

-tenellus, 605.

Epeira, 187.

Epepeotes luscus, 126, 215, 352.

Ephemeridae, 100, 403.

Ephippium bilineatum, 113.

Ephydatia bogorensis, 407.
Epicauta, อ̄6อ.

Epicedia maculatrix, 369.

Epilachna, 126, 292, 485.

-pusillanima, 292.

- pytho, 292.

- territa, 292.

Epilampra, 604.

Epimys, 416.

Epiplemidae, 151.

Episcapha glabra, 567.

-quadrimaculata, 567.

Episomus chlorostigma, 565.

Episparis variabilis, 150.

Equula, 396.

Erionota thrax, 136, 209.

Eristalis splendens, 280 .

Erotylidae, 127, 567.

Erythrura prasina, 263.

Euagoras, 578.

Euchromia horsfieldi, 143.

Eucosmetus, 604.

Eucyrtus, 123.

-splendens, 536.

Eudynamis honorita, 235.

Eugnathus viridanus, $125,565$.

Eulyes amoena, $576,577$.

Eumelea, 151.

Eumenes, 49, 163, 481.

-blanchardi, 167.

- circinalis, 167.

- esuriens, 167.

Eumenidae, 167.

Eumeta crameri, 355.

-layardi, 355.

-variegata, 339, 355, 365.

Eumolpinae, 485.

Eumorphus marginatus, 127.

-quadrinotatus, 566.

Eu-neuroptera, 509.

Euphaea variegata, 510. 
Euphitrea micans, 126.

Euplocia, 146.

-membliaria, 570.

Euploea diocletianus, 479.

- eyndhovii, 479.

- gamelia, 568.

-leucostictos, 479.

-midamus, 130.

- radamanthus, 479.

Euproctis, 146.

- binnaculata, 285.

-digramma, 285.

-flexuosa, 364.

- virguncula, 285.

Eupterotidae, 142.

Euripus halitherses, 521.

Eurydema pulchrum, 487.

Eurylaemus javanicus, 553.

Enrystomus orientalis, 356 ,

492.
Eurytrachelus bucephalus, 343.

Euschema militaris, 572.

-minervaria, 572.

Euscopus rufipes, 575.

Eusemia maculatrix, 570 .

Eustathes splendida, 564.

Eusthenes robustus, 487.

Euteliinae, 148.

Euthalia, 133, 216, 479.

Eutrachelus temminckii, 561 .

Evania appendigaster, 91.

Evaniidae, 610.

Exalfactoria lineata, 274, 435 .

Exopholis, 40.

-hypoleuca, 122, 342.

Exoprosopa tantalus, 343 .

Exorista, 280.
Falco ernesti, 543.

-papuanus, 275.

-tinnunculus, 219.

Felis bengalensis, 218.

-melas, 503.

-minuta, 218.

-pardus, 326, 421, 503.

-tigris, 326, 420.

- viverrina, 442.

Filodes fulvidorsalis, 154.
Flagellata, 317.

Flatidae, 581.

Fregatvogels, 460.

Fringilla, 7 .

Focillinae, 150, 571.

Forficula, 92.

Forficulidae, 91, 605.

Fossores, 50.

Fulgora oculata, 580 .

Fulgoridae, 106, 215, 260, 358. gaäng, 98 .

Gaasvliegen, 837.

gadjaän, 458 .

gagak, 273.

Gagrella celerrima, 586.

Gallicrex cinerea, 466.
Gallinago gallinago, 268.

-stenura, 267.

Gallinula chloropus, 466 .

Gallinulidae, 46t;.

Gallus ferrugineus, 435 .

-varius, 435. 
Galmuggen, 254.

Galwespen, 512.

ganggarangan, 358.

gaok, 75, 273.

Gaperschelpen, 448.

Garnalen, 253.

Garrulacidae, 546.

Garrulax rufifrons, $5+6$.

Garzetta nigripes, 265.

Gasteracantha arcuata, 490.

-brevispina, 345.

-leucomelaena, 34 .

- praetextata, 345.

- roseolimbata, 345 .

Gaviaal, 376.

Gecinus puniceus, 50 ว.

-vittatus, 504.

Gecko monarchus, 78.

-stentor, 78.

-verticillatus, 78 .

gedoewo, 554 .

Geitenmelkers, 34, 231.

Geocichla interpres, 548.

-rubecula, 236.

-sibirica, 548.

Geometridae, $50,151,568,572$.

Geopelia striata, 74, 312.

Geophilidae, 190.

Geoplana, 597.

Geotelphusa kühlii, 401.

Gerris fluviorum, 401.

-fossarum, 401.

Gerygone modiglianii, 443,451 .

Gierzwaluwen, 70, 451.

Glareola orientalis, 268.

glatik, 67, 263.

glatik batoe, 63 .

glatik moengoek, 75 .

Glaucidium castanopterum,

508.
Glazenmakers, $247,455,510$.

Glenea, 563.

-lineosa, 563.

-novemguttata, 352.

-ochracea, 563.

Glottula dominica, 147 .

Glycyphana, 120, 564 .

-torquata, 565.

-albomaculata, $\check{5} 65$.

Glyphodes bicolor, 1 ว’3.

-bivitralis, 153, 370 .

- caesalis, 153.

- celsalis, 153.

-dilectalis, 153.

-indica, 153.

-negatalis, 153.

-psittacalis, 153, 365.

- spectandalis, 153.

-stolalis, 1 10.

-unionalis, 370.

Glyptosternum platypogon, 385.

Gnathobdellidae, 406 .

Gnoma, 563.

Gobiidae, 396, 444.

Gobius belosso, 396.

- giuris, 396.

-pleurostigma, 396.

-tambujon, 396.

goeramih, 397.

Gonophora orientalis, 127.

Gonopterinae, 148.

Gonyocephalus chamaeleon-

-kuhli, 555.

Gorsachius melanolophus, 315.

Goudduif, 528.

Goudsnip, 467 .

Goudvisch, 359. 
Goudwespen, 163.

Graafbijtjes, 172.

Graafwespen, $46,163,282,403$,

411.

Gracilaria cramerella, 351 .

Graculipica melanoptera, 311.

Grammodes, 150.

Graptodera cyanea, 126.

Graptolitha schistaceana, 306.

Graptomyza longirostris, 280.

Graptostethus servus, 603.

Greenia, 177.

Haas (javaansche), 311.

Hadena, 147, 25.2.

Haemadipsa, 598.

Haematobia exigua, 317.

Haematopota irrorata, 317.

-javana, 317.

-lunulata, 317.

Hagedissen, 46.

Halcyon choris, 65, 227.

-coromandus, 449 .

- cyaniventris, 227.

-sanctus, 442, 449.

Haliaetus leucogaster, 4う̄6.

Haliastur intermedius, 455 .

Halictus, 172.

Ha palarpactes rein wardti, 553.

Haplochilus javanicus, 394.

-panchax, 393.

Haplopeltura boa, 255 .

Haplosoma ventralis, 126.

Haplosonyx, 173.

Haringen, 393.

Harpactes orescios, 553.

Hedylepta ustalis, 154.

Helicidlae, 561 .
Gruto's 268, 458.

Gryllidae, 97, 411, 452, 605.

Gryllotalpa, 278.

-africana, 98.

Gryllus, 411.

-orientalis, 605 .

Gymnodactylus marmoratus,

555.

Gymnodontidae, 399.

Gynacantha subinterrupta,

247.

Gyrinidae, 250 .

\section{II.}

Helictis orien talis, $34,218,415$.

Heliocopris bucephalus, 412.

Heliothis armigera, 147, 282,

291.

Helix, 561.

Helopeltis, 352, 365.

-antonii, 360.

- theivora 360 .

Helophilus bengalensis, 280.

-pilipes, 280, 337.

Helota semifulva, j667.

-vigorsi, 567.

Hemicercus concretus, 505 .

Hemidactylus, 76.

- frenatus, 76-

- garnoti, 76.

-mutilatus, 76.

-Hemipus obscurus, 349, 492.

Hemiramphus amblyurus 394 .

- buffonis, 395.

- dispar, 395.

-fluviatilis, 394.

Hemixus virescens; 552.

Henicuridae, 10, 506.

Henicurus leschenaulti, 506. 
Herodias, 75, 310.

-alba, 265.

- garzetta, 265 .

-intermedia, 266.

Herpestes javanicus, 358, 415.

Herpobdellidae, 595.

Herten, 326, 346, 371, 425.

Hesperia brunnea, 439 .

- conjuncta, 258, 439.

-mathias, 258, 439.

-philino, 258, 439.

-toona, 439.

Hesperidae, 136, 205, 209, 258, 2S5, 307, 310, 479.

Hestia belia, 531 .

-lynceus, 531.

Heterocera, 137, 568.

Heterodera, 196.

Heteroderes malaisianus, 122.

Heterometrus, 180.

Heteroneuridae, 612.

Heteropoda venatoria, 184.

Heteroptera, 106.

Hexarthrius rhinoceros, 343.

Heylaertsia, 355 .

Hidari irava, 20 5.

hiengkiek, 220, 222.

Hierococcyx fugax, 235.

-sparveroides, 234.

hileud boegbroeg, 364.

—koeda, 360 .

-merang, 364.

- setetaroe, 36t,

- sinanangkeup, 364.

Himantocera plumosa, 563.

Himantopus candidus, 466.

-leucocephalus, 466.

Hippoboscidae, 115.

Hipposiderus diadema, 59.

Hirundo, 69.
Hirundo gutturalis, 69.

-jaranica, 69.

-striolata, 69, 356.

Hispa, 494.

Hispella, 484.

- wakkeri, 306.

Hispidae, 127, 48:3.

Histeridae, 210, 410, 609.

Histia libelluloides, 569.

Hooiwagens, 595.

Holılepta, 210, $\$ 10$.

Holoniara picescens, 299.

Homalopsis buccata, 85, 472.

Homaloptera ophiolepis, 387.

-paronina, 387.

-wassikii, 387,

Hommels, 178, 512, 594.

Homoeocerus albiguttulus,

574.

-angulatus, 574 .

Homoptera, 105, 578.

-umbrina, 149.

Honden (wilde), 326, 416.

Honigzuigers, 63, 228.

Hoplia, 486.

Horia cephalotes, $123,176$.

Hormurus australasiae, 181.

Houtbijen, 123, 174.

Houtwespen, 162.

Huechys incarnata, 580 .

Huisjesslakken, 195.

Huismusch (javaansche), 67.

Huisvlieg, 112.

Hyblaea puera, 148, 325.

Hydaticus vittatus, 249.

Hydrachna, 404.

Hydrachnidae, 404.

Hydrocampinae, 153.

Hydrochelidon, 459.

Hydrocychla relata, 506 . 
Hydrometra vittata, 402.

Hydrometridae, 401.

Hydrophilidae, 117, 250.

Hydrophilus olivaceus, 250.

Hylesinus, 217.

Hylobates leuciscus, 540.

-syndactylus, 541.

Hylobius, 565.

Hylodes caranea, 149.

Hylomys suillus, 346 .

Hylotoma, 594.

Hymenoptera, 157, 481, 511,

610.

Hymenopus coronatus, 93.

Hypaetra isubo, 150.

Hypena, 151.

Hypochrosis, 572 .

Hypolimnas, 480.

-bolina, 133.

Ibrdae, 267, 468.

Ibis melanocephala, 468 .

Icaria, 170.

-bioculata, 170.

- ferruginea, 170.

- pendula, 170.

Icerya purchasi, $3: 37$.

Ichnaspis, 337.

Ichneumonidae, :63, 610.

Ichthyophis glutinosa, 86 .

Ichthyoxenus jellinghausii,

Ideopsis gaura, 532.

Ijsvogels, 65, 269.

ikan bawon, 385 .

-belanak, 39s.

- belosso, 396.

-boentak, 399.

-bosso, 396 .
Hypolimnas misippus, 133, 339.

Hypomeces curtus, 344.

Hypotaenidia striata, 467.

Hypothymis occipitalis, 236.

Hyposidra infixaria, 339.

- talaca, 339.

Hypsa alciphron, 146, 285.

- complana, 146, 285.

- egens, 146, 370.

-heliconia, 146.

-javana, 146.

-marmores, 146, 570.

-monycha, 146.

-producta, 146.

Hypsidae, 146, 570.

Hypsirhina enhydris, 498.

- plumbea 472.

Hystrix javanica, 224.
1.

ikan djambal, 384 .

-gaboes, 397.

-gaboes laoet, 396.

- hampal, 390.

-kapala tima, 393.

-kèkèl, 385.

-kipar, 395.

-kodok, 444.

-koero, 395.

-lais, 385.

-lajoer, 395.

-lèlèh, 384.

-lida, 398.

-limpoh, 385.

-manjoeng, 385.

-mas, 390.

-paling, 381 .

-pepèrèk, 396.

-poentang, 396. 
ikan supat. 398.

-soempit, 395.

-tambra, 389, 390.

-tjangoep, 385.

-tèri, 393.

Inquilinen, 514.

Iontha umbrina, 571.

Irene turcosa, 528.

Iridomyrmex myrmecodiae,

Ischnogaster mellyi, 169.
Ischyja manlia, 150.

Isometrus formosus, 181.

-- maculatus, 181.

-mucronatus, 181.

Isopoda, t50, 602.

-terrestria, 193.

Isyndus heros, 578.

Ixodidae, 61, 118, 224, 317, 349.

539. Ixalus aurifasciatus, 558.

-flavosignatus, 558.
Jassidae, 106, 260, 583.

Judas-oor, 447.

Jufferduiven, 73.

Junonia asterie, 132. -atlites, 132.

-erigone, 132.

-wallacei, 310.

Jyngipicus auritus, 235. kadal, so.

kadantja, 554 .

kihkè, 65.

kakap, 395.

- merah, 395.

kakarèwan, 316.

Kakkerlakken, 90, 604.

kaleng, 69.

Kallima paralekta, 519.

kalong, 200, 225, 460.

Kaneelduiven, 495.

kangkareng, 504.

kantjil, 326, 426, 503.

katjilan, 275.

kapassan, 75.

kapi-pihi, 331.

kapinis, 69.

kapirat, 393.

kapodang, 64 .

karbouw, 246.

Karper, 3\$9.
Karperachtigen, 386.

kasintoe, 43 う.

katik, 73.

katik kembang, 73 .

kedassi itam, 234.

kèkè, 417.

kètèk, 326, 502.

Ketengus typus 385.

Ketupa javanensis, 222.

kidang, 326, 425.

kiki, 417.

kievit, 465.

Kikvorschen, 86, 254, 379, 557.

Klappereekhoorn, 200.

Klapperrat, 200.

Klappertor, 202.

Klauwieren, 237.

Klimbaars, 398.

Kluiten, 466 .

koekang, 522.

Koekoeken, 232. 
Koekoeksbij, 173.

koendoel, 266.

-malam, 76.

koenjoek, 326, 502 .

koetilang, 61 .

-mas, 527.

koetjita, 62 .

-batoe, 274.

-oetan, 237.

koewil, 268.

koewoek, 218.

Koffie-snuitkevertje, 125.

kokkokan, 266.

Labia, 92.

Labio chrysophekadion, 388.

-erythropterus, 388.

Labyrinthici, 397.

Labyrinthvisschen, 397.

Lacera alope, 149.

Lachesis graminea, 436.

-punicea, 436.

Lachnosterna, 40, 122, 342.

Laelia suffusa, 285.

lagog, 417.

Lagoptera juno, 150.

Lagriidae, 536.

Lais hexanema, 385.

Lalage fimbriata, 549 .

-terat, 75.

Lamellibranchia, 448.

Lamellicornia, 342, 353, 361,

Lamera cana, 355.

365.

Laminonyx punctifrons, 190.

Lamprophorus, 607.

landak, 224.

Landpissepedden, 193.

Landplanariën, 197.
Kokkokan laut, 470.

kombang, 174.

korèis, 239.

kowi, 326.

kraaien, 75, 241.

Krabben, 253, 450.

Krabspinnen, 184.

krapoe, 395.

Kreeftachtige Dieren, 193, 253.

Krekels, 276.

krokodillen, 374.

Kuif koekoek, 234

kwartels, 243.

Landschildpadden, 379.

Landslakken, 194.

Languridae, 534.

Langwantsen, 285.

Laniellus leucogrammicus,

544.

Lanius bentet, 237, 357, 441.

-superciliosus, 237.

-tigrinus, 237.

Lantaarndragers, 580.

-laraq, 381.

-laron's, 72.

Larra, 411.

-maura, 283.

Larve van Perty, 607.

Lasiocampidae, 145, 364.

Lasioderma testaceum, 125.

Lasius, 161.

Laterigradae, 184.

Lates calcarifer, 395.

Latrodectus, 320.

-lawak, 392.

Lecanium hemisphaericum, 337.

-tenebricophilum, 335. 
Lecanium viride, 3:35.

Leeuwerik (javaansche), $2 \bar{\imath}$.

lehat, $38 \mathrm{~s}$.

Lema, 4.92.

Lepidiota stigma, $122,3+2$.

Lepidocephalichthys hasseltii, 387.

Lepidocyrtus, 603.

Lepisma cincta, 179.

Lepterodius sacer, 457.

Leptis ferruginea, 281.

Leptobelus, 106.

Leptochirus, 410 .

Leptocircus, 510.

-libelluloides, 511.

Leptocorisa acuta. 43, 107, 259.

Leptoglossus membranaceus,

574.

Leptopanorpa, ว10.

Leptoptilus dubius, 469.

- javanicus, 469 .

Leptosaltria, 579.

Leptoterna, 297.

Lepus nigricollis, 311.

Lethe. 478 .

-mekara, 132.

Leucania, 147, 281.

-hamifera, $1+7$.

Leucophlebia lineata, 307.

Libella, 247.

Libellen, 11, 45.5.

Libellulidac, 247, 510.

Lijsters, 62, 235.

lika, 386.

Limacodidae, 50, 144, 205.

Limantriidae, 146, 284.

Limenitis procris, 132 .

Limnaea javana, 405 .

Limnaeidae, 405.

Limnobaetus fuscus, 467 .
Limnophila crux, 111.

Limosa-limosa, 4.5.

-norae-zeelandiae, 458.

Limosina, (i11.

Limulus moluccanus. 451.

Linsang, 589.

Lipurinae, 411 .

Liris aurata, 283.

Lita solanella, 295.

-tabacella, 295.

Lithobiidae, 192.

Lithorhynchus wilyrmidon 565 .

Lithosiinae, 570.

Littorina bullata, 446 .

- carinifera, 446.

- scabra, 446.

- undulata, 446.

- vilis, 446.

Lixus. 125.

Lobivanellus cucullatus, 465 .

Lobopelta, 159.

Locustidae, 95, 369, 584 .

loebing, 381.

Loepa katinka, 142.

loetoeng, 326, 502 .

loewak, 33, 57, 301, 328.

londok, 79 .

Longipalpi, 36z.

lontrok, 495.

Lophotriorchis kieneri, 543.

lori, 522.

Loriculus pusillus, 496.

Loxoblemnus, 411.

Lucanidae, 50, 119, 343.

Lucilia, 45, 112.

Luciola vittata, 122.

Lumbricidae, 196.

Lumbricus, 196.

Lutjanus annularis, 395.

Lutra leptonyx, 33, 374. 
Lycaenidae, 134, 310, 479.

Lycodon aulicus, 83.

-subcinctus, 83.

Lycosa, 185.

Lygaeidae, 285, 488, 574, 603.

Lygaeus hospes, 575, 603.

Lygopria quaternalis, 154.
Lygosoma chalcides, 80.

-olivaceum, 80.

-temminckii, 556.

Lymantria ascetria, 146.

-similis, 146.

Lymexylonidae, 535.
Maanvlinder, 141.

Mabuia multifasciata, 80, 556 .

-rugifera, 556.

Macacus cynomolgus, 326, 502.

Macaria, 151.

Macroglossinae, 569.

Macrogomphus, 247.

Macromeris splendida, 481 .

Macrones gulio, 385.

-nemurus, 385.

Macronota, 120, 564.

-egregia, 565.

-monacha, 565.

-regia, 565.

- variegata, 565 .

Macropistodon rhodomelas,

255.

Macropteryx longipennis, 70. Macropygia emiliana, 496.

-leptogrammica, 496.

-ruficeps, 496.

Macropygidae, 495.

Macrura, 401.

Mainatus javanensis, 493.

Malacodermidae, 122.

Malacopterum lepidocepha-

mandar, 464.

$$
\operatorname{lum}, 530 \text {. }
$$

Manis javanica, 223.

manjar, 264, 304.

-kembang, 304. manoek apoeng, 274.

- boea, 238.

-kaso, 434.

-koeda, 546.

-madoe, 63.

- mbè, 525.

-petir, 73.

-sĕpa, 63.

-tjatjing, 236.

Mantidae, 92, 585.

Mantis, 92, 361 .

-burmeisteri, 585.

-religiosa, 92.

Mantispa, 510.

Viaotys, 170.

Maruca testulalis, 154.

Masicera, 280.

Mastacembelidae, 396.

Mastacembelus maculatus,

397.

-unicolor, 397.

Mastax, 95.

Mastigophorus, 572.

Matapa aria, 439.

-druna, 439.

matjan gembong, 422 .

-loreng, 422.

Maxates, 572.

Mecistocephalus, 190.

Mecocerus gazella, 534 .

Mecopoda elongata, 278. 
Mecoptera, 509.

Meervallen, 383.

Mees (javaansche), 62.

-(malabaarsche), 2:38.

Negacerus, 562.

Megachile, 173.

-bicolol, 482 .

-disjuncta, 482.

-heteroptera, 482.

- melampyga, 482 .

- semivestita, 482.

-thoracica, 173.

Megalodon ensifer, 584.

Megalophrys hasselti, 557.

- montana, 557.

Megalurus palustris, 270, 357 .

Megarhina, 109.

Megarhynchus rostratus, 289.

-truncatus, 289.

Megapenthes, 122.

Megaspis errans, 112, 280.

-zonatus, 280.

Megymenum, 487.

Meimuna, 579.

Melampus, 447.

Melania. 194.

-scabra, 404.

- testudinaria, 404.

- tuberculata, 404.

Melaniidae, 405.

Melanitis, 41.

-leda. 131, 259, 439.

Melanotus, 122.

Melipona, 173, 454 .

Nelittophagus leschenaulti,

meliwies, 463.

- batoe, 462, 463 .

- oetan, 463.

Melolonthidae, 50.
Membracidae, 106, 582.

mendjangan, 426 .

M enida formosa, tis

mentjek, 4.25 .

meong gedeh, $42 \%$.

-hideung, 503.

-keroed, 503.

-koembang, 503.

-malangbong, 503.

- santjang, $4: 2$.

- tjongkok, 218.

-toetoel, 5 ().3.

merak, 4.35.

meroetoe, 109.

Meropidae, 228.

Merops philippinus, 228.

-sumatranus, 228.

Merula fumida, 615 .

-javanica, 615.

-whiteheadi, 615.

Mesophoyx, 266.

Mesostenus, 163.

Metachrostis, 148.

Metanastria hyrtaca, 364.

Metopidius indicus, 465.

Metrocoris, 402.

Microgaster, 163.

Microgastridae, 143, 259.

Microhierax fringillarius, 434 .

Microhyla. 557.

-achatina, 557.

Micronecta, 251.

Micropternus brachyurus, 505 .

Micropus pacificus, 356.

Microtarsus, 349, 492.

-chalcocephalus, $3+9$.

-melanocephalus, 349.

Mictis, 285.

- fulvicornis, 285.

Mieren, 515. 
Mierenleeuwen, 99.

Miervogels, $27 t$.

Mijt (oranje), 363.

-(roode), 363.

Mijten, 188, 363, 413.

Milionea zonea, 572.

Milleria intercisa, 569.

Millioeńpooten, 192.

Miltochrista, 147.

Mimastra violaceipennis, 126.

Mineerlarven, 306.

Miniopterus schreibersi, 59.

minjawak, 80, 262, 376.

Miolispa, 562.

Miratra javanica, 274.

Miresa, 97.

Miscelus unicolor, 116.

Mixornis, 550 .

moa, 381 .

Modderkruipers, 386.

moeka, 522.

moentjang, 470.

Moerasslakken, 405.

Molukkenkreeft, 451 .

monjet, 326, 502.

Monohammus fistulator, 353,

Monolepta quadrinotata, 126.

Monomorium pharaonis, 158.

Monopterus javensis, 382.

Mordellidae, 534.

Morio orientalis, 116.

Mormolyce phyllodes, 606.

Morphna, 604.

Mottenschildluizen, 305.

Mugil planiceps, 398.

Mugilidae, 398.

Munia atricapilla, 263.

-ferruginea, 263.

-maja, 263.
Munia nisoria, 67, 263.

-oryzivora, 67, 263.

Muraena, 382.

Muraenidae, 381.

Mus decumanus, 55, 56.

-musculus, 57.

-neglectus, 416.

-rattus, 56, 262.

Musca domestica, 112.

Muschvalk, 434.

Muscicapidae, 366.

Muscicapula melanoleuca, 366 ,

492.

Muscidae, 113, 254, 410.

Mustela, 7.

-flavigula, 614.

Mutilla, 512.

Mycalesis, 132, 439, 478 .

-horsfieldi, 439.

-medus, 439.

- perseus, 439.

Mycetophagidae, 119.

Mycetophylidae, 611.

Mycteristes rhinophyllus,

564.

Mydas-oor, 447.

Mydaus meliceps, 367.

Mygale, 264.

Myiphoneus cyaneus, 548 .

-flavirostris, 548.

Mylabris pustulata, ว65.

Myllocerus isabellinus, 125 ,

344 .

Myristicivora bicolor, 8, 443.

Myrmeleon, 100.

Myrmeleontidae, 99.

Myrmicaria, 518.

Myrmicinae, 157, 515 .

Mysothra gemella, 212. 
Naaktslakken, 195.

Naja bungarus, 472.

-tripudians, var. leucodira,

499.

-tripudians, var. sputatrix, $82,499$.

Nandidat, 395.

Nanina, $56 b^{2} 1$.

Necrophorus, 608 .

Nectarinidae, 47, 63, 228.

Nemachilus fasciatus, 387.

Neopus malayensis, 433.

Neorina chrishna, 478.

Nepa robusta, 253.

Nepheronia valeria, 532.

Nephila kühlii, 186.

-maculata, 186.

- malabariensis, 186.

Nephotettix, 260.

Nepidae, 253.

Neptis, 133.

Neritina crepidularia, 447.

Nerius, 114.

Nesocia setifera, 416.

Netspinnen, 318.

Nettion gibberifrons, 463.

Neuroptera, 98, 403.

Neurothemis fluctuans, 247.

Neushoornvogels, 503.

Nezara griseipennis, 288.

-viridula, 107, 259, 288.

nilem, 388.

Ninox borneensis, 508 .

Nitidulidae, 119.

njentek, 218.
Noctuidae, 147, 281, 571.

Nodostoma aeneomicans, 485.

-bohemanni, 212.

Nomia strigata, 172, 284. nonol, 339.

Notobitus meleagris, 574.

Notodela diana, 550.

Notonecta, 251.

Notonectidlae, 108, 251.

Notopteridae, 39?.

Notopterus chitala, 39:3.

-kapirat, 393.

Numenius arcuatus, 458 .

-cyanopus, 458.

-phaeopus, 458.

Nupserha fricator, 126.

Nyctalemon patroclus, 151.

Nyctemera coleta, 147.

-latistriga, 147.

Nycteribidae, 115.

Nycticebus tarigradus, 522.

Nycticejus kühli, 59.

Nycticorax griseus, 76, 316.

Nyctipao crepuscularis, 148.

-hieroglyphica, 148.

-macrops, 148.

Nyctobates impressa, 536.

- valgus, 536.

Nymphalidae, 132, 519, 531,

$56 \mathrm{~S}$.

Nymphula depunctalis, 153 ,

256.

-fluctuosalis, 153.

-stagnalis, 256. 
Ocinara dilectula, 142, 370.

-signifera, 370.

Ocydromus, 450.

Ocypoda, 450.

-cordimana, 401.

Odonata, 98, 247, 510.

Odonestis plagifera, 364.

Odontolabis bellicosus, 343 .

Odontomachus, 160, 184.

-haematodes, 160.

-rixosus, 160.

Odontoponera transversa, 159.

Oecophylla smaragdina, 162 ,

oedjah, 388. $214,453,515$.

oelar babi, 84 .

-boengka laoet, 84 .

-kadoet, 85 .

-kapala doea, 82.

-karoeng, 471.

-kissik, 84.

-korros, 83.

-lëma, 275.

-pitjoeng, 84.

-santja, 81.

-sapi, 255.

- sendoq, 83.

- sěrĕt, 340.

-soerapari, 82.

-taliwangsa, 85.

-tambang, 84 .

-tjabeh, 86.

-tjahe, 84 .

-tjèlèng, 332.

-welang, 82.

-weling, 82.

oeloeng-oeloeng djamboel, 223. oentjal, 426.

oesang-èsang, 417.

Oesters, 448.
Oeverlooper, 458.

Odynerus, 169.

Olfersia spinifera, 115.

Oligochacta, 196.

Oligodon subtorquatus, 437.

Ulios, 185.

Oligostigma, 153.

Oligura superciliaris, 551.

Oncocephala angulata, 127.

Oncocephalus squalidus, 576.

Oniticellus femoratus, 120.

-tesselatus, 120.

Onthophagus sagittarius, 120.

-trituber, 120.

omo menteg, 295.

Ommatius fulvus, 455 .

Omotemnus, 203.

Ooievaars, 457, 469.

Oorslakken, 447.

Oorwormen, 91, 411.

Opatrum acutangulum, 299.

-depressum, 299.

-truncatum, 299.

Ophichthys loro, 382.

Ophideres, 149, 571.

-fullonica, 149.

-hypermnestra, 149.

-salaminia, 149.

Ophiocephalidae, 397.

Ophiocephalus gachua, 397.

-lucius, 397.

—striatus, 397.

Ophionea, 117.

Ophionidae, 163.

Ophiusa absentimacula, 149.

-adusta, 149.

-algira, 149.

- arctotaenia, 149.

- arcuata, 149.

-coronata, 149. 
Ophiusa fulvotaenia, 149.

-honesta, 149.

-illibata, 149.

-joviana, 149.

-melicerte, 149, 294.

-onelia, 149 .

-palmmba, 149.

- serva, 149, 294.

-simillima, 149.

oraj bedoedak, 85 .

-bondol, 25.5.

- gadoeng, 85.

-keupeul, 255.

-lema goenoeng, 436 .

-santja manoek, S5.

-teropong, 82.

Orbitelariae, 186.

Orchestia parvispinosa, 602 .

Orcus janthinus, 336.

Oregma lanigera, 304.

Oreocichla horsfieldi, 548 .

Oreta extensa, 332.

Oriolus cruentus, 549.

-galbula, 65 .

-maculatus, 64, 507.

-xanthonotus, 507.

Ornithoptera, 35.

-pompeus, 129, 130.

Orphnaeus brevilabiatus, 190.

Ortalinae, 279, 612.

Orthaga euadrusalis, 213.
Orthetrum pruinosum, 247.

-sabina, $2+7$.

-testaceum, 247 .

Orthogonius, 116.

-alternans, 410 .

-brunnilabris, 410.

Orthomorpha, 193.

Orthoptera, 11, 90, 276, 411.

Orthotomidae, 47,64 .

Orthotomus sepium, 64.

Ortothereua, 192.

Oryctes rhinoceros, 121, 202,

Oscinis, 3:38.

411.

Osmotreron griseicauda, $7: 3$.

-olax, 73.

-vernans, 73.

Osphromenus olfax, 397.

—striatus, 397.

-trichopterus, 397.

Osteochilus hasseltii, 388.

Ostracoda, 253, 400.

Ostrea cucullata, 448.

-mytiloides, 448.

Ostreidae, 448.

Otidognathus, 534.

Otostigmus spinosus; 189.

Otter, 33.

Oxya, 95, 278.

Oxyglossus lima, 88, 254.

Oxyrhynchus lateralis, 565.
Pachyarches, 365.

Pachycephala grisola, 530 .

Pachycondyla insularis, 160.

Pachylocerus pilosus, 563.

Pachymerus, 604.

Pachyrhina fasciata, 362.

Padden, 87.

\section{P.}

Paederus peregrinus, 118.

Pagodia, 355.

Palaemon, 253.

-dispar, 101.

- elegans, 401.

-lar, 401.

-pilimanus, 401. 
Palaeornis alexandri, 232.

Palamnaeus longimanus, 181.

-spinifer, 181.

Palimna tesselata, 126.

Palindiinae, 148.

Paludinidae, 405.

Pamera annulicornis, 603.

Pamphila augias, 258, 439.

-dara, 258, 439.

Pandercetes decipiens, 491.

Panesthia aethiops, 604.

Pangasius djambal, 384.

Panomaea pardalina, 485.

Panorpa, 510.

Panter, 326, 421, 503.

Pantala flavescens, 247.

Papegaaiduiven, 73, 314.

Papilio, 35, 129.

-agamemnon, 130 .

-antiphates, 130.

-aristolochiae, 129, 130.

-arjuna, 129, 479.

- coon, 129, 130.

-demolion, 129, 130.

-jason, 130.

-memnon, 129, 130.

- peranthus, 479.

-polytes, 129.

- sarpedon, 130.

Paracritheus trimaculatus,

487.

Paradoxurus hermaphroditus, 33, 57, 218, 301, 328415.

-leucomystax, 57.

-trivirgatus, 497.

parai, 392.

Parasa bicolor, 205, 340.

Parasietvliegen, 280.

Paratelphusa convexa, 401.

-tridentata, 401.
Paratoxodera cornicollis, 93.

Parmarion, 195, 369, 560.

Parra's 465.

Parthenos gambrisius, 521.

Parus cinereus, 62.

Passalidae, 343.

Passer montanus, 67.

Patella, 445.

Paussidae, 103, 119.

Pauw, 326, 435.

Pavo muticus, 326, 435.

peking, 67, 263.

Pelobatidae, 557.

Pelochelys cantoris, 474.

Pelochyta astrea, 570.

peloeng, 464.

Pelargoderus bipunctatus, 126.

353.

Pelargopsis leucocephala, 449.

Pendulinus laminatus, 574.

pengantenan, 465.

Pentatoma plebeja, 337.

Pentatomidae, 573.

pepiko, 274.

Percidae, 395.

pergum, 528, 554 .

Pericalus 4-maculatus, 410.

Perichaeta capensis, 196.

-indica, 196.

-musica, 599.

Perichaetidae, 196.

Pericocrotus, 492.

-exsul, 348.

-miniatus, 348, 366.

-peregrinus, 238, 348.

Perionyx violaceus, 196.

Periophthalmus, 444.

Periplaneta australasiae, 91.

Perittopus rufus, 402.

perkoetoet, 74, 312. 
Pernis ptilonorhynchus, 219. petikrak, 64.

petjoek, 463 .

-oelar, 463.

peusing, 223.

peutjang, 486.

Phalacrocorax javanicus, 463.

Phalangoidae, 585.

Phalera, 307.

Phasmidae, 92.

Pheidole javana, 158.

-plagiaria, 158.

Pheidologeton 516.

-affinis, 158.

Phenice maculosa, 304.

Pheropsophus javanus, 117,

Phidole, 516.

118.

Philentoma velatum, 530 .

Philodicus javanus, 455.

Philoscia, 194.

-pallida, 602.

Phissama transiens, 147, 284.

Phlebotomus, 110.

Phodilus badius, 34, 221, 508.

Phoridae, 611.

Phoyx, 265.

-manillensis, 468.

Phrynichidae, 182, 601.

Phrynichus phipsoni, 601.

Phyllium pulchrifolium, 536.

-siccifolium, 536.

Phyllocharis undulata, 485.

Phyllocnistis minutella 155.

Phyllodes consobrina, 571.

Phyllophaga, 121.

Phyllopoda, 400.

Physodera, 566.

Physodera dejeani, 410.

Physomerus calcar, 285 .
Physomerus parvulus, 285.

Physopelta gutta, 575 .

Phytoptidae, 188.

Phytoscapha triangularis, 365 .

Pieper, 274.

Pieridae, 134.

Pieris amasene, 134.

-coronea, 134.

-nero, 480.

-panda, 480.

-pandione, 480.

-paulina, 480.

Piet van Vliet, 74.

Pimpla, 333.

Pintia metachloros, 144.

Pirates affinis, 604.

Piratinae, 577, 604.

Piroplasma bigeminum, 317.

Pissepedden, 193, 412.

pitè wono, 435 .

Pitechir melanurus, 524.

Pitta cyanura, 10, 241, 527.

- muelleri, 527.

Pittidae, 242.

Placosternum taurus, 573.

Plaesius, 210.

Plagiodera melusa, 212.

Plagiolepis longipes, 161, 299.

Planariën, 597.

Planipennia, 509.

Planorbis compressus, 405 .

platok, 74.

-bawang, 341.

Platvisschen, 398.

Platylomia, 579.

Platylophus galericulatus, 525 .

Platypleura nobilis, 579.

Platypria, 484.

Platyrhacus, 193.

Platysoma, 410. 
Platystoma punctiplena, 279. Platythomisus phryniformis,

Plecia fulvicollis, 111.

Plectognathi, 399.

Plegadis falcinellus, 468.

Pleuronectidae, 398.

Plevierachtigen, 459.

Plevieren, 268.

Ploceëlla, 264.

-javanensis, 302.

Ploceidae, 67, 262.

Ploceus, 264.

-manjar, 302.

Plotus melanogaster, 463.

Plumatella, 407.

Plusia, 150.

-eriosoma, 299.

-orichalcea, 299.

-signata, 299.

Pneupyga rufa, 551.

Podiceps philippensis, 462.

Podontia affinis, 485.

Podops vermiculatus, 107, 259.

Poduridae, 489.

Poecilobdella granulosa, 406.

-javanica, 406.

Poeciloptera stollii, 215, 233.

poejoeh, 242.

-gonggong, 531, 593.

poenai, 73.

poetjoek kiray, 383.

Polioaetus ichthyaetus, 456.

Poliolimnas cinereus, 467.

Polistes hebraeus, 511, 618.

Polydesma, 149.

Polydesmidae, 193, 600.

Polynemidae, 395.

Polynemus tetradactylus, 395.

Polydontophis geminatus, 499.
Polypedates javanus, 559.

-leucomystax, 88.

-reinwardti, 88 .

Polyptychus dyras, 568 .

Polyrhachis, 162, 518.

Pomatorhinus montanus, 29,

494.

Pompelon subcyanea, 569.

Pompilidae, 166.

Pompilus, 166.

Pomponia, 579.

Poneridae, 159, 518.

Pontoscolex corethrurus, 197.

Popilia biguttata, 361.

Porana volubilis, 105.

Porceleinhoentje, 467.

Porcellio pruinosus, 194.

- sundaicus, 194.

Porphyrio calvus, 464.

Potamides cingulatus, 446.

-ornatus, 446.

-palustris, 446.

-sulcatus, 446.

-telecopium, 446.

Praonetha, 563.

-melanura, 353.

Pratincola caprata, 274, 357.

Precis ida, 132.

-iphita, 132.

Priassus spiniger, 573.

priendjak, 64 .

priet, 67, 221, 263.

- benggala, 263.

Prinia blythi, 270.

-familiaris, 64.

- polychroa, 552.

Prionochilus percussus, 544 .

Prionodon gracilis, 589.

Prionopidae, 349.

Priolonomia heros, 574. 
Pristhevarna bipunctata, 577.

Pristis, 381.

Proctotrupidae, 16:- 610.

Prorlenia litoralis, 147, 282.

Prophthalmus, 562.

Prosopis, 172, 454.

Protaetia, 564.

Prothoe angelica, 520.

Protoparce convolvuli, 138.

Psalis, 92.

Psaltria exilis, :365, 492.

Psammobiinae, 448.

Psammodynastes pulverulen-

Pselaphidae, 119. tus, 255.

Pselliophora, 362.

Pseudagenia, 166.

Pseudolasius, 161.

Pseudophoraspis, 604.

Pseudophyllus, 95, $27 \mathrm{~S}$.

Pseudoscorpiones, 182.

Pseudoscorpionidae, 452.

Pseudosphynx discistriga, 569.

Pseudoterpna, 572.

Psilocnemis marginipes, 510.

Psilopidae, 254.

Psilopus, 113, 281, 304, 489.

Psocidae, 100.

Psychidae, 354, 361, 365.

Psylliodes, 212.

Ptererythrius aenobarbus, 544 .

-flaviscapis, 544, 616.

Pterophora, 155.

Pteropus edulis, 200, 225, 460. -nicobaricus, 200.

Ptilocera quadriclentata. 11:3.

Ptilocerus, 107.

-ochraceus, 107.

Ptycho\%oon homalocephalum,

77.

P'tilomera laticaulata, 401.

Ptilona, 279.

Ptilopus jambu, 529, 554.

-melanocephalus, 73, 529.

-roseicollis, 593.

Ptinidae, 125.

Pulmonata, 447.

Pulvinaria maxima, 335.

Puntius, 392.

Purana, 579.

Purperspreeuw, 69.

Pycnonotus analis, 61, 239.

-aurigaster, 61, 239.

-bimaculatus, 357, 492, $\$ 16$.

-plumosus, 239.

- simplex, 239.

Pygidicrania marmoricrura,

605.

-pallidipennis, 606.

Pyralidae, 151, 256.

Pyrausta machoeralis, 324 .

Pyraustinae, 153.

Pyrocoelia lateralis, 122 .

Pyrops dohrni, 580.

Pyrrhocoridae, 575.

Pythia pantherina, 447.

Python molurus, 473.

-reticulatus, S1, 262, 37\%.

Quadrifinae, 147, 148.

\section{(A.}

Querquedula circia, 463.

\section{IR.}

Radena vulgaris, 131.

Raderdiertjes, 407. 
Rallidae, 467.

Rallina fasciata, 467 .

Ralreiger, 470.

Rana chalconota, 254, 558 .

-erythraea, 88, 254.

-grunniens, 254.

-javanica, 558.

-jerboa, 379.

-kuhlii, 558.

-limnocharis, 88, 254.

-macrodon, 88, 254. mirodisca, 255.

-tigrina, 254.

Ranatra asiatica, 25:.

rangkok, 504 .

rangrang, 453, 51 .

Ranidae, 558 .

Rasbora argyrotaenia, 392.

rassi, 33, 218, 345.

Rat (bruine), 55 .

-(zwarte), 56.

Ratten, 55, 301.

Retitelariae, 318.

red spider, 363.

Reduviidae, 488, 576, 603.

Regenwulp, 458 .

Reigers,75, 265, 266, 457,

Remigia archesia, 150. $468,469$.

-frugalis, 150.

Rhacophorus, 88.

Rhimpalea ochalis, 153.

Rhinia discolor, 280.

Rhinoceros sundaicus, 426 .

Rhinococcyx curvirostris,

Rhinomyias baliensis, 530 .

Rhinoscapha amicta, 344 .

Rhipicephalus, 188.

-australis, 317.
Rhipidoglossa, 447.

Rhipidura javanica, 62.

-phoenicura, 547, 592, 616.

Rhodoneura myrtaea, 371.

Rhomborrhina gigantea, 564 .

Rhopalocera, 127, 478.

Rhynchites betuleti, 365 .

Rhynchium haemorrhoidale, 168.

Rhynchobdella aculeata, 397.

Rhynchobdellidae, 406.

Rhynchophorus, 203.

Rhynchota, 104, 251, 486, 603.

Rhysida longipes, 189.

Rhytidoceros undulatus, 504.

Rhytitodera, 126, 216.

Ricania atrata, 358.

-fuliginosa, 358.

Rietzangers, 270.

Rijstboorder, 152.

Rijstklander, 125.

Ringmusch, 67.

Rioxa, 279, 489.

Roerdomp, 315.

Roggen, 381.

Roofvliegen, 281.

Roofvogels, 60.

Roofwantsen, 575 .

Rostratula capensis, 467.

Rouwmugjes, 111.

Rubigula dispar, 527.

-squamata, 527.

Rugzwemmers, 251.

Ruigpootarend, 433.

Ruiters, 268, 458.

Rupsvogels, 75, 238, 348, 366. 
Sabelsprinkhanen, 95, 276.

saëran, 71 .

Sagra buqueti, 4.93

sakit poetiln, 257 .

salagoenting, 7 .

Salius bipartitus, 482.

- ducalis, 482.

-verticalis, 482 .

Salticus, 184 .

Saltigradae, 183.

Sameodes cancellalis, 154 .

sangsan, 425 .

santran, 388 .

Saprinus, 609.

Sapromyzidae, 612.

Sarax, 182.

Sarrothripinae, 148.

Sasia abnormis, 507.

Sastrapada flava, 576 .

Satyridae, 41, 131, 439, 478.

Scansores, 74.

Scaphididae, 119.

Scatophagus argus, 395.

Sceliphron, 164, 166.

-javanum, 165.

-madraspatanum, 165.

- violaceum, 165.

Scelodonta nitidula, 485,

Schildluis (op doekoe), 205.

Schildluizen, 104

- (op suikerriet), 304.

Schildpadden. 377, 474.

Schoenobiinae, 152, 439.

Schoenobius bipunctifer, 152,

257.

Schorpioenen, 180, 601.

Schorpioenspinnen, 181.

Sciaenidae, 395.

Sciara 111, 611.

Scincidae, 556.
Scirpophaga, 15.2.

-intacta, 306.

Sciuropterus lepidus 201.

- sagitta, 33, 201.

Sciurus bicolor, 542 .

-insignis, 497.

-melanotis, $5+2$.

-notatus, 58, 200, 301.

Scleropterus, 411.

Scolia capitata, 167.

—rubiginosa, 167.

Scoliidae, 167.

Scolopax saturata, 593.

Scolopendra gigantea, 190.

- gracillima, 189.

-pinguis, 189.

- subspinipes, var. dehaani,

189.

Scolopendridae, 189.

Scolytidae, 124, 216.

Scomberesocidae, 394.

Scops lempiji, 34, 60, 200.

Scutelleridae, 286, 293.

Scutigera longicornis, 192.

Scydmaenịdae, 119, 410, 608.

Scymnus, 126.

Selenocosmia, 320 .

- javanensis, 264 .

Seling, 69.

Semnopithecus, maurus, 502.

-mitratus, 541 .

- pyrrhus, 502, 326, 502.

senggal, 385.

serak, 60.

Serica, 121.

-javana, 354, 361 .

-pulchella, 354, 361 .

Seriendiet, 496 .

Sero, 374.

Serowot, 387. 
Serranus, 395.

Serrodes inara, 150.

sesarma, 253.

- nodulifera, 401.

Sesiidae, 50, 511.

Setomorpha tineoides, 154 .

Setora nitens, 97, 144.

Sicydium, 396.

sigoeng, 367.

siamang, 541.

Siliqua, 448.

Silphidae, 413.

Siluridae, 383.

Silvanus surinamensis, 119.

Sima, 516.

simeut salak, 584 .

Simotes fasciatus, 472 .

-octolineatus, 255, 499.

Simplicia, 151.

Simulium, 611.

singsèwan, 274.

Sinoxylon, 124.

Sintor, 534.

Siphia banyumas, 235.

-vordermanni, 616.

Sirthenea flavipes, 604.

Sitala, 561.

Sitta azurea, 552.

-frontalis, 75, 552.

Slakken, 560 .

Slangen, 255, 275, 436, 470,

Sluipwespen, 162.

498.

sminthocoris pictus, 577.

- rufus, 577.

-singularis, 577 .

Snippen, 267, 467.

snijdervogels, 64 .

soengkeat, 391.

soerili, 541 .
Solen, 448.

Solenidae, 448.

Sparassus, 185.

Spechten, 504.

Sperwer, 275.

Sphaerodema rusticum, 252.

Sphegidae. 166, 282.

Sphenocercus korthalsi, 555.

-oxyurus, 555, 616.

Sphenocorynus seminudus, 484.

Sphenophorus planipennis, 209.

- sericans, 565.

Sphenoraja javana, 485 .

Sphenura, 563.

- funerula, 563.

-picta, 563.

Sphex argentatus, 282.

-aurulentus, 282.

Sphingidae, 138, 364, 568.

Sphingomorpha chlorea, 149.

Spilornis baccha, 222 .

Spilosoma maculifascia, 147, 284.

-strigatulum, $147,2 \triangleleft 4$.

Spinnen, 182, 318, 412, 490.

Spirama retorta, 150 .

Spirostreptus javanicus, 193.

Spitsmuizen, 33, 57.

Spizaetus limnaetus, 217.

Spongilla alba, 407.

--proliferens, 407.

Spongillidae, 407.

Sponzen, 407.

Spookdiertje, 523.

Spoorkoekoeken, 432.

Sporaeginthus amandava, 263.

Spreeuwen, 68, 310.

Springspinnetjes, 183. 
Sprinkhanen, 276.

Squamipennes, 395.

Squatarola helvetica, 459 .

Squilla, 537.

sribombok, 316.

Stachyris thoracica, 496.

Staphylinidae, 117, 410, 60 S.

Stasiasticus montis, 617.

Stauropus alternus, 360 .

Steenlooper, 459 .

Steltkluiten, 466 .

Stenogyra, 195.

Stenopterina aenea, 112.

Sterna, $4 \check{9} 9$.

-media, 460.

Sternidae, 459.

Stibochia coresia, 521.

Stictoptera cuculloides, 210.

Stictopterinae, 148.

Stigmatomma reclinata, 160 .

Stilbomyia fuscipennis, 113.

Stilbum cyanurum, 163.

Stiltia isabella, 459.

Stizus pusillus, 403.

Stomoxys calcitrans, 317.

stoparola indigo, 366, 492.

Strandloopers, 268, 457.

Strandvarken, 20.

Stratiomyidae, 113, 611.

Strepsilas interpres, 459.

Striglina scitaria, 339.

Strix flammea, var. javanica,

-javanica, 34 .

Stromatium, 32t.

Strongylium, 123.

—ambiguum, 5.36.

Strongylosoma, 193.
Strophidia fasciata, 151.

Strumigenys, 158.

Sturnia sturnina, 470 .

Sturnopastor, 311.

-jalla, 6s.

Sturnus vulgaris, 69.

Suada swerga, 439.

Suana concolor, 145, 36t.

Suikergast, 179.

Sula piscator, 460 .

Sulidae, 460.

Surniculus lugubris, 234.

Sus verrucosus, 273, 301, 326,

424.

- vittatus, 20, 27:3, 301, 326,

423.

Sutoria edela, 64 .

Sycanus collaris, 578.

Sylepta multilinealis, 154 .

Sylphidae, 119, 608.

Sylviidae, 270.

Symbranchidae, 382.

Symbranchus bengalensis, 383.

Symphaedra dirtea, 479.

Sympis rufibasis, 150 .

Synaptura commersoniana,

398.

-leucorhyncha, 398.

Syngnathidae, 398.

Syngnathus spicifer, 398.

Synonycha grandis, 305.

60. Syntomidae, $143,511$.

Syrnium sinense, 508.

Syrphidae, 112, 279, 3:37, 489.

595.

Syrphus, 112.

-aegrotus, 280 .

Tabanidae, 317.

Tabanus, 113. 
Tabanus brunneus, 317.

-brunnipennis, 317.

-rubidus, 113, 317.

- striatus, 317.

Tachina, 280.

Tachinidae, 113, 254, 280.

Tachornis infumata, 70 .

Tachydromia, 611.

Tachydromus sexlineatus, 79.

Tachytes, 283, 411.

Taenioglossa, 446.

Tagora amoena, 142.

Tantalus cinereus, 468 .

Tarache, 148.

Tarsius spectrum, 523.

Tarsolepis remicauda, 143.

tawes, 392.

'Iectocoris cyanipes, 212, 289,

Teken, 188, 317.

tekoekoer, 312, 313.

Telchinia violae, 479 .

teledoe, 367.

Telphusa, 253.

- granulata, 401.

Tenaris horsfieldii, 520 .

Tenebrionidae, 123, 299, 353.

Tephritis, 489.

Tephrodornis virgatus, 530 .

Terastia egialealis, 154, 329.

-meticulosalis, 154, 329.

terèh, 268.

Terias, 310 .

- harina, 532.

-hecabe, 26, 135, 334, 532.

- sari, 135, 532.

-tilaha, อ̌32.

Terinos clarissa, 520.

terkoewak, 316.

Termieten, 11, 371, 409.
Termitidae, 100.

Terpsiphone affinis, 526.

Territelariae, 320 .

Tesseratoma javanica, 573.

Testudo, 379.

Tetralanguria elongata, 127.

Tetragnatha, 187.

Tetramorium pacificum, 158.

Tetranychus bioculatus, 43 ,

363.

Tetrigidae, 95, 605.

Tetrodon fluviatilis, 399.

-leiurus, 399.

-lunaris, 399.

-oblongus, 399.

-patoca, 399.

- sceleratus, 399.

-Tettigoniella ferruginea, 583.

Tettix, 411.

Texaskoorts, 317.

Thalassodes, 151.

Thaumantis odana 520.

Thea cincta, 336 .

Thelyphonus caudatus, 181 .

Theretra actea, 139.

-nessus, 139.

Theridion, 318.

Theronia, 163.

-concinna, 333.

Thessitus insignis, 581.

-mortuifolia, 580.

Thestias venilia, 454 .

Thinopteryx crocoptera, 572.

Thodelmus falleni, 576.

Tholymis tillarga, 247.

Thriponax javensis, 505.

Thyca, 568.

Thysia tricincta, 533.

Thyrididae, 339, 372.

Thyropygus, 193. 
Tiarodes versicolor, 577.

Tiga javanensis, $341,505$.

Tijger, 326, 345, 420 .

Tijgeroortje, $4+7$.

tikoesan, 467 .

Timelia pileata, 434 .

'Timeliidae, 506550.

Tinea granella, 154.

Tineidae, 15t, 306.

Tinoleus eburneigutta, 150 .

Tipula pedata, 362.

-umbrina, 362.

Tipulidae, 110, 362.

tiril, 268.

titihan, 462 .

tiworo, 393.

tjamperlali, 466.

tjamperling, 69 .

tjangehgar, 435.

tjangkeurilang, 61 .

tjangkiloeng, 207.

tjareuh, 57.

tjeladi loemoet, 75 .

tjèlèng, 423.

tjelepoek, 34, 60 .

tjeloektjoek, 61 .

tjeroeroet, 57.

tjetjodot, 58 .

tjetjrong, 241.

tjipôh, 61 .

tjitjak, 76 .

tjitjakorek, 270.

tjitjarawah, 347 .

tjitji, 65 .

tjoelik-tjoelik, 235.

toehoe, 2:35.

toepai, 346.

tokkè, 78 .

Tomistoma schlegelii, 376.

tongèrret, 10 ว.
Torenvalk, 219.

Tortricidae, 154.

Tortrix, 324.

Tosena fasciata, 597 .

'Totanus calidris, 458.

- glareola, 458.

-glottis, 458.

-hypoleucus, 458.

-stagnatilis, 458 .

Toxotes jaculator, 395.

Trabala vishnu, 145, 294.

Trachycomus ochrocephalus,

Tragulidae, 426.

347.

Tragulus javanicus, 326,426 ,

trenggiling, 223.

503.

Treronidae, 73, 314.

Trichiuridae, 395.

Trichiurus glossodon, 395.

Tricholepis grandis, 122, 342 .

Tricondyla cyanea, 344 .

Trictenotoma, 5̋ว.

Trifinae, 147, 281.

Trigonodes, 150, 571.

Trigonotoma, 566.

Trilophidia, 278.

'T'ringa acuminata, 457.

-alpina, 458.'

-arenaria, 457.

- arquata, 457.

-crassirostris, 458.

-minuta, 457 .

-platyrhyncha, 458.

- subarquata, 457.

-subminuta, 457.

'Tringidae, $45 \overline{7}$.

trinil, 268.

Trionyx cartilagineus, 377.

-subplanus, 378. 
Triplatoma c-notata, 567.

Trithemis trivialis, 247.

Trochonanina, 561.

troelek, 268.

troelek besar, 459 .

Trogons, כ55.3.

Trogosita mauritanica, 119.

Trogositidae, 119.

Trombidiidae, 363.

Tropidonotus chrysargus, 498.

- piscator, 255.

-quincunciatus, 84.

-subminiatus, 84.

-trianguligerus, 84.

- vittatus, 84 .

Trox costatus, 608.

Trygodes divisaria, 572.

Trygon, 381.

Trypanosoma, 317.

Trypauchen vagina, 396.

Trypeta, 279, 489.

Uilen, 508.

Uloma denticornis, 123.

Unionidae, 405.

Uraniidae, 151, 572.

Urapteroides, 572.
Trypetinae, 279.

Trypoxylon bicolor, 164 .

Tryxalis, 95, 278.

Tubitelariae, 186.

Tupaja ferruginea, 346 .

-javanica, 346.

Turdinus, 550.

Turdus, 7.

-merula, 62.

'Tureluur, 458.

Turnix pugnax, 242, 435.

Turtur bitorquatus, 312 .

-tigrinus, 312.

Turturidae, 312.

Tylognathus falcifer, 388.

-hispidus, 388.

Typhlocyba, 331 .

Typhlops, 80, 82.

-braminus, 82.

-lineatus, 82,
Vaginula, 195.

Vanessa cardui, 478, 618.

Varanidae, 474.

Varanus salvator, 80,262,376.

Veldsprinkhanen, 276.

Velitra rubropicta, 577.

Verania afflicta, 289.

-lineata, 485.

Vespa analis, 170.

- cincta, 170. $\mathbf{u}$

Urochaetidae, 197.

Uroloncha leucogastroides,

Uropodidae, 413.
Vespa velutina, 171.

Vesperugo, 59 .

Vespidae, 167.

Vestalis lugens, 510.

Vijgeninsecten, 513.

Vischpissebedden, 391.

Visitekapel, 132.

Visschen, 380, 474.

Viverricula malaccensis, 33, $218,345,415$. 
Vivipara javanica, 405.

Vleermuizen, 58, 200, 542.

Vliegen, 485.
Vliegenrangers, 65, 235, 505.

Vogelspin, 26tit.

Vorkstaarten, 506.
Waadvogels, 457, 464.

wadder, 392.

wadon, 392.

-goenoeng, 38s

walangkada, $315,469$.

walang nonna, 92.

-sangit, 43, 259 .

- sembah, 92.

walet, 69 .

walik, 73.

Wallago attu, 385.

Wandelende Bladen, 536.

-Takken, 536.

Waterhoentjes, 316, 466.

Waterlongslakken, 405 .

Watermijten, 404.

\section{W.}

Waterroofkevers, 249 .

Waterschorpioenen, 253.

wau-wau, 540.

wawar, 417.

Webspinnen, 186.

Weekdieren, 194, 404, 445.

welingsang, 374 .

Wespendief, 219.

Wevervogels, 264, 302.

Wielewaal (indische), 64 .

Wolfsspinnen, 185.

Wormen, 195. 406.

Woudaapjes, 469.

Wouw, 271.

Wulpen, 45.

Xantharpyia amplexicaudata, | Xylocopa, 50, 123, 174.

58. -aestuans, 175.

Xantholaema australis, 525. - coerulea, 175.

-rosea, 66.

Xanthoptera, 148.

Xanthopygia tricolor, 256 .

Xenodermus javanicus, 498.

Xenodon purpurascens, 437.

Xenopeltis unicolor, 255.

Xyleborus coffeae, 344.

Xylinades rugosus, 535.

-westermanni, 534.

-collaris, 175

-latipes. 175.

-mesoxantha, 175.

-pictifrons, 175.

Xylotrechus javanicus, 32.

-quadrupes, 32.

Xylotrupes gideon, 121, 411.

Xystrocera festiva, 126, 340 .

Yolinus sufflatus, 578.

| Yphthima, 132, 478.

Zaagvisschen, 381.

$\mathbf{z}$.

| Zalissa transiens, 570. 
Zamenis korros, 83.

-mucosus, 437.

Zanclostomus javanicus, 495.

Zandoogjes, 41.

Zeenaalden, 398.

Zeeschildpadden, 450 .

Zeeslangen, 456.

Zeezwaluwen, 459.

Zephronia, 192.

-nigricepsi, 192.

Zethus, 49.

-cyanopterus, 481.

Zeuzera coffeae, 339, 354 .

Zeuxidia amethystus, 520.

-doubledayi, 520.

-luxeri, 520.
Zinckenia recurvalis, 153.

Zoetwaterschildpadden, 378.

Zoetwatersponzen, 407.

Zonitidae, 560.

Zoothera andromedae, 548.

Zosterops, 240.

-auriventer, 240.

-fallax, 240, 591, 616.

-flava, 240.

- melanura, 240.

Zwaluwen, 69, 356.

Zwaluwplevier, 268, 459.

Zwemvogels, 459.

Zwijnen (wilde), 273, 301,

$326,346,371,423,450$.

Zygaenidae, 204, 569. 


\section{Alphabetisch Register der Plantennamen.}

aardappel, 292.

Acacia tomentosa, 308.

Achras sapota, 58, 216.

Adiantum, 68, 104.

Advocaatboom, 141.

Agave, 543.

alang-alang, 14, 104, 414 .

Albizzia, 48, 340.

Albizzia moluccana, 334 .

-stipulata, 334.

Allamanda, 68.

Alocasia, 139.

-antiquorum, 139.

Amaranthus gangeticus, 311.

Anaphalis, 617.

Anona muricata, 104, 130.

Anonaceae, 130.
Antidesma bunias, 65, 315 .

Antigonum, 105.

A rachis hypogaea, 273, 284.

Areca, 203.

-catechu, 68, 204.

A renga saccharifera, 309.

arènpalm, 309.

Aristolochia, 106, 129.

Artemisia, 6.

-vulgaris, 6.

Artocarpaceae, 11.

Artocarpus integrifolia, 58, 96.

Arum, 139.

Aschersonia, 336.

Asclepiadaceae, 537.

Asplenium nidus, 600. babadottan, 311.

bajam merah, 311.

Balanophora, 425.

bamboe, 206, 414.

bandottan, 311 .

bataten, 294.

\section{IB.}

Bignoniaceae, 325.

Borassus flabelliformis, 415 .

Botrytis, 342 .

Bridelia lanceolata, 315 .

Butea frondosa, 143.

-monosperma, 414 . cacao, 126, 351.

Caladium, 139.
Calamus, 203.

Calophyllum inophyllum, 455 . 
Calotropis gigantea, 454 .

Canarium commune, 58, 126, 141.

Capsicum annuum, 292.

Carica papaja, 58.

Cassave, 273, 294.

Cassia florida, 27.

Castilloa elastica, 371.

Casuarina, 71.

Chavica betle, 142.

Citroenachtige gewassen, 155.

Clematis, 67.

Clerodendron, 68.

coca, 354 .

Cocos nucifera, 121, 200. cocospalmen, 132.

Codiaeum, 133.

Coffea arabica, 328.

-robusta, 327.

Convolvulaceae, 138.

Convolvulus batatas, 294.

Conchophyllum, 537.

Cordyceps, 103, 342.

Corticium javanicum, 338.

Corypha gebanga, 415.

Crinum, 120, 148.

Croton, 133.

Cucurbitaceae, 292.

Cycadeeën, 11.

\section{ID.}

dadap, 142, 327.

Dammara alba, 354.

dammarboom, 354.

Datura alba, 309.

Dioscorea, 142, 273, 294.

Dischidia, 537.

djoear, 27.

djamboe, 145, 211.

djarak, 294.

djati, 38, 101, 322.

doekoe, 59, 93, 205, 238.

\section{E.}

Elaeis guineensis, 60, 92, 203. Erythrina lithosperma, 327. Elettaria, 427.

Empusa, 336.

Ericaceae, 617.

Eriodendron anfractuosum,

330.

Erythrina, 26, 142.

Erythroxylon coca, 354.

Eucharis, 14.8.

Eugenia, 211.

Eupatorium javanicum, 14.

-pallescens, 309.

Euphorbiaceae, 140.

\section{F.}

Ficus, 65̃, 73, 513.

Ficus elastica, 26, 97, 368.

-benjamina, 142, 314, 370. Funtumia elastica, 370. 
gebang, 415 .

glagah, 14,414 .

glonggong, 414 .

Glycine soja, $273,284$.

\section{(x.}

Gnaphalium, 6.

Gnetum, 106.

Gramineae, 132.

Guettarda, 139.

Hevea, 368.

II.

Hibiscus rosa-sinensis, 154. -schizopetalus, 154. -tiliaceus, 211.

Hydnophytum myrmicarum, 538.

Hyptis suaveolens, 311.

Imperata arundinacea, 14, Ipomaea, 67, 105, 106.

$104,414$.

Ipomaea brexii, 143.

Isaria, 342

Ixora, 139, 332.

kajoe koeda, 126, 330.

Ii.

kanarieboom, อ๊ , 74 .

kandri, 31 .

kapok, 330.

karet, 368.

kasso, 14, 414 .

katjang, 273, 284.

katjang bogor, 273, 284.

-idjo, 284.

-kedele, 273, 284.

-koro, 284.

-kratok, 284.

-pandjang, 284.

-tanah, 273, 284.

-tjina, 284.

Katoen, 289.

kelor wono, 308.

kembang sepatoe, 154.

kesambi, 414.

ketapang, 141.

ketjoeboeng, 309.

Kickxia, 370.

kina, 363.

kiray, 383.

klampis, 308.

klapper, 121, 200.

koffie, 327.

-(Java), 327.

-(robusta), 327.

Komkommerachtige gewassen, 292.

krinjoe, 309.

1.

Lansium domesticum, 59, 93, Leea rubra, 142.

Lantana, 14, 309, 312.

205, 238. - -sambucina, 139, 142.

Lauraceae, 11, 554 .

Litsea citrata, $う 54$.

Livistona, 70, 121. 
Livistona rotundifolia, 415. 'lontar, 415.

Loranthus, 63, $134530 . \quad$ Lycopersicum esculentum 292.

\section{M.}

Mais, 288.

malaka, 414.

Malvaceae, 212, 289.

Manihot utilissima, 273, 294.

Metroxylon, 383.

Musa, 427.

Mangifera, 9, 39, 74, 133, 213.

-foetida, 133.

-indica, 126, 139.

Mangistan, 210.

Manihot glaziovii, 371 .

-paradisiaca, 136.

Myristica fragrans, 330.

Myrmecodia echinata. 538.

Myrtaceae, 11.

nangka, 58, 96.

Nephelium lappaceum, 104.

Nerium oleander, 130.

Nicotiana tabacum, 292, 295.

njamploeng, 455 .

nootmuskaat, 330 .

\section{(1.}

Odina gummifera, 74, 126, 330. Orchideeën, 127.

oebi, 273, 294.

Oroxylum indicum, 325.

Oleander, 139.

P.

pakoe kedaka, 6000 .

papaja, วั8.

Palaquium, 294, 371.

Palmen, 11.

Pandaneeën, 11.

Parkia speciosa, 39, 74, 232.

Pavetta, 139, 332.

pelasa, 414 .

peper, 126.

Peper (spaansche), 292.

Persea gratissima, 141, 145.

peteh, 39, 232.

Phaseolus, 138.

-lunatus, 284.

Phaseolus mungo, 284.

-radiatus, 284.

Phragmites, 14.

Phyllanthus emblica, 414.

pinang, 68, 204.

pisang, 136, 209.

ploso, 414.

Poa annua, 6.

Polyporaceae, 127, 566.

Premna, 142.

Primula, 6.

-imperialis, 593.

Psidium guajava, 145, 211.

\section{R.}

ramboetan, 104.

Ranunculus diffusus, 617.

-javanicus, 617. 
Rhizophoren, 443.

Ricinus communis, 294.
Rubiaceae, 139, 332.

Rubus. 30.

Saccharum arundinaceum, 414 . -spontaneum, 14, 414. sadang, 415 .

Sanchesia nobilis, 194. sawoe manila, 58, 216. Schleichera trijuga, 414, Sesbania aegyptiaca, 308. -grandiflora, 308. sirih, 142.

\section{8.}

soja hispida, 284.

Solanaceae, 292.

Solanum, 485.

-melongena, 292.

-tuberosum, 292.

Spathodea campanulata, 61 .

Stephanotes (roode) 143.

Sterculiaceae, 11.

Suikerriet, 300.

\section{T.}

tabak, 292, 295.

tamarinde, 308.

terong, 292.

thee, 355 .

Thunbergia javanica, 150. tjinteh, 14. teak, 322,

Tectona grandis, $38,101,148$, toeri, 30 s.

322. tomaat, 292.

Terminalia cattapa, 141, 146.

Uncaria, 487.

Vaatcryptogamen, 11.

Vaccinium, 615.

Valeriana, 6.

Varens, 11.

Verbenaceae, 142, 325.

Viscum articulatum, 64 .

\section{v.}

Vigna catjang, 284.

-sinensis, 284.

Viola, 6.

Vlier (indische), 139.

Voandzeia subterranea, 273 , 284.

W.

\begin{tabular}{l|l} 
Waringin, $142,314,370$. & widoeri, 454.
\end{tabular}

Waroe, 211. woenie, 65, 314 .

Zingiberaceae, 483.

\section{T.}

zuurzak, 104, 130. 


19

$7+2$

$-x+2=0$

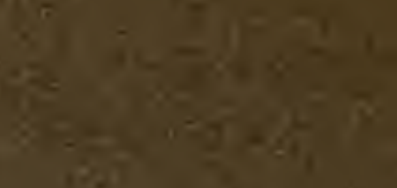

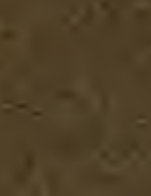

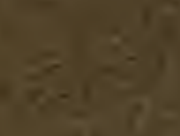

